\title{
Design Manual for Management of Solid By-Products from Advanced Coal Technologies
}

\author{
Topical Report
}

Work Performed Under Contract No.: DE-AC21-86MC22118

For

U.S. Department of Energy

Office of Fossil Energy

Morgantown Energy Technology Center

P.O. Box 880

Morgantown, West Virginia 26507-0880

\author{
By \\ Radian Corporation \\ 8501 Mopac Boulevard \\ P. O. Box 201088 \\ Austin, Texas 78720-1088
}

October 1994

¿Nofilo 


\title{
Design Manual for Management of Solid By-Products from Advanced Coal Technologies
}

\author{
Topical Report
}

October 1994

Work Performed Under Contract No.: DE-AC21-86MC22118

For

U.S. Department of Energy

Office of Fossil Energy

Morgantown Energy Technology Center

Morgantown, West Virginia

By

Radian Corporation

Austin, Texas 


\section{DISCLAIMER}

This report was prepared as an account of work sponsored by an agency of the United States Government. Neither the United States Government nor any agency thereof, nor any of their employees, makes any warranty, express or implied, or assumes any legal liability or responsibility for the accuracy, completeness, or usefulness of any information, apparatus, product, or process disclosed, or represents that its use would not infringe privately owned rights. Reference herein to any specific commercial product, process, or service by trade name, trademark, manufacturer, or otherwise does not necessarily constitute or imply its endorsement, recommendation, or favoring by the United States Government or any agency thereof. The views and opinions of authors expressed herein do not necessarily state or reflect those of the United States Government or any agency thereof.

This report has been reproduced directly from the best available copy.

Available to DOE and DOE contractors from the Office of Scientific and Technical Information, 175 Oak Ridge Turnpike, Oak Ridge, TN 37831; prices available at (615) $576-8401$.

Available to the public from the National Technical Information Service, U.S. Department of Commerce, 5285 Port Royal Road, Springfield, VA 22161; phone orders accepted at (703) 487-4650. 


\section{DISCLAIMER}

Portions of this document may be illegible in electronic image products. Images are produced from the best available original document. 


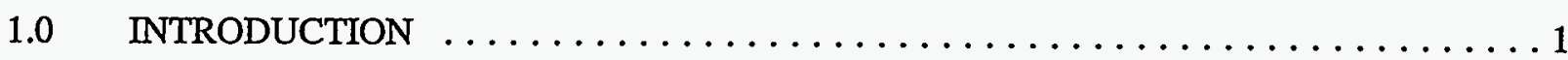

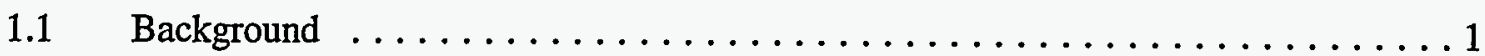

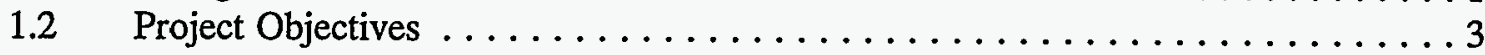

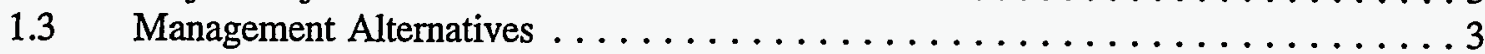

1.4 Report Organization $\ldots \ldots \ldots \ldots \ldots \ldots \ldots \ldots \ldots \ldots \ldots \ldots \ldots$

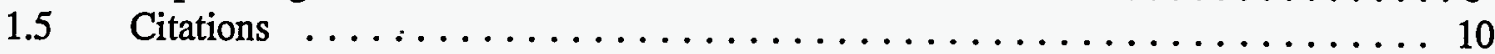

2.0 ADVANCED COAL TECHNOLOGY DESCRIPTIONS $\ldots \ldots \ldots \ldots \ldots \ldots \ldots$

$2.1 \quad$ Furnace Sorbent Injection (FSI) $\ldots \ldots \ldots \ldots \ldots \ldots \ldots \ldots \ldots \ldots \ldots$

$2.2 \quad$ Atmospheric Fluidized Bed Combustion (AFBC) $\ldots \ldots \ldots \ldots \ldots \ldots \ldots \ldots$

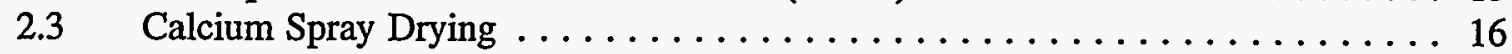

2.4 Pressurized Fluidized Bed Combustion (PFBC) $\ldots \ldots \ldots \ldots \ldots \ldots \ldots \ldots$

2.5 Dry Sodium and Calcium In-Duct Injection $\ldots \ldots \ldots \ldots \ldots \ldots \ldots \ldots$

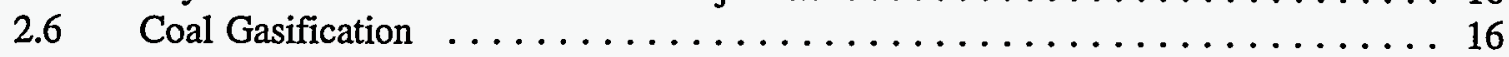

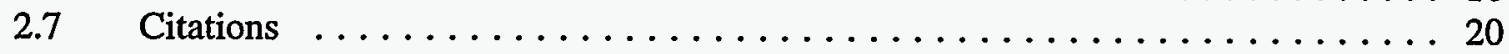

3.0 PROPERTIES OF ADVANCED COAL TECHNOLOGY BY-PRODUCTS $\ldots \ldots \ldots 23$

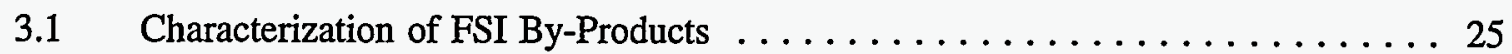

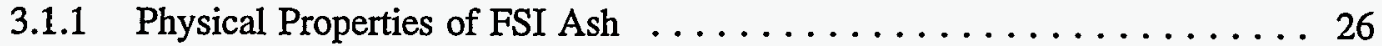

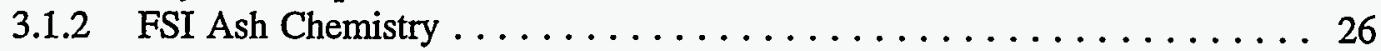

3.1.3 FSI Ash Leachate . . . . . . . . . . . . . . . . . . . . 29

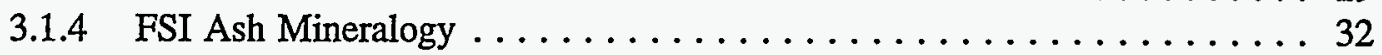

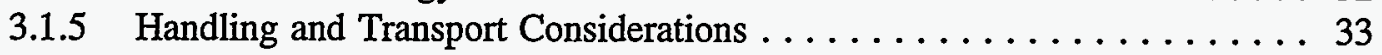

$3.2 \quad$ AFBC By-Product Characteristics $\ldots \ldots \ldots \ldots \ldots \ldots \ldots \ldots \ldots \ldots \ldots \ldots \ldots \ldots$

3.2.1 Physical Properties of AFBC Ash $\ldots \ldots \ldots \ldots \ldots \ldots \ldots \ldots \ldots \ldots \ldots \ldots$

3.2.2 AFBC Ash Chemistry ........................ 34

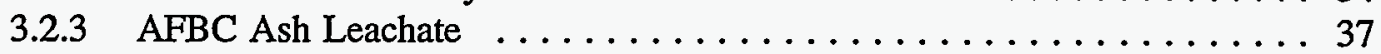

3.2 .4 AFBC Ash Mineralogy . . . . . . . . . . . . . . . 38

3.2.5 Transport and Handling Considerations . . . . . . . . . . . . . . 39

3.3 Calcium Spray-Dryer By-Product Characteristics $\ldots \ldots \ldots \ldots \ldots \ldots \ldots . \ldots . \ldots$

3.4 Pressurized Fluidized Bed Combustion By-Product Characteristics $\ldots \ldots \ldots \ldots 40$

3.5 Dry Sodium In-Duct Injection By-Products $\ldots \ldots \ldots \ldots \ldots \ldots \ldots \ldots$

3.6 Dry Calcium In-Duct Injection By-Product Characteristics $\ldots \ldots \ldots \ldots \ldots \ldots 44$

3.7 Coal Gasification Slag Characteristics $\ldots \ldots \ldots \ldots \ldots \ldots \ldots \ldots \ldots \ldots \ldots$

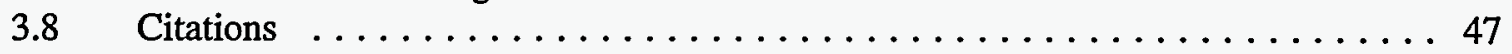




\section{TABLE OF CONTENTS (Continued)}

Page

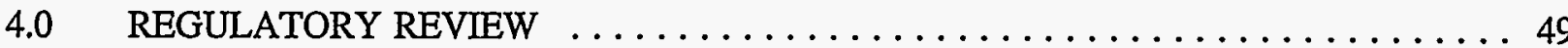

4.1 Federal Regulatory History of Wastes from the Combustion of Coal . . . . . . 49

4.2 General Overview of the Current Federal Regulatory Program . . . . . . . . . 53

4.2.1 Part 257 Criteria for Classification of Solid Waste

Disposal Facilities . . . . . . . . . . . . . . . . . . 54

4.2.2 Part 258 Criteria for Municipal Solid Waste Landfills . . . . . . . . . 54

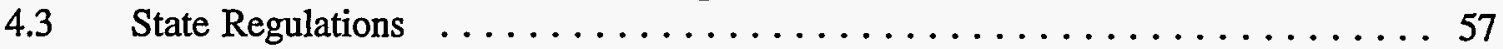

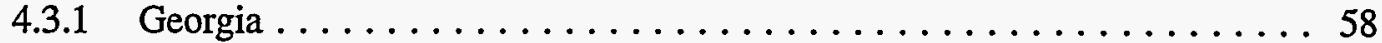

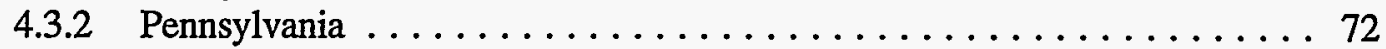

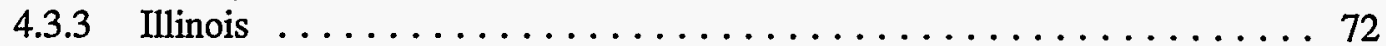

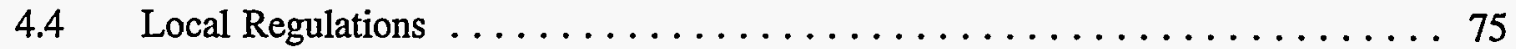

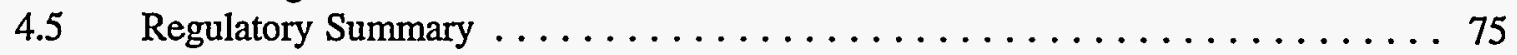

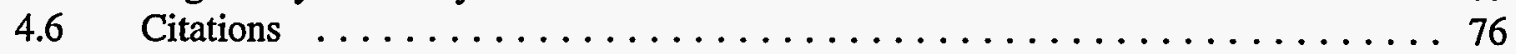

$5.0 \quad$ SITE SELECTION AND PERMITTING $\ldots \ldots \ldots \ldots \ldots \ldots \ldots \ldots \ldots \ldots$

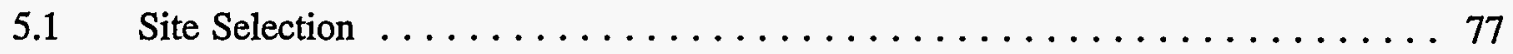

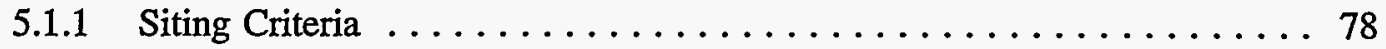

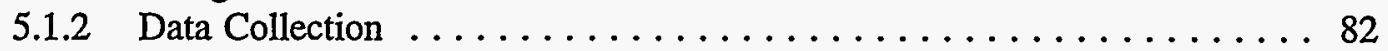

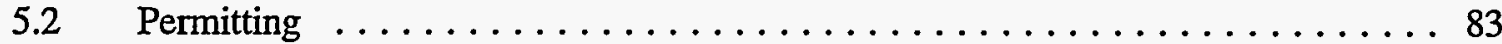

5.2.1 Number and Types of Permits . . . . . . . . . . . . 83

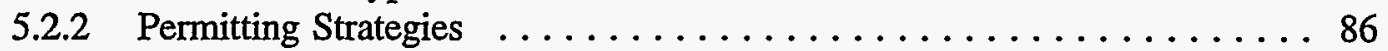

5.2 .3 Public Hearing Process $\ldots \ldots \ldots \ldots \ldots \ldots \ldots \ldots \ldots \ldots \ldots$

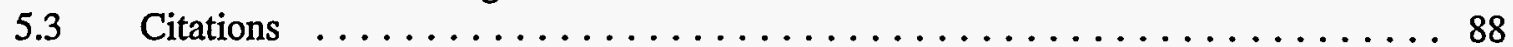

$6.0 \quad$ COMPONENTS AND EQUIPMENT $\ldots \ldots \ldots \ldots \ldots \ldots \ldots \ldots$

$6.1 \quad$ Disposal Facility Components . . . . . . . . . . . . . . . . 89

6.1 .1 Typical.Landfill Configurations . . . . . . . . . . . . . . 89

6.1 .2 Stormwater Management . . . . . . . . . . . . . . . . . 93

6.1 .3 Erosion Control . . . . . . . . . . . . . . . . . . 97

6.1.4 Groundwater Monitoring Systems . . . . . . . . . . . . 102

6.1.5 Miscellaneous Support Facilities . . . . . . . . . . . . . 112

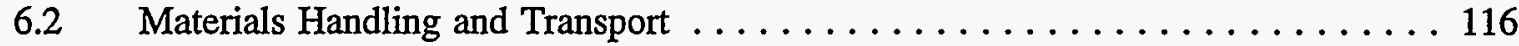

6.2 .1 By-Product Storage . . . . . . . . . . . . . . . . . 116

6.2 .2 By-Product Transportation Alternatives . . . . . . . . . . . . . 118

6.3 Material Processing at the Disposal Site . . . . . . . . . . . . . . . . . . 119

6.3.1 Storage Equipment . . . . . . . . . . . . . . . . . . . 123

6.3 .2 Material Transfer Equipment ................... 124

6.3.3 By-Product Hydration Equipment $\ldots \ldots \ldots \ldots \ldots \ldots \ldots \ldots \ldots \ldots \ldots$

6.3.4 By-Product Pelletization System . . . . . . . . . . . . . . . 139

6.3.5 Processed Material Transportation Options . . . . . . . . . . . . 141 


\section{TABLE OF CONTENTS (Continued)}

Page

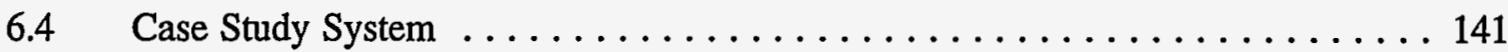

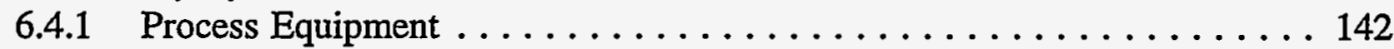

6.4 .2 Construction Procedures .......................... 144

6.4 .3 Lessons Learned . . . . . . . . . . . . . . . . . . 145

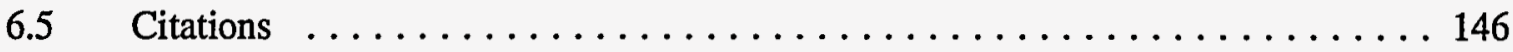

7.0 MANAGEMENT ALTERNATIVES $\ldots \ldots \ldots \ldots \ldots \ldots \ldots \ldots \ldots \ldots \ldots \ldots$

7.1 Alternative 1-Traditional Landfill Containment Systems . . . . . . . . . 151

7.1.1 Containment System Design . . . . . . . . . . . . . . . . . . 151

7.1.2 Level of By-Product Processing Required Before Disposal . . . . . . . 157

7.1.3 Economic Analysis of Alternative 1 . . . . . . . . . . . . 157

7.2 Alternative 2 -Reduced Requirement Landfill Designs . . . . . . . . . . . 158

7.2.1 Reduced Requirement Containment Systems . . . . . . . . . . . . . . 159

7.2.2 Use of By-Product Material as a Barrier Layer . . . . . . . . . . . 161

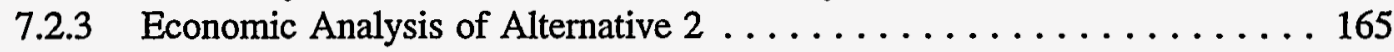

7.3 Alternative 3-By-Product Stacking Disposal Methods $\ldots \ldots \ldots \ldots \ldots \ldots$

7.3.1 Stack Design . . . . . . . . . . . . . . . . . . . 167

7.3 .2 Stack Operation . . . . . . . . . . . . . . . . . . . 171

7.4 Alternative 4-Mine Reclamation and Backfill Uses . . . . . . . . . . . . 171

7.4.1 Mining and By-Product Disposal Techniques . . . . . . . . . . 173

7.4 .2 Required Design Information . . . . . . . . . . . . . 173

7.4 .3 Economic Analysis . . . . . . . . . . . . . . . . . 177

$7.5 \quad$ Alternative $5-$ By-Product Reuse Options $\ldots \ldots \ldots \ldots \ldots \ldots \ldots \ldots \ldots \ldots \ldots$

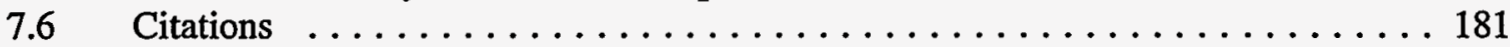

8.0 PERFORMANCE-BASED DESIGN PROCESS $\ldots \ldots \ldots \ldots \ldots \ldots \ldots \ldots$

8.1 Performance-Based Design Demonstration . . . . . . . . . . . . . 184

8.1.1 Determination of Leachate Quality . . . . . . . . . . . . . 185

8.1.2 Determine Leachate Quantity ... . . . . . . . . . . . . . . 189

8.1.3 Fate and Transport of Leachate Constituents . . . . . . . . . . . . 192

$8.2 \quad$ Design Example . . . . . . . . . . . . . . . . . . . . . . . . 194

8.2.1 Characteristics of the Example By-Product Landfill . . . . . . . . . . . 194

8.2.2 Characteristics of the Proposed By-Product Material . . . . . . . . . . 199

8.2.3 Regulatory Requirements ... . . . . . . . . . . . . . . . . 199

8.2.4 Demonstration Example . . . . . . . . . . . . . . . . 201

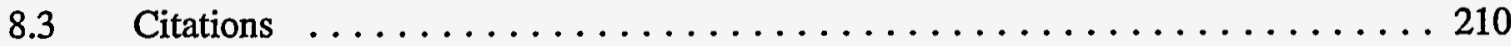


TABLE OF CONTENTS (Continued)

Page

$9.0 \quad$ RESULTS AND CONCLUSIONS FROM CASE STUDIES $\ldots \ldots \ldots \ldots \ldots \ldots$

9.1 Conceptual Model of Landfill Behavior . . . . . . . . . . . . . 211

9.1.1 Weathering and Changes in Mineralogy, Physical, and

Chemical Properties ........................ 212

9.1.2 Leachate Generation and Attenuation . . . . . . . . . . . . . 216

9.1.3 Behavior of Other Advanced Coal Technology By-Products . . . . . . . 218

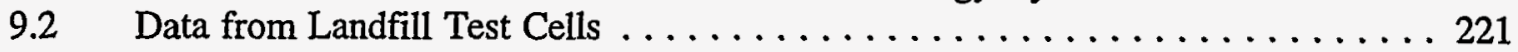

9.2.1 Colorado Site Results . . . . . . . . . . . . . . . . 221

9.2 .2 Ohio Site Results . . . . . . . . . . . . . . . . . . 224

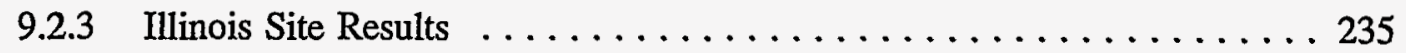

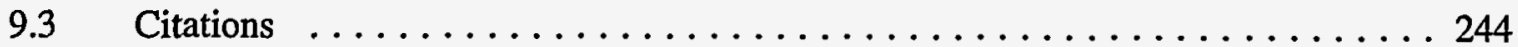

APPENDIX A HELP Model-Recharge Estimate

APPENDIX B HELP Model—Open Landfill

APPENDIX C MULTIMED Model Results-Open Landfill

APPENDIX D HELP Model—Closed Landfill

APPENDIX E MULTIMED Model Results—Closed Landfill 


\section{List of Figures}

\section{Page}

1 Alternative 1 -Traditional Landfill Containment Systems $\ldots \ldots \ldots \ldots \ldots \ldots$

2 Alternative 2 -Reduced Requirement Landfill Systems $\ldots \ldots \ldots \ldots \ldots \ldots \ldots \ldots$

3 Alternative 3 -Typical By-Product Stacking Method ...............9

4 Possible By-Product Utilization Options $\ldots \ldots \ldots \ldots \ldots \ldots \ldots \ldots \ldots$

$5 \quad$ Report Organization Flow Diagram $\quad \ldots \ldots \ldots \ldots \ldots \ldots \ldots \ldots \ldots \ldots$

6 Furnace Sorbent Injection Diagram $\ldots \ldots \ldots \ldots \ldots \ldots \ldots \ldots \ldots \ldots$

$7 \quad$ Atmospheric Fluidized Bed Combustion Diagram $\ldots \ldots \ldots \ldots \ldots \ldots \ldots$

$8 \quad$ Calcium Spray-Dryer Diagram $\ldots \ldots \ldots \ldots \ldots \ldots \ldots \ldots \ldots \ldots \ldots \ldots$

$9 \quad$ Pressurized Fluidized Bed Combustion $\ldots \ldots \ldots \ldots \ldots \ldots \ldots \ldots \ldots \ldots$

$10 \quad$ Calcium/Sodium In-Duct Injection Diagram $\ldots \ldots \ldots \ldots \ldots \ldots \ldots$

11 Gasification Combined Cycle Diagram $\ldots \ldots \ldots \ldots \ldots \ldots \ldots \ldots \ldots \ldots$

12 Physical and Engineering Properties of FSI Ash $\ldots \ldots \ldots \ldots \ldots \ldots \ldots$

13 Additional Physical and Engineering Properties of FSI Ash . . . . . . . . . 27

14 Range of Reported EP Leachate Compositions for FSI Ash . . . . . . . . . . 30

15 Additional Ranges of EP Leachate Compositions for FSI Ash $\ldots \ldots \ldots \ldots \ldots$

16 XRD Mineralogy of Conditioned and Unconditioned FSI Ash Samples . . . . . . 32

17 Physical and Engineering Properties of AFBC Ash $\ldots \ldots \ldots \ldots \ldots \ldots$

18 Additional Physical and Engineering Properties of AFBC Ash $\ldots \ldots \ldots \ldots$

19 XRD Mineralogy of $\mathrm{CFBC}$ and BFBC By-Products $\ldots \ldots \ldots \ldots \ldots$

$20 \quad \mathrm{XRD}$ Mineralogy of PFBC By-Products $\ldots \ldots \ldots \ldots \ldots \ldots \ldots \ldots \ldots \ldots \ldots \ldots$ 


\section{LIST OF FIGURES (Continued)}

Page

21 Regulations Governing Advanced Coal By-Product Disposal . . . . . . . . . . . . 49

22 RCRA Bevill Status of Coal Combustion Wastes $\ldots \ldots \ldots \ldots \ldots \ldots \ldots \ldots$

23 States Included in the Regulatory Review $\ldots \ldots \ldots \ldots \ldots \ldots \ldots \ldots$

24 Disposal Area Site Design Process $\ldots \ldots \ldots \ldots \ldots \ldots \ldots \ldots \ldots \ldots \ldots$

25 Site Evaluation Criteria $\ldots \ldots \ldots \ldots \ldots \ldots \ldots \ldots \ldots \ldots \ldots \ldots \ldots \ldots$

26 Decision Process for Completing Required Permit Applications . . . . . . . . . . 83

27 Typical Solid Waste Permitting Process $\ldots \ldots \ldots \ldots \ldots \ldots \ldots \ldots \ldots$

28 Heaped and Valley Landfill Configurations $\ldots \ldots \ldots \ldots \ldots \ldots \ldots \ldots$

29 Side-Hill Landfill Configuration $\ldots \ldots \ldots \ldots \ldots \ldots \ldots \ldots \ldots \ldots \ldots \ldots \ldots$

30 General Guidelines for Top and Side Slope Configurations . . . . . . . . . . 92

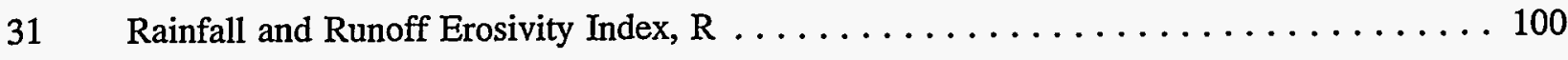

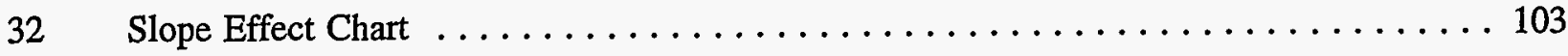

33 Leachate Migration Processes and a Typical Monitoring System . . . . . . . . . 105

34 Typical Plan for Determining Magnitude and Direction of the

Hydraulic Gradient . . . . . . . . . . . . . . . . . . . . . 106

35 Representative Ranges of Saturated Hydraulic-Conductivity Values for

Geologic Materials . . . . . . . . . . . . . . . . . . . . 110

36 Typical Monitor Well Construction $\ldots \ldots \ldots \ldots \ldots \ldots \ldots \ldots \ldots \ldots \ldots \ldots \ldots$

37 Porous-Cup Lysimeter Design $\ldots \ldots \ldots \ldots \ldots \ldots \ldots \ldots \ldots \ldots \ldots \ldots \ldots \ldots \ldots$

$38 \quad$ Pan Lysimeter Design $\ldots \ldots \ldots \ldots \ldots \ldots \ldots \ldots \ldots \ldots \ldots \ldots \ldots \ldots \ldots \ldots$

39 Material Handling Processes Flowchart $\ldots \ldots \ldots \ldots \ldots \ldots \ldots \ldots \ldots \ldots \ldots$

$40 \quad$ Examples of Storage Silos and Hoppers $\ldots \ldots \ldots \ldots \ldots \ldots \ldots \ldots \ldots$ 


\section{LIST OF FIGURES (Continued)}

Page

41 Guidelines for Selecting a Transport Mode Based Upon Particle Size . . . . . . . . . 120

42 Guidelines for Selecting a Transport Mode Based Upon Flow Rate . . . . . . . . 121

43 Guidelines for Selecting a Transport Mode Based Upon Distance . . . . . . . . . 122

44 Approximate Capital Costs for the Various Transfer Alternatives

Based Upon Capacities . . . . . . . . . . . . . . . . . . . 125

45 Illustrations of Dilute Phase Pneumatic Conveyors $\ldots \ldots \ldots \ldots \ldots \ldots \ldots$

46 Illustrations of Dense Phase Pneumatic Conveyors $\ldots \ldots \ldots \ldots \ldots \ldots \ldots \ldots$

47 Illustration of an Air-Activated Gravity Conveyor $\ldots \ldots \ldots \ldots \ldots \ldots \ldots$

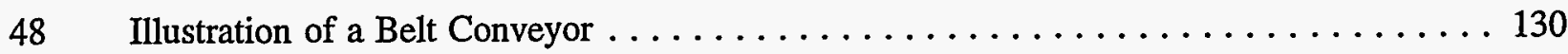

49 Illustration of a Screw Conveyor $\ldots \ldots \ldots \ldots \ldots \ldots \ldots \ldots \ldots \ldots \ldots \ldots \ldots \ldots$

50 Illustration of Various Types of Chain Conveyors $\ldots \ldots \ldots \ldots \ldots \ldots \ldots$

51 Illustration of a Vibrating Conveyor $\ldots \ldots \ldots \ldots \ldots \ldots \ldots \ldots \ldots \ldots \ldots \ldots$

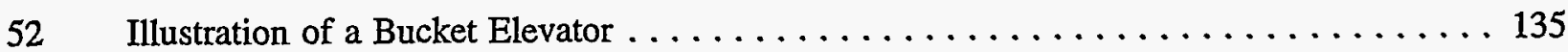

53 Processing Equipment Suitable to Hydrate By-Product Materials . . . . . . . . . 137

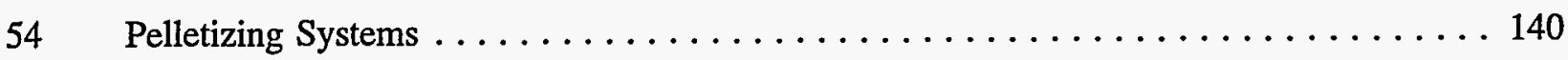

55 Equipment Components Used During Case Study . . . . . . . . . . . . . 143

56 Construction Procedures for Case Study $\ldots \ldots \ldots \ldots \ldots \ldots \ldots \ldots \ldots$

57 Summary of General Design Requirements for the Five Alternatives . . . . . . . 148

$58 \quad$ Typical Industrial Landfill Containment System . . . . . . . . . . . . . . . . 149

$59 \quad$ Reduced Requirements Landfill Design . . . . . . . . . . . . . . . 150

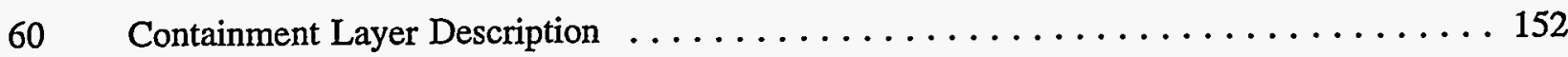

$61 \quad$ Cover Layer Assessment $\ldots \ldots \ldots \ldots \ldots \ldots \ldots \ldots \ldots \ldots \ldots \ldots \ldots \ldots \ldots \ldots \ldots$ 


\section{LIST OF FIGURES (Continued)}

Page

$62 \quad$ Arid Area Cover Layer Assessment $\ldots \ldots \ldots \ldots \ldots \ldots \ldots \ldots \ldots \ldots$

63 Leachate Collection System Plan View and Typical Section $\ldots \ldots \ldots \ldots \ldots$

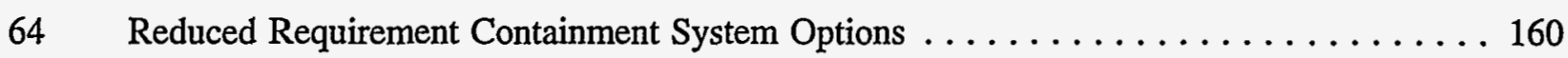

65 Standard Proctor Curve Developed During Pre-Construction Study . . . . . . . . 162

66 Strength Gain During Pre-Construction Study $\ldots \ldots \ldots \ldots \ldots \ldots$

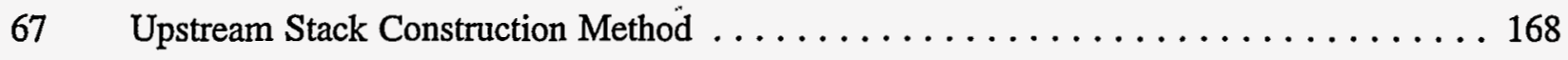

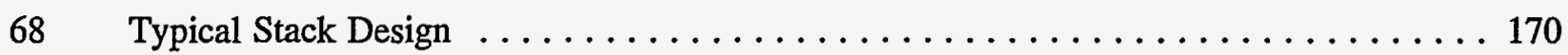

69 Disposal of By-Product in Area Surface Mine $\ldots \ldots \ldots \ldots \ldots \ldots \ldots \ldots$

70 Disposal of By-Product in Contour Surface Mine . . . . . . . . . . . . . . 175

71 Methods Used in Demonstrating a Performance-Based Design . . . . . . . . 186

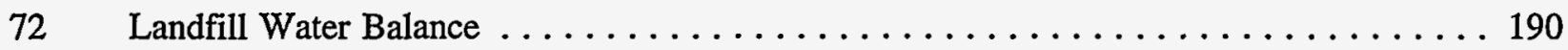

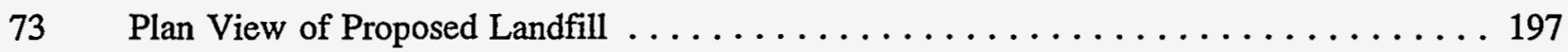

74 Detail of Landfill Shape Cover Design $\ldots \ldots \ldots \ldots \ldots \ldots$

75 Demonstration Procedure for an Active Landfill . . . . . . . . . . . . . . . . 202

76 Closed 200 -Acre Landfill Scenario Model . . . . . . . . . . . . . . . . 207

77 Conceptual Model for Hydration and Weathering of Calcium-Based

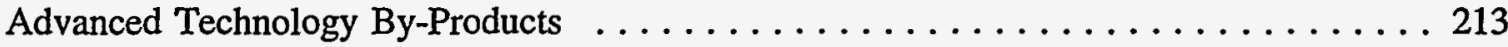

78 Average Physical Properties of Core Samples from the Colorado Test

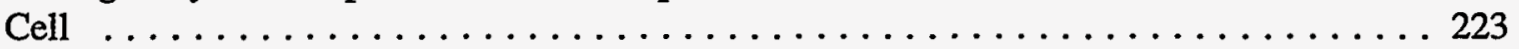

79 Mineralogy of Core Samples Collected from the Colorado Test Cell . . . . . . . . 224

80 Concentration Trends for the RCRA Trace Metals in Deionized Water

Leachates of Colorado Ash Cores . . . . . . . . . . . . . . . . . . 225 


\section{LIST OF FIGURES (Continued)}

Page

81 Average Physical Properties of Ohio Ash Core Samples . . . . . . . . . . . 227

82 Fracturing in the North Cell . . . . . . . . . . . . . . . . . . . . . 229

$83 \quad$ Fracturing in the South Cell . . . . . . . . . . . . . . . . . . . . . 229

84 Field Permeameter Results from the Ohio Test Site $\ldots \ldots \ldots \ldots \ldots \ldots \ldots$

85 X-ray Diffraction Mineralogy of Ash Cores from the Ohio Test Cells $\ldots \ldots \ldots \ldots$

86 Average Concentrations of Selected Analytes in ASTM Deionized Water

Leachates of the Initial Ash Composite and Quarterly and Annual Core

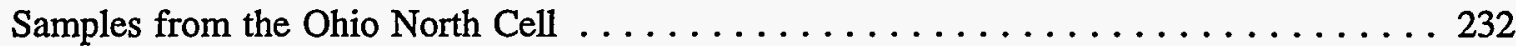

87 Chemistry of Pore Waters from the North Cell $\ldots \ldots \ldots \ldots \ldots \ldots \ldots \ldots$

88 Average Trace Element Concentrations in North Cell Lysimeters and

Deionized Water Leachates of Core Samples for Each Sampling Event . . . . . . . 233

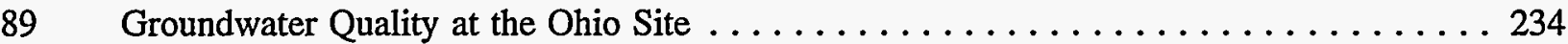

90 Average Physical Properties of Illinois Cell 1 Core Samples . . . . . . . . . . . . 236

91 Field Permeability Measurements from Illinois Cell $1 \ldots \ldots \ldots \ldots \ldots \ldots$

92 X-ray Diffraction Mineralogy of Illinois Cell 1 Ash Cores $\ldots \ldots \ldots \ldots \ldots \ldots$

93 Comparison of the Major Element Chemistry of Average ASTM

Deionized Water Leachates of Ash Core and Average Lysimeter Samples

Collected in Six Month Intervals . . . . . . . . . . . . . . . . . 241

94 Average Trace Metal Concentrations in Cell 1 Pore Waters

and Deionized Water Leachates of Core Samples . . . . . . . . . . . . . . 242

95 Concentration Trends of the Four Species in the Shallow Groundwater

that are Affected by Leachate Migration from Illinois Cell $1 \ldots \ldots \ldots \ldots \ldots . \ldots 243$ 


\section{List of Tables}

Page

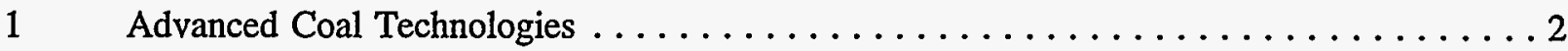

2 Implementing Strategies for By-Product Management $\ldots \ldots \ldots \ldots \ldots \ldots \ldots \ldots$

3 Handling and Disposal Goals Related to By-Product Properties . . . . . . . . . . 24

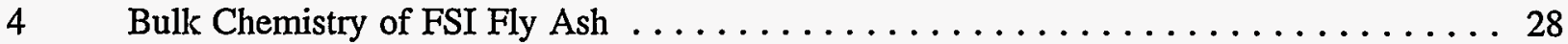

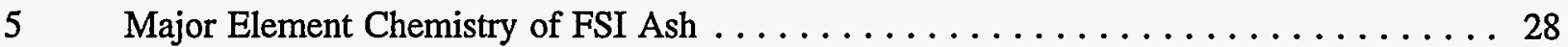

6 Minor and Trace Element Chemistry of FSI Ash .................. 29

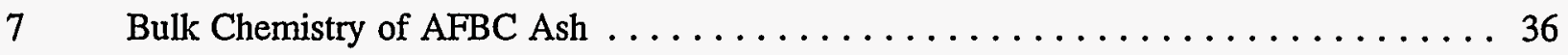

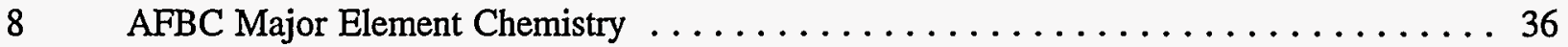

$9 \quad$ AFBC Minor and Trace Element Chemistry $\ldots \ldots \ldots \ldots \ldots \ldots \ldots \ldots \ldots \ldots$

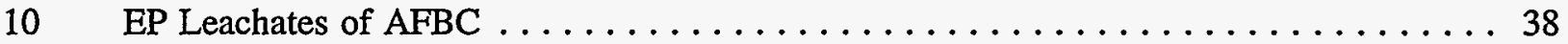

$11 \quad$ PFBC Major Element Chemistry $\ldots \ldots \ldots \ldots \ldots \ldots \ldots \ldots \ldots \ldots \ldots \ldots$

12 PFBC Minor and Trace Element Chemistry $\ldots \ldots \ldots \ldots \ldots \ldots \ldots \ldots$

13 Physical and Engineering Properties of Sodium-Injection Ash $\ldots \ldots \ldots \ldots$

14 EP Leachates of Coal Gasification Slag $\ldots \ldots \ldots \ldots \ldots \ldots \ldots \ldots \ldots \ldots \ldots \ldots \ldots$

15 Crystalline Phases in Gasification Ash $\ldots \ldots \ldots \ldots \ldots \ldots \ldots \ldots \ldots \ldots \ldots \ldots \ldots$

16 Summary of Subtitle D Part 258 Criteria $\ldots \ldots \ldots \ldots \ldots \ldots \ldots \ldots \ldots \ldots \ldots \ldots \ldots \ldots \ldots$

17 Summary of Select Current State Coal Combustion Waste Regulations . . . . . . . . . 59

18 Summary of Georgia's Solid Waste Criteria $\ldots \ldots \ldots \ldots \ldots \ldots \ldots \ldots \ldots \ldots$

19 Summary of Requirements for a Pennsylvania Class II Residual Waste

Landfill . . . . . . . . . . . . . . . . . . . . . . . . 73

20 Summary of Requirements for a Pennsylvania Class III Residual Waste

Landfill . . . . . . . . . . . . . . . . . . . . . . . . 74 


\section{LIST OF TABLES (Continued)}

Page

21 Typical Permits or Regulatory Actions Required for Nonhazardous

Solid Waste Disposal . . . . . . . . . . . . . . . . . . . . 84

22 Typical Information Required in a Solid Waste Permit Application . . . . . . . . 85

23 References for Hydraulic Design $\ldots \ldots \ldots \ldots \ldots \ldots \ldots \ldots \ldots \ldots \ldots$

24 Approximate Values of Factor $\mathrm{K}$ for USDA Textural Classes $\ldots \ldots \ldots \ldots \ldots 1$

25 Factor $\mathrm{C}$ for Permanent Pasture, Range, and Idle Land . . . . . . . . . . . . 101

26 P Factors for Contouring, Contour Stripcropping and Terracing . . . . . . . . . 102

27 Summary of Methods to Measure Hydraulic Conductivity Values in the

Field and Laboratory . . . . . . . . . . . . . . . . . . 108

28 Suggested Haul Road Design Criteria $\ldots \ldots \ldots \ldots \ldots \ldots \ldots \ldots \ldots \ldots \ldots \ldots$

29 Compacted Clay vs. Geomembrane Liners . . . . . . . . . . . . . . . . 155

30 Strength and Permeability Results for Both Mix Types $\ldots \ldots \ldots \ldots \ldots \ldots$

$31 \quad$ Mining for Advanced Coal Technology By-Products $\ldots \ldots \ldots \ldots \ldots \ldots \ldots \ldots$

32 Reuse Options for Advanced Coal Technology By-Products . . . . . . . . . . . . 179

33 Chemicals of Concern Listed in RCRA Subtitle D, Part $258 \ldots \ldots \ldots \ldots \ldots$

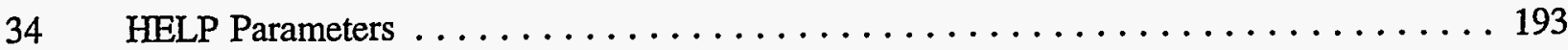

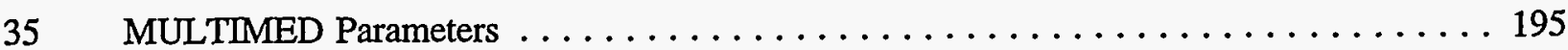

36 Typical FBC By-Product Characteristics . . . . . . . . . . . . . . . . . 199

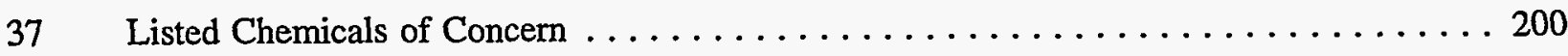

38 Pre-Construction Groundwater Recharge Rate $\ldots \ldots \ldots \ldots \ldots \ldots \ldots \ldots$

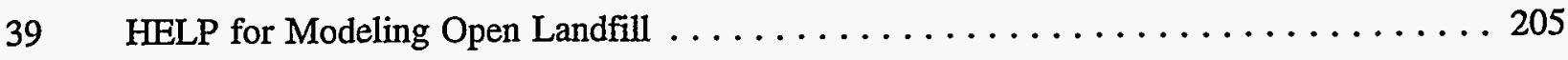

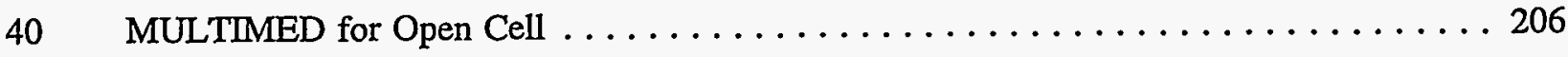

$41 \quad$ HELP for Modeling Closed Landfill Cell $\ldots \ldots \ldots \ldots \ldots \ldots \ldots$ 


\section{LIST OF TABLES (Continued)}

Page

42 Estimated Leachate Contribution to COC Concentrations at Point of Compliance

43 Theoretical Mineralization Potential and Chemical Water Demand of Advanced Coal Combustion By-Products .................... 214

44 Management Issues for Various Advanced Coal Technologies . . . . . . . . . . . . 220

45 Colorado Site Hydrologic Budget Simulation Results for Long-Term (20-Year) Simulation, Average Values . . . . . . . . . . . . . . . . 222

46 Ohio Site Hydrologic Budget Simulation Results for Long-Term (20-Year) Simulation, Average Values 


\section{Acronyms, Abbreviations, and Units of Measure}

\section{Acronyms and Abbreviations}

ACT

AEP

$\mathrm{ALJ}$

AFBC

ASTM

BFBC

CFBC

$\mathrm{CO}$

$\mathrm{CO}_{2}$

$\mathrm{COC}$

DAF

EP

EPRI

ESP

ET

FBC

FFC

FGD
Advanced Coal Technology

American Electric Power Service Corporation

Administrative Law Judge

Atmospheric Fluidized Bed Combustion

American Society for Testing and Materials

Bubbling Fluidized Bed Combustion

Circulating Fluidized Bed Combustion

Carbon Monoxide

Carbon Dioxide

Chemical of Concern

Dilution-Attenuation Factor

Extraction Procedure (Toxicity Test)

Electric Power Research Institute

Electrostatic Precipitator

Evapotranspiration

Fluidized Bed Combustion

Fossil Fuel Combustion

Flue Gas Desulfurization 


\section{ACRONYMS, ABBREVIATIONS, AND UNITS OF MEASURE (Continued)}

\section{$\underline{\text { Acronyms and Abbreviations (Continued) }}$}

FSI

$\mathrm{H}_{2}$

HE

HELP

HiV

HSW

IDP

IGCC Integrated Gasification Combined Cycle

LIMB Limestone Injection Multistage Burners

MCL Maximum Contaminant Level (Safe Drinking Water Act)

MSWLF Municipal Solid Waste Landfill

MULTIMED Multimedia Exposure Assessment (Computer) Model

MWe Megawatt Electric

$\mathrm{N}_{2} \quad$ Nitrogen

$\mathrm{NO}_{\mathrm{x}} \quad$ Nitrogen Oxide

NDP Notice of Draft Permit

NOA Notice of Application

NOD Notice of Deficiency 


\section{Acronyms and Abbreviations (Continued)}

$\begin{array}{ll}\text { NOR } & \text { Notice of Receipt } \\ \text { NPDES } & \text { National Pollutant Discharge Elimination System } \\ \text { OSHA } & \text { Occupational Safety and Health Administration } \\ \text { P } & \text { Precipitation } \\ \text { PA } & \text { Permit Application } \\ \text { PAH } & \text { Polycyclic Aromatic Hydrocarbon } \\ \text { PCB } & \text { Polychlorinated Biphenyl } \\ \text { PFA } & \text { Pulverized Coal Fly Ash } \\ \text { PFBC } & \text { Pressurized Fluidized Bed Combustion } \\ \text { PFD } & \text { Proposal for Decision } \\ \text { POC } & \text { Point of Compliance } \\ \text { PVC } & \text { Polyvinyl Chloride } \\ \text { R } & \text { Surface Runoff Volume } \\ \text { RCRA } & \text { Resource Conservation and Recovery Act } \\ \text { RTC } & \text { Report to Congress } \\ \text { S } & \text { By-Product Moisture Storage Volume } \\ \text { SCS } & \text { Scanning Electron Microscope } \\ \text { SEM } & \end{array}$




\section{ACRONYMS, ABBREVIATIONS, AND UNITS OF MEASURE (Continued)}

\section{Acronyms and Abbreviations (Continued)}

\begin{tabular}{ll} 
SO & Sulfur Oxide \\
SQG & Small-Quantity Generator \\
TCLP & Toxicity Characteristic Leaching Procedure \\
TDS & Total Dissolved Solids \\
TIC & Total Inorganic Carbon \\
TNRCC & Texas Natural Resource Conservation Commission \\
TS & Technical Summary \\
UCS & Unconfined Compressive Strength \\
USDA & United States Department of Agriculture \\
U.S. EPA & United States Environmental Protection Agency \\
USGS & United States Geologic Survey \\
USLE & Universal Soil Loss Equation (USDA) \\
in/yr & Inch(es) per Year \\
XRD & X-Ray Diffraction \\
Units of Measure \\
cm/s & Centimeter(s) per Second \\
\hline${ }^{3}$ & Degrees Celsius \\
\hline
\end{tabular}




\section{ACRONYMS, ABBREVIATIONS, AND UNITS OF MEASURE (Continued)}

\section{$\underline{\text { Units of Measure (Continued) }}$}

$\begin{array}{ll}\mathrm{lb} & \text { Pound(s) } \\ \mathrm{lb} / \mathrm{ft}^{3} & \text { Pound(s) per Cubic Foot (pcf) } \\ \mathrm{m}^{2} & \text { Square Meter(s) } \\ \mathrm{m}^{2} / \mathrm{g} & \text { Square Meter(s) per Gram } \\ \mathrm{mg} / \mathrm{g} & \text { Milligram(s) per Gram } \\ \mathrm{mg} / \mathrm{L} & \text { Milligram(s) per Liter } \\ \mathrm{mm} & \text { Millimeter(s) } \\ \mathrm{m} / \mathrm{yr} & \text { Meter(s) per Year } \\ \mathrm{pcf} & \left.\text { Pound(s) per Cubic Foot (lb/ft }{ }^{3}\right) \\ \mathrm{psi} & \left.\text { Pound(s) per Square Inch (lb/in }{ }^{2}\right) \\ \mathrm{rpm} & \text { Revolution(s) per Minute } \\ \text { wt } & \text { Weight }\end{array}$




\section{Introduction}

\subsection{Background}

Advanced coal technologies encompass a wide range of processes designed to convert coal into energy in a cleaner, more efficient manner. These processes target new approaches to coal combustion, gas cleanup, or coal conversion prior to combustion. The technologies addressed in this document include all types of fluidized bed combustion (FBC), furnace or duct injection dry scrubbing, spray drying, coal gasification, and fuel cell processes. Refer to Table 1 for a listing and brief description of each. All these processes represent emerging technologies that may improve the efficiency or environmental performance of conventional pulverized coal combustion technology with standard wet limestone flue gas desulfurization.

Developing coal conversion technologies have faced major obstacles in the area of by-product management. The materials generated by advanced coal combustion technologies have not been studied as extensively as conventional coal combustion by-products. Management practices for advanced technology by-products have not been standardized and their regulatory status has not been finalized. Earlier studies of advanced coal by-products $1,2,3,4$ focused on laboratory characterization of the materials. Although material characterization is an important first step toward defining the regulatory status of these materials in disposal settings, and in identifying suitable reuse opportunities, characterization alone will not support a comprehensive management strategy. This project has developed several management strategies based on field trials of small-scale landfills in an earlier phase of the project, as well as on published and unpublished sources detailing regulatory issues, current industry practice, and reuse opportunities.

The success or failure of a by-product management strategy will be largely determined by physical and chemical interactions between the by-products and the environment in which they are reused or disposed of. The physical and chemical behavior of interest is influenced by weathering and leaching, groundwater transport and attenuation, and many other phenomena. Landfill behavior must ultimately comply with by-product disposal and groundwater protection regulations. Reuse options may also be subject to a wide variety of codes and standards, depending on the particular reuse identified and the location and market sector targeted.

Advanced coal by-products typically are classified as industrial solid wastes which are regulated at the state level. Most state solid waste regulations specify that composite liner and cap systems should be included in the design of a disposal facility. However, most state regulatory agencies will also reduce these standard requirements if the facility can demonstrate that an alternative design will not adversely affect the environment.

Most state approvals are pre-construction approvals. This means that the applicant must assure the agency that the state criteria will be met, usually by providing technically based predictions of future performance. However, predictions are best developed on the basis of previous experience, and little longterm field experience with advanced coal byproducts has been available before this project. 


\section{Table 1 Advanced Coal Technologies}

\begin{tabular}{||l|l||}
\hline \multicolumn{1}{|c|}{ Technology } & \multicolumn{1}{c|}{ Description } \\
\hline $\begin{array}{l}\text { Atmospheric Fluidized } \\
\text { Bed Combustion (AFBC) }\end{array}$ & $\begin{array}{l}\text { Boiler tubes placed directly in combustion zone; crushed coal and } \\
\text { sorbent are fluidized by air jets beneath bed. }\end{array}$ \\
\hline $\begin{array}{l}\text { Pressurized Fluidized Bed } \\
\text { Combustion (PFBC) }\end{array}$ & $\begin{array}{l}\text { Similar to above, but combustion takes place at elevated pressures to } \\
\text { improve combustion efficiency and sorbent utilization (see also IGCC } \\
\text { systems). }\end{array}$ \\
\hline $\begin{array}{l}\text { Furnace Sorbent Injection } \\
\text { (FS) }\end{array}$ & $\begin{array}{l}\text { Includes technologies such as Limestone Injection Multistage Burner } \\
\text { (LIMB) and other processes where SO }{ }_{x} \text { control sorbents are injected } \\
\text { directly into the boiler combustion zone. }\end{array}$ \\
\hline Duct Injection & $\begin{array}{l}\text { Similar to above, but sorbent injection takes place downstream of boiler. } \\
\text { Ca- and Na-based sorbents have been tested. }\end{array}$ \\
\hline Spray Drying & $\begin{array}{l}\text { Sorbent slurry is atomized into hot flue gases, scrubbing SO } x \text {. Excess } \\
\text { water evaporates, leaving dry solid by-product. }\end{array}$ \\
\hline Advanced Wet FGD & $\begin{array}{l}\text { Traditional wet limestone FGD systems modified by addition of } \\
\text { chemical additives such as organic acids or process modifications to } \\
\text { improve scrubbing efficiency or control the chemical form of the by- } \\
\text { products. }\end{array}$ \\
\hline Coal Gasification & $\begin{array}{l}\text { Partial combustion of coal in a mildly oxidizing to mildly reducing } \\
\text { environment to produce a process of fuel gas. Both fixed bed (e.g., } \\
\text { Luogi, Wellman Galusha) and entrained bed (e.g., Texaco) designs have } \\
\text { been tested. }\end{array}$ \\
\hline $\begin{array}{l}\text { Integrated Gasification } \\
\text { Combined Cycle (IGCC) }\end{array}$ & $\begin{array}{l}\text { Coal gasification produces a hot, high pressure gas stream which powers } \\
\text { a gas turbine. Secondary combustion of this gas stream, potentially in a } \\
\text { PFBC boiler, powers a steam turbine to increase overall process } \\
\text { efficiency. }\end{array}$ \\
\hline
\end{tabular}

Field testing, which forms the basis for several of the disposal alternatives presented in this design manual, was limited to by-products from calcium-based dry $\mathrm{SO}_{2}$ control technologies, including Limestone Injection Multistage Burner (LIMB) trials at the Ohio Edison Edgewater Plant in Lorain, Ohio; circulating fluidized bed combustion ash from the Colorado Ute (now Tri-State Generation and Transmission Association) Nucla Plant in Montrose, Colorado; and bubbling bed fluidized bed combustion ash from the Midwest Grains Plant in Pekin, Illinois. Data on by-products from other advanced coal technologies and on reuse opportunities are drawn from other sources (see citations following Chapter 3).

These field tests generate the long-term data required to evaluate the performance of advanced coal technology by-products in disposal settings and help identify issues important for reuse applications. Many advanced coal technology by-products have cementitious properties and can develop substantial strength and reduced permeability 
on exposure to water. These self-hardening characteristics are attractive to landfill designers, since they can be used to minimize infiltration and leachate production. Such characteristics are also attractive to engineers seeking low-cost materials for road bases, structural fills, embankments, and as replacement for low- to medium-strength Portland cement concrete. However, before this project, little field data have been available to evaluate the durability of the materials under continuous exposure to the environment.

\subsection{Project Objectives}

The overall objective of this research program is to develop guidelines for the management of by-products from advanced coal combustion processes. At the inception of the project this overall goal was divided into the following three broad areas of application for field data: 1) as input to predictive models; 2) as input to develop design guidelines; and 3) as evidence of material behavior in the disposal environment. Since that time (1986), the regulatory climate has changed: source reduction and waste minimization are now key components of any by-product management strategy. Therefore, we have added reuse considerations to this design manual.

Field results from the five test cases examined under this project, together with results from other ongoing research, provide a basis for predictive modeling of the long-term performance of some advanced coal byproducts on exposure to ambient environmental conditions. This predictive capability is useful to designers of disposal facilities and largevolume reuse applications, and the designers, managers, operators, and staffs of regulatory agencies who must evaluate proposed facilities.

This manual is intended to provide a reference database and development plan for designing, permitting, and operating facilities where advanced coal technology by-products are managed. The design guidelines and case studies presented in this report are intended to be used for informational purposes only; proposed reuse or disposal plans should be evaluated for each site individually.

Finally, it is hoped that the test program described in this manual and in previous reports on the individual test sites will serve as a model for collecting and interpreting data to be used in the permitting process. In the course of the study many different monitoring techniques were evaluated. Although some techniques performed as expected, many proved to be poorly suited to particular materials or site conditions (see discussion in Chapter 9).

Table 2 illustrates how the overall goals and strategies described in this manual fit with the actions necessary to effectively manage advanced coal by-products. It also shows how the project goals and strategies mesh with the constraints and uncertainties involved in developing and operating a byproduct management facility over a design lifetime of 30 years or more. For each subject, relevant chapters of this design manual are indicated.

\subsection{Management Alternatives}

The management alternatives discussed in this design manual include both disposal and reuse options. The disposal alternatives are based on a review of representative state and federal regulations and on field experience from a number of small-scale landfills constructed in an earlier phase of this project. Experience with these landfill test cases provided the basis for developing the three basic design alternatives for facilities handling the final disposal of advanced coal by-products which are discussed in this manual. Reuse alternatives include both beneficial uses of raw by-products in large-volume applications, such as mine remediation and reuse of processed byproducts in higher-value, lower-volume manufactured products. 
Table 2

Implementing Strategies for By-Product Management

GOAL: Efficient Cost-Effective Management of Advanced Coal By-Products

\begin{tabular}{|c|c|c|c|}
\hline Strategy & Necessary Actions & Constraints or Uncertainties & $\begin{array}{c}\text { Relevant } \\
\text { Chapters } \\
\text { in Manual }\end{array}$ \\
\hline $\begin{array}{l}\text { Meet all state and federal } \\
\text { regulatory requirements. }\end{array}$ & $\begin{array}{l}\text { Review requirements for treatment } \\
\text { storage and disposal }\end{array}$ & Future regulations & $4,5,8$ \\
\hline Waste minimization. & Evaluate reuse options & $\begin{array}{l}\text { Transport options/costs } \\
\text { Competing materials } \\
\text { Properties of by-product } \\
\text { Pre-treatment/mixing needs } \\
\text { End-use specifications }\end{array}$ & $\begin{array}{l}3,6 \\
3 \\
3 \\
6 \\
*\end{array}$ \\
\hline $\begin{array}{l}\text { Design handling and } \\
\text { transport systems. }\end{array}$ & $\begin{array}{l}\text { Prevent dusting and flash setting } \\
\text { Control heat of hydration }\end{array}$ & $\begin{array}{l}\text { Hydration properties of material } \\
\text { Rate and quantity of moisture } \\
\text { addition }\end{array}$ & $\begin{array}{l}3,9 \\
3\end{array}$ \\
\hline $\begin{array}{l}\text { Design storage/disposal } \\
\text { facility. }\end{array}$ & $\begin{array}{l}\text { Control leachate production and } \\
\text { runoff } \\
\text { Maintain groundwater quality } \\
\text { Minimize liner/cap requirements }\end{array}$ & $\begin{array}{l}\text { Local climate } \\
\text { Site conditions, by-product } \\
\text { properties, cost vs ease of } \\
\text { permitting }\end{array}$ & $\begin{array}{l}6,8 \\
5,6,8\end{array}$ \\
\hline $\begin{array}{l}\text { Permit storage/disposal } \\
\text { facility. }\end{array}$ & $\begin{array}{l}\text { Develop permitting strategy } \\
\text { Present plans to agencies }\end{array}$ & $\begin{array}{l}\text { Multiple agencies/groups may be } \\
\text { involved } \\
\text { Some design alternatives may } \\
\text { require more effort to permit }\end{array}$ & $\begin{array}{l}4,5 \\
5,6,8\end{array}$ \\
\hline $\begin{array}{l}\text { Cost-effective operation } \\
\text { and monitoring of landfill } \\
\text { performance. }\end{array}$ & $\begin{array}{l}\text { Implement construction quality } \\
\text { assurance and environmental } \\
\text { monitoring program }\end{array}$ & $\begin{array}{l}\text { Changes in process conditions } \\
\text { may affect material properties } \\
\text { Long-term material stability may } \\
\text { change } \\
\text { Regulatory standards and } \\
\text { monitoring requirements may be } \\
\text { revised } \\
\text { Local geology and hydrology } \\
\text { Groundwater monitoring well } \\
\text { placement }\end{array}$ & $\begin{array}{l}3,6 \\
9 \\
4,6\end{array}$ \\
\hline
\end{tabular}

* See ASTM and industry specifications. 
The design alternatives presented in this manual are intended to give the reader information covering a broad range of options. This broad focus is necessary because of the diverse state regulations that currently govern the disposal of advanced coal by-products and the variety of possible beneficial uses of the materials. The following basic design alternatives are discussed in this manual:

Alternative 1-Traditional Landfill
Containment System Designs;
- Alternative 2-Reduced Requireme
Landfill Designs;
- Alternative 3-By-product Stacking
Disposal
Alternative 5-By-product Reuse
Options.

Alternatives 1 through 3 correspond to the basic landfill classifications typically listed in state industrial solid waste regulations governing advanced coal by-product disposal. For example, most states specify that certain design elements be included in the design of an industrial solid waste landfill. These design elements typically include composite cap, liner, and leachate collection systems. However, most state regulators will reduce these standard requirements if the facility operator can demonstrate that an alternative design will provide equivalent protection of the environment. Methods used to make these demonstrations are discussed in Chapter 8 of this design manual.

State regulatory agencies also have reduced requirements for by-product disposal if it can be classified as a beneficial use (e.g., mine reclamation, structural fill). In fact, some states exempt such uses from the permitting process to encourage industry to find beneficial uses for this type of material. Where byproduct materials are reused in manufactured products which are not directly placed in the environment, other types of certification may be required, such as compliance with American Society for Testing and Materials (ASTM) standards, product quality specifications, or building codes.

Each alternative is discussed in detail in Chapter 7; however, brief overviews of the alternatives appear below.

Alternative 1 includes the design elements that most states require for traditional industrial solid waste landfills. However, these regulations cover a broad range of industrial wastes which, in most cases, are considered to have a higher degree of hazard than advanced coal by-products. An example of the design elements that are typically required at an industrial solid waste facility are shown in Figure 1. This is a general figure derived from regulations from several states; design requirements vary greatly from state to state. The complex liner/leachate collection system in this design makes Alternative 1 the high-cost, low-liability alternative.

Alternative 2 takes advantage of reduced design requirements accepted by many states. This alternative is supported by the laboratory and field research carried out as an earlier part of this project (see Chapter 9) which provided data on site conditions and byproduct types generally suitable for these disposal facility designs. The effect of eliminating other design elements such as leachate collection and groundwater monitoring systems is discussed in Chapter 7. Alternative 2 may contain several variations on the facility shown in Figure 2. Most states allow a reduction in the number and type of design elements specified in their basic industrial solid waste landfill/requirements if it can be demonstrated that the design modifications will provide equivalent protection of environmental resources. For most types of advanced coal by-products, reduced requirements will include eliminating or reducing the leachate collection liner and final cover system requirements. 


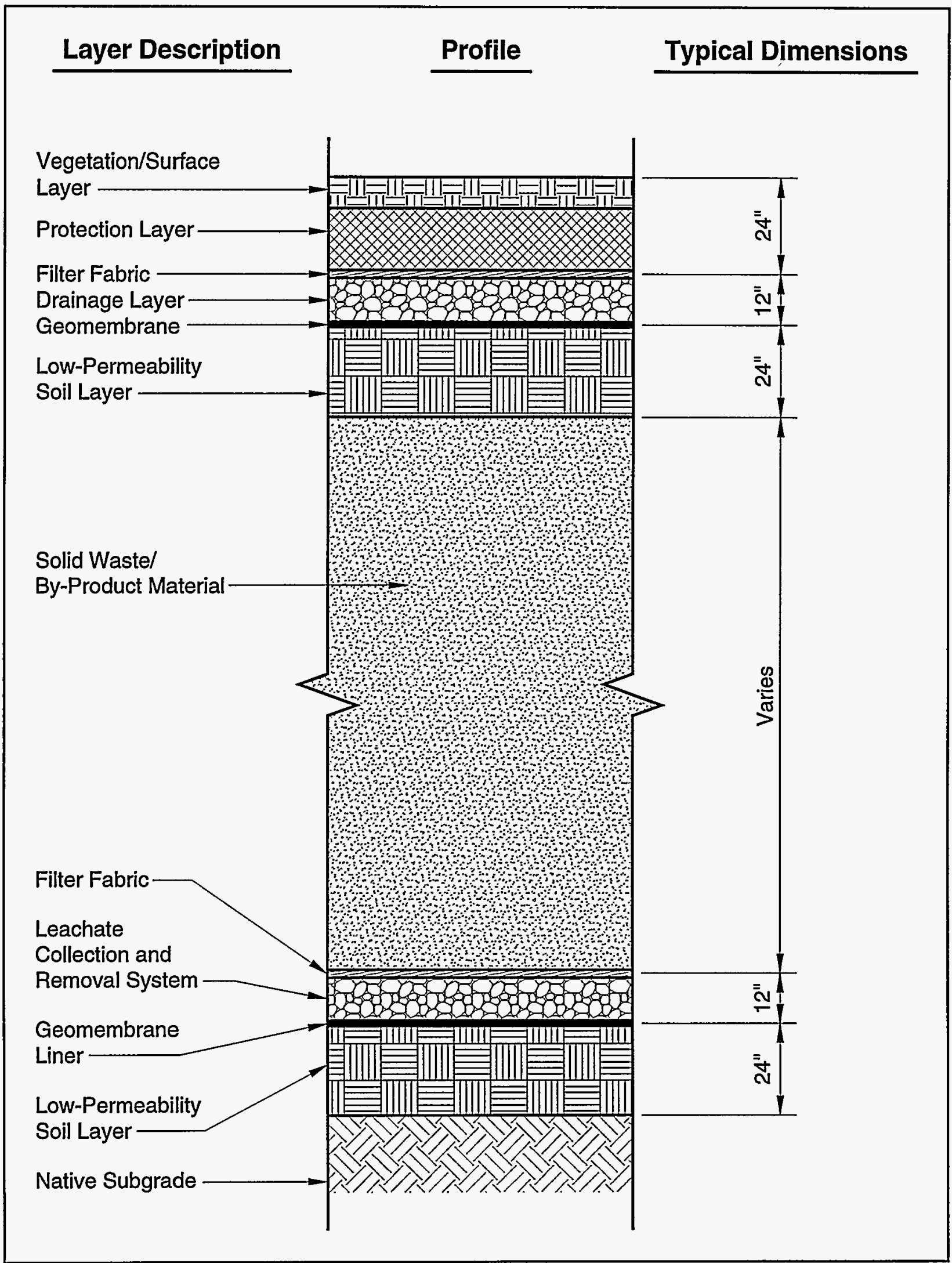

Figure 1. Alternative 1-Traditional Landfill Containment Systems 


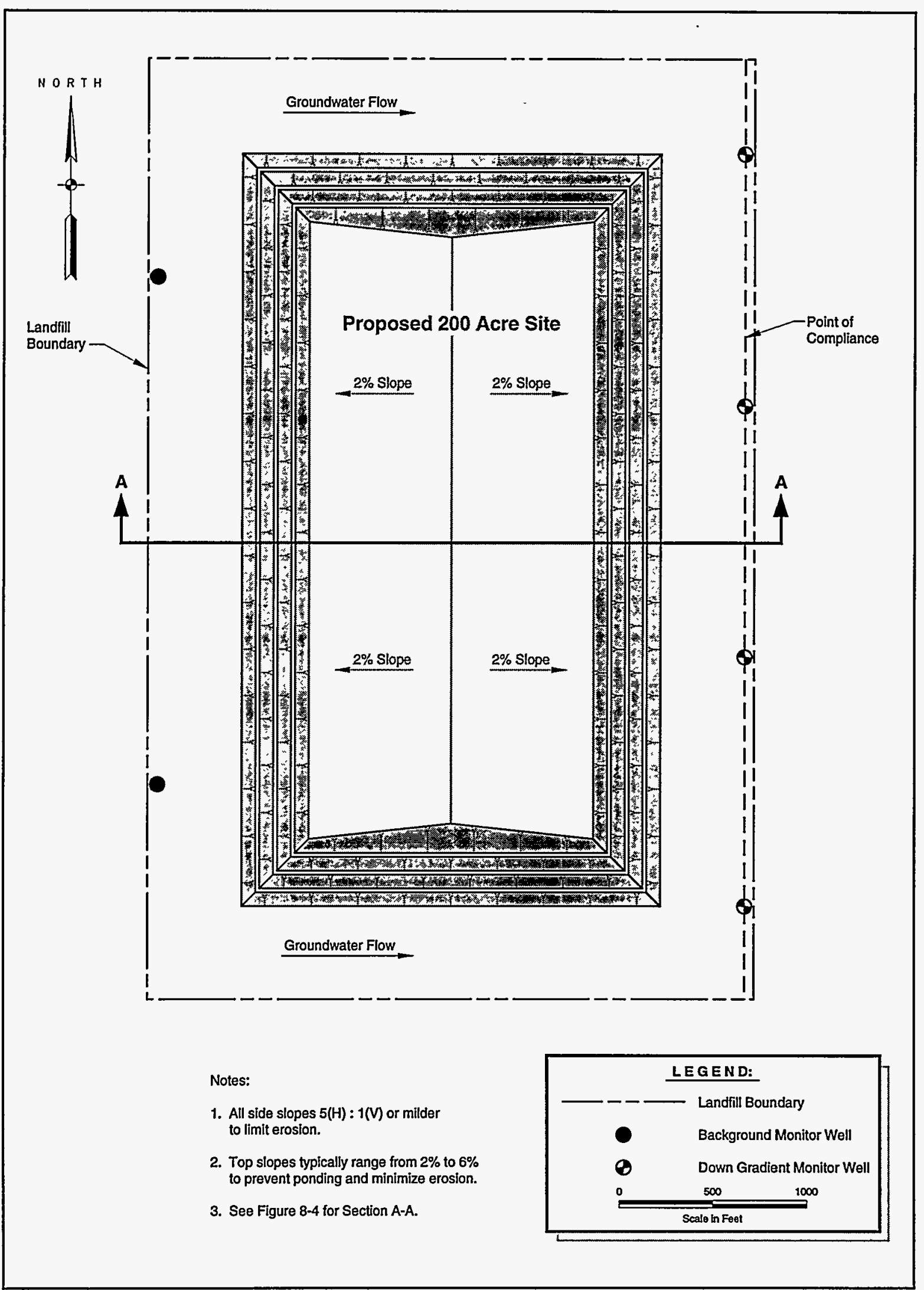

Figure 2. Alternative 2-Reduced Requirement Landfill Systems 
This alternative takes advantage of the cementitious properties of some advanced coal combustion by-products and by-product mixtures to limit leachate production.

The costs of this alternative may be substantially lower than for facilities designed with standard containment systems, but additional engineering and environmental characterization of the by-product and site may be required to limit potential liability.

Alternative 3 (by-product stacking method) is patterned after a method of disposal typically associated with by-product gypsum from the phosphate fertilizer industry. As opposed to the previous alternatives, Alternative 3 discusses a "wet" disposal technique. In this method, illustrated in Figure 3, an earthen starter dike is first constructed around a lined sedimentation pond and stacking area. Byproduct is then pumped to the sedimentation pond in slurry form, usually 15 to $20 \%$ solids, and allowed to settle and drain. Process water is decanted and returned to the plant. Once sufficient sediments build up within the pond, the material is excavated with a dragline to raise the perimeter dikes of the stack. The process of sedimentation, excavation, and raising of the perimeter dikes continues regularly during the active life of the stack.

Alternative $\mathbf{4}$ discusses by-product uses deemed beneficial, mine applications, including mine reclamation, and mine backfill. This alternative has the capacity to manage large volumes of by-product for a low cost and can take advantage of back-haul transport by rail or truck lines that deliver feed coal to the plant.

Alternative 5 discusses by-product reuse in other industrial applications. Several reuse alternatives have been proposed over the years, particularly for FBC by-products. Suggested applications, listed in Figure 4, range from use of the by-product as a lime and nutrient source for agriculture and mining reclamation to use in the production of construction products and materials such as cement, concrete, and structural blocks. Additional uses range from neutralization and stabilization of acidic waste sludges to materials recovery. Few of these options have been demonstrated to be both technically and commercially viable on a large scale. Some options have the potential to use only small volumes of by-products and do not offer realistic management alternatives, although they may provide revenues to help offset disposal costs. A detailed investigation of each of these alternatives is beyond the scope of this manual. Selected applications that can use moderate to large volumes of material andthat have a performance record from demonstration projects are evaluated.

\subsection{Report Organization}

The flowchart shown in Figure 5 illustrates how this report might be used to develop a waste management strategy and how waste management fits into the overall process of technology development. The advanced coal technologies are briefly defined and described in Chapter 2. Simplified process schematics and information on the developmental status of each technology considered in the body of the report are provided.

The physical and chemical properties of advanced coal by-products are discussed in Chapter 3. This chapter includes a discussion of process conditions and other variables that affect the properties of the by-products. Handling and conditioning alternatives are briefly described.

Chapter 4 includes a regulatory summary that discusses both existing and proposed federal regulations that affect coal combustion by-products in general and advanced coal technology wastes in particular as they apply to the design alternatives. A detailed review of the current and proposed regulations was conducted for three major coal-producing states. Summary information is provided on regulations in several other coal producing states. 


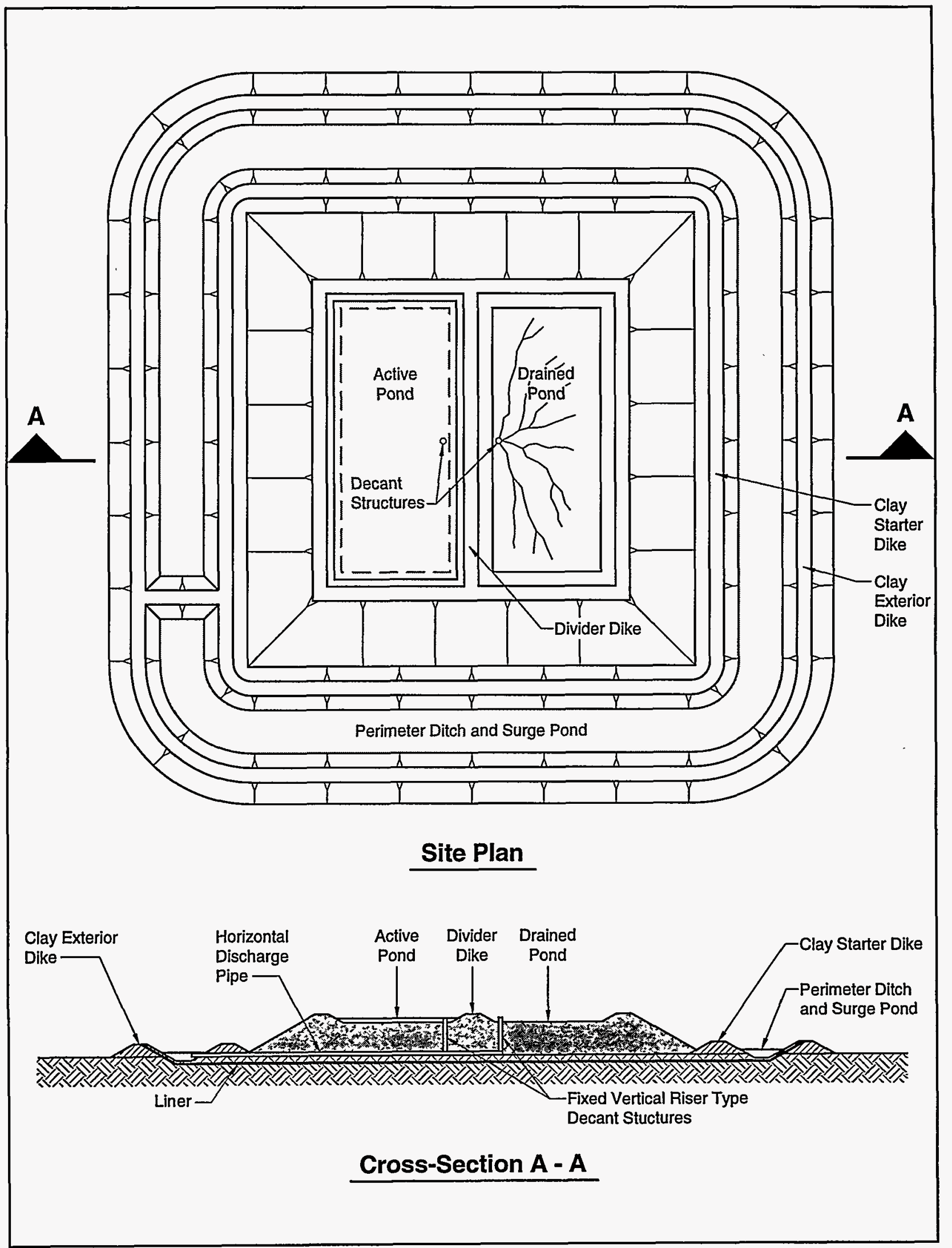

Figure 3. Alternative 3-Typical By-Product Stacking Method 


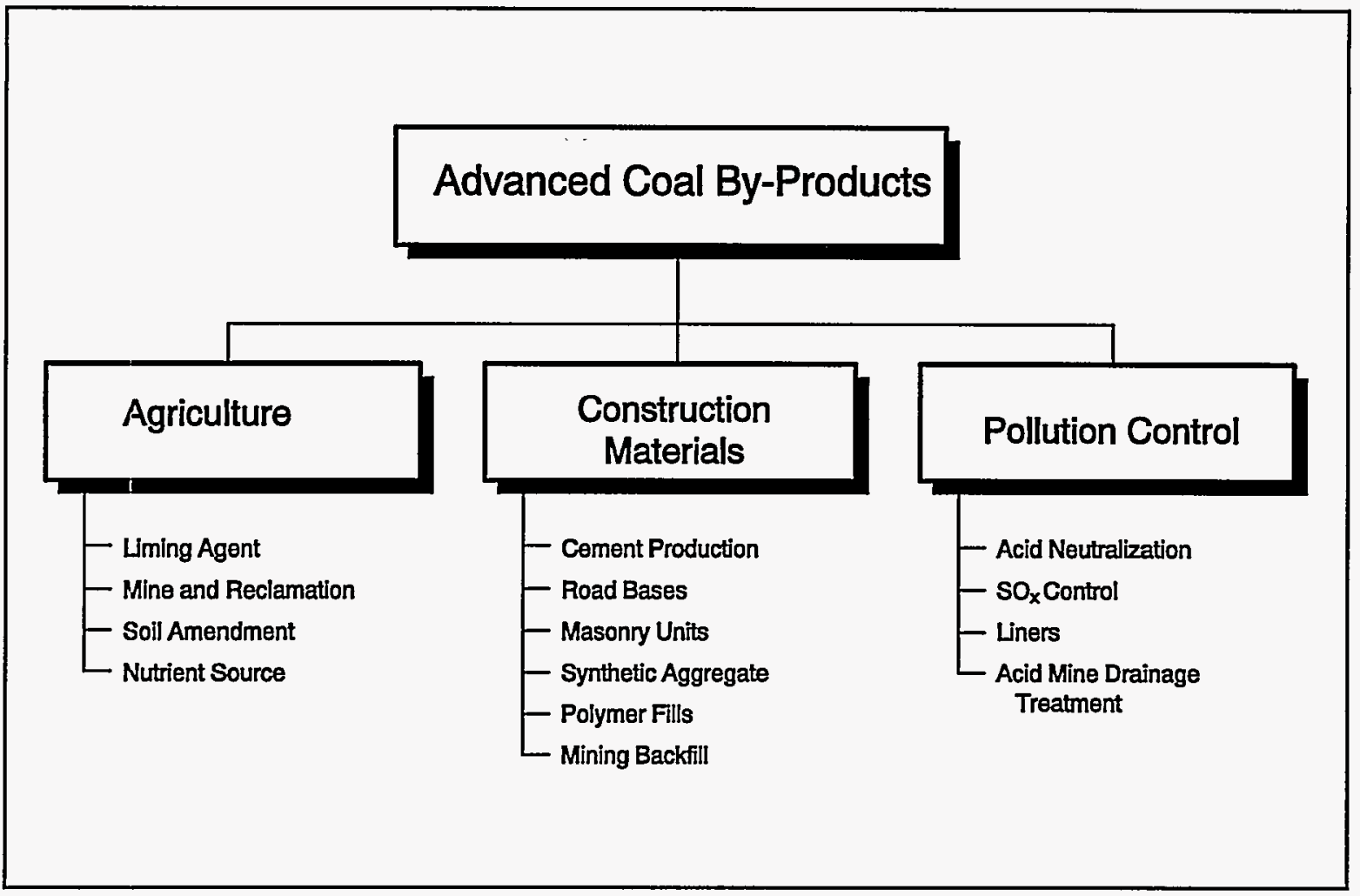

Figure 4. Possible By-Product Utilization Options

Site selection and permitting are discussed in Chapter 5. Chapter 6 discusses management facility components and equipment, including runoff and erosion controls, groundwater monitoring systems, support facilities and equipment to store, transport, and process byproduct materials. A detailed evaluation of each design alternative is included in Chapter 7 , including a discussion of design elements, permitting, construction and operating procedures, and economic feasibility. Chapter 8 contains a case study applying computer techniques to develop a performance-based design. Chapter 9 presents the results and conclusions from the test cell case studies.

\subsection{Citations}

1. Electric Power Research Institute. EPRI CS-2559. Landfill Disposal of Limestone Dual Alkali Flue Gas Desulfurization Waste. Palo Alto, California, 1982.
2. Electric Power Research Institute. EPRI CS-3715. Composition and Leaching of FBC Wastes at the Alliance Test Facility. Palo Alto, California, 1984.

3. Electric Power Research Institute. EPRI GS-6439. Long-Term Leaching Tests with Coal Gasification Slag. Palo Alto, California, 1989.

4. U.S. Environmental Protection Agency, Industrial Environmental Research Laboratory. Project Summary: Assessment of Fluidized-Bed Combustion Solid Wastes for Land Disposal. Research Triangle Park, North Carolina, 1983. 


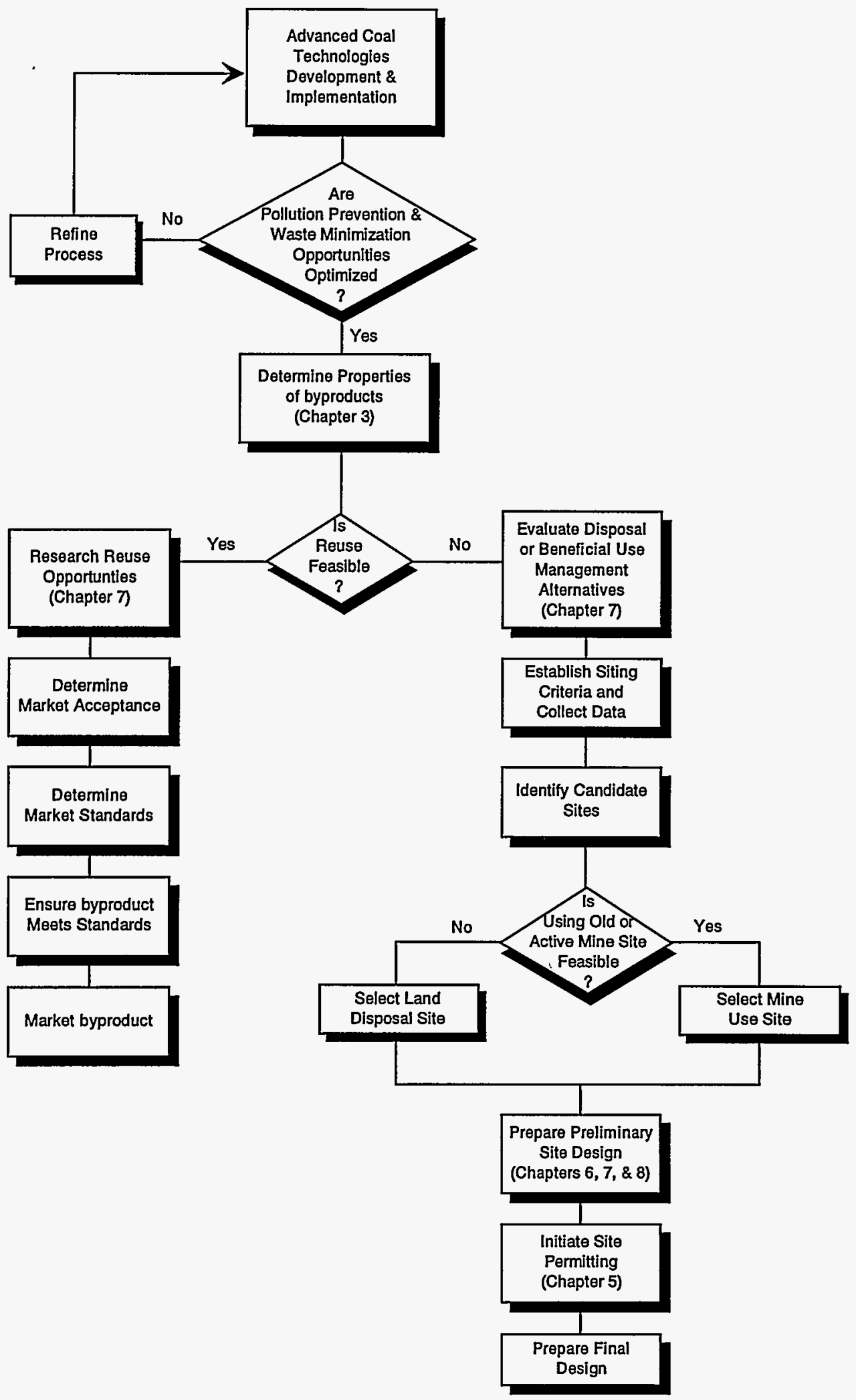

Figure 5. Report Organization Flow Diagram 
This Page Intentionally Left Blank 


\section{Advanced Coal Technology Descriptions}

This chapter gives a general overview of some of the more common advanced coal technologies, with an emphasis on furnace sorbent (lime or limestone) injection and atmospheric fluidized bed combustion. Summary information on pressurized fluidized bed combustion, calcium spray drying, dry sodium- and calcium-duct injection, and coal gasification technologies is also included. The purpose of this chapter is not to provide a complete survey of advanced coal technology processes, but rather to give general process information on the various technologies.

\subsection{Furnace Sorbent Injection} (FSI)

FSI technology involves the injection of a powdered sorbent, either lime or limestone, directly into the combustion zone of the boiler along with the pulverized coal. Injection may be through separate nozzles or by mixed feed through one set of nozzles. In the boiler, the calcium-based sorbent mixes with $\mathrm{SO}_{\mathrm{x}}$ to form calcium-sulfate or -sulfite compounds. By injecting sorbent in the combustion zone, the residence time is longer than for downstream injection, increasing $\mathrm{SO}_{\mathrm{x}}$ removal from the flue gas. The amount of $\mathrm{SO}_{\mathrm{x}}$ removal achieved depends on the type of sorbent used and on the degree of mixing between pulverized coal and sorbent in the boiler ${ }^{1}$. The unspent sorbent and reaction products are then collected along with the coal ash in conventional particulate control systems. A schematic diagram of the FSI process is shown in Figure 6.

FSI technology can be retrofit relatively easily and inexpensively on existing boilers, and can be used in conjunction with other retrofit technologies such as multi-phase burners. Lime or limestone injection multiphase burner (LIMB) systems are used to decrease both $\mathrm{SO}_{\mathrm{x}}$ and $\mathrm{NO}_{\mathrm{x}}$ emissions simultaneously.

Currently, only one plant employing FSI technology is in full operation: the Cherokee Plant, a 350-megawatt plant located in Denver, Colorado, operated by Public Service Company of Colorado.

\subsection{Atmospheric Fluidized Bed Combustion (AFBC)}

AFBC is an advanced coal technology that reduces $\mathrm{SO}_{\mathrm{x}}$ emissions by introducing a coarsely crushed alkaline sorbent, usually limestone, into the combustion zone. Highvelocity air is forced into the boiler, suspending and mixing the sorbent and coal during combustion. The primary heat tubes in AFBC boilers are located within the fluidized combustion bed, increasing the efficiency of heat transfer and allowing the coal to be burned at lower temperatures than those encountered in conventional coal combustion, limiting the formation of $\mathrm{NO}_{\mathrm{x}}$ compounds. Figure 7 is a schematic diagram of the AFBC process.

During combustion, the limestone is calcined to lime, which reacts with $\mathrm{SO}_{\mathrm{x}}$ generated from sulfur in the coal to produce calcium sulfate. The calcium sulfate and any unreacted sorbent are removed along with the coal ash, either as bed drain material or as fly ash captured using conventional particulate control systems. 


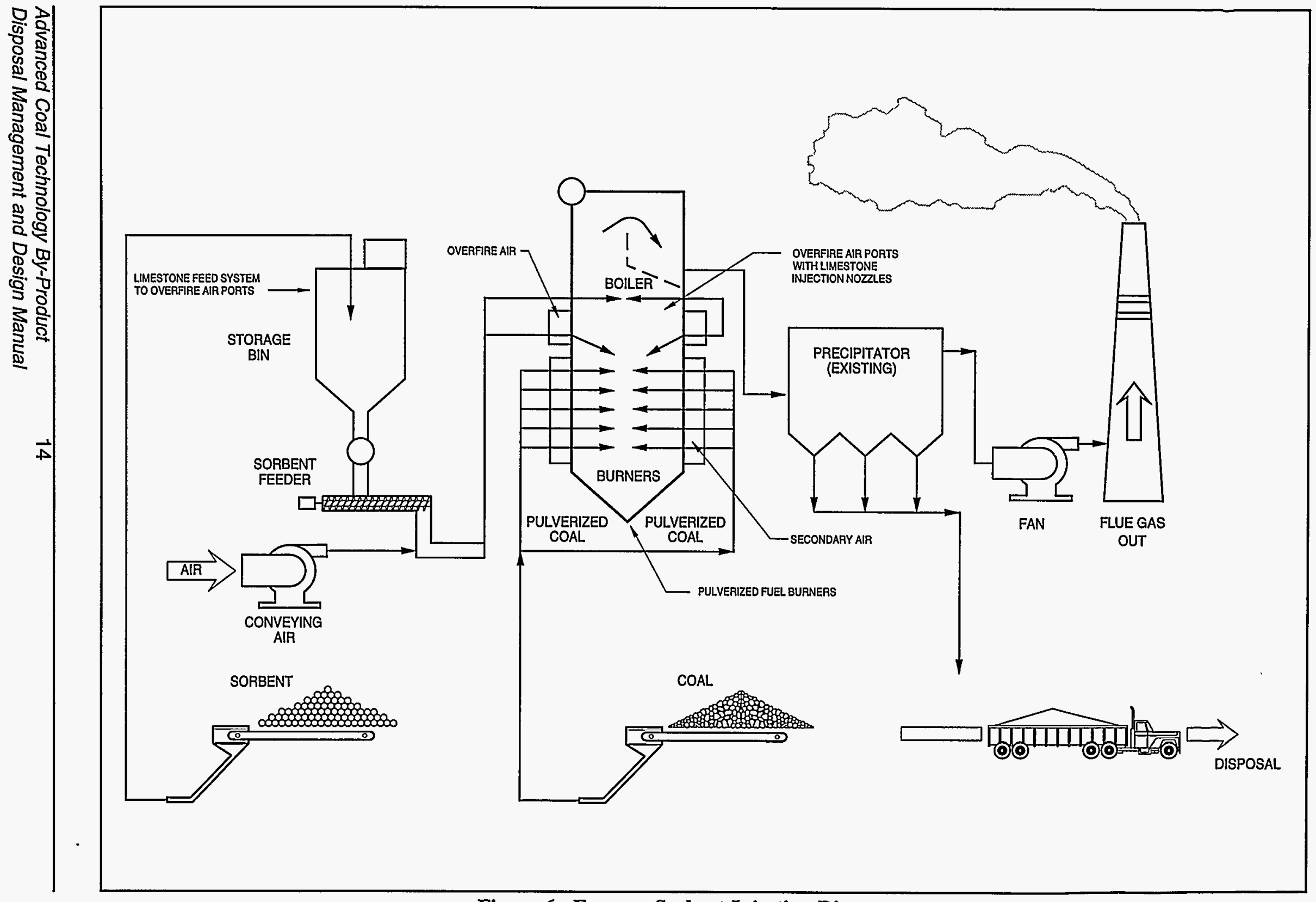




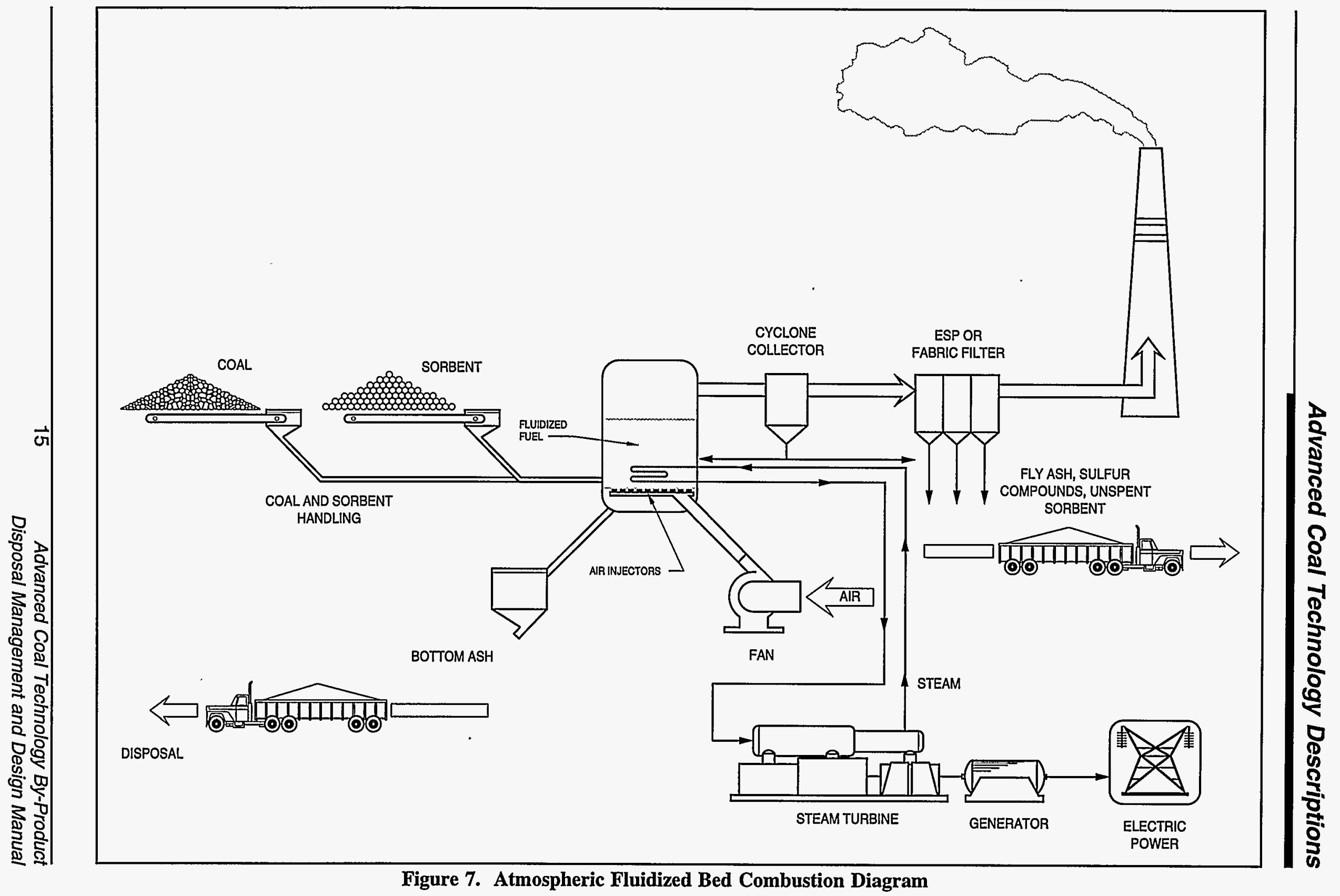


Several utilities currently operate AFBC plants, ranging from 25 to 200 megawatts. The Nucla (Colorado), Shawnee (Kentucky), TNP One and Two (Texas), and Tacoma Two (Washington) plants all have at least one operational unit using AFBC technology. Wisconsin Electric and Power currently has three 200-megawatt AFBC units planned for its Oak Creek NE Plant. Many industrial AFBC units are also in operation.

\subsection{Calcium Spray Drying}

Spray-dryer systems introduce an atomized slurry of alkaline sorbent, usually slaked (hydrated) lime, into the hot flue gas. The lime reacts with the $\mathrm{SO}_{\mathrm{x}}$ in the flue gas to form calcium sulfate and sulfite particles that are removed by fabric filters or ESPs. Although the sorbent is introduced as a slurry, it is dried in the hot gas stream resulting in a dry waste material. Figure 8 shows a schematic diagram of the calcium spray drying process.

\subsection{Pressurized Fluidized Bed Combustion (PFBC)}

Three types of PFBC technology are now in development: bubbling, circulating, and second generation. Figure 9 shows a diagram of a generalized $\mathrm{PFBC}$ system. PFBC systems are similar to AFBC systems, except that combustion takes place at pressures of 10 to 16 atmospheres. The increased pressure of the system allows combustion to take place at lower temperatures and in a more compact bed while maintaining overall thermal efficiency. Under the combustion conditions in PFBC boilers, the sorbent is not generally calcined to lime. Increased residence times and greater fuel flexibility are two of the benefits of PFBC. $\mathrm{PFBC}$ has the potential to be used as a retrofit technology ${ }^{2}$.

In the United States, seven PFBC demonstration systems are either on-line or in the planning or construction stage. Ohio Power's Tidd Plant in Brilliant, Ohio, is the first full-scale PFBC system (70-MWe) in the country. Two 340-MWe PFBC plants are currently in the planning stage; one will be in West Virginia, the other in Japan.

\subsection{Dry Sodium and Calcium In- Duct Injection}

This $\mathrm{SO}_{\mathrm{x}}$ control process involves the injection of a sodium- or calcium-based sorbent directly into the flue gas downstream of the boiler. The process is generally the same whether a sodium- or calcium-based sorbent is used. Figure 10 is a schematic diagram of an in-duct injection system. Common sodiuminjection sorbents are sodium carbonate, bicarbonate, or sesquicarbonate; calcium-injection systems generally use lime or hydrated (slaked) lime. Steam or a fine mist of water may also be injected with the sorbent to improve the $\mathrm{SO}_{\mathrm{x}}$ removal efficiency ${ }^{3}$. The reaction products and unspent sorbent are then removed along with the coal ash by conventional methods.

\subsection{Coal Gasification}

Several different coal gasification technologies have been developed, including fixed-bed, entrained-bed, fluidized-bed, atmospheric, and pressurized designs. Most of these systems employ the same basic chemical steps of devolatilization in a reducing atmosphere and combustion in an oxidizing atmosphere to convert the coal into a gaseous fuel. In many gasifiers these two processes occur sequentially as the coal moves through the gasifier. In fixed bed designs, coal feeds into the top of the gasifier, where heat from the combustion zone lower in the reactor dries and devolatilizes it. In the reducing atmosphere in this portion of the gasifier, the gas extracted form the coal consists of hydrogen, carbon monoxide, methane, nitrogen, carbon dioxide, and steam ${ }^{4}$. As the devolatilized coal continues to move through the gasifier, it reaches the combustion zone in the lower portion of the reactor. Here air (or oxygen) and steam are fed in through a grate, producing high-temperature-combustion of the remaining 


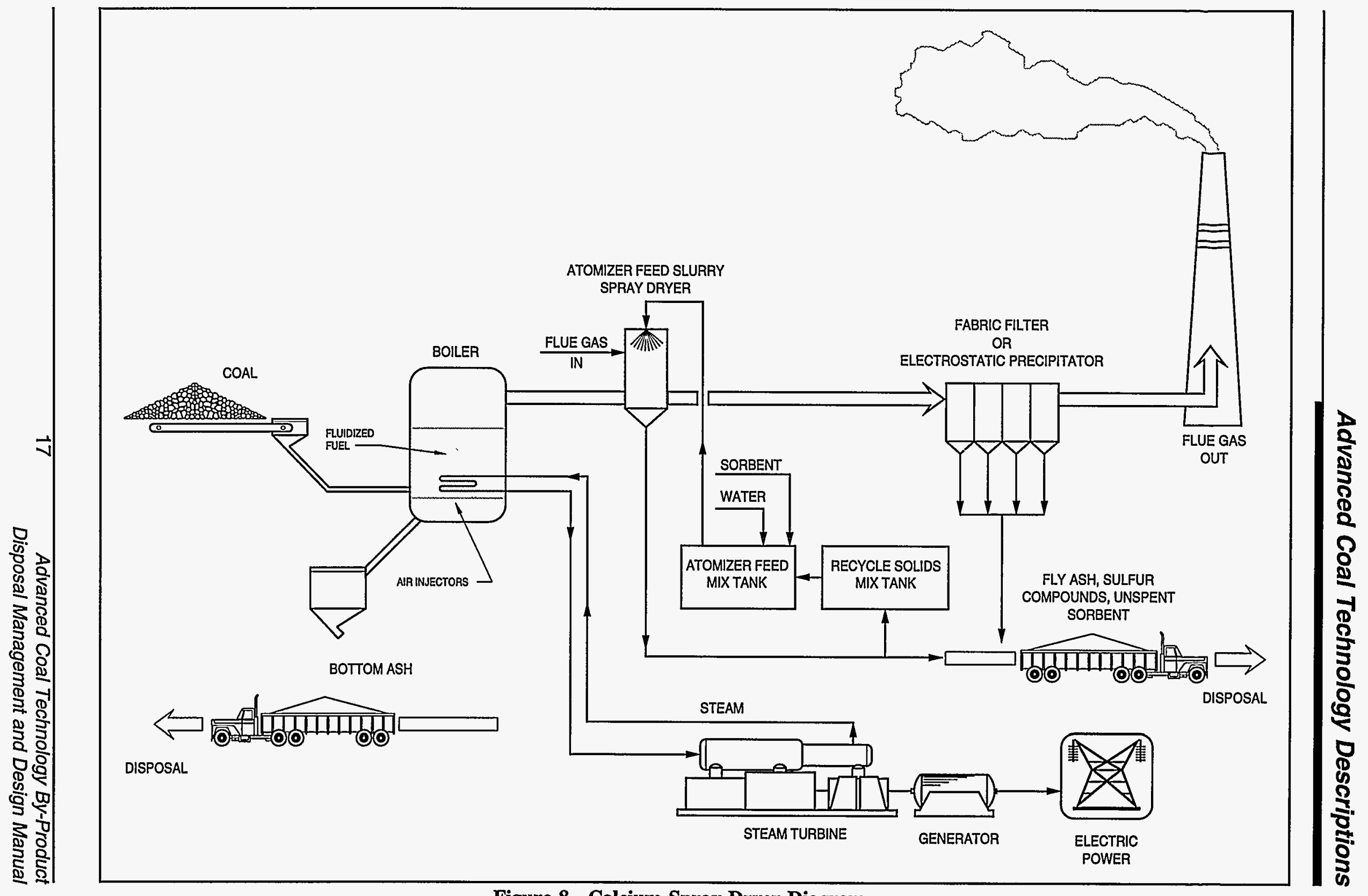

Figure 8. Calcium Spray-Dryer Diagram 


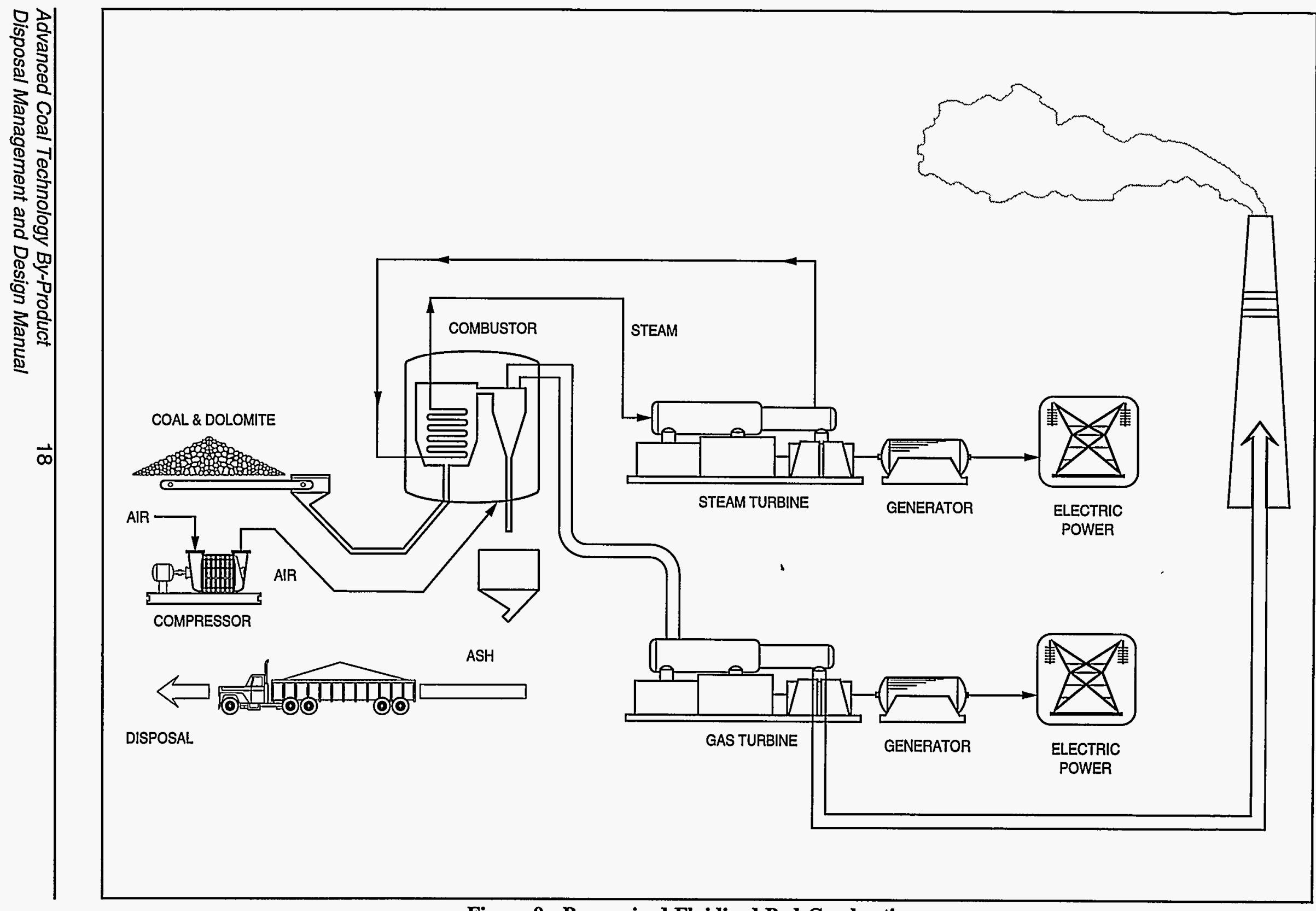




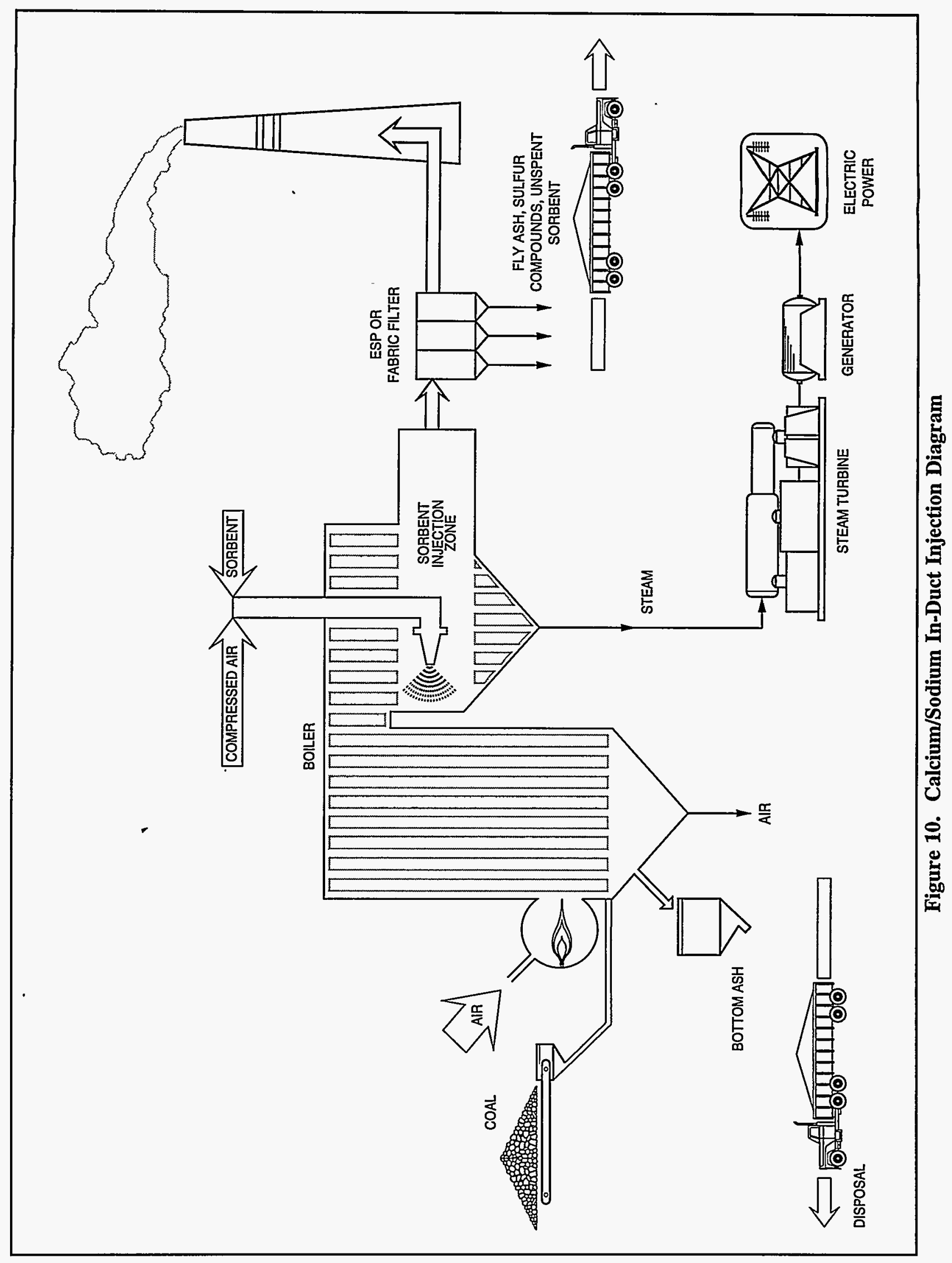


carbon in the coal. In many cases, the combustion temperatures are high enough ( $c a$ $1600^{\circ} \mathrm{C}$ ) to produce a molten slag from the coal ash fractions.

The fuel gas derived from the gasification is treated to remove particulate matter and condensible hydrocarbons before further use. Sulfur in the fuel gas may be removed as elemental sulfur by selective catalytic reduction, or it may be scrubbed from the combustion gases after the fuel gas is burned by using a PFBC system or other $\mathrm{SO}_{x}$ control technology. If hot-gas cleanup procedures are used in conjunction with a pressurized gasifier design, the fuel gases may by used to drive a gas turbine downstream from the gasifier and then be combusted to power a secondary steam turbine in an integrated coal gasification combined-cycle (IGCC) operation, as shown in the schematic in Figure 11. IGCC systems have the potential for significantly higher thermal efficiencies than standard coal-fired steam-electric power plants.

Currently, 11 coal gasification plants are operating worldwide; five of these are in the U.S. Approximately 64 gasification plants are either in the planning or construction stage throughout the world. Fifty-five of these 64 will be used to produce electricity; the remainder are used for chemical production. The United States has the greatest number of coal gasification plants in the planning or construction phase, with 15; the People's Republic of China is currently planning or building eight.

\subsection{Citations}

1. Electric Power Research Institute. EPRI CS-5783. Laboratory Characterization of Advanced $\mathrm{SO}_{2}$ Control ByProducts: Furnace Sorbent Injection Wastes. Palo Alto, California, 1988.

2. Dellefield, R.J. "The Systems and the Developmental Targets for PFBC." In: Proceedings of the Coal-Fired Power Systems 93-Advances in IGCC and PFBC Review Meeting. U.S. Department of Energy, Office of Fossil Energy, Morgantown Energy Technology Center, Morgantown, West Virginia, 1993. pp. 103-120.

3. Electric Power Research Institute. EPRI GS-6622. Laboratory Characterization of Advanced $\mathrm{SO}_{2}$ Control ByProducts: Dry Sodium and Calcium In-Duct Injection Wastes. Palo Alto, California, 1989.

4. Electric Power Research Institute. EPRI EA-2867. Comparison of Solid Wastes from Coal Combustion and Pilot Coal-Gasification Plants. Palo Alto, California, 1983. 


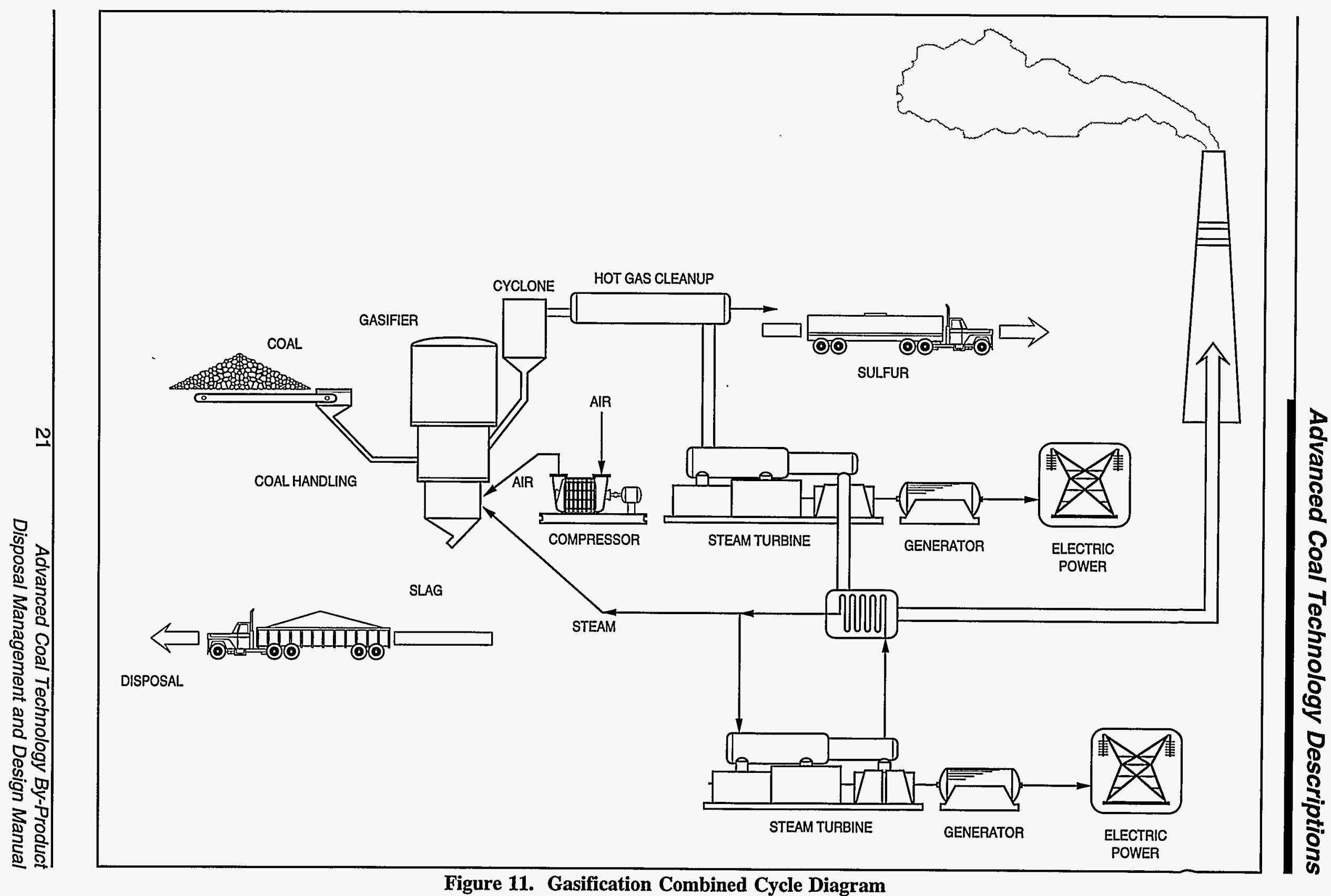


This Page Intentionally Left Blank 


\section{Properties of Advanced Coal Technology By-Products}

This chapter provides a general overview of the physical, chemical, and mineralogical characteristics of by-products from some of the more common advanced coal technologies, with an emphasis on furnace sorbent (lime or limestone) injection (FSD) and atmospheric fluidized bed combustion (AFBC). Summary information on by-products of pressurized fluidized bed combustion (PFBC), calcium spray drying, dry sodium and calcium injection, and coal gasification technologies is also included.

This manual does not intend to provide a complete survey of the chemical and physical properties of advanced coal technology byproducts reported in the literature, but rather to provide some general information that may be used to predict the behavior of landfilled materials. For the sake of consistency, emphasis was placed on presenting data generated by known and comparable methods. Other reports are available that provide the results of more exhaustive literature searches for this type of information ${ }^{1}$.

There are several important differences between the by-products of conventional coal combustion and those from advanced coal technologies. The most important of these are the differences in the physical properties, chemical properties, and volume. Differences in the physical and chemical properties are particularly important because they affect byproduct reactivity, stability, and leachate production. These differences mean that the management methods used for the by-products of conventional coal combustion may not be suitable for the by-products of advanced coal technologies.
There is great variability in the reported characteristics of by-products from advanced coal burning processes, even among by-products derived from the same general process. The chemical and physical characteristics of the by-products are strongly influenced by the operating conditions and the type of coal burned at each facility. Therefore, the information presented in this chapter should be used as a general guide in predicting byproduct characteristics.

The determination of physical, chemical, and mineralogical properties of the by-product will allow the utility operator to answer several important questions:

- How should the by-product be handled-dry or water-conditioned (i.e., will dusting, heat generation, or flash-setting be a problem)?

- How will the by-product behave once it is landfilled? Is the by-product likely to swell, fracture, or produce excess leachate?

- Will the by-product meet the appropriate regulations? Does it pose a long-term liability?

Additional important questions are: "What is the approximate volume of by-product that will be generated?" and "Does a reuse option exist for the by-product?" Table 3 relates handling and disposal goals to the various physical, chemical, and mineralogical properties of advanced coal technology by-products and summarizes the variables that affect by-product behavior. 


\section{Table 3}

Handling and Disposal Goals Related to By-Product Properties

\begin{tabular}{|c|c|c|}
\hline Goal: & $\begin{array}{l}\text { Design handling and transport systems to: } \\
\text { environmental and safety needs. }\end{array}$ & 1) save money and resources, and 2) meet \\
\hline Strategy: & \multicolumn{2}{|l|}{ Use material properties to select best design. } \\
\hline Necessary Action & Properties (Methods) & Explanation \\
\hline $\begin{array}{l}\text { Determine transport } \\
\text { and storage } \\
\text { volumes. }\end{array}$ & $\begin{array}{l}\text { - Coal composition } \\
- \text { Sorbent addition rate }\end{array}$ & $\begin{array}{l}\text { Coal type and/or required scrubbing } \\
\text { efficiency may change, affecting by-product } \\
\text { volume. }\end{array}$ \\
\hline \multirow{4}{*}{$\begin{array}{l}\text { Determine wetting } \\
\text { and dusting } \\
\text { behavior. }\end{array}$} & -Mineralogy & $\begin{array}{l}- \text { By-product will consist of ash, reacted } \\
\text { reagent, and unused reagent. }\end{array}$ \\
\hline & $\begin{array}{l}\text { Particle size (ASTM D 422) } \\
\text { P Particle specific gravity (ASTM D 854) }\end{array}$ & $\begin{array}{l}\rightarrow \text { Particle size, shape, and density may all affect } \\
\text { dusting potential. }\end{array}$ \\
\hline & -Heat of hydration (ASTM C 110) & $\begin{array}{l}\text { - Truck beds may be damaged by high } \\
\text { temperatures. }\end{array}$ \\
\hline & -Available lime index (ASTM C 25) & $\begin{array}{l}\text { - Large amounts of unreacted lime may } \\
\text { increase moisture demand and heat production } \\
\text { upon water addition, and may increase flash-set } \\
\text { potential. }\end{array}$ \\
\hline Goal: & \multicolumn{2}{|c|}{$\begin{array}{l}\text { Design storage and disposal facility to: 1) save money and resources, and 2) meet } \\
\text { environmental and safety needs. }\end{array}$} \\
\hline Strategy: & \multicolumn{2}{|l|}{ Use material properties to select best design. } \\
\hline Necessary Action & Properties (Methods) & Explanation \\
\hline \multirow[t]{3}{*}{$\begin{array}{l}\text { Determine disposal } \\
\text { volumes. }\end{array}$} & $\begin{array}{l}\rightarrow \text { Properties affecting potential for reuse } \\
\text { such as strength, mineralogy, etc. }\end{array}$ & $\begin{array}{l}\text {-By-product utilization may reduce disposal } \\
\text { volume. }\end{array}$ \\
\hline & $\begin{array}{l}\text { - Coal composition } \\
\text {-Sorbent addition rate }\end{array}$ & $\begin{array}{l}\text { Coal type and/or required scrubbing } \\
\text { efficiency may change, affecting by-product } \\
\text { volume. }\end{array}$ \\
\hline & -Maximum dry density (ASTM D 698) & $\begin{array}{l}\text {-Determine as-built, mass-to-volume } \\
\text { relationship. }\end{array}$ \\
\hline $\begin{array}{l}\text { Optimize material } \\
\text { properties for } \\
\text { disposal }\end{array}$ & $\begin{array}{l}\text {-Optimum moisture content (ASTM D698) } \\
\text {-Unconfined compressive strength (ASTM } \\
\text { D 2166) } \\
\text {-Mineralogy } \\
\text {-Permeability (ASTM D 2434) } \\
\text {-Dimensional stability (ASTM C 490) }\end{array}$ & $\begin{array}{l}\text {-Material properties constrain design } \\
\text { specifications including height, slope, } \\
\text { sedimentation pond size, etc. } \\
\text {-Site-specific conditions, including climate, } \\
\text { topography, and proximity to populations may } \\
\text { also influence design. }\end{array}$ \\
\hline $\begin{array}{l}\text { Predict } \\
\text { environmental } \\
\text { behavior. }\end{array}$ & $\begin{array}{l}\text {-Leachability (TCLP) } \\
\text {-Permeability }\end{array}$ & $\begin{array}{l}\text {-Additional testing may be required by the } \\
\text { state. } \\
\text {-Data may be used as input to predictive } \\
\text { modeling. } \\
\text {-Site-specific conditions, including climate, } \\
\text { topography, and proximity to populations may } \\
\text { also influence design. }\end{array}$ \\
\hline
\end{tabular}


The properties of many calcium- and sodium-based advanced coal technology byproducts can change significantly with exposure to water as both short-term and long-term reactions take place. The amount of heat generated by the by-products is largely determined by the water reactivity of sorbent materials. Excess sorbent contained in byproducts from dry calcium- and sodium-based advanced coal technologies, such as AFBC and FSI, contributes considerable chemical reactivity to these materials.

In these processes, sorbent is introduced into the combustion zone at high temperatures. The calcium or sodium carbonate sorbent is converted to the oxide. Calcium and sodium oxides are highly reactive, rapidly forming hydroxides in the presence of water and releasing considerable amounts of heat. Calcium and sodium hydroxides also contribute to a high by-product $\mathrm{pH}$. In contrast, sorbent injected into ducts downstream from the boiler, either in powder (duct inject) or mist (spray dryer) form, experiences lower temperatures. These processes generally convert less sorbent to the oxide form, producing a less reactive, less alkaline byproduct.

Many advanced coal technologies produce a larger quantity of solid combustion by-product per unit of energy than does conventional coal combustion. The potential increase in volume is caused by the collection of reacted and unreacted sorbent material along with coal ash in processes such as AFBC, FSI, and other dry sorbent technologies. Other advanced coal technologies, such as coal gasification, may actually produce smaller byproduct volumes per unit of energy produced relative to conventional coal combustion. Factors including the required scrubbing efficiency, sorbent injection rate, and the sorbent-to-sulfur ratio influence the amounts of reacted and unreacted sorbent present in byproducts from dry sorbent technologies.
Potential increases in by-product volume may be offset if reuse markets can be developed for advanced coal technology byproducts. However, the perspective of this manual is that reuse options will augment, rather than replace, landfill disposal as the primary by-product management strategy. Chapter 7, Sections 7.4 and 7.5 discuss the reuse options for these materials.

Facilities that manage several byproduct streams (i.e., fly ash, bottom ash, cyclone ash) may choose to composite the materials or to manage them separately. For facilities that composite several by-products, it is important to note that consistent blending of these materials and stable operating conditions enable better prediction of the characteristics of the by-products. This in turn will lead to more reliable behavior of the landfilled materials.

The remainder of this chapter describes the properties of as-produced by-products from several advanced coal technologies. Chapter 9 provides more detail on long-term weathering reactions that can affect advanced coal technology by-products continuously exposed to the environment in disposal or reuse settings.

\subsection{Characterization of FSI By-Products}

FSI technology involves the injection of a powdered sorbent, either lime or limestone, into the boiler where it scrubs acid gases from the flue gas. The unspent sorbent and reaction products are then collected along with the coal ash in conventional particulate control systems. FSI technology can be retrofit relatively easily and inexpensively on existing boilers. It can be used in conjunction with other retrofit technologies such as multiphase burners. Lime or limestone injection multiphase burner (LIMB) systems are used to decrease both $\mathrm{SO}_{\mathrm{x}}$ and $\mathrm{NO}_{\mathrm{x}}$ emissions simultaneously. 


\subsubsection{Physical Properties of FSI Ash}

Physical and engineering properties of FSI by-products are shown in Figures 12 and 13. The following points summarize the physical properties of the FSI by-products:

- The optimum moisture content for compacting the ash ranged from 35.6 to $52 \%$ on a dry basis;

- $\quad$ Maximum dry densities ranged from 68 to $80 \mathrm{lb} / \mathrm{ft}^{3}$;

- FSI ash has a wide range of permeabilities ( $3.8 \times 10^{-9}$ to $2.8 \times 10^{-5}$ $\mathrm{cm} / \mathrm{sec}$ );

- Unconfined compressive strength values were moderate to high (120 to 504 psi);

- Particle-specific gravity ranged from 2.61 to 3.05 ; and

- The mean particle size of the FSI byproducts ranged from 0.009 to 0.027 $\mathrm{mm}$, and specific surface area ranged from 2.8 to $10.7 \mathrm{~m}^{2} / \mathrm{g}$.

\subsubsection{FSI Ash Chemistry}

FSI by-products are characterized by high lime and calcium sulfate content (up to $50 \%$ or more) relative to pulverized coal fly ash (PFA) where these two compounds generally contribute less than $5 \%$ of the total mass. These components are contributed by reacted and unreacted sorbent materials. The unreacted lime contributes a high alkalinity to FSI byproducts. The ranges of chemical parameters for FSI ash are given in Tables 4 through 6 .

Tables 4 and 5 show the range of bulk and major element chemistry, respectively, of FSI by-products. Major element chemistry is fairly consistent among the FSI by-products considered. The addition of lime or limestone to the combustion process has a great effect on the major species present in the solid combustion by-products. FSI ash has a much higher calcium content than PFA. An excess of sorbent is used to improve the capture of acid gases. Calcium-to-sulfur ratios (molar) generally range from 1.5:1 to 2.5:1 or higher, depending on the required $\mathrm{SO}_{\mathrm{x}}$ removal. In addition to the unspent sorbent present as lime, sulfur species that would otherwise be released from the stack are reacted with the sorbents and recovered in electrostatic precipitators (ESPs) or fabric filters.

The minor and trace element chemistry of the FSI ash is given in Table 6. Major differences in the trace element chemistries shown can most likely be attributed to differences in the geographic source of the coal. However, the introduction of sorbents into the combustion process may have an effect on the speciation, and, therefore, behavior of trace elements in FSI ash.

The following points summarize the total chemistry of the FSI ash from three different systems:

- Calcium, present largely as lime $(\mathrm{CaO})$, accounts for 12 to $32 \%$ of the ash, consistent with the large amounts of lime or limestone that are injected into these systems for $\mathrm{SO}_{2}$ control;

- Silicon, aluminum, and iron, largely derived from the mineral fraction of the coal, each make up $5-10 \%$ of the ash;

- Total acid-soluble sulfur constitutes up to $6 \%$ of the ash (18\% if calculated as sulfate);

- Magnesium, potassium, titanium, and sodium are each present at approximately $1 \%$ or less;

- Sulfate is generally the most abundant water-soluble anion (1-4\%); 

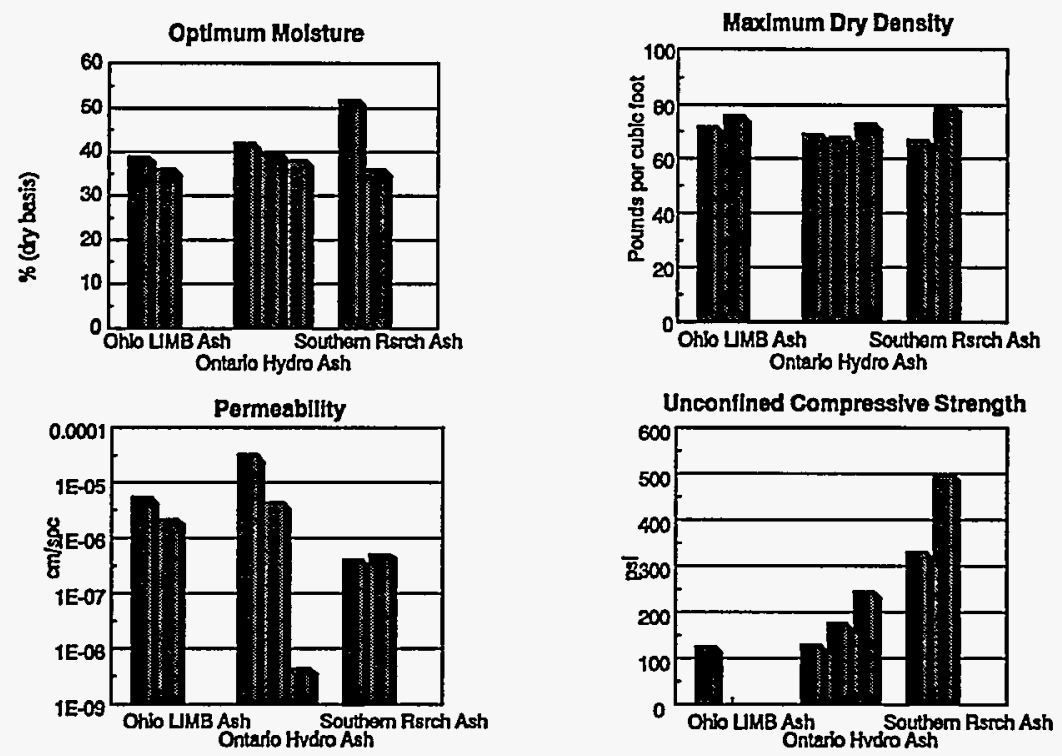

\section{Figure 12. Physical and Engineering Properties of FSI Ash}

Sources: Electric Power Research Institute. Laboratory Characterization of Advanced SO, Control By-Products: Fumace Sorbent Injection Wastes. CS-5783. Palo Alto, California, 1988.

U.S. Dept. of Energy, Morgantown Energy Technology Center. Advanced Coal Technology Waste Disposal: Ohio LIMB Site Assessment Report. drafi. Morgantown, WV, 1994.
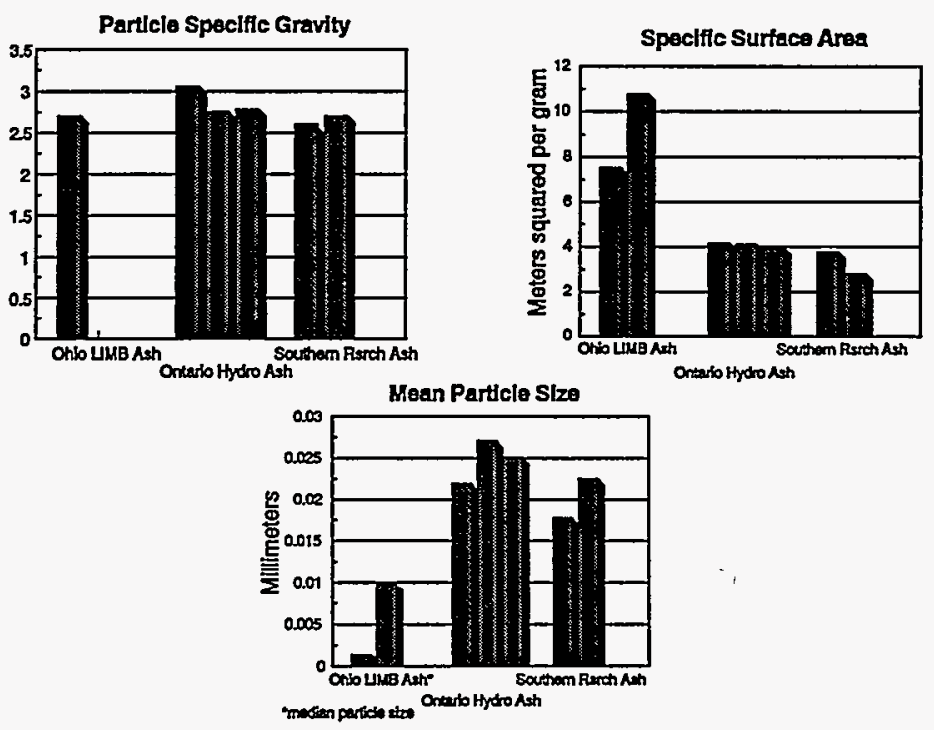

Figure 13. Additional Physical and Engineering Properties of FSI Ash

Sources: Electric Power Research Institute. Laboratory Characterization of Advanced SO, Control By-Products: Furnace Sorbent Injection Wastes. CS-5783. Palo Alto, California, 1988.

U.S. Dept. of Energy, Morgantown Energy Technology Center. Advanced Coal Technology Waste Disposal: Ohio LIMB Site Assessment Report. draft. Morgantown, WV, 1994. 
Table 4

Bulk Chemistry of FSI Ash

\begin{tabular}{|c|c|c|c|c|}
\hline Parameter & Units & $\begin{array}{l}\text { Ohio LIMB } \\
\text { Ash }^{1}\end{array}$ & $\begin{array}{l}\text { Ontario Hydro } \\
\text { Fly Ash }{ }^{2}\end{array}$ & $\begin{array}{c}\text { Southern Research } \\
\text { Fly Ash }{ }^{2}\end{array}$ \\
\hline \multicolumn{5}{|l|}{ Bulk Chemistry } \\
\hline Available lime index & wt. \% & $29.6-41.8$ & NA & NA \\
\hline Heat of hydration, temp. & $\mathrm{C}$ & $63-69$ & NA & NA \\
\hline Heat of hydration, time & minutes & $3-7$ & NA & NA \\
\hline Loss on ignition & $\%$ & $5.7-6.8$ & NA & NA \\
\hline Sulfate sulfur & wt. \% & $4.99-5.51$ & NA & NA \\
\hline Total inorganic $\mathrm{C}$ in solids & $\mathrm{mg} \mathrm{CO}_{3} / \mathrm{g}$ & $48-60$ & NA & NA \\
\hline \multicolumn{5}{|c|}{ Acid- or Water-Soluble Anions } \\
\hline Carbonate, water-soluble & $\mathrm{mg} / \mathrm{g}$ & $171-216$ & $<2.5$ & $<2.5$ \\
\hline Chloride, water-soluble & $\mathrm{mg} / \mathrm{g}$ & $2.1-2.4$ & $1-2$ & $0.4-0.5$ \\
\hline Fluoride, water-soluble & $\mathrm{mg} / \mathrm{g}$ & 0.29 & $0.3-0.7$ & $0.3-0.4$ \\
\hline Sulfate, water-soluble & $\mathrm{mg} / \mathrm{g}$ as $\mathrm{S}$ & 43 & $12-20$ & 36 \\
\hline Sulfur, acid-soluble & $\mathrm{mg} / \mathrm{g}$ as $\mathrm{S}$ & $55-60$ & $14-25$ & $45-50$ \\
\hline
\end{tabular}

NA - Not analyzed.

${ }^{1}$ Source: U.S. Department of Energy, Morgantown Energy Technology Center. Advanced Coal Technology Waste Disposal: Ohio LIMB Site Assessment Report, draft. Morgantown, West Virginia, 1994.

${ }^{2}$ Source: Electric Power Research Institute. EPRI CS-5783. Laboratory Characterization of Advanced SO 2 Control By-Products: Furnace Sorbent Iniection Wastes.

\section{Table 5}

\section{Major Element Chemistry of FSI Ash (mg/kg)}

\begin{tabular}{||l|c|c|c||}
\hline \multicolumn{1}{|c|}{ Analyte } & Ohio LIMB Ash & Ontario Hydro Fly Ash & \\
\hline Aluminum & $46,000-50,700$ & $45,300-79,000$ & $43,500-45,600$ \\
\hline Calcium & $199,000-317,000$ & $120,000-285,700$ & $205,900-208,200$ \\
\hline Iron & $71,000-72,000$ & $41,700-59,000$ & $49,700-57,700$ \\
\hline Magnesium & $3,910-5,120$ & $3,760-4,210$ & $4,910-15,000$ \\
\hline Potassium & $<6,000-9,720$ & $4,500-8,800$ & $11,800-12,300$ \\
\hline Silicon & $85,600-86,100$ & $73,500-130,000$ & $82,700-90,200$ \\
\hline Sodium & $2,590-2,930$ & $1,790-3,800$ & $6,090-6,560$ \\
\hline Titanium & 12,000 & $2,460-4,400$ & $2,550-2,670$ \\
\hline
\end{tabular}

'Source: U.S. Department of Energy, Morgantown Energy Technology Center. Advanced Coal Technology Waste Disposal: Ohio LIMB Site Assessment Report, draft. Morgantown, West Virginia, 1994.

${ }^{2}$ Source: Electric Power Research Institute. EPRI CS-5783. Laboratory Characterization of Advanced SO 2 Control By-Products: Furnace Sorbent Injection Wastes. 
Table 6

Minor and Trace Element Chemistry of FSI Ash (mg/kg)

\begin{tabular}{||l|c|c|c||}
\hline \multicolumn{1}{|c|}{ Analyte } & Ohio LIMB Ash & \\
\hline Arsenic & $60-66$ & Ontario Hydro Fly Ash & \\
\hline Barium & $250-260$ & $15-32$ & $60-62$ \\
\hline Cadmium & $0.3-0.32$ & $230-450$ & $220-240$ \\
\hline Chromium & $40-98$ & $<1.8$ & $0.56-0.74$ \\
\hline Copper & $14-19$ & $82-100$ & $77-99$ \\
\hline Lead & $13-16$ & $40-77$ & $22-23$ \\
\hline Manganese & $1,000-1,200$ & $9.2-4.2$ & $2.4-2.8$ \\
\hline Mercury & NA & $140-160$ & $140-240$ \\
\hline Molybdenum & $<5$ & $0.45-0.55$ & $0.55-0.93$ \\
\hline Nickel & $54-99$ & $<9.8$ & $3.3-4.1$ \\
\hline Selenium & $<0.5$ & $69-110$ & $44-54$ \\
\hline Silver & $<2.50$ & $<0.4-17$ & $<2$ \\
\hline Strontium & $26-150$ & $1.8-3.5$ & $2.5-3.2$ \\
\hline Vanadium & $<40$ & $410-790$ & $180-290$ \\
\hline Zinc & $130-160$ & $150-190$ & $100-160$ \\
\hline \hline
\end{tabular}

NA - Not analyzed

'Source: U.S. Department of Energy, Morgantown Energy Technology Center. Advanced Coal Technology Waste Disposal: Ohio LIMB Site Assessment Report, draft. Morgantown, West Virginia, 1994.

${ }^{2}$ Source: Electric Power Research Institute. EPRI CS-5783. Laboratory Characterization of Advanced SO 2 Control By-Products: Fumace Sorbent Injection Wastes.

- Water-soluble carbonate is present in a very wide range of concentrations $(<0.25-21.6 \%)$, where higher concentrations may reflect poor calcination of limestone sorbent in the boiler;

- Heat of hydration is very high (from 63 to $69^{\circ} \mathrm{C}$ ) and is generated very quickly (3-7 minutes); and

- Loss on ignition values of 6-7\% are consistent with total inorganic carbon (TIC) analyses at zero moisture content.

\subsubsection{FSI Ash Leachate}

The leachability of the FSI ash was assessed using the Resource Conservation and Recovery Act (RCRA) Extraction Procedure (EP) Toxicity Test. The EP, rather than the Toxic Characteristic Leaching Procedure TCLP, was the established RCRA test at the time these analyses were conducted although the TCLP has since replaced it. The results of the EP and TCLP are thought to be generally comparable for materials such as FSI ash, which are highly alkaline. The compositions of EP leachates derived from three types of FSI ash, along with a conventional western coal ash, are shown in Figures 14 and 15. 


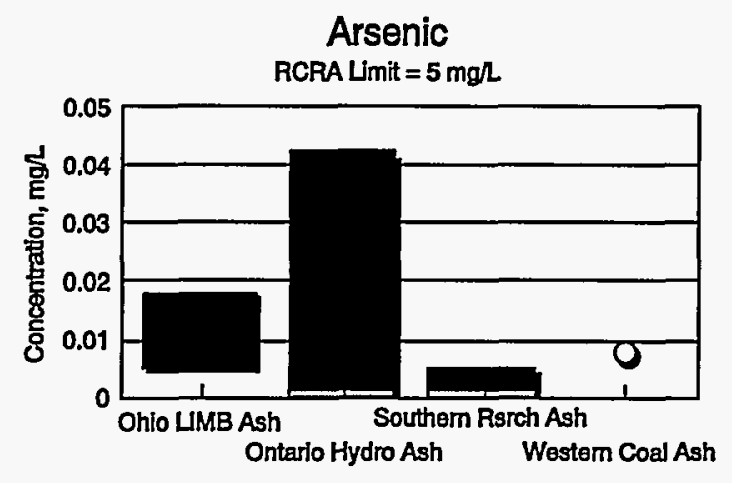

Cadmium

RCRA Limit $=1 \mathrm{mg} / \mathrm{L}$

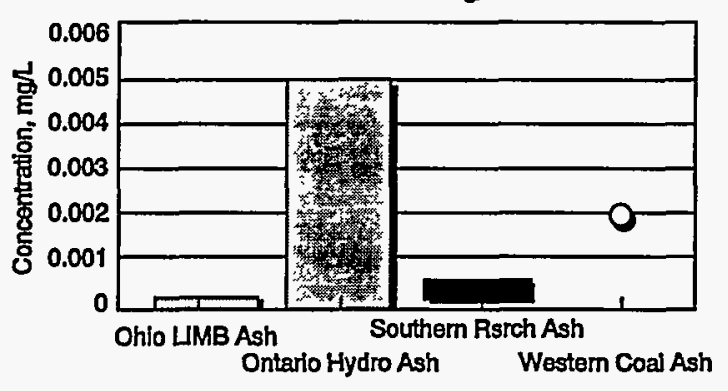

Range of values reported above detection limit

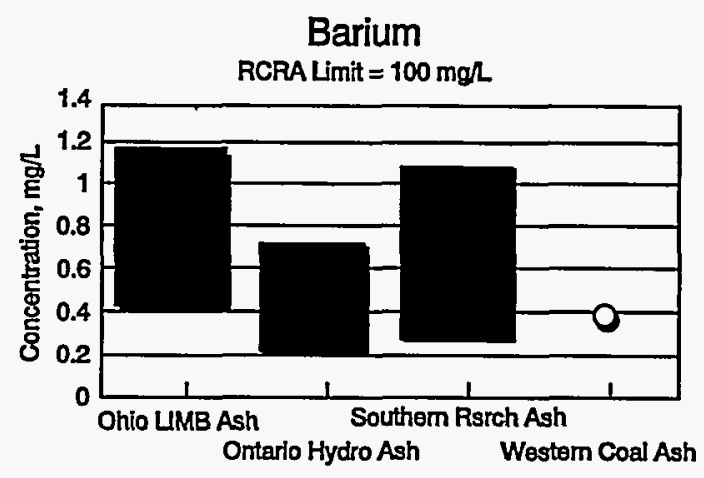

Chromium

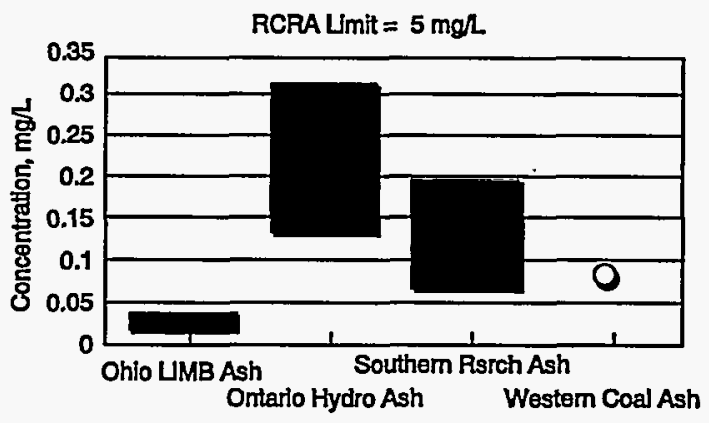

Figure 14. Range of Reported EP Leachate Compositions for FSI Ash

Sources: Electric Power Research Institute. EPRI CS-5783. Laboratory Characterization of Advanced SO ${ }_{2}$ Control By-Products: Furnace Sorbent Injection Wastes.

U.S. Department of Energy, Morgantown Energy Technology Center. Advanced Coal Technology Waste Disposal: Ohio LIMB Site Assessment Report, draft. Morgantown, West Virginia, 1994. 


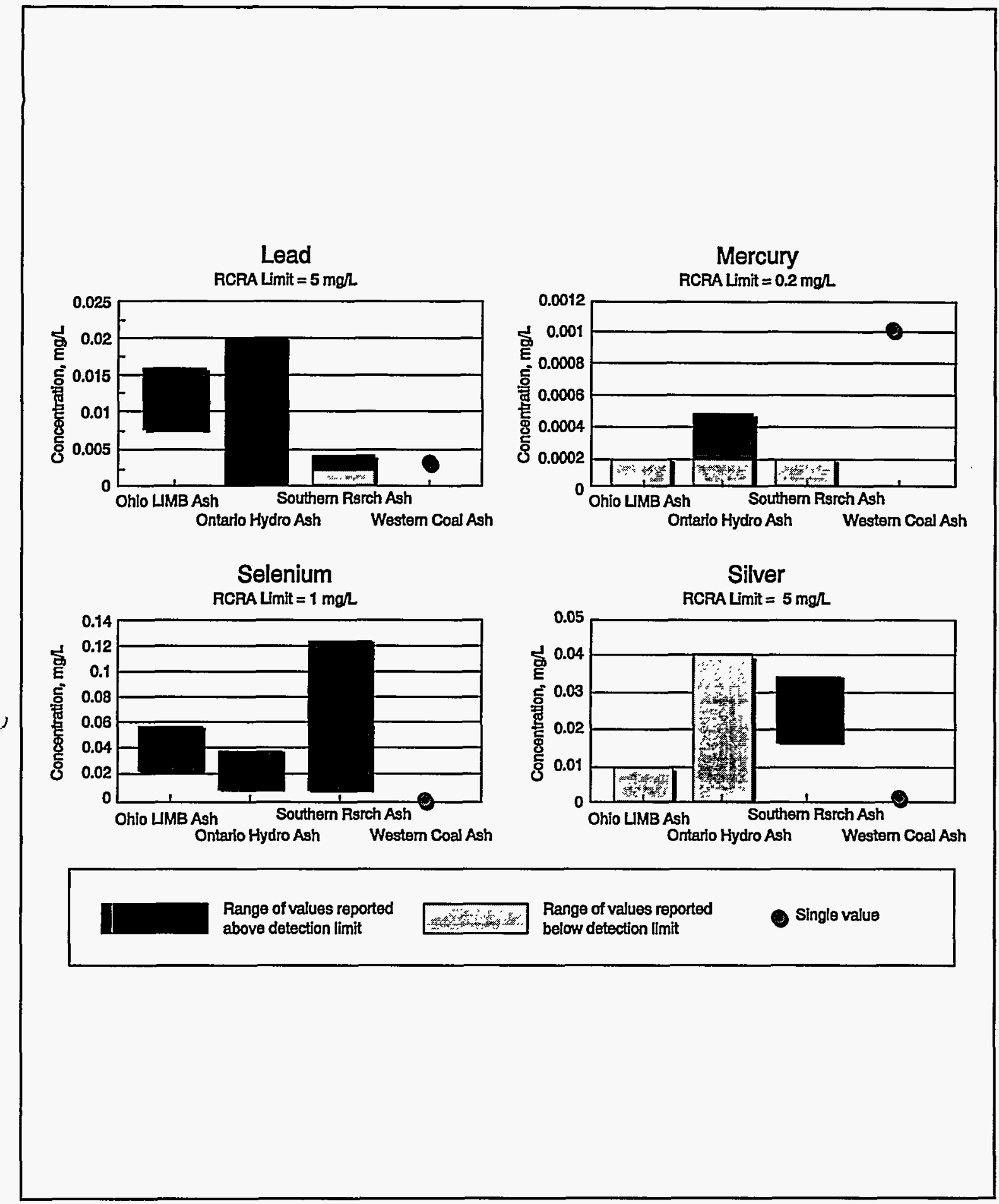

\section{Figure 15. Additional Ranges of Reported EP Leachate Compositions for FSI Ash}

Sources: Electric Power Research Institute. EPRI CS-5783. Laboratory Characterization of Advanced SO 2 Control By-Products: Furnace Sorbent Injection Wastes.

U.S. Department of Energy, Morgantown Energy Technology Center. Advanced Coal Technology Waste Disposal: Ohio LIMB Site Assessment Report, draft. Morgantown, West Virginia, 1994. 
The RCRA EP leachates generated from the FSI ash were analyzed for the eight EP Toxicity Characteristic metals: arsenic, barium, cadmium, chromium, lead, mercury, selenium, and silver. All of these were found to be well within regulatory requirements, as shown in Figures 14 and 15. Because different laboratories and analytical methods are shown together on the graphs, there is no unique reporting limit value; results both above and below reporting limits are represented by ranges in the figures. With the exception of selenium and chromium, the concentrations of the RCRA metals were more than two orders of magnitude below the RCRA limit. None of the FSI leachates differed markedly from the Western Coal Ash leachate. The highest $\mathrm{pH}$ of the EP leachate was 12.4 , reflecting the high lime content of the ash. This value is just below the regulatory limit for corrosivity of 12.5. Leachates from FSI by-products with higher lime content may exceed this limit.

\subsubsection{FSI Ash Mineralogy}

Figure 16 shows the mineralogy of two composite samples of Ohio LIMB ash. The mineralogy shown in Figure 16 is for dry material only. FSI by-products which are conditioned (wetted) for handling will show markedly different mineralogy. Other factors which influence FSI mineralogy are coal chemistry, combustion temperatures, residence times, and oxygen levels. The following points summarize the X-ray diffraction (XRD) mineralogy of the Ohio LIMB ash:

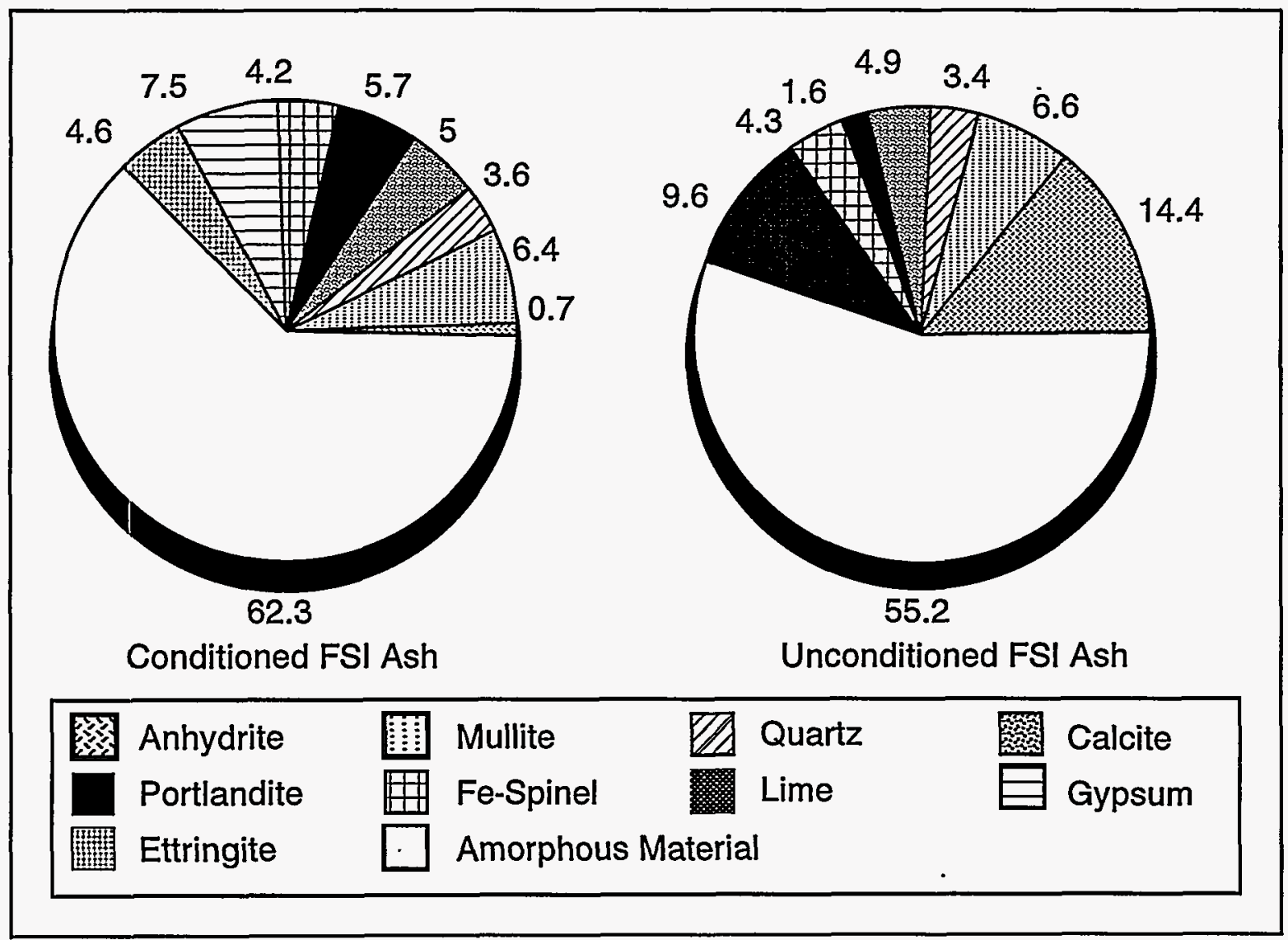

Figure 16. XRD Mineralogy of Conditioned and Unconditioned FSI Ash Samples

All results are expressed as percent dry weight. 
- The crystalline mineralogy of the FSI ash samples is dominated by anhydrite, a by-product of $\mathrm{SO}_{\mathrm{x}}$ removal;

- Lime and calcite, the unreacted sorbent materials, also make up a significant portion of the FSI by-product;

- Quartz, mullite, and Fe-spinel, coalderived minerals that are essentially unreactive in the disposal environment, are present in both samples; and

- Both of the samples contain over $50 \%$ amorphous and glassy materials, which do not produce a clear diffraction pattern.

Significant mineralogical differences were noted for the Ontario Hydro and Southern Research Institute FSI ashes. Lime made up more than half of the crystalline species in the Ontario Hydro ash, reflecting low sorbent utilization ${ }^{2}$. The Southern Research Institute ash contained $15-50 \%$ lime. The Ontario Hydro ash contained significantly less anhydrite (5-15\%) than the Southern Research Institute ash (15-50\%). These data agree with the lower total sulfur content of the Ontario Hydro ash and probably reflect differences in the sulfur content of the coal being burned. The Ca:S ratio of the Ontario Hydro fuel was approximately $3: 1$; the Ca:S ratio of the Southern Research Institute fuel was approximately $2: 1$.

\subsubsection{Handling and Transport Considerations}

Heat production, swelling, selfhardening and high $\mathrm{pH}$ values are the characteristics of FSI by-products that may have an effect on handling and transport (handling and transport alternatives are presented in Chapter 7). These problems should not arise if the by-products are kept dry during all stages of handling; however, dry handling may present problems with dusting because of the generally small particle size of the reacted and unreacted sorbents. The addition of small amounts of water may be useful in controlling dusting if the appropriate precautions are taken. Water addition should take place where heat generation will not cause problems, and flash-setting must be prevented. If transport distances are small, conditioning should cause few problems. Pelletizing FSI wastes may also be considered to reduce dusting problems while maintaining the byproduct in a dry state.

Another consideration for handling and transport systems is the increased volume of by-product. Whereas conventional coal combustion produces primarily fly ash and bottom ash, FSI systems produce these solids plus reacted and unreacted sorbent materials and scrubbed sulfur compounds. Increased storage and transport equipment capacity may be required.

\subsection{AFBC By-Product Characteristics}

Atmospheric fluidized bed combustion (AFBC) is an advanced coal technology which reduces $\mathrm{SO}_{\mathrm{x}}$ emissions by introducing the pulverized coal and an alkaline sorbent, usually limestone, into the combustion zone. During combustion, high-velocity air is forced into the combustor, suspending and mixing the coal and limestone during combustion. The limestone is calcined to lime, which reacts with $\mathrm{SO}_{\mathrm{x}}$ generated during combustion to produce calcium sulfate. This reduces $\mathrm{SO}_{x}$ emissions to the atmosphere and eliminates the need for a separate flue gas desulfurization system.

Since many coal types can be used in an $A F B C$ system, AFBC by-products have a wide range of chemical and physical properties. Differences in operating parameters also will influence the properties of AFBC by-products. The by-product characteristics of the two main types of AFBC - circulating fluidized bed combustion (CFBC) and bubbling fluidized bed combustion (BFBC)-produce wastes which are very similar. The composition of the coal 
and the operating conditions play a larger role in determining the characteristics of these byproducts than the type of AFBC unit.

However, there are differences between the two systems which do result in different waste characteristics. The main differences between CFBC and BFBC that affect waste characteristics are ${ }^{4}$ :

- $\quad$ BFBC systems operate at lower temperatures than CFBC systems, affecting the mineralogy of the ash; and

- $\quad$ BFBC units have lower velocities and greater mean particle size than CFBC units, resulting in a longer residence time in a well-defined bed.

\subsubsection{Physical Properties of AFBC Ash}

The physical and engineering properties of AFBC by-product are given in Figures 17 and 18. In general, the physical properties of the cyclone ash are generally more similar to those of the fly ash than to those of the bottom ash. The following points summarize the physical properties of the different AFBC ash types:

- Optimum moisture is generally lower for bottom ash (20 to 32\%) than for fly ash and cyclone ash (35 to $50 \%$ ).

- Maximum dry density is significantly higher for bottom ash (approximately $\left.90 \mathrm{lb} / \mathrm{ft}^{3}\right)$ than for fly ash and cyclone ash (approximately $70 \mathrm{lb} / \mathrm{ft}^{3}$ ).

- Reported permeabilities of AFBC ash ranged from $10^{-11}$ to $10^{-4} \mathrm{~cm} / \mathrm{sec}$, with bottom ash permeability consistently lower than that of fly ash.

- Strengths are adequate for landfill construction and may be sufficient for some construction applications:

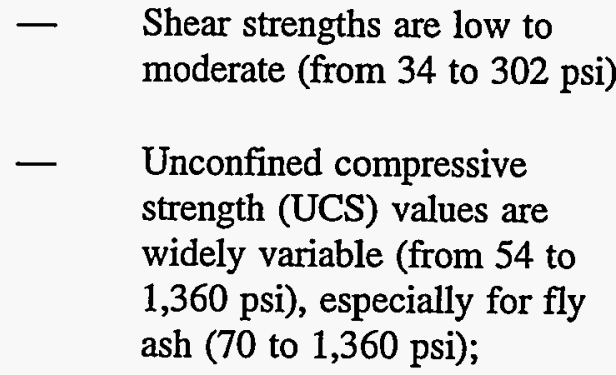

- Fly ash and cyclone ash have a smaller mean particle size than bottom ash and have a greater specific surface area; and

- Particle-specific gravities ranged from 2.39 to 3.10 (with fly ash being the lightest and bottom ash the heaviest).

\subsubsection{AFBC Ash Chemistry}

The bulk and major element chemistry of AFBC by-products reported in the literature is shown in Tables 7 and 8 , respectively. The introduction of limestone to the bed has a significant effect on the major element chemistry of the AFBC ash. High concentrations of calcium from the sorbent and sulfur compounds from the scrubbed $\mathrm{SO}_{\mathrm{x}}$ characterize these byproducts.

Table 9 gives the ranges of minor and trace element concentrations in AFBC ash.

The geographic source and type of coal are the major influences on the trace element composition of AFBC by-products. However, the presence of sorbent-related compounds can affect the speciation, and, therefore, the solubility of trace elements in the ash (see Chapter 3, Section 3.2.3).

The following points summarize the total chemistry of AFBC by-products:

- Calcium, silicon, aluminum, iron, magnesium, potassium, and sodium are the major chemical components of AFBC by-products; 

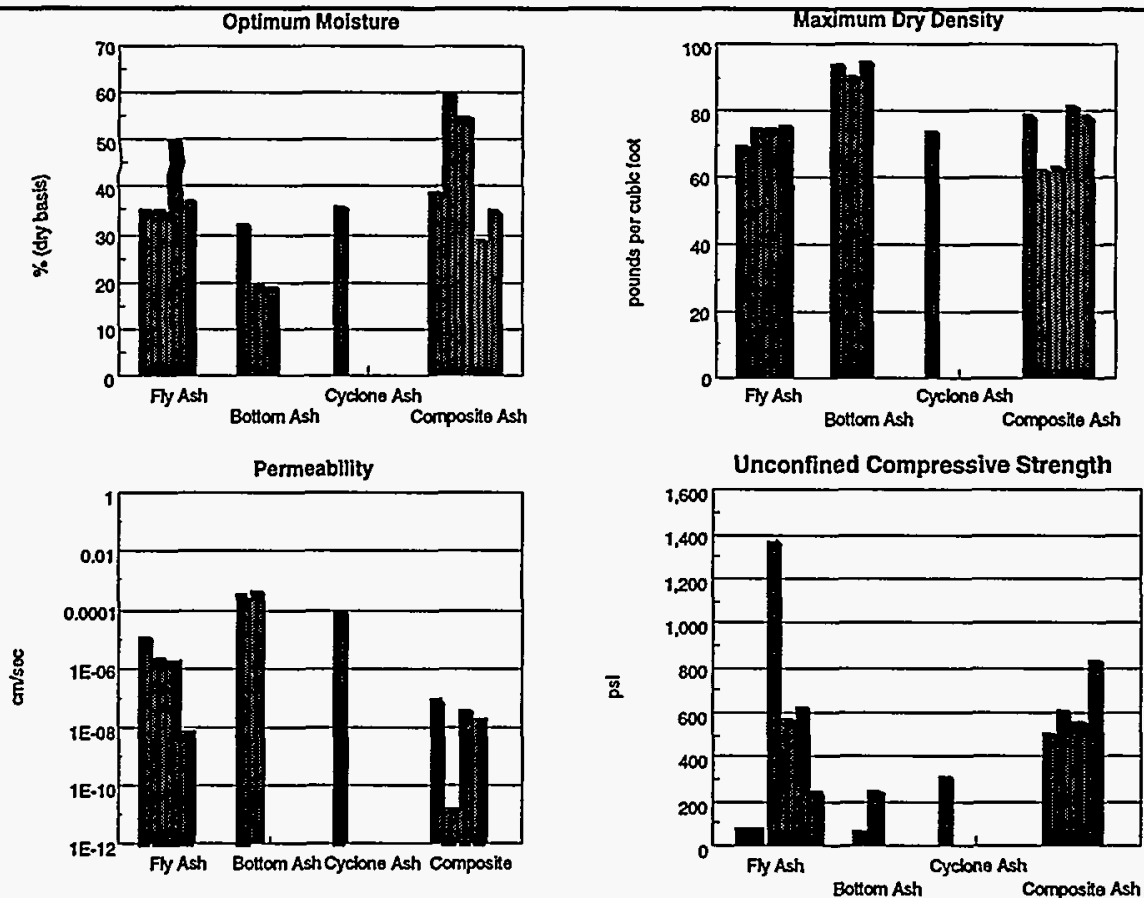

Figure 17. Physical and Engineering Properties of AFBC Ash

Sources: Characterization of Atmospheric Fluidized-Bed Combustion By-Products, for presentation at the 83rd Annual AWMA Meeting and Exhibition, Pinsturg PA, 1990

U.S. Department of Energy, Grand Forks Energy Technology Center. Chemical and Physical Characterization of Western Low-Rank Coal Waste Materials, Part 2: By-Products from an Atmospheric Fluidized Bed Combustion System. DOE/FCI 0200-13. Grand Forks, ND, 1982

U.S. Department of Energy, Morgantown Energy Technology Center. Field Study of Circulating Fluidized-Bed Ash draft. Morgantown, WV, 1994.
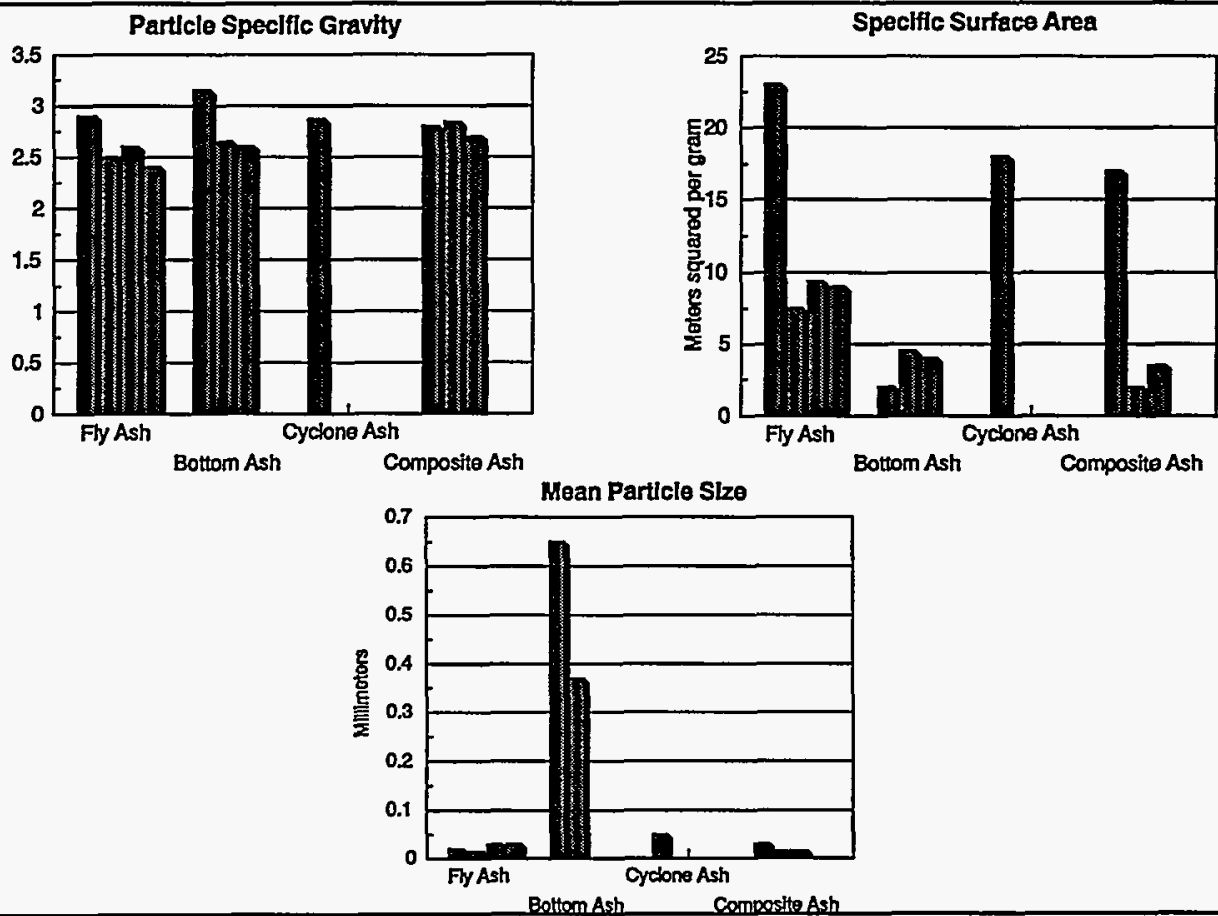

Figure 18. Additional Physical and Engineering Properties of AFBC Ash

Sources: Characterization of Atmospheric Fluidized-Bed Combustion By-Products, for presentation at the 83rd Annual AWMA Meeting and Exhibition,

Pittsburgh, PA, 1990. U.S. Department of Energy, Grand Forks Energy Technology Center. Chemical and Physical Characterization of Western Low-Rank Con
Materials, Part 2: By-Products from an Atmospheric Fluidized Bed Combustion System. DOEJFCI10200-13. Grand Forks, ND, 1982.

U.S. Department of Energy, Morgantown Energy Technology Center. Field Study of Circulating Fuidized-Bed Ash draff. Morgantown, WV, 1994. 
Table 7

Bulk Chemistry of AFBC Ash

\begin{tabular}{|c|c|c|c|c|c|}
\hline Parameter & Units & Fly Ash & Bottom Ash & Cyclone Ash & Composite Ash \\
\hline \multicolumn{6}{|l|}{ Bulk Chemistry } \\
\hline Available lime index & wt. \% & 6.8 & 7.4 & NA & 26 \\
\hline Heat of hydration, temp. & $\mathrm{C}$ & $21-55$ & $11-38$ & 58 & $34-37$ \\
\hline Heat of hydration, time & minutes & 40 & 4 & NA & NA \\
\hline Loss on ignition & $\%$ & 8.7 & 1.2 & $\mathrm{NA}$ & 19 \\
\hline Sulfate sulfur & wt. \% & 1.93 & 3.5 & $\mathrm{NA}$ & NA \\
\hline Total inorganic $\mathrm{C}$ in solids & $\mathrm{mg} \mathrm{CO}_{3} / \mathrm{g}$ & 0.444 & 1.329 & NA & 38 \\
\hline \multicolumn{6}{|c|}{ Acid- or Water-Soluble Anions } \\
\hline Carbonate, water-soluble & $\mathrm{mg} / \mathrm{g}$ & $0.7-45$ & $<2.5-60$ & $<2.5$ & $<3-10$ \\
\hline Chloride, water-soluble & $\mathrm{mg} / \mathrm{g}$ & $0.5-0.6$ & $<0.01-0.2$ & 0.3 & $<0.5-0.85$ \\
\hline Fluoride, water-soluble & $\mathrm{mg} / \mathrm{g}$ & $0.2-0.4$ & $<0.05-0.015$ & 0.3 & $0.01-0.2$ \\
\hline Sulfate, water-soluble & $\mathrm{mg} / \mathrm{g}$ as $\mathrm{S}$ & $14-56$ & $14.5-21$ & 55 & $2.5-25$ \\
\hline Sulfur, acid-soluble & $\mathrm{mg} / \mathrm{g}$ as $\mathrm{S}$ & $20-69$ & $26-50$ & 80 & $36-53$ \\
\hline
\end{tabular}

NA - Not analyzed

Sources: Characterization of Atmospheric Fluidized-Bed Combustion By-Products, for presentation at the 83rd Annual AWMA Meeting and Exhibition, Pittsburgh, PA, 1990.

U.S. Department of Energy, Grand Forks Energy Technology Center. Chemical and Physical Characterization of Western Low-Rank Coal Waste Materials, Part 2: By-Products from an Atmospheric Fluidized Bed Combustion System. DOE/FCI10200-13. Grand Forks, ND, I982.

U.S. Department of Energy, Morgantown Energy Technology Center. Field Study of Circulating Fluidized-Bed Ash, draft. Morgantown, WV, 1994. Previously unpublished data from this study.

\section{AFBC Major Element Chemistry (mg/kg)}

\begin{tabular}{||l|c|c|c|c||}
\hline \multicolumn{1}{|c|}{ Parameter } & Fly Ash & Bottom Ash & Cyclone Ash & Composite Ash \\
\hline Aluminum & $24,000-126,000$ & $7,200-94,100$ & 19,300 & $16,200-66,000$ \\
\hline Calcium & $68,000-161,700$ & $105,000-321,900$ & 219,900 & $254,000-279,500$ \\
\hline Iron & $13,000-120,000$ & $5,700-37,900$ & 46,200 & $16,000-59,900$ \\
\hline Magnesium & $2,900-24,000$ & $2,700-5,660$ & 2,860 & $3,240-14,000$ \\
\hline Potassium & $2,500-8,020$ & $500-10,500$ & 3,230 & $3,010-8,700$ \\
\hline Silicon & $600-216,000$ & $3,200-203,000$ & 37,200 & $28,200-120,000$ \\
\hline Sodium & $490-30,000$ & $240-3,250$ & 180 & $1,070-24,000$ \\
\hline Titanium & $1,200-2,360$ & $430-3,600$ & 890 & $870-2,900$ \\
\hline
\end{tabular}

Sources: Characterization of Atmospheric Fluidized-Bed Combustion By-Products, for presentation at the 83rd Annual AWMA Meeting and Exhibition, Pittsburgh, PA, 1990

U.S. Department of Energy, Grand Forks Energy Technology Center. Chemical and Physical Characterization of Western Low-Rank Coal Waste Materials. Part 2: By-Products from an Aumospheric Fluidized Bed Combustion System. DOE/FC/10200-13. Grand Forks, ND, 1982.

U.S. Department of Energy, Morgantown Energy Technology Center. Field Study of Circulating Fluidized-Bed Ash, draft. Morgantown, WV, 1994.

Previously unpublished data from this study. 
Table 9

AFBC Minor and Trace Element Chemistry (mg/kg)

\begin{tabular}{||l|c|c|c|c||}
\hline \multicolumn{1}{|c|}{ Parameter } & Fly Ash & Bottom Ash & Cyclone Ash & Composite Ash \\
\hline Arsenic & $2.8-50$ & $4-31$ & 11 & $7.5-19$ \\
\hline Barium & $100-1,600$ & $57-280$ & 90 & $50-2,500$ \\
\hline Cadmium & $0.34-3.7$ & $0.1-2.2$ & 0.6 & $0.2-0.4$ \\
\hline Chromium & $13-140$ & $5.4-32$ & 46 & $<1.7-76$ \\
\hline Copper & $14-82$ & $4.2-36$ & 14 & $12-48$ \\
\hline Lead & $<0.18-85$ & $1.8-37$ & 1.1 & $4.3-47$ \\
\hline Manganese & $110-410$ & $87-160$ & 140 & $140-570$ \\
\hline Mercury & $<0.1-1.4$ & $<0.05$ & $<0.05$ & $0.05-0.19$ \\
\hline Molybdenum & $<0.4-85$ & $<4.6-81$ & 9.4 & $<9.6-16$ \\
\hline Nickel & $18-71$ & $6.8-80$ & 16 & $<3.8-81$ \\
\hline Selenium & $<0.7-18$ & $<0.17-12$ & $<0.7$ & $<0.4-9$ \\
\hline Silver & $<2.4-22$ & $<2.4$ & 7.5 & $<1.7-2$ \\
\hline Strontium & $140-2,300$ & $210-260$ & 230 & $170-2,700$ \\
\hline Vanadium & $19-150$ & $19-64$ & 68 & $110-192$ \\
\hline Zinc & $37-690$ & $13-290$ & 190 & $6-76$ \\
\hline \hline
\end{tabular}

Sources: Characterization of Atmospheric Fluidized-Bed Combustion By-Products, for presentation at the 83rd Annual AWMA Meeting and Exhibition, Pittsburgh, PA, 1990.

U.S. Department of Energy, Grand Forks Energy Technology Center. Chemical and Physical Characterization of Western Low-Rank Coal Waste Materials, Part 2: By-Products from an Atmospheric Fluidized Bed Combustion System. DOE/FC/10200-13. Grand Forks, ND, 1982.

U.S. Department of Energy, Morgantown Energy Technology Center. Field Study of Circulating Fluidized-Bed Ash, draft. Morgantown, WV, 1994. Previously unpublished data from this study.

- Significant amounts of titanium, strontium, barium, zinc, and manganese are found in $\mathrm{AFBC}$ ash;

- Cyclone ash and bottom ash contain more calcium than fly ash;

- Fly ash contains higher concentrations of most trace elements than cyclone or bottom ash;

- Heats of hydration range from $11^{\circ}$ to $58^{\circ} \mathrm{C}$ with the largest temperature change for cyclone ash and the smallest temperature change for bottom ash, probably due to the larger particle size and slower reaction times;
- The available lime index ranges from 7 to $26 \%$;

- The loss on ignition ranges from 1 to 19\%; and

- Sulfate and carbonate are the main water-soluble anions.

\subsubsection{AFBC Ash Leachate}

The leachability of the AFBC ash was assessed using the RCRA EP and the newer TCLP. Results from these tests are generally comparable for AFBC by-products. The compositions of EP and TCLP leachates of AFBC ash are shown in Table 10. 


\section{Table 10 \\ EP Leachates of AFBC (mg/L)}

\begin{tabular}{||l|c|c|c|c|c||}
\hline \multicolumn{1}{c|}{ Analyte } & Fly Ash & Bottom Ash & Cyclone Ash & Composite Ash & $\begin{array}{c}\text { Conventional } \\
\text { Western Coal Ash }\end{array}$ \\
\hline Arsenic & $0.003-0.007$ & $<0.005$ & $<0.003$ & $<0.005$ & 0.008 \\
\hline Barium & $<0.077-0.32$ & $0.082-0.21$ & 0.18 & $0.15-14$ & 0.377 \\
\hline Cadmium & $<0.0005-0.3$ & $<0.005$ & $<0.0005$ & $<0.008$ & 0.002 \\
\hline Chromium & $<0.01-0.13$ & $<0.01-0.13$ & 0.055 & $0.016-0.083$ & 0.078 \\
\hline Lead & $<0.002-0.4$ & $<0.002$ & $<0.002$ & $<0.002-0.013$ & 0.003 \\
\hline Mercury & $<0.0002-0.0005$ & $<0.0002$ & $<0.0002$ & $<0.0002$ & 0.001 \\
\hline Selenium & $<0.005-0.25$ & $<0.005$ & $<0.003$ & $<0.03$ & 0.018 \\
\hline Silver & $<0.01-0.06$ & $<0.01-0.2$ & 0.34 & $<0.1$ & 0.001 \\
\hline pH & $5.5-12.1$ & $11.6-12.4$ & 12.2 & $11.7-12.4$ & NA \\
\hline \hline
\end{tabular}

NA - Not analyzed

Sources: Characterization of Atmospheric Fluidized-Bed Combustion By-Products, for presentation at the 83rd Annual AWMA Meeting and Exhibition, Pittsburgh, PA, 1990.

U.S. Department of Energy, Grand Forks Energy Technology Center. Chemical and Physical Characterization of Western Low-Rank Coal Waste Materials, Part 2: By-Products from an Atmospheric Fluidized Bed Combustion System DOE/FC110200-13. Grand Forks, ND, 1982.

U.S. Department of Energy, Morgantown Energy Technology Center. Feld Study of Circulating Fluidized-Bed Ash. draft. Morgantown, WV, 1994. Previously unpublished data from this study.

The EP and TCLP leachates were analyzed for eight regulated metals: arsenic, barium, cadmium, chromium, lead, mercury, selenium, and silver. All of these elements were found in concentrations below regulatory levels and were similar to EP leachates from conventional western coal ash, which are shown for comparison. The highest $\mathrm{pH}$ of the AFBC leachate was 12.4 , reflecting the high lime content of the ash. This value is just below the regulatory threshold of 12.5 for corrosivity.

\subsubsection{AFBC Ash Mineralogy}

The mineralogy of AFBC ash by XRD analysis is shown in Figure 19. Differences in firing temperatures and moisture content of the ash will significantly affect the mineralogy. Certain minerals, such as mullite, form only at temperatures above approximately $1000^{\circ} \mathrm{C}$. The formation of mullite generally reflects the presence of hot spots in the bed, or anomalously high combustion temperatures.
Samples of AFBC by-product which have been wetted (e.g., for dust control) will form hydrous minerals, which will decrease the available moisture content and may cause selfcementation. The results shown in Figure 19 are for dry material only.

The following points summarize the mineralogy of AFBC ash:

- Quartz and anhydrite are the main crystalline species;

- $\quad$ CFBC ash contains significant amounts of mullite, possibly reflecting the higher temperatures of $\mathrm{CFBC}$ systems, while $\mathrm{BFBC}$ ash contains more calcite and portlandite;

- Between 50 and $65 \%$ of the ash is amorphous or glassy material, which does not produce a clear diffraction pattern; 


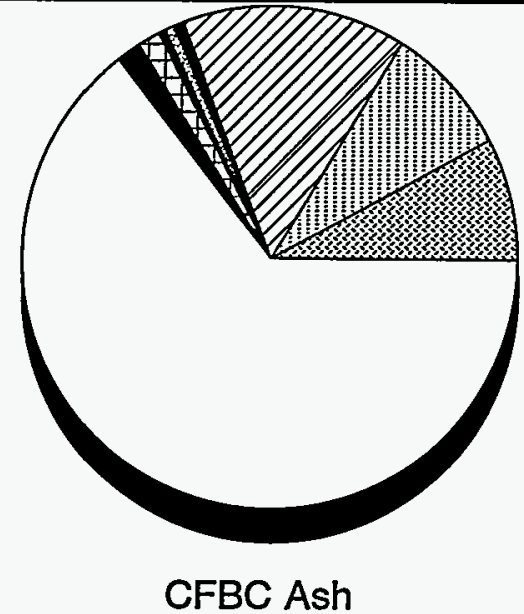

Source: Weinberg et al., 1993

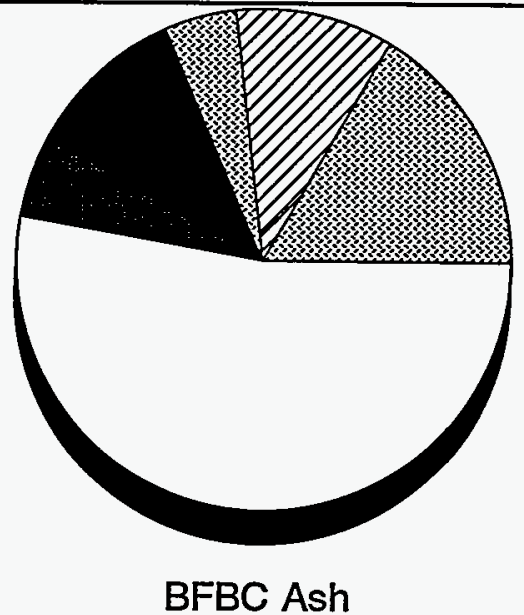

Source: Unpublished date, this study.

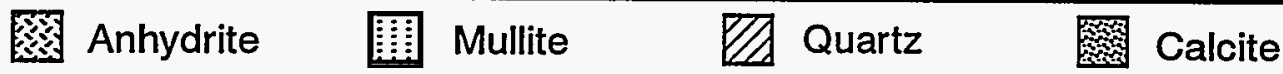 \\ 1 Portlandite \\ 曹 Fe-Spinel \\ Lime \\ Gypsum}

Ettringite

Amorphous Material

Figure 19. XRD Mineralogy of CFBC and BFBC By-Products

All results are expressed as percent dry weight.

Source: U.S. Department of Energy, Morgantown Energy Technology Center. Field Study of Circulating Fluidized-Bed Ash, draft. Morgantown, WV, 1994.

- Moisture addition produces heat and forms hydrous minerals such as gypsum, portlandite, and ettringite at the expense of anhydrous minerals such as anhydrite and lime; and

- Quartz, mullite, and Fe-spinel are essentially unreactive in the disposal environment.

\subsubsection{Transport and Handling Considerations}

High heats of hydration, alkalinity, self-hardening, and increased ash volumes in comparison to conventional pulverized coal fly ash (PFA) may affect handling and transport system design for AFBC by-products. Some studies suggest that the angular nature of $\mathrm{AFBC}$ ash particles may require the implementation of abrasion control measures ${ }^{4}$. Boiler tubes in the AFBC systems are especially subject to abrasion since they are directly exposed to fluidized particles in the bed during combustion.
The generation of heat upon water addition, along with the alkaline and selfhardening properties of the by-products, may necessitate dry handling. However, dry handling may cause problems with dust. The increased volume of wastes due to the addition of lime or limestone and recovery of sulfur compounds may also be a consideration in the storage and transpiort of AFBC by-products. Pelletizing wastes may be considered as a method to reduce by-product volume and control dust.

\subsection{Calcium Spray-Dryer By-Product Characteristics}

Spray-dryer systems introduce an atomized slurry of alkaline sorbent (usually slaked lime) into the hot flue gas. The lime reacts with the $\mathrm{SO}_{\mathrm{x}}$ to form calcium sulfate and sulfite particles that are removed by fabric filters or ESPs. The resultant by-product is a dry mixture of fly ash, unreacted lime, calcium sulfates, and calcium sulfites, making it chemically similar to AFBC and FSI byproducts. 
Physical characteristics of spray dryer by-products are similar to those for conventional fly ash. The following points summarize the physical and chemical characteristics of spray dryer ash ${ }^{5}$ :

- Optimum moisture ranges from 16 to 38 percent;

- Maximum dry density is much lower than for AFBC or FSI ash (from 70 to $\left.100 \mathrm{lb} / \mathrm{ft}^{3}\right)$;

- Mean particle size ranges from 0.016 to $0.045 \mathrm{~mm}$, and specific surface area ranges from 1.64 to $7.47 \mathrm{~m}^{2} / \mathrm{g}$;

- Particle specific gravity ranges from 2.29 to 2.80 ;

- Permeability is low-from $10^{-9}$ to $10^{-7}$ $\mathrm{cm} / \mathrm{sec}$; and

- Unconfined compressive strength (with optimum moisture and 7-day cure) is highly variable-from 54 to 684 psi.

Calcium is the most abundant major element in spray dryer by-products. The sulfur content of the ash depends on the sulfur content of the coal burned and the efficiency of the $\mathrm{SO}_{\mathrm{x}}$ removal process. The following points summarize the major element chemistry of spray dryer by-products ${ }^{5}$ :

- Calcium content of the ash ranges from approximately 14 to 22 percent;

- $\quad$ Other major elements, present in amounts from greater than 0.5 to $12 \%$, are silicon, aluminum, iron, magnesium, and sodium;

- Acid-soluble (total) sulfur ranged from $4-7 \%$ and sulfite, rather than sulfate, is the dominant species; and

- Heats of hydration are relatively low $\left(<30^{\circ} \mathrm{C}\right)$, because most of the lime that is not consumed up in $\mathrm{SO}_{2}$ removal is present as $\mathrm{CaOH}$.

The minor element chemistry of spray dryer by-products, like that of AFBC and FSI by- products, is controlled primarily by the trace element composition of the coal being burned.

One study of spray dryer by-product leachates found that all samples were nonhazardous according to EP toxicity characteristics ${ }^{5}$. The $\mathrm{pH}$ of EP leachates from calcium spray dryer ash is generally lower than those of AFBC and FSI ash, with the exception of some AFBC fly ash samples. The spray dryer EP leachate $\mathrm{pH}$ values range from 7.65 to 12.0 , beneath the regulatory limit for corrosivity of 12.5.

Mineralogy of calcium spray dryer ash differs from AFBC and FSI ash most notably in the absence of calcium sulfate minerals (anhydrite or gypsum). Only one of eight samples investigated contained gypsum (from $5-15 \%$ ) and none were found to contain anhydrite. Presumably, the scrubbed sulfur is present in the amorphous fraction of the ash. Due to the introduction of slaked (hydrated) lime to the system, portlandite $\left[\mathrm{Ca}(\mathrm{OH})_{2}\right]$ was the dominant calcium-bearing mineral in over half the samples.

The lower heats of hydration and $\mathrm{pH}$ may make calcium spray dryer ash slightly easier to handle and store than AFBC and FSI ash. As with AFBC and FSI systems, increased by-product volume results from the addition of sorbent and the removal of $\mathrm{SO}_{2}$ from flue gas. Other than the need to handle increased volumes, equipment designed for the handling and transport of conventional fly ash should be suitable for use with calcium spray dryer ash.

\subsection{Pressurized Fluidized Bed Combustion By-Product Characteristics}

$\mathrm{PFBC}$ systems are similar to AFBC systems, except that combustion takes place at pressures of 10 to 16 atmospheres. The increased pressure of the system allows combustion to take place at lower temperatures and in a more compact bed. Under the combustion conditions in PFBC boilers, the sorbent is not generally calcined to lime. Increased residence times and greater fuel flexibility are two of the benefits of PFBC. PFBC may be used as a retrofit technology. Only one PFBC demonstration plant is 
currently operating in the United States-the American Electric Power Service Corporation (AEP) Tidd Plant in Brilliant, Ohio. The following discussion on PFBC by-product is based on an ash sample from this plant.

The engineering and physical properties of PFBC ash do not indicate any potential engineering problems associated with landfilling this material. The following points summarize the available data ${ }^{6}$ :

- UCS values are in the same range as those reported for FSI and FBC byproducts-approximately 200 to 1100 psi following a 7-day cure;

- $\quad$ Maximum dry density of PFBC byproduct was found to be higher, at 112 $\mathrm{lb} / \mathrm{ft}^{3}$, than for AFBC or FSI ash;

- Particle density for PFBC by-product was measured at $2.92 \mathrm{~g} / \mathrm{cm}^{3}$ for bottom ash and $2.70 \mathrm{~g} / \mathrm{cm}^{3}$ for cyclone ash;

- Particle size of PFBC cyclone ash fell primarily in the silt range $(0.002$ to $0.05 \mathrm{~mm}$ ), whereas the bulk of the PFBC bottom ash particles were found to be greater than $0.25 \mathrm{~mm}$; and

- $\quad$ Specific surface area was significantly lower for PFBC bottom ash $\left(1.28 \mathrm{~m}^{2} / \mathrm{g}\right)$ than for PFBC cyclone ash $\left(6.50 \mathrm{~m}^{2} / \mathrm{g}\right)$.

The major element chemistry of the PFBC by-product is dominated by calcium and magnesium, at 17.5 and $10.6 \%$, respectively. This magnesium concentration is approximately one to two orders of magnitude higher than in AFBC and FSI ash. The reason for these high levels of magnesium is the use, in this case, of dolomite $\left[\mathrm{CaMg}\left(\mathrm{CO}_{3}\right)_{2}\right]$ in place of lime or limestone as the sorbent. Other major elements, shown in Table 11, are similar in concentration to those in AFBC and FSI byproducts.

Minor and trace elements, shown in Table 12 , are also generally within the ranges given for AFBC and FSI ash and, again, are probably strongly dependent on the chemistry of the coal. The flexibility of PFBC systems with regard to fuel suggests that the trace element composition of PFBC by-products may be highly variable.

Table 11

PFBC Major Element Chemistry (mg/kg)

\begin{tabular}{||l|c|}
\hline \multicolumn{1}{|c|}{ Analyte } & PFBC Ash \\
\hline Aluminum & 39,300 \\
\hline Calcium & 175,300 \\
\hline Iron & 51,700 \\
\hline Magnesium & 106,400 \\
\hline Potassium & 5,000 \\
\hline Silicon & 72,400 \\
\hline Sodium & 10,300 \\
\hline
\end{tabular}

U.S. Department of Energy, Office of Fossil Energy, Morgantown Energy Technology Center. "Land Application Uses of

Pressurized Fluidized-Bed Combustion (FPBC) Ash." In:

Proceedings of the Coal-Fired Power Systems 93-Advances in

IGCC and PFBC Review Meeting. Morgantown, WV, 1993. pp. 103-120. 1993.

Table 12

PFBC Minor and Trace Element Chemistry $(\mathrm{mg} / \mathrm{kg})$

\begin{tabular}{||l|c|}
\hline \multicolumn{1}{|c|}{ Analyte } & PFBC Ash \\
\hline Arsenic & 1.9 \\
\hline Barium & 2,000 \\
\hline Cadmium & 1.9 \\
\hline Chromium & 36.9 \\
\hline Copper & 52.5 \\
\hline Lead & 16.0 \\
\hline Molybdenum & 6.6 \\
\hline Nickel & 52.1 \\
\hline Selenium & 5.6 \\
\hline Zinc & 74.0 \\
\hline
\end{tabular}

U.S. Department of Energy, Office of Fossil Energy, Morgantown Energy Technology Center. "Land Application Uses of

Pressurized Fluidized-Bed Combustion (FPBC) Ash." In:

Proceedings of the Coal-Fired Power Systems 93-Advances in

IGCC and PFBC Review Meeting. Morgantown, WV, 1993. pp. 103-120. 1993. 
An EPA study ${ }^{8}$ conducted deionizedwater leaching experiments and concluded that cadmium, manganese, sulfate, and total dissolved solids (TDS) may pose leaching problems for PFBC landfills. Elevated levels of sulfate (3136 and $5154 \mathrm{mg} / \mathrm{L}$ ) and TDS (1699 and $1569 \mathrm{mg} / \mathrm{L}$ ) were also reported in ASTM leachates in a recent study ${ }^{6}$, but cadmium and manganese concentrations were below detection limits. None of the EP trace metals analyzed in these samples were found to exceed primary drinking water standards in either ASTM or TCLP leachates of PFBC byproduct, and the concentrations of all eight elements were several orders of magnitude lower than the RCRA limits. The ASTM (deionized water) leachate $\mathrm{pH}$ was measured at 11.42 for cyclone ash and 11.77 for bottom ash.
The mineralogy of PFBC by-products is shown in Figure 20. The mineralogy of these samples differs markedly from the mineralogy of AFBC and FSI by-products. Anhydrite still makes up a major portion of the crystalline material (21 to $46 \%$ ) and calcite is present in significant amounts in cyclone and bottom ash. However, dolomite (unspent sorbent) makes up $17-24 \%$ of the ash. Periclase $(\mathrm{MgO})$, a mineral formed by the reaction of dolomite at an elevated temperature and pressure $\left[\mathrm{CaMg}\left(\mathrm{CO}_{3}\right)_{2} \rightarrow \mathrm{CaCO}_{3}+\mathrm{MgO}+\mathrm{CO}_{2}\right]$ is also present at 14 and $27 \%$ in cyclone and bottom ash, respectively. Lime is present in small amounts (4\%) in the bottom ash. The remainder of the PFBC by-product is amorphous material (i.e., fly ash).

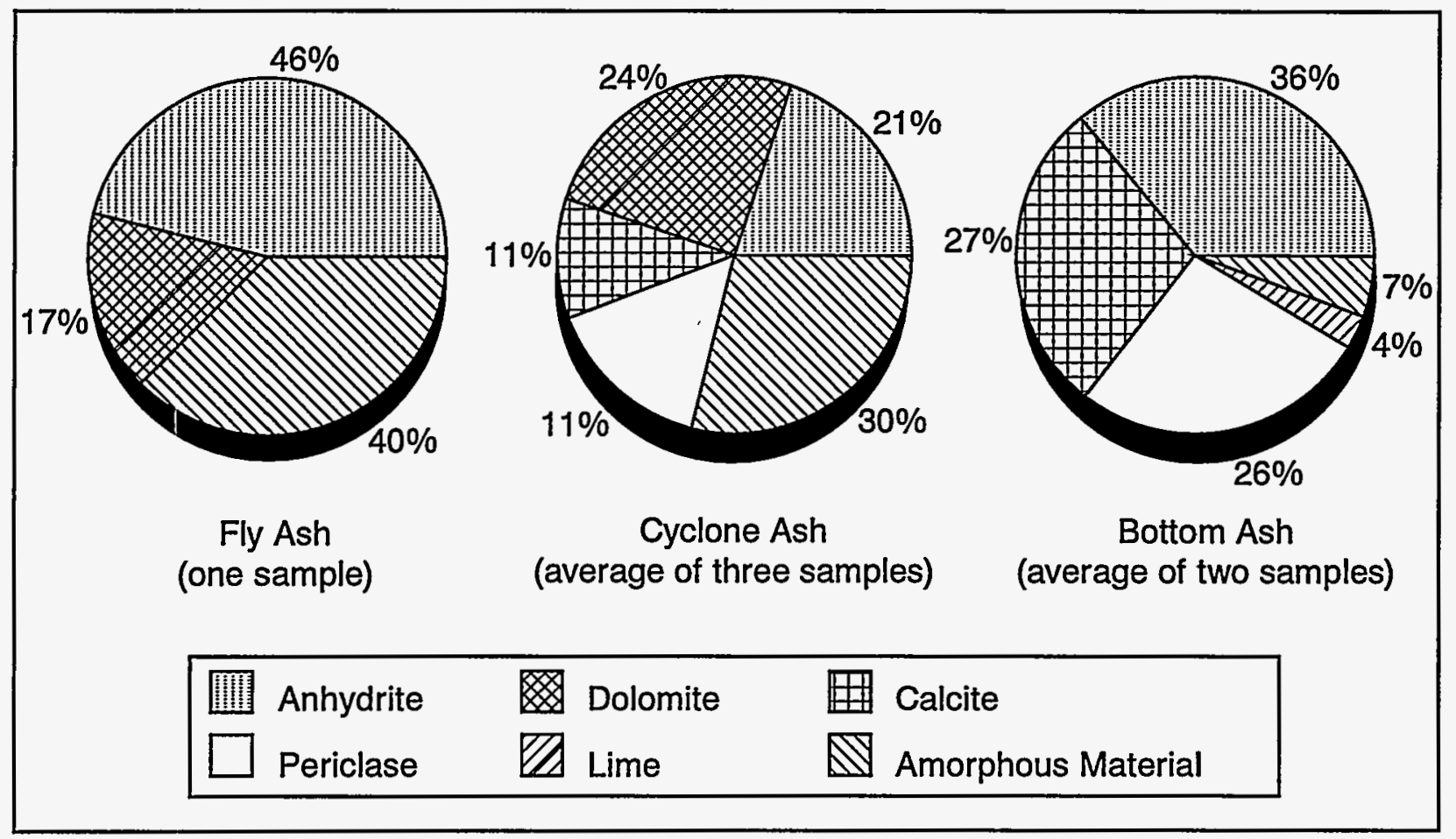

Figure 20. XRD Mineralogy of PFBC By-Products

All results are expressed as percent dry weight.

Source: U.S. Department of Energy, Office of Fossil Energy, Morgantown Energy Technology Center. "Land Application Uses of Pressurized Fluidized-Bed Combustion (PFBC) Ash." In: Proceedings of the Coal-Fired Power Systems 93-Advances in IGCC and PFBC Review Meeting. Morgantown, WV, 1993. pp. 103-120. 1993. 
The presence of only small amounts of lime in the PFBC by-products will produce lower heats of hydration relative to AFBC and FSI by-products. Lower leachate $\mathrm{pH}$ may also cause fewer problems with corrosion and may increase the stability of some chemical elements which are mobilized at elevated $\mathrm{pH}$.

\subsection{Dry Sodium In-Duct Injection By-Products}

This $\mathrm{SO}_{\mathrm{x}}$ control process involves injection of a sodium-based sorbent directly into the flue gas downstream of the boiler. The particulate matter is then collected by conventional methods.

The physical and engineering properties of two sodium-injection by-products are shown in Table 13. Optimum moisture and maximum dry density are very low relative to FSI and AFBC by-products. Although mean particle size is fairly small compared to most of the FSI and AFBC ash samples, specific surface area is also low, suggesting less porous particles. Particle specific gravities are lower than the values reported for FSI and AFBC ash. Permeability of the sodium-injection ash was similar to FSI and AFBC ash. UCS varied by an order of magnitude for the two sodiuminjection samples, from 26 to $268 \mathrm{psi}$. Because of its high solubility, sodium-injection ash will experience considerable deterioration in its engineering properties when exposed to moisture.

The sodium-injection by-products contain more sodium and less calcium than AFBC and FSI by-products. By-products from two sodium-injection test facilities, one using nahcolite $\left(\mathrm{NaHCO}_{3}\right)$ and the other using trona $\left(\mathrm{Na}_{2} \mathrm{CO}_{3} \cdot \mathrm{NaHCO}_{3} \cdot 2 \mathrm{H}_{2} \mathrm{O}\right)$ as sorbents, were investigated ${ }^{7}$. Chemical analysis of the byproducts from these two facilities gave the following results:

- $\quad$ Silicon (12-16\%) and aluminum (8\%) were the most abundant elements;

- Sodium concentrations were 5-9 percent;

Table 13

Physical and Engineering Properties of Sodium-Injection Ash

\begin{tabular}{||l|c|c|c||}
\hline \multicolumn{1}{|c|}{ Parameter } & Units & $\begin{array}{c}\text { Trona Sorbent } \\
\mathrm{Na}_{2} \mathrm{CO}_{3} \cdot \mathrm{NaHCO}_{3} \cdot 2 \mathrm{H}_{2} \mathbf{O}\end{array}$ & $\begin{array}{c}\text { Nahcolite Sorbent } \\
\mathrm{NaHCO}_{3}\end{array}$ \\
\hline Optimum Moisture & $\%$ (dry basis) & 20 & 29 \\
\hline $\begin{array}{l}\text { Maximum Dry } \\
\text { Density }\end{array}$ & $\mathrm{lb} / \mathrm{ft}^{3}$ & 90.7 & 80.6 \\
\hline Permeability & $\mathrm{cm} / \mathrm{sec}$ & $9.4 \times 10^{-6}$ & $3.0 \times 10^{-5}$ \\
\hline UCS & $\mathrm{psi}$ & 26 & 268 \\
\hline Mean Particle Size & $\mathrm{mm}$ & $<0.001$ & 0.009 \\
\hline $\begin{array}{l}\text { Particle Specific } \\
\text { Gravity }\end{array}$ & $\mathrm{none}$ & 2.36 & 2.16 \\
\hline Specific Surface Area & $\mathrm{m}^{2} / \mathrm{g}$ & 2.26 & 1.58 \\
\hline \hline
\end{tabular}

Source: Electric Power Research Institute. EPRI GS-6622. Laboratory Characterization of Advanced SO 2 Control By-Products: Dry Sodium and Calcium In-Duct Injection Wastes. 
- Calcium concentrations were about 3\%, generally an order of magnitude less than FSI and AFBC by-products;

- Total sulfur makes up 3.1 to $4.8 \%$ of the ash;

- Water-soluble sulfate ranges from 2.7 to $3.7 \%$ as sulfur;

- Water-soluble carbonate was present at 3.0 and $4.5 \%$; and

- Heat of hydration was between 30 and $40^{\circ} \mathrm{C}$.

Minor element chemistry of the sodiuminjection by-products did not differ significantly from the compositions reported for FSI and AFBC by-products.

Sodium-injection by-product leachates may have extremely high total dissolved solids concentrations, owing to the high solubility of most of the sodium compounds they contain. EP leachates from the sodium-injection materials contained higher levels of arsenic than the AFBC and FSI ash, even though total arsenic levels were not higher. This may indicate the presence of a more soluble species of arsenic in the sodium-injection ash. Other elements in the EP leachates were present at similar or lower concentrations than in FSI or AFBC leachates. None of the concentrations exceeded RCRA levels. The $\mathrm{pH}$ values reported for the two samples varied significantly: 8.7 for the trona-based ash and 4.95 for the nahcolite-based ash. These relatively low $\mathrm{pH}$ values reflect good utilization of the sorbent.

The mineralogy of the crystalline fraction of the two sodium-injection byproducts was qualitatively determined by XRD. Lime, mullite, and quartz were the species documented in both samples. In addition to these minerals, mirabilite $\left(\mathrm{Na}_{2} \mathrm{SO}_{4} \cdot 10 \mathrm{H}_{2} \mathrm{O}\right)$, nahcolite $\left(\mathrm{NaHCO}_{3}\right)$, and thenardite $\left(\mathrm{Na}_{2} \mathrm{SO}_{4}\right)$ were tentatively identified in one or both of the samples. All of these sodium minerals are soluble, and would be expected to leach rapidly from the ash ${ }^{7}$.

Although dry handling of sodiuminjection ash may be desirable to avoid generating heat and potentially corrosive leachate, the small mean particle size of this waste suggests that dusting may be a problem. The low density of the material, along with increased by-product generation (fly ash plus sorbent plus removed sulfur) may result in a significantly higher volume of material to transport and store.

\subsection{Dry Calcium In-Duct Injection By-Product Characteristics}

Dry calcium in-duct injection is similar to sodium injection (described in Chapter 3 , Section 3.4.3), but uses calcium-based sorbents such as lime or hydrated lime. The handling and disposal properties of the by-products should be similar to those of an FSI system. The physical and chemical properties data below are from an in-duct injection system using hydrated lime as a sorbent ${ }^{7}$.

The physical and engineering properties of the calcium-injection ash are not significantly different from those reported for other advanced coal by-products. Like the sodium-injection ash, the calcium-injection ash has a lower maximum dry density and particle specific gravity than the AFBC and FSI byproducts. Values for optimum moisture, permeability, UCS, specific surface area, and mean particle size are all within the ranges given for AFBC and FSI by-products.

The chemistry of the calcium-injection by-product is similar to that of other advanced coal processes that utilize calcium-based sorbents. Calcium is the dominant element, with sulfur, aluminum, iron, magnesium, potassium, sodium, and titanium also making up a significant portion of the ash. The heat of hydration of this sample was relatively low-approximately $30^{\circ} \mathrm{C}$. Minor element composition of calcium-injection ash would not be expected to be significantly different from those reported for AFBC or FSI ash.

The chemistry of EP leachates derived from the calcium-injection ash does not differ significantly from the chemistry of AFBC and FSI ash leachates. Concentrations of the eight RCRA metals are well within regulatory limits. At 12.4 , the $\mathrm{pH}$ is just below the regulatory threshold of $\mathbf{1 2 . 5}$ for corrosivity. 
Since sorbent is injected into relatively cool combustion gases in this technology, there is less opportunity for reaction between coal ash glass and sorbent to form reactive mineral phases. Quartz and portlandite were the only two minerals identified in a sample from a calcium-injection system that used hydrated lime as the sorbent. This is comparable to the mineralogy of ash from a calcium spray dryer system, another very similar technology.

As with the sodium-injection byproducts, the main transport, storage, and handling concern is likely to be the increased volume of by-product produced by this technology.

\subsection{Coal Gasification Slag Characteristics}

The process of coal gasification converts coal to a gaseous fuel. The main byproducts of the coal gasification process are char or tars, slag or bottom ash, and sulfur in either elemental or sulfate form. Several reuse options exist for elemental sulfur in the agricultural and chemical industries; landfilling of elemental sulfur is considered unlikely. Sulfate sulfur, scrubbed by an FBC boiler or another $\mathrm{SO}_{x}$ control technology, is discussed in detail under those technologies. Char and tars are generally recycled to the combustor; slag, or bottom ash, is the most voluminous byproduct of coal gasification. The following discussion centers on slag characteristics.

The physical and chemical properties of the coal gasification by-product are largely dependent on the type of coal burned and the combustion process. Some coal gasifiers produce ash whereas others fire the coal at a higher temperature so that the ash fuses to slag. Both types of by-product generally differ from other advanced coal combustion by-products due to the lack of sorbent addition during combustion. Fluidized bed gasifiers do feature sorbent addition in the combustion zone. Detailed treatment of all types of gasifiers is beyond the scope of this report. A Gas Research Institute study ${ }^{9}$ described the physical and chemical properties of several different ashes from fixed-bed gasification of lignite. An EPRI study ${ }^{10}$ investigated the differences between by-product from slaggingbottom gasification and conventional coal combustion, both burning Pittsburgh coal. The following paragraphs refer to these reports.

For both types of coal gasification byproduct, the mean particle size is much larger than for FSI or AFBC ash. The mean particle size for the slag sample was measured at 1.6 $\mathrm{mm}$; from 49 to 73 weight percent of the ash particles was greater than $2 \mathrm{~mm}$. The surface area of the slag was found to be significantly lower $\left(0.56 \mathrm{~m}^{2} / \mathrm{g}\right)$ than the AFBC and FSI byproducts and, as would be expected, the hydraulic conductivity of the slag is very high $\left(3.5 \times 10^{-1} \mathrm{~cm} / \mathrm{sec}\right)$. Specific gravity of the slag (2.82) is within the range reported for AFBC and FSI by-products, but much higher than the calcium- or sodium-injection byproducts. No surface area, hydraulic conductivity, or specific gravity data were reported for the gasification ash samples.

The absence of any sorbent material in the coal gasification process suggests that the major element chemistry of the by-products will more closely resemble conventional coal ash than that of other clean coal technologies. Compared to FSI and AFBC by-products, the calcium content reported for the coal gasification slag is very low and other major elements are relatively high. However, the calcium content reported for gasification ash samples was relatively high and fell within the range of concentrations reported for FSI and AFBC ash. As with other coal combustion byproducts, the minor element chemistry of coal gasification slag is strongly dependent on the minor element chemistry of the coal from which it is derived. For the most part, the trace element concentrations reported for the coal gasification by-products resemble those of conventional combustion ash.

RCRA EP leachate data for coal gasification slag are given in Table 14 . Although the RCRA metal concentrations are below regulatory limits, they are generally higher than those for AFBC and FSI, especially for the elements arsenic, barium, and chromium. The $\mathrm{pH}$ of the slag leachate is 5.0, which is much more acidic than most of the 
Table 14

EP Leachates of Coal Gasification Slag (mg/L)

\begin{tabular}{||l|c|c||}
\hline \multicolumn{1}{|c|}{ Analyte } & Concentration & $\begin{array}{l}\text { RCRA } \\
\text { Limits }\end{array}$ \\
\hline Arsenic & 0.55 & 5.0 \\
\hline Barium & 58 & 100 \\
\hline Cadmium & 0.06 & 1.0 \\
\hline Chromium & 1.45 & 5.0 \\
\hline Lead & 0.53 & 5.0 \\
\hline Mercury & 0.058 & 0.2 \\
\hline Selenium & $<1$ & 1.0 \\
\hline Silver & $<0.05$ & 5.0 \\
\hline pH (units) & 4.6 & $2.0<\mathrm{pH}<12.5$ \\
\hline
\end{tabular}

Source: Electric Power Research Institute, EPRI EA-2867. Comparison of Solid Wastes from Coal Combustion and Pilot Coal-Gasification Plants.

Table 15 Crystalline Phases in Gasification Ash

\begin{tabular}{||l|l||}
\hline \multicolumn{1}{|c|}{ Mineral } & \multicolumn{1}{c|}{ Composition } \\
\hline Dicalcium Silicate & $\mathrm{Ca}_{2} \mathrm{SiO}_{4}$ \\
\hline Merwinite & $\mathrm{Ca}_{3} \mathrm{Mg}\left(\mathrm{SiO}_{4}\right)_{2}$ \\
\hline Fe Spinel & $(\mathrm{Mg}, \mathrm{Fe})(\mathrm{Fe}, \mathrm{Al})_{2} \mathrm{O}_{4}$ \\
\hline Periclase & $\mathrm{MgO}$ \\
\hline Melilite & $\mathrm{Ca}_{2}(\mathrm{Mg}, \mathrm{Al})(\mathrm{Si}, \mathrm{Al})_{2} \mathrm{O}_{7}$ \\
\hline Carnegieite & $\mathrm{Na}_{1.5} \mathrm{Al}_{1.5} \mathrm{Si}_{0.5} \mathrm{O}_{4}$ \\
\hline Hematite & $\mathrm{Fe}_{2} \mathrm{O}_{3}$ \\
\hline Nepheline & $\mathrm{NaAlSiO}_{4}$ \\
\hline Quartz & $\mathrm{SiO}_{2}$ \\
\hline Calcite & $\mathrm{CaCO}_{3}$ \\
\hline Sodalite-structure & $\begin{array}{l}\left(\mathrm{Na}_{2}, \mathrm{Ca}\right)_{8}(\mathrm{Al}, \mathrm{Si})_{12} \mathrm{O} \\
{ }_{24}\left(\mathrm{SO}_{4}\right)_{1-2}\end{array}$ \\
\hline
\end{tabular}

Source: Gas Research Institute. Characterization, Extraction and Reuse of Coal Gasification Solid Wastes. Volume 1: Characterization of Coal Gasification Solid Wastes. Chicago, IL, 1988.
$\mathrm{AFBC}$ and FSI leachates. The lower $\mathrm{pH}$ may contribute to the higher concentrations of some trace metals in the EP leachates of the coal gasification slag. No leachate data were reported for the gasification ash samples.

$\mathrm{XRD}$ analysis of coal gasification slag revealed no crystalline component of the byproduct. This is consistent with the hightemperature fusion of the coal, resulting in a glassy material. XRD analysis of coal gasification ash showed a higher degree of crystallinity than conventional combustion ashes. Non-crystalline phases were found to contribute approximately $25 \%$ by weight of the bulk gasifier ash. Although the ash samples were found to be mineralogically inhomogeneous, certain phases were identified in all samples. These phases are presented in Table 15.

Abrasion is likely to be the major problem involved in handling and transporting coal gasification slag. Transport piping may require re-engineering to reduce bends or distance transported, or abrasion-resistant piping may be used. The larger particle size of the coal gasification slag and ash may result in less problems with dusting relative to AFBC and FSI ash. Heat generation upon hydration and self-hardening are not likely to be a problem with slag; however, gasification ash was found to self harden due to the presence of sodium aluminosilicates. The problem was resolved at one utility by sluicing the ash with a sodium chloride solution. Corrosivity due to elevated $\mathrm{pH}$ may also be a consideration in the handling of coal gasification ash. 


\subsection{Citations}

1. Electric Power Research Institute. EPRI CS-5076. Management of Solid By-Products from Advanced $\mathrm{SO}_{2}$ Control Systems. Palo Alto, California, 1987.

2. Electric Power Research Institute. EPRI CS-5783. Laboratory Characterization of Advanced $\mathrm{SO}_{2}$ Control By-Products: Furnace Sorbent Injection Wastes. Palo Alto, California, 1988.

3. U.S. Department of Energy, Morgantown Energy Technology Center. Advanced Coal Technology Waste Disposal: Ohio LIMB Site Assessment Report, draft. Morgantown, West Virginia, 1994.

4. Characterization of Atmospheric Fluidized-Bed Combustion ByProducts, for presentation at the 83rd Annual AWMA Meeting and Exhibition, Pittsburgh, Pennsylvania, 1990.

5. Electric Power Research Institute. EPRI CS-5782. Laboratory Characterization of Advanced $\mathrm{SO}_{2}$ Control By-Products: Spray Dryer Wastes. Palo Alto, California, 1988.

6. U.S. Department of Energy, Office of Fossil Energy, Morgantown Energy Technology Center. "Land Application Uses of Pressurized Fluidized-Bed Combustion (PFBC) Ash." In: Proceedings of the Coal-Fired Power Systems 93--Advances in IGCC and PFBC Review Meeting. Morgantown, West Virginia, 1993. pp. 103-120. 1993.
7. Electric Power Research Institute. EPRI GS-6622. Laboratory Characterization of Advanced $\mathrm{SO}_{2}$ Control By-Products: Dry Sodium and Calcium In-Duct Injection Wastes. Palo Alto, California, 1989.

8. U.S. Environmental Protection Agency. Laboratory and Field Studies of Pressurized FBC Waste Leachate Generation and Attenuation: Technical Note. 214-338-11. April, 1980.

9. Gas Research Institute.

Characterization, Extraction and Reuse of Coal Gasification Solid Wastes, Volume 1: Characterization of Coal Gasification Solid Wastes. Chicago, Illinois, 1988.

10. Electric Power Research Institute. EPRI EA-2867. Comparison of Solid Wastes from Coal Combustion and Pilot Coal-Gasification Plants. Palo Alto, California, 1983. 
This Page Intentionally Left Blank 


\section{Regulatory Review}

This chapter explains how current regulations governing the disposal of coal combustion wastes were developed. Section 4.1 gives a brief historical summary of how the federal regulations were developed. Section 4.2 gives an overview of current federal regulations, and Section 4.3 presents various state regulatory programs. An overview of regulations governing advanced coal by-product disposal is shown in Figure 21.

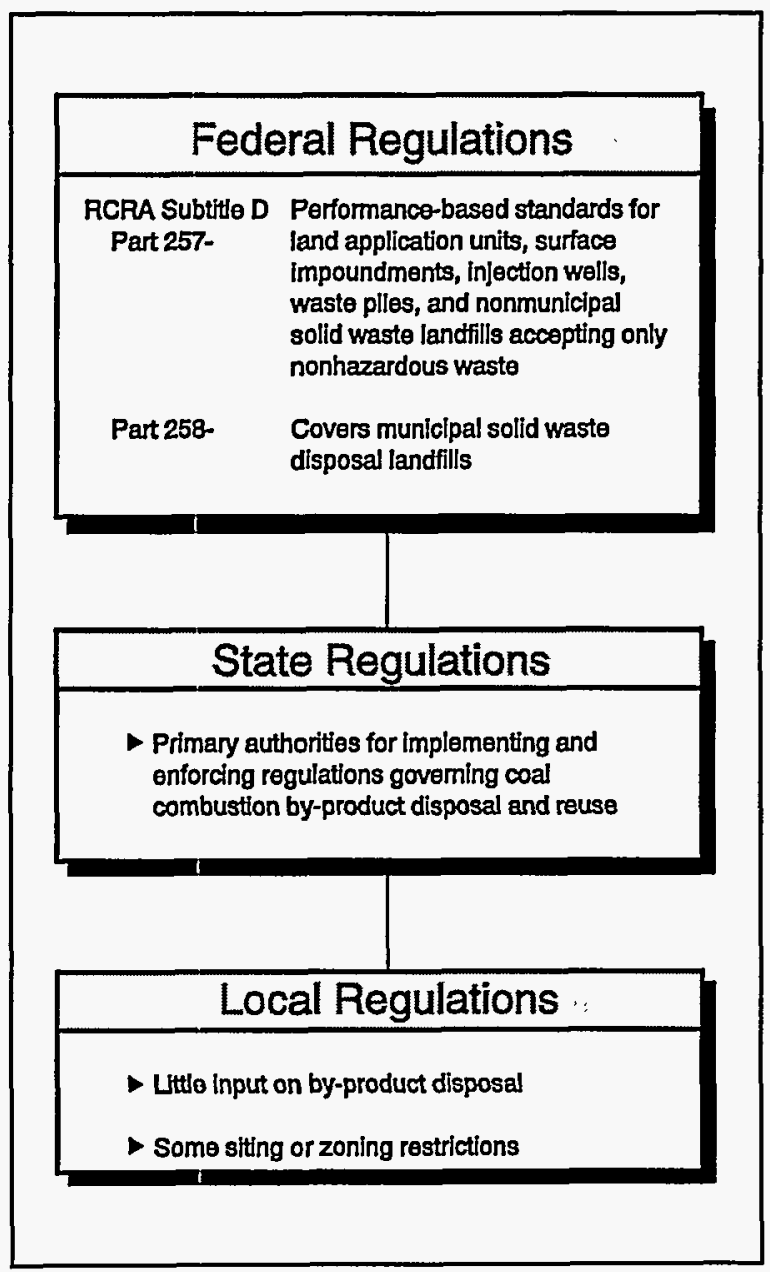

Figure 21. Regulations Governing Advanced Coal By-Product Disposal
The primary focus of this discussion is on regulations affecting the disposal of coal combustion wastes in landfills. Potential reuse options are being increasingly considered by by-product generators. There are no federal requirements for reusing coal combustion byproducts. State requirements for the beneficial reuse of industrial waste residuals, to the extent they exist, are identified in Section 4.3.

\subsection{Federal Regulatory History of Wastes from the Combustion of Coal}

Before 1976, there were no federal regulations specifically relating to coal combustion wastes. The two major federal laws addressing solid wastes, the Solid Waste Disposal Act of 1965 and the Resource Recovery Act of 1970 , were aimed primarily at municipal solid waste and had no specific language directed to coal combustion wastes. Furthermore, there was little authority in these laws to issue regulations. The federal government issued general guidelines and provided technical assistance, but had little power to regulate waste-generating operations.

The 1976 Resource Conservation and Recovery Act (RCRA) greatly expanded the role of the federal government in regulating solid waste handling and disposal. Under RCRA, solid wastes were originally divided into two broad categories: 1) hazardous wastes, and 2) all other solid wastes. Subtitle C of RCRA addresses hazardous wastes; Subtitle $D$ focuses on nonhazardous wastes. Under RCRA, solid wastes are classified as hazardous if they are specifically listed by the U.S. Environmental Protection Agency (EPA), or exhibit characteristics of ignitability, corrosivity, reactivity, and/or toxicity as defined by EPA. Since EPA regulations did not embrace a degree-of-hazard concept, any 
waste qualifying as hazardous would be subject to stringent management restrictions. Recognizing the cost implications for certain highvolume wastes and anticipating imminent RCRA reauthorization addressing this issue, EPA created a third "special waste" category for low-hazard residuals, which were so designated on the basis of testing by generating source. Wastes within this category were excluded from regulation as hazardous wastes under RCRA Subtitle C. The regulatory exemption, however, was not universal: several states, which can implement programs that are more stringent than the federal government's, require generators of special waste to test for the RCRA characteristics to determine whether it is hazardous waste.

A provision of the Solid Waste Disposal Act Amendments, enacted in October 1980 , temporarily exempted from regulation as Subtitle $C$ hazardous wastes certain highvolume wastes generated primarily from the combustion of coal or other fossil fuels, pending completion of an EPA Report to Congress (RTC) and a subsequent regulatory determination of whether such regulation is warranted. (One provision, the "Bevill exemption," is named after the sponsoring Congressman.) Specifically, EPA was directed to conduct a detailed and comprehensive study and submit an RTC on the adverse effects on human health and the environment, if any, from the disposal and utilization of fly ash, bottom ash, boiler slag, and flue dust ("largevolume wastes"), and other by-product materials generated primarily from the combustion of coal or other fossil fuels ("lowvolume wastes"). [Low-volume wastes are within the Bevill exemption only if they are co-managed with large volume waste. Lowvolume wastes that are independently managed are not and never have been within the scope of the Bevill exemption, and are, therefore, subject to RCRA Subtitle $C$ if they exhibit a hazardous characteristic.] A flow chart describing waste classification under the Bevill exemption is presented in Figure 22.
With the Hazardous and Solid Waste Amendments of 1984 (HSWA), Congress legislated greater flexibility into the waste management program for high-volume wastes by authorizing EPA to promulgate management requirements for fossil fuel combustion (FFC) wastes that were less restrictive than management standards for hazardous wastes, as long as human health and the environment were protected. Under the amendments, if EPA determined that any wastes from FFC should be regulated as hazardous, the agency could relax certain stringent requirements of the Subtitle C program to consider the special characteristics of the wastes, the practical difficulties of implementing the standards, and site-specific characteristics.

EPA submitted the RTC in February $1988{ }^{1}$, summarizing its analysis of the potential effects of the four large-volume wastes, as well as data on other wastestreams typically generated in lower volumes ("low-volume wastes") by coal-fired utilities. [The report identified low-volume wastes generated by coal-fired electric utilities (e.g., boiler blowdown, cooling tower blowdown, coal pile runoff, boiler cleaning wastes) that may exhibit the corrosivity and toxicity hazardous waste characteristics and are typically mixed with, co-disposed, or co-treated with the four largevolume wastes. EPA indicated that additional study of low-volume wastes was warranted.] The report, however, addressed only wastes from the combustion of coal by electric utilities, and deferred to a later date study of the disposal and utilization of wastes generated by oil- and gas-fired utilities, as well as coal combustion in industries other than the electric utility industry. EPA was primarily concerned with the potential for waste leachate causing groundwater contamination at utility waste management facilities. On the basis of its analysis, EPA indicated that the four largevolume wastes are generally nonhazardous. EPA determined that leachate concentrations of three metals (cadmium, chromium, and arsenic) were occasionally detected above the toxicity 
Acronyms

BIF - Boller or industrial fumace FBC - Fuldized bed combustion

FFC - Fossil fuel combustion

HW - Hazardous waste

IPPz - Independent power producers not engaged in any other industral activity

LgVW - Large-volume waste

LOVW-Low-yolume waste

RCRA - Rescurce Conservation and Recovery Aa

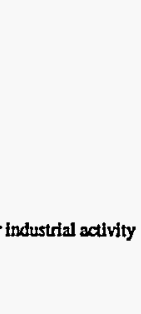

Subject to RCRA Subitie C/State HW Regutation

C HW Regulation

Subject to Subtitle D/

State Regulation

4

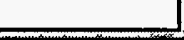

Footrotes

1 To be ellgible for the Bevill exemption afforded under RCRA Section 3001 (b) $3 \times(A)(i)$ for fly ash waste, bottom ash waste, slag wastc, fluc gas enission control waste, and other by-product materfals generalted primstily from the combustlon of coal, EPA. longstanding pollcy is that the fuel mixture must be at least $50 \%$ cosl.

2 Large-volume wastes are fly ash, bottom ash, boiler slag, and nue gas emission control wastes.

3 Low-volume wastes are wastes produced in conjunction with the combustion of cosal and are not necessarily associated with the

production energy (by-product matertals). Only low-volume wastes

that are typically mixed with and co-disposed or co-treated with

the large-volume wastes are eligible for Bevill status. These may

include boller blowdown, cooling tower blowdown, coal pile rusoor,

boller cleaning wastes, ele. (see 58 Fodernl Register 42470, Au gust

9, 1993). Low-volume wastes that are segregated and disposed of

separatcly from coal combustion waste are not eligible for the

4 Sce EPA's Flngl Regulatory Determinaston on Four Large.Volume (1903

5 "These wastes are "remaining wastes" outside of the Final

Regulatory Determination referenced in footnote 4 and remaln

temporarily exempe from RCRA Subtitle C hazardous waste

requirements unili April 1, 1998, at the latest.

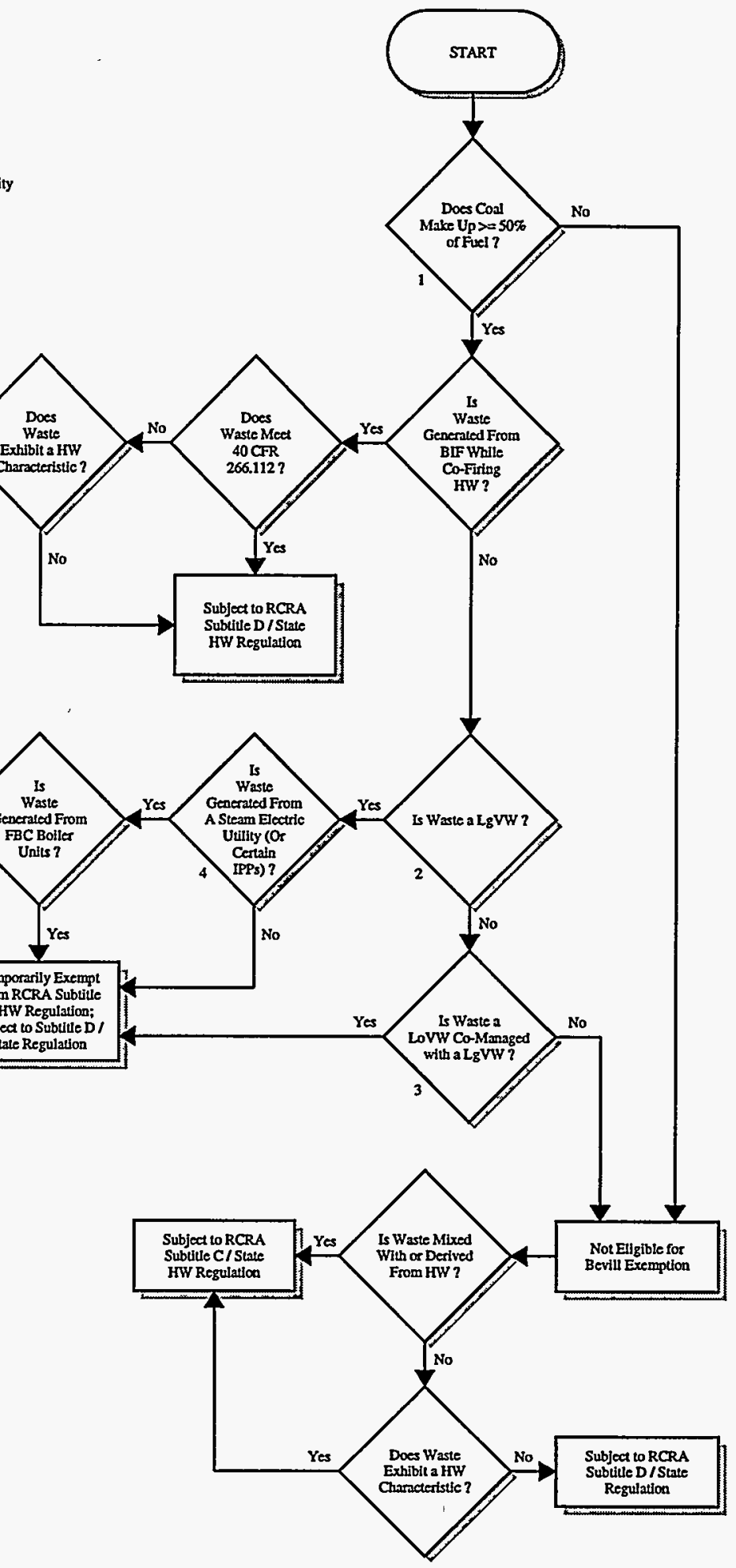

Figure 22. RCRA Bevill Status of Coal Combustion Wastes 
characteristic regulatory levels in ash or sludge samples. EPA also determined that the migration of potentially hazardous constituents from utility waste disposal sites resulted in few exceedances of primary drinking water standards downgradient from the sites and that exceedances of surface water quality standards were of low magnitude. This information, coupled with findings that exposure routes were unlikely and that current waste management practices appeared adequate, led EPA to tentatively recommend in the RTC that the four large-volume wastes remain exempt from Subtitle $C$ regulation.

EPA was to issue the final regulatory determination within six months after the RTC. After missing that deadline, EPA was sued and agreed to complete the determination for FFC wastes in two phases: 1) a regulatory determination for fly ash waste, bottom ash waste, slag waste, and flue gas emission control waste (high-volume wastes) would be finalized by August 2, 1993; and 2) for all remaining wastes (low-volume wastes), EPA would complete further studies by September 30,1997 , and issue a final regulatory determination by April 1, 1998.

After receiving public comments on the RTC, collection of supplemental data, and subsequent analysis, EPA published a final regulatory determination on August 9, 1993, concluding that, except for fluidized bed combustion (FBC) wastes as explained below, regulation as hazardous waste under Subtitle C is inappropriate for the four waste streams studied because of the limited risks they pose and the existence of adequate state and federal regulatory programs. The determination, effective September 2, 1993, applies only to the large-volume wastes generated by coalfired units at steam electric utility power plants, including independent power producers not engaged in other industrial activity, as long as the wastes are managed separately from other FBC wastes.
Therefore, while the four large-volume wastes generated by coal-fired electric utilities (and certain independent power producers) are permanently exempt from Subtitle $C$ regulation by EPA's August 9, 1993 regulatory determination, the following wastes are not covered by the determination:

- Large-volume wastes (i.e., fly ash, bottom ash, boiler slag, or flue gas emission control wastes) that are mixed with, co-disposed, co-treated, or otherwise co-managed with low-volume wastes generated in conjunction with the combustion of coal or other fossil fuels (e.g., boiler blowdown discharged to a large-volume waste impoundment, oil ash disposed of in a large-volume landfill).

- Wastes generated while co-firing coal and other materials. (However, if the other material is hazardous waste, the residue continues to remain exempt from Subtitle $\mathrm{C}$ regulation as long as $50 \%$ of the feed is coal and the residue passes a two-part test specified in the boiler and industrial furmace rules in 40 CFR Part 266, Subpart H.)

- Large-volume wastes generated by utilities with units firing fossil fuels other than coal.

- Large-volume wastes generated by non-utility boilers burning any type of fossil fuel.

- Large- and low-volume wastes from FBC units.

- Low-volume wastes.

These wastes are now assigned to the category of "remaining wastes" that will continue to be temporarily exempt from Subtitle C regulation until at least April 1, 1998, when EPA will make its final determination of whether hazardous waste 
regulation is warranted for the "remaining wastes." In the interim, these wastes will continue to be regulated as nonhazardous waste by individual states under RCRA Subtitle D and state solid waste laws, resulting in substantial variation in applicable requirements. [Note that the large-volume wastes from coalfired utilities covered by the August 1993 final regulatory determination will be regulated by the same authorities (i.e., Subtitle D or state) as the wastes just listed, but the exemption for the listed wastes is temporary, pending the later determination by EPA.]

\subsection{General Overview of the Current Federal Regulatory Program}

Subtitle D of RCRA establishes a framework for the control and management of nonhazardous solid waste. The federal role is limited; the responsibility for planning and implementing solid waste programs under Subtitle D rests principally with state and local governments. The federal government provides: 1) technical assistance to states; and 2) general regulatory direction to state and local governments by mandating minimum federal standards contained in 40 CFR 256, 257 , and 258. State plans for managing solid waste are required to be developed and submitted to EPA for approval under federal guidelines found at 40 CFR 256. State and local governments have the option to implement solid waste management programs that are more stringent than those specified by the federal criteria.

Minimum technical standards for solid waste disposal facilities are contained in 40 CFR 257, Criteria for Classification Solid Waste Disposal Facilities and Practices ${ }^{2}$, and a recently promulgated and subsequently amended 40 CFR 258, Criteria for Municipal Solid Waste Landfills ${ }^{3}$. Part 257 was first promulgated in 1979 under Subtitle D authority; Part 258 was developed in response to a provision in the Hazardous and Solid Waste Amendments (HSWA) of 1984 that directed EPA to revise the Part 257 criteria for the subset of facilities that "may receive hazardous household wastes or hazardous wastes from (RCRA) conditionally exempt small quantity generators (SQGs)." [Conditionally exempt small quantity generators generate $\leq 100$ kilograms (about 200 pounds or 25 gallons) of nonacute hazardous waste and/or $\leq 1$ kilogram (about 2 pounds) of acute hazardous waste in a calendar month. This waste may be disposed of in a hazardous waste facility or municipal or industrial solid waste facility.] EPA identified the scope of the HSWA mandate to include: 1) municipal solid waste landfills (MSWLFs); and 2) some industrial solid waste disposal facilities and certain other Subtitle D facilities which may receive conditionally exempt SQG hazardous waste. EPA is undertaking revisions to the Part 257 criteria in two phases: the first phase, the establishment of a new Part 258 addressing MSWLFs, is completed; the second phase, which is under development at the agency, must address other Subtitle D facilities, such as noncommercial nonhazardous waste landfills that accept small quantities of hazardous waste (such as industrial landfills that accept hazardous waste). Pursuant to a judicial consent decree, the second phase Subtitle D regulations must be proposed by EPA by May 15, 1995, and promulgated by July 1, 1996. The new Part 258, establishing minimum national criteria for the location, design, operation, cleanup, and closure of MSWLFs, is far more comprehensive than Part 257 and may be representative of how EPA will approach the second phase regulation of nonmunicipal industrial disposal facilities that accept hazardous waste.

Part 257 applies to all facilities (landfills, surface impoundments, land application units, and waste piles) used for disposal of all types of solid waste (municipal, industrial, commercial, agricultural, mining, and oil and gas waste) regulated under Subtitle $D$, with certain exceptions. One of those exceptions is for any municipal solid waste landfill unit subject to the new Part 258. Part 258 contains 
minimum criteria that apply to landfills that receive household waste (even though the landfills may accept other types of waste as well, i.e., commercial and industrial hazardous waste, nonhazardous sludge). Therefore, a nonmunicipal (i.e., industrial) landfill that accepts only nonhazardous waste is subject to Part 257.

The criteria of Parts 257 and 258 are used to determine which solid waste facilities and practices may adversely affect human health or the environment. Facilities that do not meet the specified criteria in Part 257 and Part 258 are considered "open dumps" for purposes of state solid waste management planning. Under RCRA and its regulations, there is a ban on "open dumping"; new open dumps are prohibited and existing open dumps are required to be upgraded or closed.

\subsubsection{Part 257 Criteria for Classification of Solid Waste Disposal Facilities}

Part 257 contains general environmental siting and performance standards for affected solid waste disposal facilities that address the following areas: 1) floodplains; 2) endangered species; 3) surface water; 4) groundwater; 5) land application; 6) disease; 7) air; and 8) safety. A brief description of these standards appears below.

1) Facilities or practices in floodplains must not interfere with the floodplain or result in carrying away of solid waste so as to present a hazard to human life, wildlife, or land or water resources.

2) Facilities or practices must not cause or contribute to the taking of any endangered or threatened species or result in the destruction or adverse modification of the critical habitats of these species.

3) Facilities must not cause an unauthorized discharge of pollutants or dredged or fill material to waters of the United States, and facilities or practices must not cause unauthorized non-point source pollution of such waters.

4) Facilities or practices must not cause or contribute to exceedances of the Safe Drinking Water Act Maximum Contaminant Levels (MCLs) in an underground drinking water source beyond the solid waste unit boundary or beyond an alternative boundary specified by the State.

5) Facilities or practices involving the application of waste to land used for producing food crops must meet certain restrictions about the concentrations of cadmium and polychlorinated biphenyls (PCBs) contained in the wastes.

6) Facilities or practices must implement appropriate disease vector controls, such as the periodic application of cover material.

7) Facilities or practices must not openly burn solid waste (with specified exceptions) and must comply with applicable provisions of State Implementation Plans developed under section 110 of the Clean Air Act.

. 8) Facilities or practices must control explosive gases, fires, bird hazards to aircraft, and public access to the site.

\subsubsection{Part 258 Criteria for Municipal Solid Waste Landfills}

Part 258 prescribes siting restrictions, design standards, operating criteria, groundwater monitoring and corrective action requirements, and closure/post-closure standards for municipal solid waste landfills. States receiving authorization to implement their own programs will have more flexibility in program implementation, such as adopting standards to meet more site-specific conditions. To receive 
authorization, states must establish municipal solid waste landfill (MSWLF) permit programs. Strict compliance with federal standards will be required in states without approved programs. Most provisions of the Part 258 criteria were effective for most MSWLF units on October 9, 1993. A brief list of the Part 258 criteria is presented in Table 16.

Since the original promulgation of Part 258 in October 1991, EPA was sued, in 1992, by two environmental groups. The suit was based, in part, on two allegations: 1) the 1991 rule, which exempted small MSWLFs from groundwater monitoring requirements, conflicted with the statutory mandate to require such monitoring at all landfills; and 2) in issuing the October 1991, Part 258 rule for only MSWLFs, EPA failed to carry out the statutory mandate that EPA promulgate revisions to Part 257 (i.e., issue Part 258) addressing all "facilities that may receive hazardous household wastes or hazardous wastes from small quantity generators," which would also include nonmunicipal Subtitle D facilities such as industrial landfills that receive small quantities of hazardous waste. [Note that Congress had established a statutory deadline of March 31, 1988, for EPA to issue revised regulations.]

In its May 7, 1993, opinion ${ }^{4}$, the court agreed that the statute does mandate groundwater monitoring at all Subtitle D facilities, vacated that part of the small landfill exemption, and required EPA to revise the rule so that "small" MSWLFs are not exempt from groundwater monitoring requirements. EPA published a regulatory amendment to that effect on October 1, 1993.

Furthermore, the court agreed that EPA was required to complete, by the deadline in the statute (which had already passed), rulemaking revisions for all facilities noted in 2) above, and not just MSWLFs (the "second phase" of the revisions to Part 257 previously mentioned). However, the court did not rule on that claim, asserting that the district court, rather than the court of appeals, had jurisdiction. Note that, at a minimum, EPA has to promulgate by July 1,1996 , a rule addressing the limited universe of nonmunicipal (e.g., industrial) facilities that receive small quantities of hazardous waste. The rule could, but is not required to address, for example, an industrial landfill that accepts only nonhazardous waste. The scope of the rule is undetermined at this point. If it does not address nonmunicipal nonhazardous waste facilities, they would still be regulated by the environmental performance standards of Part 257.

As evidenced by the above discussion, the federal regulatory history of Subtitle D facilities and wastes is checkered and reveals a trend toward stricter regulation. In past negotiations over RCRA reauthorization, congressional attempts have been made to increase the stringency of Subtitle D requirements by making them similar to the Subtitle $\mathrm{C}$ hazardous waste management scheme. In addition, with promulgation of more burdensome Part 258 regulations and judicial sentiment affirming that a Subtitle D management program for certain nonmunicipal industrial waste facilities is statutorily required, it is likely that the federal minimum criteria for industrial solid waste facilities receiving small quantities of hazardous waste will be more like Subtitle $C$ hazardous waste requirements than Part 258 requirements. If the scope of the future regulation encompasses industrial nonhazardous waste facilities (even though it is not required to do so), states will be required to follow suit. Upcoming RCRA reauthorization debate is likely to include a discussion of risk-based approaches to facility engineering and design, as well as other changes to the current system of numerical performance standards. 


\section{Table 16}

\section{Summary of Subtitle D Part 258 Criteria}

\begin{tabular}{|c|c|}
\hline Criteria & Restrictions or Requirements \\
\hline Location & $\begin{array}{l}\text { Six siting restrictions address airport safety, floodplains, wetlands, faults, } \\
\text { seismic impact zones, and unstable areas. All apply to new MSWLFs and } \\
\text { lateral expansions of existing MSLFs; only airport safety, floodplain, and un- } \\
\text { stable area criteria apply to existing MSWLFs. If existing units are unable to } \\
\text { meet applicable requirements by a specified date, they must close. }\end{array}$ \\
\hline Design & $\begin{array}{l}\text { Design criteria are established for new MSWLFs and lateral expansions, unless } \\
\text { the conditions of a small community exemption are met. If a MSWLF unit is } \\
\text { located in a state without an EPA-approved permit program, a composite liner } \\
\text { system, consisting of a flexible membrane liner and a compacted soil } \\
\text { component, and a leachate collection removal system, is required. If the unit is } \\
\text { located in a state with an EPA-approved state permit program, a design for the } \\
\text { unit must be developed to meet the performance standard and must be } \\
\text { approved by the state. The performance standard requires that the design } \\
\text { ensure that maximum contaminant levels (MCLs) will not be exceeded at the } \\
\text { relevant point of compliance (to be determined by the state). When evaluating } \\
\text { whether the performance standard is met, the state must consider such site- } \\
\text { specific factors as climate, hydrogeology, and groundwater use. }\end{array}$ \\
\hline Operating & $\begin{array}{l}\text { Operating criteria applicable to all MSWLFs include preventing disposal of } \\
\text { hazardous and PCB wastes, providing at least six inches of daily cover, } \\
\text { controlling on-site disease vectors, routinely monitoring methane gas, eliminat- } \\
\text { ing most open burning, controlling public access, constructing run-on and run- } \\
\text { off control systems, controlling discharges to surface waters, halting disposal of } \\
\text { most liquid wastes, and keeping records of compliance. }\end{array}$ \\
\hline $\begin{array}{l}\text { Groundwater } \\
\text { Monitoring }\end{array}$ & $\begin{array}{l}\text { All MSWLF units (except for MSWLF units that are granted waivers because } \\
\text { site-specific conditions prevent groundwater contamination) are required to } \\
\text { install groundwater monitoring systems and institute a three-tiered sampling and } \\
\text { analysis program (detection monitoring, assessment monitoring, and corrective } \\
\text { action) during the active life of the facility, closure, and post-closure, similar to } \\
\text { that conducted at hazardous waste landfills. }\end{array}$ \\
\hline $\begin{array}{l}\text { Closure and } \\
\text { Post Closure }\end{array}$ & $\begin{array}{l}\text { For MSWLFs, closure and post-closure plans must be developed. During } \\
\text { closure, units must install a final cover to minimize infiltration and erosion; } \\
\text { such cover must include an } 18 \text {-inch soil layer with a permeability 1) less than } \\
\text { or equal to the permeability of the bottom liner system or natural subsoils, or 2) } \\
\text { no greater than } 1 \times 10^{-5} \mathrm{~cm} / \mathrm{sec} \text {, whichever is less. The layer must be overlain } \\
\text { by a 6-inch layer of soil capable of sustaining native plant growth. Post- } \\
\text { closure care, conducted for } 30 \text { years, must include maintenance of the final } \\
\text { cover, and continuance of groundwater monitoring, gas monitoring, and } \\
\text { leachate management. }\end{array}$ \\
\hline
\end{tabular}




\subsection{State Regulations}

As illustrated in Section 4.2, state agencies are, and may continue to be, the primary authorities for implementing regulations covering the disposal of wastes from advanced coal combustion technologies, and state regulations vary widely. Some states, such as Texas, have issued regulations for MSWLFs that conform to Part 258, but do not have regulations pertaining to industrial nonhazardous waste disposal. As a result, MSWLFs affected by the Texas rules would require permits, liners, leachate collection, groundwater monitoring, closure and postclosure care, etc. An industrial nonhazardous landfill may be governed by state guidelines and may not be required to incorporate such protections. As another example, Kentucky has crafted a special waste category for disposal of coal combustion by-products and generally has environmental performance standards and siting requirements that apply.

Some states have required industrial nonhazardous wastes to be disposed of in MSWLFs, which, before 1991, simply meant disposal into landfills meeting the eight environmental performance standards of Part 257. With the promulgation of Part 258, states have been upgrading their MSWLF standards to conform to Part 258, and, in many cases, have included industrial nonhazardous waste within the scope of their revised Subtitle D MSWLF regulations, even though they are not required to include them. In those states, standards for industrial nonhazardous waste disposal have been strengthened.

Most states have sufficiently broad legislative authority to regulate coal combustion waste disposal to some degree. Some states have laws that allow the direct control of solid wastes. Other states have indirect control through the implementation of regulations designed to protect groundwater or limit activities in floodplains. Because there are no generally accepted criteria for disposing of wastes generated by advanced coal technologies, and because the material is relatively new, some states have imposed regulations developed for other materials. Requirements have been derived from regulations such as those for municipal waste landfills, sewage lagoons, phosphate slime disposal, acid mine drainage sludges, and mine and smelter tailings. Some of these requirements may apply, but many may be irrelevant or unnecessary. Because of this problem, most states that have to review permits for advanced coal combustion waste disposal will proceed cautiously, issuing permits on a case-by-case basis.

Several states (shown in Figure 23) were selected to illustrate the diversity of state regulations. Table 17 presents a summary of certain requirements listed in various state coal combustion waste disposal regulations. As shown, many states do allow disposal sites to modify or be exempt from certain design elements, such as liner systems, groundwater monitoring, and/or leachate collection systems if it can be demonstrated that performancebased standards will still be met. Such reduced requirements may also be permitted for design elements that do not apply to a specific waste type; for example, daily cover requirements or methane gas monitoring may not apply to most coal combustion wastes. However, state regulations do vary significantly from state to state and are subject to change.

In addition to Table 17, the following chapters discuss some of the regulations that apply to coal combustion wastes in the States of Georgia, Pennsylvania, and Illinois. The discussion on Georgia is more extensive than those on the other states in order to illustrate some of the detailed standards contained in state rules. Applicable state regulations, however, must be carefully reviewed and evaluated before proceeding with the site selection or design process. 


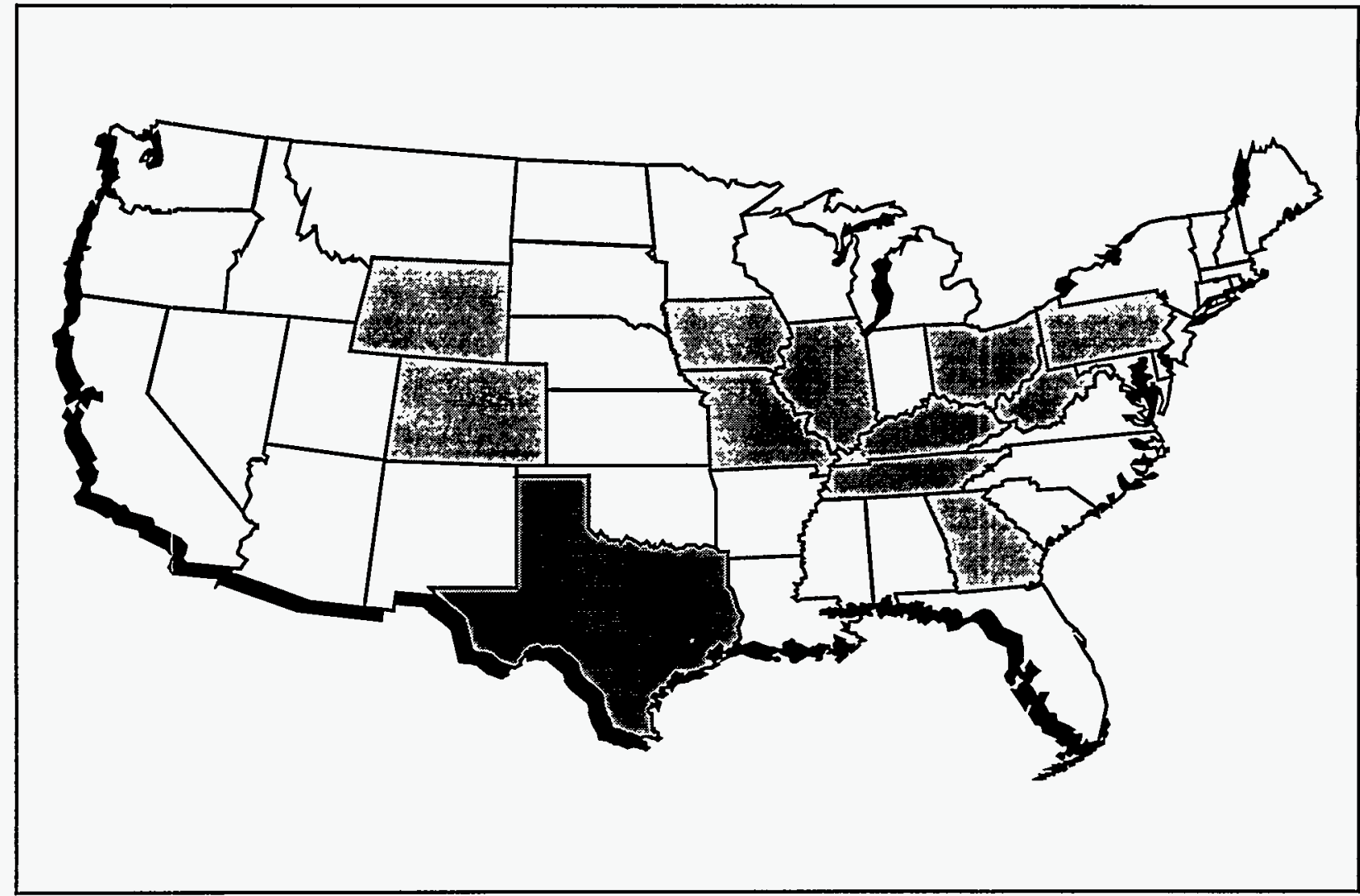

Figure 23. States Included in the Regulatory Review

\subsubsection{Georgia}

Georgia's solid waste regulations ${ }^{5}$ were recently amended and became effective on June 27, 1993. In Georgia, permits are required to construct or operate a solid waste handling facility. The wastes resulting from coal combustion are classified as industrial wastes (if they are not hazardous waste when tested).

An industrial waste disposal facility permitted as a monofill (receiving only a single type of industrial waste) or receiving only a single industry's waste may be given a variance from certain requirements. A variance may be granted if the applicant can demonstrate to the satisfaction of the Director of the Department of Natural Resources that the waste to be disposed of would not cause ground or surface water contamination, cause odors, attract disease vectors or birds, or generate methane gas. Variances may be granted for any or all state requirements at the discretion of the Director. Disposal facilities that accept waste from more than one source, or monofills that cannot demonstrate the above must meet all standards that apply to MSWLFs.

General performance standards (Section 391-3-4-.04) exist to protect human health and the environment against disease vectors, animal nuisances, degradation of air or ground or surface waters, and other public health and safety hazards. The standards also prohibit burning waste, scavenging, and operating an open dump. Siting criteria, landfill design, operations standards, closure criteria and post-closure care standards are mandated by state regulations and are briefly summarized in Table 18. 
Table 17

\section{Summary of Select Current State Coal Combustion Waste Regulations}

\begin{tabular}{|c|c|c|c|}
\hline \multicolumn{4}{|l|}{ State: Colorado } \\
\hline State Program & Liner System & \multicolumn{2}{|l|}{ Leachate Collection System } \\
\hline $\begin{array}{l}\text {-Coal combustion wastes are } \\
\text { industrial wastes; landfill } \\
\text { disposal is regulated by the } \\
\text { same regulations that apply } \\
\text { to municipal solid waste } \\
\text { landfills, Code of Colorado } \\
\text { Regulations, Title 6, Depart- } \\
\text { ment of Health, Chapter } \\
1007 \text { - Waste Management } \\
\text { Division, Article 2, Parts 1- } \\
\text { 3. }\end{array}$ & $\begin{array}{l}\text {-Liner design must consider } \\
\text { permeability, thickness, } \\
\text { porosity, slope, hydraulic } \\
\text { head, etc., } 3.2 .5 \text {. } \\
\text {-Barrier layer must be natural } \\
\text { lithology, compacted soil, or } \\
\text { composite liner, and meet } \\
\text { performance standards of } 40 \\
\text { CFR } 258.40(a)(1) ; \\
\text { requirements also specify } \\
\text { thickness, hydraulic con- } \\
\text { ductivity, moisture content, } \\
\text { etc., for each liner type, } \\
\text { 3.2.5(C). } \\
\end{array}$ & \multicolumn{2}{|c|}{$\begin{array}{l}\text {-Leachate collection system design to maintain less than } 12 \text { inch depth of } \\
\text { leachate over barrier layer, and to promote leachate transport from collection } \\
\text { to removal system in less than } 12 \text { months; factors to consider include waste } \\
\text { type, leachate generation rate, slope, barrier layer, hydraulic conductivity of } \\
\text { the drainage layer, and long-term performance, } 3.2 .5(D)(1) \text {. } \\
\text {-Leachate removal system design must meet performance standards, } \\
\text { 3.2.5(D)(2). }\end{array}$} \\
\hline \begin{tabular}{|c|} 
Groundwater Monitoring \\
\end{tabular} & Final Cover & Reduced Requirements & Comments \\
\hline $\begin{array}{l}\text {-Landfill must comply with } \\
\text { "groundwater protection } \\
\text { standards" (i.e., } 40 \text { CFR } \\
258.55(h) \text { and (i)), 1.2, } \\
2.1 .15 \text {, and Appendix B. } \\
\text {-Establish background con- } \\
\text { centrations, sample quarterly } \\
\text { for first year for (1) 17 } \\
\text { indicator parameters } \\
\text { (Appendix IA, which } \\
\text { includes potassium, calcium, } \\
\text { chloride, sulfate, and pH); } \\
\text { and (2) Appendix IB consti- } \\
\text { tuents (identical to } 40 \text { CFR } \\
\text { Part } 258, \text { Appendix I), i.e., } \\
15 \text { inorganics (including } \\
\text { arsenic, barium, cadmium } \\
\text { chromium, copper, lead, } \\
\text { selenium, silver, and zinc), } \\
\text { and } 47 \text { vOCs; repeat } \\
\text { sampling and analysis } \\
\text { required during active life } \\
\text { (including closure) and post- } \\
\text { closure care; at least } \\
\text { semiannual sampling during } \\
\text { active life unless alternative } \\
\text { frequency established, } \\
\text { Appendix B, B4(B). } \\
\text {-Semi-annual detection } \\
\text { monitoring for Appendix IA } \\
\text { and IB constituents, } \\
\text { Appendix B, B4(A). } \\
\text {-On a site-specific basis and } \\
\text { after consulting with local } \\
\text { governing authority, state } \\
\text { may add or delete } \\
\text { parameters to be monitored, } \\
\text { Appendix B, B4(A)(1) and } \\
\text { (2). }\end{array}$ & $\begin{array}{l}\text {-Soil or composite final cover } \\
\text { allowed: soil cover require- } \\
\text { ments specify infiltration } \\
\text { layer and erosion layer } \\
\text { thickness, and infiltration } \\
\text { layer permeability; composite } \\
\text { cover requirements specify } \\
\text { soil and membrane thickness; } \\
\text { grading/ slope specified, } 3.5 .2 \\
\text { and 3.5.3. } \\
\text { - Factors to consider for } \\
\text { composite covers include } \\
\text { permeability, seam strength, } \\
\text { friction properties, puncture } \\
\text { resistance, rooting layer, } \\
\text { 3.5.3(B)(2). }\end{array}$ & $\begin{array}{l}\text {-A waiver from } \$ \$ 2 \text { through } 13 \text { may be granted if certain } \\
\text { site-specific technical information is provided and deter- } \\
\text { mined to be adequate justification. Request must be } \\
\text { made to state and local authority, } 1.5 .1,1.5 .2 \text {. } \\
\text { - On a case-by-case demonstration basis, the application } \\
\text { of Section } 3 \text {, standards for solid waste disposal landfill } \\
\text { sites and facilities, to non-MSWLF facilities (e.g., indus- } \\
\text { trial landfills) may be altered provided the alternative } \\
\text { standard is equivalent in protection, } 3.0 .2 \text {. } \\
\text {-Alternative liner systems, including geosynthetic clay } \\
\text { liners, natural lithology without compaction, soil admix- } \\
\text { tures, geomembranes, polymers, and other variations, } \\
\text { may be approved, } 3.2 .5(C)(4) \text {. } \\
\text {-Alternative final cover designs (including geocomposite } \\
\text { materials, soil admixtures, polymers, and other variations) } \\
\text { may be approved and must minimize infiltration and ero- } \\
\text { sion, 3.5.3(C). } \\
\text {-Alternative groundwater monitoring systems may be } \\
\text { approved based on site-specific technical information and } \\
\text { may include vadose zone monitoring, wet/dry monitoring, } \\
\text { or other systems, Appendix B, B2(D). } \\
\text {-Explosive gas monitoring required: within facility struc- } \\
\text { tures, } 25 \% \text { of lower explosive limit (LEL)(1\% by volume } \\
\text { in air for methane); at the boundary, the LEL is 5\% by } \\
\text { volume in air for methane, } 2.3 \text {. } \\
\text {-Recycling regulations under } \$ 8 \text { are being drafted; should } \\
\text { be final fall 1994. } \\
\text {-Certificate of designation (permit) is unnecessary where } \\
\text { owner/operator disposes of own solid waste on site and } \\
\text { CO Dept of Health determines disposal operations will } \\
\text { comply with regulations, } 1.4 .1 \text {. } \\
\text {-Groundwater monitoring requirements of Appendix B } \\
\text { may be waived by the Dept. after consultation with the } \\
\text { local authority if facility demonstrates there is no migra- } \\
\text { tion potential. If waived, the facility must make demon- } \\
\text { stration every five years, Appendix B, BI. } \\
\text {-Waiver of } 3.2 \text { Design Criteria and/or } 2.2 \text { Groundwater } \\
\text { Monitoring and Corrective Action requirements may be } \\
\text { granted if demonstrated less than } 20 \text { tons/ day of } \\
\text { municipal solid waste is disposed of, and other specified } \\
\text { site-specific characteristics are met, } 1.5 .3 \text {. }\end{array}$ & \\
\hline
\end{tabular}


Table 17

(Continued)

\begin{tabular}{|c|c|c|c|}
\hline \multicolumn{4}{|l|}{ State: Georgia } \\
\hline State Program & Liner System & \multicolumn{2}{|l|}{ Leachate Collection System } \\
\hline $\begin{array}{l}\text { Rules and Regulations of } \\
\text { GA, Title 391, Article 3, } \\
\text { Chapter 4, Solid Waste } \\
\text { Management }\end{array}$ & $\begin{array}{l}\text {-Liner and leachate collections } \\
\text { system required and must } \\
\text { ensure that concentrations of } \\
24 \text { constituents (those in } 40 \\
\text { CFR Part } 258, \text { Subpart E, } \\
\text { Design Criteria) are not } \\
\text { exceeded, 391-3-4-.7(1)(d). } \\
\text {-If landfill is located in area of } \\
\text { higher pollution susceptibility } \\
\text { as defined by rules, or in a } \\
\text { significant groundwater } \\
\text { recharge area, as defined, then } \\
\text { systems requirement specifies } \\
\text { a composite liner of certain } \\
\text { thickness, density, hydraulic } \\
\text { conductivity, etc., be used, } \\
391-3-4-.07(1)(d) 1 . \\
\end{array}$ & \multicolumn{2}{|l|}{ See liner requirements. } \\
\hline \begin{tabular}{|l|} 
Groundwater Monitoring \\
\end{tabular} & Final Cover & Reduced Requirements & Comments \\
\hline $\begin{array}{l}\text {-At least semiannual } \\
\text { detection monitoring } \\
\text { required for same } 62 \\
\text { constituents as that in } 40 \\
\text { CFR Part 258, Subpart E } \\
\text { (Groundwater monitoring } \\
\text { and corrective action), } \\
\text { Appendix I, 391-3-4-,14(4) } \\
\text { and (21). }\end{array}$ & $\begin{array}{l}\text { Final cover must be installed } \\
\text { that complies with } 40 \text { CFR } \\
\text { Part 258, Subpart F, } 258.60 \\
\text { (i.e., erosion layer underlain by } \\
\text { an infiltration layer of spe- } \\
\text { cified thickness and } \\
\text { permeability), 391-3-4-11. }\end{array}$ & $\begin{array}{l}\text {-Disposal facility permitted to receive single type } \\
\text { industrial waste (monofill) or only a single industry's } \\
\text { waste may apply for variance from liner/ leachate } \\
\text { collection system, groundwater monitoring and methane } \\
\text { gas monitoring requirements, 391-3-4-07(4)(a). } \\
\text {-Groundwater monitoring requirements may be } \\
\text { suspended if demonstrated that there is no potential for } \\
\text { migration of hazardous constituents from the unit to the } \\
\text { uppermost aquifer during its active life and post-closure } \\
\text { care period, } 391-3-4-14(2) \text {. } \\
\text {-Director may delete any of Appendix I groundwater } \\
\text { monitoring constituents if can be shown that removed } \\
\text { constituents are not reasonably expected to be contained } \\
\text { in or derived from the waste in the unit, 391-3-4 } \\
\text {.14(21)(a). } \\
\text {-Indicator parameters for groundwater sampling may be } \\
\text { chosen for inorganic constituents in Appendix I for } \\
\text { groundwater detection monitoring, 391-3-4-.14(21)(b). } \\
\text {-Alternate groundwater monitoring frequency (no less } \\
\text { than annual) for Appendix I constituents or indicator } \\
\text { parameters may be approved by state, 391-3-4-14(22). } \\
\text {-Alternate final cover design may be approved by state } \\
\text { if equivalent in protection, } \\
391-3-4-11 \text {. }\end{array}$ & $\begin{array}{l}\text {-Surface water } \\
\text { monitoring required } \\
\text { in accordance with } \\
\text { approved plan to } \\
\text { determine impact of } \\
\text { facility on adjacent } \\
\text { surface waters, 391- } \\
3-4-.07(1)(1) \text {, and } \\
(3)(j) \text { and }(v) \text {. }\end{array}$ \\
\hline
\end{tabular}




\section{Table 17 (Continued)}

\begin{tabular}{|c|c|c|c|}
\hline \multicolumn{4}{|l|}{ State: Illinois } \\
\hline State Program & Liner System & \multicolumn{2}{|c|}{ Leachate Collection System } \\
\hline $\begin{array}{l}\text { Coal combustion waste is both a } \\
\text { special waste and a chemical } \\
\text { waste, regulated by Ill. Admin. } \\
\text { Code, Title 35, Subtitle G, } \\
\text { Chapter 1, Parts } 811-815 \text {. }\end{array}$ & $\begin{array}{l}\text {-Compacted earth liner re- } \\
\text { quirement specifies thickness, } \\
\text { hydraulic conductivity, with con- } \\
\text { stituent compatibility and con- } \\
\text { struction quality assurance } \\
\text { performance standards, } \\
811.306(d) \text {. } \\
\text {-Geomembranes, or slurry } \\
\text { trenches and cutoff walls used to } \\
\text { prevent leachate migration, may } \\
\text { be used only with compacted } \\
\text { earth liner, } 811.306(\mathrm{e}) \text {. }\end{array}$ & \multicolumn{2}{|c|}{$\begin{array}{l}\text {-Leachate drainage and collection system required, } 811.307-811.309 . \\
\text {-Both design specifications (e.g., headspace, hydraulic conductivity, } \\
\text { chemical compatibility, collection pipe design) and performance } \\
\text { standards included. } \\
\text {-Quarterly leachate monitoring for waste-specific constituents of } \\
\text { concern, including pH, total dissolved solids, regulated discharges to } \\
\text { POTWs or in NPDES permit, groundwater monitoring constituents, } \\
811.309(\mathrm{~g})(1),(3) \text {. }\end{array}$} \\
\hline Groundwater Monitoring & Final Cover & Reduced Requirements & Comments \\
\hline $\begin{array}{l}\text {-Hydrogeologic site investigation } \\
\text { required before permit application } \\
\text { (if required), } 811.315 \text {. } \\
\text {-Broad authority to choose con- } \\
\text { stituents for quarterly detection } \\
\text { monitoring, i.e., those expected to } \\
\text { be in leachate and may contribute } \\
\text { to groundwater contamination; } \\
\text { Organics analysis must be as } \\
\text { comprehensive and sensitive as } \\
\text { tests for } 51 \text { organic chemicals in } \\
\text { drinking water, any organics with } \\
\text { state groundwater quality standard } \\
\text { or criterion, } 811.319 \text { (a). }\end{array}$ & $\begin{array}{l}\text {-Low permeability layer overlain } \\
\text { by final protective layer, } 811.314 \text {. } \\
\text {-Low permeability layer may be } \\
\text { specified compacted earth layer, } \\
\text { geomembrane layer of equivalent } \\
\text { performance to earth layer, or } \\
\text { low permeability layer equivalent } \\
\text { in performance. } \\
\text {-Performance standard for final } \\
\text { protective layer. }\end{array}$ & $\begin{array}{l}\text {-Alternative liner specifications may be } \\
\text { used for hydraulic conductivity and } \\
\text { thickness provided specified conditions } \\
\text { are met and achieves equivalent } \\
\text { performance, } 811.306(d)(5) \text {. } \\
\text {-Alternative liner configurations, special } \\
\text { construction techniques, and admixtures } \\
\text { may be used provided they achieve } \\
\text { equivalent performance, successfully } \\
\text { utilized elsewhere, and QAVQC for } \\
\text { manufacturing and construction, } \\
811.306 \text { (g). } \\
\text { - On case-by-case basis, may seek } \\
\text { permanent adjustment of any standard } \\
\text { (may be more cost-effective than } \\
\text { permit process), section } 28.1 \text { Ill. Envi- } \\
\text { ronmental Protection Act; could allow } \\
\text { beneficial reuse of waste. } \\
\text {-Indicator constituents may be chosen, } \\
\text { reducing number of constituents for } \\
\text { detection monitoring, } 811.319 \text { (a)(2)(B). }\end{array}$ & $\begin{array}{l}\text {-On-site disposal of wastes } \\
\text { generated on-site are ex- } \\
\text { empt from requirement to } \\
\text { obtain permit for disposal } \\
\text { operations but must } \\
\text { comply with all standards } \\
\text { for special and chemical } \\
\text { wastes, section } 21(d), \text { Ill. } \\
\text { Environmental Protection } \\
\text { Act. } \\
\text {-A landfill gas monitoring } \\
\text { and landfill gas } \\
\text { management systems may } \\
\text { be required if certain } \\
\text { conditions are met, and } \\
\text { landfill gas processing and } \\
\text { disposal systems are en- } \\
\text { couraged, } 811.310-811.312 \text {. }\end{array}$ \\
\hline \multicolumn{4}{|l|}{ State: Iowa } \\
\hline State Program & Liner System & \multicolumn{2}{|c|}{ Leachate Collection System } \\
\hline $\begin{array}{l}\text { IA Admin. Code, Div. 567, Title } \\
\text { VIII, Chapter 103, Sanitary } \\
\text { Landfills, 103.2(455B). }\end{array}$ & $\begin{array}{l}\text { Recompacted soil liner re- } \\
\text { quirement specifies thickness, } \\
\text { permeability, density, 103.2(1)d. }\end{array}$ & \multicolumn{2}{|c|}{$\begin{array}{l}\text { Leachate collection, storage and treatment, and disposal system } \\
\text { requirement specifies grading, headspace depth, permeability, } \\
\text { collection pipe placement and construction, waste compatibility, } \\
\text { capacity, etc., 103.2(11). }\end{array}$} \\
\hline Groundwater Monitoring & Final Cover & Reduced Requirements & Comments \\
\hline $\begin{array}{l}\text {-First year sampling: quarterly for } \\
16 \text { constituents, including arsenic, } \\
\text { barium, cadmium, chromium, } \\
\text { lead, mercury, zinc, 103.2(4)d. } \\
\text {-Semiannual sampling for } 7 \text { pa- } \\
\text { rameters, including pH, chloride, } \\
\text { and any other parameters deemed } \\
\text { necessary, 103.2(4)e. } \\
\text {-Annual sampling for } 2 \text { parame- } \\
\text { ters and any other parameters } \\
\text { deemed necessary, 103.2(4)f. }\end{array}$ & $\begin{array}{l}\text { Compacted soil layer and } \\
\text { uncompacted soil layer require- } \\
\text { ments specify thickness, } \\
\text { permeability, composition, drain- } \\
\text { age, slope, etc., 103.2(13)b., c., } \\
\text { and d. }\end{array}$ & $\begin{array}{l}\text {-Waste-specific alternative liner system } \\
\text { providing equivalent protection as soil } \\
\text { liner may be approved; however, undis- } \\
\text { turbed soil will not be allowed for use } \\
\text { as liner material } 103.2(1) \text { e. } \\
\text {-Alternate methods and materials for } \\
\text { final cover may be permitted if } \\
\text { equivalent in performance, } \\
103.2(13) b .(4) \text {. } \\
\text {-Director may issue variances from any } \\
\text { of the listed rules. }\end{array}$ & $\begin{array}{l}\text {-Chapter 108, Reuse of } \\
\text { Solid Waste, establishes } \\
\text { conditions under which } \\
\text { coal combustion residue } \\
\text { may be reused. } \\
\text { - An approved landfill gas } \\
\text { monitoring and collection } \\
\text { or ventilation system as re- } \\
\text { quired by the closure } \\
\text { permit must be in place or } \\
\text { operating at closure unless } \\
\text { determined to be } \\
\text { unnecessary by state, } \\
103.2(13) g .\end{array}$ \\
\hline
\end{tabular}




\section{Table 17 \\ (Continued)}

\begin{tabular}{|c|c|c|c|}
\hline \multicolumn{4}{|l|}{ State: Kentucky } \\
\hline State Program & Liner System & \multicolumn{2}{|c|}{ Leachate Collection System } \\
\hline $\begin{array}{l}\text {-Coal combustion byproducts (see definition } \\
\text { in } 401 \text { Kentucky Administrative Regulations } \\
\text { (KAR) } 45: 010 \text {, Sec. } 1(4) \text { ) are special wastes } \\
\text { regulated by Kentucky special waste } \\
\text { regulations ( } 401 \mathrm{KAR} 30 \text { and } 45 \text { ). } \\
\text {-To be designated special waste, among other } \\
\text { criteria, levels of waste constituents must be } \\
\leq: \text { arsenic } 0.05 \mathrm{mg} / \mathrm{L} \text {; barium } 1.0 \mathrm{mg} / \mathrm{L} \text {; cad- } \\
\text { mium } 0.01 \mathrm{mg} / \mathrm{L} ; \text { hexavalent chromium } 0.05 \\
\text { mg/L; lead } 0.05 \mathrm{mg} / \mathrm{L} \text {; mercury } 0.002 \mathrm{mg} / \mathrm{L} \text {; } \\
\text { nitrate } 10.0 \mathrm{mg} / \mathrm{L} \text {; selenium } 0.01 \mathrm{mg} / \mathrm{L} \text {; and } \\
\text { silver } 0.05 \mathrm{mg} / \mathrm{L}, 401 \mathrm{KAR} 45: 210 \text {, Sec. } 2 \text {. } \\
\text {-Main thrust of special waste regulations is to } \\
\text { demonstrate compliance with environmental } \\
\text { performance standards of } 401 \mathrm{KAR} 30: 031 \\
\text { and Siting Requirements for Special Waste } \\
\text { Landfills) of } 401 \mathrm{KAR} 45: 130401 \mathrm{KAR} \\
45: 110 ; \text { technical requirements for special } \\
\text { waste landfills are found in } 401 \mathrm{KAR} 45: 030 \\
\text { (Obtaining a special waste site or facility } \\
\text { permit) and } 401 \mathrm{KAR} 45: 110 \text { (Technical and } \\
\text { operating requirements for special waste } \\
\text { landfills). }\end{array}$ & $\begin{array}{l}\text {-Compatibility with } \\
\text { waste and permeability } \\
\text { of liner must be consid- } \\
\text { ered, if a liner is re- } \\
\text { quired. Liner shall en- } \\
\text { sure containment of } \\
\text { waste on site and com- } \\
\text { pliance with } 401 \text { KAR } \\
\text { 30:031, } 401 \text { KAR } \\
\text { 45:110 Secs. 1(1) and } \\
\text { (4). }\end{array}$ & \multicolumn{2}{|c|}{$\begin{array}{l}\text {-Design of leachate control system must consider physical } \\
\text { characteristics of waste, climatic conditions of specific location, } \\
\text { and volume of leachate, } 401 \mathrm{KAR} 45: 110 \text { Sec. 1(7). }\end{array}$} \\
\hline Groundwater Monitoring & Final Cover & Reduced Requirements & Comments \\
\hline $\begin{array}{l}\text {-Groundwater monitoring system shall } \\
\text { accurately analyze groundwater quality and } \\
\text { characterize regional and local groundwater } \\
\text { flow and flow systems, } 401 \mathrm{KAR} 45: 160 \mathrm{Sec} \text {. } \\
2 \text {. } \\
\text {-Baseline groundwater quality characterization } \\
\text { parameters are specified for special waste } \\
\text { Iandfills used solely for disposal of coal } \\
\text { combustion byproducts, and include chloride, } \\
\text { pH, copper, nickel, zinc, arsenic, cadmium, } \\
\text { lead, mercury, selenium, calcium, potassium, } \\
\text { and sulfate, } 401 \mathrm{KAR} 45: 160 \text { Sec. } 7(2) \text {. } \\
\text {-Semiannual monitoring is required for } \\
\text { special waste landfills used solely for disposal } \\
\text { of coal combustion byproducts. Parameters } \\
\text { include chloride, pH, and copper. Monitoring } \\
\text { of additional parameters may be required } \\
\text { based on a significant increase from baseline } \\
\text { characterization, } 401 \mathrm{KAR} 45: 160 \text { Sec. } \\
\text { 8(2)(a) and (c). }\end{array}$ & $\begin{array}{l}\text {-Closure plan must be } \\
\text { submitted that includes } \\
\text { a closure design } \\
\text { specifying function and } \\
\text { design of final cover } \\
\text { considering type and } \\
\text { amount of waste, } \\
\text { mobility and migration } \\
\text { expected of waste or } \\
\text { leachate constituents, } \\
\text { site characteristics, cli- } \\
\text { matic conditions, cha- } \\
\text { racteristics of cover } \\
\text { material, including its } \\
\text { chemical and physical } \\
\text { composition, erodibility, } \\
\text { slope stability, final sur- } \\
\text { face contours, thickness, } \\
\text { porosity, permeability, } \\
\text { slope, length of run of } \\
\text { slope, type of vegetation } \\
\text { on cover, geology and } \\
\text { soil profiles, and surface } \\
\text { and subsurface } \\
\text { hydrology, } 401 \text { KAR } \\
45: 110 \text { Sec. 5(2)(e). }\end{array}$ & $\begin{array}{l}\text { See performance criteria } \\
\text { listed under liner system. }\end{array}$ & $\begin{array}{l}\text {-If the following operations are } \\
\text { common to an industry, are not in } \\
\text { violation of } 401 \text { KAR } 30: 031 \text {, do } \\
\text { not pose a threat to human health } \\
\text { or environment, and meet other } \\
\text { conditions specified in rule, then } \\
\text { they may be deemed to have a } \\
\text { special waste permit by rule with- } \\
\text { out having to submit permit appli- } \\
\text { cation: } \\
\text {-Person who beneficially reuses } \\
\text { coal combustion byproducts as an } \\
\text { ingredient or substitute ingredient } \\
\text { in manufacturing of products, in- } \\
\text { cluding cement, concrete, paint, } \\
\text { and plastics, antiskid material, } \\
\text { highway base course, structural fill, } \\
\text { blasting grit, or roofing granules, } \\
401 \text { KAR } 45: 060 \text { Sec. } 1(7) ; \\
\text {-Owner/operator of a facility } \\
\text { that disposes of coal combustion } \\
\text { fly ash, bottom ash, and scrubber } \\
\text { sludge in active mining operation } \\
\text { provided owner/operator has a min- } \\
\text { ing permit under KY Revised } \\
\text { Statutes Ch. 350 that includes } \\
\text { disposal of special waste and } \\
\text { complies with mining permit con- } \\
\text { ditions, } 401 \text { KAR } 45: 110 \\
\text { (Technical and operating } \\
\text { requirements for special waste } \\
\text { landfills). }\end{array}$ \\
\hline
\end{tabular}




\section{Table 17 (Continued)}

\begin{tabular}{|c|c|c|c|}
\hline \multicolumn{4}{|l|}{ State: Missouri } \\
\hline State Program & Liner System & \multicolumn{2}{|c|}{ Leachate Collection System } \\
\hline $\begin{array}{l}\text { Coal combustion waste is a special waste and } \\
\text { may be disposed of in a sanitary landfill if } \\
\text { permitted to receive such waste, or a special } \\
\text { waste landfill permitted to receive such waste, } \\
\text { Missouri Code of State Regulations, Title } 10 \text {, } \\
\text { Division } 80 \text {, Solid Waste Management, Chap- } \\
\text { ters } 1-3 \text {. Almost all requirements have general } \\
\text { performance-based requirements, followed by } \\
\text { technical specifications. }\end{array}$ & $\begin{array}{l}\text { A two-component composite } \\
\text { liner must be installed on all } \\
\text { surfaces to minimize leachate } \\
\text { migration: } \\
\text {-Upper component must be of } \\
\text { specified minimum thickness; } \\
\text { - Lower component must consist } \\
\text { of compacted soil of specified } \\
\text { minimum thickness, hydraulic } \\
\text { conductivity, lifts, compaction } \\
\text { with moisture content. } \\
\text {-Soil of lower component must } \\
\text { be classified under a specified } \\
\text { soil classification system and } \\
\text { meet minimum specifications of } \\
\text { size, liquid content, plasticity, } \\
\text { and permeability, 80- } \\
3.010(7)(B) 1 . G .\end{array}$ & \multicolumn{2}{|c|}{$\begin{array}{l}\text { Performance-based design, construction, maintenance, and } \\
\text { operation standards require collection and removal of } \\
\text { leachate, construction of materials chemically resistant to } \\
\text { waste and leachate, sufficient strength and thickness, } \\
\text { proper functioning, and design/ construction to maintain } \\
\text { less than } 1 \text { foot leachate depth over liner, } 80 \text { - } \\
3.010(7)(B) 1 . F .\end{array}$} \\
\hline Groundwater Monitoring & Final Cover & Reduced Requirements & Comments \\
\hline $\begin{array}{l}\text { - Monitoring program must determine } \\
\text { landfill's impact on underlying groundwater, } \\
80-3.010(8)(A) \text {. } \\
\text {-Baseline quality shall be established by } \\
\text { analyzing for } 29 \text { parameters, including chlor- } \\
\text { ide, pH, calcium, magnesium, silver, arsenic, } \\
\text { barium, cadmium, chromium, mercury, man- } \\
\text { ganese, lead, and selenium, } 80 \text { - } \\
3.010(4)(B) 7 . D .(I) . \\
\text {-Quarterly sampling of } 7 \text { parameters including } \\
\text { chlorides, and pH, } 80-3.010(8)(C) 3 . B \text {. } \\
\text {-Semiannual sampling of } 28 \text { inorganic } \\
\text { (including arsenic, barium, cadmium, calcium, } \\
\text { chromium, copper, lead, manganese, mercury, } \\
\text { nickel, selenium, silver, sulfate vanadium, and } \\
\text { zinc) and 47 organic constituents, } 80 \text { - } \\
\text { 3.010(8)(C)3.C. } \\
\text {-State may add or delete monitoring } \\
\text { parameters on a site-by-site basis and specify } \\
\text { altemative sampling/analysis frequency, } 80 \text { - } \\
\text { 3.010(8)(C)3.D. }\end{array}$ & $\begin{array}{l}\text {-Performance requirements } \\
\text { specified to ensure cover can } \\
\text { perform certain functions; } \\
\text {-Technical specifications } \\
\text { requiring less than or equal to } \\
331 / 3 \% \text { slope, specified mini- } \\
\text { mum permeability and } \\
\text { compacted clay thickness as } \\
\text { well as soil cover thickness } \\
\text { requirements, } 80-3.010(14) \text {. }\end{array}$ & $\begin{array}{l}\text {-Groundwater monitoring require- } \\
\text { ments may be waived/ altered if no } \\
\text { potential for migration of leachate to } \\
\text { groundwater is demonstrated, } 80 \text { - } \\
\text { 3.010(8)(B)1. } \\
\text {-State may approve an alternative } \\
\text { final cover system provided that it is } \\
\text { at least equivalent to that required by } \\
80-3.010(14) \text { (C)3, 80-3.010(14)(C)4. } \\
\text {-For proposed landfill that will } \\
\text { accept only special wastes and } \\
\text { operate differently than Title 10, } \\
\text { Division } 80, \text { Chapters } 1-3, \text { written } \\
\text { request must accompany permit, } \\
\text { explain waste characteristics, and } \\
\text { justify differing design/operating } \\
\text { procedures, } 80-2.020(8) . \\
\text {-State may exempt landfill from } \\
\text { permit requirement if receives only } \\
\text { fly ash and/or bottom ash from coal } \\
\text { combustion, and certain information } \\
\text { is submitted (including demonstration } \\
\text { of beneficial use and/or reclamation } \\
\text { and that a public nuisance/health } \\
\text { hazard will not be created), 80- } \\
\text { 2.020(9)(B). }\end{array}$ & \\
\hline
\end{tabular}




\section{Table 17 (Continued)}

\begin{tabular}{|c|c|c|c|}
\hline \multicolumn{4}{|l|}{ State: Ohío } \\
\hline State Program & Liner System & \multicolumn{2}{|l|}{ Leachate Collection System } \\
\hline $\begin{array}{l}\text { "Nontoxic" fly ash and "nontoxic" } \\
\text { bottom ash are exempt from the solid } \\
\text { waste regulation provided that they are } \\
\text { not commingled with other air } \\
\text { pollution control wastes (e.g., flue gas } \\
\text { desulfurization or fluid bed combustion } \\
\text { wastes) and disposal occurs only in } \\
\text { OH EPA-approved disposal areas } \\
\text { dedicated to non- toxic fly ash, bottom } \\
\text { ash, and/or foundry sand, but they are } \\
\text { subject to guidelines on the disposal of } \\
\text { such waste, Policy } 4.07 \text {, effective Aug. } \\
1,1988, \text { revised Feb. } 24,1988 \text {. Using } \\
\text { EP Toxicity Test, nontoxic }=\text { arsenic } \leq \\
1.5 \text { mg/L, barium } \leq 30 \text { mg/L, cadmium } \\
\leq \text { 0.3mg/L, chromium } \leq 1.5 \text { mg/L, } \\
\text { Iead } \leq 1.5 \text { mg/L, mercury } \leq 0.06 \\
\text { mg/L, and selenium } \leq 0.3 \text { mg/L, } \\
\text { Policy } 4.07 \text { p. } 2 . \text { Non-toxic fly/bottom } \\
\text { ash may also be disposed of in a } \\
\text { residual waste landfill (RWLF) and a } \\
\text { MSWLF. } \\
\text { Toxic fly/bottom ash and other coal } \\
\text { combustion wastes may be disposed of } \\
\text { in a landfill in compliance with OH } \\
\text { Administrative Code (OAC) } 3745-30 \\
\text { (and in a MSWLF in compliance with } \\
\text { OAC } 3745-27 \text { ). These wastes would } \\
\text { probably be classified as a Class II or } \\
\text { III residual waste. } \\
\text { This table addresses Policy } 4.07 \text { and } \\
\text { residual waste landfill requirements. }\end{array}$ & $\begin{array}{l}\text { Policy } 4.07: \text { Recompacted soil liner at } \\
\text { least } 1 \text { and } 1 / 2 \text { feet thick, and thick } \\
\text { enough to allow fluid migration time of } \\
\text { travel from top of soil liner to upper- } \\
\text { most aquifer of not less than } 15 \text { years, } \\
\text { calculated using specified equation, p. } 4 \text {. } \\
\text { RWLF: Recompacted soil liner require- } \\
\text { ments specify lift thickness and perme- } \\
\text { ability, clod size, soil particle size, } \\
\text { compaction density, moisture content, } \\
\text { placement, slope, liner thickness, hydro- } \\
\text { static uplift safety factor, and protection } \\
\text { from weather and puncture, } 3745-30- \\
\text { 07(C)(1)(a)-(g), (k)-(1). } \\
\text {-Class II: } \\
\text { - Soil liner must be at least } 3 \text { feet } \\
\text { thick; an alternative thickness no less } \\
\text { than one and one-half feet may be } \\
\text { approved if certain calculations are met, } \\
3745-30-07(C)(1)(j)(i i) \text {. } \\
\text { - Geomembrane must be placed on } \\
\text { recompacted soil liner and be negligibly } \\
\text { permeable, physically and chemically } \\
\text { resistant to waste and leachate, be } \\
\text { seamed to allow no more than negli- } \\
\text { gible leakage, and be protected from the } \\
\text { drainage layer by a cushion layer, } 3745- \\
30-07(C)(2) \text {. } \\
\text {-Class III: } \\
\text { - Soil liner must be at least one and } \\
\text { one-half feet thick or at least } 3 \text { feet } \\
\text { thick if no geomembrane is to be used, } \\
3745-30-07(C)(1)(j)(i) \text {. } \\
\text { - No geomembrane required. }\end{array}$ & \multicolumn{2}{|c|}{$\begin{array}{l}\text { Policy 4.07: Underdrain system for disposal area, with } \\
\text { contaminated drainage directed to a wastewater } \\
\text { treatment facility, p. } 4 \text {. } \\
\text { RWLF: } \\
\text {-Performance-based design standards to contain and } \\
\text { collect leachate, function without clogging, prevent } \\
\text { crushing/damage to components, and be chemically } \\
\text { resistant, 3745-30-07(C)(3) } \\
\text { (a),(c)-(e). } \\
\text {-Leachate level limited in areas other than lift stations to } \\
1 \text {-foot maximum and granular material used for drainage } \\
\text { must have permeability no less than } 1 \times 10^{-3} \mathrm{~cm} / \mathrm{sec} \text {, } \\
3745-30-07(C)(3)(b) \text {. } \\
\text {-Leachate conveyance or storage structure outside limits } \\
\text { of waste placement must be as protective as landfill and } \\
\text { be monitored, if required, have spill containment for } \\
\text { storage tanks, double-casing for leachate pipelines, and } \\
\text { have at least one week storage capacity, using design } \\
\text { assumptions simulating a final cap system, 3745-30- } \\
\text { 07(C)(3)(f). }\end{array}$} \\
\hline Groundwater Monitoring & Final Cover & Reduced Requirements & Comments \\
\hline $\begin{array}{l}\text { Policy 4.07: No monitoring require- } \\
\text { ments, but surface evaluation and } \\
\text { siting criteria apply to facilities, } \\
\text { including requirements (1) not to } \\
\text { locate over an unconsolidated aquifer } \\
\text { capable of yielding greater than } 100 \\
\text { gal/min to a well within } 1,000 \text { feet of } \\
\text { waste placement limits, and (2) provide } \\
\text { an isolation distance between the } \\
\text { uppermost aquifer and liner bottom no } \\
\text { less than } 5 \text { feet of insitu or added geo- } \\
\text { logical material acceptable to state and } \\
\text { not exceeding maximum permeability } \\
\text { of } 1 \times 10^{-5} \text { cm/sec., pp. 2-4. } \\
\text { RWLF: } \\
- \text { Quarterly baseline monitoring for } 1 \\
\text { year for } 29 \text { parameters including pH, } \\
\text { sulfate, calcium, arsenic, barium, cad- } \\
\text { mium, chromium, lead, mercury, } \\
\text { selenium, silver, chloride, and } \\
\text { manganese, 3745-30-08(D)(3). } \\
\text {-After first year, semiannual sampling } \\
\text { for } 7 \text { parameters, including pH, sulfate, } \\
\text { and calcium, 3745-30-08(D)(4). } \\
\text {-After first year, annual sampling for } \\
17 \text { parameters, including arsenic, } \\
\text { barium, cadmium, chromium, lead, } \\
\text { mercury, selenium, silver, chloride, and } \\
\text { manganese, 3745-30-08(D)(5). }\end{array}$ & $\begin{array}{l}\text { Policy 4.07: Cap of at least } 2 \text { foot } \\
\text { thickness with permeability of less than } \\
1 \times 10^{-7} \mathrm{~cm} / \mathrm{sec} \text {, and } 6-12 \text { inch } \\
\text { vegetative cover, final grade of } 2-25 \% \text {. } \\
\text { RWLF: } \\
\text {-Recompacted soil liner requirements } \\
\text { specify lift thickness and permeability, } \\
\text { clod size, soil particle size, compaction } \\
\text { density, moisture content, slope, and } \\
\text { erosion rate, } 3745-30-09 \text { (F)(3). } \\
\text {-Soil vegetative layer of thickness such } \\
\text { that top of the recompacted soil barrier } \\
\text { layer is below frost depth, } 3745-30- \\
09(F)(3) \text {. }\end{array}$ & $\begin{array}{l}\text { Policy 4.07: Certain beneficial uses do } \\
\text { not require approval of the Division of } \\
\text { Water Pollution Control, p. } 5 \text {. } \\
\text { RWLF: } \\
\text {-Alternatives to certain liner requirements } \\
\text { may be used if demonstrated each lift } \\
\text { will have a permeability of } 1 \times 10^{-7} \\
\text { cm/sec, } 3745-30-07(C)(1)(1) \text {. } \\
\text {-To allow for alternate technologies, } \\
\text { alternate liner thickness may be approved } \\
\text { if equivalent in protection, 3745-30- } \\
\text { 07(C)(1)(j). } \\
\text {-To allow for alternate technologies, } \\
\text { alternate design that does not incorporate } \\
\text { a geomembrane may be approved for } \\
\text { Class II landfill if equivalent in } \\
\text { protection, 3745-30-07(C)(2)(e). } \\
\text {-Alternate list of groundwater quality } \\
\text { parameters to be monitored may be } \\
\text { approved if equivalent in protection, } \\
\text { 3745-30-08(D)(2). } \\
\text {-Alternative materials and/or thickness } \\
\text { for soil barrier and vegetative layers of } \\
\text { cap system may be approved, 3745-30- } \\
\text { 09(F)(3). } \\
\text {-Variance from any provisions may be } \\
\text { approved by state if adequate } \\
\text { justification submitted, } 3745-30-15(B) \text {. }\end{array}$ & $\begin{array}{l}\text { Policy 4.07: } \\
\text { requires a } \\
\text { permit to } \\
\text { install, air } \\
\text { permit to } \\
\text { operate, and } \\
\text { unless } \\
\text { exempted for } \\
\text { acceptable } \\
\text { beneficial } \\
\text { uses, a } \\
\text { NPDES } \\
\text { permit to be } \\
\text { issued by OH } \\
\text { EPA for dis- } \\
\text { posal sites for } \\
\text { nontoxic } \\
\text { fly/bottom } \\
\text { ash, p.1. } \\
\text { RWLF: } \\
\text {-Post-closure } \\
\text { care period } \\
\text { for Class II is } \\
\text { 20 years; for } \\
\text { Class III is } 15 \\
\text { years, 3745- } \\
30-10(A)(2) \\
\text { and (3). }\end{array}$ \\
\hline
\end{tabular}


Table 17

(Continued)

\begin{tabular}{|c|c|c|c|}
\hline \multicolumn{4}{|l|}{ State: Pennsylvania } \\
\hline State Program & Liner System & \multicolumn{2}{|c|}{ Leachate Collection System } \\
\hline $\begin{array}{l}\text { Coal combustion waste is a residual waste } \\
\text { (Pennsylvania Code, Article IX, Chapter } \\
\text { 287, section 287.1) regulated by Chapters } \\
\text { 287-289. Residual waste landfills are } \\
\text { classified as Class I, II, or III, depending } \\
\text { on potential adverse effects on ground- } \\
\text { water, public health, safety, and environ- } \\
\text { ment. Class I has greatest potential ad- } \\
\text { verse effects, and Class III, the least. Only } \\
\text { captive facilities (facility located upon } \\
\text { property owned by generator of residual } \\
\text { waste and operated for disposal solely of } \\
\text { generator's residual waste) and coal ash } \\
\text { monofills qualify as Class III residual } \\
\text { waste landfills, 288.621(b). }\end{array}$ & $\begin{array}{l}\text { Class II: Liner system, consisting of } \\
\text { subbase, leachate detection zone, } \\
\text { composite liner, protective cover, and } \\
\text { leachate collection zone must comply } \\
\text { with performance standards and also } \\
\text { meet such minimum specifications as } \\
\text { thickness, permeability, density, } \\
\text { isolation distances, bearing capacity, } \\
\text { slope, lined berm, } 288.531-533 \text {. } \\
\text { Class III: Requirements, } 288.624 \text {, } \\
\text { specify an attenuating soil base must be } \\
\text { provided: } \\
\text { - At least } 4 \text { feet thick or } 1 \text { foot for } \\
\text { every } 4 \text { feet of waste, whichever } \\
\text { greater; } \\
\text { - At least } 4 \text { feet separate seasonal high } \\
\text { water table, perched water table, or } \\
\text { bedrock from lowest area where waste } \\
\text { is deposited, provided seasonal high } \\
\text { water table is not located within } \\
\text { attenuating soil base; } \\
\text { - At least } 8 \text { vertical feet separate } \\
\text { regional groundwater table from lowest } \\
\text { area where waste is deposited, provided } \\
\text { regional groundwater table is not } \\
\text { located within attenuating soil base; } \\
\text { and } \\
\text { - Soil must meet specified soil } \\
\text { classification system, particle size, } \\
\text { combustible/coal/organic carbon } \\
\text { content, cation exchange capacity, and } \\
\text { exclude large rock fragments. }\end{array}$ & \multicolumn{2}{|c|}{$\begin{array}{l}\text { Class II: } \\
\text {-Leachate detection zone, leachate collection system } \\
\text { within protective cover requirements, } 288.534- \\
\text { 288.537, have both detailed performance standards } \\
\text { and design specifications. } \\
\text {-Detection zone design requirements specify thick- } \\
\text { ness, permeability, particle size, slope, material } \\
\text { requirements, and piping system specifications. } \\
\text {-Collection system requirements specify leachate } \\
\text { depth, minimum pipe diameter, wall thickness, slope, } \\
\text { grade, and material of piping system. }\end{array}$} \\
\hline Groundwater Monitoring & Final Cover & Reduced Requirements & Comments \\
\hline $\begin{array}{l}\text { Class II and II: } \\
\text {-Quarterly sampling for } 18 \text { parameters, } \\
\text { including calcium, chloride, pH, sulfate, } \\
\text { potassium, and manganese, 288.254(a)(1). } \\
\text {-Annual sampling for } 11 \text { metals, arsenic, } \\
\text { barium, cadmium, chromium, copper, lead, } \\
\text { mercury, selenium, silver, and zinc, } \\
\text { 288.254(a)(3). } \\
\text {-Annual sampling for } 14 \text { VOCs, } \\
\text { 288.254(a)(4). } \\
\text {-Other constituents contained in the waste } \\
\text { or leachate may be added to monitoring } \\
\text { lists, } 288.254(a)(5) \text {. }\end{array}$ & $\begin{array}{l}\text { Class II: } \\
\text {-Cap with uniform and compacted } 2 \text {-ft } \\
\text { layer of clay over each final lift, } \\
\text { permeability no more than } 1 \times 10^{-7} \\
\text { cm/sec; drainage layer to transmit flow } \\
\text { and prevent erosion must be placed } \\
\text { over cap; layer to support vegetation } \\
\text { and protect cap over drainage layer; } \\
\text { and performance-based and specified } \\
\text { design requirements for final slope, } \\
\text { 288.234(a), (f), and (g). } \\
\text {-In lieu of } 2 \text {-foot clay layer, state may } \\
\text { approve specified synthetic materials of } \\
\text { type and specifications for final cover } \\
\text { as for primary liners (288.436) and for } \\
\text { caps (Appendix A, Table In), } \\
\text { 288.234(a). } \\
\text {-Layer to support vegetation and } \\
\text { protect cap must meet performance } \\
\text { standards as well as specified design } \\
\text { requirements, 288.234(d),(e). }\end{array}$ & $\begin{array}{l}\text { Class II and III: } \\
\text {-State may waive or modify cap } \\
\text { and drainage layer requirements } \\
\text { if demonstrated not necessary } \\
\text { to limit infiltration, } 288.234(b) \text {. } \\
\text {-State may reduce groundwater } \\
\text { monitoring parameters and } \\
\text { frequency for residual waste } \\
\text { monofills, except for } 18 \text { param- } \\
\text { eters in } 288.254(a)(1) \text { to be } \\
\text { quarterly monitored, } \\
\text { 288.254(b). } \\
\text {-Coal ash may be used for } \\
\text { beneficial uses (e.g., use as } \\
\text { structural fill, or soil substitute } \\
\text { or additive without permit, } \\
\text { provided that certain criteria are } \\
\text { met, } 287.661-287.666 . \\
\text {-Equivalency review procedure } \\
\text { available allowing alternative } \\
\text { designs for some parameters } \\
\text { (e.g., subbase, leachate de- } \\
\text { tection zone, liner, final cover), } \\
287.231 \text {. }\end{array}$ & \\
\hline
\end{tabular}




\section{Table 17}

(Continued)

\begin{tabular}{|c|c|c|c|}
\hline \multicolumn{4}{|l|}{ State: Tennessee } \\
\hline State Program & Liner System & \multicolumn{2}{|l|}{ Leachate Collection System } \\
\hline $\begin{array}{l}\text { Coal combustion waste is both a special } \\
\text { waste and an industrial waste regulated by } \\
\text { Tenn. Solid Waste Processing and Disposal } \\
\text { regulations, Chapter } 1200-1-7 \text {, Sections }-.01 \\
\text { through }-.08 \text {, and may be disposed of in } \\
\text { either a Class I (i.e., a sanitary landfill) or } \\
\text { Class II (i.e., landfill receiving wastes, } \\
\text { including industrial wastes, generated by one } \\
\text { or more industrial/manufacturing plants). }\end{array}$ & $\begin{array}{l}\text { - Liner system performance standards } \\
\text { for compatibility, strength, and thick- } \\
\text { ness must be met in all cases, } 1200 \text { - } \\
1-7.04(4)(a) 1 \text {. } \\
\text {-Compacted earth liner requirement } \\
\text { specifies thickness and allows use of } \\
\text { admixtures and special construction } \\
\text { techniques with thickness restriction, } \\
1200-1-7.04(4)(\text { a)3.(i). } \\
\text {-Geomembrane liners may be used } \\
\text { only with compacted earth liner; re- } \\
\text { quirements specify thickness, } \\
\text { hydraulic conductivity, compatibility, } \\
\text { and strength, 1200-1-7.04(4)(a)3.(ii). } \\
\text {-Geologic buffer of specified } \\
\text { thickness and placement (or equiva- } \\
\text { lent in performance) must underly } \\
\text { liners, 1200-1-7.04(4)(a)2. }\end{array}$ & \multicolumn{2}{|c|}{$\begin{array}{l}\text {-Leachate collection/removal system performance } \\
\text { standards address compatibility, strength, thickness, } \\
\text { design and/or operational standards to protect against } \\
\text { equipment mishandling, leachate depth, and collection } \\
\text { reservoir construction, capacity, and sampling, 1200- } \\
\text { 1-7.04(4)(a)4., 6., and 7. }\end{array}$} \\
\hline Groundwater Monitoring & Final Cover & Reduced Requirements & Comments \\
\hline $\begin{array}{l}\text { Class I Landfills (1200-1-7.04(7)(a) } \\
\text {-Quarterly baseline monitoring, for } 1 \text { year } \\
\text { for } 14 \text { indicator parameters (including } \\
\text { calcium, chloride, manganese, potassium, } \\
\text { and pH) and } 9 \text { inorganics (including arsenic } \\
\text { barium, cadmium, chromium, lead, mercury, } \\
\text { selenium, and silver), } 1200-1-7.04(7)(a) 4 \text {. } \\
\text {-After the first year, monitor semiannually, } \\
\text { for } 14 \text { indicator parameters and annually, for } \\
23 \text { vOCs, } 1200-1-7.04(7)(a) 4 \text {. } \\
\text { Class II Landfills (1200-1-7.04(7)(b) } \\
\text {-Same requirements as Class I Landfills, } \\
\text { except not required to perform analysis for } \\
23 \text { vOC's unless specifically required by } \\
\text { state } 1200-1-7.04(7)(b) 1 \text {. } \\
\text {-State may require analysis for other water } \\
\text { quality parameters and other parameters cha- } \\
\text { racteristic of waste to be disposed, } 1200-1- \\
7.04(7)(b) 4 . \\
\text {-Develop and submit a groundwater quality } \\
\text { assessment plan, } 1200-1-7.04(7)(b) 5 \text {. }\end{array}$ & $\begin{array}{l}\text {-Final cover design must minimize } \\
\text { liquids migration, minimize main- } \\
\text { tenance, promote drainage, etc., } \\
1200-1-7-.04(4) \text { (a)5. } \\
\text {-Compacted final cover material (e.g., } \\
\text { soil) requirements specify minimum } \\
\text { thickness, and design so that } \\
\text { infiltration volume of water is equi- } \\
\text { valent to percolation volume through } \\
\text { bottom liner meeting specified mini- } \\
\text { mum design standards, } 1200-1- \\
7.04(8)(c) 3 \text {. }\end{array}$ & $\begin{array}{l}\text {-Alternate liners may be used if } \\
\text { equivalent in performance, and } \\
\text { manufacturing QA/QC is implemented, } \\
1200-1-7.04(4) \text { (a)3.(iii). } \\
\text {-Groundwater monitoring requirements } \\
\text { may be reduced or eliminated for a } \\
\text { Class II facility if it is demonstrated } \\
\text { that, due to the nature of the waste or } \\
\text { operation, facility will not generate } \\
\text { harmful leachate in significant quanti- } \\
\text { ties, } 1200-1-7.04(7)(b) \text { ) } \\
\text {-Any standard may be waived by the } \\
\text { state if the operator can demonstrate } \\
\text { that it is inapplicable, inappropriate, or } \\
\text { unnecessary, or alternative standards or } \\
\text { requirements are equivalent, } 1200-1-7- \\
\text {.01(5). } \\
\text {-A coal ash fill area is deemed to have } \\
\text { a permit by rule (i.e., is not subject to } \\
\text { permit application procedures provided } \\
\text { that, among many other restrictions: } \\
\text { - The coal ash is fly/bottom ash } \\
\text { from fossil fuel combustion; } \\
\text { - Disposal is limited to use of ash as } \\
\text { light weight aggregate, road base and } \\
\text { subbase materials; } \\
\text { - Ash is in engineered structure or } \\
\text { used in activities before site } \\
\text { development (e.g., structural fill, soil } \\
\text { stabilization), or other Dept-approved } \\
\text { uses; } \\
\text { - There is compliance with location } \\
\text { and design (e.g., geologic buffer, } \\
\text { drainage) requirements to prevent water } \\
\text { contamination, 1200-1-7-.02(1)(c)1.(ii). }\end{array}$ & \\
\hline
\end{tabular}




\section{Table 17}

(Continued)

\begin{tabular}{|c|c|c|c|}
\hline \multicolumn{4}{|l|}{ State: Texas } \\
\hline State Program & Liner System & \multicolumn{2}{|c|}{ Leachate Collection System } \\
\hline $\begin{array}{l}\text { Coal combustion waste is Class } 1,2 \text {, or } 3 \\
\text { industrial solid waste (nonhazardous); } \\
\text { Class } 1 \text { has greatest potential adverse } \\
\text { effects, and Class } 3 \text {, the least (see defi- } \\
\text { nition of "industrial solid waste," TX } \\
\text { Admin. Code, Title } 31 \text {, Part IX, Ch. } 335 \text {, } \\
\text { Subch. A, 335.1 Definitions, and Class } 1 \text {, } \\
2 \text {, and } 3 \text { waste determinations, } 335.505 \text { - } \\
33.5 .507 \text { ). There are no enforceable design } \\
\text { standards for industrial solid waste } \\
\text { landfills; instead, TX Water Commission } \\
\text { (now TX Natural Resource Conservation } \\
\text { Commission) issued on } 5 / 3 / 76 \text { Technical } \\
\text { Guideline (TG) No. } 3 \text {, industrial solid } \\
\text { waste management, revised } 4 / 21 / 89 \text {, and } \\
\text { TG No. } 6 \text {, monitoring systems and leachate } \\
\text { collection, issued } 5 / 3 / 76, \text { revised } 3 / 21 / 80, \\
\text { to apply to landfills on case-by-case basis. } \\
\text { While industrial solid waste may be } \\
\text { disposed of in a MSWL under Chapter } \\
330, \text { if permitted to accept such waste, } \\
\text { only TGs Nos. } 3 \text { and } 6 \text { are briefly } \\
\text { summarized as they pertain to Class } 1 \text { and } \\
2 \text { industrial solid waste landfills. }\end{array}$ & $\begin{array}{l}\text { TG No. 3: } \\
\text {-Containment barriers for base and } \\
\text { sides compatible for waste should be } \\
\text { provided, see page } 2 \text {; } \\
\text {-If natural in-place soil, constructed } \\
\text { soil liner, or synthetic membrane/ com- } \\
\text { pacted soil liner used, minimum thick- } \\
\text { ness, hydraulic conductivity, and } \\
\text { plasticity, and waste particle size and } \\
\text { liquid limit specified, see Table I of } \\
\text { TG No. 3, page 3; -Lift thickness, } \\
\text { length, density, moisture content for } \\
\text { soil material to be compacted for liner, } \\
\text { see page 4; } \\
\text {-Composite liner of compacted clay } \\
\text { beneath synthetic membrane liner } \\
\text { recommended for Class } 1 \text { landfill con- } \\
\text { taining leachable waste. Synthetic } \\
\text { membrane material must be thick for } \\
\text { reliable seaming and for puncture } \\
\text { resistance, installed on clay-rich soil } \\
\text { under lining, and protected by thick } \\
\text { soil cover. Leak detection system also } \\
\text { may be appropriate, see page } 4 \text {; } \\
\text {-Use QA/QC program for installation } \\
\text { of Class } 1 \text { liners (e.g., US EPA Pub. } \\
530-S W-85-010) \text {, see Page } 4 \text {. }\end{array}$ & \multicolumn{2}{|c|}{$\begin{array}{l}\text {-Leachate monitoring/collection systems recommend- } \\
\text { ed for Class } 1 \text { landfills, and for landfills with Class } 2 \\
\text { wastes with easily leachable components, including } \\
\text { Class } 2 \text { landfills where groundwater is less than } 6 \text { feet } \\
\text { from bottom of facility, see TG No. 3, page 5, and } \\
\text { TG No. 6, page 6; } \\
\text {-Basic design recommendations in TG No. 6: leachate } \\
\text { collection system consisting of gravity flow drainfield } \\
\text { on top of facility liner with collection sump } \\
\text { recommended for Class } 1 \text { landfills; underdrain system } \\
\text { consisting of gravity flow drainfield and collection } \\
\text { point under facility liner and above secondary liner } \\
\text { (in-place soils of low permeability may serve as se- } \\
\text { condary liner, or synthetic liners may be used where } \\
\text { surrounding soils are permeable), TG No. 6, see } \\
\text { pages 6-7. }\end{array}$} \\
\hline Groundwater Monitoring & Final Cover & Reduced Requirements & Comments \\
\hline $\begin{array}{l}\text { TG No. } 6 \text { contains design recom- } \\
\text { mendations for subsurface monitoring } \\
\text { systems and: } \\
\text {-Before waste management activities begin, } \\
\text { obtain groundwater and surface water } \\
\text { samples to establish background } \\
\text { conditions, see page } 1 \text {. } \\
\text {-Appropriate techniques for monitoring } \\
\text { depend on site- and waste-specific charac- } \\
\text { teristics, and methods of waste man- } \\
\text { agement, see page } 1 \text {. } \\
\text {-Monthly monitoring for the first year of } \\
\text { site operation, and quarterly thereafter for } \\
\text { parameters based on site- and waste- } \\
\text { specific characteristics, see page } 1 \text {. }\end{array}$ & $\begin{array}{l}\text { TG No. } 3 \text { : } \\
\text {-Compacted, well-graded, fine-grained, } \\
\text { clay-rich, relatively impermeable soil } \\
\text { designed to meet performance } \\
\text { guidelines, see page } 6 ; \\
\text {-Recommended minimum compacted } \\
\text { clay cover thickness is } 4 \mathrm{ft} \text {. for Class } 1 \\
\text { or } 3 \mathrm{ft} . \text { for Class } 1 \text {, unless equivalent } \\
\text { multilayer cover system is used, in } \\
\text { which case minimum is } 3 \mathrm{ft} \text {. for Class } \\
1 \text {, and } 2 \mathrm{ft} \text {. for Class } 2 \text {, see page } 6 ; \\
\text {-Lift size, density, scarification depth, } \\
\text { and grade specifications recommended, } \\
\text { see page } 6 ; \\
\text {-Minimum of } 18 \text {-inch vegetative cover } \\
\text { (with shallow root zone depth to mini- } \\
\text { mize disruption, except for dry } \\
\text { climates) or other acceptable material } \\
\text { to minimize erosion, see pages } 6-7 ; \\
\text {-If runoff is concentrated, drainage } \\
\text { structures recommended to minimize } \\
\text { erosion, see page } 7 \text {. }\end{array}$ & & $\begin{array}{l}\text {-TG No. } 3 \text { contains } \\
\text { additional } \\
\text { recommendations } \\
\text { (particularly for lateral con- } \\
\text { tainment dikes) for above- } \\
\text { grade landfills containing } \\
\text { nonhazardous industrial } \\
\text { solid waste to provide pro- } \\
\text { per containment and ero- } \\
\text { sion control, see pages 7-9; } \\
\text {-TG No. } 6 \text { recommends: } \\
\text { monitoring the unsaturated } \\
\text { zone to detect migration of } \\
\text { waste or leachate before } \\
\text { contaminants enter ground- } \\
\text { water; and specifies recom- } \\
\text { mended techniques/devices } \\
\text { for soil sampling, see } \\
\text { pages 5-6; } \\
\text {-Also see TG No. 1, Waste } \\
\text { Evaluation/Classification, } \\
\text { TG No. 2, Industrial Solid } \\
\text { Waste Landfill Site } \\
\text { Selection, and TG No. 9, } \\
\text { Noncompatible Wastes, as } \\
\text { well as other applicable } \\
\text { guidelines. }\end{array}$ \\
\hline
\end{tabular}


Table 17

(Continued)

\begin{tabular}{|c|c|c|c|}
\hline \multicolumn{4}{|l|}{ State: West Yirginia } \\
\hline State Program & Liner System & \multicolumn{2}{|c|}{ Leachate Collection System } \\
\hline $\begin{array}{l}\text { Coal combustion by-products are } \\
\text { regulated under WV Code of State } \\
\text { Regulations, Title 47, Legislative } \\
\text { Rules, Series } 38 \text {, Solid Waste } \\
\text { Management Regulations, 47-38-1 } \\
\text { through } 47-38-6 \text {. Facilities that dis- } \\
\text { pose of coal combustion wastes are } \\
\text { designated as Class F solid waste } \\
\text { facilities and regulated under } 47- \\
\text { 38-5.5. While only landfill } \\
\text { requirements are summarized here, } \\
\text { coal combustion by-products are } \\
\text { also allowed to go to solid waste } \\
\text { disposal surface impoundments } \\
\text { (see 5.5.2.a.E. - 5.5.2.a.H.). }\end{array}$ & $\begin{array}{l}\text { Liner system must } \\
\text { consist of clay having } \\
\text { specified thickness, } \\
\text { permeability, and } \\
\text { standard Proctor density, } \\
\text { and a } 60 \text { mil synthetic } \\
\text { liner must be installed on } \\
\text { top of the compacted } \\
\text { clay liner, 5.5.2.a.A. }\end{array}$ & \multicolumn{2}{|c|}{$\begin{array}{l}\text { - Leachate collection system must be a perforated pipe system on top of } \\
\text { the synthetic liner and meet design specifications for the drainage layer } \\
\text { thickness and permeability. The drainage layer, which can consist of } \\
\text { bottom ash, shall be the protective cover for the synthetic liner, 5.5.2.a.A. } \\
\\
\text { - Semiannual sampling of leachate for } 19 \text { parameters, including arsenic, } \\
\text { barium, cadmium, calcium, chloride, total and hexavalent chromium, lead, } \\
\text { manganese, sulfate, zinc, and any other parameters specified by State, } \\
\text { 5.5.2.c.A. }\end{array}$} \\
\hline Groundwater Monitoring & Final Cover & Reduced Requirements & Comments \\
\hline $\begin{array}{l}\text { Baseline and quarterly sampling } \\
\text { for a combination of } 29 \text { parameters } \\
\text { including: } \mathrm{pH} \text {, calcium, manganese, } \\
\text { chloride, sulfate, arsenic, copper, } \\
\text { nickel, selenium, zinc, barium, } \\
\text { mercury, total and hexavalent chro- } \\
\text { mium, lead, molybdenum, cadmi- } \\
\text { um, and vanadium (parameters to } \\
\text { be monitored should be submitted } \\
\text { as part of permit application and } \\
\text { depends on waste types which are } \\
\text { reasonably expected to be present), } \\
\text { 4.11.1.d. and 4.11.2.b. }\end{array}$ & $\begin{array}{l}\text { Final cover of specified } \\
\text { grade must consist of: } \\
\text {-One-foot layer of a } \\
\text { material with high hy- } \\
\text { draulic conductivity } \\
\text { placed on refuse mass to } \\
\text { facilitate gas control; } \\
\text {-Clay cap of specified } \\
\text { thickness and per- } \\
\text { meability placed over } \\
\text { each final lift in 6-inch } \\
\text { lifts; a cap of synthetic } \\
\text { material may be } \\
\text { approved; } \\
\text {-Drainage layer of spe- } \\
\text { cified thickness and } \\
\text { permeability to transmit } \\
\text { flow and prevent erosion } \\
\text { placed over cap; } \\
\text {-Compact soil layer of } \\
\text { specified thickness to } \\
\text { support vegetation placed } \\
\text { over drainage layer, § } \\
\text { 6.1.5. }\end{array}$ & $\begin{array}{l}\text {-Leachate monitoring may be waived by } \\
\text { the State, 5.5.2.c.A. } \\
\text { - Alternate liner system design may be } \\
\text { used if meets minimum specifications: } \\
\text { clay thickness, permeability, and density; } \\
\text { an appropriate groundwater interceptor } \\
\text { drainage system, also serving as a } \\
\text { leachate detection system, must be } \\
\text { installed under clay liner; an appropriate } \\
\text { leachate collection system, which can be } \\
\text { bottom ash, of specified permeability, } \\
\text { must be installed on top of compacted } \\
\text { clay liner, but may not be used in major } \\
\text { domestic use aquifer areas, major alluvial } \\
\text { aquifers, or karst regions, 5.5.2.a.B. } \\
\text { - Other liner systems may be approved } \\
\text { on case-by-case basis, based on waste } \\
\text { and facility type, site characteristics, } \\
\text { operating experience of similar landfills, } \\
\text { and groundwater protection, 5.5.2.a.C. } \\
\text {-State may waive/modify final cover } \\
\text { requirements based upon waste type, } \\
\text { facility, site characteristics, and engineer- } \\
\text { ing judgment, } 6.1 .1 . a . \\
\text { - Waivers/modifications may be } \\
\text { requested for requirements in 5.5.1.a } \\
\text { (from } \$ 3 \text {, Solid Waste Facility and } \\
\text { Permitting Requirements) and 5.5.1.b } \\
\text { (from certain } \$ 4, \text { Landfill Standards, } \\
\text { e.g., gas monitoring) based on site- } \\
\text { specific conditions and information, } \\
5.5 .1 .\end{array}$ & $\begin{array}{l}\text { - Certain beneficial uses of coal } \\
\text { combustion byproducts do not } \\
\text { require a permit: use in } \\
\text { manufacturing another product } \\
\text { or used as a substitute for a } \\
\text { product or natural resource; use } \\
\text { for the extraction or recovery of } \\
\text { materials contained within the } \\
\text { coal combustion byproduct; used } \\
\text { as a stabilization/solidification } \\
\text { agent for other wastes; use } \\
\text { under the authority of the WV } \\
\text { Department of Energy; use as } \\
\text { pipe bedding or as a composite } \\
\text { liner drainage layer; use as daily } \\
\text { or intermediate cover for a Class } \\
\text { A, B or C solid waste facility; } \\
\text { use as a construction material } \\
\text { for roads or parking lots with } \\
\text { asphalt or concrete surfaces; use } \\
\text { as anti-skid material (for bottom } \\
\text { ash or boiler slag only), 5.5.2.d. } \\
\text { (Note: Use of coal combustion } \\
\text { byproducts as structural fill and } \\
\text { soil amendment will be con- } \\
\text { sidered in future rulemakings.) }\end{array}$ \\
\hline
\end{tabular}




\section{Table 17}

\section{(Continued)}

\begin{tabular}{|c|c|c|c|}
\hline \multicolumn{4}{|l|}{ State: Wyoming } \\
\hline State Program & Liner System & \multicolumn{2}{|c|}{ Leachate Collection System } \\
\hline $\begin{array}{l}\text { Coal combustion waste may go to a } \\
\text { sanitary Iandfill or an industrial landfill, } \\
\text { Solid Waste Management Rules and Reg- } \\
\text { ulations, Chapters I - III }\end{array}$ & $\begin{array}{l}\text {-Engineered containment systems: Liners } \\
\text { and/or caps, leachate collection and leak } \\
\text { detection systems required when soils are } \\
\text { permeable, when waste types or practices } \\
\text { create reasonable potential for soil/ } \\
\text { groundwater contamination, site hydrologic } \\
\text { conditions do not sufficiently protect ground- } \\
\text { water, or if sanitary landfill receives }>500 \\
\text { short tons of unprocessed household refuse } \\
\text { or mixed household and industrial refuse/day } \\
\text { on a monthly average, or if industrial landfill } \\
\text { receives }>500 \text { tons of industrial solid } \\
\text { waste/operating day, on a monthly average, } \\
\text { Chap. II, sec. 4(i), and Chap. III, sec. } 4 \text { (g). } \\
\text {-Specifications for caps/ liners include con- } \\
\text { struction material, thickness, hydraulic } \\
\text { conductivity, slope, etc., Chap. II, sec. } 4(\mathrm{j}) \text {, } \\
\text { (1), and Chap. III. sec.4(h), (j). } \\
\text { - Refuse cells requiring containment system } \\
\text { may not exceed capacity greater than } \\
300,000 \text { cubic yards, except cells dedicated } \\
\text { only for on-site disposal of coal ash generat- } \\
\text { ed at coal-fired power plants may not exceed } \\
2,500,000 \text { cubic yards, Chap. II, sec. } 4(\mathrm{k}) \text {, } \\
\text { and Chap. III, sec.4(i). }\end{array}$ & & \\
\hline Groundwater Monitoring & Final Cover & Reduced Requirements & Comments \\
\hline $\begin{array}{l}\text { Sanitary Landfills--Baseline monitoring, } \\
\text { quarterly for } 1 \text { year, } 31 \text { parameters } \\
\text { including pH, chloride, calcium, potassium, } \\
\text { sulfate, copper, manganese, arsenic, } \\
\text { cadmium, chromium, lead, mercury, } \\
\text { selenium and silver, Ch.II, 6(b)(iv)(A). } \\
\text {-Routine semiannual monitoring: state may } \\
\text { reduce parameters, but must include: pH, } \\
\text { TDS, and chlorides, Ch.II, 6(b)(iv)(B). If } \\
\text { groundwater impacted, state may revise pa- } \\
\text { rameters and schedule, Ch.II, 6(b)(iv)(C). } \\
\text {-Additional parameters may be required } \\
\text { Ch.II, 6(b)(iv)(D). } \\
\text { Industrial Landfills--Baseline monitoring, } \\
\text { quarterly for 1 year, for parameters that } \\
\text { may be (1) present in waste and (2) listed } \\
\text { in Water Qual, Div. Ch.VIII, including } \\
\text { arsenic, cadmium, chromium, copper, lead, } \\
\text { manganese, mercury, nickel, selenium, } \\
\text { silver, sulfate, vanadium, zinc, and pH, Ch. } \\
\text { III, 6(b)(iv)(A). } \\
\text {-Routine annual monitoring: state may } \\
\text { reduce set of parameters, Ch.III, 6(b) } \\
\text { (iv)(B). -If groundwater impacted, state } \\
\text { may revise sampling parameters and } \\
\text { schedule, Ch.III, 6(b)(iv)(C). }\end{array}$ & $\begin{array}{l}\text { Compacted soil layer, or materials specified } \\
\text { in permit, requirements specify thickness and } \\
\text { grading and must meet design criteria spe- } \\
\text { cified for engineered containment systems in } \\
\text { liner system column, Chap. II, secs. } 4(\mathrm{i}),(\mathrm{j}) \\
\text { and } 7(\mathrm{~g}) \text {, and Chap. III, secs. } 4(\mathrm{~g}),(\mathrm{h}) \text {, and } \\
7(\mathrm{~g}) \text {. }\end{array}$ & $\begin{array}{l}\text { State has adopted } \\
\text { provisions to allow } \\
\text { facilities to be subject to } \\
\text { reduced requirements or be } \\
\text { exempt from certain design } \\
\text { components (liners, } \\
\text { leachate collection systems, } \\
\text { groundwater monitoring } \\
\text { systems, etc.). }\end{array}$ & \\
\hline
\end{tabular}




\section{Table 18 \\ Summary of Georgia's Solid Waste Criteria}

\begin{tabular}{|c|c|}
\hline Criteria & Restrictions/Requirements \\
\hline \multirow[t]{8}{*}{ Siting } & $\begin{array}{l}\text { The site must conform to all local zoning/land use ordinances and must not be located in the } \\
100 \text {-year floodplain unless the flow of the } 100 \text {-year flood and storage capacity of the flood- } \\
\text { plain is not restricted, and a washout of solid waste must not occur. }\end{array}$ \\
\hline & A facility must not locate in a wetland unless permitted to do so. \\
\hline & $\begin{array}{l}\text { New landfill units and lateral expansions of existing landfills: must not locate within } 200 \\
\text { feet of a fault that has had displacement in Holocene time unless demonstrated that an alter- } \\
\text { native setback distance is protective; must not locate in seismic impact zones, unless demon- } \\
\text { strated that the design of all containment structures can resist the maximum horizontal accel- } \\
\text { eration in lithified earth material. }\end{array}$ \\
\hline & $\begin{array}{l}\text { All landfills located in unstable areas must demonstrate that the integrity of the structural } \\
\text { components of each unit will not be disrupted. }\end{array}$ \\
\hline & $\begin{array}{l}\text { All solid waste handling facilities must perform a hydrological assessment evaluating speci- } \\
\text { fied factors and must have an assessment report prepared addressing all applicable siting } \\
\text { criteria. }\end{array}$ \\
\hline & $\begin{array}{l}\text { New disposal facilities or lateral expansions of existing facilities that accept waste from } \\
\text { more than one source, or new monofills (or lateral expansions) that are required to meet } \\
\text { MSWLF standards may not be located within } 10,000 \text { feet of any airport runway end used by } \\
\text { turbojet aircraft or within } 5,000 \text { feet or any airport runway end used by only piston-type air- } \\
\text { craft. If existing units are located within the above distances to airports, a demonstration } \\
\text { must be made that the units do not pose a bird hazard to aircraft. }\end{array}$ \\
\hline & $\begin{array}{l}\text { Existing units that are not permitted as monofills or are permitted to accept waste from more } \\
\text { than one industry must close by October } 9,1996 \text {, and conduct post-closure care activities if } \\
\text { they cannot comply with the airport, floodplain, or unstable area restrictions listed above. }\end{array}$ \\
\hline & $\begin{array}{l}\text { Industrial waste landfills permitted to receive only a singe type of industrial waste (monofill) } \\
\text { or permitted to receive only a single industry's waste must comply with siting criteria con- } \\
\text { tained in "Criteria for Performing Site Acceptability Studies for Solid Waste Landfills in } \\
\text { Georgia," Circular 14, Appendix A. This appendix basically requires classification of waste } \\
\text { streams into one of three classification--low potential, moderate potential, and high potential- } \\
\text {-that are generally determined based on the potential for groundwater contamination and the } \\
\text { presence of putrescible waste. }\end{array}$ \\
\hline \multirow[t]{4}{*}{ Design } & $\begin{array}{l}\text { Landfills must provide at least a } 200 \text {-foot buffer between the waste disposal boundary and } \\
\text { the property line, and at least a } 500 \text {-foot buffer between the waste disposal boundary and } \\
\text { any occupied dwelling and its domestic water supply well, if any. }\end{array}$ \\
\hline & $\begin{array}{l}\text { Site survey control must be provided to ensure that landfill operations occur only on per- } \\
\text { mitted lands. }\end{array}$ \\
\hline & $\begin{array}{l}\text { Appropriate sediment and erosion control measures or devices must direct surface runoff } \\
\text { from disturbed areas, with sediment basins designed to handle both the hydraulic loading for } \\
\text { the } 25 \text {-year, 24-hour storm and the sediment loading from the drainage basin for the life of } \\
\text { the site; also, runoff must flow through permanent sediment control impoundments that } \\
\text { regulate discharges. }\end{array}$ \\
\hline & $\begin{array}{l}\text { Final grading not less than } 3 \% \text { nor greater than } 33 \% \text { must ensure stability, control erosion } \\
\text { and runoff, allow vegetation of cover material, minimize percolation of precipitation, and } \\
\text { meet closure requirements. }\end{array}$ \\
\hline
\end{tabular}




\section{Table 18}

(Continued)

\begin{tabular}{|c|c|}
\hline Criteria & Restrictions/Requirements \\
\hline $\begin{array}{l}\text { Design } \\
\text { (Continued) }\end{array}$ & $\begin{array}{l}\text { Except for industrial waste landfills permitted as a monofill or receiving only a single indus- } \\
\text { try's waste that are granted a variance from the following requirements, landfills must com- } \\
\text { ply with the following: } \\
\text { - A liner and leachate collection system must be installed and constructed to ensure } \\
\text { that specified MCLs will not be exceeded in the uppermost aquifer at the relevant } \\
\text { point of compliance, as defined in the regulations. If the landfill is located in an } \\
\text { area of higher pollution susceptibility or in a significant groundwater recharge area, } \\
\text { more stringent design requirements apply (composite liner and leachate collection } \\
\text { specifications). } \\
\text { At least once each operating day, disposed solid waste must be covered with six } \\
\text { inches of earthen material or alternative approved materials. } \\
\text { - To ensure that methane gas generated by the landfill does not exceed specified } \\
\text { limits, a routine methane monitoring program must be established in accordance } \\
\text { with the regulations. }\end{array}$ \\
\hline & $\begin{array}{l}\text { A groundwater monitoring system must be installed in accordance with detailed } \\
\text { specifications and a three-tiered sampling and analysis program (detection monitor- } \\
\text { ing, assessment monitoring, and corrective action) must be implemented. } \\
\text { - A surface water monitoring plan to determine the impact of the facility on all adja- } \\
\text { cent surface waters must be included. }\end{array}$ \\
\hline Operations & $\begin{array}{l}\text { - Unauthorized access around the site must be prevented and access to vehicles must } \\
\text { be provided and maintained. } \\
\text { Disturbed areas exposed for more than three months must be vegetated within two } \\
\text { weeks of final cover placement. } \\
\text { - A detailed sequence of filling the site must be provided to minimize drainage and } \\
\text { access problems. } \\
\text { At least one day's quantity of cover material must be maintained within } 200 \mathrm{ft} \text {. of } \\
\text { the working face for fire protection. } \\
\text { The design must provide for closure and post-closure care in accordance with appli- } \\
\text { cable regulations. } \\
\text { A uniform compacted layer of clean earth cover at least one foot in depth must be } \\
\text { placed over each portion of any intermediate lift following completion of that lift. }\end{array}$ \\
\hline $\begin{array}{l}\text { Closure \& } \\
\text { Post-Closure } \\
\text { Care }\end{array}$ & $\begin{array}{l}\text { The closure and post-closure care requirements of } 40 \text { CFR } 258 \text { (described above under } \\
\text { Chapter } 4.2 .2 \text { for the federal regulatory program) apply to landfills. }\end{array}$ \\
\hline
\end{tabular}




\subsubsection{Pennsylvania}

Comprehensive revisions to Pennsylvania residual waste landfill management regulations were published on July 4, $1992^{6}$. If they do not meet the criteria of hazardous waste, coal combustion wastes are classified in Pennsylvania as "residual waste"; standards exist specific to "residual waste landfills," and a permit must be obtained before operating such a facility. [Note that coal ash may be used for beneficial uses (e.g., as structural fill, or as a soil substitute or additive) without a permit, if certain criteria specified by the state are met. (See $\S \S$ 287.661 - 287.666.)] Three types of residual waste landfills are identified: Class I, involving the disposal of residual waste with the greatest potentially adverse effects on groundwater and having the greatest potential impact on public health, safety, and the environment; Class II, representing intermediate degrees of such potentially adverse effects and impacts; and Class III, representing the least potentially adverse effects and impacts. Detailed operating requirements ${ }^{7}$ apply to all classes of landfills and address daily operations (e.g., access control, air quality protection, nuisance control, unloading), cover and revegetation, water quality protection and monitoring, gas control and monitoring, and closure/post-closure. In addition to application requirements that pertain to all landfills (e.g., requirement to conduct an extensive site analysis), there are additional requirements for each class of landfill ${ }^{8}$. Generally, a landfill's classification depends on the characterization of the waste to be disposed of and the characteristics of the landfill site. For the purpose of summarizing the state requirements, it is assumed that coal combustion waste would be disposed of at a Class II or III landfill. [If more than one type of waste contaminant is identified in the chemical and leaching analyses, the waste must be disposed of at the most protective class of facility required.] The criteria for these disposal facilities are listed in Tables 19 and 20 , respectively ${ }^{9}$.

\subsubsection{Illinois}

Illinois Solid and Special Waste Management regulations ${ }^{10}$ were amended in 1990. Unless classified as hazardous waste, coal combustion wastes are both special wastes and chemical wastes according to the regulations. Special waste means any hazardous waste, industrial process waste, or pollution control waste that has not been declassified. A chemical waste is a non-putrescible solid whose characteristics are such that any contaminated leachate is expected to be formed by chemical or physical processes, rather than by biological processes, and no gas is expected to be formed as a result.

Section 21(d) of the Illinois Environmental Protection Act exempts from permit requirements persons conducting on-site disposal operations for wastes generated by that person's own activities; however, $\S 815.101$ (a) of the regulations requires an onsite disposal operation to file an initial facility report that includes information about the location and the disposal practices at the facility. The information is the same as that required of other facilities applying for a permit. Consequently, an on-site disposal facility would not be required to obtain a permit for its operations, but it still must comply with the standards specified for special wastes and chemical wastes in Illinois.

Standards specific to special wastes disposed of in landfills, found in Subpart D, $\S \S 811.401-811.406$, address manifesting, waste profile identification records, and recordkeeping requirements ${ }^{11}$. General provisions for all new landfills apply to location, surface water drainage (runoff from disturbed areas, and the diversion of runoff from undisturbed areas), survey and boundary controls, compaction, daily cover, operations, open burning, controls on dust, noise, and disease and nuisance vectors, litter and fire measures, salvaging, closure, and post-closure. Briefly, facilities must meet requirements under the federal Wild and Scenic Rivers Act, must not 


\section{Table 19 \\ Summary of Requirements for a Pennsylvania Class II Residual Waste Landfill}

\begin{tabular}{|c|c|}
\hline Criteria & Restrictions/Requirements \\
\hline Siting & $\begin{array}{l}\text { Except for areas that were permitted before July } 4,1992 \text {, Pennsylvania mandates } \\
\text { isolation distances for locations of Class II landfills: in 100-year floodplains, and near } \\
\text { wetlands, streams, water, drinking water sources, dwellings, property lines, mineral } \\
\text { formations and refuse, and airports if putrescible waste is involved. }\end{array}$ \\
\hline $\begin{array}{l}\text { Acceptable } \\
\text { Waste }\end{array}$ & $\begin{array}{l}\text { If certain criteria are not met regarding the type of waste to be disposed, then the } \\
\text { landfill classification will be raised up from a Class II to a Class I classification, which } \\
\text { has more stringent requirements. Briefly, the Class II minimum requirements for } \\
\text { acceptable waste include, in part, the following: } \\
\text { - } \\
\text { Leachate analysis of the waste may not show that the maximum concentration } \\
\text { for a contaminant exceeds } 50 \text { times the groundwater parameter for that } \\
\text { contaminant. The Director of the State Environmental Quality Board, however, } \\
\text { may allow the disposal of such waste if the state MCL is the groundwater } \\
\text { parameter for the contaminant and it can be demonstrated that groundwater } \\
\text { degradation exceeding the state MCL or exceeding the background level will } \\
\text { not occur for that contaminant; and } \\
\text { Only residual waste with a pH between } 5.0 \text { and } 12.5 \text {, unless otherwise approved } \\
\text { in the permit, may be disposed of at the Class II landfill; the pH may be } \\
\text { adjusted to meet this requirement. }\end{array}$ \\
\hline $\begin{array}{l}\text { Liner and } \\
\text { Leachate } \\
\text { Collection } \\
\text { System }\end{array}$ & $\begin{array}{l}\text { A liner system, consisting of a subbase, leachate detection zone, composite liner, and } \\
\text { protective cover and leachate collection zone must be installed and designed in } \\
\text { accordance with performance standards as well as in accordance with minimum } \\
\text { technical standards contained in the regulations. For example, in addition to } \\
\text { performance standards that liners must meet, there are minimum technical design } \\
\text { standards that address permeability and, depending on the liner materials used and its } \\
\text { function, minimum field thickness and liner density specifications. In addition, } \\
\text { isolation distances must be maintained between the top of the subbase of the liner } \\
\text { system and specified hydrogeological features and between the waste and the liner } \\
\text { edge. A lined berm must also be constructed at least } 4 \mathrm{ft} \text {. high along the liner edge to } \\
\text { prevent the escape of leachate. }\end{array}$ \\
\hline $\begin{array}{l}\text { Leachate } \\
\text { Treatment }\end{array}$ & $\begin{array}{l}\text { Operating requirements concerning acceptable leachate treatment methods, leachate } \\
\text { recirculations, and leachate collection, storage, and analysis are detailed in the } \\
\text { regulations pertaining to Class II landfills. }\end{array}$ \\
\hline
\end{tabular}


Table 20

Summary of Requirements for a Pennsylvania Class III Residual Waste Landfill

\begin{tabular}{|c|c|}
\hline Criteria & Restrictions/Requirements \\
\hline Siting & Siting criteria for Class III landfills are identical to those for Class II landfills. \\
\hline $\begin{array}{l}\text { Acceptable } \\
\text { Waste }\end{array}$ & $\begin{array}{l}\text { If certain criteria are not met regarding the type of waste to be disposed, then the } \\
\text { landfill classification will be raised up from a Class III to a Class II classification, } \\
\text { which has more stringent requirements. Some of the minimum requirements for } \\
\text { acceptable wastes include: } \\
\text { - } \\
\text { feachate analysis of the waste may not show that the maximum concentration } \\
\text { contaminant, or for any other contaminant, exceeds the groundwater parameter } \\
\text { for that contaminant. } \\
\text { Disposal of a waste at the Class III landfill is prohibited if } 1 \text { ) the Department } \\
\text { of Natural Resources requires its disposal at a Class II facility because } \\
\text { monitoring data indicate migration of the waste or its contaminants or analyses } \\
\text { cannot predict the leachability of the waste; or } 2 \text { ) groundwater degradation at } \\
\text { one or more monitoring points exceeds the degradation at those same points } \\
\text { that would occur if the facility were a Class II landfill. } \\
\text { The waste must have a pH between } 5.5 \text { and } 9.5 \text {, unless otherwise approved in } \\
\text { the permit; the pH may be adjusted to meet this requirement. } \\
\text { The waste may not have a petroleum-based oil and grease content that exceeds } \\
1 \% \text { by dry weight. } \\
\text { The waste and its leachate must be attenuated by the soil under the disposal } \\
\text { area and must not react with other waste to adversely affect the ability of the } \\
\text { attenuating soil to prevent degradation of the groundwater. } \\
\text { - }\end{array}$ \\
\hline $\begin{array}{l}\text { Attenuating } \\
\text { Soil Base }\end{array}$ & $\begin{array}{l}\text { Minimum technical standards for the physical attributes of the attenuating soil base } \\
\text { and its placement at the disposal areas are specified to protect groundwater. The } \\
\text { requirements address such parameters as soil texture, soil composition and size, and } \\
\text { cation exchange capacity. }\end{array}$ \\
\hline
\end{tabular}


restrict the flow of storm waters in a 100-year floodplain, and are subject to restrictions on locating near areas of historic and archaeological significance, and areas that are nature preserves or where endangered species exist. Other significant general provisions require a uniform daily cover of at least 6 inches to be placed on all exposed waste, as well as compliance with performance standards concerning the size and slope of the working face and post-closure maintenance standards.

More detailed standards for chemical waste landfills are found in Subpart C, $\S \S 811.301$ - 811.323. Siting restrictions establish isolation distances from aquifers, roads, occupied dwellings, schools, hospitals, and aircraft runways. To ensure the structural integrity of disposal units, standards prescribe performance criteria for foundation and mass stability analyses, and foundation construction. All units must be equipped with leachate drainage, collection, and management systems and a compacted earth liner, for which there are regulatory performance and technical standards. Liner configurations other than those specified, special construction techniques, and admixtures may be used as long as the alternative has been successfully used or demonstrated and provides performance at least equivalent to the regulatory requirements. Landfill gas monitoring systems are required if putrescible wastes are disposed of in the unit, and landfill gas management systems are required if methane gas is detected or leachate is recycled. A one-foot intermediate cover is required on waste and the final cover system must consist of a low-permeability layer overlain by a final protective layer constructed in accordance with the regulations (e.g., for the low-permeability layer, a minimum three-foot thickness and permeability of $1 \times 10^{-6} \mathrm{~cm} / \mathrm{sec}$ ).

A three-phase hydrogeologic site investigation is required to perform a groundwater impact assessment and establish a groundwater monitoring system. Standards for the design, construction, and operation of groundwater monitoring systems, as well as for three-tiered (detection and assessment monitoring and remedial action) groundwater monitoring programs are also prescribed in detail. Finally, owners of chemical waste landfills must comply with standards addressing waste placement, final slope and stabilization design and construction, and a waste load checking program.

\subsection{Local Regulations}

Local regulations are imposed primarily through zoning ordinances that restrict siting and that may require a license to construct and operate. Although these factors are relatively minor with respect to design considerations, they should not be viewed lightly. Local opposition to siting is often exercised through zoning ordinances and has become a major impediment to new disposal facilities.

\subsection{Regulatory Summary}

Unless wastes generated by advanced coal technologies are RCRA Subtitle C hazardous wastes (because they exhibit $\mathrm{pH}$ equal to or in excess of 12.5 or because they leach concentrations of certain constituents in excess of toxicity characteristic regulatory levels), they will probably be classified and disposed of as nonhazardous solid wastes. Although federal solid waste regulations affect coal combustion waste management and disposal, states are the primary regulators of Subtitle D nonhazardous industrial waste.

As illustrated above, the states do vary in their requirements; however, the trend is clearly toward stricter standards. Such standards may include compliance with either landfill performance standards or the installation of liner and leachate collection systems. Operating requirements, groundwater monitoring programs that include corrective action requirements, and closure and postclosure standards may also be specified. 
In many states, regulatory provisions allow either the use of alternative specifications or variances for such requirements as liners, cover systems, etc., as long as a demonstration can be made that the variance or alternative is protective of human health and the environment. The burden of proof is on the disposal facility.

Where state permits or approvals are required for landfill construction and operation, contact with regulatory agencies should be initiated as soon as possible if permit variances are sought. This will allow adequate time for negotiation and development of technical data to support an alternative landfill design incorporating a reduced level of engineered controls.

\subsection{Citations}

1. United States Environmental Protection Agency, Report to Congress, Wastes from the Combustion of Coal by Electric Utility Power Plants, EPA/530SW-88-002, February 1988.

2. 56 Federal Register 50978 (October 9, 1991).
3. 58 Federal Register 51536 (October 1, 1993).

4. $\quad$ Sierra Club v. U.S. EPA, 992 F.2d 337 (D.C. Cir. 1993).

5. Rules and Regulations of the State of Georgia, Title 391, Article 3, Chapter 4, Solid Waste Management Rules.

6. Pennsylvania Code, Chapters 287-289.

7. Pennsylvania Code, Chapter 288, Subchapter C, §§ 288.201 - 288.292.

8. Pennsylvania Code, Chapter 288, Subchapters D - F, $\S \S 288.401$ 288.625 .

9. Pennsylvania Code, Chapter 288, Subchapters E-F, §§ 288.501-288.557 and $\S 288.601-288.625$.

10. Illinois Administrative Code, Title 35, Subtitle G, Chapter 1, Parts 807 - 815 .

11. Illinois Administrative Code, Subpart D: Management of Special Wastes At Landfills, $\S \S 811.401$ - 811.406. 


\section{Site Selection and Permitting}

The purpose of this chapter is to provide an overview of the site selection and permitting process for facilities that manage advanced coal technology by-products (either by disposal or by beneficial use). An outline of these processes is presented in Figure 24. Both site selection and permitting are discussed in this chapter. Aspects of site design are presented in Chapters 6, 7, and 8. Section 5.1 is a summary developed from information contained within the FGD By-product Disposal Manual ${ }^{1}$ and the Design, Construction and Monitoring of Sanitary Landfill ${ }^{2}$.

\subsection{Site Selection}

Locating and permitting a disposal site can be a long and controversial process. However, careful investigation of possible disposal areas during the site selection process can mitigate adverse environmental impacts, simplify design and permitting problems, and reduce costs. For example, selecting a site away from local residents, having lowpermeability soils and aquifers used for drinking water and will enhance regulatory and public acceptance of the facility and will probably reduce site development costs.

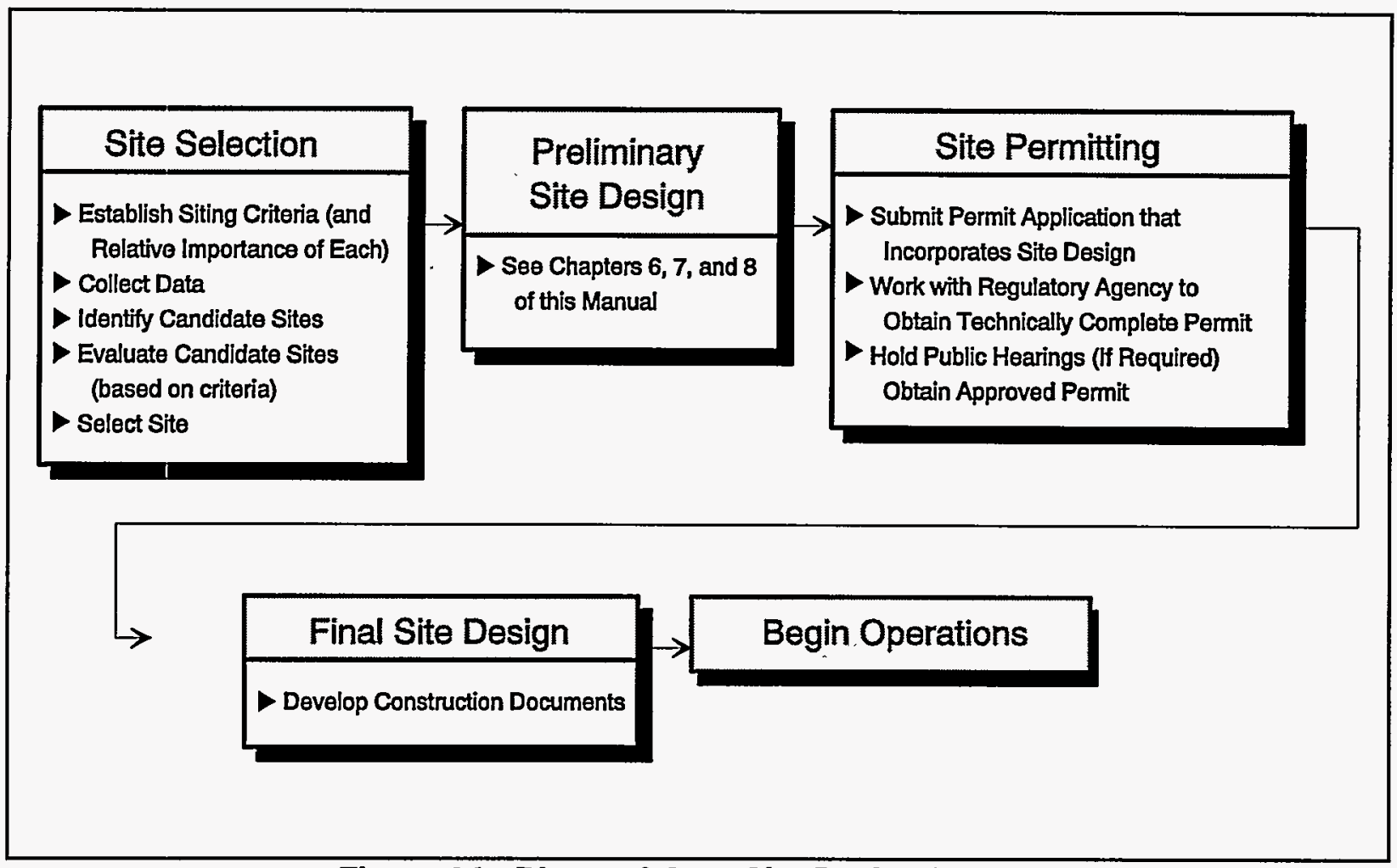

Figure 24. Disposal Area Site Design Process 
Siting a new disposal facility generally is required in the following cases:

- A new station (at a previously undeveloped site) that is to be equipped with boilers that use advanced coal technology (ACT);

- $\quad$ An existing station being equipped with a new unit;

- $\quad$ An existing station being retrofit with a new ACT boiler; and

- $\quad$ An existing station equipped with ACT boilers that has exhausted its existing disposal area.

For new stations, disposal area siting should be an integral part of the overall power plant siting process. Many new stations are in fact "mine-mouth" facilities where the generating station is co-located with, or within a few miles of, the coal source. Therefore, returning the by-products to backfill the cavities created by coal removal should be considered. Whether or not the new station is a "mine mouth" facility, combining power plant and disposal area siting eliminates the need for a separate siting study and reduces the distances wastes will be transported. However, because of the amount of land required, on-site disposal is not always possible; although it definitely should be considered, particularly for new generating stations.

For existing stations, siting a new disposal area should begin years before the area is needed. Four to six years may be necessary to identify, investigate, procure, design, permit, and develop a new disposal area. Therefore, once a need for additional disposal capacity is identified, siting the facility should begin.

The process of selecting a disposal site should be carried out at a level of detail appropriate for the situation. A rigorous search is preferable but not always necessary if the utility has a good knowledge of local conditions and potential sites. The familiarity of utility personnel with the area will be an important asset when beginning the siting process at an existing plant. Their experience at the plant has probably acquainted them with potential disposal sites near the vicinity of the plant.

The magnitude of the task of selecting a site is given perspective by envisioning the quantities of by-product material to be generated during the operating life of the power plant. This concept helps to underscore the importance of minimizing the distance between the disposal site and the power plant.

Properly carrying out the site selection process may require a multi-disciplinary team competent in the fields of engineering and environmental science, socioeconomics, political science, and land-use planning. The initial steps of the site selection process (siting criteria and data collection) are discussed in the following two sections. Once siting criteria have been established and data have been collected, candidate sites can be selected and evaluated. Then the final site can be selected.

\subsubsection{Siting Criteria}

Siting criteria (or factors) can be divided into four broad categories: engineering, environmental, economic, and political and regulatory. The major criteria within each of these categories are shown in Figure 25 and discussed in the following sections. Note that these criteria are generalized; applicable state regulations should be consulted for more specific criteria.

\section{Engineering Criteria}

- Physical size-Sufficient acreage must be provided to accommodate the byproduct material and related facilities for the design period (usually the life of the plant). Where possible, the active disposal area should be 


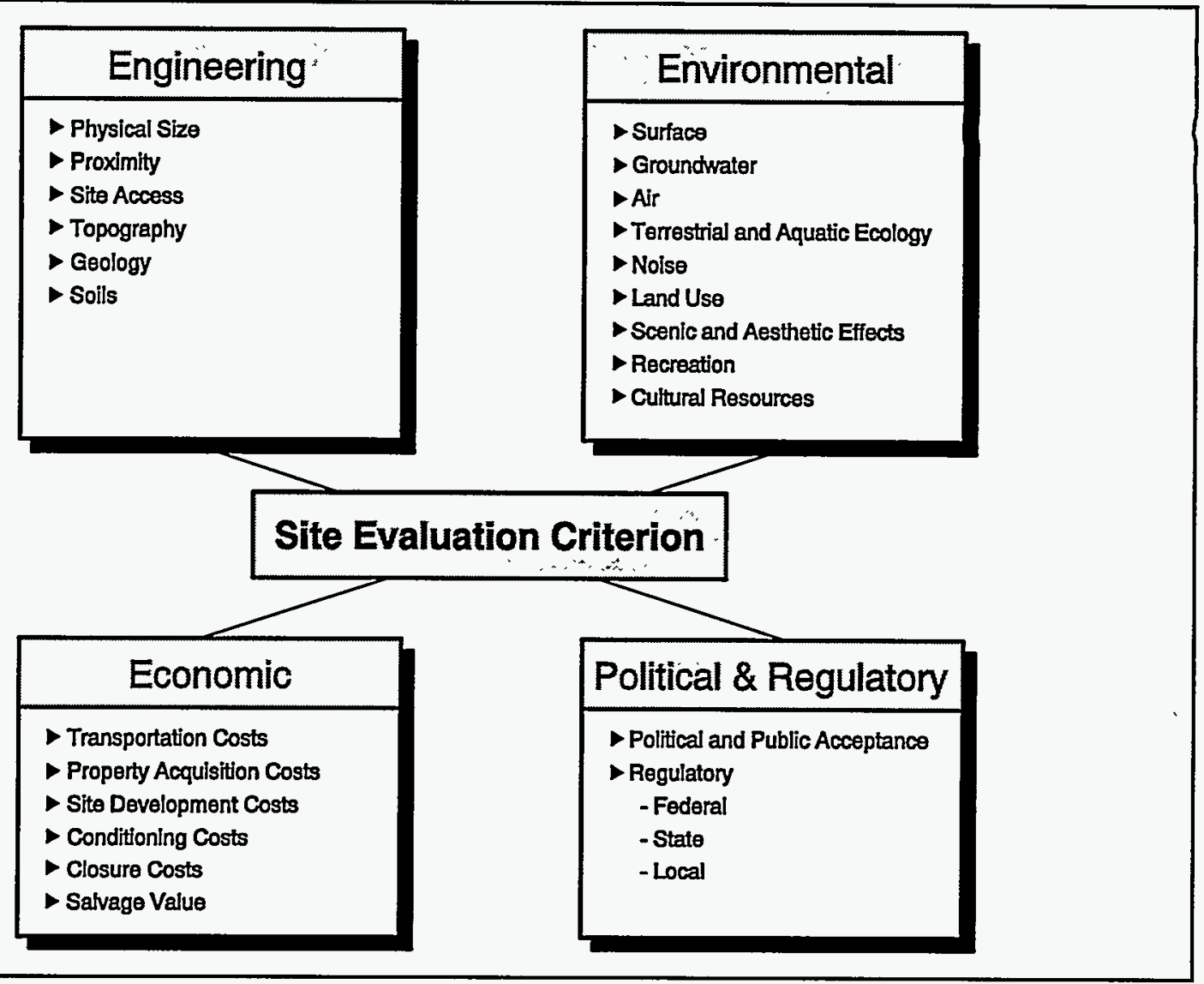

Figure 25. Site Evaluation Criteria

Source: Electric Power Research Institute. FGD By-Product Disposal Manual, 3rd ed. CS-2801, Palo Alto, California, 1983.

surrounded by at least $100 \mathrm{ft}$. of unoccupied space which serves as a buffer zone between the disposal area and site boundary.

- Proximity-The site should be as close as possible to the power plant to minimize the transportation costs.

- Site access-The site must have sufficient access for construction purposes as well as for delivery of by-product during operation. Where truck or rail transport of by-product is considered, the access route is especially important in relation to environmental factors such as safety, noise, and fugitive dust emissions. If existing routes are used, they must be of adequate width and load capacity; traffic congestion should be avoided.

- Topography-The site should be able to be developed with a minimum of earthmoving activity by using the natural contour of the land. Minimal site preparation should be required for diverting surface drainage away from the active disposal operations. Small valleys and ravines may be advantageous since they are capable of receiving large volumes without extensive modifications to the natural topography.

- Geology-Geotechnical hazard areas (such as those prone to slides and faults), as well as areas with underlying, adjacent, or interconnected 
mines, quarries, sinkholes or solution cavities should be avoided. The strength of the underlying strata should be capable of supporting any of the necessary surface structures.

- Soils-There should be an adequate depth of soil between the base of the disposal area and groundwater. The availability of sufficient clay material for use as a low-permeability in situ or remolded liner is also important.

Suitable construction materials for dikes, berms, and final cover should be available on site. The final cover material should be capable of inhibiting water flow and of developing a good stand of vegetation, if growing conditions permit.

\section{Environmental Criteria}

In general, environmental criteria are not as rigid as engineering criteria. However, environmental factors are equally or more important since they may affect the ultimate acceptance or rejection of the site and must be considered for all potential candidate sites. Environmental factors that should be considered include:

- Surface Water-The site should be located outside the 100-year flood plain to prevent inundation. Locations near surface water (rivers, creeks, ponds, swamps, wetlands, seeps, and springs) should be avoided whenever possible.

- Groundwater-Groundwater contamination is less likely to occur where there is sufficient depth between the bottom of the landfill and the historical seasonal high groundwater table. Preventing contamination is particularly important where the site overlies an aquifer which is either potentially or presently used as a water supply. The potential effect on water supplies, both groundwater and surface water, should be considered in the site location. In addition, the site's effect on groundwater quantity and quality should be minimized by locating away from groundwater recharge areas.

Air-Wind intensity and direction should be considered, particularly with regard to minimizing the effects of fugitive emissions from dry transport and disposal.

- Terrestrial and Aquatic Ecology-The alteration of any unique habitat should be avoided. Detrimental effects on any rare or endangered species (resident or migratory) must be prevented.

- Noise-The local effects of transportation (truck or rail traffic), construction, and operation should be minimized.

- Land Use-Populated areas and areas of conflicting land use, such as parks, nature preserves, wilderness areas, and airports, should be avoided. The use of potential farm and timber land should be minimized. The site should have the capability for beneficial land use at the termination of disposal operations.

- Scenic and Aesthetic Effects-Sites should be visually isolated as much as possible. Visual effects should be minimized by maintaining natural barriers such as a ridge of ground or a belt of trees. The presence of such natural barriers may preclude the need for constructing artificial screening devices.

- Cultural Resources-Unique archaeological, historical, and paleontological areas should be avoided. A thorough archaeological investigation should be performed at each site. 
Many of the criteria listed above can be satisfied by selecting a disposal site in an isolated area. The desirability of isolation, however, must be balanced against the increased cost (longer transport distance) often necessary to obtain isolation.

\section{Economic Criteria}

Project costs are always an important criterion which should be considered in evaluating alternative sites.

- Transportation Costs-Consider the distance by-products will be transported. The major cost consideration in site selection is locating the disposal site as close to the generating station as possible so as to minimize transport costs.

- Property Acquisition Costs-Consider actual land costs plus indirect costs such as legal fees, realtor costs, and related items.

- Site Development Costs-Consider factors relating to site development and construction such as excavation, grading, and new roads.

- Conditioning Costs-Consider on-site availability of clay, gravel, and other construction materials.

- Closure Costs-Consider the expense of the final covering of the site and preparing it for subsequent land use.

- Post-Closure Costs-Cost of maintaining and monitoring the site during the post-closure period, which may extend 30 years after closure.

- Salvage Value-Consider the value of land after the site is closed.

In addition to the listed factors, another consideration is the past use of the site. Select a site that has a low potential for being contaminated by previous activity. The need to monitor the site will lead to discovery and subsequent liability.

\section{Political and Regulatory Criteria}

\section{Political and Public Acceptance-}

Political acceptance means acceptance by local elected representatives such as county commissioners, town councils, local planning commissions, mayors, and supervisors. These individuals often wield considerable influence locally and can stop projects by various means, both direct (such as refusing to grant a zoning variance or preventing the transfer of property, or enacting a non-disposal ordinance) and indirect (using personal persuasion and influence to block property transfer). Public acceptance means acceptance by the public at large, including special interest groups such as sportsman clubs, nature clubs, and environmental groups.

When evaluating candidate sites, the generating station should anticipate and avoid areas and issues which are locally sensitive. Many of these relate to the environmental criteria mentioned earlier. It is important, for example, to avoid siting near parks and recreation areas, unique historical and archaeological sites, and similar areas of local concern in order to gain political and public acceptance.

Political acceptance and public acceptance may not always be the same thing. It is possible for elected officials to act in a way which they perceive to be in the public interest, allowing a project to proceed, while a sector of the public-at-large feels the project should not proceed because of a damage to its interest. It may not be possible to satisfy all these interests, for they are sometimes conflicting. However, in the site selection and evaluation process, it is best to anticipate what the opposing forces are likely to be. If these forces cannot be avoided, negotiations may succeed in reducing opposition at some increase in cost by implementing additional 
mitigating measures. Mitigating measures might include additional engineered controls to protect groundwater or prevent dusting, improved access roads, or even set-asides of land to compensate for development in certain ecologically sensitive areas.

In many cases, it is necessary to conduct a public information and public relations program concurrent with the site selection process to win political and public acceptance of the project. Both are necessary in order to proceed effectively with the project.

\section{Regulatory Requirements-The} expansion of an existing site may be made without undue difficulty because the agencies (and the general public) have become conditioned to the presence of a disposal operation. However, a new site may present greater problems because of the intrusion of an operation into a new area. Whatever the situation, it is generally advisable, as a first step, to identify and contact the relevant regulatory agencies to determine the permitting and monitoring requirements. It will be necessary for a new disposal area to meet permitting conditions, so these conditions should be determined early. The potential for reduction of certain permit requirements should be determined early in the process also, so that sufficient time is available for whatever design studies may be required. Early contacts with agency staff may also bring to light areas of concern that need to be addressed and overcome before the permits can be successfully processed.

\subsubsection{Data Collection .}

As much information as possible should be gathered to support the evaluation of each candidate site. A brief discussion of some data sources and planning tools are listed below ${ }^{2}$.

\section{Topographic Maps}

The topography of the area indicates low and high areas, natural surface water drainage pattern, streams, and wetlands. A topographic map will help find sites that are not on natural surface water drainages or within a wetland. Topography may also indicate potential groundwater recharge or discharge zones which may be subject to more stringent regulations. Local land uses are also typically shown on topographic maps.

\section{Land Use Plans}

These plans are useful when delineating areas with definite zoning restrictions. There may be restrictions on the use of agricultural land or on the use of forest land for landfill purposes. These maps are used to delineate possible sites that are sufficiently far away from inhabitations and to satisfy zoning criteria within the search area.

\section{Transportation Maps}

These maps, which indicate roads, railways, and locations of airports, are used to determine the transportation needs when developing a site. If clay needs to be hauled from a distant source for constructing a liner for a site, for example, these maps may be used to estimate the hauling distance. Allowable axle loads on roads leading to a potential site must be studied to find out whether any road improvement will be necessary.

\section{Sources of Water}

Information or maps on local sources and uses of water are not always readily available. However, once potential areas are delineated, the water use in those areas must be investigated. A plan detailing the following items should be developed: private and public wells indicating the capacity of each well; major and minor drinking water supply line(s); water intake located on surface water bodies; and open wells. A safe distance $(2,000$ feet or 
more) should be maintained from all drinking water sources. A minimum distance may be specified by the regulatory agency.

\section{Floodplain Maps}

These maps are used to delineate areas within a 100-year flood-plain. In some cases, landfills may be located within the 500-year floodplain. Landfill siting must be avoided within the floodplains of major rivers.

\section{Soil Maps}

These maps, primarily meant for agricultural use, show the types of soil near the surface. Although limited in use, these maps do provide preliminary information on area soils, drainage, and slopes.

\section{Geologic Maps}

These maps indicate geologic features, such as faults and surface geology. A general idea about soil type and drainage can be developed from a geologic map based on the type of rock exposed at the surface. Geologic maps are also very helpful for identifying clay borrow sources, gravel pits, and other potential sources of construction materials, again based on the types of deposits exposed in the area.

\section{Aerial Photographs}

Aerial photographs may not exist for the entire search area. Once a list of potential sites is developed, aerial photographs, or, preferably, a photogrameteric survey of each of the sites, may prove extremely helpful. Surface features, such as small lakes, intermittent stream beds, and current land use, which may not have been identified in earlier map searches can be easily identified using aerial photographs.

\subsection{Permitting}

Once the site has been selected, the next phase is to obtain the required permits.
The number of permits required for a disposal site can vary from 1 to 2 or to more than 10 . The scope and complexity of documentation required to secure approval can range from simple forms to a several-volume permit application that includes a complete design of the facility. Figure 26 represents a summarized decision process for completing the required permit applications. Additional information is provided in the following two sections on the number and types of permits and permitting strategies.

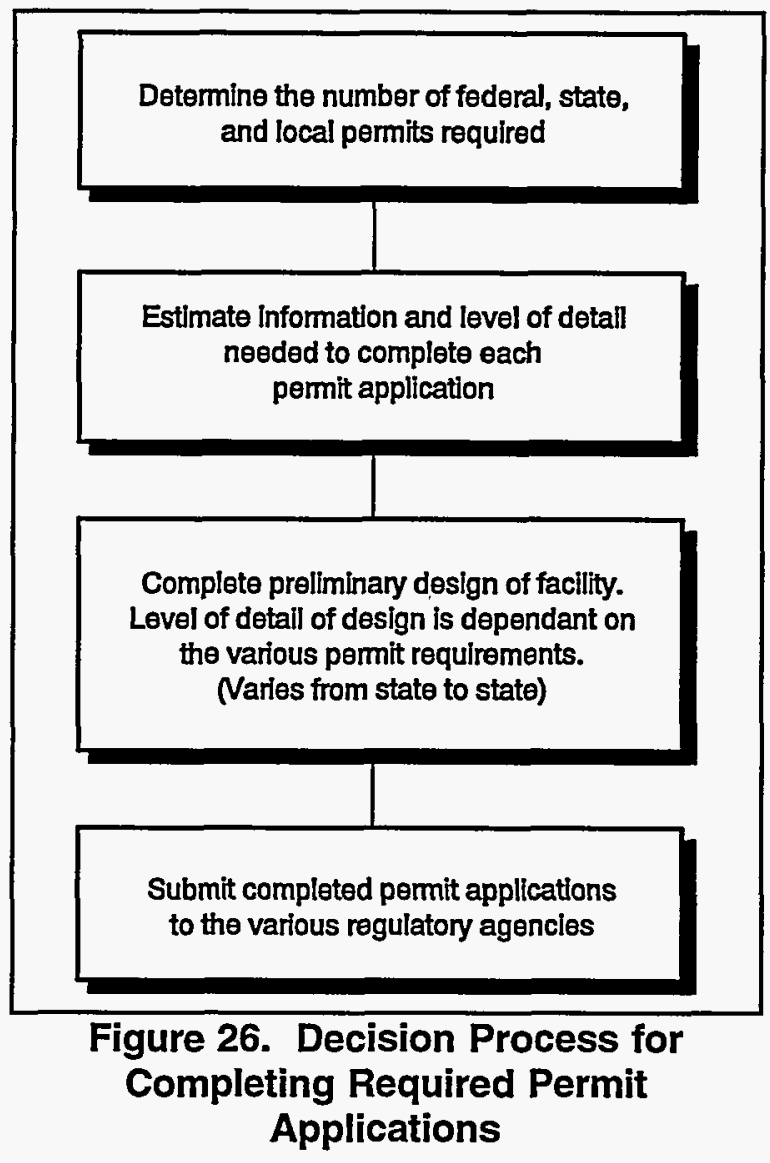

\subsubsection{Number and Types of Permits}

The number and types of permits required by various federal, state, and local regulatory agencies will depend on the specific situation and extent of the proposed facility. It is not possible to list all the permits that must be obtained because they vary drastically from state to state. However, a list of some typical permits that may be required is included in Table 21. 
Table 21

Typical Permits or Regulatory Actions Required for
Nonhazardous Solid Waste Disposal

\begin{tabular}{|c|c|c|}
\hline Government Level & Agency & Permit \\
\hline \multirow{2}{*}{ Federal } & $\begin{array}{l}\text { U.S. Environmental } \\
\text { Protection Agency }\end{array}$ & $\begin{array}{l}\text { Clean Water Act NPDES Permit } \\
\text { (including stormwater) }\end{array}$ \\
\hline & $\begin{array}{l}\text { U.S. Army Corps of } \\
\text { Engineers }\end{array}$ & $\begin{array}{l}\text { Clean Water Act Section } 404 \text { Dredge } \\
\text { and Fill Permit }\end{array}$ \\
\hline \multirow{3}{*}{ State } & $\begin{array}{l}\text { State environmental and/or } \\
\text { natural resource agency }\end{array}$ & $\begin{array}{l}\text { 1) Solid waste disposal permit } \\
\text { 2) Stream encroachment permit } \\
\text { 3) Wastewater/stormwater discharge } \\
\text { permit } \\
\text { 4) Dike permit }\end{array}$ \\
\hline & $\begin{array}{l}\text { State energy or public } \\
\text { utility agency }\end{array}$ & Solid waste disposal authorization \\
\hline & State highway department & $\begin{array}{l}\text { Authorization to build or relocate } \\
\text { roads }\end{array}$ \\
\hline Local & $\begin{array}{l}\text { City and/or county land } \\
\text { use/building regulation } \\
\text { agencies }\end{array}$ & $\begin{array}{l}\text { Zoning variance (if needed) } \\
\text { Building permit }\end{array}$ \\
\hline
\end{tabular}

NPDES $=$ National Pollutant Discharge Elimination System

An option which may be available to the facility is the "permit by rule," which may be allowed by the state for certain types of environmental activities. Under a permit by rule program, the criteria for authorization to construct and operate a certain type of facility, or to discharge or release a certain type of effluent, are specified in the rules. As long as the facility can meet these criteria, it is considered as having a "permit by rule." It is essentially a self-implementing approval process, with no formal application or agency rule or opportunity for public participation.

There is sometimes just a notification requirement to the agency.
Generally, there are two types of permit applications: 1) the main application that includes the facility design information; and 2) issue-oriented permits, such as wetland or stormwater discharge permits. The main permit application, usually required by the state agency that regulates solid waste disposal, typically includes very detailed site and facility information. Table 22 is a list of information that may be required in a permit application when a substantial amount of detailed information is required. 


\section{Table 22}

Typical Information Required in a Solid Waste Permit Application

\begin{tabular}{|c|c|c|}
\hline Item & General Description & Maps/Drawings \\
\hline $\begin{array}{l}\text { Soil and Geology } \\
\text { Information }\end{array}$ & $\begin{array}{l}\text { Geotechnical report including classification of sub- } \\
\text { surface soils and geology. Typically, groundwater } \\
\text { information is also presented here. Report is usually } \\
\text { produced after an extensive subsurface investigation } \\
\text { program is completed. }\end{array}$ & $\begin{array}{l}\text { Soil borings, area } \\
\text { geology maps, } \\
\text { groundwater level } \\
\text { contour maps }\end{array}$ \\
\hline $\begin{array}{l}\text { Area Land Use } \\
\text { Information }\end{array}$ & $\begin{array}{l}\text { Generally includes a description of area land use } \\
\text { (nearby residences, businesses, etc.), growth trends, } \\
\text { and access routes }\end{array}$ & $\begin{array}{l}\text { Highway traffic } \\
\text { information, USGS } \\
\text { topographical maps, } \\
\text { aerial photographs, site } \\
\text { survey and legal des- } \\
\text { criptions }\end{array}$ \\
\hline $\begin{array}{l}\text { Stormwater } \\
\text { Controls }\end{array}$ & $\begin{array}{l}\text { Description of all stormwater controls (includes } \\
\text { channel and retention pond design). Floodplain and } \\
\text { control of leachate are also typically discussed. }\end{array}$ & $\begin{array}{l}100 \text {-year floodplain } \\
\text { preliminary engineering } \\
\text { drawings }\end{array}$ \\
\hline $\begin{array}{l}\text { Groundwater } \\
\text { Characterization } \\
\text { and Monitoring }\end{array}$ & $\begin{array}{l}\text { Typically includes a complete description of ground- } \\
\text { water conditions beneath the site, including an } \\
\text { assessment of background conditions. A ground- } \\
\text { water monitoring plan detailing sampling and } \\
\text { analysis procedures planned for the life of the facil- } \\
\text { ity is also included. }\end{array}$ & $\begin{array}{l}\text { Details of monitor wells, } \\
\text { area groundwater maps }\end{array}$ \\
\hline $\begin{array}{l}\text { Site Operations } \\
\text { Plan }\end{array}$ & $\begin{array}{l}\text { Includes a description of how the site will be devel- } \\
\text { oped and personnel needed to operate the site. May } \\
\text { also include specifications addressing liner or cover } \\
\text { construction. }\end{array}$ & $\begin{array}{l}\text { Landfill sequencing } \\
\text { drawings }\end{array}$ \\
\hline $\begin{array}{l}\text { Closure and Post- } \\
\text { Closure Plans }\end{array}$ & $\begin{array}{l}\text { These plans contain information regarding closure of } \\
\text { the site after the facility has reached its capacity. } \\
\text { The post-closure plan will contain information } \\
\text { regarding the long-term care and monitoring of the } \\
\text { site after closure. }\end{array}$ & Engineering drawings \\
\hline
\end{tabular}

USGS = United States Geological Survey

As mentioned previously, the level of detail and information required in the solid waste and other permit applications is quite variable. In fact, some states require only general information and conceptual designs; others require specific information and detailed design information.

Regarding the local regulatory system, note that zoning maps can be obtained from the local planner's office. Local officials will likely prefer that sites be developed in areas currently zoned for non-residential use (e.g., heavy and light industrial and unproductive agricultural lands). Areas zoned residential, commercial, and recreational should be avoided; otherwise, a zoning variance must be secured. Proposing an ultimate beneficial use of the disposal area is likely to be advantageous in the local approval process, 
although a facility may not want to commit to future land uses.

In summary, any one permit (federal, state, or local) can result in a disruption of the disposal site development if not properly considered. Therefore, to prevent unnecessary, unanticipated delays in plan implementation, it is best to determine the following information early in the planning process:

- Number and type of permits required;

- Type of information to be reviewed by the agencies (e.g., conceptual or detailed design);

- Anticipated duration of review period; and

- Possibility of public hearings required as part of the review process.

With this background information, the permitting activities can be interfaced with the planning and design effort in the development of a comprehensive implementation schedule ${ }^{1}$.

\subsubsection{Permitting Strategies}

In some instances, the time needed to select a site and file the permit application (including the necessary engineering required to develop the preliminary site design) is less than the time needed to obtain the required permits. For example, completing the site selection and permit applications will typically take between one and three years; however, the permitting process may take three to six years. Therefore, utilities need to plan their disposal needs several years in advance of when a new site will be needed.

An example of a solid waste permitting process is shown as a flow chart in Figure 27. Included in this example are several regulatory comment periods in which the applicant would need to address regulatory agencies' concerns. Permitting process may include some revisions to the permit application, gathering of additional information, and a subsequent public hearing. The strategy of when to bring in key regulatory agency personnel for discussion prior to the filing of an application varies.

No single approach is best in all cases. Some utilities favor an open communication with regulatory agencies, bringing them in before the selection process begins, keeping them informed as the work progresses, and making them an integral part of the selection process. Other utilities have favored opening communications with regulatory agencies after the permit application is submitted. The best approach to use is a matter of judgement to be decided on the basis of a knowledge of individuals and agencies involved and other factors related to the situation ${ }^{1}$.

Many state regulatory agencies will have little knowledge of the properties and behavior of advanced coal technology byproducts. This may have a significant effect on the permitting process, because regulators will typically tend to act conservatively during the permit review period when dealing with a new material. Therefore, if a performancebased design demonstration is included in the permit, the applicant may need to supply a substantial amount of information regarding the physical, chemical, and engineering properties of the waste, including design information on the expected leachate quantities and characteristics. These topics are further discussed in Chapter 8 of this manual.

If a proposed facility is not located in a rural area near an existing utility or mine, the most critical element of the permitting process probably will be public acceptance of the disposal facility. In situations where a proposed facility is planned to be located in relatively close proximity (within a 1 to 2 mile radius) of local residences, the public should be informed regarding the possibility of siting a disposal facility in their area as soon as a list of potential sites is developed. Generally, the public is less suspicious and more open to 

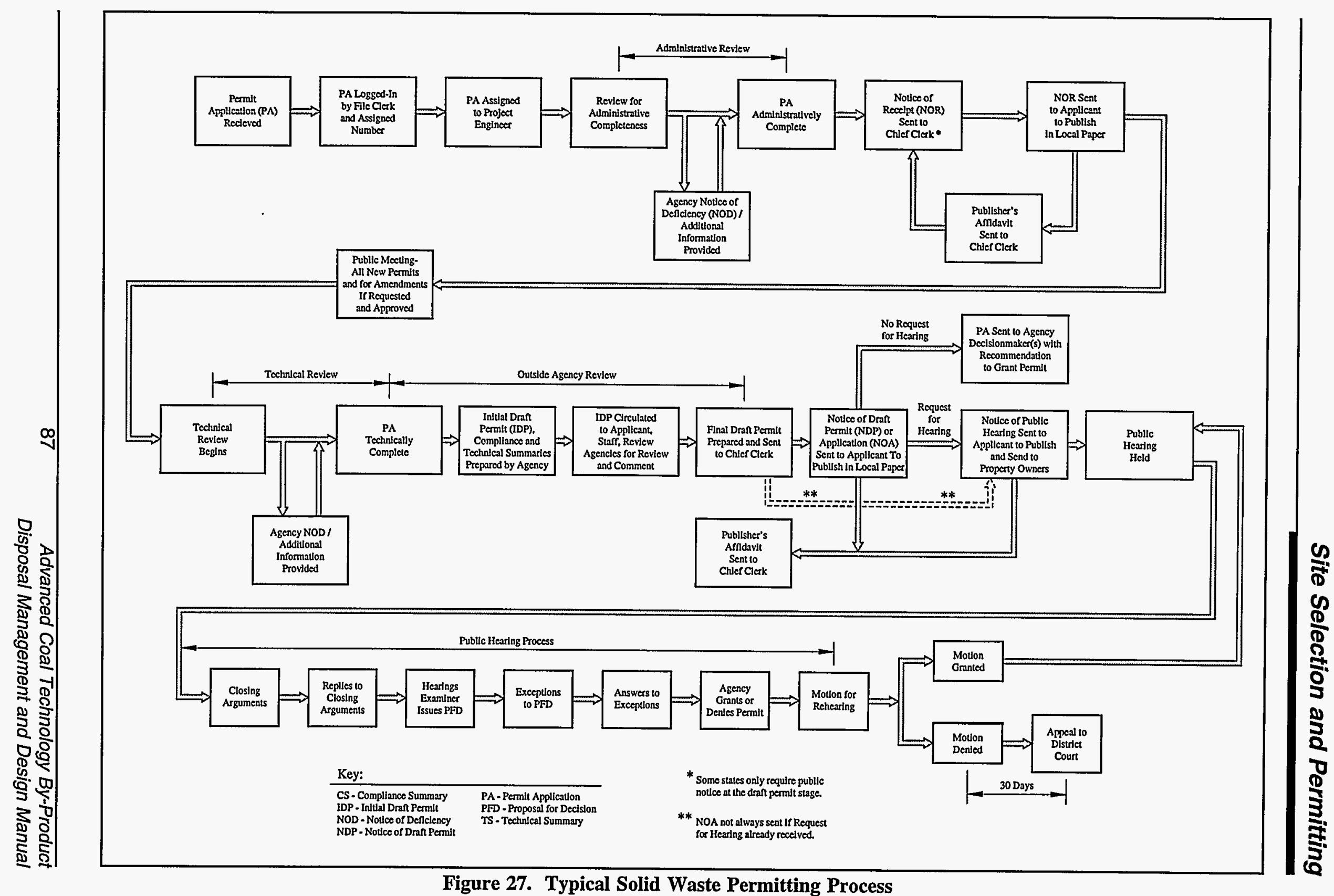

Figure 27. Typical Solid Waste Permitting Process 
discussion if they are informed by the owner rather than getting the news from other sources.

A site may be technically acceptable to regulators and economically acceptable to the generating station, but it may be strongly opposed by the public or environmental groups within the public. The "not in my backyard" sentiment is typically high initially. However, with proper public information programs and discussion, it can be overcome in some cases. Residents around the proposed site may be more inclined to cooperate if the utility listens to their concerns and considers them when designing and operating the site.

It is interesting that, whereas regulators are typically concerned with protecting surface and groundwater quality, the public is generally more concerned with noise, dust, odor, increased traffic volume, and a reduction in property values.

\subsubsection{Public Hearing Process}

By law in every state and at the federal level, persons who may be affected by a proposed waste disposal site must be notified of the proposed construction and have the right to comment on the proposal and/or request a formal public hearing. Notice to affected persons is typically required to be provided by the applicant upon submittal of the application to the regulatory agency, when the agency issues a draft permit, or both. Notice is provided by mail to adjacent land owners and to the general public through publication in a local newspaper.

A public hearing, if requested, is a formal, trial-like proceeding before a state administrative law judge (ALJ) or hearings examiner (HE). The applicant has the burden of proof to demonstrate that the technical criteria of the applicable permitting rules are adequately addressed in the application. Evidence is presented through testimony of sworn witnesses, and all parties are usually represented by attorneys. At the conclusion of the hearing process, the ALJ or HE prepares a proposal for decision (PFD) that recommends granting or denying the permit. The PFD is then presented to the governing body of the state agency who makes the final decision. Any party unhappy with the final decision may then appeal to state district court.

The public hearing process will typically delay the project from approximately 4 to 8 months. Therefore, it is usually to an applicant's advantage to anticipate potential local opposition and initiate an effective public relations campaign.

\subsection{Citations}

1. Electric Power Research Institute. FGD By-Product Disposal Manual, 3rd ed. CS-2801. Palo Alto, California, 1983.

2. Bagchi, Amalendu. Design, Construction, and Monitoring of Sanitary Landfill. John Wiley \& Sons, New York, 1990. 


\section{Components and Equipment}

Basic management system design components, equipment, and design guidelines are discussed in this chapter. These design elements will generally be required for operation of any land disposal facility or temporary by-product stockpile where materials are transported, processed, or stored. This chapter covers components common to disposal facilities and equipment which may be used for either land disposal or beneficial use/reuse facilities (such as for handling, transport, or processing). Finally, a brief description of materials handling and processing procedures used in construction and operation of landfill test cells at one site studied as part of this project is provided as a case study.

\subsection{Disposal Facility Components}

There are several features that are common to each of the landfill disposal alternatives discussed in Chapter 1. These features include: landfill configurations, stormwater management, erosion control, groundwater monitoring systems, and miscellaneous support facilities (access roads, fencing, etc.). These features are presented in the following five sections.

\subsubsection{Typical Landfill Configurations}

The critical factors involved with the selection of a configuration for an above-grade landfill are capacity, topography, erosion control, and management of stormwater. Landfill configurations are typically classified as either heaped, valley or sidehill. However, configurations of by-product material fills are typically more complex for mine reclamation and backfill. Additional information specific to mine applications will be presented in
Chapter 7. The three main landfill classifications are further defined below.

Heaped Fill-The simplest and most straightforward landfill configuration to design is the heaped above-grade fill shown in Figure 28. This type of landfill is typically used in areas where the terrain is level. Slope stability and site preparation problems are usually minimal with this configuration because of its flexibility. For example, if the by-product material is determined to have low shear strength the steepness of the side slopes can be reduced in order to achieve a stable fill. This configuration can also easily be modified to accommodate erosion control measures and containment system designs. A heaped landfill configuration, however, does not blend in with the surrounding level terrain and is highly visible. For this reason, surrounding communities may find this method more objectionable than types of fill construction "

Valley Fill-The most common type of landfill in hilly terrain is a valley fill, also shown in Figure 28. Since valleys are natural avenues for surface runoff and, in non-arid regions commonly have springs along the side slopes, control of surface water and groundwater may be necessary in these areas. It is important to direct surface runoff water under or around the fill to avoid impounding water and to help control erosion and possible contamination of runoff water (surface water controls are discussed in more detail in the following subsection). Similarly, valleys that contain perennial springs should be avoided during the site selection process to reduce leachate generation and slope stability problems. In general, site preparation is more difficult with valley fills than with other landfill configurations ${ }^{1}$. 


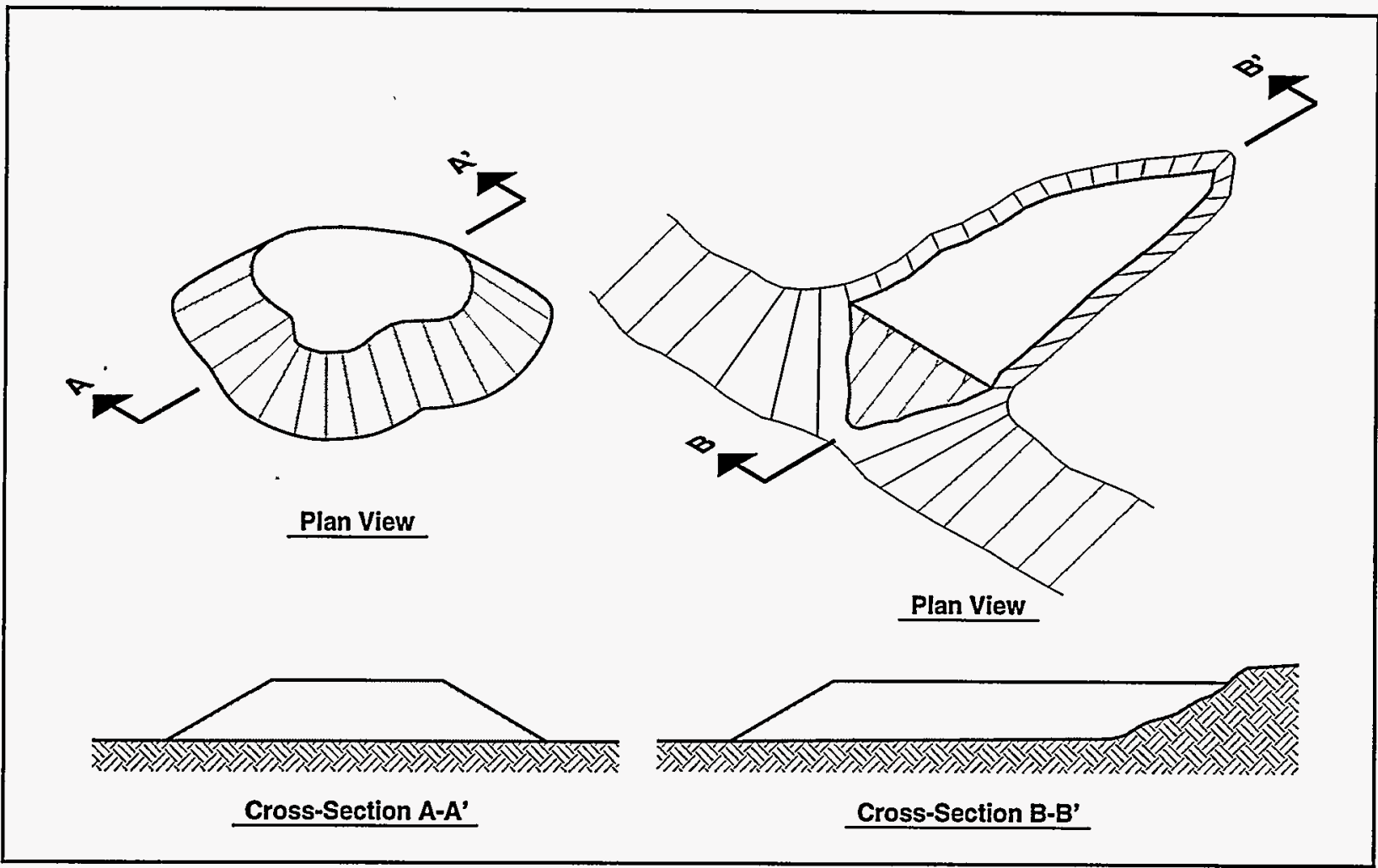

Figure 28. Heaped and Valley Landfill Configurations

Side-Hill Fill-In hilly or gently sloping terrain, side-hill construction as shown in Figure 29 is often possible. The fill may be constructed along the side of a hill or valley. Properly constructed, side-hill fills may blend well with the existing terrain and may also provide valuable property when reclaimed. Site preparation and slope stability considerations may be more complex than with heaped fills; however, this can be addressed through proper engineering ${ }^{1}$.

Additional considerations that affect each of these basic landfill configurations include slope stability, stormwater control, and erosion control. Examples of how erosion and stormwater controls affect landfill configuration are shown in Figure 30. These two items will be discussed further in Sections 6.1.2 and 6.1.3.
Slope instability is a necessary consideration for all coal combustion byproduct disposal areas. Stability is influenced by physical waste properties such as waste density, strength, degree of saturation, effective cohesion, effective angle of shearing resistance, and behavior during shearing (dilettante versus densifying); site conditions including geotechnical characteristics of the in-place foundation material and potential for seismic shaking; and geometric factors such as the heights and outslopes (or slope angles) of embankments ${ }^{2}$. Many advanced coal technology by-products exhibit initial cementation which increases slope stability significantly. However, the physical properties may deteriorate over a period of months to years with exposure to the environment. Safety factors for slope stability which are calculated based on initial strength development may be misleading. 


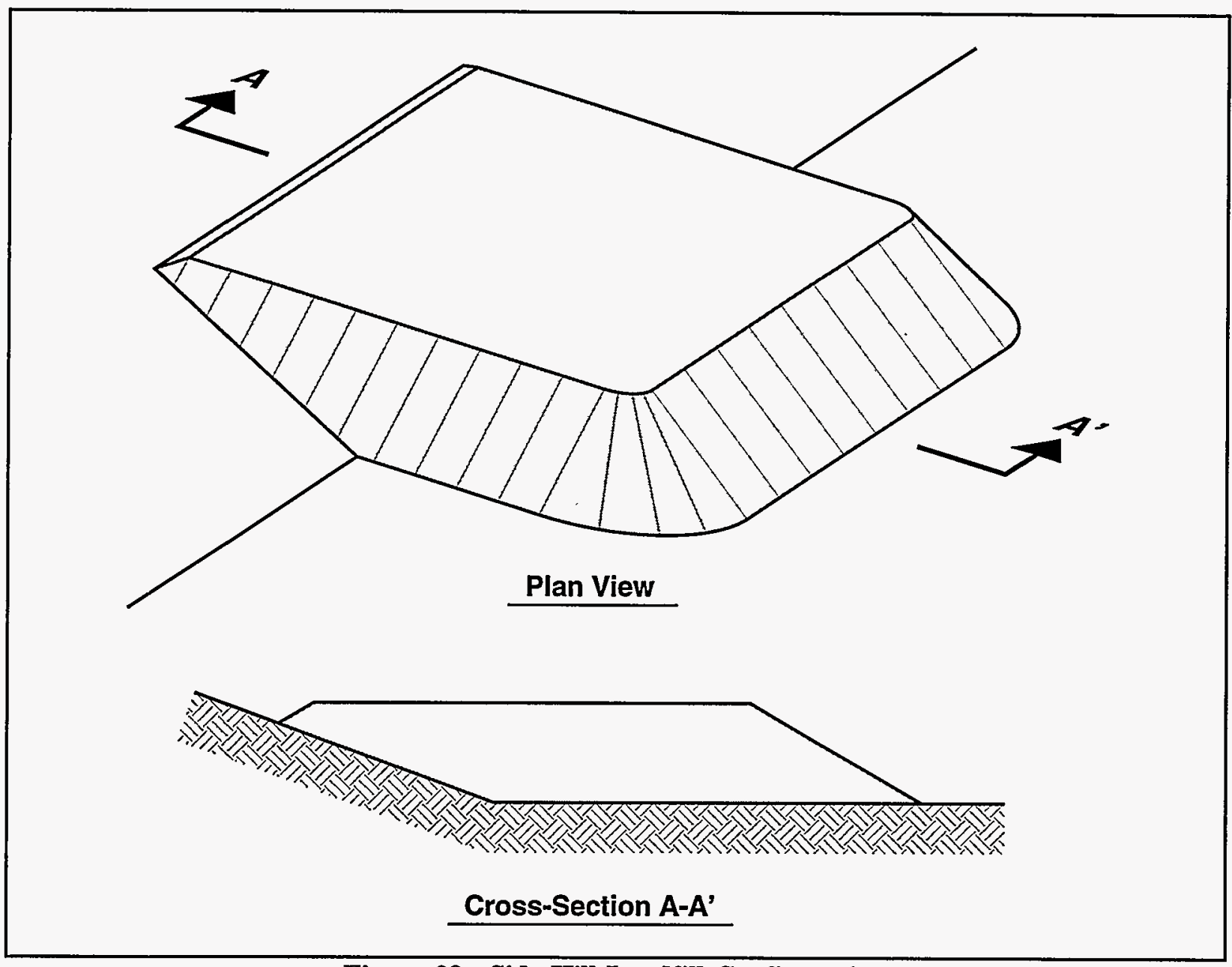

Figure 29. Side-Hill Landfill Configuration

In general, for a given material, the maximum safe embankment height decreases with increasing slope angle ${ }^{2}$. The effective slope angle of the embankment may be flattened by either lowering the slope angle (outslope) itself or by constructing benches. Benches also aid in the control of erosion (as discussed in Section 6.1.3) and in providing access to all areas of the landfill face. In fact, many state regulations require benches on embankments and dictate minimum spacing and sizes.

Foundation material also should be analyzed; weak underlying material can lead to instability and slope failure. Design measures should be taken to minimize any potential problems with weak foundation material. Surface water and groundwater controls also influence the amount of moisture in the waste material and foundation, and therefore affect the stability of the fill.

The stability of a fill is important in relation to safety aspects and hazard potential. Safety is especially critical when ${ }^{2}$ :

- The site is located where a slope failure (landslide, slumping, or sloughing) would have a high possibility of causing injury, death, or extensive property damage. 


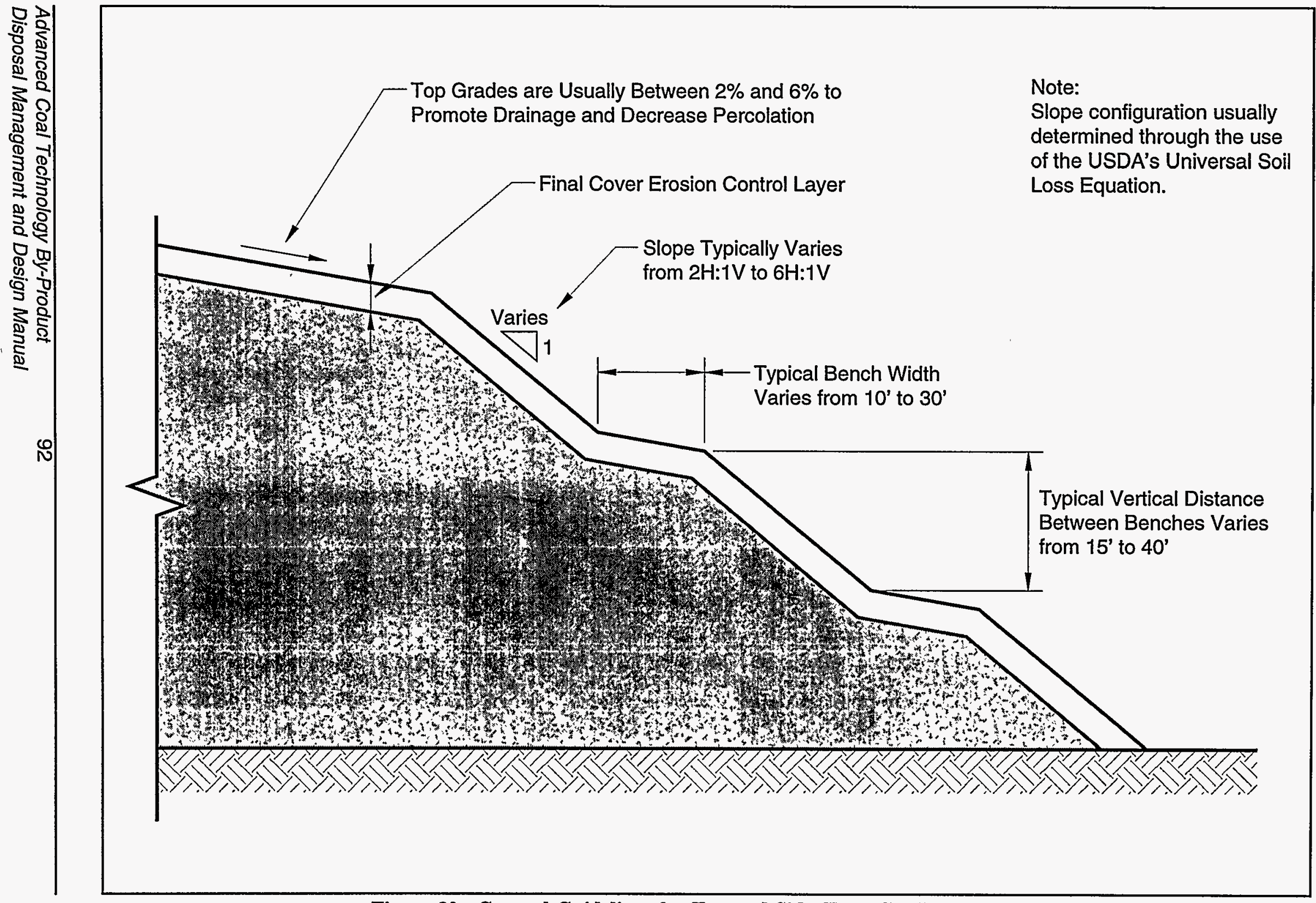

Figure 30. General Guidelines for Top and Side Slope Configurations 
- The site is located adjacent to a stream where significant sloughing or movement of the embankment could block or restrict stream flow, creating a temporary impoundment which could release a floodwave upon breaching.

- The site is staged in such a manner that the potential exists to unexpectedly impound water during some stage of development, despite the existence of an underlying drainage system. This unanticipated accumulation of water could structurally weaken the fill to the point where slumping or sloughing results.

When a landfill is designed and permitted, some type of stability analysis must be performed to show that outslopes are stable. The result of this analysis is a calculated "factor of safety." Most regulatory agencies specify a minimum factor of safety that must be demonstrated; this factor of safety can vary depending upon the agency involved. The calculated factor of safety can be increased by the following measures ${ }^{2}$ :

- Flattening the outslope of landfill embankments. This can be done by either reducing the slopes of the landfill itself or by adding benches.

- Improving landfill foundation conditions.

- Constructing a granular underdrain system beneath the landfill to ensure that pore water pressure will not adversely affect stability.

- Sloping the top of landfill for drainage and constructing diversion channels at the perimeter to minimize surface water entering the landfill.

\subsubsection{Stormwater Management}

An important factor in the construction of any landfill is the stormwater controls that will be utilized at the site. The development of a stormwater management plan for the life of the site is usually required in most solid waste permit applications. The development of a landfill can be thought of as a long-term construction project which typically takes 20 to 30 years to complete. Therefore, it is important to consider what stormwater management measures will be needed as site development progresses. The design of a stormwater management system is usually a very complex task and is dependent upon individual site characteristics. Therefore, the objective of this section is to provide the reader with an overview of the design criteria and stormwater control techniques common to landfills. Additional design information can be obtained from the reference list provided in Table 23.

Stormwater runoff volumes calculated on the basis of soil characteristics may not adequately represent runoff from the active portions of an advanced coal technology byproduct landfill. Field results and calculations (see Chapters 8 and 9) indicate that runoff may account for a very small percentage of the landfill water balance, even under quite wet conditions.

As with most landfill design elements, the design criteria set forth by regulatory agencies vary from state to state; however, a few of the general criteria are listed below.

- A facility should generally be located outside the boundaries of the 100 year flood plain unless it can be demonstrated that flow from the 100 year flood and storage capacity of the floodplain are not restricted. 
Table 23

References for Hydraulic Design

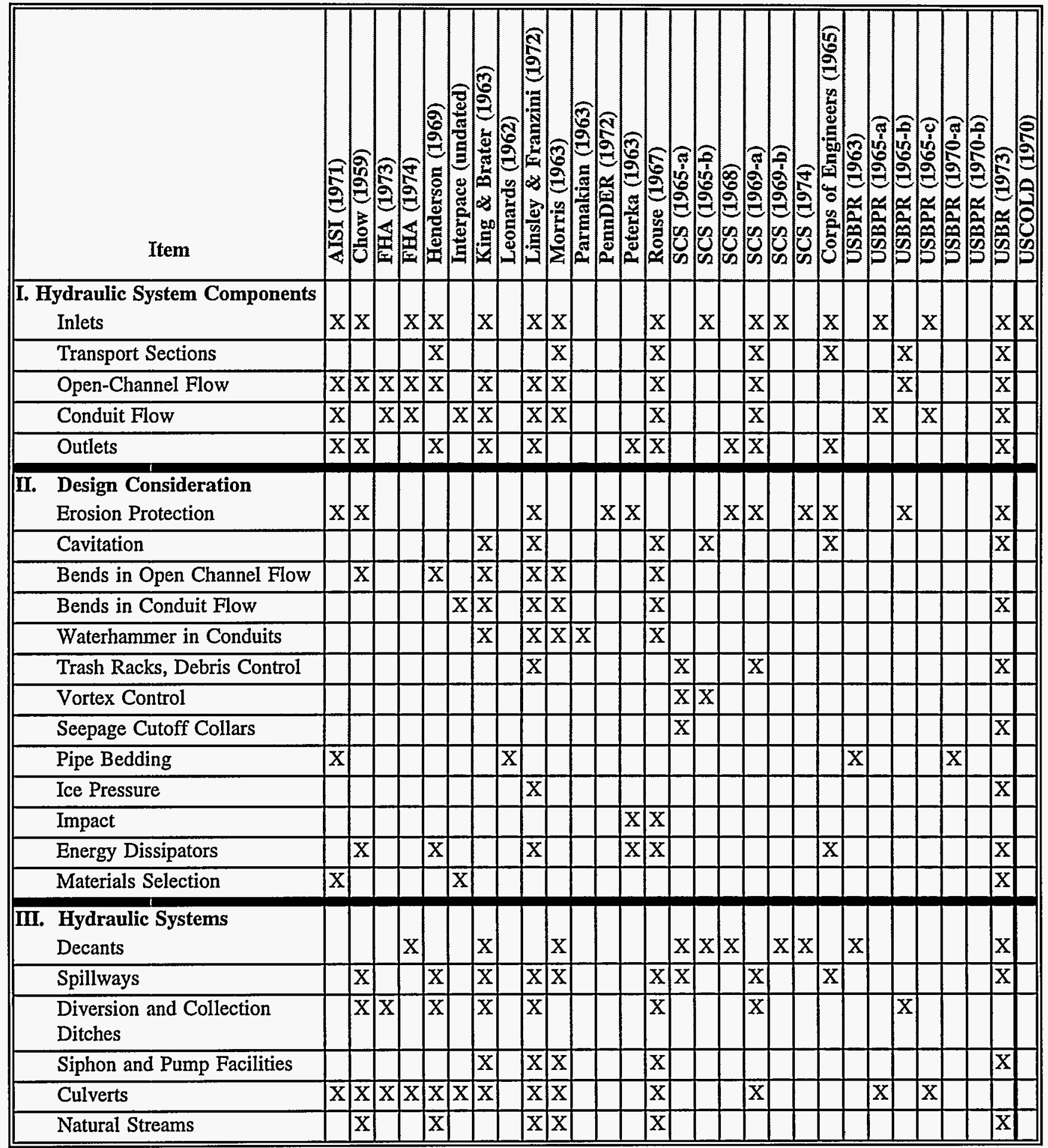

Source: E.D. Appolonia Consulting Engineers, Inc., Engineering and Design Manual Coal Refuse Disposal Facilities, U.S. Department of Interior, Mining Enforcement and Safety Administration, 1975. 


\section{Table 23}

(Continued)

1. American Iron and Steel Institute (AISI), "Handbook of Steel Drainage and Highway Construction Products, 1971.

2. Chow, V.T., Open-Channel Hydraulics, McGraw-Hill Book Company, 1959.

3. Federal Highway Administration (FHA), "Design Charts for Open-Channel Flow," U.S. Department of Transportation, 1973.

4. Federal Highway Administration (FHA), "Hydraulic Design of Improved Inlets for Culverts, " U.S. Department of Transportation, 1974.

5. Henderson, F.M., Open Channel Flow, The Macmillan Company, 1969.

6. Interpace Corporation, "Engineering Manual," Lock Joint Concrete Pressure Pipe, Parsippany, New Jersey, undated.

7. King, H.W., and Brater, E.F., Handbook of Hydraulics, McGraw-Hill Book Company, 1963.

8. Leonards, G.A., ed. Foundation Engineering, McGraw-Hill Book Company, 1962.

9. Linsley, R.K., and Franzini, J.B., Water-Resources Engineering, McGraw-Hill Book Company, 1972.

10. Morris, H.M., Applied Hydraulics in Engineering, The Ronald Press Company, 1963.

11. Parmakian, J., Waterhammer Analysis, Dover Publications, 1963.

12. Pennsylvania Department of Environmental Resources (PennDER), Soil Erosion and Sedimentation Control Manual, 1973.

13. Peterka, A.J., "Hydraulic Design of Stilling Basins and Energy Dissipators," A Water Resources Technical Publication, Engineering Monograph No. 25, Bureau of Reclamation, U.S. Department of the Interior, 1963.

14. Rouse, H., ed. "Engineering Hydraulics," Proceedings, Fourth Hydraulics Conference, Iowa Institute of Hydraulic Research, June 1949, John Wiley and Sons, Inc., 1967.

15. Soil Conservation Service (SCS), "Engineering Memorandum - 27," U.S. Department of Agriculture, 1965-a.

16. Soil Conservation Service (SCS), "Hydraulics of Two-Way Covered Risers," Technical Release No. 29, U.S. Department of Agriculture, 1965-b.

17. Soil Conservation Service (SCS), "Armored Scour Hole for Cantilever Outlet," Design Note No. 6, U.S. Department of Agriculture, 1968.

18. Soil Conservation Service (SCS), "Engineering Field Manual, For Conservation Practices," U.S. Department of Agriculture, 1969-a.

19. Soil Conservation Service (SCS), "Entrance Head Losses in Drop Inlet Spillways," Design Note No. 8, U.S. Department of Agriculture, 1969-b.

20. Soil Conservation Service (SCS), "Erosion and Sediment Control Handbook for Urban Areas, West Virginia," U.S. Department of Agriculture, 1974.

21. U.S. Bureau of Public Roads (USBPR), "Reinforced Concrete Pipe Culverts," U.S. Department of Commerce, 1963.

22. U.S. Bureau of Public Roads (USBPR), "Capacity Charts for the Hydraulic Design of Highway Culverts," U.S. Department of Commerce, 1965-a.

23. U.S. Bureau of Public Roads (USBPR), "Design of Roadside Drainage Channels," U.S. Department of Commerce, 1965-b.

24. U.S. Bureau of Public Roads (USBPR), "Hydraulic Charts for the Selection of Highway Culverts," U.S. Department of Commerce, 1965-c.

25. U.S. Bureau of Public Roads (USBPR), "Corrugated Metal Pipe, Structural Design Criteria and Recommended Installation Practice," U.S. Department of Transportation, 1970-a.

26. U.S. Bureau of Public Roads (USBPR), "Use of Riprap for Bank Protection," Hydraulic Engineering Circular No. 11, U.S. Department of Transportation, 1970-b.

27. U.S. Bureau of Reclamation (USBR), "Design of Small Dams," A Water Resources Technical Publication, U.S. Department of the Interior, 1973.

28. U.S. Committee, International Commission on Large Dams, (USCOLD), "Criteria and Practices Utilized in Determining the Required Capacity of Spillways," 1970. 
- Drainage that flows onto the site from surrounding areas should be diverted around the perimeter of the site before disposal activities begin.

- Development of the site should not cause a significant change to area drainage patterns. This guideline is imposed by some states to protect structures that are located upstream and downstream of the disposal facility.

- Run-off that is produced from precipitation that falls directly on active disposal areas should be diverted to a sediment basin. Typically, these basins are designed to handle runoff from the 25-year, 24-hour storm event.

- Channels that convey stormwater from the facility to the sediment or detention pond are typically designed to handle runoff produced from a 25 year storm event.

\section{Off-Site Run-On Protection}

Protection from off-site run-on is generally provided at disposal facilities to limit the quantity of stormwater that flows into the internal drainage system of a landfill. Run-on protection is advantageous to facility operations because it limits the quantity of water that flows through the facility, thereby decreasing the size of any required sedimentation or detention pond (discussed further in the following subchapter). Diversion berms and drainage channels are typically used to prevent off-site drainage from entering the landfill. The height of the perimeter berms or capacity of the drainage channels is determined by analyzing the surrounding watershed area and estimating design flows. A variety of computer programs are available to assist the design professional in evaluating and designing these systems. Stormwater run-on control measures are typically designed to prevent flow from the 100-year storm event from entering the facility.
In some cases, existing creeks or streams may need to be relocated to allow site development. This may require major permitting, design, and construction efforts; however, for an otherwise acceptable site, the problems with relocating a small stream usually are not major. Stream location subsystems must be specified to safely pass runoff from a design storm (usually 100-year frequency) as detailed above. The frequency of the specified storm usually is a function of drainage area size and hazard potential ${ }^{2}$.

\section{On-Site Stormwater Management}

On-site stormwater management involves managing all precipitation that falls within the boundaries of the perimeter diversion berms and channels. If possible, it is advantageous to separate this stormwater into the following two categories:

- Precipitation that falls directly on the active portion of the landfill and comes in contact with the by-product material is typically defined as "contaminated" water; and

- Precipitation that falls on natural ground or closed areas and does not come into direct contact with byproduct material is typically defined as "clean" water.

Contaminated water (as defined above) is usually channeled to sedimentation ponds for clarification before discharging. National Pollutant Discharge Elimination System (NPDES) permits are usually required for sedimentation discharge points. If it is anticipated that "contaminated" surface water runoff will need to be treated (e.g., if treatment for the removal of metals will be required) before discharge, the cost to operate the disposal facility will increase substantially. As an alternative to treatment (if required), conveying the runoff discharge to the plant for use or treatment and disposal should be considered. Another option is to use this runoff water to hydrate and 
condition the by-product material before disposal.

Sedimentation ponds usually are sized to hold the runoff from a specified precipitation event (typically the 25-year, 24-hour storm event) and to provide adequate detention time for runoff. The sedimentation pond should be designed to perform in the following manner.

- Promote sedimentation of suspended solids carried by the runoff from the disposal area.

- Allow passage of extreme storm events without structural damage to embankments (i.e., emergency spillways).

- Include capability for pond dewatering to accommodate subsequent storm events and to enable removal of accumulated solids in the pond. Depending on the regulations, solids removal may be required when accumulation reaches anywhere from $25 \%$ to $70 \%$ of design capacity ${ }^{2}$.

Runoff that does not come into contact with by-product material will also need to be managed according to applicable regulations. Typically "clean" stormwater is managed by one of the methods listed below.

- Channel the runoff to a "clean" detention pond. This pond is separate from the sedimentation pond; however, it is designed following the same criteria and methods listed above for a sedimentation pond. The purpose of the detention pond is to provide temporary or long-term storage of excess runoff that occurs as a result of the development of the site. This may be required to protect downstream or upstream structures or developments. In addition, regulators may require a detention pond to collect erosion that may occur from areas that have received final cover.
- No detention of "clean" runoff. In some cases a detention pond may not be needed or required, allowing clean runoff to directly flow off-site. Under this option, care must be taken, during the development of the site, to ensure that the active area is completely segregated from the undeveloped or closed areas.

\subsubsection{Erosion Control}

As with other major design elements, most state regulatory agencies require adequate design information from the facility operator to show how erosion and soil loss from the final cover material will be minimized. Erosion controls include the use of appropriate side slopes, vegetation, and structural erosion control measures. These erosion control elements, as well as a summary of how to use the Universal Soil Loss Equation to analyze specific designs, are discussed in the following subchapters.

\section{Establishment of the Vegetation Layer}

A well established vegetated cover not only improves the appearance of the disposal site, but also controls erosion of the final cover material. The vegetation layer is typically defined as 18 to 24 inches of topsoil and a grass layer. The purpose of this layer (with respect to erosion control only) is to provide for the long-term erosional stability of the landfills slopes after the site is closed. The topsoil layer should be specified to achieve the following three items:

- Provide enough thickness to retain an adequate supply of water and nutrients in the specified root zone for the vegetation;

- Provide sufficient plant density to minimize cover soil erosion; and 
- The root zone should also be thick enough to allow for the total depth needed for the roots of vegetative growth while not impinging on any underlying drainage or barrier layers.

The most important criterion in selecting the vegetation for the final cover layer is to choose species that are known to grow well in that geographic region and to select plants that can be expected to provide a complete surface covering within a reasonably short time. Local soil conservation service offices or state agricultural service extension personnel can provide expert assistance in selecting appropriate vegetation.

\section{Slope Configuration and Other Structural Controls}

The main variables in determining appropriate slope configurations to minimize erosion are slope steepness and slope length. These variables directly affect the velocity of stormwater runoff flowing over the final cover layer. To minimize erosion, this velocity will need to be less than the permissible velocity for a specific cover material. For the type of final cover described in the previous subchapter (18 to 24 inches of topsoil seeded with a native vegetative cover), it is generally suggested ${ }^{3}$ that the vegetation layer will only control erosion if the slopes are flatter than $4 \mathrm{H}$ (horizontal):1V (vertical) or about 15 degrees slope, and the slope length is less than 60 feet (i.e., a bench would be constructed every 60 feet of slope length). For slope lengths greater than 100 feet, a milder slope of approximately $6(\mathrm{H}): 1(\mathrm{~V})$, or about 10 degrees, would be needed to control erosion. These examples were derived from using the universal soil loss equation which is discussed in more detail in the next subchapter.

Another method that is often utilized to reduce slope length, in addition to benching, is to construct a system of diversion berms or intercepter trenches that extend perpendicular to the slope. These structural controls intercept stormwater flow down the slope and channel the flow to lined chutes which convey stormwater to the base of the landfill. The narrow chutes are typically lined with rip-rap or concrete to protect the underlying cover material from erosion.

\section{Universal Soil Loss Equation}

One method of estimating soil loss from final cover designs is the universal soil loss equation (USLE) developed by the U.S. Department of Agriculture (USDA) ${ }^{3}$. The variables of the soil loss equation are presented below.

$$
A=(R)(K)(L S)(C)(P)
$$

where: $A=$ the computed soil loss in tons per acre per year, obtained by multiplication of the remaining factors.

$R=$ the rainfall and runoff factor, (tons/acre year)

$K=$ the soil erodibility factor, (unitless factor)

$\mathrm{LS}=$ the topographic factor or the slope-steepness factor, (unitless factor)

$\mathrm{C}=$ the cover and management factor, (unitless factor)

$\mathrm{P}=$ the support factor, (unitless factor)

Before the soil loss equation can be used to select re-vegetation alternatives, soil loss tolerance values must be established for the final cover area under study. Currently, these values are estimated and they vary from state to state. However, typical values range between 2 and 5 tons/acre/year depending on the type of soil, depth of final cover, and various physical properties. The following items should be considered while developing limits for allowable soil losses:

- Maintain an adequate soil depth favorable for sustained growth over a long period of time. The effect of soil 
erosion on vegetative productivity should be considered for the anticipated mixed soil materials under consideration.

- Soil losses should be held below those that cause serious rilling and gully development.

- Soil losses should be held below those causing serious siltation in waterways, terrace channels, drainage ditches, road ditches, etc.

- Erosion causes seeding losses and poor crop stands through washouts, siltation, or loss of plant nutrients. Soil losses should be kept below the point where this becomes a serious problem.

- Soil losses in excess of tolerance levels affect the maintenance, cost, and effectiveness of surface water control structures such as open ditches, retention ponds, and other structures affected by sediment.

- It should be kept in mind that the soilloss equation gives the soil loss for a particular soil cover and slope-length revegetation system. Soil loss measurements for a given soil cover, slopelength, and rainfall intensities can also be made directly in the field. Such measurements may help establish actual soil losses under the site-specific cover and slope-length conditions and can serve as a field demonstration to verify the validity of applicable USLE or configuration design parameters.

The variables of the soil loss equation are detailed below:

The rainfall factor $(\mathbf{R})$ is a numerical value which expresses the capacity of the locally expected rainfall to erode soil from an unprotected (fallow) field. The factor $R$ in the USLE can be calculated empirically from climato- logical data. For average annual soil loss determinations, however, $\mathrm{R}$ can be obtained directly from Figure 31 .

Soil Erodibility Factor (K) is a measure of the inherent erodibility of a given soil. Values for $\mathrm{K}$ typically range from 0.10 to 0.45 with high-sand and high-clay content soils having lower values and high-silt content soils having higher values. Long-term plot studies under natural rainfall have produced $\mathrm{K}$ values generalized in Table 24 for the USDA designated soil types. Estimated $\mathrm{K}$ values can also be obtained from local U.S. Soil Conservation Service (SCS) data or USDA/SCS soil survey reports.

The Cover and Management Factor (C) in the USLE is the ratio of soil loss from land cropped under specified conditions to that clean-tilled, continuous fallow. Therefore, $\mathrm{C}$ combines effects of vegetation, crop sequence, management, and agronomic (as opposed to engineering) erosion-control practices. On landfills, freshly covered and without vegetation or special erosion-reducing procedures of cover placement, $\mathrm{C}$ will usually be about unity. Where there is vegetative cover or significant amounts of gravel, roots, or plant residues or cultural practices which increase infiltration and reduce runoff velocity, $C$ is much less than unity. Estimated $\mathrm{C}$ values from Table 25 for anticipated cover management can be used. However, these values should be adjusted with seasonal or annual changes that may occur in percent cover and plant density. For most landfills, $C$ values from the top row (no appreciable canopy) are most appropriate. The $\mathrm{C}$-factor is perhaps the most important USLE factor because it represents conditions that can be managed most easily to reduce erosion. 


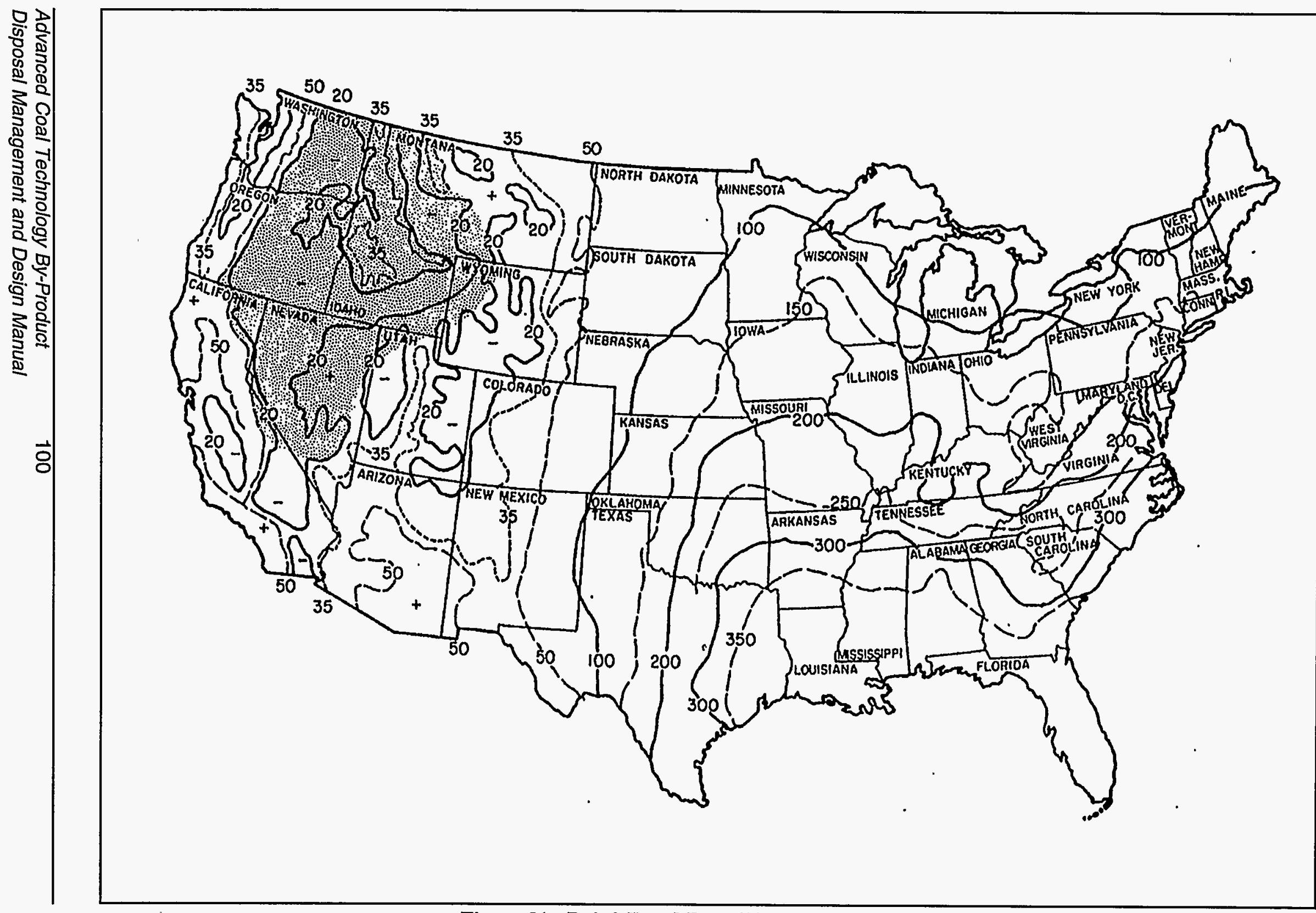

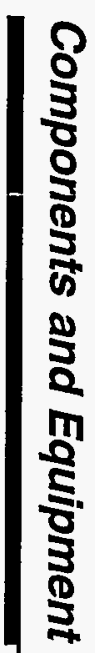

Figure 31. Rainfall and Runoff Erosivity Index, $R$

Source: U.S. Department of Agriculture, Ag. Res. Service. Control of Water Pollution from Cropland. ARS-H-5-1 and ARS-H-5-2. Washington, D.C., 1976. 
Table 24

Approximate Values of Factor K for USDA Textural Classes ${ }^{1}$

\begin{tabular}{|c|c|c|c|}
\hline \multirow[b]{2}{*}{ Texture Class } & \multicolumn{3}{|c|}{ Organic Matter Content } \\
\hline & $\begin{array}{c}<0.5 \% \\
\mathrm{~K}\end{array}$ & $\begin{array}{c}2 \% \\
\mathrm{~K}\end{array}$ & $\begin{array}{c}4 \% \\
\mathrm{~K}\end{array}$ \\
\hline Sand & 0.05 & 0.03 & 0.02 \\
\hline Fine Sand & 0.16 & 0.14 & 0.10 \\
\hline Very Fine Sand & $\overline{0.42}$ & 0.36 & 0.28 \\
\hline Loamy Sand & 0.12 & 0.10 & 0.08 \\
\hline Loamy Fine Sand & $\overline{0.24}$ & 0.20 & $\overline{0.16}$ \\
\hline Loamy Very Fine Sand & 0.44 & 0.38 & 0.30 \\
\hline Sandy Loam & 0.27 & 0.24 & 0.19 \\
\hline Fine Sandy Loam & 0.35 & 0.30 & 0.24 \\
\hline Very Fine Sandy Loam & 0.47 & 0.41 & 0.33 \\
\hline Loam & 0.38 & 0.32 & 0.29 \\
\hline Silt Loam & 0.48 & 0.42 & 0.33 \\
\hline Silt & 0.60 & 0.52 & 0.42 \\
\hline Sandy Clay Loam & $\overline{0.27}$ & 0.25 & 0.21 \\
\hline Clay Loam & 0.28 & 0.25 & 0.21 \\
\hline Silty Clay Loam & 0.37 & 0.32 & 0.26 \\
\hline Sandy Clay & 0.14 & 0.13 & 0.12 \\
\hline Silty Clay & 0.25 & 0.23 & 0.19 \\
\hline Clay & \multicolumn{3}{|c|}{$0-13-0.29$} \\
\hline
\end{tabular}

1 The values shown are estimated averages of broad ranges of specific-soil values. When a texture is near the borderline of two texture classes, use the average of the two $K$ values.

Source: U.S. Department of Agriculture, Ag. Res. Service. Control of Water Pollution from Cropland. ARS-H-5-1 and ARS-H-5-2.

Washington, D.C., 1976.

Table 25

Factor $\mathbf{C}$ for Permanent Pasture, Range, and Idle Land ${ }^{1}$

\begin{tabular}{|c|c|c|c|c|c|c|c|}
\hline \multicolumn{2}{|c|}{ Vegetative Canopy } & \multirow{2}{*}{\multicolumn{6}{|c|}{$\begin{array}{c}\text { Cover That Contacts the Soil Surface } \\
\text { Percent Ground Cover }\end{array}$}} \\
\hline \multirow[b]{2}{*}{ Type and Height ${ }^{2}$} & \multirow[b]{2}{*}{ Percent Cover $^{3}$} & & & & & & \\
\hline & & $\mathbf{0}$ & 20 & 40 & 60 & 80 & $95+$ \\
\hline No Appreciable Canopy & & 0.45 & 0.20 & 0.10 & 0.042 & 0.013 & 0.003 \\
\hline \multirow{3}{*}{$\begin{array}{l}\text { Tall weeds or short brush } \\
\text { with average drop fall } \\
\text { height of } 20 \text { inches }\end{array}$} & 25 & 0.36 & 0.17 & 0.09 & 0.038 & 0.013 & 0.011 \\
\hline & 50 & 0.26 & 0.13 & 0.07 & 0.035 & 0.012 & 0.003 \\
\hline & 75 & 0.17 & 0.10 & 0.06 & 0.032 & 0.011 & 0.003 \\
\hline
\end{tabular}

Source: United States Department of Agriculture, Agriculture Handbook Number 537

'The listed $C$ values assume that the vegetation and mulch are randomly distributed over the entire area.

${ }^{2}$ Canopy height is measured as the average fall height of water drips falling from the canopy to the ground. Canopy effect is inversely proportional to drop fall height and is negligible if fall height exceeds 33 feet.

${ }^{3}$ Portions of total-area surface that would be hidden from view by canopy in a vertical projection (a bird's-eye view). 
Slope-Length Factors/Topographic Factor (LS)-Solution of the soil loss equation is made easier by combining the equations for length and percentage of slope. The values used in the equation are ratios of loss for any steepness and length of slope with an arbitrarily selected standard being a $9 \%, 72.6$ foot slope. The family of curves presented in Figure 32 has been prepared for use in solution of the soil-loss equation. The field slope length is used in determining the value of the slope-length factor in the erosion equation for both contouring and contour strip-cropping. But, with benching, the recommended horizontal distance (horizontal spacing) is used in place of the field slope length. Soil loss is much more sensitive to changes in slope steepness than to changes in slope length. In the present USLE, a $10 \%$ error in slope steepness gives about a $20 \%$ error in computed soil loss. Thus, special attention should be given to obtaining good estimates of slope steepness.

Support Practice Factor $(P)-O$ all the USLE factors, values for the $P$ factor are the least reliable. The $P$ factor (Table 26) mainly represents how surface conditions affect flow paths and flow hydraulics. For example, with contouring, tillage marks are credited with directing runoff around slope at much reduced grades. However, slight changes in grade can change runoff erosivity greatly. Contouring appears to produce its maximum average effect on medium slopes ( 2 to $7 \%$ ). Here, soil losses with contouring are about one-half that occurring with up- and down-hill farming. As land slope increases from medium to steeper slopes, contour row capacity diminishes until, at steep slopes, there is very little capacity to detain water or soil. Furthermore, contouring provides almost complete protection for individual storms of low intensity, but for severe storms that cause extensive row breakage, contouring provides little or no protection.

\section{Table 26}

P Factors for Contouring, Contour Stripcropping, and Terracing

\begin{tabular}{|c|c|c|c||}
\hline $\begin{array}{c}\text { Land } \\
\text { Slope }\end{array}$ & \multicolumn{3}{|c|}{ P Values } \\
\hline$\%$ & Contouring & $\begin{array}{c}\text { Contour } \\
\text { Stripcropping }\end{array}$ & Terracing \\
\hline 2.0 to 7 & 0.50 & 0.25 & 0.50 \\
\hline 8.0 to 12 & 0.60 & 0.30 & 0.60 \\
\hline 13.0 to 18 & 0.80 & 0.40 & 0.80 \\
\hline 19.0 to 24 & 0.90 & 0.45 & 0.90 \\
\hline
\end{tabular}

${ }^{1}$ Contouring and terracing columns are suitable for landfill cover. Contour stripcropping is not suitable for the type of vegetative cover normally practiced at landfills.

Source: U.S. Department of Agriculture, Ag. Res. Service. Control of Water Pollution from Cropland. ARS-H-5-1 and ARS-H-5-2. Washington, D.C., 1976.

\subsubsection{Groundwater Monitoring Systems}

A groundwater monitoring program may be required for landfills containing coal combustion by-products, including those from advanced coal technologies, to determine if leachate migration has affected groundwater quality. The following paragraphs outline the basic elements of a groundwater monitoring program. For specific examples of state requirements see Table 17 in Chapter 4.

If sufficient precipitation infiltrates a landfill that is unlined and has no leachate collection and removal system, leachate may migrate from the base of the landfill and eventually affect groundwater quality. Several factors affect the migration of leachate once it 


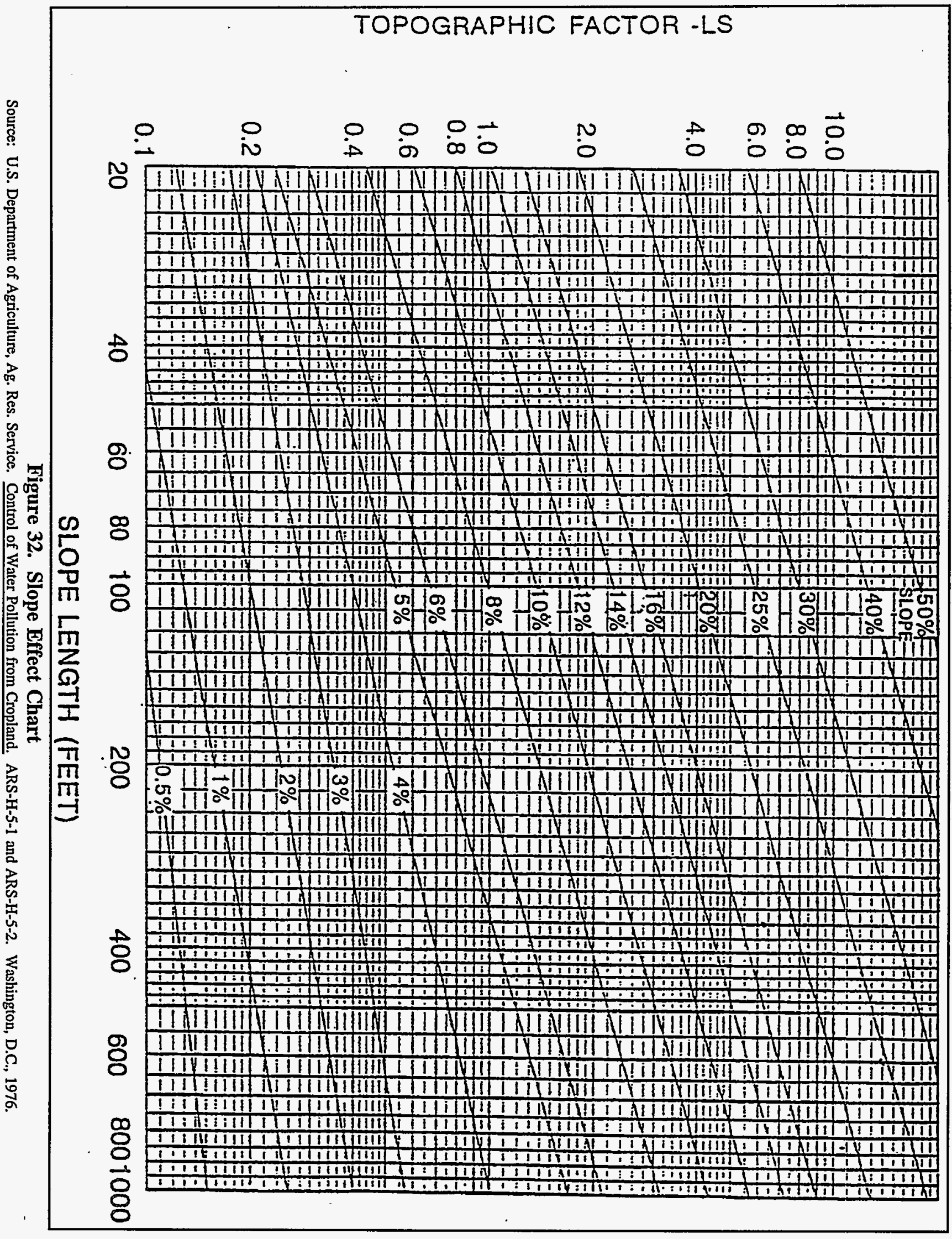


leaves the base of the landfill. If the landfill is situated so that its base is above the water table, the leachate must migrate through the vadose (unsaturated) zone before it can affect groundwater quality. In the vadose zone, the movement of the leachate is driven by gravity and capillary action. Clays, organic matter, and oxides and hydroxides of iron and manganese may attenuate certain chemical species in the leachate. Other species are unlikely to attenuate and continue to migrate with the leachate front. Upon hitting the saturated zone, the leachate is physically transported by the groundwater flow.

Attenuation on soil particles may continue to take place. Dispersion, or the movement of solutes from an area of high concentration to areas of low concentration, also affects the movement of leachate components in groundwater. Generally, leachate constituents from an above-ground landfill will be concentrated at the top of the uppermost aquifer. A properly planned and implemented groundwater monitoring program can allow the utility operator to track the movement of landfill leachate and provide input to predictive models. Figure 33 shows a schematic diagram of the leachate migration process and a typical monitoring system.

\section{Groundwater Flow Direction and Rate}

The first step to implementing a groundwater monitoring program is to determine the depth to groundwater and the horizontal component of flow. This is necessary to predict the path of potential leachate migration. A general idea of the direction of groundwater flow, or hydraulic gradient, can be obtained by observing the site topography, aerial photographs, and topographic maps. However, small-scale topographic features and subsurface geology, such as fractures or abandoned stream channels, can have a major affect on the direction of flow on a local scale. It is more accurate to use direct observation of water levels in observation wells or piezometers to calculate the hydraulic gradient. For this approach, a minimum of three wells or piezometers are necessary to define flow. After determining the static water level in each well, the water levels are contoured to define the potentiometric surface. The horizontal hydraulic gradient is perpendicular to the contours that define this surface. Figure 34 shows schematically the relationship between measured water levels, the piezometric surface, and groundwater flow. Determinations of horizontal hydraulic gradient should be made at different times throughout the year to determine if there are seasonal affects on groundwater flow.

Groundwater may also have a vertical component of flow. A cluster of observation wells or piezometers, screened at different depths, can be used to determine the vertical hydraulic gradient. These wells can be installed in separate-but closely spaced-borings, or multiple wells can be installed in one boring.

After determining the direction of groundwater flow, it may be desirable to also calculate a flow rate for use in groundwater flow or leachate migration models. Darcy's Law defines the velocity of groundwater flow, or specific discharge, by the following equation:

$$
\mathrm{v}=-\mathrm{Ki}
$$

where: $v=$ velocity of groundwater flow in units of length/time $(\mathrm{L} / \mathrm{T})$;

$\mathrm{K}=$ hydraulic conductivity $(\mathrm{L} / \mathrm{T})$; and

$\mathrm{i}=$ hydraulic gradient $(\mathrm{L} / \mathrm{L}$, or unitless).

By convention, the hydraulic gradient, or change in hydraulic head over change in distance, is negative, so the specific discharge is a positive value.

Hydraulic conductivity, sometimes referred to as the coefficient of permeability, 


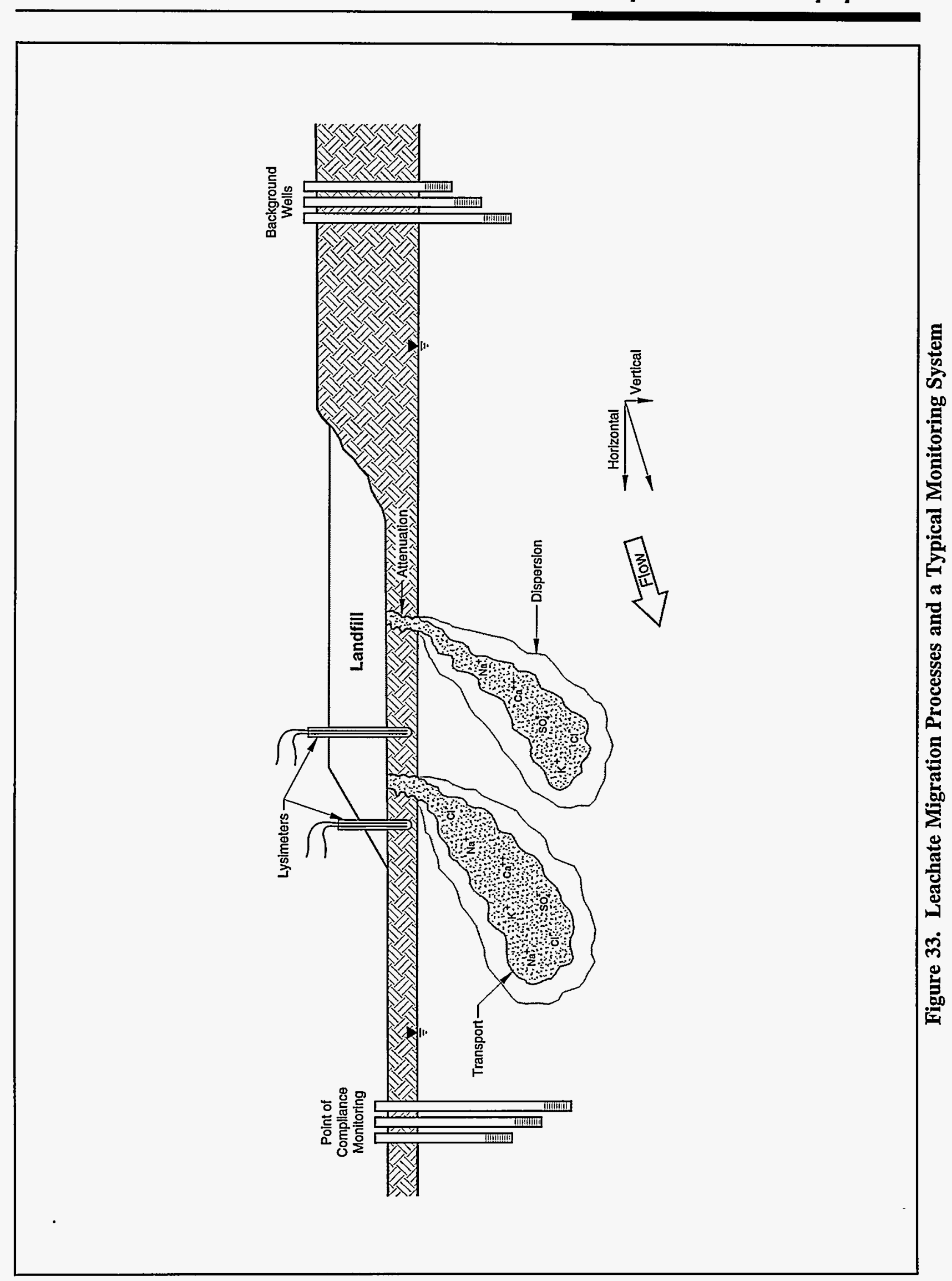



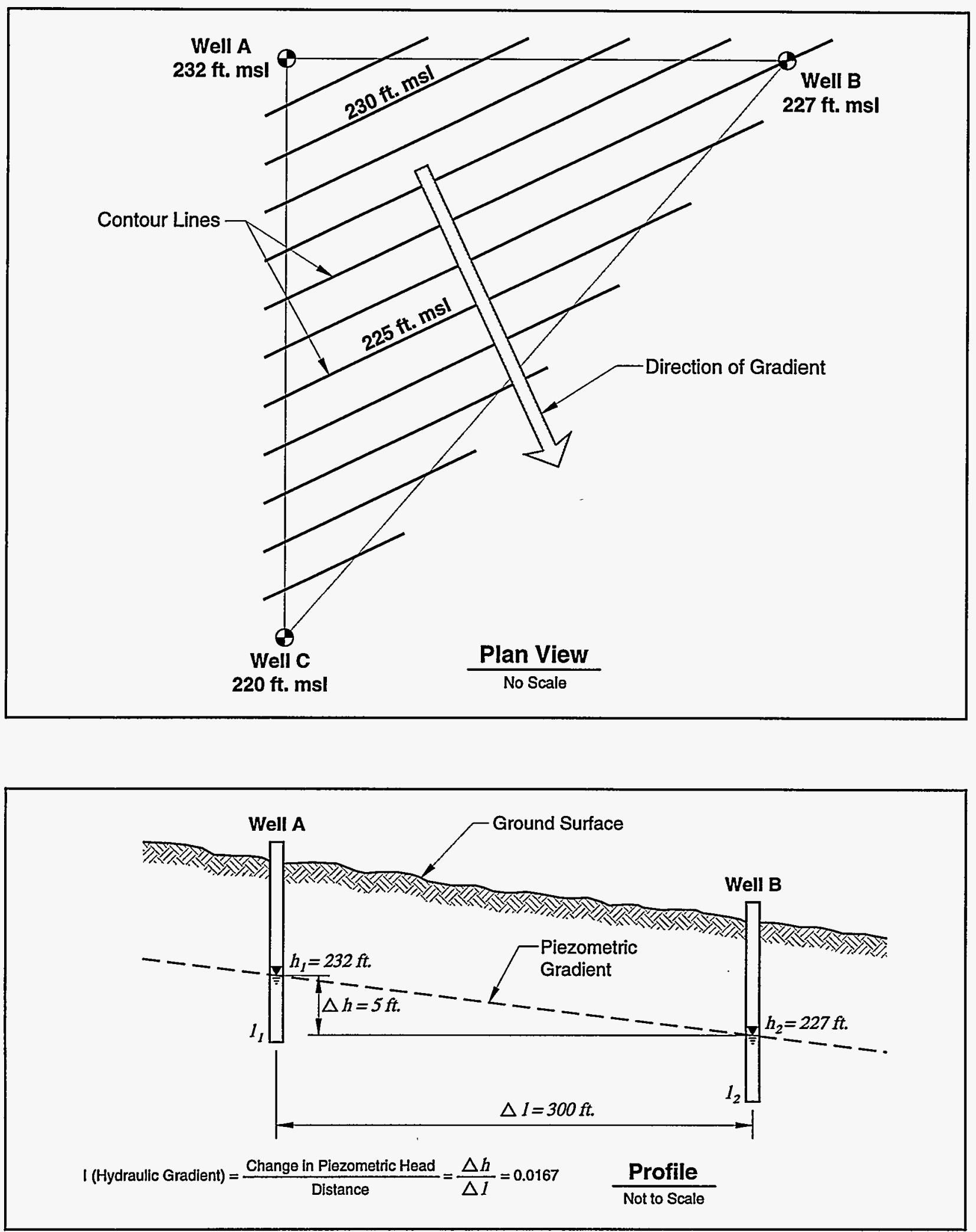

Figure 34. Typical Plan for Determining Magnitude and Direction of the Hydraulic Gradient 
can be measured by conducting a pumping test on a well surrounded by a series of wells screened at different depths within the same water-bearing formation. The central well, or pumping well, is pumped at a constant rate while water level readings are taken in the surrounding observation wells to measure the degree of drawdown at various distances from the pumping well. The pumping is continued until steady state conditions are reached, and the rate of recovery is monitored in the wells. The rate of recovery is proportional to the hydraulic conductivity. [Pumping tests are also measures of the communication between different depths of the aquifer and can be used to determine the lower limits of an aquifer.] If the aquifer is considered isotropic and homogeneous, it is possible to use a single well method, or slug test, to determine hydraulic conductivity. In this method, a weight, or "slug" is lowered (or removed) from the well displacing a known volume of water, and the rate of recovery of the water level is monitored. There are several other methods of evaluating hydraulic conductivity both in the field and on undisturbed cores in the laboratory. Table 27 outlines some of these methods. It is also possible to estimate hydraulic conductivity based on the subsurface geology of the site. Figure 35 provides a list of methods to estimate hydraulic conductivity for various geologic materials.

\section{Determination of Background}

Many states require the establishment of background or baseline conditions of groundwater at a landfill site. These conditions can be established in two ways: 1) by sampling groundwater at a site prior to construction of a landfill, or 2) by installing at least two monitor wells hydraulically upgradient of the landfill. Installing wells upgradient of the landfill allows for continued monitoring of background conditions. If monitoring of the background wells follows the same schedule as that for downgradient wells, a direct comparison of the data over time is possible. If a baseline is being established prior to landfill construction, it is important to collect several rounds of samples to determine seasonal or other variability in water quality. The distribution of these data can then be established, and statistical comparisons can be made to samples collected downgradient of the landfill. For example, if the analytical results for several samples of background groundwater show that calcium is normally distributed, this information can be used to infer an upper tolerance limit for naturally occurring calcium. That is, a maximum expected background concentration of calcium is defined. Calcium data from downgradient monitoring at the site can then be compared to this upper tolerance limit to determine if the upgradient and downgradient concentrations are significantly different. Specific approaches to determining background may be required by some states.

\section{Monitor Well Installation and Placement}

A major element of any groundwater monitoring program is the installation of wells downgradient from the potential source. Monitor wells generally consist of a PVC or stainless steel casing and screen centered within a boring. [Due to the potential for elevated levels of chloride and corrosivity in some utility leachates, the use of PVC is recommended.] Figure 36 shows a crosssectional diagram of a typical monitor well. The screened interval is surrounded by a filter pack of sand or gravel, depending on the particle size of the formation. A seal is placed above the screened interval to prevent water from higher up in the aquifer from infiltrating the well. [A seal should also be used when drilling through a confining layer to prevent cross-contamination from an upper aquifer.] The screened interval may be very large, to ensure that any leachate migration is detected, or very small, to determine conditions at a discrete depth. A large screened interval may lead to the dilution of target analytes and a small screened interval may miss "seeing" a leachate plume if it is placed at the wrong depth. The recommended approach is to install 
Table 27

\section{Summary of Methods to Measure Hydraulic Conductivity Values in the Field and Laboratory}

\begin{tabular}{|c|c|c|}
\hline Method & Application & Reference \\
\hline \multicolumn{3}{|l|}{ Saturated } \\
\hline Slug Test & $\begin{array}{l}\text { Confined aquifers with fully-penetrating wells screened along the entire aquifer } \\
\text { thickness. Single-well test for wells not intended for sampling. }\end{array}$ & $\begin{array}{l}\text { Hvorslev, } 1951 \\
\text { Bouwer and Rice, } \\
1976 \\
\text { Lohman, } 1972 \\
\end{array}$ \\
\hline Pumping Test & $\begin{array}{l}\text { Complex multiple-well test for confined or unconfined aquifers with fully or } \\
\text { partially penetrating wells. Used for wide range of aquifer permeabilities. } \\
\text { Test wells can be used for sampling. Tests a relatively large volume of the } \\
\text { aquifer. }\end{array}$ & $\begin{array}{l}\text { Bureau of } \\
\text { Reclamation, } 1977 \\
\text { Stallman, } 1971 \\
\text { Driscol, } 1986 \\
\text { Lohman, } 1972\end{array}$ \\
\hline $\begin{array}{l}\text { Steady-state } \\
\text { Permeameter }\end{array}$ & $\begin{array}{l}\text { Laboratory method to determine sample hydraulic conductivity within a range } \\
\text { from } 1.0 \mathrm{~cm} / \mathrm{sec} \text { to } 10^{-5} \mathrm{~cm} / \mathrm{sec} \text {. }\end{array}$ & $\begin{array}{l}\text { Klute and Dirksen, } \\
1986\end{array}$ \\
\hline $\begin{array}{l}\text { Falling-head } \\
\text { Permeameter }\end{array}$ & $\begin{array}{l}\text { Laboratory method to determine sample hydraulic conductivity within a range } \\
\text { from } 10^{-3} \mathrm{~cm} / \mathrm{sec} \text { to } 10^{-9} \mathrm{~cm} / \mathrm{sec} \text {. }\end{array}$ & $\begin{array}{l}\text { Klute and Dirksen, } \\
1986\end{array}$ \\
\hline \multicolumn{3}{|l|}{ Unsaturated } \\
\hline $\begin{array}{l}\text { Constant-head } \\
\text { Borehole } \\
\text { Infiltration }\end{array}$ & $\begin{array}{l}\text { Field method in open or partially cased borehole. Most commonly used } \\
\text { method. Includes a relatively large volume of porous media in test. }\end{array}$ & $\begin{array}{l}\text { Bouwer, } 1978 \\
\text { Stephens and } \\
\text { Neuman, 1982a, b, c, } \\
\text { Amoozegar and } \\
\text { Warrick, } 1986\end{array}$ \\
\hline $\begin{array}{l}\text { Guelph } \\
\text { Permeameter }\end{array}$ & $\begin{array}{l}\text { Field method in open, small-diameter borehole ( }>5 \mathrm{sm}) \text {. Relatively fast } \\
\text { method ( } 5 \text { to } 60 \text { minutes) requiring small volume of water. } \mathrm{K}_{\mathrm{s}}, \mathrm{K}(\Psi) \text { and } \\
\text { sorptivity are measured simultaneously. Many boreholes and tests may be } \\
\text { required to fully represent heterogeneities of porous media. }\end{array}$ & $\begin{array}{l}\text { Reynolds and Elrick, } \\
1986\end{array}$ \\
\hline $\begin{array}{l}\text { Air-Entry } \\
\text { Permeameter }\end{array}$ & $\begin{array}{l}\text { Field method. Test performed in cylinder which is driven into porous media. } \\
\text { Small volume of material tested; hence, many tests may be needed. Fast, } \\
\text { simple method requiring little water }(10 \mathrm{~L}) \text {. }\end{array}$ & Bouwer, 1966 \\
\hline $\begin{array}{l}\text { Instantaneous } \\
\text { Profile }\end{array}$ & $\begin{array}{l}\text { Field or lab method. Field method measures vertical } \mathrm{K}(\theta, \psi) \text { during drainage. } \\
\text { Measurement of moisture content and hydraulic head needs to be rapid and } \\
\text { non destructive to sample. Commonly used method and reasonably accurate. }\end{array}$ & $\begin{array}{l}\text { Bouma, Baker, and } \\
\text { Veneman, } 1974 \\
\text { Klute and Dirksen, } \\
1986\end{array}$ \\
\hline $\begin{array}{l}\text { Crust-Imposed } \\
\text { Steady Flux }\end{array}$ & $\begin{array}{l}\text { Field method. Measure vertical } \mathrm{K}(\psi) \text { during wetting portion of hysteresis } \\
\text { loop. Labor and time intensive. }\end{array}$ & $\begin{array}{l}\text { Green, Ahuja, and } \\
\text { Chong, } 1986\end{array}$ \\
\hline $\begin{array}{l}\text { Sprinkler- } \\
\text { Imposed } \\
\text { Steady Flux }\end{array}$ & $\begin{array}{l}\text { Field method. Larger sample area than for crust method. Useful only for } \\
\text { relatively high moisture contents. }\end{array}$ & $\begin{array}{l}\text { Green, Ahuja and } \\
\text { Chong, } 1986\end{array}$ \\
\hline $\begin{array}{l}\text { Parameter } \\
\text { Identification }\end{array}$ & $\begin{array}{l}\text { Results of one field or lab test are used by a numerical approximation method } \\
\text { to develop } K(\theta), K(\psi) \text {, and } \psi(\theta) \text { over a wide range of } \theta \text { and } \psi \text {. Relatively } \\
\text { fast method, however, unique solutions are usually not attainable. }\end{array}$ & $\begin{array}{l}\text { Zachmann et al., } \\
1981 a, 1981 b, 1982 \\
\text { Kool et al., } 1985\end{array}$ \\
\hline $\begin{array}{l}\text { Empirical } \\
\text { Equations }\end{array}$ & $\begin{array}{l}\text { Each empirical equation has its own application based upon the assumptions of } \\
\text { the equation. Relatively fast technique. }\end{array}$ & $\begin{array}{l}\text { Brooks-Corey, } 1964 \\
\text { Van Genuchten, } 1980 \\
\text { Mualem, } 1986\end{array}$ \\
\hline
\end{tabular}




\section{Table 27 \\ (Continued)}

Source: Electric Power Research Institute. EPRI EN-6637. Techniques to Develop Data for Hydrogeochemical Models. Palo Alto, California, 1989.

References:

Amoozegar, A. and A.W. Warrick. "Hydraulic Conductivity of Saturated Soils: Field Methods." In A. Klute (ed.) Methods of Soil Analysis, Part 1. Madison, WI: Soil Science Society of America, Agronomy Monograph No. 9 (2nd ed.), 1986, pp. 799-824.

Bouma, J., F.G. Baker, and P.L.M. Veneman. "Measurement of Water Movement in Soil Pedons Above the Water Table." University of Wisconsin, Extension Geological and Natural History Survey, Information Circular No. 27, 1974.

Bouwer, H., "Rapid Field Measurement Air Entry Value and Hydraulic Conductivity of Soil as Significant Parameters in Flow System Analysis." Water Resources Research 2:279-738, 1966.

Bouwer, H., Groundwater Hydrology. New York, N.Y.: McGraw, Inc., 1978.

Bouwer, H., and R.C. Rice. "A Slug Test for Determining Hydraulic Conductivity of Unconfined Aquifers with Completely or Partially Penetrating Wells." Water Resources Research 12(3):423-428, 1976.

Brooks, R.H., and A.T. Corey. "Hydraulic Properties of Porous Media." Fort Collins, CO: Colorado State University, Hydrology Paper 3, 1964.

Bureau of Reclamation. Groundwater Manual, a Water Resources Technical Publication. Washington, D.C.: Bureau of Reclamation, U.S. Government Printing Office, 1977.

Driscoll, F.G. Groundwater and Wells. Second Edition. St. Paul, MN: Johnson Division, 1986.

Green, R.E., L.R. Ahuja, and S.K. Chong. "Hydraulic Conductivity, Diffusitivty, and Sorptivity of Unsaturated Soils - Field Methods." In A. Klute (ed.) methods of Soil Analysis, Part 1. Madison, WI: Soil Science Society of America, Agronomy Monograph No. 9 (2nd ed.), 1986, pp. 771-798.

Hvorslev, J.V. "Time Lag and Soil Permeability in Ground Water Observations." Vicksburg, MS: U.S. Army Corps of Engineers, Waterways Experiment Station Bulletin No. 36, 1951.

Klute, A., and C. Dirksen. "Hydraulic Conductivity and Diffusivity: Laboratory Methods." In A. Klute (ed.) Methods of Soil Analysis, Part 1. Madison, WI: Soil Science Society of America, Agronomy Monograph No. 9 (2nd ed.), 1986, pp. 687-734.

Kool, J.B., J.C. Parker, and M.T. Van Genuchten. "Determining Soil Hydraulic Properties from One-Step Outflow Experiments by Parameter Estimation: I. Theory and Numerical Studies." Soil Sic. Soc. Am. J. 49:1348-1354, 1985.

Lohman, S.W. "Groundwater Hydraulics." U.S. Geological Survey Professional Paper 708. Washington, DC: U.S. Government Printing Office, 1972 (reprinted in 1975 and 1979).

Mualem, Y. "A New Model for Predicting the Hydraulic Conductivity of Unsaturated Porous Media." Water Resourc. Res. 12:593-622, 1976.

Reynolds, W.D., and D.E. Elrick. "A Method for Simultaneous In Situ Measurement in the Vadose Zone of Field Saturated Hydraulic Conductivity, Sorptivity and the Conductivity-Pressure Head Relationship." Ground Water Monitoring Review 6(1):8695, 1986.

Stephens, D.B., and S.P. Neuman. "Vadose Zone Permeability Tests: Summary." J. Hydraulics Div. ASCE 198(HY5):623-639, $1982 a$.

Stephens, D.B., and S.P. Neuman. "Vadose Zone Permeability: Steady State Results." J. Hydraulics Div. ASCE 198(HY5):640$659,1982 \mathrm{~b}$.

Stephens, D.B., and S.P. Neuman. "Vadose Zone Permeability: Unsteady Flow." J. Hydraulics Div. ASCE 198(HY5):660-677, $1982 \mathrm{c}$.

Van Genuchten, M.T. "A Closed Form Equation for Predicting the Hydraulic Conductivity of Unsaturated Soils." Soil Sci. Soc. Am. J. 44:892-989, 1980.

Zachmann, D.W., P.C. DuChateau, and A. Klute. "The Calibration of the Richards Flow Equation for a Draining Column by Parameter Identification." Soil Sci. Soc. Am. J. 45:1012-1015, 1981a.

Zachmann, D.W., P.C. DuChateau, and A. Klute. "The Estimation of Soil Hydraulic Properties from Inflow Data." In V. Singh (ed.) Proc. of the Symposium on Rainfall-Runoff Modeling. Littleton, Co: Mississippi State University Resources Pub., 1981b, pp. 173-180.

Zachmann, D.W., P.C. DuChateau, and A. Klute. "Simultaneous Approximation of Water Capacity and Soil Conductivity by Parameter Identification." Soil Sci. 134:157-163, 1982. 


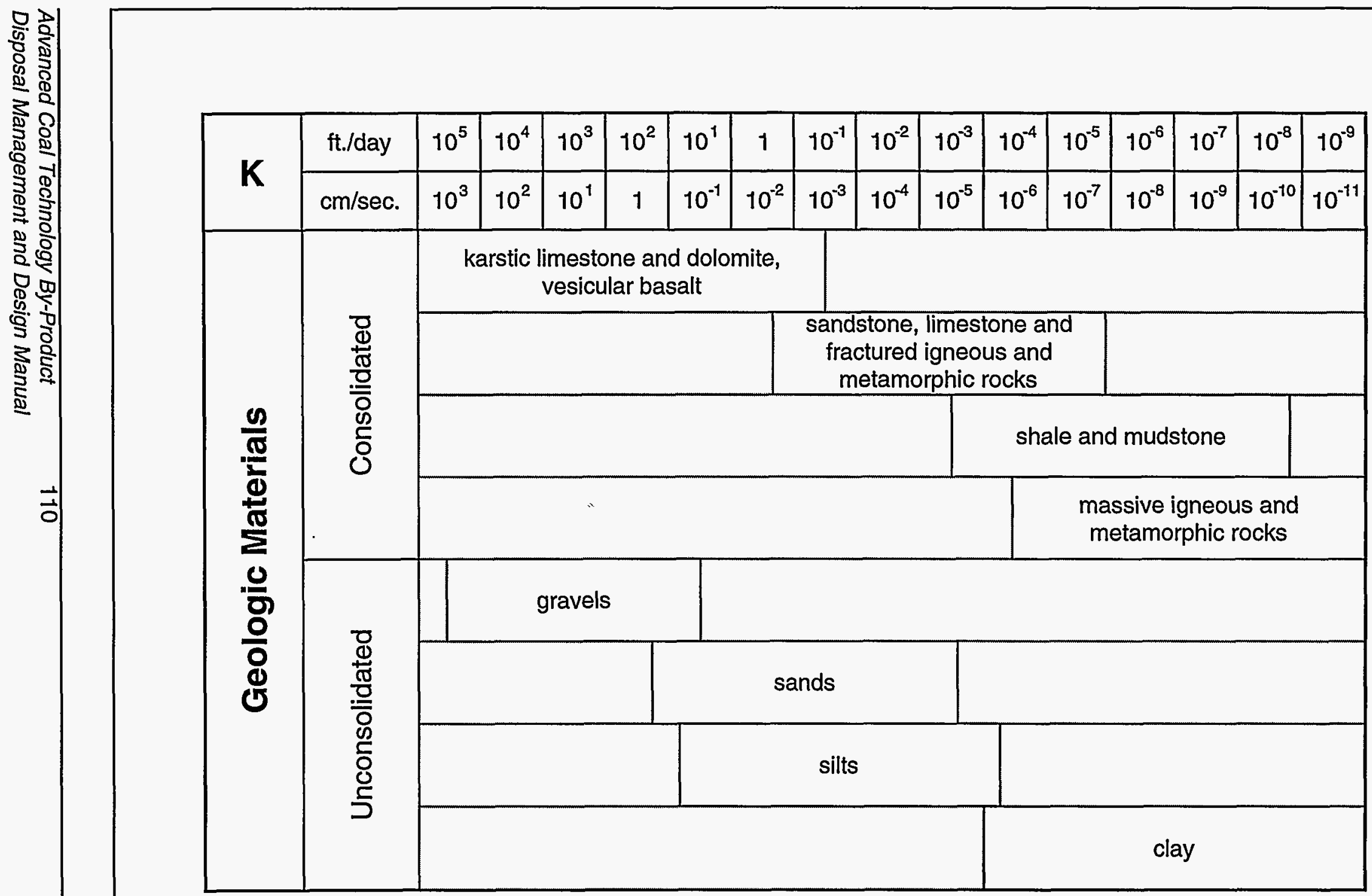

Figure 35. Representative Ranges of Saturated Hydraulic-Conductivity Values for Geologic Materials (Adapted from Freeze, R.A., and J.A. Cherry. Groundwater. Prentice-Hall, Inc., Englewood Cliffs, NJ, 1979.) 


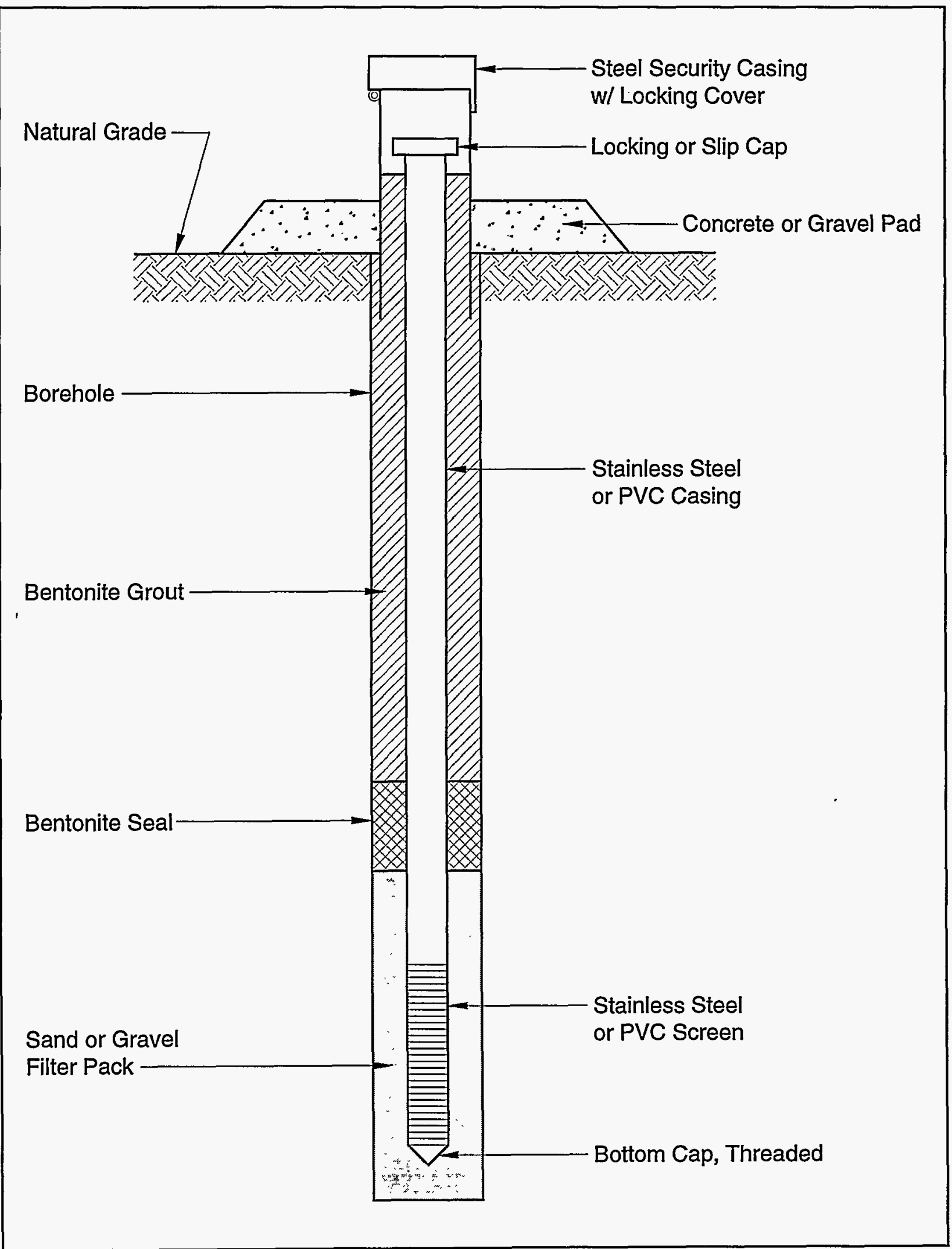

Figure 36. Typical Monitor Well Construction 
a cluster of monitor wells, each screened at a different discrete interval, especially if conditions of perched groundwater or strong vertical hydraulic gradients are anticipated.

The location and screened intervals of the monitor wells will be determined by the local hydrogeology, and by using horizontal and vertical gradients to predict the path of leachate migration. In general, the farthest downgradient well cluster should be placed at the point of compliance, or the downgradient property boundary. Additional clusters of monitor wells may be placed upgradient of the point of compliance as an "early warning system." Figure 33, previously presented, shows a potential placement scheme for monitor wells at a landfill site.

\section{The Monitoring Program}

Several states have regulations that dictate the frequency of groundwater monitoring and the analytical methods for landfill sites. Table 17 in Chapter 4 gives examples of the monitoring frequency and minimum analyte list required by some states. The Toxicity Characteristic Leaching Procedure (TCLP) (EPA Method 1311) may be required to estimate the composition of leachate from a specific advanced coal technology by-product and to determine its regulatory status. This method involves the leaching of a solid for 18 hours using a weak acid solution in a ratio of 1:20 solid:liquid. The leachate is then analyzed for a variety of organic compounds and inorganic elements, using EPA SW846 methods.

Chapter 3 provides a discussion of the solid and leachate compositions of several types of advanced coal technology by-products, and may be helpful in putting together a list of potential analytes to be monitored if one is not dictated by state regulations. Much information can be gained from monitoring for a few water quality parameters, such as $\mathrm{pH}$ (EPA method SW9040), total dissolved solids (TDS) (EPA 160.1), and alkalinity (SM 403). In general, the major elements that occur in leachates from advanced coal process byproducts are dictated by the sorbent. For example, if a calcium-based sorbent such as lime or limestone is used, calcium will dominate the major element chemistry of the by-product. Sulfate, the result of $\mathrm{SO}_{x}$ removal, is almost always present in advanced coal technology by-products in high concentrations. Trace metals, whose concentrations are usually dictated by the composition of the fuel source, also need to be monitored in most states. The eight RCRA elements that are generally monitored are arsenic, barium, cadmium, chromium, lead, mercury, selenium, and silver. Monitoring for some of these species may be waived if the by-products can be demonstrated to contain negligible concentrations of these elements.

\section{Porewater Monitoring}

In addition to groundwater monitoring, it may be advantageous to monitor potential leachate migration through the vadose zone. The installation of lysimeters at the base of the landfill will allow the monitoring of leachate from the earliest point of generation, and provide input for leachate migration models. If no leachate collection system is installed, this may be accomplished with a porous cup or pan lysimeter. Pan lysimeters must be installed during landfill construction, whereas porous cup lysimeters may be installed at any time. However, pan lysimeters monitor a larger area and are generally more reliable. Figures 37 and 38 are schematic diagrams of these types of lysimeters.

\subsubsection{Miscellaneous Support Facilities}

There are several support facilities that are needed at any disposal facility and it is important not to overlook these facilities during the planning or design phase. These facilities are discussed in the following subsections. 


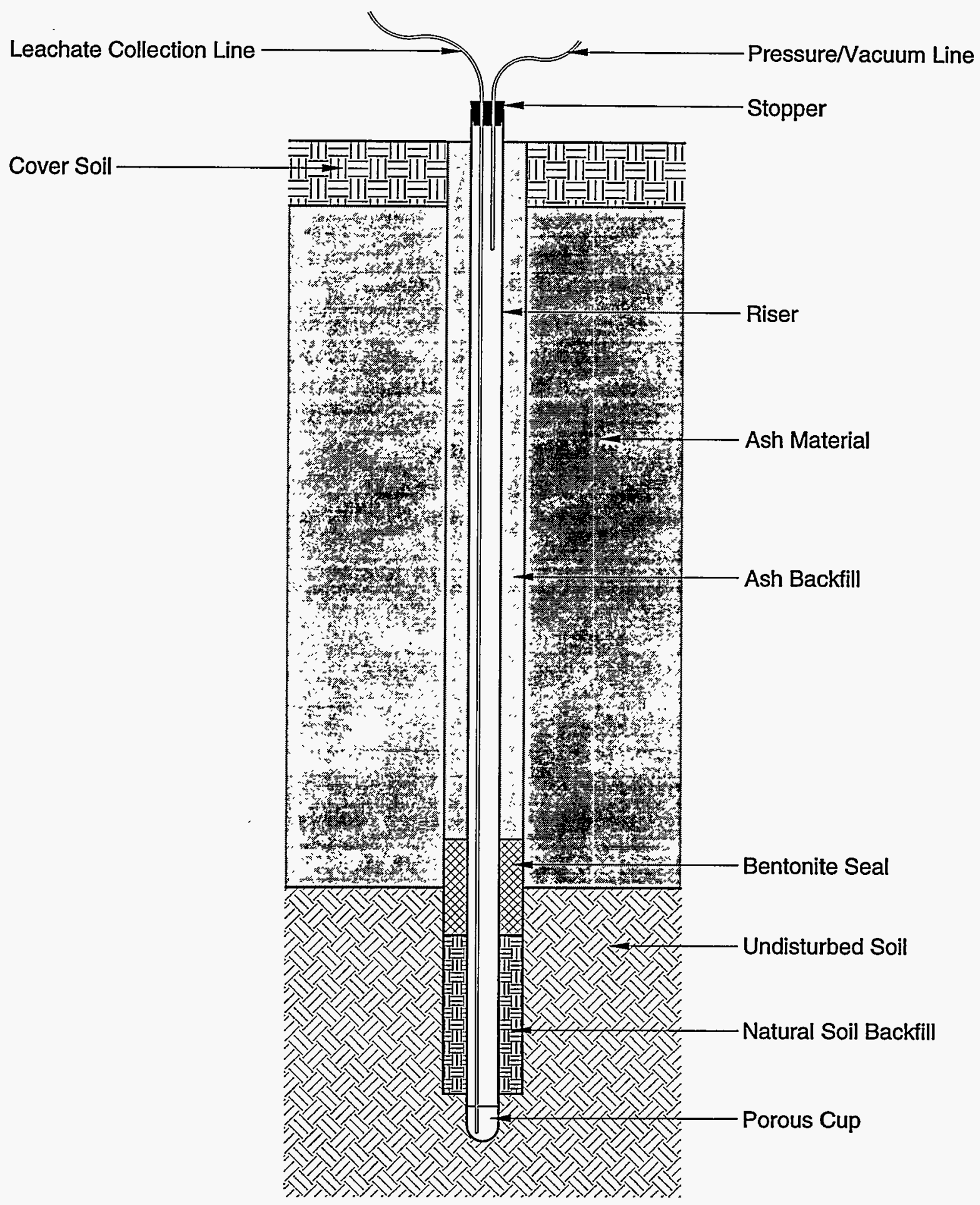

Figure 37. Porous-Cup Lysimeter Design 


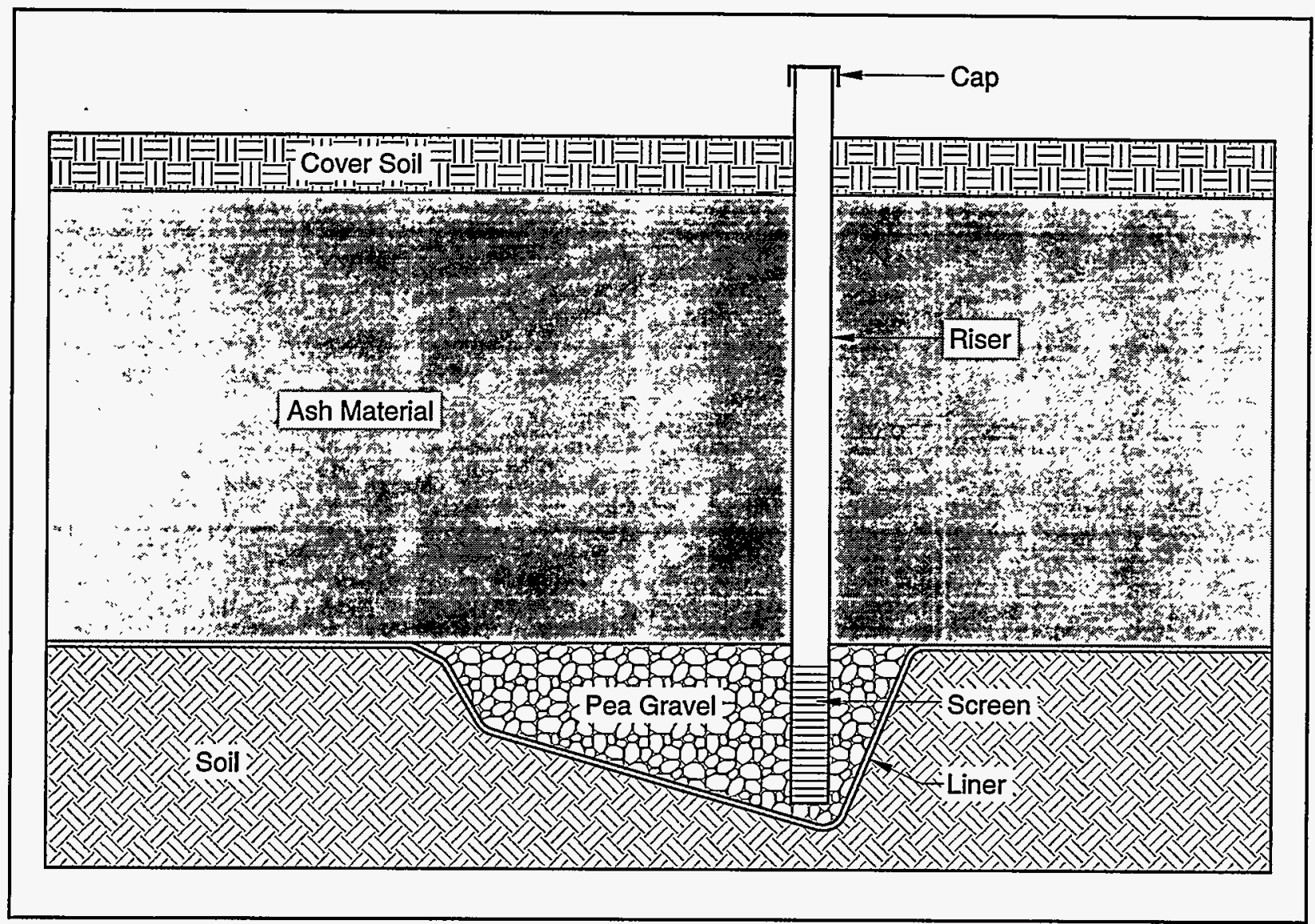

Figure 38. Pan Lysimeter Design

\section{Access Roads}

If the by-product material is to be transported to the landfill by truck, an allweather access road must be provided to the site. This road or roads should be designed to accommodate the anticipated volume of truck traffic. The road should normally be wide enough ( $24 \mathrm{ft}$.) for two lanes of traffic and strong enough to carry the trucks.

The pavement configuration will vary depending on local conditions and use. The access road is typically constructed with some type of bituminous covering because its location will not be changed for a long time.

Usually, a soil surface, gravel, crushed aggregate, or bottom ash road will be appropriate for haul roads on the site. Sometimes the permit provisions for dust control will require haul road surface treatment with lime, portland cement, or asphalt as binders.

The roadway width, curve dimensions, site distances, and other physical features of haul roads are primarily a function of the physical dimensions and probable speed of the trucks. Table 28 presents criteria for radius of curvature and super-elevations for various speeds and grades.

Entry points to the site from a public road should be carefully designed to reflect traffic volumes and safety requirements. These considerations should be cleared with the local highway authority. The access point should be designed to:

- Minimize traffic interference on the public road; 


\section{Table 28 \\ Suggested Haul Road Design Criteria}

\begin{tabular}{||l|c|c|c|c|c||}
\hline $\begin{array}{c}\text { Operating } \\
\text { Design Speed } \\
\text { (MPH) }\end{array}$ & $\mathbf{1 0}$ & $\mathbf{1 0 - 2 0}$ & $\mathbf{2 0 - 3 0}$ & $\mathbf{3 0 - 4 0}$ & $\mathbf{4 0 - 5 0}$ \\
\hline $\begin{array}{l}\text { Maximum } \\
\text { sustained grade }\end{array}$ & $9 \%$ & $8 \%$ & $8 \%$ & $7 \%$ & $6 \%$ \\
\hline $\begin{array}{l}\text { Minimum } \\
\text { radius of } \\
\text { curvature, ft. }\end{array}$ & 50 & 150 & 300 & 600 & 1,000 \\
\hline $\begin{array}{l}\text { Super-elevation, } \\
\mathrm{ft} / \mathrm{ft} \text { of width }\end{array}$ & 0.04 & 0.05 & 0.05 & 0.05 & 0.05 \\
\hline
\end{tabular}

Re-printed with permission from Pflieder, E.P., ed. Surface Mining, p. 678, AIME, New York, 1968.

- Minimize turn around time;

- Assist in screening the site from the public; and

- Present an attractive point of entry.

Ideally, separate entrance and exit roads should be utilized to minimize traffic congestion and increase safety. If the access easement is wide enough, the roads can be offset $20^{\circ}$ to $50^{\circ}$ to improve traffic flow. If the easement is narrow, it is usually feasible to plan a wide access road with a central island.

\section{Fencing}

Fencing should be provided to control and limit access to the landfill site. Permanent woven or chain link fencing is commonly used for these purposes. A gate should be provided at the site entrance and should be closed and locked when the site is unattended. This is required by most regulatory agencies.

\section{Buildings}

Equipment used at the landfill should be provided with a shelter. In northern states, the facility should provide protection against freezing temperatures. A single building or shed may be provided for both equipment maintenance and storage. If the landfill is adjacent to the utility, a central facility for all major earth-moving equipment may be utilized. Even if this is the case, it may be advantageous to have an enclosed area on site where routine maintenance can be conducted. The size of the building utilized and the equipment in the building will depend upon how much maintenance is anticipated to be conducted there.

Appropriate sanitary facilities should be provided for the landfill operators. Portable chemical toilets can be utilized for this purpose. At larger sites, workers may be provided with shower, locker, and lunchroom facilities. The size of the facility will depend upon the number of people employed and regulatory requirements. Often, mobile trailers can be adapted for employee facilities.

\section{Utilities}

The landfill should be provided with power, water, and telephone or radio. Power is used for operating on-site equipment and lighting. Water is needed for drinking and sanitary purposes, for machine maintenance, and for dust control. Water may also be required for by-product conditioning at the landfill site. A telephone or radio is necessary for communications, particularly in the event of a fire or accident at the site. Fire extinguishers should be provided in accordance with local safety codes and Occupational Safety and Health Administration (OSHA) regulations.

\section{Other Facilities}

A knowledge of the amount of byproduct material placed in the fill is important to control the operation and monitor the progress of fill. Records of the volume of fill which has been placed may also be required by regulations. Provision should, therefore, be made to monitor and record the number of loads placed in the fill. It is not ordinarily necessary to weigh every vehicle loaded with by-product material. Rather, periodic weight 
surveys will usually suffice to monitor byproduct volume and density. Scales already available at the utility, such as those used for weighing coal vehicles, are often suitable. If these are not available, portable scales can be used periodically. The scales should be large enough to weigh the largest transport vehicle and simultaneously weigh all axles.

\subsection{Materials Handling and Transport}

The previous sections of this chapter have all dealt with disposal facility issues. Equally important both from an economic and a technical standpoint are material handing and transport issues. These issues, such as material storage at the generating plant and transportation to the disposal site, should not be overlooked during the site selection, design, or permitting phases of a disposal facility. Both of these issues are discussed in the following sections. The materials handling processes that will be presented in this section and in Section 6.3 are listed in Figure 39.

\subsubsection{By-Product Storage}

After by-products from advanced coal technologies are produced, they are usually stored temporarily prior to transport to the disposal site. A typical storage facility consists of enclosed vessels called bins or silos. Silos can either be cylindrical or rectangular in shape; both types having a lower converging chamber referred to as a hopper (although some silos are flat bottomed) as shown in Figure 40. The cost of a silo depends upon capacity. For a silo compatible with pneumatic transfer systems (which includes a dust collector and loading pipes), the (1994) price can range from $\$ 10,000$ (for $8,000 \mathrm{ft}^{3}$ ) to $\$ 20,000$ (for $12,000 \mathrm{ft}^{3}$ ). Factors that affect the design of a storage vessel are listed below:

- By-product flow properties (which may vary with moisture content, temperature, compacting pressure, and storage time);

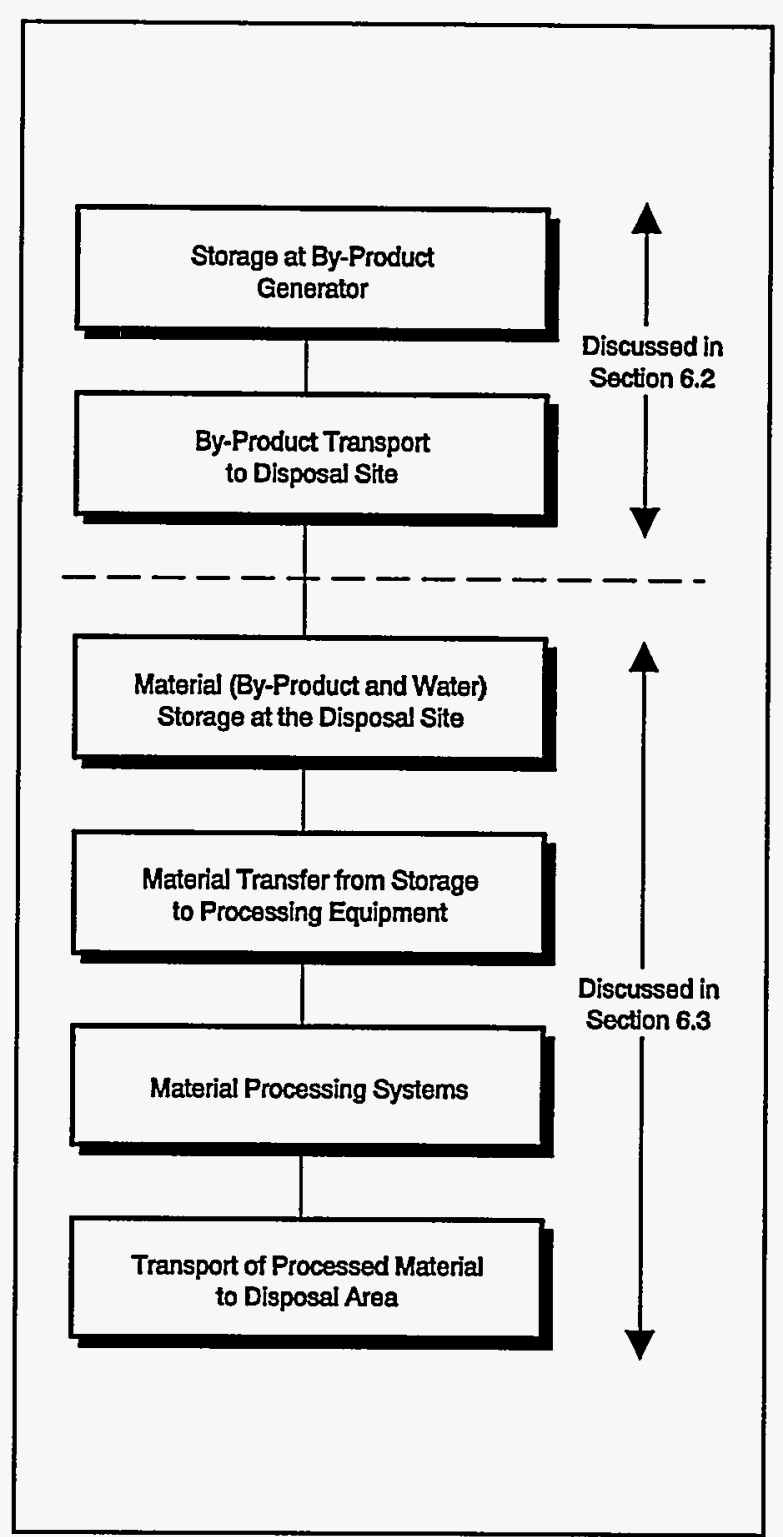

Figure 39. Material Handling Processes Flowchart

- Vessel configuration (which includes the size and shape of the bin or silo);

- Hopper geometry (which includes the size and shape of the hopper along with the side wall angle); and

- Materials of construction. 

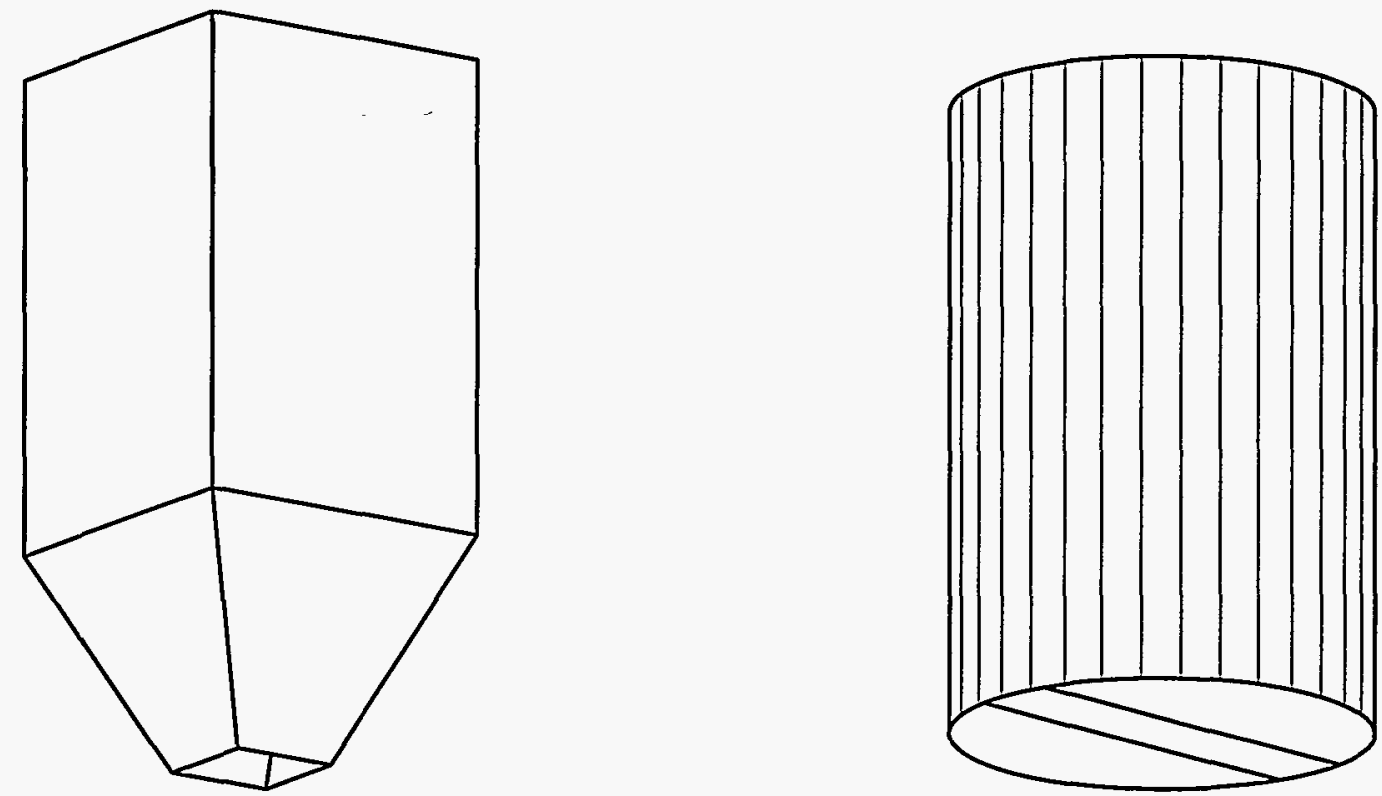

Rectangular Silo

Flat Bottom Cylindrical Silo
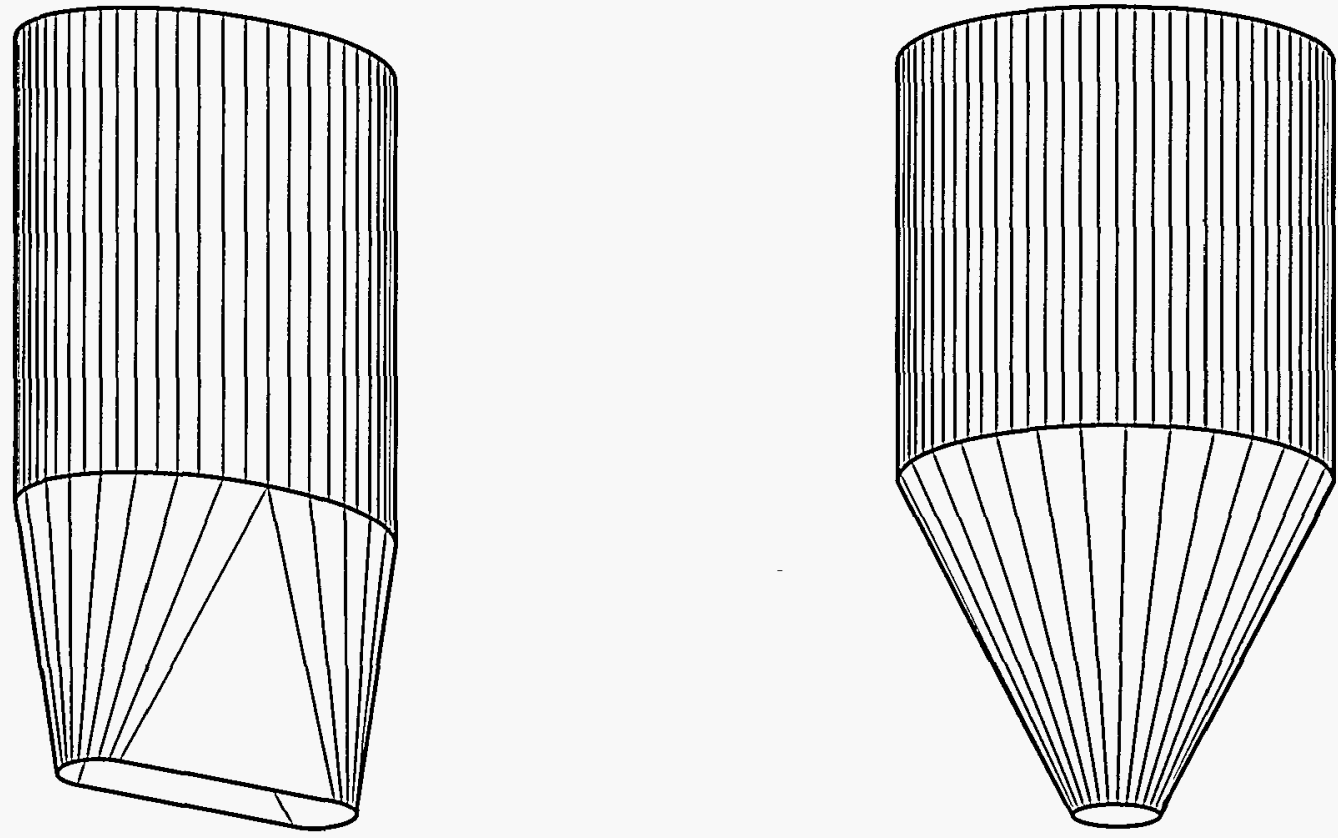

Transitional Hopper

Conical Hopper

Figure 40. Examples of Storage Silos and Hoppers 
In order to determine the flow properties of the by-product material, direct shear and controlled strain tests must be performed. From these tests, the following characteristics can be determined: bulk density, effective angle of internal friction during flow, angle of internal friction during incipient flow, kinematic angle of wall friction, and unconfined yield strength. If these tests are conducted while taking into account the flow properties listed above, the results can be used to determine proper hopper geometry and outlet size for steady discharge from the storage vessel.

If the outlet is not properly sized, rat-holing and arching may occur. Rat-holing or piping occurs when a stable stagnant channel forms above the outlet and prevents the complete discharge of material. This condition decreases the effective storage volume and contributes to erratic flow patterns. Arching occurs when a stable dome of material forms above the outlet, preventing additional material from discharging. This disrupts flow and, when the arch is broken, could possibly damage equipment due to the impact of the mass and associated high-air pressure ${ }^{2}$.

To improve flow characteristics from the vessel, flow activators may be used. These include aeration devices and vibrators. Aeration devices, such as stones or pads, are placed within the hopper section of the vessel along the interior walls. When dry air flows through the device, the material adjacent to the wall is aerated making it more fluid; hence, flow characteristics are improved. Vibrators can be used in several ways such as on hopper extensions, discharge feeders, and hopper walls. In order to prevent the packing of solids, vibrators should be used cautiously and only when the obstruction that disrupts steady flow can be cleared. The vibrators should be operated only long enough to resume steady flow.
Another consideration for storage facility design is capacity, which is a function of the rate of by-product production and rate of disposal. Using the maximum average peak by-product production rate, the facility should have the capacity to store all by-product produced during the longest possible period in which disposal operations cease (such as holiday weekends or during transportation equipment failure).

Because of potential exothermic hydration reactions and self-hardening of some types of by-product material, moisture must be excluded while the by-products are stored. The storage vessel should maintain water-tight integrity during all anticipated weather conditions.

\subsubsection{By-Product Transportation Alternatives}

The by-product material will need to be transported from the storage facility to the disposal site. Again, due to the self-hardening characteristics of some by-products, intrusion of moisture may cause fouling of transfer lines or may limit the effectiveness of the means of transportation (due to material caking on sidewalls and floors). Therefore, pretreatment of by-product materials having self-hardening characteristics with water to reduce fugitive dust emissions during transportation is not recommended unless several engineering concerns have been addressed. The transport distance should be minimal if freshly conditioned by-product, which may set up during transport, is hauled in bulk containers. The transportation vehicle must be able to withstand the extreme temperatures which may result from the exothermic hydration reaction, and a means to wash down sidewalls, floors, etc., of the transportation vehicle should be available at the disposal site where off-loading occurs.

Transportation of the dry by-product to the disposal site may be accomplished by several means, the selection of which is 
dependent upon availability, distance to the site, and topography. The by-product production rate and particle size may also affect the choice of transport systems. Because capital and operating costs for the transportation system may be a substantial portion of the total waste management cost, considerable attention should be given to its selection and design. Potential transportation alternatives are listed below.

- Trucks such as dump or pneumatic (if conditioning with water occurs prior to transport, dump trucks are required);

- Railroads;

- Barges;

- Belt conveyors (the by-products must be less than $300^{\circ} \mathrm{F}$ and dust suppression measures must be taken);

- Pneumatic conveyors; and

- Aerial trams (metal box cars attached to a supported haul cable).

Currently, the most common means of transporting by-products is by truck, which typically is the most flexible and practical alternative when considering the nature of landfill operations. Railroads, on the other hand, may be an economical alternative if haul distances are great and rail-haul routes are available. Likewise, barges may be feasible if haul distances are great (over 100 miles) and if the plant and disposal sites are located on navigable waterways. If, however, the distance to the disposal site is minimal, conveyors or trams may be feasible (provided that dust suppression measures are taken).

The three following figures show the relevant differences between the alternatives with regard to distance from plant to disposal site, by-product production rate, and particle size. Figure 41 provides general guidelines for selecting a transport mode based upon particle size. It should be noted that due to the fine particle size of the by-products, transport modes that do not totally enclose the byproducts during transport may cause a dusting problem. If the anticipated by-product flow rate is known, Figure 42 will assist in the selection of an appropriate transport system. Figure 43 provides general guidelines for selecting a transport mode relative to distance from generating station to disposal area. Specific site conditions may affect rates significantly. The distance serviceable by the various transport modes may also be affected by site conditions.

\subsection{Material Processing at the Disposal Site}

Material handling and processing at the disposal facility is another important item in achieving a technically and economically feasible by-product management plan. Several potential operational, human health, and environmental problems are associated with the storage, transfer, and processing of some types of by-product materials. Among these concerns are fugitive dust emissions, high initial temperature of the material, and temperature increases due to exothermic reactions. As noted in Chapter 3, some unconditioned by-products contain high levels of caustic material; therefore, inhalation or dermal contact must be minimized. For these reasons, the design of material handling systems that limit exposure to by-product material is critical.

The discussion of materials handling at the disposal site will be limited to dry disposal (dry in comparison to transporting the waste in slurry form). Handling and disposal of slurried (or wet) by-product material are discussed in Section 7.3. Even though the methods to handle this material are considered "dry," this type of by-product material is typically hydrated before disposal to improve the material's physical and chemical properties, as well as aid in placement and compaction of the material in the disposal facility. The procedures and equipment used in the storage, 


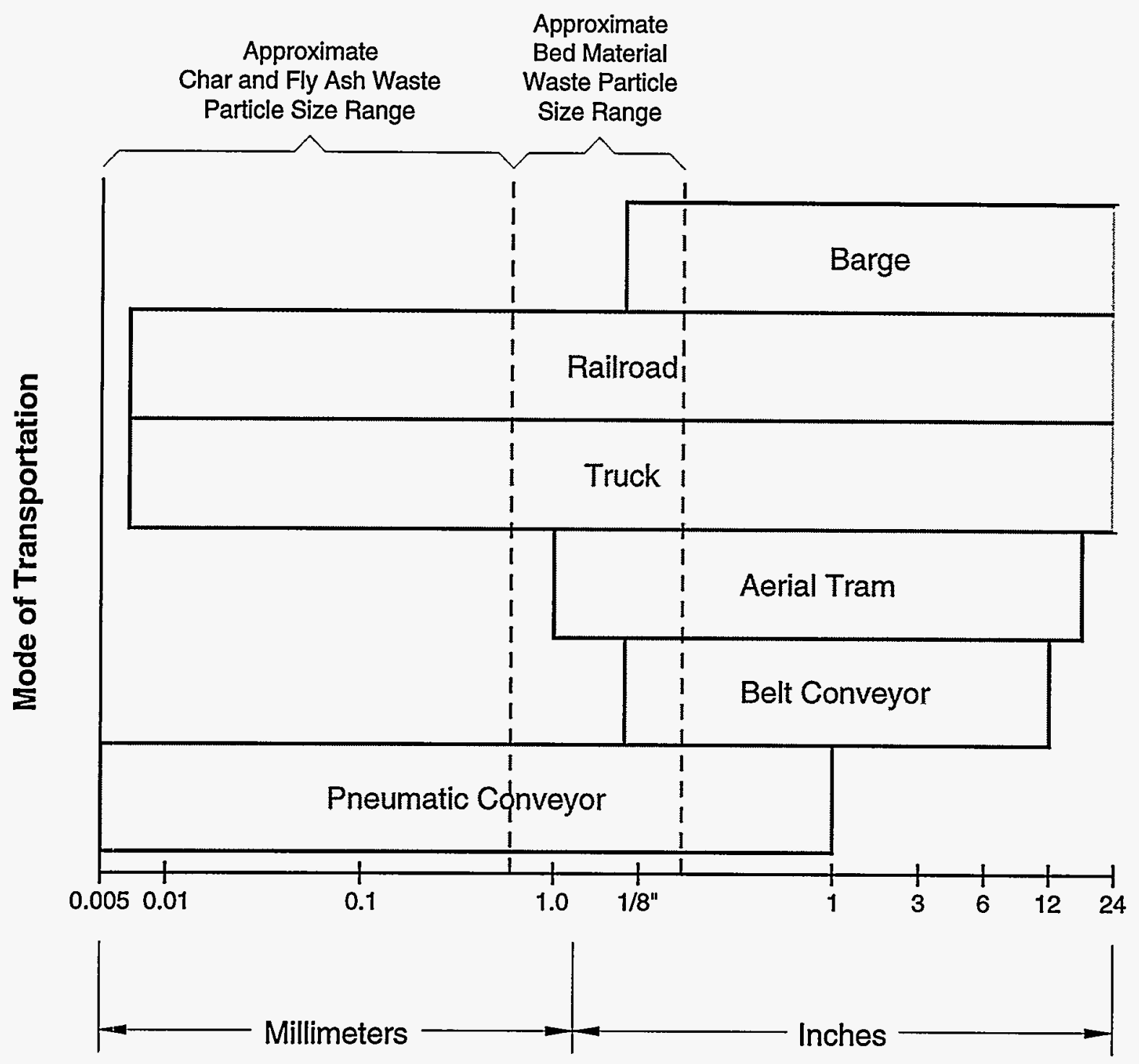

Particle Size

Note:

The Lower limits shown for belt conveyors, barges, and aerial trams are applicable for dry material. The moisture content and bulk density of the material being conveyed will influence (lower) these lower limits.

\section{Figure 41. Guidelines for Selecting a Transport Mode Based Upon Particle Size}

Re-printed with permission from Electric Power Research Institute. EPRI CS-6053. Atmospheric Fluidized-Bed Combustion Waste Management Design Guidelines. 


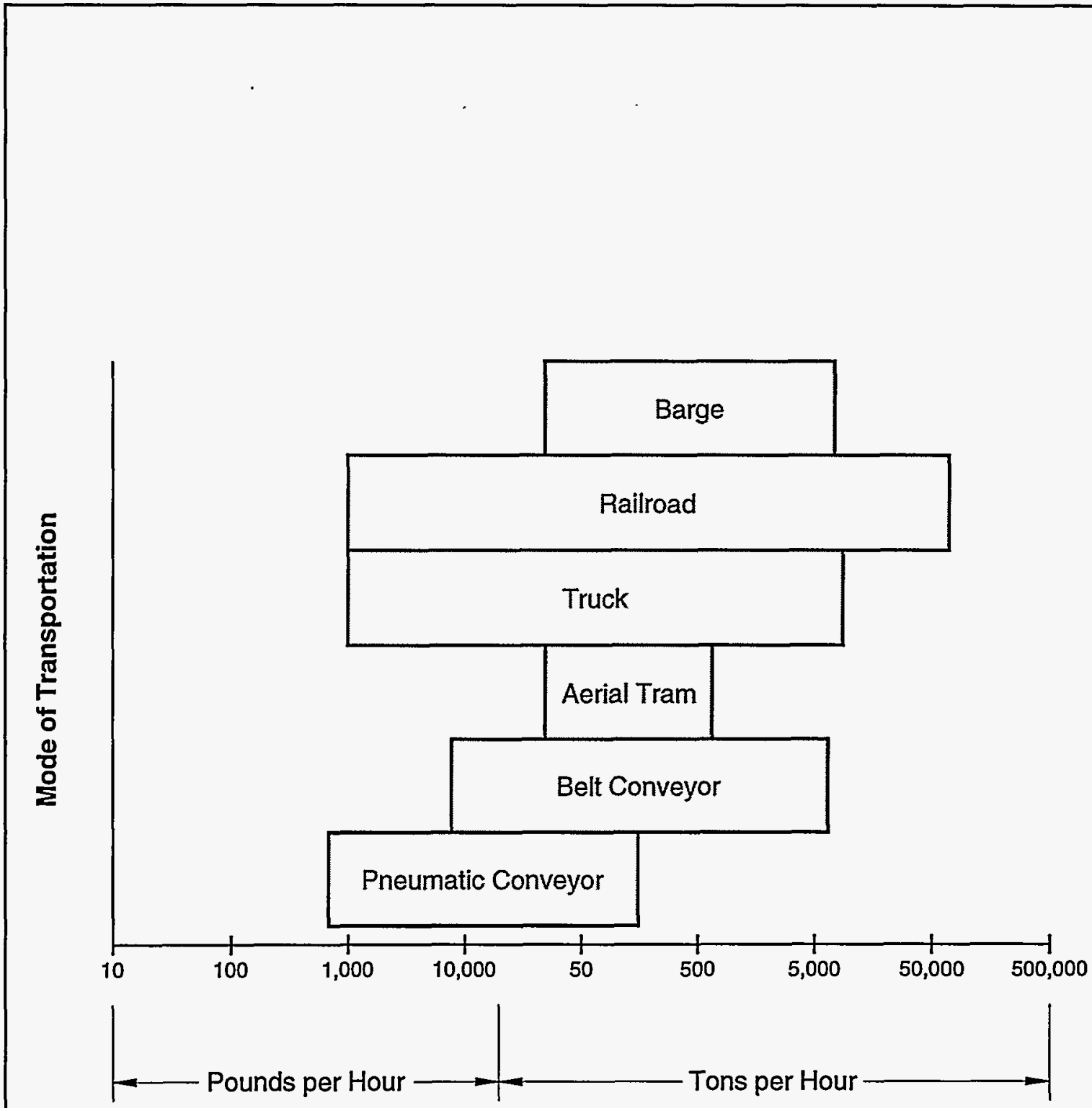

Flow Rate

Figure 42. Guidelines for Selecting a Transport Mode Based Upon Flow Rate

Re-printed with permission from Electric Power Research Institute. EPRI CS-6053. Atmospheric Fluidized-Bed Combustion Waste Management Design Guidelines. 


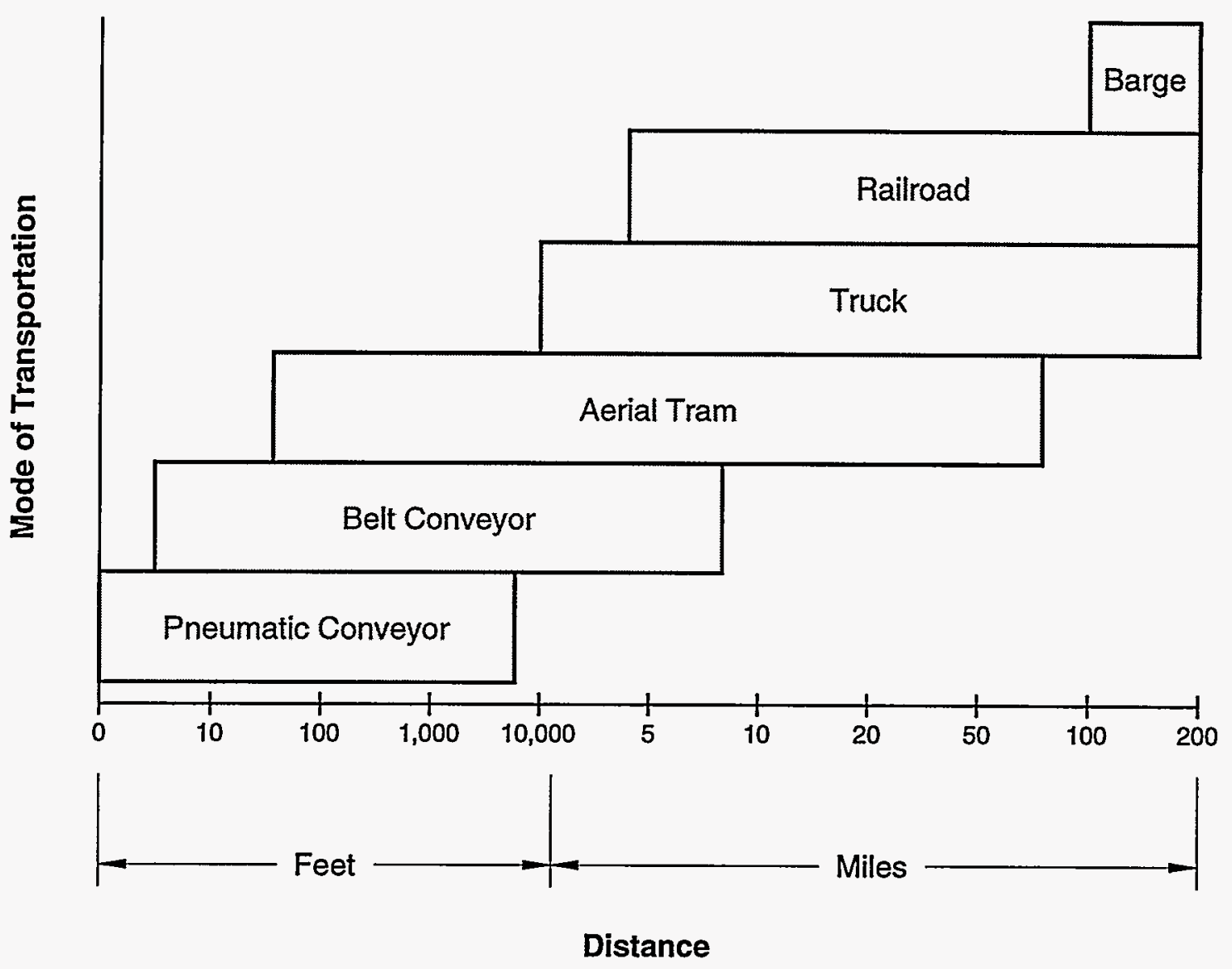

Figure 43. Guidelines for Selecting a Transport Mode Based Upon Distance Re-printed with permission from Electric Power Research Institute. EPRI CS-6053. Atmospheric Fluidized-Bed Combustion Waste Management Design Guidelines. 
transfer, and processing of by-product materials at the disposal facility are discussed in the following subsections. These processes are further illustrated in a discussion of the construction procedures employed at one of the test cells constructed in support of this design manual (Section 6.4).

\subsubsection{Storage Equipment}

Equipment necessary for the temporary storage of by-product materials and water at a disposal site (before being transferred to the processing equipment) are:

- By-product silos (cylindrical or rectangular); and

- Water tanks (if a water supply is not available at the site).

\section{By»Product Storage}

Silos (see Figure 40, previously presented) used at the disposal site temporarily store the dry by-products which are transported from the generating plant. The by-product material is transferred, as needed, from the silos to the disposal-site processing (hydration) equipment. The costs and design considerations for these storage silos are similar to those discussed in Section 6.2.1. If, however, hydration of the by-product material is to occur at the generating plant, storage silos at the disposal site are not necessary. This is an option only if the distance from the plant to the disposal site is minimal and the total residence time of hydrated by-products in the transport vehicles is less than the time it takes them to set into an adherent mass. In addition, a washdown facility should be provided in order to remove residual hydrated by-products from the transport vehicle bed (which is usually unnecessary if the by-products are transported dry).

The storage silos should have enough capacity to ensure continuous disposal operations. Factors which effect capacity include:
- Plant maximum average by-product production rate;

- Disposal rate (taking into consideration the work week schedule and hours of operations); and

- Rate and capacity of transportation (including down time for equipment failure and maintenance).

When determining the type and design of the storage silos, several factors should be addressed: ash flow properties, vessel configuration, hopper geometry, and materials of construction. As stated in Section 6.2.1, a direct shear and controlled strain test should be performed on the by-products in order to determine the characteristics which affect flow. If these tests are conducted while taking into account flow property variances of materials stored at the disposal site, the results can be used to determine proper hopper geometry and outlet size for steady discharge from the storage vessel. If, however, the hopper is improperly designed, rat-holing and arching may occur.

Also, consideration must be given to the prevention of moisture intrusion while the ash is stored. Due to exothermic hydration reactions and the self-hardening nature of most advanced coal technology by-product material, the storage vessel should maintain water-tight integrity during all anticipated weather conditions.

\section{Water Storage}

If a water supply is not available at the disposal site, water storage is necessary. Tank materials range from steel to plastic. The capacity of the water storage system depends on the same factors as by-product storage and, in addition, the percent of water by weight necessary to achieve the required hydration. The cost of a typical large covered steel storage tank depends upon capacity and can range from $\$ 42,000$ for a 21,000 -gallon tank to 
$\$ 71,000$ for a 126,000 -gallon tank. For plastic tanks, prices can range from $\$ 1,200$ for a 2,000 -gallon tank to $\$ 12,000$ for a 12,000 gallon tank.

\subsubsection{Material Transfer Equipment}

Transferring the stored by-product material from the storage silos to the processing equipment is accomplished using equipment consisting of both feeder and conveyor components. These components are intimately related and typically are selected and designed as one subsystem. If the distance from the storage facility to the mixing system is minimal (such as may be the case at a disposal site), one component may serve as both the feeder and conveyor. If the mixing equipment is located directly underneath the storage vessel, only a feeder is necessary. This will control the rate in which material is delivered to the mixing equipment.

The transfer system should be sized on the basis of the by-product production rate, disposal rate, and mixing rate. Conveyors and feeders should be able to transfer, at a minimum, enough material to supply the mixing equipment while operating at peak capacity (which depends upon plant maximum by-product production rate and the operating schedule of the disposal site). Equipment selected should also be constructed of materials able to withstand the abrasive nature of the byproducts.

Conveyors typically are the major components of the transfer subsystem and may be either pneumatic or mechanical.

Descriptions of the conveying alternatives and feeders considered feasible for this type of material are summarized in the following subchapters. Approximate capital costs for the various alternatives based upon capacities are presented in Figure 44. This figure does not reflect operating costs, which may be significant.

\section{Pneumatic Conveyors}

Pneumatic conveyors transport dry, free-flowing, granular material in suspension within a pipe or duct by means of a highvelocity airstream (dilute phase transport) or by the energy of expanding compressed air within a comparatively dense column of fluidized or aerated material (dense phase transport). Another means uses compressed air to fluidize material residing on an inclined surface allowing gravity to influence transport. Capacities for the various types of pneumatic conveyors range from less than 100 pounds per hour to 200 tons per hour; the respective price range is between $\$ 12,000$ and $\$ 300,000$ per $50 \mathrm{ft}$ of length.

Dilute Phase-This type of pneumatic conveying system uses large volumes of high velocity, low pressure (<15 psig) air to transport solids. Within the transporting airstream, the solids to air ratio is low. This type of system can operate using negative pressure, positive pressure, or a combination of the two. Refer to Figure 45 for illustrations.

For the Negative Pressure System (vacuum), material is drawn into the conveying line (or material transport pipe), fluidized, and transported by a high-velocity airstream established by a vacuum pump (or exhauster) which is commonly a positive displacement or centrifugal blower. Upon reaching the final destination, the material is separated from the air and deposited into the storage vessel.

For the Positive Pressure System, a high velocity air stream is established in the conveying line by a blower. Material is withdrawn from a storage vessel by gravity, mechanical conveyors, or low air pressure (i.e., blow tank), and delivered to an airlock feeder or outlet valve. From there, it is fed into the air stream and transported via pipeline to the discharge points, where it is separated from the transporting air. 
jenuew ub!sag pue łuamabeuew jesods! a

lonpold-Kg КБо

GZL

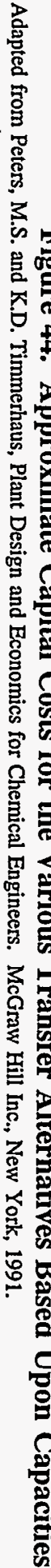

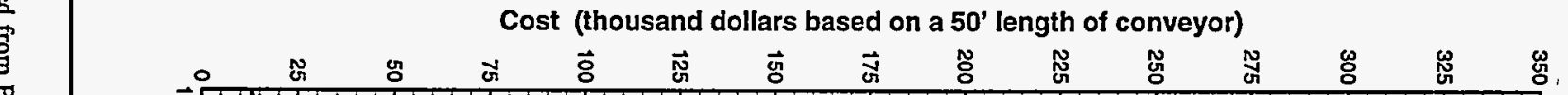

㓚

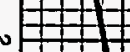

$+1$

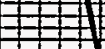

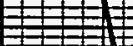

$\because=$

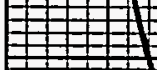

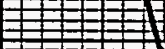

$=$

$\infty$

?

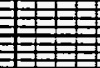

o

$+2$

$+$

\begin{tabular}{l} 
涪 \\
\hline
\end{tabular}

蛋

17

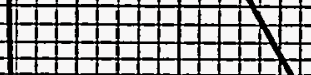

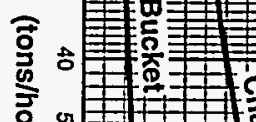

$\square$

$1+12$

3

\begin{tabular}{l}
$17 \quad$ Y \\
\hline
\end{tabular}

ป

疒

安

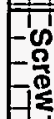

$+1$

थH

-

-

\&ั

$+2$

㭋

客

10

䓇

\#

車

妾

难

突

7

8

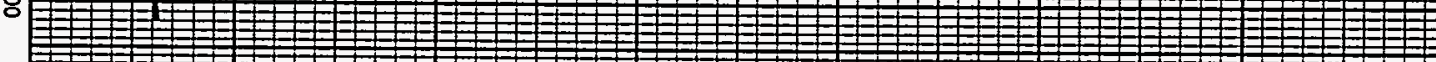

吅 Y

欢

$\overrightarrow{\mathrm{\delta}}$ 


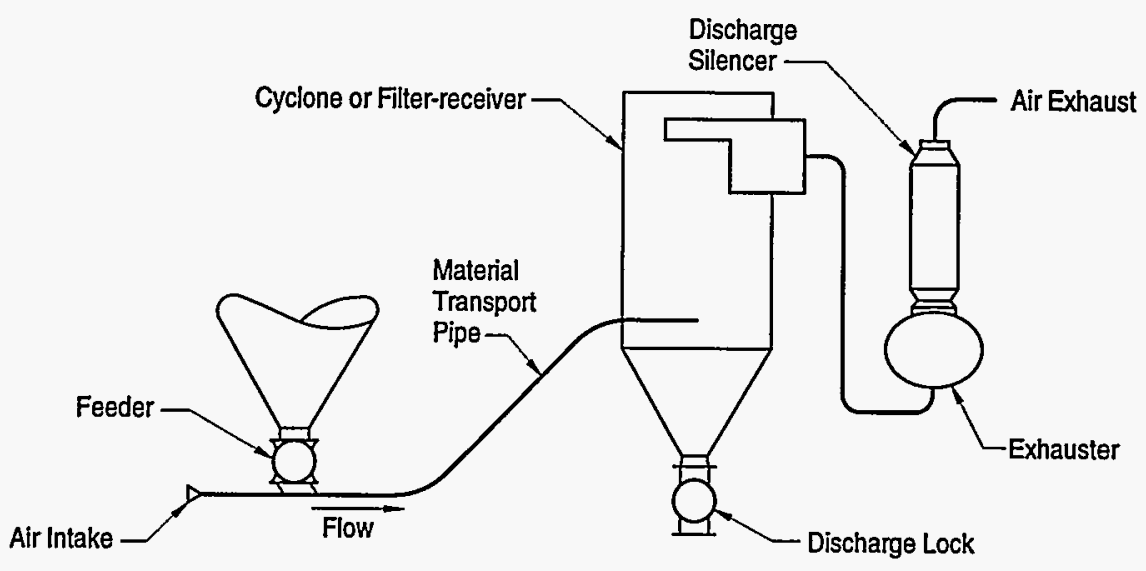

Negative Pressure (Vacuum) System

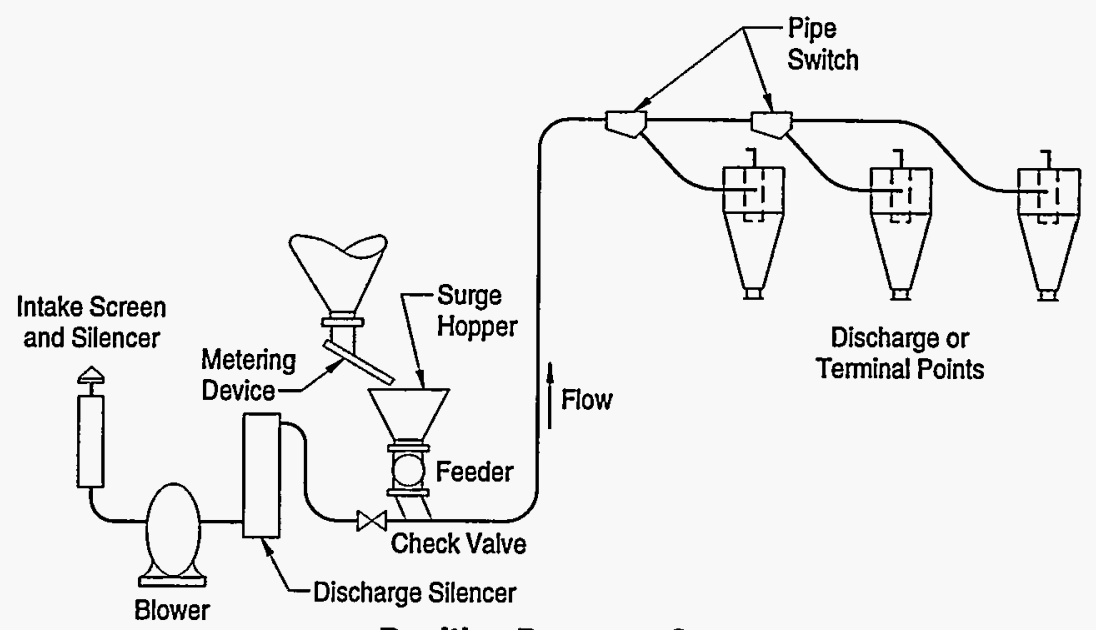

Positive Pressure System

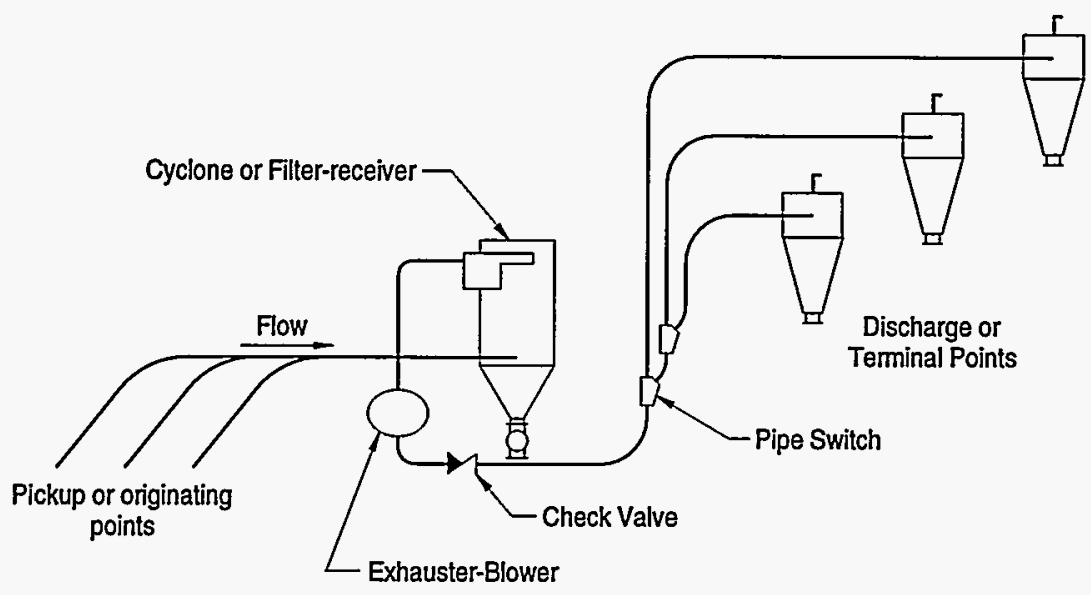

Combination Vacuum-Positive Pressure System

Figure 45. Illustrations of Dilute Phase Pneumatic Conveyors

Adapted form Stoess, H.A. Pneumatic Conveying. Wiley \& Sons, Inc., New York, 1983. 
The Combination System (negative and positive pressure) draws material into the conveying line via negative pressure (developed by an exhauster/blower) and deposited into a vessel such as a cyclone receiver. The air stream developed by the exhauster/blower is filtered and then used to pressurize a conveying line which transports the material to the final discharge points. (A separate blower may be used to pressurize the line.)

Dense Phase-This type of pneumatic conveying system uses high pressure air (typically $>15$ psig) to transport solids. Within the transporting airstream, the solids-to-air ratio is high. Two types of dense phase systems are the pulse phase system (or slug flow) and the air mixing system (which uses a fluid solids pump). Refer to Figure 46 for illustrations.

In the Pulse Phase System (slug flow), air is used to fluidize the material within a blow tank (which is located beneath the storage bin) and to pressurize that tank to assist in the discharge of the material. After the outlet valve is opened, the material is forced under pressure into the conveying line. An air knife regulates the material flow using pulses of air. This produces a series of cohesive masses separated by intervals of compressed air. The pressure between these masses (or slugs) is maintained by air jets in the line.

The Air Mixing System uses a fluid solids pump (also called a Fuller-Kinyon pump) equipped with a differential-pitch impeller screw which compresses the material prior to being introduced into a mixing chamber. There, the material is aerated by the introduction of compressed air. The fluidized material is then conveyed through the transport line by the continuing action of the impeller and the energy of the expanding air.

Air Activated Gravity Conveyor (Air Slide)-This type of conveying system uses an inclined channel which is equipped with an airpermeable porous material forming the bottom.
An air plenum under the porous material supplies air to the entire length. The channel is sloped; therefore, the material fluidized by the air flows under the influence of gravity. Refer to Figure 47.

\section{Mechanical Conveyors}

These types of conveyors use mechanical means (such as belts, screws, chains, vibrators, and buckets) to transport materials. Following is a description of some of the various mechanical conveyors available including costs and capacities.

Belt Conveyor-An endless belt (in the form of a loop) travels on top of idlers/rollers arranged in a trough on the carrying side and flat on the return/bottom side. The driving unit moves one or more pulleys which, in turn, move the belt. Material is conveyed in the trough on the belt as shown in Figure 48. Capacities can range from 150 tons per hour to 640 tons per hour; the respective costs per 50 - $\mathrm{ft}$ length range from approximately $\$ 20,000$ to $\$ 30,000$.

Screw Conveyor-Metal flights, consisting of a long-pitch plate-steel helix mounted on a shaft or spindle, are carried in bearings within a U-shaped trough or pipe. As the flight rotates, the material fed to it is moved forward by the thrust of the lower part of the helix and is discharged through openings in the trough/pipe bottom or at the end. A diagram of a typical screw conveyor is shown in Figure 49. System costs for a 50-ft length can range from $\$ 9,000$ (55 tons per hour) to $\$ 20,000$ (250 tons per hour).

Chain Conveyor-A continuous heavy steel chain, which forms a loop, travels within an open or enclosed casing or trough, with the bottom side of the chain supported by the casing/trough. The chain transmits pull from the driving unit. Bulk material may be carried directly on the chain, on special attachments fitted to the chain, or may be slid forward by the chain or attachments. Three types of chain 


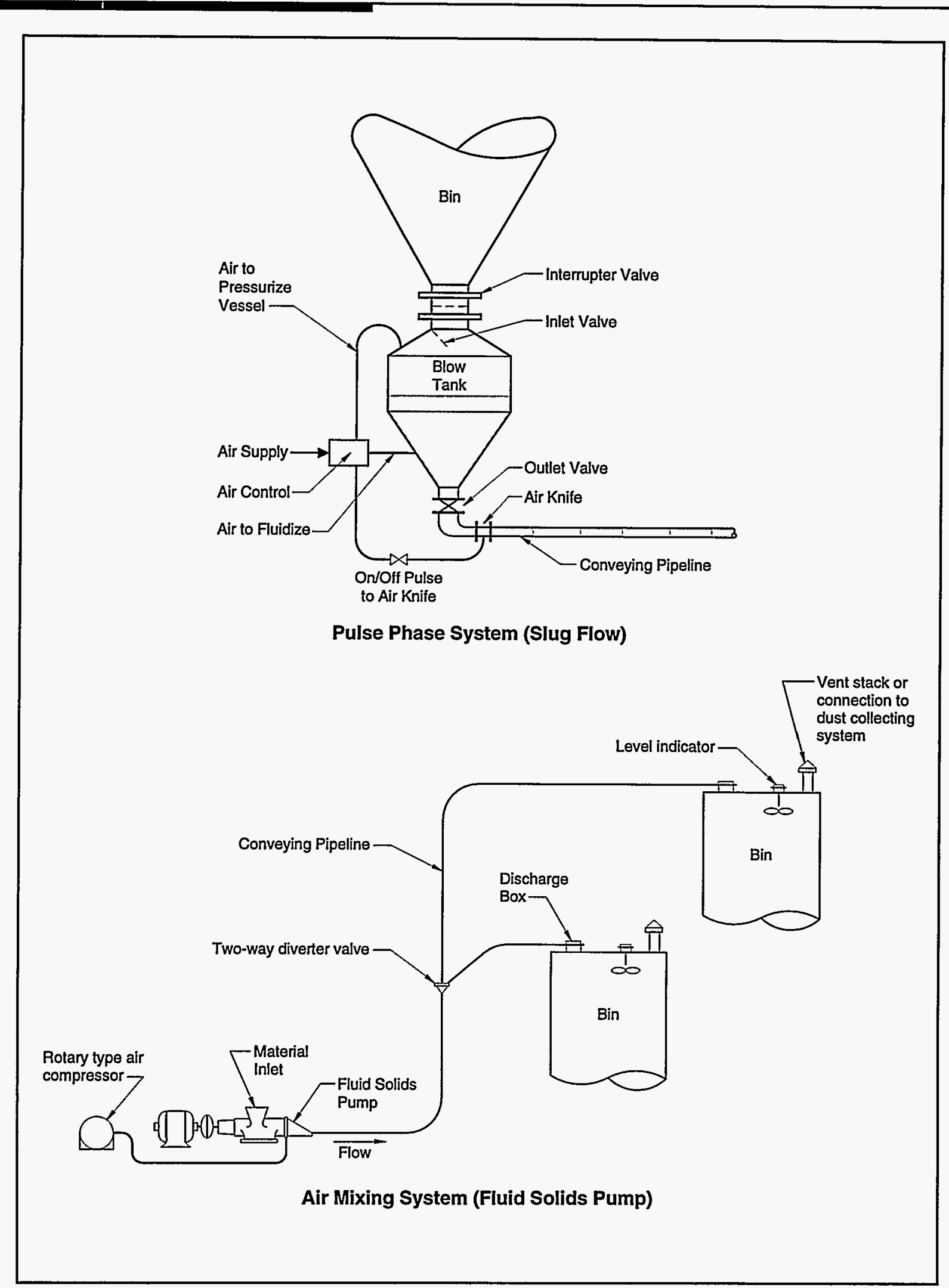

Figure 46. Illustrations of Dense Phase Pneumatic Conveyors

Adapted from Stoess, H.A. Pneumatic Conveying. Wiley \& Sons, Inc., New York, 1983. 


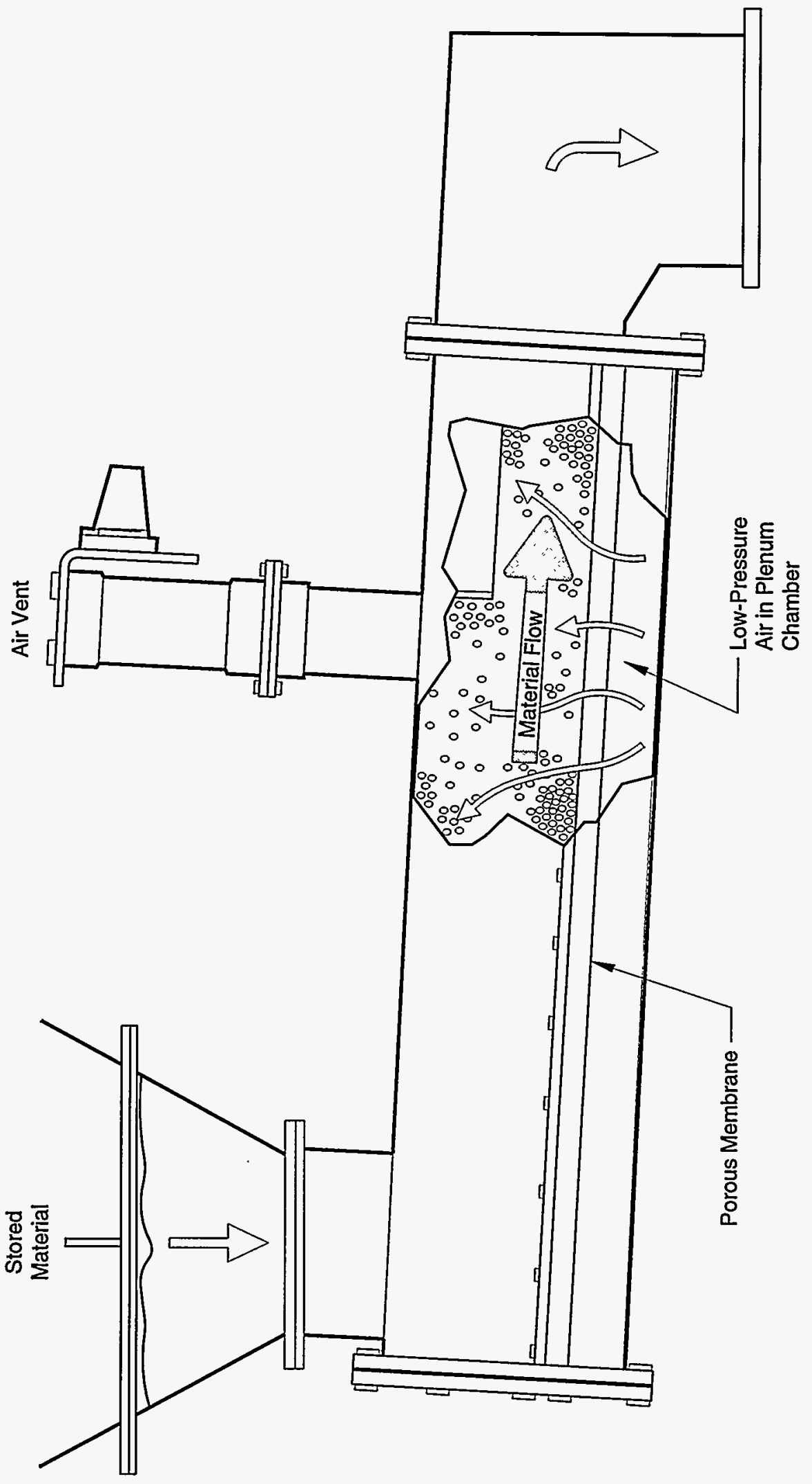




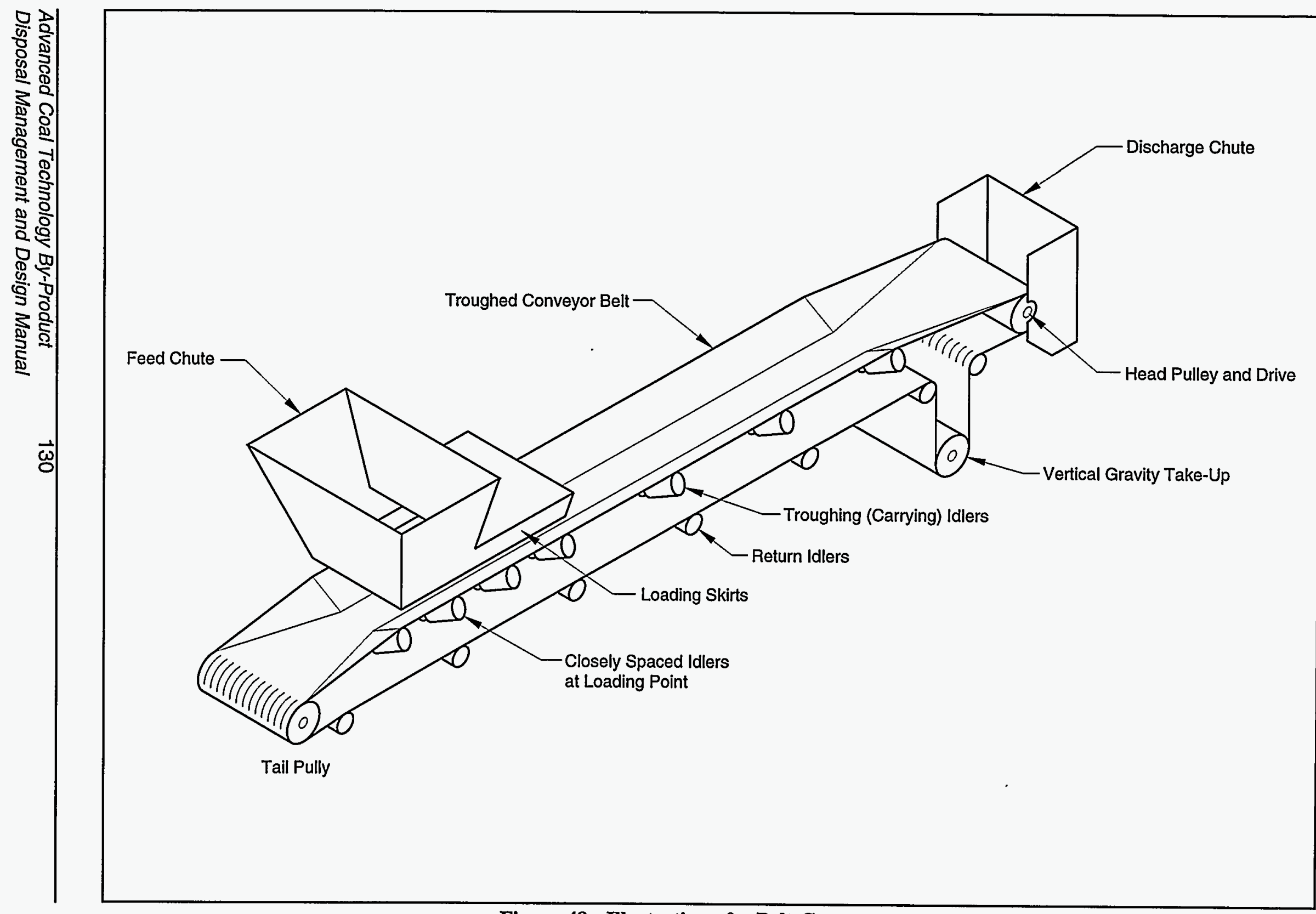




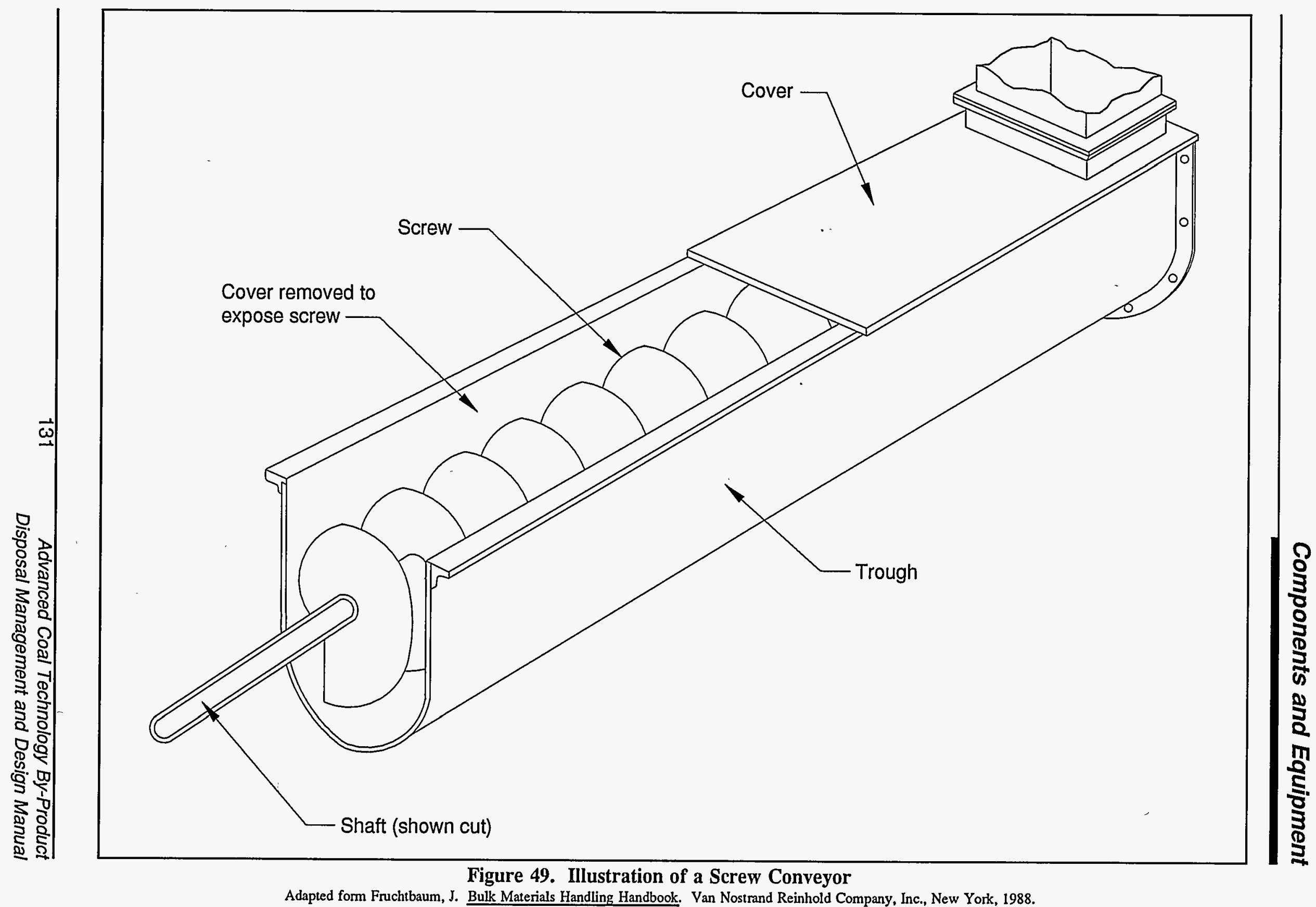


conveyors are drag, en-masse, and flight. Refer to Figure 50 for illustrations. Drag chain conveyors use an endless chain without attachments to drag material through the trough. En-masse conveyors consist of a series of skeleton or solid flights mounted on a chain which travels within a closely fitted enclosure. A flight conveyor has a series of flights attached to the chain which push the material through the trough. System costs for a $50-\mathrm{ft}$ length can range from $\$ 30,000$ (20 tons per hour) to $\$ 100,000$ (200 tons per hour).

Vibrating Conveyor (Oscillating)-A horizontal trough, mounted on inclined reactor legs and supported by a spring system, is vibrated/oscillated by a direct-connected eccentric arm, rotating eccentric weights, an electromagnet, or a pneumatic or hydraulic cylinder. This motion, which propels the particles upward and forward, conveys the material in a uniform, continuous flow. An illustration of the process is shown in Figure 51. Approximate costs for this type of conveying system can range from $\$ 20,000$ to $\$ 40,000$ per 50 -ft length. Capacities up to 25 tons per hour perform best with materials larger than 100 mesh; however, light duty systems do not convey fine materials (less than 100 mesh) well.

Bucket Elevator-A series of buckets are mounted on an endless chain or belt. Material is fed into the buckets at the boot (bottom) terminal, conveyed upward, then discharged by passing over the head wheel at the top. The entire mechanism is usually enclosed in a casing. Refer to Figure 52. Prices range from $\$ 9,000$ (14 tons per hour) to $\$ 17,000$ (150 tons per hour) per 50-ft length.

\section{Feeders}

Feeders are short conveyors or other devices used to take material from the bottom of the storage vessel and transfer it at a controlled rate to the conveyor or mixing equipment. Types of feeders considered feasible for coal combustion by-products ${ }^{2}$ are discussed below.
Rotary-This type of feeder consists primarily of a shaft with radial paddles or rotors which form pockets designed to suit the characteristics of the material to be fed. A rotary feeder can be used to regulate material flow by controlling the throughput of material volumetrically or by providing an air pressure seal between the feed source and the pressurized transport line. The latter type, referred to as an airlock feeder, is used on pneumatic conveying systems. If a rotary feeder is selected, special consideration must be given to the abrasive nature of the byproducts (such as selecting one made of abrasion-resistant materials).

Airlock and Gate-These types of feeders are used to regulate the discharge of material from equipment operating under a pressure differential (such as pneumatic systems). The types of equipment available include rotary airlock feeders (discussed previously), double-door discharge gates, and flap valves. The double-door discharge gate uses the space between the doors as an airlock. The flap valve consists of a weighted flap held in place by the operating pressure of the conveying line. When the weight of the collected material overcomes the seating pressure, the flap opens and material is discharged.

Screw-Screw feeders are similar to screw conveyors in that they use a helix to transport material volumetrically from a bin operating with little or no pressure differential between inlet and outlet. Screw feeders are typically used with mechanical transport system; however, specially adapted screw conveyors can be used with pneumatic systems.

Belt or Chain-Similar to a belt conveyor, this feeder uses a belt or chain to withdraw material from the storage bin. Weigh decks or weigh idlers may be employed to meter flow gravimetrically.

Vibrating-This type of feeder, like the vibrating conveyor, uses vibration to trans 


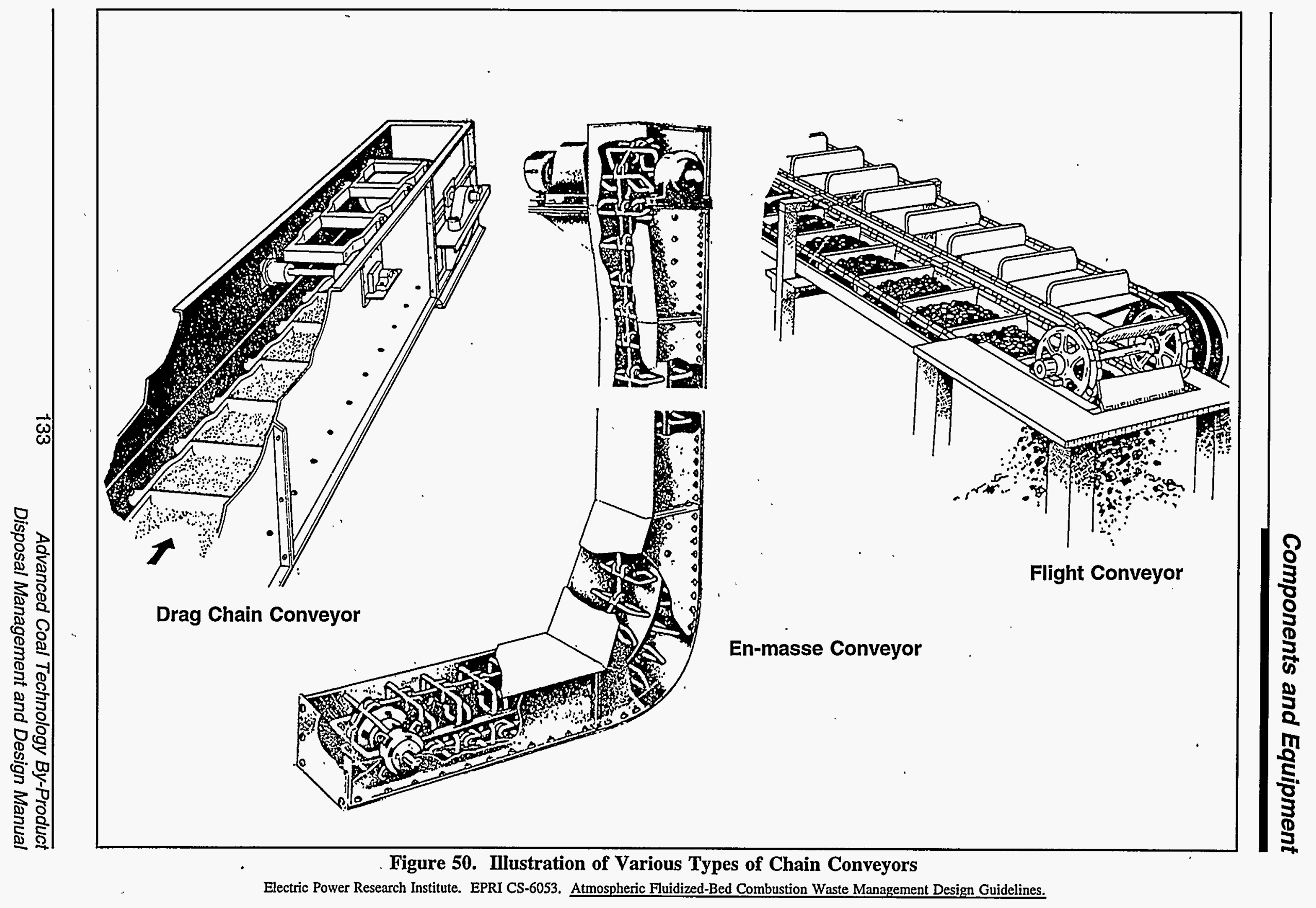




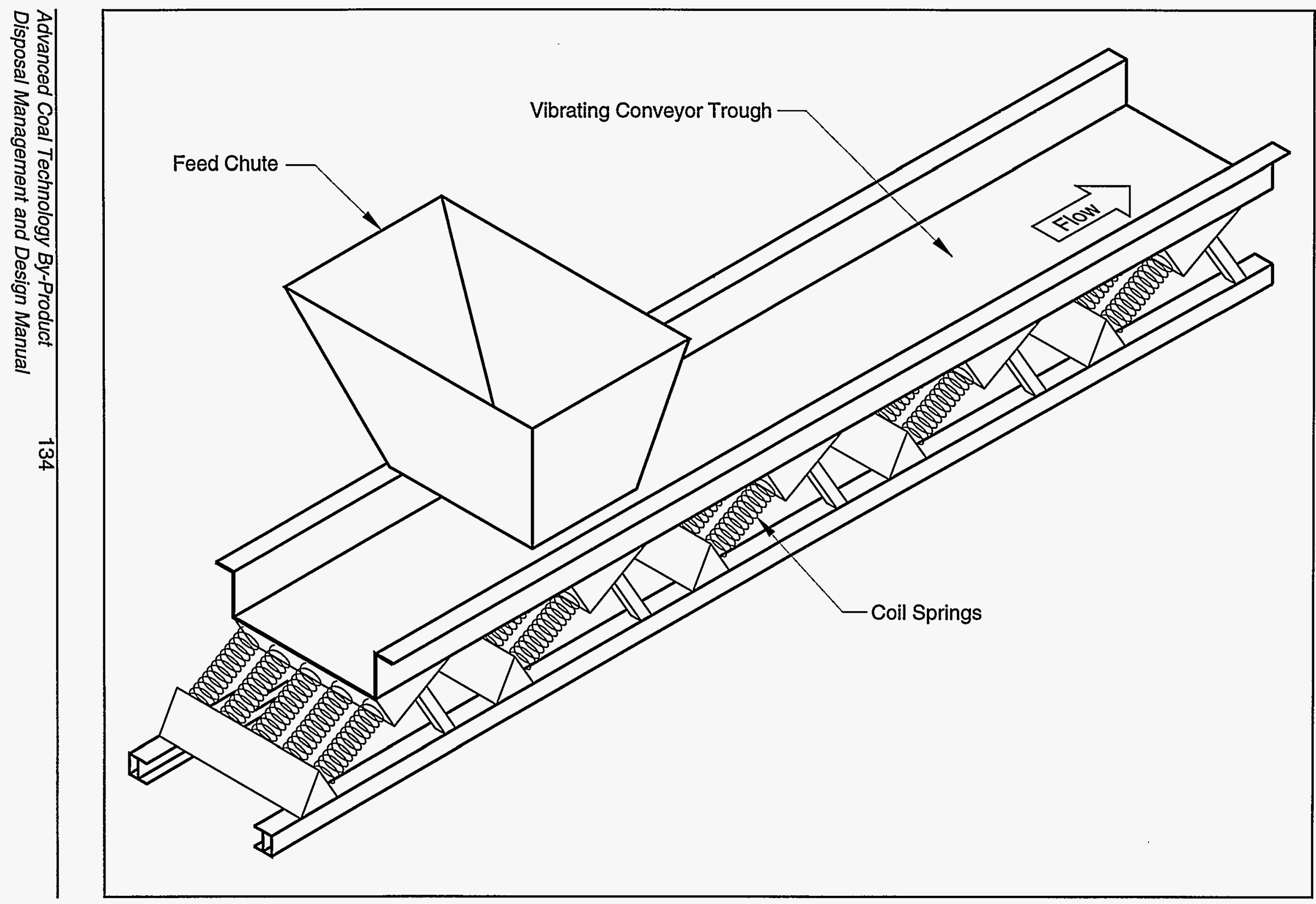




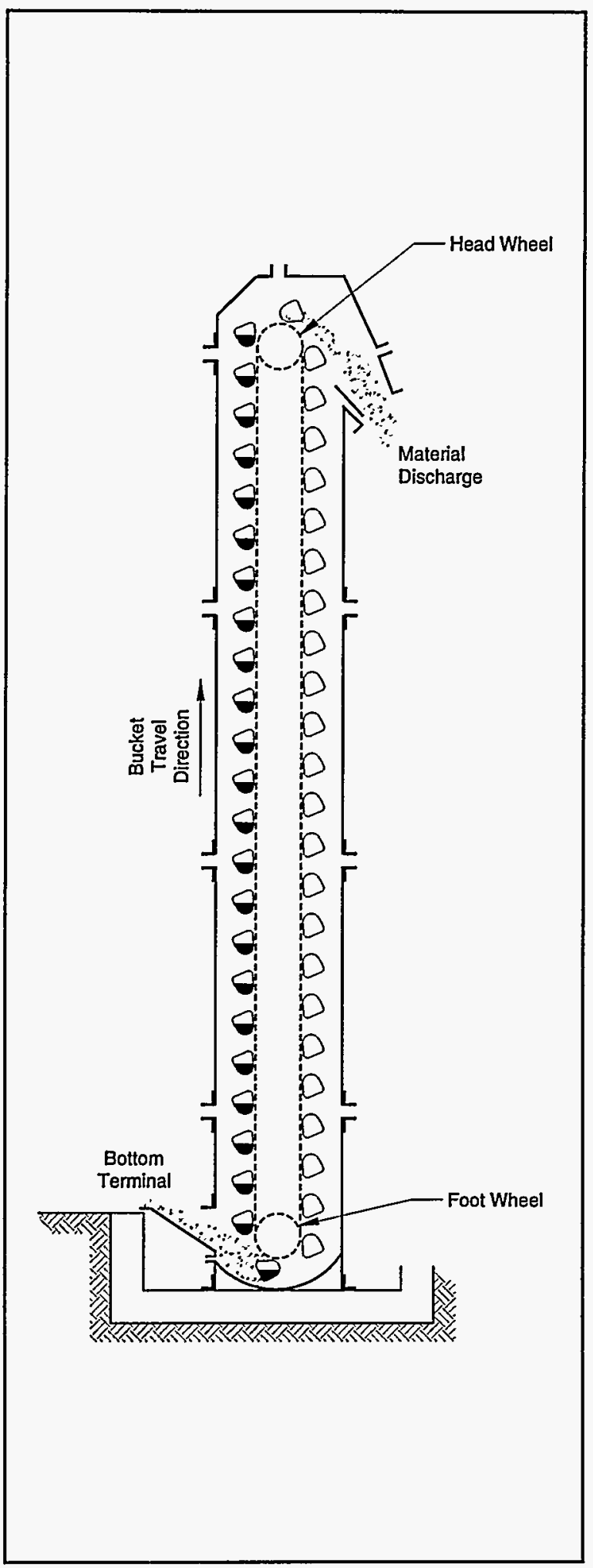

Figure 52. Ilustration of a Bucket Elevator

Adapted from Hudson, W.G. Conveyors and Related Equipment. Wiley and Sons, New York, 1949. port material forward. An inclined plate, located beneath the storage bin, is vibrated by an exciter.

\subsubsection{By-Product Hydration Equipment}

As will be discussed in Section 6.4, it has been demonstrated during the course of this project that one of the more effective ways of disposing of by-product materials containing unspent sorbent is by hydrating the dry ash, then compacting the wet material in the disposal area. This type of disposal technique may reduce the environmental impacts of some materials by improving stability and reducing leachability. With by-product materials containing unspent sorbent, exothermic reactions will occur when the wastes are mixed with water. Temperature increases associated with these reactions can be considerable (see Chapter 3). However, their impact on disposal operations will be minimized by properly hydrating the by-product material with water before disposal. The amount of water required for processing will depend on the characteristics of the by-product material and on the expected properties of the processed material. Typically, enough water will be added to complete the hydration reactions and provide for adequate compaction. After material processing, the temperature of the material is reduced by spreading the material in thin lifts ( 8 to 12 inches) before compacting it.

Several options for hydrating the byproduct material are available for either continuous or batch operations. Types of processing equipment suitable for hydrating byproduct materials are described in the following subsections and illustrated in Figure 53. Suitability of the equipment is dependent on the by-product characteristics, site conditions, and the desired properties of the hydrated material. Consultation with various equipment manufacturers is recommended prior to equipment selection. Approximate costs for the equipment range from $\$ 35,000$ (for a 15 cubic yard $\mathrm{per} / \mathrm{hr}$ auger blender equipped with 
an integral feed system) to $\$ 150,000$ (for a sophisticated 300-cubic yard per/hr turbine mixer). The required size of the mixing equipment depends on the maximum average by-product production rate and the operating schedule of the disposal site.

\section{Continuous Mixers}

These mixers typically have a mixing chamber or trough into which material is fed and water is injected. The action of blades or paddles (which may be static or dynamic), mix and discharge the material in a continuous process. Several types of continuous mixers are described below.

Horizontal Drum Mixer-This type of mixer consists of a rotating mixing drum and a screw conveyor (which is contained within and runs up the center of the mixing drum). The material travels from the inlet through a screw conveyor to the mixing drum. There it is moistened by a series of spray nozzles. As the material travels toward the discharge end (lower end) of the drum, it is agitated by the combined action of the rotating drum and a stationary scrapper. A production rate of up to 50 cubic yards per hour is possible. Due to the short residence time of the material within the mixing drum and the hard-to-wet nature of some by-products, low mixing efficiencies may result. Therefore, prior to selecting this type of mixer, a test should be performed to determine if the mixing efficiency is acceptable with respect to the disposal option selected.

Vertical Mixer-This mixer consists of three chambers: an upper feeding chamber, a metering chamber, and a lower conical mixing chamber. The material flows from the feeding chamber to the metering chamber. Flow out of the metering chamber to the mixing chamber is regulated by a rotating cone at the base of the metering chamber. Water is injected into the material via high pressure water nozzles as it descends into the mixing chamber. To prevent build up and direct flow toward the outlet, a pair of rotating scraping arms travel along the interior of the mixing chamber walls. A production rate of up to 250 cubic yards per hour is possible. As with the drum mixer, the vertical mixer has a short residence time. Therefore, a test to demonstrate mixing efficiencies should be performed to determine suitability.

Auger Blender-This type of mixer consists of single helical blending auger housed in a trough or tube. Material is introduced into the base of the housing by a feeding mechanism and carried forward by the auger. Water is injected into the housing and is mixed with the material by action of the rotating auger. A production rate of up to 120 cubic yards per hour can be achieved.

Horizontal Pug Mill-One or two shafts are housed within a horizontal cylindrical chamber or trough. The shaft(s) are fitted with short heavy cutting paddles/ blades which extend radially outward. Material is fed into the chamber at one end where water is injected. The material is mixed and pushed forward by the blades, then discharged from the opposite end at the bottom. Production rates can range between 10 to 200 cubic yards per hour depending upon the size of the mill.

Plow Blender-This is similar to a pug mill; however, this type of mixer uses plow shaped blades rather than cutting paddles. The plows are attached to either one or two shafts (depending on the size) which rotate and mix the material. Production rates as high as 200 cubic yards per hour are possible.

\section{Compulsory Mixer-This type of} mixer is also similar to a pug mill. A compulsory mixer has a horizontal chamber housing two counter-rotating shafts with radial arms with flat pitched ends which push the material forward as it is being mixed. For continuous operation, material is fed into the chamber from the top of one end where water is also injected. The material is mixed, and then discharged from the bottom at the opposite 


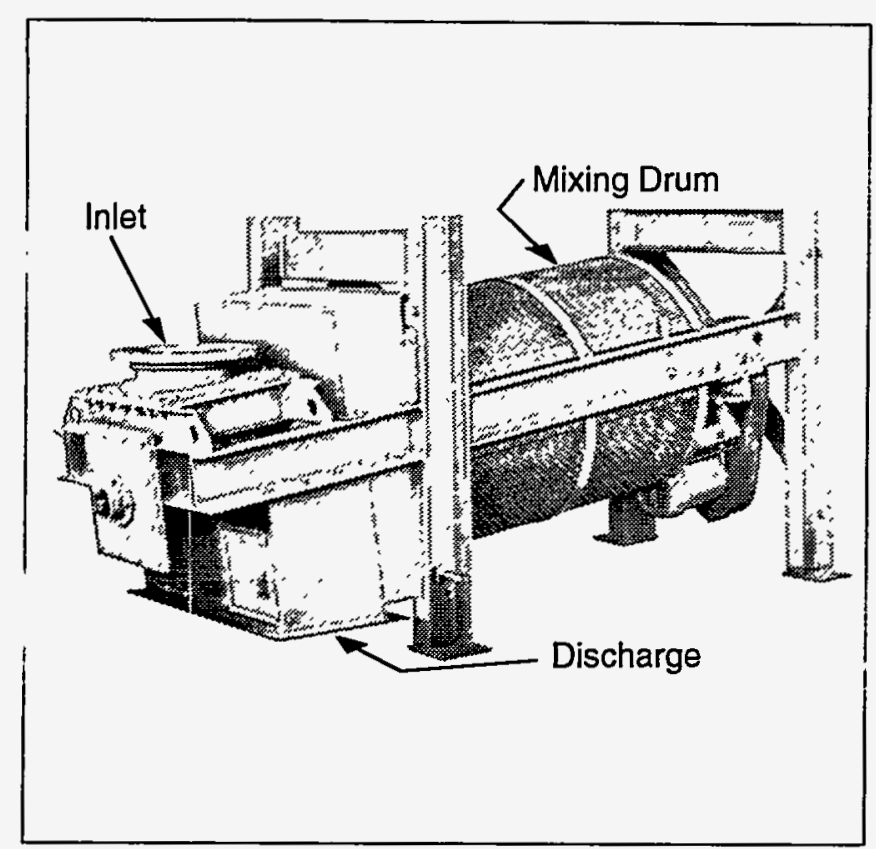

Horizontal Mixer

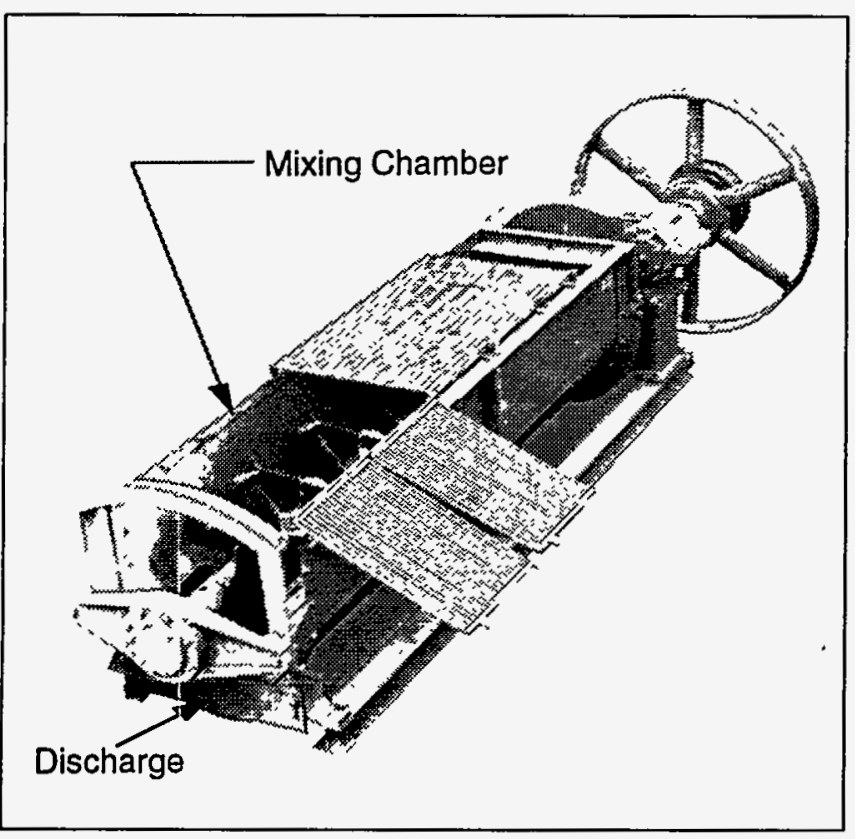

Horizontal Pug Mill

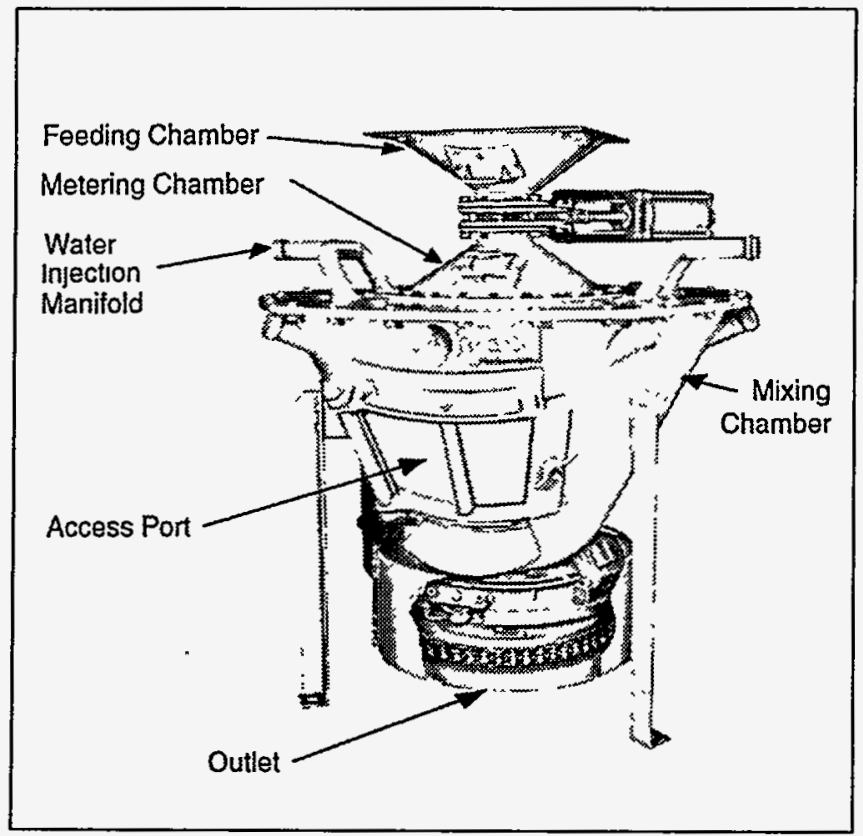

\section{Vertical Mixer}

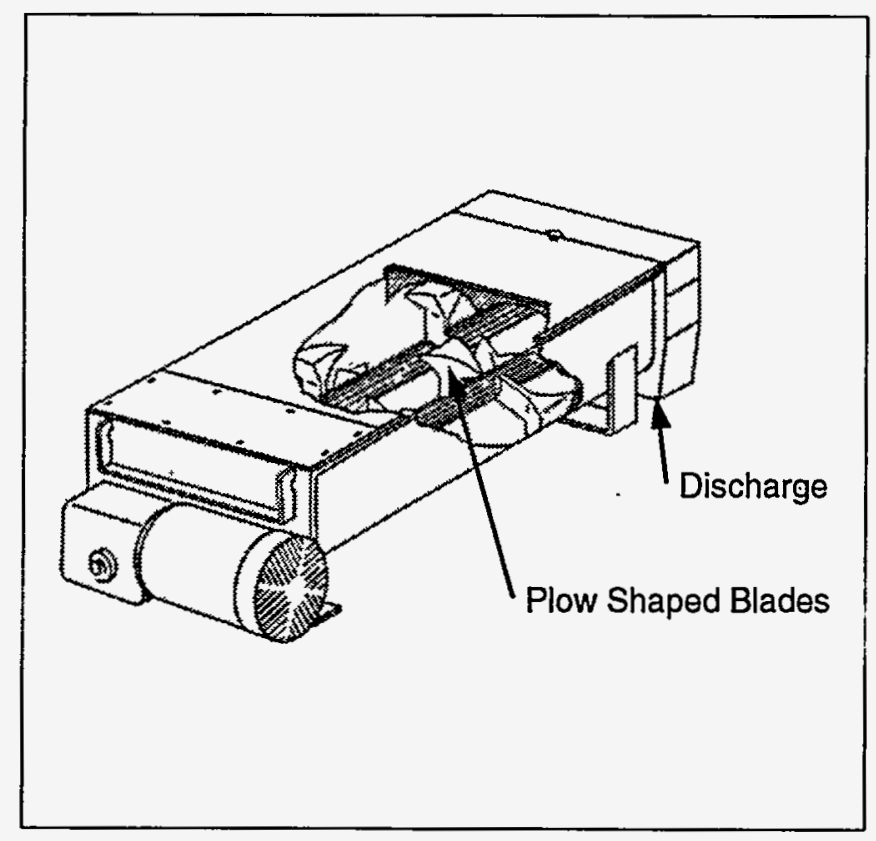

Plow Blender

Continuous Mixers

Figure 53. Processing Equipment Suitable

Photos from left to right reprinted with permission from: Joy Environmental Technologies, Inc. (Photos Water \& Wastewater Products (Photo 6); The Ross Co., Enviro Mix Division (Photo 7). 


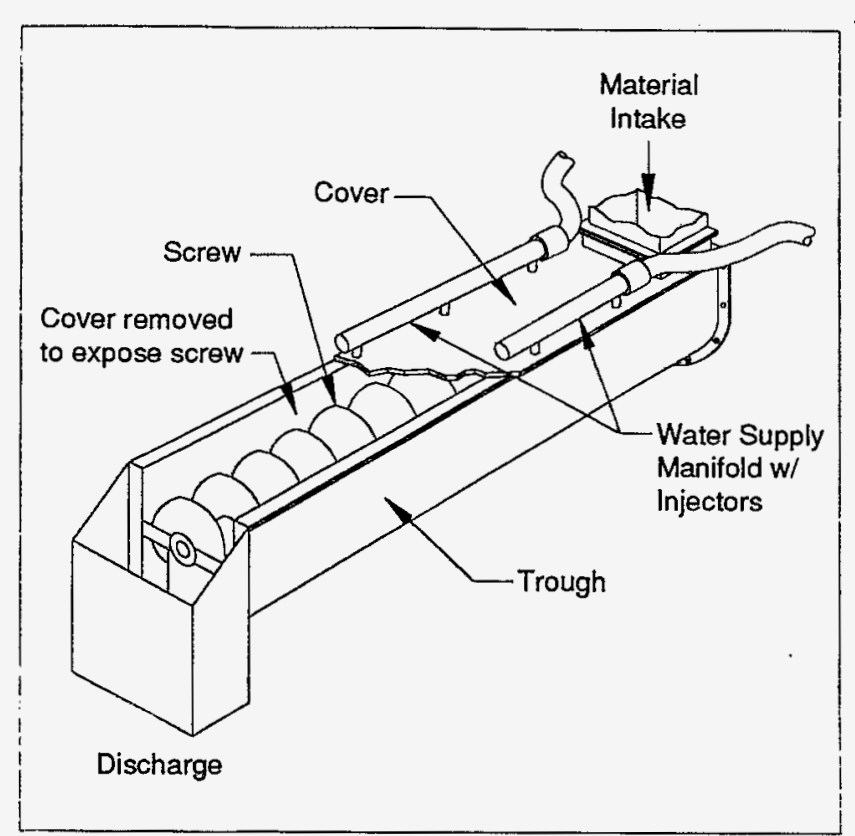

Auger Mixer

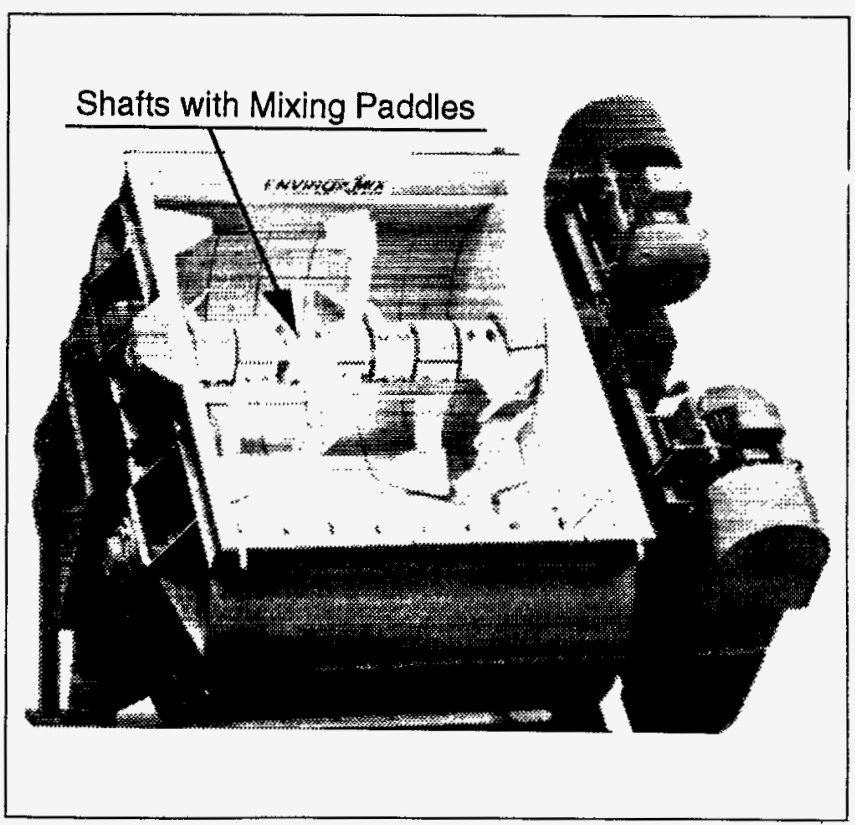

Compulsory Mixer

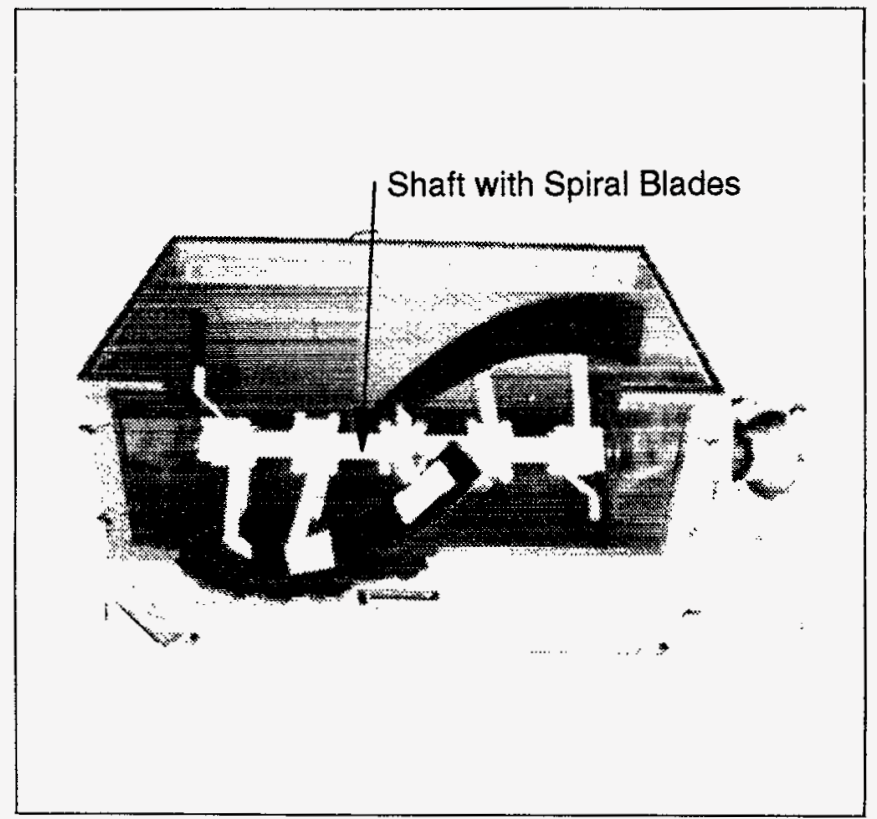

Spiral Mixer

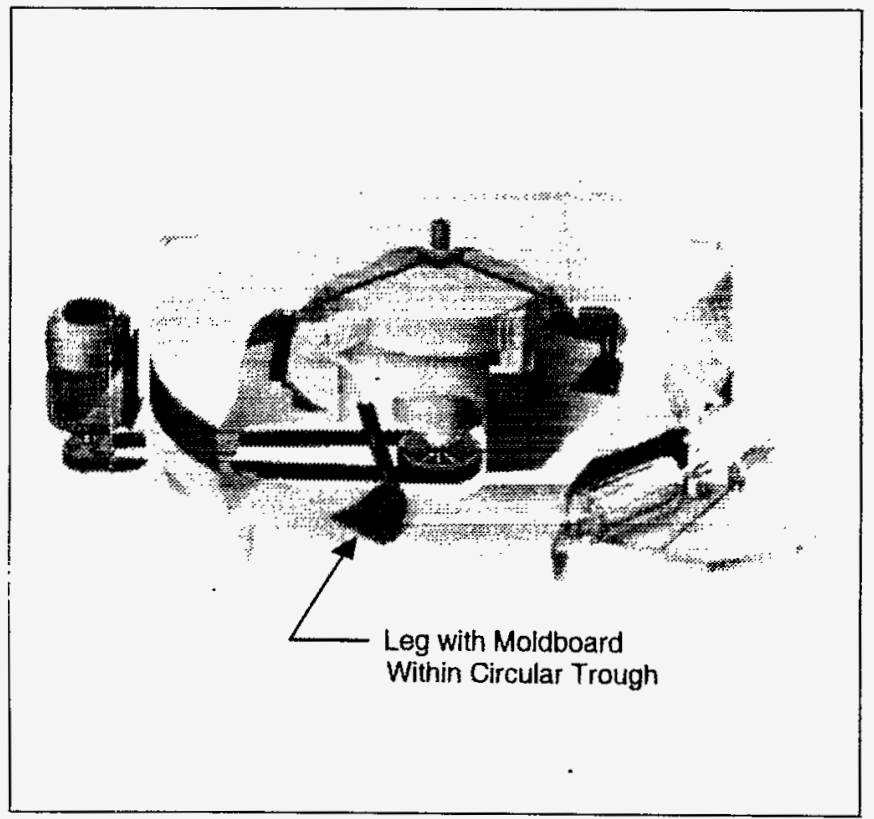

Turbine Mixer

\section{Batch Mixers}

\section{for Hydrate By-Product Materials}

1 and 2); Mixer Systems, Inc. (Photos 4 and 8); J.C. Steele \& Sons (Photo 5); Leopold 
end. Production rates range between 20 to 200 cubic yards per hour depending upon the size of the mixer. Compulsory mixers may also be used in a batch mode.

\section{Batch Mixers}

These mixers typically have a closed, static mixing chamber into which material and water is added. The material is mixed by the action of paddles or blades. The chamber is opened after mixing is complete and the batch of material is removed.

Spiral Blade Mixers-This mixer consists of a cylindrical horizontal mixing chamber which houses a single shaft having two spiral blades. Material and water are added to the chamber then, as the shaft rotates, the material is mixed. Production rates can be as high as 40 cubic yards per hour (assuming 10 batches per hour and a $4 \mathrm{yd}^{3}$ mixer).

Turbine Mixer-The mixing chamber of a turbine mixer is a circular trough. A series of revolving legs fitted with plow shares or moldboards are attached to a housing in the center of the trough. After the material and water are added, the moldboards spin around and through the circular trough, thoroughly mixing the material. Production rates as high as 200-300 cubic yards per hour can be attained (assuming 40 to 60 batches per hour and a $5 \mathrm{yd}^{3}$ mixer).

\subsubsection{By-Product Pelletization System}

Pelletization may be considered to improve handling and transport properties of by-products, or as an alternative to land disposal through the use of by-products in the production of construction materials. Dry Advanced Coal Technology (ACT) by-product materials may be formed into synthetic aggregate by pelletizing and curing the conditioned product prior to shipment. Figure 54 presents process schematics for two pelletization systems. If the by-product contains sufficient amounts of unspent sorbent (such as lime), self hardening reactions may take place when the by-product is dampened and pelletized, thereby forming synthetic gravel with splitting tensile strengths greater than 400 psi (after 30 days of curing) and a hardness comparable to that of dolomite ${ }^{5}$. Pelletization has been proposed and tested primarily as a method for utilizing the by-products as aggregate in roadbase and concrete compositions. However, waste processing prior to ultimate disposal may also be useful for the following reasons:

- To reduce the leaching potential;

- To control volume expansion when contacted with water;

- To prevent dusting; and

- To reduce overall waste volume ${ }^{6}$.

An example of this process is being demonstrated at the Applied Energy Services (AES) Thames atmospheric fluidized bed combustion plant in Connecticut, which has a FBC ash processing facility capable of producing 600 tons per day of pelletized product for backhaulage to mines in West Virginia ${ }^{7}$. Rather than mixing and pelletizing the bed and fly ash together, this process uses the bed ash (which is prehydrated) as a coating and anti-agglomeration mechanism for the pellets which are made from the fly ash. Fly ash is conditioned in pin mixers and pelletized on disc pelletization pans. After being coated, the pellets are cured for a minimum of 10 hours and then screened. The excess hydrated bed ash (recycled ash) is returned and pelletized with the fly ash. This process for pelletizing FBC by-products is composed of the following general processing steps.

1. The weight of the ashes is determined;

2. The fly ash and recycled ash is conditioned with water in a pin mixer; 


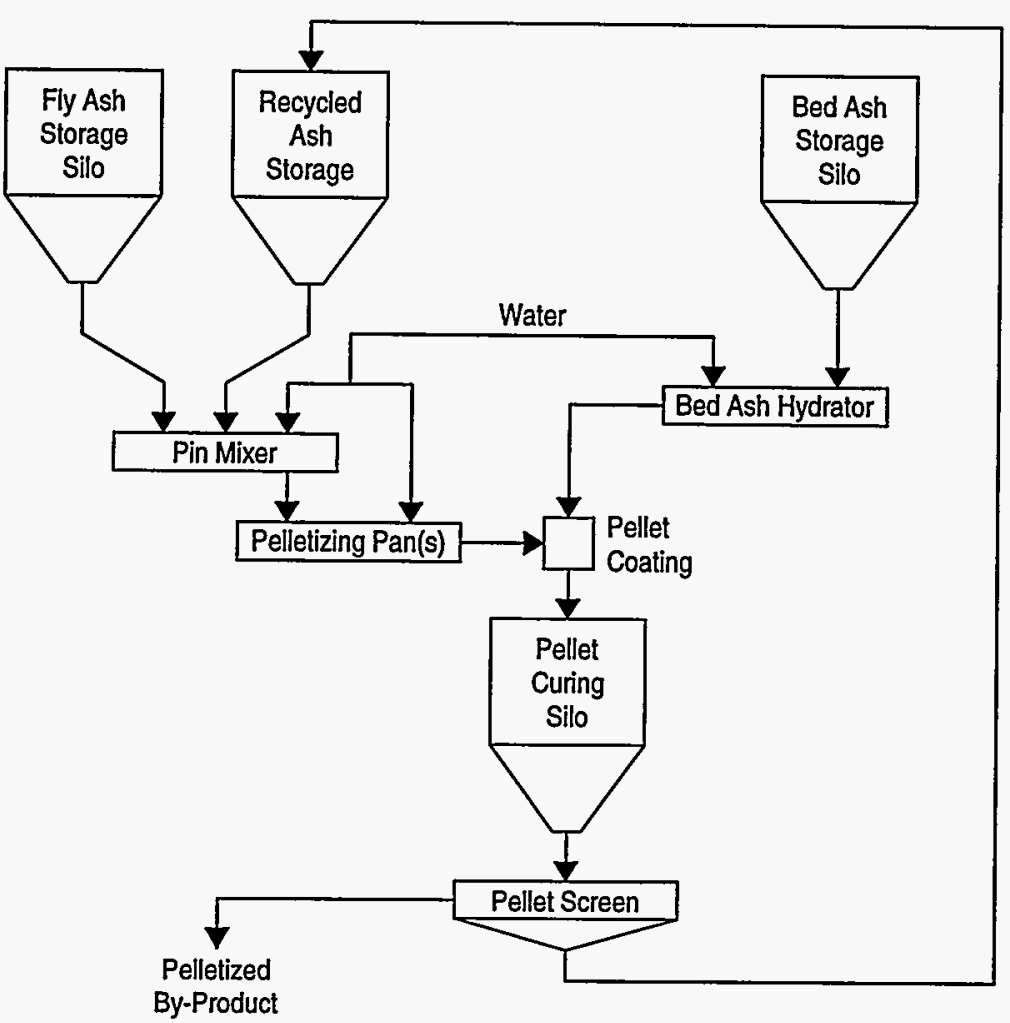

System Using Pelletizing Pan

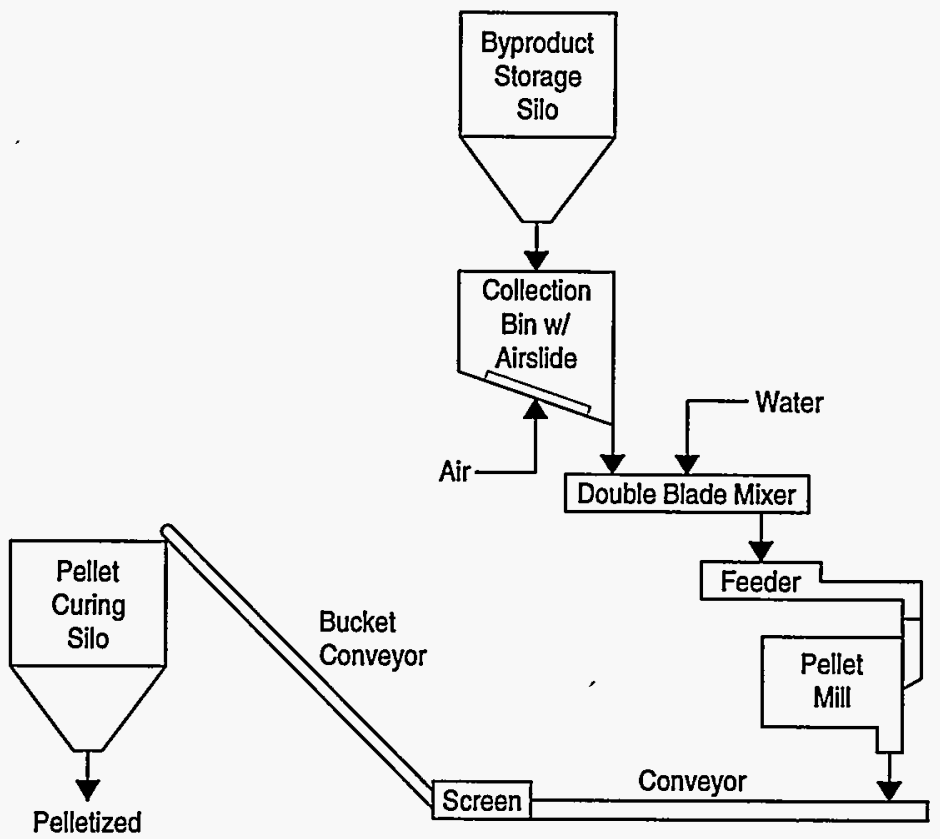

System Using Pellet Mill

Figure 54. Pelletizing Systems 
3. The conditioned ash is agglomerated on a pelletizing pan with water to form green pellets;

4. The pellets are then coated with hydrated bed ash upon discharge from the pelletizing pans;

5. Once coated, the pellets are transferred to a curing chamber and allowed to cure overnight;

6. The cured pellets and coating material are transferred to a screening area where the excess coating, smaller than 10 mesh, is removed and conveyed to a recycled ash storage area; and finally

7. The material larger than the screen size is transferred out as the pelletized product ready for transport.

Another means of pelletizing dry FGD by-products is accomplished under pressure, using special dies (within pellet mills) with a small percentage of water added as a binder (refer again to Figure 54). The amount of water added for conditioning prior to pelletization depends upon by-product characteristics. Generally, at lower water contents, more friction is produced in the pellet mill, resulting in higher densities. However, when the moisture content is too low, the friction in the die becomes so high that the pellet mill may plug.

\subsubsection{Processed Material Transportation Options}

After the by-product material is processed and discharged from the mixing equipment, it needs to be transported to the disposal area. Transportation equipment suitability should be evaluated on the basis of the distance to the disposal area from the mixing equipment, the terrain, and the production rate. Several transportation alternatives are listed below.

\section{Dump Truck}

Dump trucks generally provide a suitable mode for transporting the processed material to the disposal area. However, consideration must be given to how the trucks will be loaded (if not directly fed by the processing equipment discharge), the route in which the trucks will travel, how many trucks will be needed, what capacity will optimize efficiency, and how the dumped load will be spread out over the disposal cell. Typical transport rates (assuming round trip travel is approximately 1000 feet) can range from 240 to 800 cubic yards per day per truck.

\section{Front End Loader}

Front end loaders can be used to spread material over cell area or to load dump trucks (if necessary). Typical transport rates can range from 360 to 1480 cubic yards per day per loader.

\section{Belt Conveyor}

If the material needs to be transported a short distance (such from the processing equipment to the transportation means), a belt conveyor may be used. Capacities for belt conveyors can range from 150 tons per hour to 640 tons per hour.

\subsection{Case Study System}

A case study was performed to demonstrate the effectiveness of disposing of byproduct materials (containing unspent sorbent) by hydration and placement in a landfill. During the case study, an integrated byproduct processing system was operated and evaluated. The study, conducted at the Freeman United Mine site (near Canton, Illinois), involved the construction of two landfill test cells: one to test a by-product mixture hydrated for flowability, the other to test a mixture hydrated for compactability. Results from this Illinois test site are presented in Chapter 9, Section 9.2.3. Fluidized bed 
combustion (FBC) by-products and pulverized coal fly ash (PFA), produced at separate plants, were mixed together in equal proportions by weight then hydrated to the two moisture contents. The mixed, hydrated materials were then placed into the two 350-400 cubic yard test cells for long-term observation. The objective of mixing and hydrating the two types of materials was to obtain a material with improved disposal characteristics.

A pre-construction laboratory program determined the two mix formulations to optimize compressive strength and permeability. The two mix designs selected were: 1) a mix with sufficient moisture to produce a flowable or pumpable material; and 2) a soil-like mix at its optimum moisture content for compaction. Because of the difference in consistencies, two methods of material placement were necessary. In the Cell 2, material hydrated with $42 \%$ water by weight was poured into the cell in a fashion similar to the placement of concrete. In the adjacent Cell 3, which was hydrated with $30 \%$ water by weight, material was placed in 6 to 8 inch lifts and compacted. The following paragraphs provide a discussion of the process equipment, construction procedures, and lessons learned.

\subsubsection{Process Equipment}

Components of the mixing and placement system included a means to transport the by-products to the disposal area, storage silos, transfer conveyors, the processing/mixing unit, and a means to transport the mixed, hydrated material to the test cell. The same process equipment was used for both Cells 2 and 3; however, the placement of the processed material differed. A picture of the integrated by-product processing system is presented in Figure 55.

\section{Transportation to Disposal Area}

Transportation of the by-products to the disposal site involved a bulker truck equipped with a pneumatic trailer having a 22.5-ton capacity. Once the trailer was loaded with by-product material at either of two the generating plants, the truck transported the material to the disposal area. The maximum transport distance was $\mathbf{1 5}$ miles. The material was transferred pneumatically from the trailer to the storage silos. Air was supplied by a medium sized, trailer-mounted air compressor.

\section{By-product Storage}

Two 220-barrel (880 cubic foot) toploading storage units were used at the disposal site to store the by-products. One storage unit was an upright rectangular silo, and the other was a bulker trailer. A dust suppression system (water scrubber) was provided to reduce fugitive dust emission during pneumatic transfer of by-products.

\section{Transfer to Processing Equipment}

Each of the storage units was equipped with a screw conveyor which extended from the bottom of the unit to the mixer feed hopper (which directly fed the auger mixer/blender). These conveyors were designed to provide an instantaneous supply of material to the feed hoppers. In practice, frequent clogging of the conveyors prevented this from occurring.

\section{Material Processing}

A Zim Mixer Model 205 (produced by Zimmerman Industries, Inc.) was selected for mixing and hydrating the two types of byproduct material. This unit consists of two byproduct feed hoppers (each having a 60 cubic foot capacity), a chain feed system, and an auger mixer/blender equipped with water injection manifolds and nozzles. Material is temporarily stored in feed hoppers which supply the chain feed system. The feed chain 


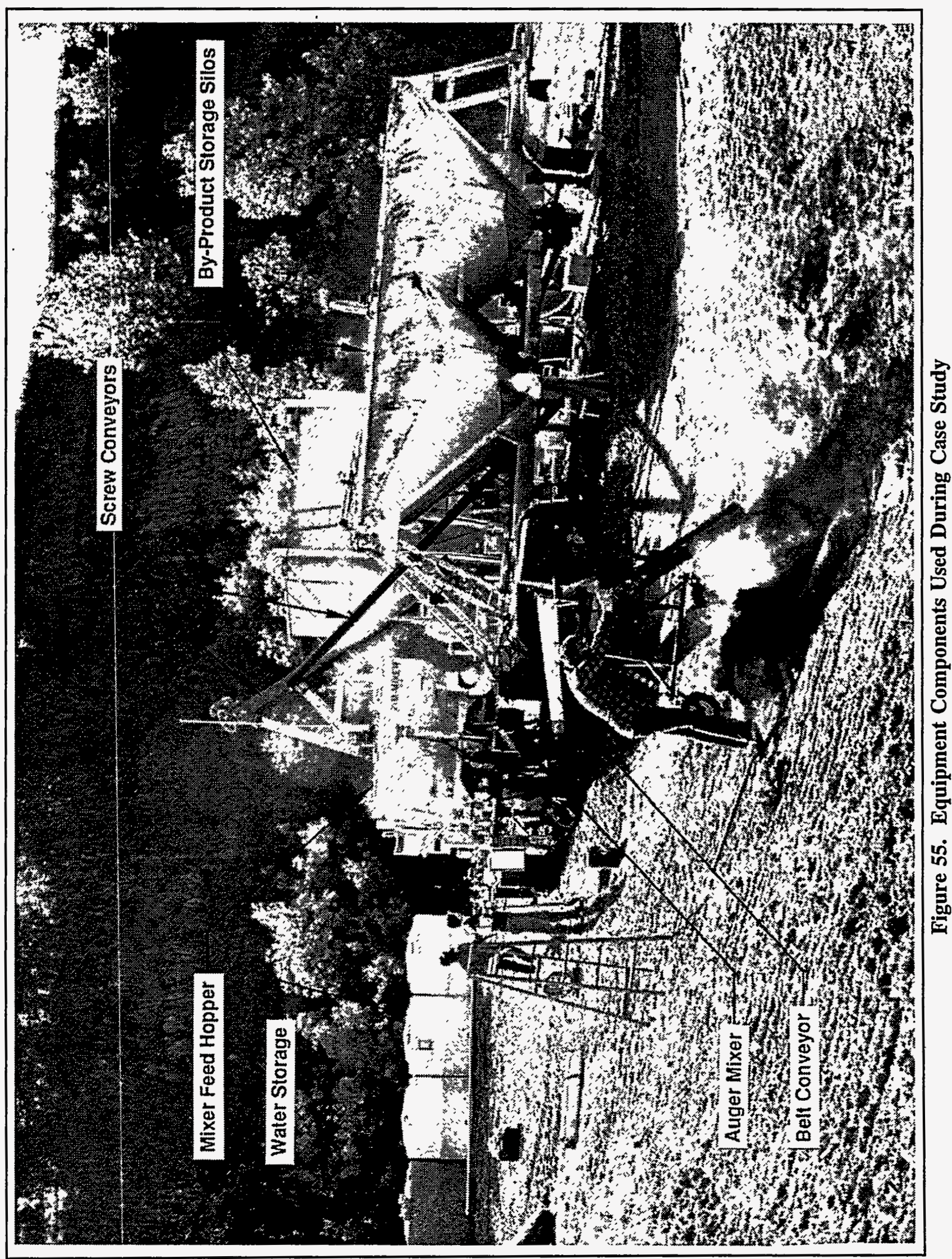


(similar to a flight chain conveyor/feeder) delivers material volumetrically to the inlet of the auger mixing chamber. Once mixed and hydrated, the material is discharged. The Model 205 has a theoretical capacity of 11 tons per hour; however, due to material supply problems and periodic equipment clogging, a rate of only 50 to 60 tons per day was achieved.

\section{Placement of Processed Material in the Cell}

After mixing and hydrating, the material was discharged onto a $50-\mathrm{ft}$ belt conveyor which discharged into a $3 / 4$ cubic yard backhoe bucket. The backhoe then placed the material into the cell area. For Cell 3, the backhoe heaped material at several locations in the cell, then a D-6 caterpillar bulldozer spread it out into 6- to 8-inch-thick lifts. A loose vibrating roller/compactor was used then to compact the lifts. In Cell 2 , the material was poured into the cell without compaction, similar to the placement of concrete.

\subsubsection{Construction Procedures}

Prior to any material being placed into the cells, the base of the cell was graded and compacted. Once the base was prepared, the material was placed into the cells as described above. Figure 56 contains photographs of several of the construction procedures used in the case study.

In order to assure construction quality, a materials testing program was conducted throughout construction operations. The program consisted of testing to determine optimum moisture content, in-situ moisture content, density, and unconfined compressive strength of the as-placed materials. Specific tests included:

- Three Standard Proctor tests (ASTM D698) performed during construction activities of the South Cell to determine optimum moisture content;
- Three types of as-placed moisture content tests performed periodically: Oven-Dry (ASTM D2216), Speedy Moisture Kit (ASTM D4944), and Nuclear Density Test (ASTM D2922);

- The nuclear density method (ASTM D2922) used to determine in-place wet density of Cell 3 material after compaction; and

- Two types of unconfined compressive strength (UCS) tests. A pocket pentrometer was used to estimate the UCS of material between placement and 7 days. The breaking strength of prepared cylinders, ASTM D2166, was used to estimate UCS between 7 days and 1 year after placement for materials from both test cells.

\subsubsection{Lessons Learned}

The case study demonstrated that laboratory simulations and results could be duplicated under field conditions, and provided valuable insight into by-product processing.

One of the first lessons learned was that the screw conveyors used to transfer material from the storage units to the feed hoppers were not properly adjusted for the fine particle size of the by-product material. Apparently, the speed at which the conveyors turned was too slow to effectively transfer the material up the casing. We increased the conveyor speed and solved this particular problem.

Another problem with material delivery was noticed in the feed hopper and chain feed system interface of the Zim Mixer.

Apparently, arching or rat-holing was occurring within feed hoppers (possibly due to improper hopper geometry or sidewall slope). This inhibited continuous flow to the feed chain. The problem was partially resolved by periodically agitating the material within the feed hoppers via an internal rotating agitation 


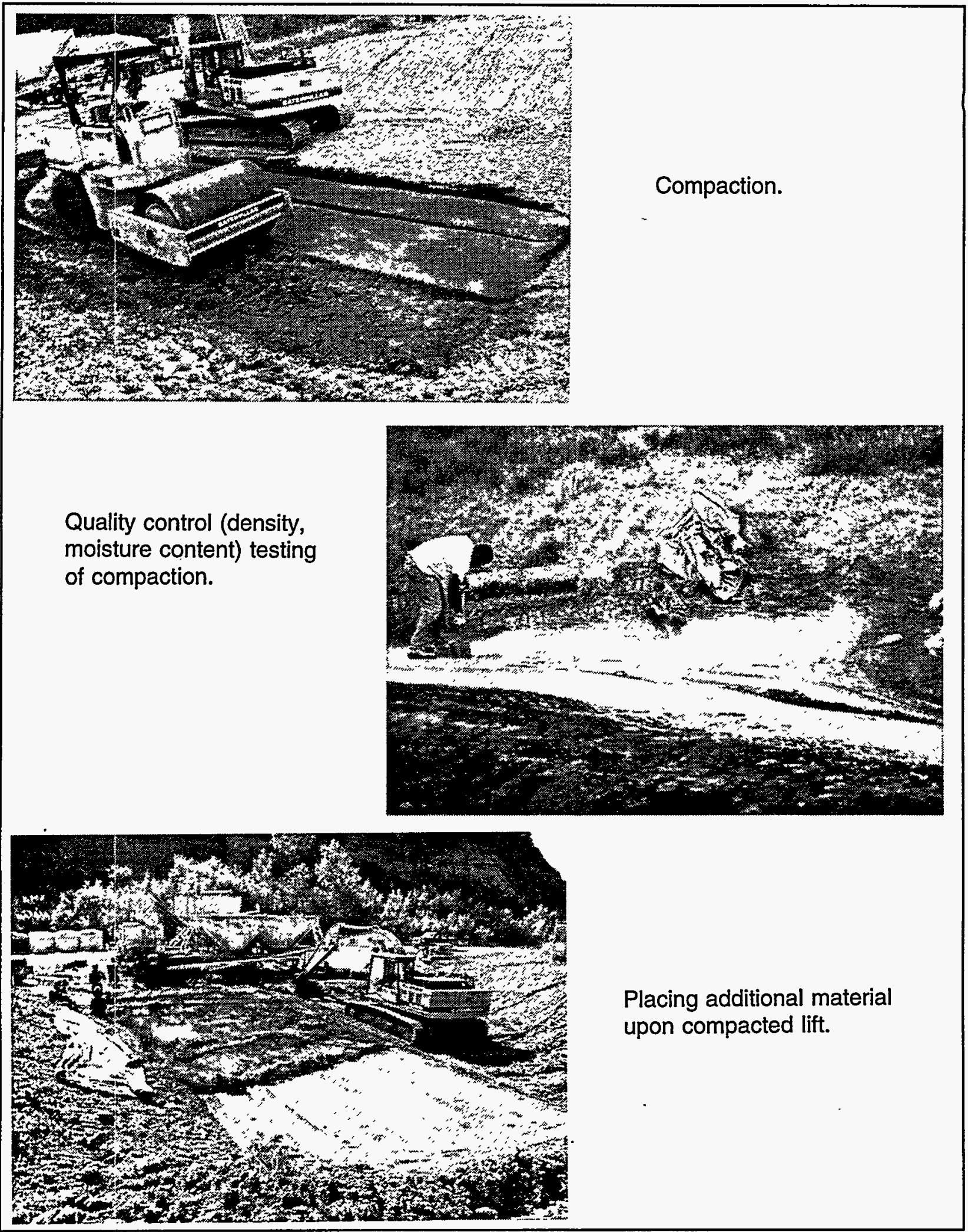

Figure 56. Construction Procedures for Case Study 
arm, by vibrators mounted on the exterior of the hoppers, and by manually stirring the material with a long metal rod. Proper hopper geometry should be researched and implemented in order to avoid this type of problem.

During material transfer from the pneumatic trailer to the storage units, it became apparent that the dust suppression system (water scrubber) was inadequate. For materials with a high dusting potential, a baghouse filter should be used, similar to that used in conjunction with dry cement transfer operations.

While processing operations were in progress, the feed hoppers had to be resupplied periodically via the screw conveyors. This was accomplished by manually starting and stopping the electric drive units on each of the conveyors. However, if the conveyors were left running after the feed hoppers had been filled, the conveyor casing would backfill and clog. To prevent this from occurring, feed hoppers should be equipped with a level switch to shut off the conveyor once the hopper is full.

The auger mixer/blender worked well; both types of by-product materials were effectively mixed and hydrated. For larger scale operations, the feed system should be modified, but the general configuration could remain the same. However, a more efficient method of placing the processed material into the disposal cell area would be required for full-scale operation.

\subsection{Citations}

1. Electric Power Research Institute. EPRI CS-2801. FGD By-Product Disposal Manual, Third Edition. Palo Alto, California, 1983.
2. Electric Power Research Institute. EPRI CS-6053. Atmospheric Fluidized-Bed Combustion Waste Management Design Guidelines. Palo Alto, California, 1988.

3. U.S. Department of Agriculture, Ag. Res. Service. Control of Water Pollution from Cropland. ARS-H-5-1 and ARS-H-5-2. Washington, D.C., 1976.

4. Ibid.

5. Donnelly, J.R., E.S. Tons, and W. C. Webster, "Synthetic Gravel from Dry Flue Gas Desulfurization EndProducts." In: The Challenge of Change: Proceedings of the Sixth International Ash Utilization Symposium, pp. 187-207, Reno, Nevada, March 7-10, 1982. DOE/METC-82-52.

6. Electric Power Research Institute. EPRI CS-1765. Recovery, Utilization, and Disposal of Solid Byproducts

Generated by Dry Flue Gas Desulfurization Systems: State of the Art and Research Needs. Palo Alto, California, 1981.

7. Bland, A.E., R. Cox, A. Rowen, E.R. Lichty, and R.A. Schumann, "Pelletization as an Ash Management Option for CFBC Ash Handling and Utilization." In: Proceedings of the 1993 International Conference on Fluidized Bed Combustion, pp. 13411350, San Diego, California. May 9-13, 1993. 


\section{Management Alternatives}

This chapter presents five management alternatives that were derived from a review of current state practices and industrial solid waste regulations (see Chapter 1 ). These five alternatives can be divided into two broad categories: land disposal and beneficial use and reuse.

\section{Land Disposal:}

\section{- $\quad$ Alternative 1-Traditional Landfill Containment Systems; \\ - $\quad$ Alternative 2-Reduced Requirement Landfill Designs; \\ - Alternative 3-By-Product Stacking Disposal Methods;}

\section{Beneficial Use and Reuse:}

- Alternative 4-Mine Reclamation and Backfill Uses; and

\section{- Alternative 5-By-Product Reuse} Options.

The main function of this chapter is to provide industry officials, regulatory agencies, and other interested parties with a common understanding of by-product management methods and also to provide general guidance in the development of these alternatives (with emphasis on land disposal options and mine reclamation/backfill uses). Figure 57 summarizes the general design requirements and considerations for the first four alternatives discussed in this chapter. For the fifth alternative, several reuse options are listed and the results of a case study are presented illustrating a potential market for advanced coal technology by-products.
For the land disposal alternatives, the main regulatory focus is upon the protection of groundwater. Therefore, the control and minimization of leachate production is a critical element in the design of these facilities. Because of these factors and due to the fact that most by-product material is currently managed in a dry state (although hydration of the material occurs at the disposal site), the majority of disposal alternatives discussed in this chapter will be restricted to dry state type (in contrast to wet disposal in impoundments). Alternative 3, on the other hand, encompasses wet disposal methods traditionally associated with gypsum stacks, and is presented to provide the reader with a broad range of disposal alternatives.

The general methodology for the disposal of by-product material (as presented in this manual) is based on hydrating the dry material (which typically contains significant quantities of unspent sorbent, such as quicklime), then placing this hydrated by-product material in the disposal facility. As the hydration reaction goes to completion, cementing of the material occurs due to the formation of gypsum, calcite, and ettringite. As shown in the construction and monitoring of the test fills constructed during the course of this project, this construction procedure generally results in a cemented material which produces a leachate that contains a low level of regulated contaminants (see Chapter 9). The information obtained from these test fills was also used in the development of Alternatives 1 through 3.

Alternatives 1 through 4 employ this hydration process prior to the by-products being placed into the landfill, stack, or mine. However, subtle differences exist between the alternatives. The difference between Alternatives 1 (Figure 58) and 2 (Figure 59) is 


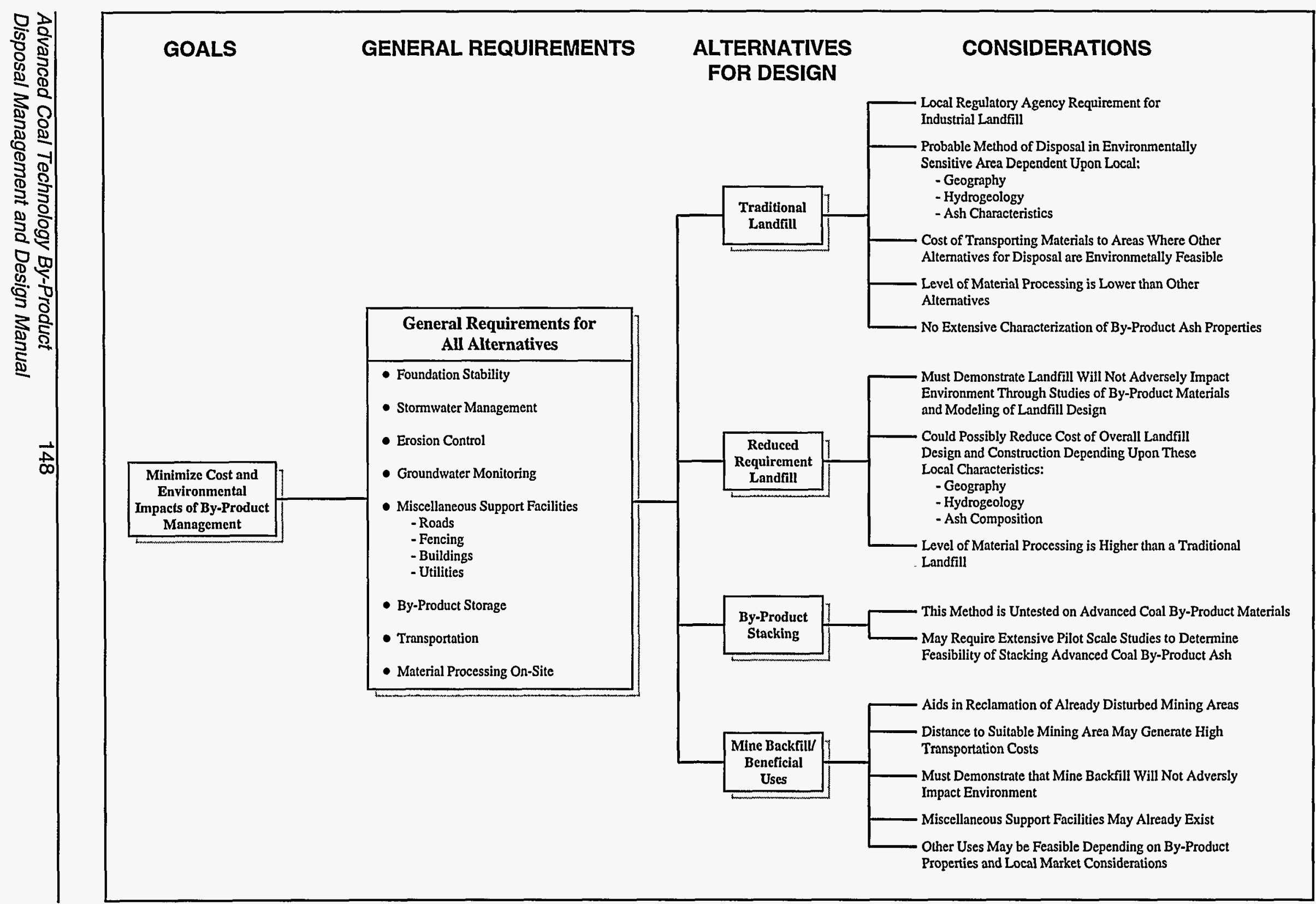

Figure 57. Summary of General Design Requirements for the Five Alternatives 


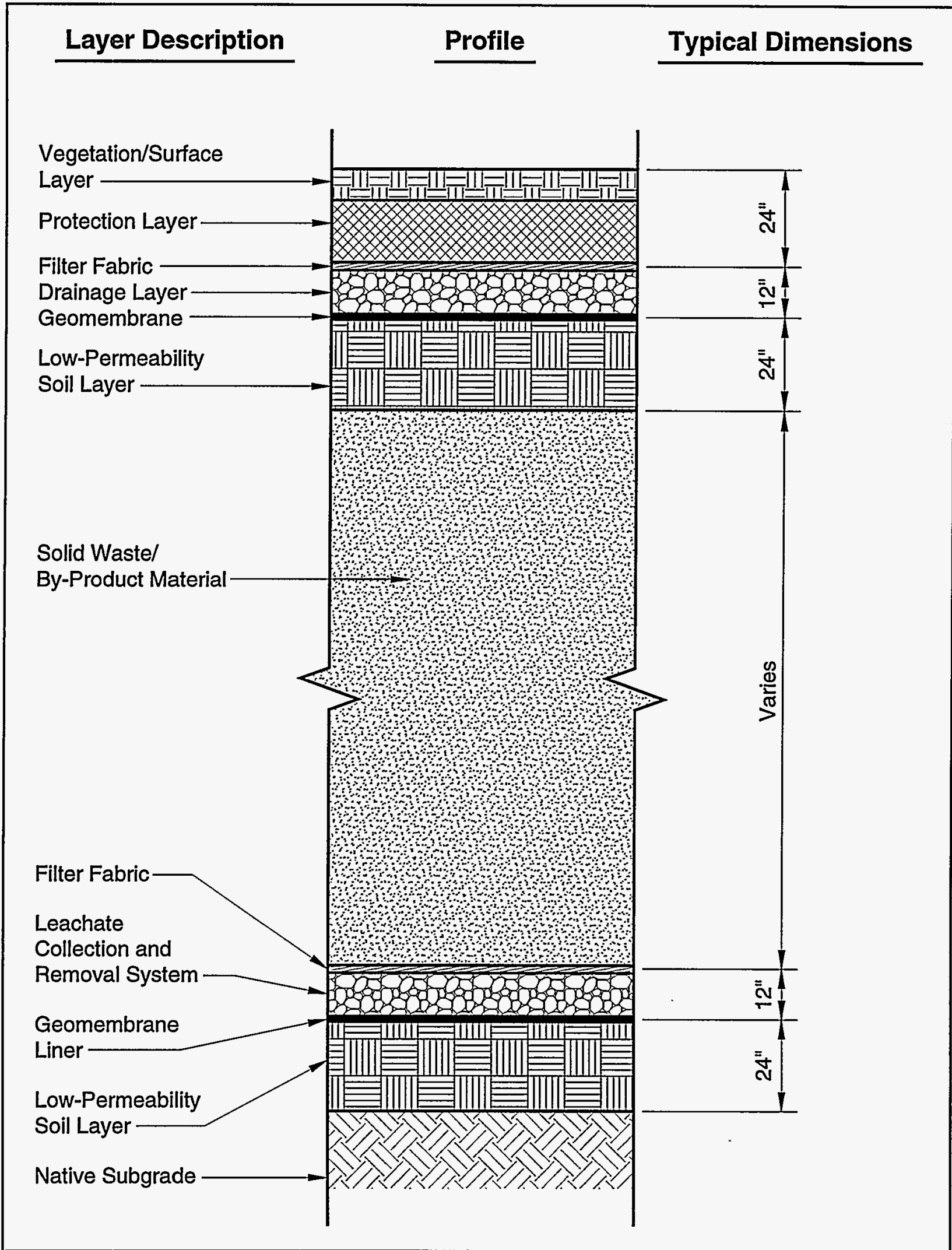

Figure 58. Typical Industrial Landfill Containment System 


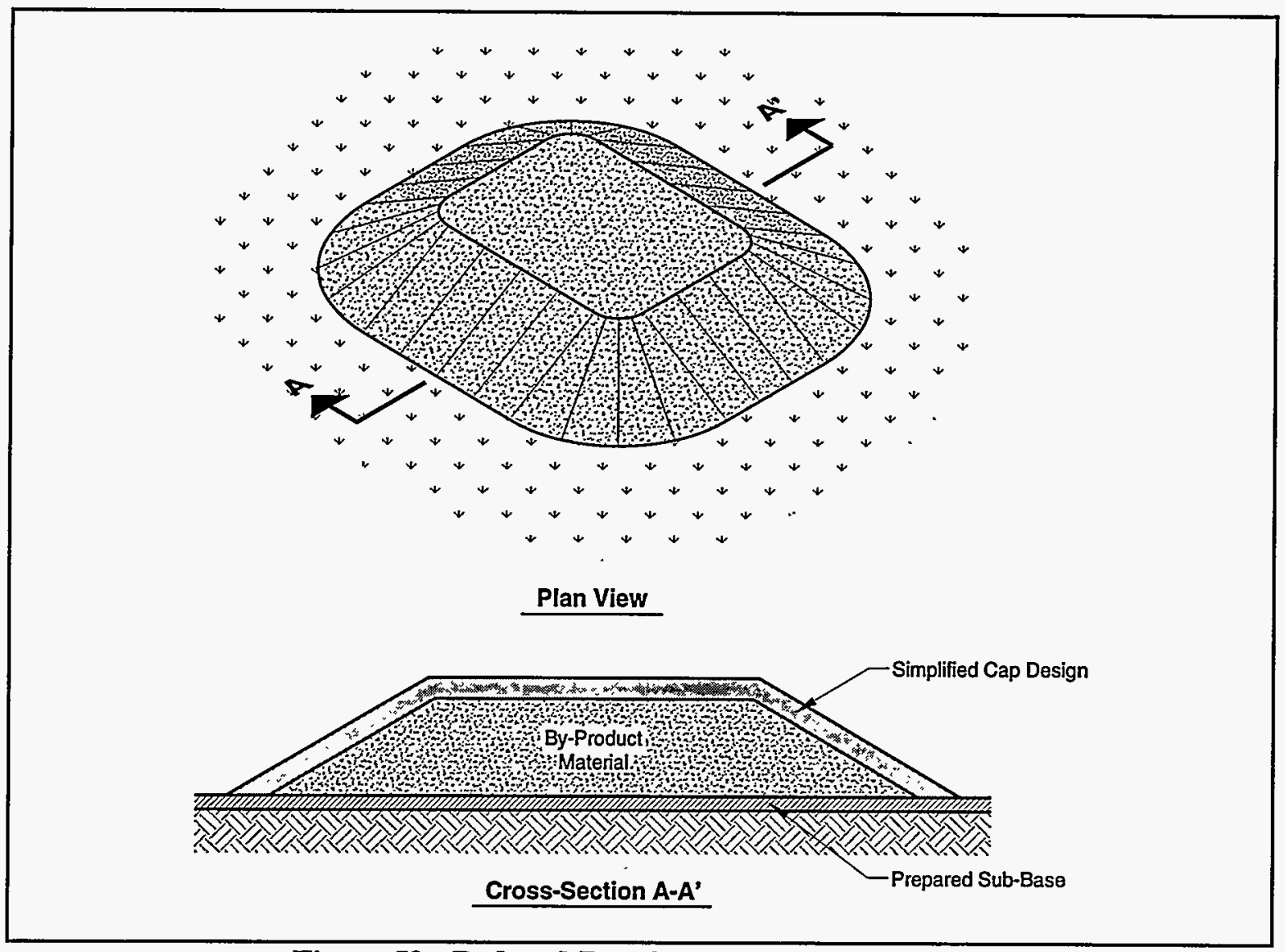

Figure 59. Reduced Requirements Landfill Design

the varying degrees of protection required by the governing regulatory agency. Some state agencies may force a facility to include all the standard containment system design elements required in their industrial solid waste regulations (Alternative 1). However, other state agencies may offer exemptions or variances from some of the more costly design elements (liners, groundwater monitoring requirements, etc.) if facilities can demonstrate that their particular design will not adversely impact the environment (Alternative 2) or will meet regulatory performance standards. Alternative 4 has developed as a result of exemptions most states offer to by-product material handlers that can show that the material is being beneficially reused (mine reclamation, mine backfill, and treatment of acid mine drainage). In fact, some states exempt most beneficial reuses of by-product material from the permitting process altogether.
However, it should be noted that this alternative is very similar to the first two alternatives insofar as material handling, mixing, and material properties are concerned. These alternatives are discussed in detail in the following sections. Design elements that are common to most of these alternatives (such as landfill configuration, surface water controls, groundwater monitoring systems, and processing equipment) are discussed in Chapter 6.

An alternative to disposal is reuse of the by-products (Alternative 5) as construction materials or possibly soil amendments for agricultural applications. A case study for one such reuse option, the manufacture of masonry block, has been conducted. The results suggest that certain by-product materials can attain sufficient strength for use in structural applications. This case study is presented in Section 7.5. 


\subsection{Alternative 1-Traditional Landfill Containment Systems}

Alternative 1 is presented to give the reader an idea of the type of requirements most state regulatory agencies specify for industrial solid waste landfills. As noted in Chapter 4 (Regulatory Requirements), most states classify by-products from advanced coal processes as industrial solid waste. However, most state regulatory agencies have developed industrial solid waste regulations to cover a broad range of solid waste materials which typically are more likely to have a negative impact on the environment than by-products from advanced coal technology processes. Therefore, the type of containment systems specified for this alternative are more complex than has typically been considered for coal combustion products in the past. However, there is a general trend toward more stringent regulations and more complex containment systems (such as those presented in this alternative) for coal combustion by-products, and this trend is expected to continue.

An example of the containment system typically required at an industrial solid waste landfill is shown in Figure 58. This is a general figure derived from reviewing regulations from several states (it should be noted that proposed designs may vary greatly from state to state). Each layer of the containment system shown in Figure 58 will be discussed in the following section. Subsequent subsections will discuss the level of by-product processing required before disposal, site development, and the economics of Alternative 1 .

\subsubsection{Containment System Design}

Landfill containment systems, like the example containment system shown in Figure 60 , are designed to meet the following three criteria:

- Minimize infiltration of stormwater;
- Collect and remove leachate produced by the landfill; and

- Prevent leachate from migrating offsite.

A description of each layer of this example containment system is presented in Figure 60. As noted earlier, requirements for industrial solid waste landfill containment systems vary from state to state. However, the major elements (e.g. cover soil, barrier layers, and leachate collection systems) are typically included.by all states. The major containment system elements are further discussed below.

\section{Cover Soil}

The two basic layers of the cover soil are the surface layer and the protective layer. The surface layer is typically composed of topsoil or a layer of soil that can sustain vegetation. However, in some arid areas, a cobble surface layer may be more appropriate if vegetation cannot be established. The advantages and disadvantages of each surface layer type are listed in Figures 61 and 62.

The protective layer is generally composed of on-site soils or locally obtained general fill. The main functions of this layer are listed below:

- Store water that has infiltrated into the cover until the water is later removed by evapotranspiration;

- Minimize the possibility of human intrusion into the landfill;

- Protect the underlying layers in the cover system from excessive wetting/drying (which may cause cracking); and

- Protect underlying layers in the cover system from freezing (which could also cause cracking). 


\begin{tabular}{|c|c|c|c|c|c|}
\hline \multirow{8}{*}{$\begin{array}{l}\overline{\overline{0}} \\
\overline{0} \\
\overline{\$} \\
\overline{8}\end{array}$} & Profile & Layer & Primary Function(s) & Usual Materials & General Considerations \\
\hline & $=11=11=$ & $\begin{array}{l}\text { 1. Surface } \\
\text { Layer }\end{array}$ & $\begin{array}{l}\text { Promote Vegetative Growth } \\
\text { (Most Covers); Promote } \\
\text { Evapotranspiration; } \\
\text { Prevent Erosion }\end{array}$ & $\begin{array}{l}\text { Topsoil (Humid Site); } \\
\text { Cobbles (Arid Site); } \\
\text { Geosynthetic Erosion } \\
\text { Control Systems }\end{array}$ & $\begin{array}{l}\text { Surface Layer for Control of Water } \\
\text { and/or Wind Erosion is Always } \\
\text { Required }\end{array}$ \\
\hline & 更 & $\begin{array}{l}\text { 2. Protection } \\
\text { Layer }\end{array}$ & $\begin{array}{l}\text { Store Water; Protect } \\
\text { Underlying Layers from } \\
\text { Intrusion by Plants, } \\
\text { Animals, and Humans; } \\
\text { Protect Barrier Layer from } \\
\text { Desiccation and Freeze/ } \\
\text { Thaw; Maintain Stability }\end{array}$ & Mixed Soils; Cobbles & $\begin{array}{l}\text { Some Form of Protective Layer is } \\
\text { Always Required; Surface Layer } \\
\text { and Protective Layer May Be } \\
\text { Combined Into a Single "Cover } \\
\text { Soil" Layer }\end{array}$ \\
\hline & 300 in & $\begin{array}{l}\text { 3. Drainage } \\
\text { Layer }\end{array}$ & $\begin{array}{l}\text { Drain Away Infiltrating } \\
\text { Water to Minimize } \\
\text { Barrier Layer Contact } \\
\text { and To Dissipate } \\
\text { Seepage Forces }\end{array}$ & $\begin{array}{l}\text { Sands; Gravels; } \\
\text { Geotextiles; Geonets; } \\
\text { Geocomposites }\end{array}$ & $\begin{array}{l}\text { Drainage Layer is Optional; } \\
\text { Necessary Only Where Excessive } \\
\text { Water Passes Through Protection } \\
\text { Layer or Seepage Forces are } \\
\text { Excessive }\end{array}$ \\
\hline & 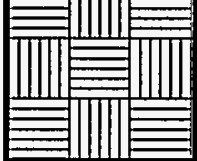 & $\begin{array}{l}\text { 4. Barrier } \\
\text { Layer }\end{array}$ & $\begin{array}{l}\text { Minimize Infiltration of } \\
\text { Water Into Waste }\end{array}$ & $\begin{array}{l}\text { Compacted Clay Liners; } \\
\text { Geomembranes; } \\
\text { Geosynthetic Clay } \\
\text { Liners }\end{array}$ & $\begin{array}{l}\text { Barrier Layer is Usually Required; } \\
\text { May Not Be Needed at Extremely } \\
\text { Arid Sites }\end{array}$ \\
\hline & किसा & $\begin{array}{l}\text { 5. By-Product } \\
\text { Material }\end{array}$ & & & $\begin{array}{l}\text { By-Product Material Should Provide } \\
\text { Enough Strenth to Support Cover } \\
\text { Layers and Ensure Stability of an } \\
\text { Above Ground Fill }\end{array}$ \\
\hline & 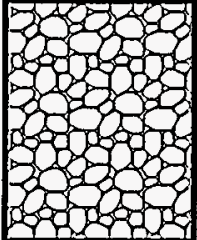 & $\begin{array}{l}\text { 6. Leachate } \\
\text { Collection } \\
\text { and Removal } \\
\text { System }\end{array}$ & $\begin{array}{l}\text { Collect and Remove } \\
\text { Leachate Produced } \\
\text { from Landfill }\end{array}$ & $\begin{array}{l}\text { Sands; Gravels; } \\
\text { Geotextiles; Geonets; } \\
\text { Geocomposites. } \\
\text { Perforated Pipe to } \\
\text { Drain Leachate to } \\
\text { Sumps is Also Needed }\end{array}$ & $\begin{array}{l}\text { Some Form of Leachate Collection } \\
\text { System is Usually Required; May } \\
\text { Not Be Needed at Arid Sites }\end{array}$ \\
\hline & 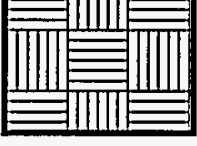 & $\begin{array}{l}\text { 7. Barrier } \\
\text { Layer }\end{array}$ & $\begin{array}{l}\text { Prevent Leachate from } \\
\text { Migrating Off-Site }\end{array}$ & $\begin{array}{l}\text { Compacted Clay Liners; } \\
\text { Geomembranes; } \\
\text { Geosynthetic Clay } \\
\text { Liners }\end{array}$ & $\begin{array}{l}\text { Materials and Thickness of } \\
\text { Barrier Layers is Usually } \\
\text { Speciffed by State Regulatory } \\
\text { Agencles }\end{array}$ \\
\hline
\end{tabular}

Figure 60. Containment Layer Description 


\section{Topsoil Overlying Protective Soil}

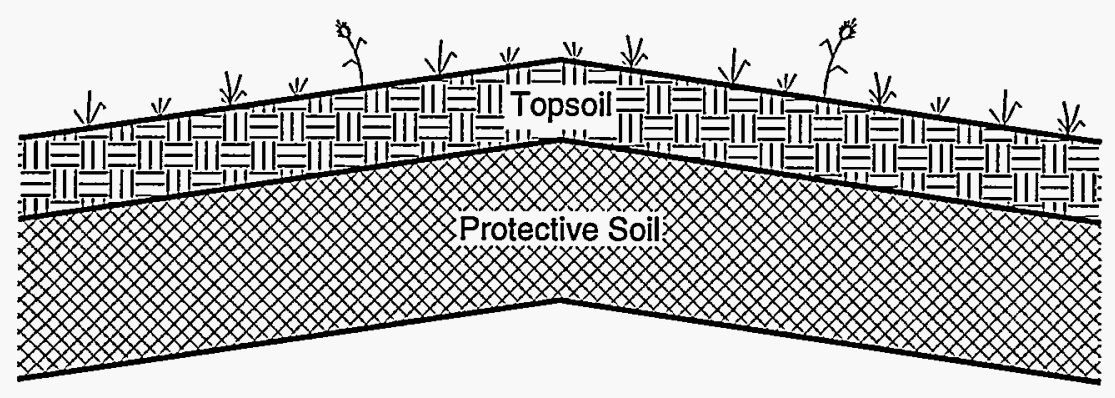

\section{ADVANTAGES}

1. Construction materials are usually available locally.

2. Topsoil and protective soil layer store water that has infiltrated; plants return much of this water to the atmosphere via evapotranspiration.

3. Plants not only retum water to the atmosphere but also reduce soil erosion and stabilize the topsoil.

4. Thickness of protective soil layer can be adjusted as necessary (e.g., to prevent underlying barrier layer from freezing) without affecting the thickness of topsoil.

5. Plant roots tend to be confined to nutrient-rich topsoil.

\section{DISADVANTAGES}

1. Requires adequate precipitation to support growth of vegetation on topsoil (design unsuitable for some arid sites).

2. Irrigation could be required during periods of drought to maintain vegetative cover.

3. Establishing growth of vegetation may be difficult if weather conditions are unfavorable immediately after seeding.

4. Excessive wind or water erosion may occur prior to establishment of vegetative cover or if vegetative cover becomes thin.

5. Little resistance to intrusion by burrowing animals.

\section{ASSESSMENT:}

This is the most common soil cover design used in cover systems and is the minimum required cover soil design established by many regulatory agencies. The main problems experienced with this design are maintaining a vegetative growth during drought periods and formation of erosion gullies in the top soil during excessive precipitation periods. This design can be very effective at sites that receive adequate rainfall but generally requires maintenance.

\section{Figure 61. Cover Layer Assessment}




\section{Cobbles Over Protective Soil}

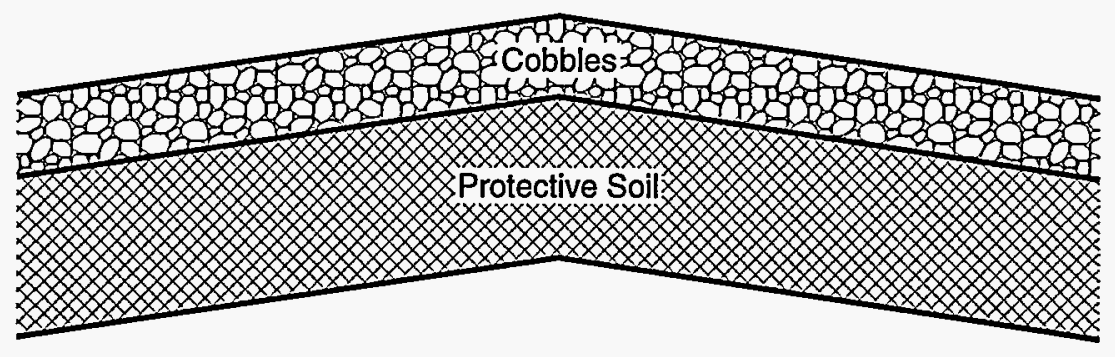

\section{ADVANTAGES}

1. No need to establish or maintain vegetative growth (particularly advantagous for arid sites or sites subject to periodic long droughts).

2. Cobbles provide protection from wind or water erosion; effectiveness of cobbles not dependent upon maintenance of vegetative growth.

3. Cobbles may minimize penetration from burrowing animals if rocks are of adequate size.

4. Cobbles minimize growth of plants with deep roots that could penetrate underlying barrier layers.

\section{DISADVANTAGES}

1. Cobbles must be adequately large to resist washout; materials may not be readily available locally.

2. Minimal evaporation of water from underlying soil (cobbles allow water to percolate downward but insulate soil from surface evaporation).

3. Wind-blown materials may fill voids between cobbles; deeply-rooted plant growth may eventually become established and require maintenance.

4. Stability concerns for steep slopes.

\section{ASSESSMENT:}

This design is usually considered only for arid sites. Provided problems with burrowing animals and lack of water evaporation from protective soil layer are not too serious, this design may be the most appropriate one for arid sites.

Figure 62. Arid Area Cover Layer Assessment 


\section{Barrier Layers}

The barrier layers in a containment system are often considered the most critical component of the cover and liner systems. Traditionally, both cover and liner barrier layers for hazardous waste facilities have consisted of compacted clay layers that were specified to achieve a permeability of $1 \times 10^{-7}$ $\mathrm{cm} / \mathrm{sec}$ during construction. However, for nonhazardous waste sites, $1 \times 10^{-6} \mathrm{~cm} / \mathrm{sec}$ clay has been more typically specified. More recent state regulations specify that composite cap and liner systems be utilized for industrial solid waste facilities. Composite cap systems typically consist of an 18 inch to 24 inch thick clay layer overlain by a geomembrane.

Concerns regarding the long-term performance of compacted clay liners has driven the move to composite systems. Some byproduct materials may cause substantial drying of the clay layer due to the hydration reactions in the by-products which take up any available moisture. Desiccation of the clay may produce shrinkage cracks. If a clay barrier layer is used, a drainage layer or cover soil may be required between the barrier layer and the byproduct material to prevent desiccation of the clay. Even with a composite liner system, the heat of hydration emanating from a lime-rich by-product material could drive moisture out of the clay barrier layer if the material has not been pre-conditioned with water during construction and/or if subsequent wetting occurs. Therefore careful consideration should be given to the spatial orientation of a composite liner system.

A comparison of compacted clay and geomembrane liners is presented in Table 29. Most state regulatory agencies provide minimum specifications for barrier layer materials, thicknesses, permeability, and density as well as quality assurance and quality control procedures for liner construction.

\begin{tabular}{l} 
Table 29 \\
Compacted Clay VS. \\
Geomembrane Liners \\
\begin{tabular}{|l|l|}
\hline \multicolumn{1}{|c|}{ Compacted Clay } & \multicolumn{1}{c|}{ Geomembrane } \\
\hline Predictable permeability & $\begin{array}{l}\text { Unpredictable leakage } \\
\text { rate }\end{array}$ \\
\hline Can attenuate leachate & $\begin{array}{l}\text { Minimal capacity for } \\
\text { attenuation }\end{array}$ \\
\hline Self healing & Not self healing \\
\hline $\begin{array}{l}\text { Desiccation may occur } \\
\text { especially if in contact } \\
\text { with by-product material }\end{array}$ & No desiccation \\
\hline $\begin{array}{l}\text { Vulnerable to } \\
\text { freeze/thaw damage }\end{array}$ & $\begin{array}{l}\text { Not vulnerable to } \\
\text { freeze/thaw damage }\end{array}$ \\
\hline Slow construction & $\begin{array}{l}\text { Rapid construction } \\
\text { (unroll, place, and } \\
\text { seal) }\end{array}$ \\
\hline $\begin{array}{l}\text { Susceptible to } \\
\text { differential settlement }\end{array}$ & $\begin{array}{l}\text { Can tolerate large } \\
\text { differential settlement }\end{array}$ \\
\hline Repairs are very difficult & $\begin{array}{l}\text { Easily repaired during } \\
\text { construction }\end{array}$ \\
\hline
\end{tabular} \\
\hline
\end{tabular}

\section{Leachate Collection Systems}

The purpose of the leachate collection system is to collect and remove leachate produced by the landfill. Leachate is usually defined as any liquid that passes through the solid waste in the landfill and contains soluble, suspended, or miscible materials that have been removed from the solid waste. A properly designed leachate collection system should consist of a highly permeable drainage layer (permeability of $1.0 \times 10^{-2} \mathrm{~cm} / \mathrm{sec}$ or greater) with a network of perforated collection pipes overlying a low-permeability barrier layer. The drainage layer and pipe network should be sloped to allow sufficient drainage, and designed to prevent sediment build-up and biological clogging of the collection system. Recommended slopes and pipe network spacing are shown in Figure 63 along with a 


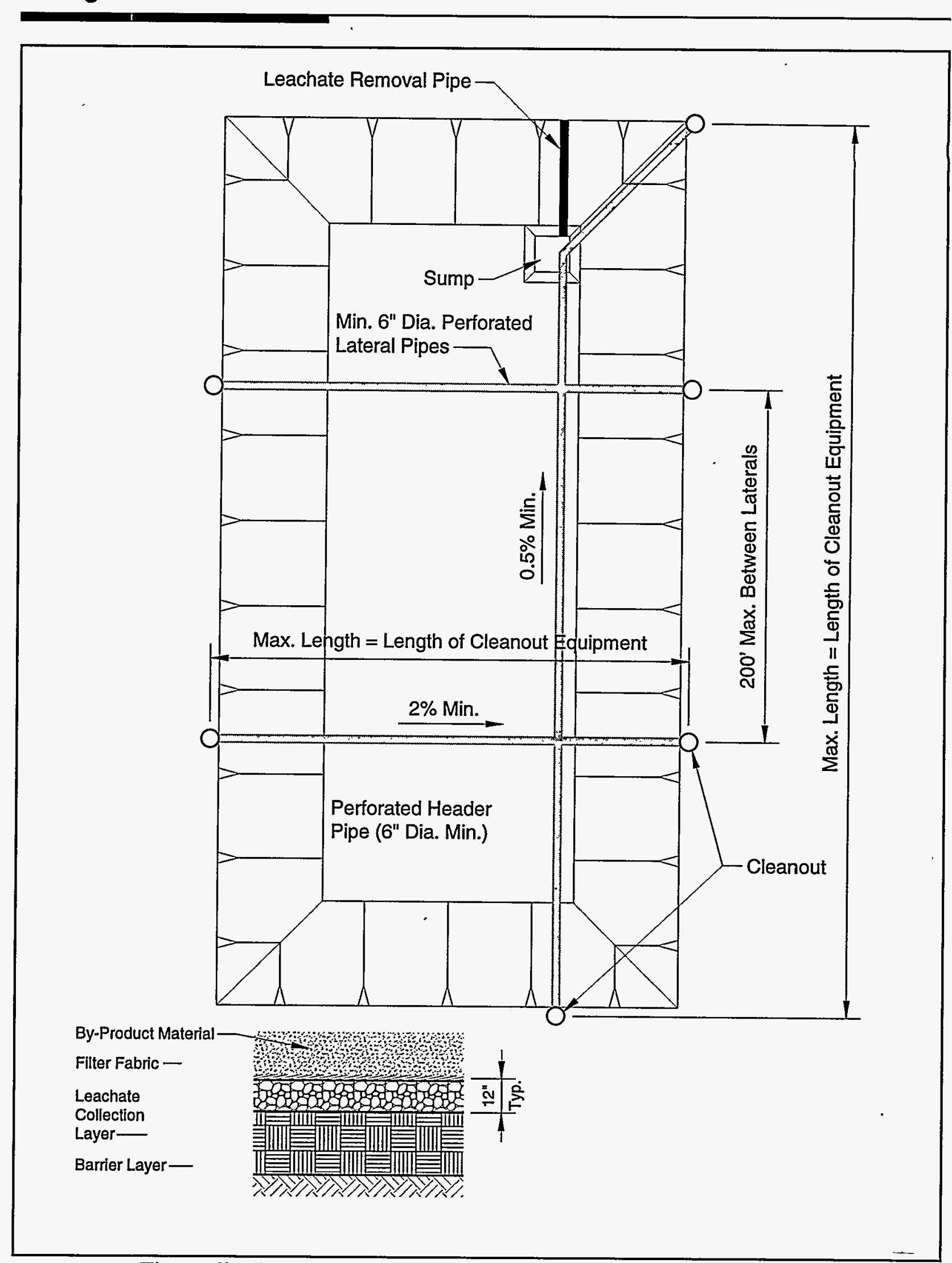

Figure 63. Leachate Collection System Plan View and Typical Section 
typical cross-section of a leachate collection layer. The filter fabric is needed to allow the passage of leachate and yet retain the finegrained materials that may be present in the by-product or protective cover. Additional criteria associated with materials used in the leachate collection system include the following:

- Materials should be chemically resistant to the leachate;

- Materials should possess sufficient strength and thickness to prevent collapse under the pressures exerted by overlying by-product material and any equipment used at the site; and

- The leachate collection system should be designed to function through the life of the site and post-closure period without extensive maintenance.

- Limestone aggregate should be avoided in leachate collection systems for landfills containing sulfate-rich byproduct materials because of potential reaction with leachate.

As with the barrier layers, most state agencies list specific criteria for leachate collection systems in their applicable regulations.

\subsubsection{Level of By-Product Processing Required Before Disposal}

One advantage of the traditional containment system, as included in Alternative 1 , is that the by-product material does not need much processing before disposal because of the protection offered by the complex containment system. Other alternatives that depend on the properties of the by-product material to ensure the protection of the environment do not have this luxury.
For Alternative 1, the material could either be disposed of dry or in a slurry form. The only criterion here is that if the landfill will be constructed above grade, the by-product material will need to have sufficient strength to ensure the stability of the fill and to support the cap system. A secondary concern is the amount of dust created by the ash and the associated health concerns if the material is disposed of dry. Both of these concerns could be overcome by some level of processing or hydration of the by-product material before or after disposal in the landfill. This could be accomplished by the methods discussed in Section 6.3 or by adding moisture to the dry material with a water truck as it is placed in the landfill.

\subsubsection{Economic Analysis of Alternative 1}

The overall design, construction, and operating costs for an Alternative 1 landfill can be broken out according to costs for each of the following tasks:

- Site selection;

- Public relations;

- Permitting;

- By-product material characterization;

- Design;

- Construction;

- Facility operation;

- By-product ash transportation; and

- By-product ash processing.

Costs associated with site selection, public relations and permitting can vary between $\$ 100,000$ and $\$ 800,000$ depending upon the level of public acceptance, regulatory requirements, and time required to approve a 
site (which can take from 4 to 6 years from site selection to permit approval for a traditional landfill system). However, by choosing to build a traditional landfill containment system, the financial burden of these tasks may be reduced because of the proven protection that this type of landfill offers to the environment.

By-product material characterization includes stability and leachate testing. The leachate testing effort for a traditional landfill is minimal compared to other alternatives because of the extensive engineering controls provided by the Alternative 1 containment system. The cost of characterization, as well as other preliminary engineering costs, is associated with permitting and site selection.

Design, construction, and facility operation costs depend on the volume and stability of the by-product material after processing, and on the degree of processing which may be necessary. Once the characteristics of the by-product that will enter the landfill have been established, design parameters can be molded to minimize the cost of construction and operation, while maintaining protection of the environment. Initial construction costs include leachate collection and treatment facilities, monitoring wells, and surface water runoff collection. These costs range from $\$ 750,000$ to $\$ 1,000,000$, depending on the size of the landfill. Cell construction will vary between $\$ 200,000$ and $\$ 300,000$ per acre.

By-product transportation and processing are also dependant upon the characteristics of the ash. The utilization of a traditional landfill containment system instead of the other alternatives will, however, require less processing of the fill material because of the protective qualities of the landfill design. Transportation and processing equipment and costs are discussed in greater detail in Chapter 6.
Although Alternative 1 is more expensive in terms of initial construction than the other alternatives, overall cost savings might be realized. If it is necessary to place the landfill in a location where extensive testing and public hearings are anticipated for permitting, building such a traditional landfill containment system may be more economically feasible than other types of disposal alternatives. This is possible because of the potential reductions in the costs of site selection, permitting, by-product characterization, and material processing associated with the standard landfill design.

\subsection{Alternative 2-Reduced Requirement Landfill Designs}

Alternative 2 is derived from the first alternative; the difference is that the properties of the processed by-product material are used advantageously to reduce the extent of the containment system required for Alternative 1, while still providing a similar level of protection to the environment. The case studies in Chapter 9 were developed to demonstrate the viability of this alternative. The results from the test cells, composed of by-product material with a varying degree of processing, generally demonstrate the adequacy of a limited containment system.

Earlier work completed for this project has shown (in laboratory and field situations) that processed fluidized bed combustion (FBC) and limestone injection multistage burners (LIMB) by-product materials possess physical properties such as low permeability (ranging from $1 \times 10^{-5}$ to $1 \times 10^{-8} \mathrm{~cm} / \mathrm{sec}$ ); high strength (500 to $1500 \mathrm{psi}$ ); and low contaminant concentrations in the leachate potentially suitable for a reduced requirement landfill design. Most state regulatory agencies allow an applicant to demonstrate that a proposed design will provide equivalent protection to the environment when compared to the state's standard design requirements. If such a demonstration is accepted, considerable disposal cost reductions may be realized. 
In this section, typical reduced requirement disposal alternatives are discussed; the suitability of each alternative will depend on the characteristics of the by-product to be disposed. Obviously, the number of alternatives that could fall under this category are endless and depend greatly upon site-specific criteria such as area geology, depth to groundwater, climate, etc. However, the containment systems shown in Figure 64 are typical of reduced requirement landfill designs. The methods used to demonstrate the adequacy of a selected design are presented in Chapter 8. This section presents information on typical reduced requirement landfill configurations, the level of by-product processing required before disposal, the use of by-product material as a barrier layer, and the economic impacts of the alternative.

\subsubsection{Reduced Requirement Containment Systems}

The reduced requirement containment systems described in this section take advantage of the self-cementing and/or pozzolanic properties of many advanced coal technology by-products which may be suitable for barrier layer construction, serving as a supplement to either the liner or the cover. These cementitious properties have been demonstrated for FBC by-products from several sources, and may be generally applicable to coal combustion by-products containing significant amounts of lime. However, the performance of individual by-products and the suitability of by-products from other types of advanced coal technologies for barrier layer construction must be evaluated on an individual basis.

The primary objectives of any containment system are to protect and preserve both surface water and groundwater quality. Surface water controls have been discussed in detail in Section 6.1.2, so the discussion in this section will concentrate on the protection of groundwater. To protect groundwater, a landfill containment system should be designed to adequately minimize, collect and contain leachate from a landfill. A containment system for this alternative can be divided into the following three basic components:

\section{- Soil cover; \\ - Processed by-product; and \\ - Liner system.}

The level of by-product processing can be the most critical variable affecting a proposed design. The level of processing is defined as the amount of effort needed to handle, mix or blend, hydrate, and place byproduct material in the disposal facility. As noted in Figure 64, previously presented, there are two levels of effort discussed in the processing of by-product material.

Processed by-products used for liner and cover barrier layers are referred to as processed by-product and fly ash material. Processed FBC and fly ash mixtures have been shown in laboratory and field-scale tests to have physical properties (e.g., low permeability and high strength) that may meet the performance requirements of a standard barrier layer. However, the long-term performance of such mixtures has not been adequately documented. Examples of mixes and testing programs to demonstrate the adequacy of this type of material for use as a barrier layer are further discussed in Section 7.2.2 and in Chapter 8.

Minimally processed by-product material is defined, for the purposes of this report, as a material that has undergone some processing (i.e., hydration, mixing, and possible compaction); however, the material has not been processed to the degree described above. Minimally processed by-product material generally makes up the majority of the body of the landfill. In this case, no special requirements would be specified for the material except that it possess adequate strength to support the cap material and also that it remain stable. In most 


\section{Management Alternatives}

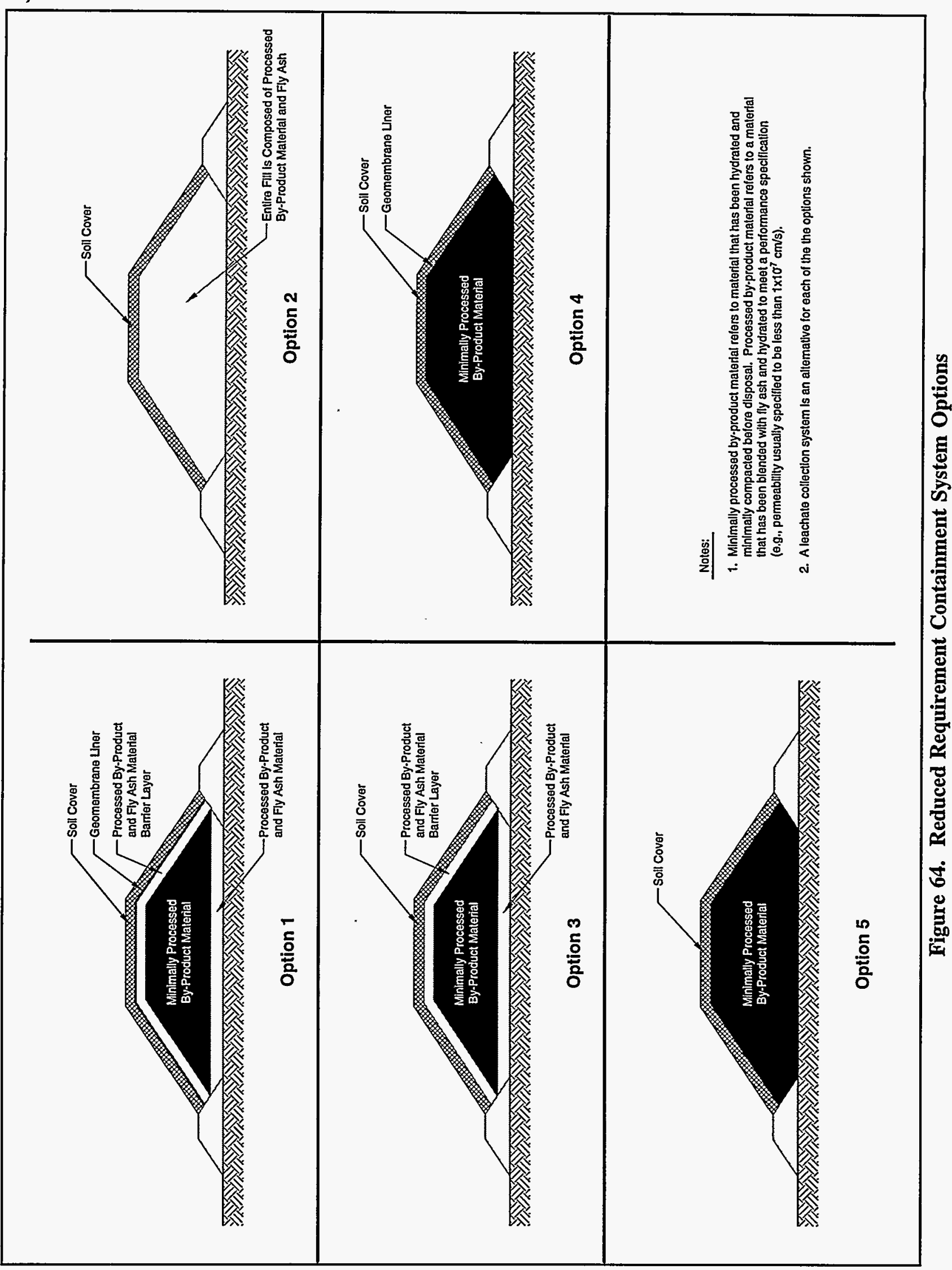


cases this minimal processing will simply mean adding the minimum amount of water required to control dusting to the dry material and placing it in the landfill.

Minimally processed by-product may serve a secondary function during landfill construction by absorbing rainfall incident on the landfill. Precipitation may be taken up by continuing hydration reactions, minimizing the amount of leachate which is generated.

The containment system options, shown in Figure 64, are generally arranged from the system that provides the most protection (Option 1) to the option that provides the least amount of protection (Option 5). However, each of these options may be applicable in certain situations. For example, Option 5 may be applicable for some arid (less than 25 inches of annual precipitation) areas of the country because of the minimal threat of leachate production. Option 1 may be better suited to areas that receive a substantial amount of precipitation. Options 1 and 3 are similar to the more standard containment system designs presented in Alternative 1. The main difference between these specific alternatives is that processed by-product material is used for a barrier layer in Options 1 and 3 instead of the compacted clay layers used in Alternative 1. Options 1 and 4 rely on a flexible membrane liner as part of the cap to minimize leachate production. Option 2 calls for a high level of material processing for the entire body of by-product, as well as a soil cover, to minimize leachate production. One common component of each of these alternatives is that a vegetated soil cover is provided to ensure surface water quality, protect the waste material from erosion, and minimize infiltration by promoting evapotranspiration.

As noted earlier, the design of an adequate containment system depends greatly upon site-specific criteria such as the local geology, depth to groundwater, and climate. Design procedures will be discussed in more detail in Chapter 8.

\subsubsection{Use of By-Product Material as a Barrier Layer}

As discussed in the previous section, several of the reduced requirement options presented as part of Alternative 2 involve the use of by-product material as a barrier layer. Information gathered from this project and other research projects indicates that certain types of advanced coal technology by-product material may be suitable for use as barriers if processed correctly. The information in this section is also intended to give the reader a general understanding of what may be required to demonstrate the performance of a landfill barrier layer composed of by-product material. For example, the construction of a test pad may be required by some state regulatory agencies to demonstrate the effectiveness of a by-product barrier layer. A test pad should be designed to demonstrate the construction techniques that will be used to build a barrier layer. Subsequent monitoring demonstrates its performance as a barrier layer. The monitoring program mainly consists of permeability testing; however, other properties of the material may also be tested, including the strength and leaching potential of the byproduct material.

Two test pads were constructed during this project (as previously described in Section 6.4) to investigate potential mix designs, barrier layer quality assurance testing, and construction techniques. An overview of the information gathered during the construction and monitoring of the test pads is presented in this section. More detailed information can be found in Chapter 9.

\section{Pre-Construction Laboratory Testing Program}

The objective of the two Illinois test pads (or cells) was to produce a material possessing a permeability of no greater than 1 $x 10^{-7} \mathrm{~cm} / \mathrm{sec}$. This is the permeability value typically used by regulatory agencies to define a barrier layer. However, a barrier layer may 
perform its design function even with a higher permeability as shown in the discussion of performance based design procedures in Chapter 8 . The types of by-product material used to construct the test pad were material from a bubbling fluidized bed combustion (BFBC) process and a Class $F$ pulverized coal fly ash (PFA). It was determined during the testing program that samples that were composed of a 1 to 1 ratio (measured by weight) of BFBC and PFA consistently had the highest strength and lowest permeability results of the mixes tested.

In order to demonstrate two different barrier layer construction techniques, a mix design that produced a flowable or pumpable material (similar to grout) was chosen for one test pad and a mix that could be compacted in lifts similar to standard clay liner construction practices was used for the other test pad. The following two mix designs were selected:

- Soil-Like Mix-30\% total moisture content (19.7\% optimum free moisture content) added by weight to a $1: 1$ mixture (by weight) of dry BFBC and PFA.

- Flowable Mix-42\% total moisture content added by weight to a $1: 1$ mixture (by weight) of dry BFBC and PFA.

A standard Proctor curve (ASTM D698) of the 1:1 mixture of BFBC and PFA is shown in Figure 65. As noted in the figure, the moisture content is given as free moisture, not total moisture (i.e., does not account for. chemically bonded water). During this preconstruction laboratory study it was determined that the difference between the "free" moisture content and the "total" moisture content was between 10 and $12 \%$ (i.e., approximately 10 to $12 \%$ of the moisture added to the ash was chemically bonded within the mixed material). Further discussion of the procedures used to determine the moisture content of this material is provided in the materials testing subsection.

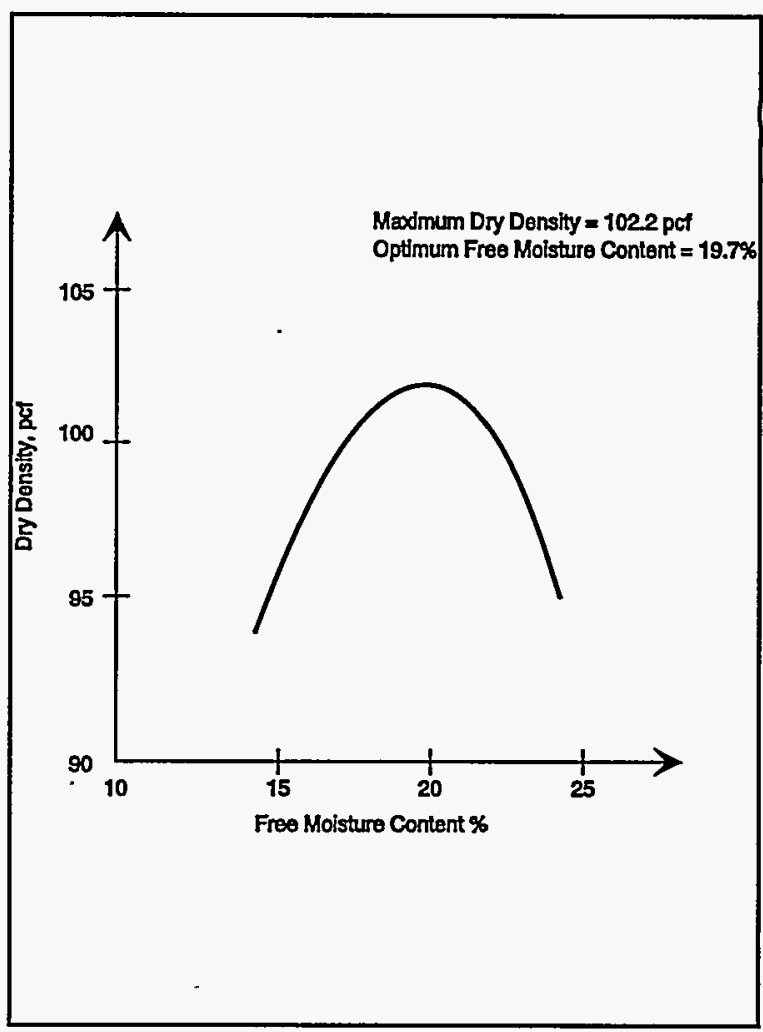

Figure 65. Standard Proctor Curve Developed During Pre-Construction Study

A graph showing unconfined compressive strength gain for the two mix designs over a 28-day period is shown in Figure 66. As shown, the strength of the soillike mix is considerably higher after 28 days than the flowable mix. Unconfined compression tests were performed on samples of the soil-like mix material that were molded (ASTM D698) in cylinders (3-inch diameter, 6inch height) using freshly mixed material. This soil-like material achieved an average 28 day strength of $1350 \mathrm{psi}$ (values ranged from 1,150 to $>1,550$ ). The flowable mix was prepared in similar cylinders; however, these samples were not compacted. The 28-day strength of this material was approximately 400 psi. Permeability tests (ASTM D5084) were also performed on representative samples from the two mixes. The permeability of the two mixes was very similar: $2.5 \times 10^{-8} \mathrm{~cm} / \mathrm{sec}$ for 


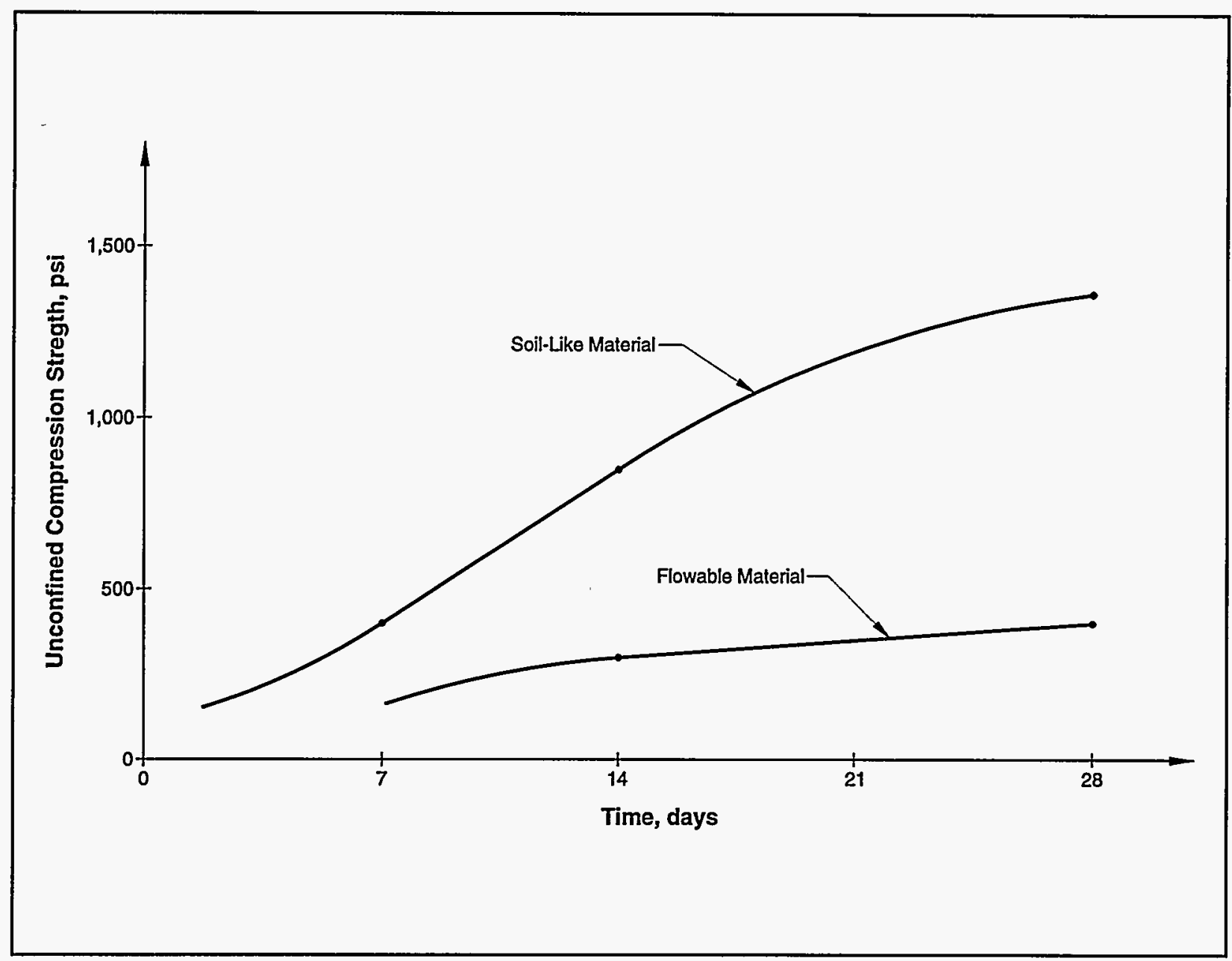

Figure 66. Strength Gain During Pre-Construction Study

the soil-like mix, and $1.2 \times 10^{-9} \mathrm{~cm} / \mathrm{sec}$ for the flowable mix.

\section{Construction Methods}

The construction equipment used to transport, handle, and process the material for the two mix described is detailed in Section 6.4. As detailed in that section, a screw mixer/conveyer was used to process (mix and hydrate) both ash materials. Approximately 50 to 60 tons/day of material was processed. The processed material was transferred to a conveyor which transported the by-product material to the two test pads.

The first test pad (Cell 2) was composed of a material that was substantially more fluid than the material used for the first cell. For this pad, the ash material was processed so that the total moisture content was $42 \%$ as opposed to $30 \%$ used in the first test pad. In this case the processed material was transferred into a backhoe bucket and then poured into the test pad area. No compactive effort was used on this test pad. The test pads achieved sufficient cohesive strength to maintain stability within approximately 30 minutes of placement of the hydrated material.

The second test pad (Cell 3) was constructed using techniques that are similar to the construction of a soil or clay barrier layer. The ash material was processed so that the free moisture content of the mixed material was close to the optimum moisture content (19.7 
percent). After the material was discharged to the pad location, the material was distributed in 6- to 8-inch thick lifts over the pad area (70 feet by 30 feet). Each lift was then compacted by a vibrating smooth drum roller.

\section{Materials Testing Program. During Construction}

The objective of the materials testing program during the test pad construction was to assure compliance with the design specifications established by the pre-construction testing program. This testing also helped to establish baseline physical and chemical properties that will be used to assess the long-term performance of the two test pads. The following subsections provide a discussion of the test methods used to quantify the physical properties of the by-product material during construction. For additional information, refer to Section 9.2.3.

\section{Standard Proctor (ASTM}

D698)—The Standard Proctor test was performed for the first test pad (soil-like mix) to determine compaction density and its relationship to moisture content, and also to monitor the as-placed compaction density in relation to the pre-construction study (refer back to Figure 65). The average optimum free moisture content for the as-placed material was $22.1 \%$, the average maximum dry density was 88.1 pcf (the most reliable values are $22.6 \%$ and $90.7 \mathrm{pcf}$ ). Both the as-placed and preconstruction Proctor tests were performed using a modified oven-dry method to obtain the moisture content. The oven temperature was reduced from $105^{\circ} \mathrm{C}$ to $50^{\circ} \mathrm{C}$ to ensure that the chemically bonded water was not driven off as specified in the ASTM method for materials containing gypsum $\left(\mathrm{CaSO}_{4} \cdot 2 \mathrm{H}_{2} \mathrm{O}\right)$. However, during one as-placed Proctor test, the moisture content was determined using ASTM D4944 (Speedy Moisture Test using calcium carbide). The Speedy test was also the method used in the field to determine moisture content (see next subsection) of the processed by-product material.
Moisture Content-The following three techniques were used to determine the moisture content of the processed by-product material:

\section{- $\quad$ Modified ASTM D2216-Oven-dry at $50^{\circ} \mathrm{C}$;}

- $\quad$ ASTM D4944-Speedy Moisture Kit; and

\section{- ASTM D2922-Nuclear Moisture-} Density Test.

Of the three techniques used, the speedy moisture kit provided the most consistent, reliable, and quickest results. The nuclear moisture-density test generally responds to both free and chemically bound water, and may require extensive, site-specific calibration to allow direct comparison with other types of moisture content measurements.

The general procedure for determining moisture content by means of a Speedy Kit or calcium carbide gas moisture tester is to place a certain weight of processed by-product material together with a certain amount of calcium carbide reagent into the apparatus and shake the tester vigorously with a rotating motion. The calcium carbide reacts with the free moisture within the ash. A simple dial reading is then made, which gives the percent moisture by wet weight of by-product, which can then be converted to percent moisture by dry weight of by-product. This procedure was used throughout the construction of both test pads. A few oven-dry tests were used to verify the Speedy tests during the construction of the first test pad. Generally, the results of the oven-dry tests were within $10 \%$ of the Speedy tests.

As stated earlier, approximately $30 \%$ of water (total moisture by weight) was added to the material placed in the first test pad (soillike mix). Generally, the free moisture content during compaction ranged from 19 to 25 percent. Optimum from the pre-construction 
Proctor was $19.7 \%, 22.1 \%$ from the as-placed. For the second test pad (flowable mix), $42 \%$ total moisture by weight was added to the dry ash material during mixing. After the flowable material had been placed in the cell and gained some strength (approximately 30 minutes) the moisture content had changed to approximately 28 to $29 \%$ free water as determined by the Speedy moisture kit. These results indicate that more complete hydration of the byproducts was achieved in the second mix, with 13 to $14 \%$ water bound by hydration, as opposed to 5 to $11 \%$ in the first mix.

Density (ASTM D2922)—The nuclear density method was used to determine the inplace wet density of the first test pad material after compaction. The wet density was converted to dry density using the Speedy moisture content. Generally, over $100 \%$ of the as-placed Standard Proctor compaction (90.7 pcf) was achieved on the material in this test pad (soil-like mix). This was mainly due to the large/heavy compaction equipment used. Dry densities after compaction ranged from 90.2 pcf to 104.2 pcf.

\section{Unconfined Compressive Strength} (ASTM D2166)-Samples of the mix types were taken during construction of both test pads and tested for unconfined compressive strength (UCS) after 7, 14, and 28 days; at 4 months; and at 8 to 10 months (Table 7-2). UCS tests were performed on cylinders formed (ASTM D698) in molds (3" diameter, 6" height) using processed material as it was placed. When compared to the preconstruction study, the as-placed material had similar early strengths and further increases in strength over time. For the soil-like material, the 28 day UCS was between 1120 and 1620 psi. For the flowable material (which was not compacted within the molds), 28 day UCS was between 760 and 790 psi.

During construction, strengths of the by-product mixes were measured using a pocket penetrometer immediately after placement in the test pad. The compacted soil- like material yielded strengths of 14 to 35 psi. Pocket penetrometer tests performed on the flowable material, approximately $\mathbf{3 0}$ minutes after placement, indicated strengths of less than $7 \mathrm{psi}$. However, the material did not slough when a vertical cut was made through the placed material. The strength approximately 24 hours after placement ranged from 20 psi to 35 psi.

Core samples from the two mix test pads were also tested for strength and permeability. These results indicate that the field performance of the compacted soil-like mix was generally similar to that predicted by the pre-construction study of the cylinders prepared from the as-placed mixture but cured in a controlled environment. Four months after placement, core samples of the compacted soillike mix had an average strength of $1980 \mathrm{psi}$ and an average permeability of $2.2 \times 10^{-7}$ $\mathrm{cm} / \mathrm{sec}$. The core samples from the flowable mix test cell indicate that this mixture has experienced rapid weathering in the field environment. The laboratory-cured cylinders indicate potential strengths of over $3000 \mathrm{psi}$, and a permeability of $2.0 \times 10^{-7} \mathrm{~cm} / \mathrm{sec}$; in contrast the field cores averaged only $400 \mathrm{psi}$ strength and a permeability of $8.2 \times 10^{-3}$ $\mathrm{cm} / \mathrm{sec}$, as shown in Table 30 .

Permeability (ASTM D5084)—The results of the permeability tests for both mix types are listed in Table 30, which includes both pre-construction and field test data. The cylinders for the permeability tests were prepared generally according to the methods described above for the UCS tests.

\subsubsection{Economic Analysis of Alternative 2}

The cost considerations for a reduced requirement landfill similar to those for Alternative 1 can be broken out according to the following categories:

- Site selection; 
Table 30

Strength and Permeability Results for Both Mix Types

\begin{tabular}{||l|c|c|c|c||}
\hline \multirow{2}{*}{\multicolumn{1}{|c|}{ Test }} & \multicolumn{2}{c|}{ Strength (psi) } & \multicolumn{2}{c||}{ Permeability (cm/sec) } \\
\cline { 2 - 5 } & Soil-Like & Flowable & Soil-Like & Flowable \\
\hline $\begin{array}{l}\text { Preconstruction Cylinders, } \\
\text { 28 days }\end{array}$ & $1150->1550$ & 400 & $2.5 \times 10^{-8}$ & $1.2 \times 10^{-9}$ \\
\hline $\begin{array}{l}\text { Field Molded Cylinders, } \\
\text { 28 days }\end{array}$ & $1120-1620$ & $760-790$ & $5.16 \times 10^{-7}$ & $2.67 \times 10^{-7}$ \\
\hline $\begin{array}{l}\text { Field Molded Cylinders, } \\
\text { 4 months }\end{array}$ & 1564 & 1163 & Not analyzed & Not analyzed \\
\hline $\begin{array}{l}\text { Field Molded Cylinders, } \\
\text { 8-10 months }\end{array}$ & 5000 & 3257 & $1.5 \times 10^{-6}$ & $2.0 \times 10^{-7}$ \\
\hline $\begin{array}{l}\text { Field Core Samples, range at } \\
4 \text { months (average) }\end{array}$ & $935-2389$ & $156-1114$ & $4.4 \times 10^{-8}-$ & $2.5 \times 10^{-7}-$ \\
& $(1890)$ & $(400)$ & $\begin{array}{c}4.6 \times 10^{-7} \\
\left(2.2 \times 10^{-7}\right)\end{array}$ & $\begin{array}{c}2.5 \times 10^{-2} \\
\left(8.2 \times 10^{-3}\right)\end{array}$ \\
\hline
\end{tabular}

- Public relations;

- Permitting;

- $\quad$ By-product material characterization;

- Design;

- Construction;

- Facility operation;

- By-product transportation; and

- By-product processing.

Depending upon the geology, hydrogeology, and local political climate of the proposed site, the costs associated with the first four factors listed above can vary greatly. Because this alternative does not have an extensive performance record, as do the traditional landfill containment systems, public opposition and regulatory scrutiny may be greater. Since the processed by-product material is used as a barrier to infiltrating precipitation, extensive characterization of the material's properties may be required. This will be necessary to demonstrate to local regulatory agencies and the community that leachate and runoff from the proposed landfill will not adversely affect the surrounding environment. It is also possible that more research will be required in the design phase since this technology is not as widely accepted. Costs associated with these four tasks could range between $\$ 300,000$ and $\$ 1,000,000$.

Design, construction, and operation of the reduced requirement landfill may be 15 to $25 \%$ less expensive than the traditional landfill because of the reduction in liners and the absence of a leachate collection system. For a traditional landfill these costs are estimated to be between $\$ 750,000$ and $\$ 1,000,000$ for startup, and another $\$ 200,000$ per acre. Transportation costs are dependent upon the distance between the landfill and the generating plant. Transportation options are discussed in detail in Section 6.2.2. The processing of the 
ash will be extensive for the reduced permeability cap and liner, but those costs should generally be less than for synthetic or clay liners. The actual fill material may also have to undergo more processing for a reduced requirement landfill since the design may require it to be of a specified permeability. Processing options are discussed in detail in Section 6.3.

If the local geology and hydrology support it, and the regulators and surrounding community are receptive to an innovative design, a reduced requirement landfill can be the least expensive method of disposal. On the other hand, the costs of design, testing and permitting delays may make this type of landfill more expensive than any of the other three alternatives presented in this section, if significant regulatory or community opposition develops.

\subsection{Alternative 3-By-Product Stacking Disposal Methods}

As opposed to the previous alternatives, Alternative 3 discusses a wet disposal technique. In this case, wet is defined as mixing enough water with the by-product material to create a flowable slurry containing approximately 10 to $15 \%$ solids. In some instances, wet disposal can simplify material handling practices. In place of conditioning and processing components and equipment (such as vehicle loading facilities, transport vehicles, and bulldozers, graders, and rollers for material placement), material handling can be accomplished with a slurry pump, a pipeline to the stacking area, and a dragline. It should be noted that wet disposal techniques were not a focus of the field portion of this project; however, this alternative is presented to familiarize the reader with a broad range of disposal alternatives.

The stacking disposal method refers to a method of disposal traditionally associated with waste gypsum produced by the phosphate fertilizer industry. The following subsections present an overview of the gypsum stacking disposal technique developed from information contained within the FGD By-Product Disposal Manual $^{1}$. By-product stacks offer several advantages over simple impoundments.

Because stacks are typically constructed aboveground, stream diversions and run-on water management problems often associated with impoundments are avoided. Stacks are also easier to site, since no natural depressions or excavations are required. Stacks may also provide more efficient use of available land since they can be built up to a uniform height. Finally, stacks typically generate less leachate than impoundments since surface water and precipitation tend to infiltrate less on their raised surface.

Gypsum stacks similar to that described here are in use for FGD by-product management at several utility sites including the advanced Chiyoda Thoroughbred-121 FGD system funded in part through the Department of Energy Clean Coal Technology program at Georgia Power Company's Plant Yates.

\subsubsection{Stack Design}

The most economical stacking method is the upstream method of construction. In this method, shown in Figure 67, an earthen starter dike is first constructed to form a sedimentation pond and stacking area over a lined excavation covering the planned area of the stack. By-product is then pumped to the sedimentation pond in slurry form, usually at 15 to $20 \%$ solids, and allowed to settle and drain. Process water is decanted and returned to the plant. Once sufficient sediments buildup within the pond, the material is excavated with a dragline to raise the perimeter dikes of the stack. The process of sedimentation, excavation, and raising of the perimeter dikes continues on a regular basis during the active life of the stack.

The experience gained from the operation and performance of phosphate gypsum and FGD sludge stacks can be used in 


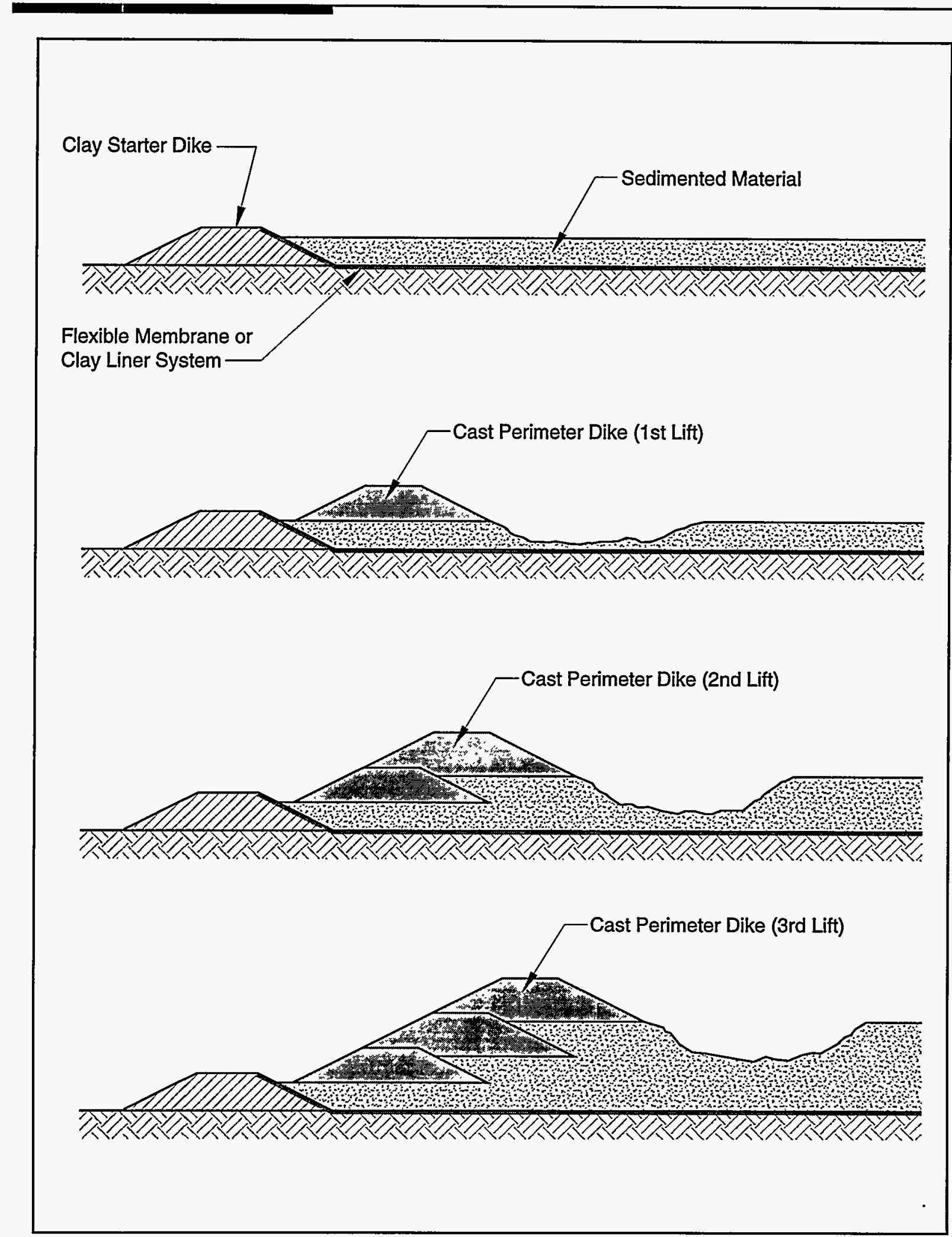

Figure 67. Upstream Stack Construction Method

Source: Electric Power Research Institute. EPRI CS-2801. FGD By-Product Disposal Manual, Third Edition. 
planning other by-product material stack disposal operations. An illustration of a typical stack design is shown in Figure 68. The specific features included in this stack are discussed below.

In plan, the stack is usually a square or a rectangle with a two to one length to width ratio. Ideally, a circular shape would give the minimum length of perimeter dike enclosing a given area. If a divider dike is included to separate the stack into two ponds the difference in length of dike between a square and circular stack is only 7 percent. Some type of liner system will generally be required to control off-site migration of leachate from the stacks or pond.

The area of the gypsum stack should be selected to allow raising the perimeter dikes approximately 5 to 8 feet per year. For a typical central Florida phosphate fertilizer plant where the production rate of gypsum is 2,700 to 5,500 tons per day, gypsum stacks have been proportioned for 11 to 170 tons per day per acre.

The gypsum stack is normally divided into at least two ponds. This allows one pond to drain while the other pond is in use. The dragline can then excavate gypsum from the drained pond to raise the perimeter dike. The divider dike typically runs parallel to one side of the stack and divides the stack into ponds of approximately equal size.

The process water surge pond is built around the perimeter of the stack. The exterior dike forming the surge pond has sufficient freeboard to contain water stored on top of the stack in the event of accidental spillage. The surge capacity of the pond is typically designed to contain 1.5 times a 25-year, 24-hour storm on the watershed of the pond with no storage on the stack. Freeboard clearance above the maximum fluid level in the pond can vary from 3 to 5 feet and is normally governed by state and local regulations.
A clay starter dike is shown in the illustration and is preferred if suitable clay material is available. Sand dikes are commonly used in Florida, but must be protected against piping, erosion, and seepage. Stacks used for disposal of coal combustion by-products will generally include a liner system which will provide this protection. The starter dike should be constructed to a crest width of 20 feet to allow easy operation of construction equipment and should not be covered with gypsum when the stack is raised. The starter dike should be high enough to allow sufficient gypsum to sediment within the stacking area for excavation and raising of the first lift of the perimeter dike. A starter dike height of 8 feet, allowing sedimentation of 5 feet of gypsum and 3 feet of freeboard, is usually sufficient.

Fixed vertical riser decant structures are shown in the center of the stack near the divider dike. This allows finer material to settle at the center of the stack and coarser material around the perimeter of the stack. This is not an essential feature; however, it does eliminate the problems of trying to use soft, fine, and wet material in construction of the perimeter dikes.

Planning of a gypsum stack and process water return system is important in the engineering design. The process constraints and climatic constraints must be initially established. The process constraints may include an estimate of gypsum production, the planned life of the plant and stack, and in-flow and out-flow process water quantities and water temperatures. Climatic conditions must be considered because they influence the process constraints. Both heat balance and water balance analyses are influenced by climatic conditions. If the plant is located in climates where severely cold winters occur, the effects of freezing on the design of the gypsum stack and process water return system, as well as the effect on limiting the construction season, must be considered. 


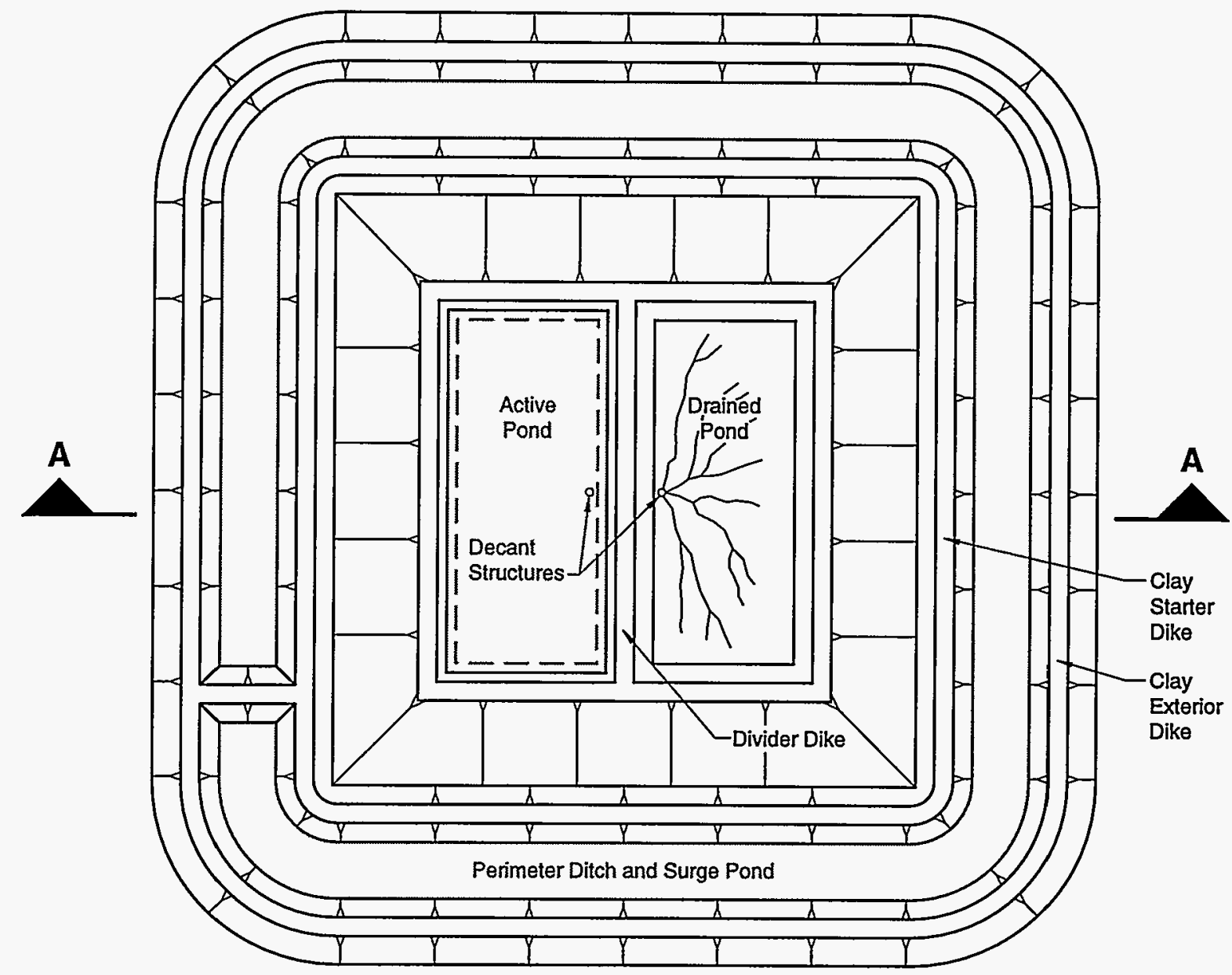

Site Plan

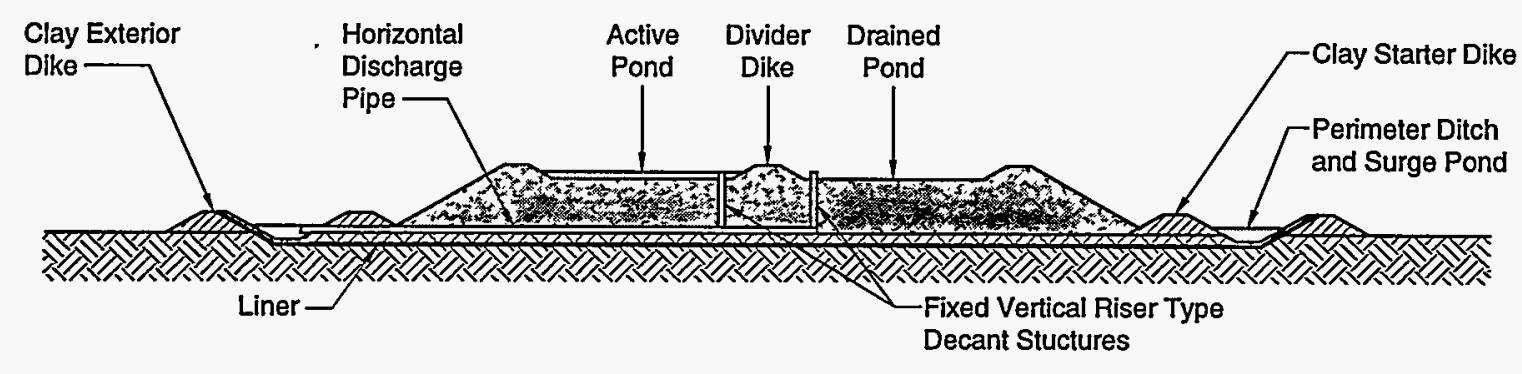

Cross-Section A - A

Figure 68. Typical Stack Design 
Once the process constraints and climatic constraints have been established, the size of the gypsum stack and process water return system can be estimated. The area required for the gypsum stack is related to the quantity of gypsum produced and design height of the stack. The height may be controlled by foundation conditions if a soft foundation underlies the stack. Otherwise, the height may be controlled by pumping considerations or even aesthetic considerations. Wind erosion and dusting may also become more severe as the stack height increases. Final cover and closure procedures for a by-product stack are similar to those discussed for landfills under Alternatives 1 and 2.

\subsubsection{Stack Operation}

The two most important considerations in the operation of a stack are the retention of fine-grained material within the stack and the characteristics of the material deposited around the periphery of the stack. If sufficient detention time is not provided within the ponded area on top of the stack, complete clarification will not occur and the finer particles will discharge through the spillway and sediment within the surge pond. This problem has occurred at several phosphate gypsum stacks and required the dredging of fine-grained gypsum from the surge pond.

Although finer-grained material can often be cast to raise the perimeter dikes, the lower permeability of fine materials does not allow drainage to occur as quickly as with coarser-grained material. Consequently, it is more difficult and time-consuming to use the finer material to raise the stack. For this reason, it is desirable to deposit the coarser material around the perimeter of the stack.

It is possible to operate a stack so that the coarser material is always deposited around the perimeter of the stack while simultaneously providing sufficient retention time for the finer particles to settle within the interior of the stack. This is accomplished by using an elevated ditch to carry the material around the perimeter of the stack and to create a ponded area within the interior of the stack.

The disposed-of material is generally cast to raise the perimeter dikes using a dragline. The cast material is then shaped to form a road on the crest of the dike using a bulldozer. In some cases, a bulldozer has been used to both raise and shape the perimeter dikes. In both cases, it is desirable to allow the elevated ditch to drain prior to raising the stack, although it is often possible, using the dragline, to raise the stack without draining the disposal area.

\subsection{Alternative 4-Mine Reclamation and Backfill Uses}

Options for by-product management considered beneficial include mine reclamation, backfill, and (to a lesser degree) acid mine drainage treatment. For issues affecting the implementation of these options, refer to Table 31. Mine reclamation and backfill applications are very similar to the options presented as part of Alternative 2; however, they can be considered beneficial uses because the by-products perform useful functions. Alternative 4, which may be considered for both active or abandoned surface and underground mines, is appealing because byproducts are returned to their point of origin. In many cases, coal contracts are negotiated that stipulate a mine to accept back-hauled combustion by-products.

Currently, underground mine disposal is used to dispose of coal mining wastes and to reduce the effects of mine subsidence. However, underground disposal will require more specialized equipment, more intense coordination efforts, and will be more expensive than surface disposal. Since most facilities using advanced coal technologies use bituminous or subbituminous coal from surface mines, or are located in areas with nearby surface mines, active surface mines appear to be the most attractive alternative for mine 


\section{Table 31}

Mining Uses for Advanced Coal Technology By-Products

\begin{tabular}{|c|c|c|}
\hline Potential Use & Issues Affecting Implementation & Tests Required \\
\hline Mine Backfill & $\begin{array}{l}\text { Expansion of material could be advantageous. } \\
\text { By-product needs limited permeability and } \\
\text { leachability. } \\
\text { By-product needs good strength properties. } \\
\text { By-product may be emplaced dry or as a } \\
\text { slurry. }\end{array}$ & $\begin{array}{l}\text { Dimensional stability } \\
\text { Permeability and TCLP analysis } \\
\text { Unconfined compressive } \\
\text { strength } \\
\text { Water requirements (available } \\
\text { lime index, particle size, etc.) }\end{array}$ \\
\hline $\begin{array}{l}\text { Acid Mine } \\
\text { Drainage } \\
\text { Treatment }\end{array}$ & $\begin{array}{l}\text { Alkaline by-products may control acid-soluble } \\
\text { metals, may increase mobility of other metals. } \\
\text { - By-product may contribute metals. } \\
\text { - Multiple regulatory agencies may be involved. }\end{array}$ & $\begin{array}{l}\text { Available lime index and calci- } \\
\text { um carbonate equivalent. } \\
\text { Chemical and TCLP analysis }\end{array}$ \\
\hline $\begin{array}{l}\text { Mined Land } \\
\text { Reclamation }\end{array}$ & $\begin{array}{l}\text { AFBC, FSI, and other alkaline ashes can pro- } \\
\text { vide alkalinity to acidic soils. } \\
\text { - By-product may react with some clays to } \\
\text { develop hardpan. } \\
\text { - By-product may contribute to metals loading } \\
\text { in soils. } \\
\text { - Demand may be limited. }\end{array}$ & $\begin{array}{l}\text { Available lime index and calci- } \\
\text { um carbonate equivalent } \\
\text { Chemical and TCLP analysis }\end{array}$ \\
\hline
\end{tabular}

disposal of by-product material. Surface mine grounds have already been disturbed by overburden removal; therefore, disposing of wastes in the mine or with the overburden during mining or reclamation eliminates the need to disturb additional land.

Mine disposal operations have several environmental and economic advantages. Perhaps the greatest environmental advantage is that additional areas are not necessary for waste disposal. It combines the area disturbed by coal mining and waste disposal into one operation and reduces the total area affected by power plant operations and associated land acquisition costs. Because the two processes are combined at one location, the need for two sets of environmental control and support facilities is also eliminated. The same diversion and collection channels, sedimentation ponds and other facilities used to control surface water for the mine also will handle all surface water associated with disposal operations. The same rail routes and haul roads used to transport coal also can be used for waste transport. This eliminates the need to construct and maintain separate hauling facilities. In some situations (such as for mine-mouth generating facilities) the same trucks or rail cars used to transport coal from a mine to a power station may be used to transport wastes from the power station to the mine, thus reducing dead-heading costs and the need for a second fleet of dedicated waste disposal vehicles.

Mine disposal, however, is not without potential disadvantages. Trucks hauling wastes to the mine site may cause congestion and disruption of mine operations. If the mine site is located a long distance from the power plant and coal haulage vehicles cannot be used to transport wastes, the additional cost of waste haulage may increase the cost of mine disposal significantly above that of a closer, conventional landfill. Also, mine disposal may present challenging regulatory concerns, which will be briefly discussed at the end of Section 7.4.2. 


\subsubsection{Mining and By-Product Disposal Techniques}

The techniques used to dispose of byproduct material in old or active mine sites are very similar to the techniques used to place this material in a landfill. The main difference (other than regulatory issues) is that disposal activities will need to be incorporated into the overall mine operation and reclamation plan in order to minimize disruption of routine mine operations. The following two subsections present a description of two disposal techniques which might be used in surface mines.

\section{Area Surface Mining and Disposal}

Surface mining in the relatively flat terrain common to midwestern and western coal fields is known as area surface mining. A typical area surface mine disposal operation is illustrated by Figure 69 . In an area surface mining operation, long strip pit cuts are opened with a dragline or power shovel to remove overburden from the coal seam. The overburden is cast aside in long piles parallel to the strip pit in areas where coal has been previously extracted. The coal is then extracted from the strip pit and loaded into trucks which haul it to a power station, rail terminal, or other destination. This process is repeated as mining progresses through the coal field. In this type of surface mining operation, by-product can be disposed of either in the pit bottom, as shown in Figure 7-13, or in the veenotches of the spoil.

\section{Contour Surface Mining and Disposal}

Surface mining on steep slopes common to the Appalachian coal fields is known as contour mining because the strip cuts follow the contour lines of hillsides. In older mines the removed overburden was dumped downhill. Successive cuts were made into the hillside until overburden depths made it uneconomical to continue. The mine was then abandoned and no reclamation work was conducted. Because of the adverse environmental impacts created, contour mining techniques have changed. Newer methods include "haul back" or "block mining." In these methods the overburden is placed behind the active mine area and the area is returned approximately to its original contour. Cross sections showing the development of a typical contour surface mine and disposal operation are shown in Figure 70. Another recently developed method is "mountain top removal" in which the entire cap of overburden on a hill is removed and placed in the upper part of an adjacent valley. With these types of surface mining techniques waste can be intermixed with spoil material. Both mine spoil and wastes are hauled by trucks and intermixed as they are placed.

\subsubsection{Required Design Information}

Design of a mine disposal operation is similar to that for a conventional landfill in that it requires a thorough knowledge of waste quantities to be generated, waste material properties, the proposed mine plan, general site conditions, and regulatory requirements. These topics are discussed in the following subsection.

\section{Waste Quantities Generated}

By-product quantities to be generated must be estimated in order to determine how much by-product will have to be disposed of in the mine. The amount (volume) of by-product disposed of in a mine, in most cases, must not exceed the amount of coal removed. The purpose of surface mine reclamation is to return the mined terrain to its original contour or to topographic configurations similar to the original terrain. Returning large quantities of coal by-products to the mine could create problems given this reclamation constraint. Another factor to be considered when estimating quantities of backfill is that the expansion of overburden during removal and 


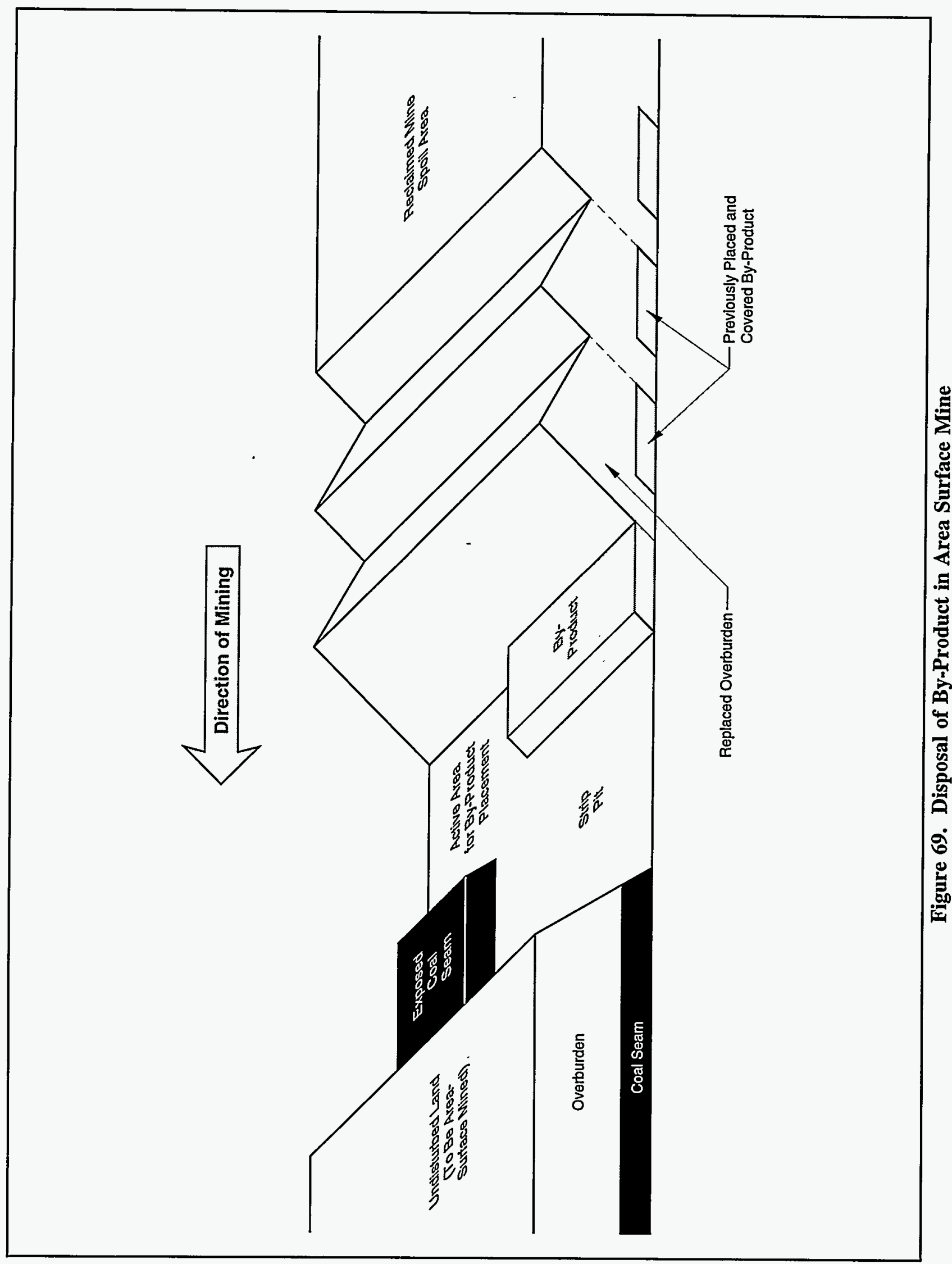




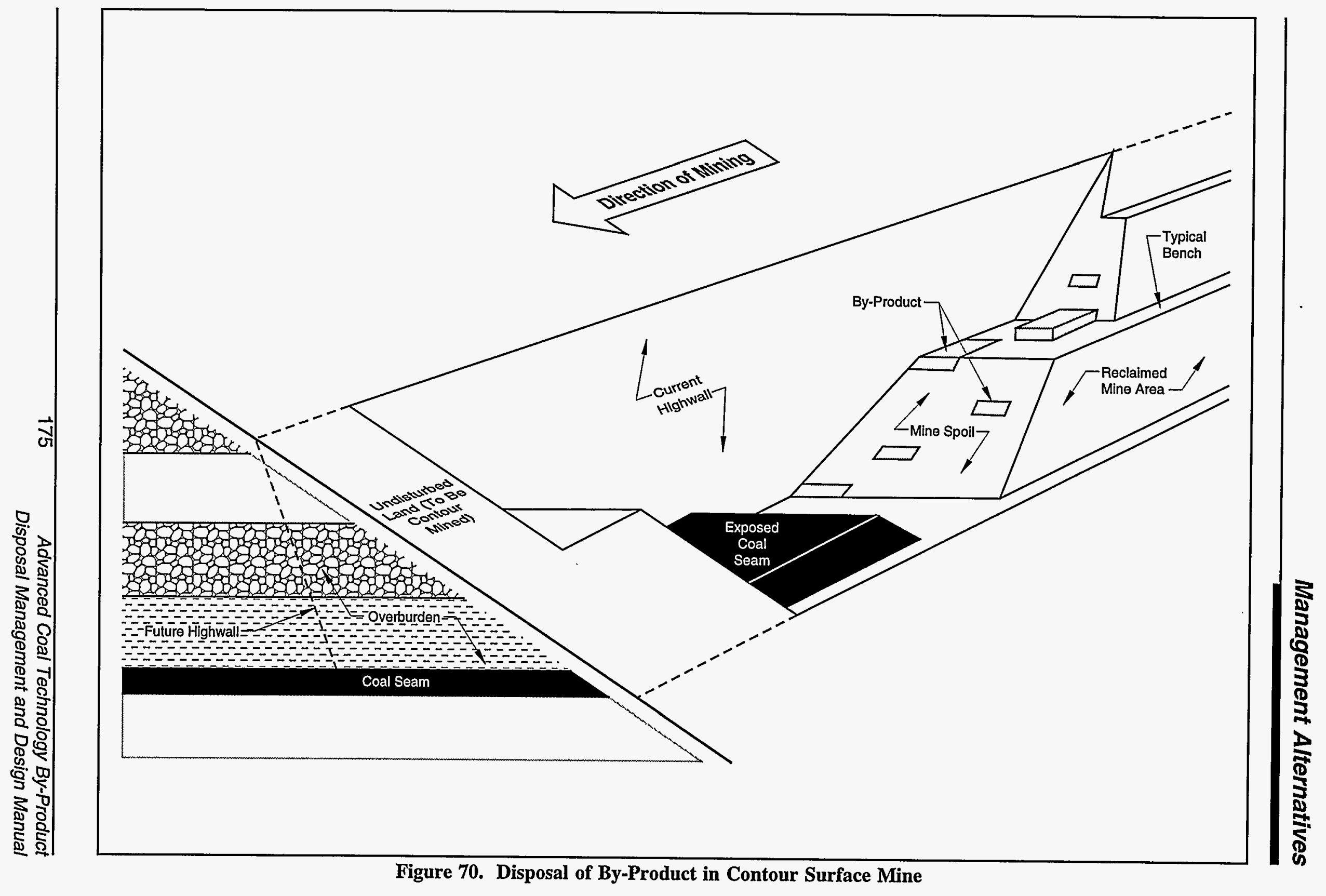


reclamation creates additional volume. Since coal ash is typically only $10-15 \%$ of the coal by weight, the return of by-products to the mine site of its origin should not cause disruption of mining activities, or produce a problem with excessive backfill.

\section{By-Product Properties}

To prepare a mine disposal plan, detailed data concerning the following byproduct properties are required: strength, permeability, leachate quality, and hydration properties. These parameters are discussed in Chapter 3 for a variety of by-product types. The strength parameters are important especially if the by-product is weaker than the overburden spoil. Weak by-product material can adversely affect stability, particularly in pit bottom disposal. This potential problem can be reduced by placing the material on the side of the strip pit farthest from the highwall (against the newly created spoil bank). This provides a region where no by-product exists when the next cut is taken, and overburden is dumped on the by-product. Low permeability by-product also can disrupt future groundwater recharge if spread continuously over a large area in pit bottom disposal. This problem, however, can be mitigated by placing the byproduct in rows sandwiched between mine spoil as described previously. Leachate quantity and quality are important in determining whether or not the by-product can be placed in a mine without adverse environmental impact. Easily eroded by-product material may require additional protective measures to minimize surface water contamination. Byproducts containing significant quantities of quicklime and/or anhydrous calcium sulfate such as Atmospheric Fluidized Bed Combustion (AFBC) ash should be preconditioned with water prior to disposal to complete any hydration reactions that otherwise could occur at the disposal site (similar to procedures described in Alternative 2). Excessive heat generation after disposal could create operating problems and impact codisposed materials if the materials are not adequately conditioned with water.

\section{Proposed Mine Plan}

The mine plan, detailing how the surface mine will be operated in conjunction with disposal activities, is critical in developing a mine by-product disposal operation. Waste disposal should not interfere with mining activities. Alterations may be required in the mine plan so that both operations can be conducted simultaneously with minimal interferences.

\section{Site Conditions}

Information concerning proposed conditions of the site after reclamation should be obtained. At a minimum, this information should include the final grading contour plan, and an estimate of the post reclamation groundwater conditions including location, flow direction and quality, and buffering and attenuation capabilities of the overburden. For example, tests conducted for disposal sites at lignite mines in North Dakota indicated that mine overburden materials had the capacity to neutralize alkaline solutions to some degree. These tests also indicated that waste disposal in the saturated zone was more likely to cause groundwater contamination. By estimating the post-reclamation site conditions, an assessment of possible adverse impacts can be made and appropriate steps taken to minimize those impacts. For example, prediction of the postclosure water table elevation would allow the operators to place the by-product high enough out of the groundwater so that leachate would be attenuated and neutralized by the overburden.

\section{Regulatory Requirements}

If the by-product material is used in mine reclamation, the regulatory agency may exempt the applicant from obtaining a solid waste permit if it can be demonstrated that the disposal method will not have adverse effects upon the environment. In many states, this regulatory agency would be the state.mining agency rather than the environmental agency; 
however, in some instances mine disposal may be subject to joint regulation.

In anticipation of widening use of advanced coal technologies, several coalproducing and coal-using states have developed special regulations pertaining to mine reclamation using by-product from coal burning operations. The resulting requirements are often included in the mine permitting process for facilities planning to accept by-product. These requirements can include the following elements:

- Additional ground water monitoring;

- Modified facility operations plan;

- Additional insurance/bonding requirements; and

- Detailed physical and chemical characterization of the by-product.

By-product placement is typically restricted to portions of the mine above the water table.

\subsubsection{Economic Analysis}

Mine disposal of advanced coal technology by-products has not been widely practiced to date; therefore, a quantitative economical analysis is difficult. However, tasks (similar to those for the other disposal alternatives) which affect the cost of a mine disposal operation can be qualitatively evaluated. These tasks are:

- Site Selection;

- Public Relations;

- Permitting;

- By-product Characterization;

$\rightarrow \quad$ Design;
- Construction;

- Operation;

- Transportation; and

- Processing.

Mine application has several environmental advantages over other disposal alternatives previously mentioned. For this reason, public relations and permitting should typically progress with less difficulty. The primary environmental advantage is that less land will have to be disturbed. Because of this, the potential for environmental degradation is greatly reduced. In addition, the mine reclamation will more closely approach the original contours of the land because of the additional fill material.

Permitting is often less complicated for mine disposal than for landfill disposal because of the elimination of a separate landfill operating permit. Additional requirements to standard mining procedures have to be met, but when compared to obtaining separate permits for mining and disposal facilities, the combined permit eliminates repetitious reporting, as well as the need to geologically characterize two separate areas for pre- and post-closure scenarios. In general, states that produce coal and burn it for energy have set up provisions to reduce some restrictive compliance monitoring requirements if it can be proven that the mine/disposal facility will not adversely effect the environment during operation and after closure.

Material characterization and processing required for mine disposal is similar to that for the reduced requirement landfill. This is necessary to demonstrate that the processed material will support overburden soil and also to verify that leachate and runoff from the proposed mine site will not adversely affect the surrounding environment. 
Because the two processes are combined at one location, the need for two sets of environmental control and support facilities is also eliminated. Therefore, the effort spent on design, construction, and operation will be significantly less than for a traditional or reduced requirement landfill. Mining equipment may have to be augmented to handle the by-product placement; however, the added cost of the equipment augmentation will be less than acquiring and maintaining a fleet of machinery necessary to operate a separate disposal facility.

The cost of transportation can significantly be reduced compared to other disposal alternatives. This is due to the possibility that haul routes and equipment used to transport coal also can be used for waste transport. This eliminates the need to construct and maintain separate hauling facilities. In some situations (such as for mine-mouth generating facilities) the same trucks or rail cars used to transport coal from a mine to a generating station may be used to transport wastes from the station to the mine, thus reducing dead-heading costs and the need for a second fleet of dedicated waste disposal vehicles.

\subsection{Alternative 5-By-Product Reuse Options}

Due to the self-cementing nature of many advanced coal by-products, a management alternative to disposal may be to market the by-products for reuse. Table 32 lists a number of reuse options ranging from a lime and nutrient source for agriculture and mining reclamation; to the production of construction products and materials such as cement, concrete, and structural blocks; from neutralization and stabilization of acidic waste sludges; to materials recovery. Marketing reuse options for advanced coal by-products can offer the generating plant a potential management alternative. However, few of these options have been demonstrated to be both technically and commercially viable for large volumes of by-product material. Some options only have the potential to utilize small volumes of byproducts; therefore, they may not offer a realistic management alternative to disposal. These options do, however, offer potential revenue sources. In addition, incentives for viable reuse programs may exist for both suppliers and users of advanced coal technology by-products in the form of "green products" specifications established by the government.

By-product properties important to reuse applications include the compressive and shear strengths, permeability, shrink swell properties, resistance to weathering, leachability, and other properties included in the discussion of the disposal properties of advanced coal by-products in Chapter 3. Other important qualities for reuse include market acceptance, by-product standardization, conformance with accepted product quality standards for the materials they are replacing, and potential interactions with other materials in the reuse setting. Table 32 lists a number of potential uses in three different broad market areas, along with specific issues affecting the implementation of these reuse applications and the testing which might be required to resolve these issues. Not included in Table 32 are broader issues, such as the resistance to use of a "waste" product, reluctance to try new sources or suppliers, and the economics of competing materials. These qualities are not discussed in this manual, and must often be addressed on a case-by-case basis. As advanced coal technologies are more widely implemented the by-products will become more widely available and better understood by industry and regulators alike. If the byproducts can consistently meet standards for product quality, this may lead to wider reuse markets.

Selected applications have proven to be able to utilize moderate to large volumes of material while compiling a successful performance record from demonstration projects. Structural block manufacture, for 
Table 32

Reuse Options for Advanced Coal Technology By-Products

\begin{tabular}{|c|c|c|}
\hline Potential Use & Issues Affecting Implementation & Tests Required \\
\hline \multicolumn{3}{|c|}{ Market Area: Agriculture } \\
\hline $\begin{array}{l}\text { Liming Agent, } \\
\text { Soil Amend- } \\
\text { ment, Nutrient } \\
\text { Source }\end{array}$ & $\begin{array}{l}\text { AFBC, FSI, and other alkaline ashes can provide alkalinity to acidic } \\
\text { soils. } \\
\text { By-product may react with some clays to develop hardpan. } \\
\text { By-product may improve soil moisture retention. } \\
\text { By-product may provide minor nutrients, but not adequate amounts } \\
\text { of macro nutrients (N, } \mathrm{P}, \mathrm{K}) \text {. } \\
\text { By-product may contribute to metals loading in soils. } \\
\text { Demand may be limited by seasonal use and limited application } \\
\text { rates. } \\
\text { There may be transportation problems associated with the lack of } \\
\text { central point of use. }\end{array}$ & $\begin{array}{l}\text { - Available lime index and } \\
\text { calcium carbonate } \\
\text { equivalent } \\
\text { - Field capacity and wilting } \\
\text { point. } \\
\text { - Chemical and TCLP } \\
\text { analysis }\end{array}$ \\
\hline \multicolumn{3}{|c|}{ Market Area: Construction } \\
\hline Cement & $\begin{array}{l}\text { By-product may substitute for low-strength concrete. } \\
\text { High sulfate content may limit addition to Portland cement. } \\
\text { - Demand may be limited by seasonal use. }\end{array}$ & $\begin{array}{l}\text { Bulk chemistry } \\
\text { Unconfined compressive } \\
\text { strength (UCS) } \\
\text { Durability (freeze/thaw } \\
\text { and wet/dry weathering) }\end{array}$ \\
\hline $\begin{array}{l}\text { Road Bases and } \\
\text { Embankments }\end{array}$ & $\begin{array}{l}\text { By-products must meet specifications for load-bearing and dynamic } \\
\text { strength. } \\
\text { - Long-term weathering effects may diminish stability and strength. } \\
\text { - By-product may react with some base soils, may stabilize others. }\end{array}$ & $\begin{array}{l}\text { USC, permeability, sheer } \\
\text { stress and deformation, } \\
\text { sheer modulus, cohesion, } \\
\text { internal friction angle } \\
\text { UCS and dimensional } \\
\text { stability }\end{array}$ \\
\hline Masonry Units & $\begin{array}{l}\text { High value use. } \\
\text { More stringent strength requirements. } \\
\text { Final product may be lighter than bricks or Portland cement con- } \\
\text { crete blocks. }\end{array}$ & $\begin{array}{l}\text { - UCS } \\
\text { - Bulk density }\end{array}$ \\
\hline $\begin{array}{l}\text { Synthetic } \\
\text { Aggregate }\end{array}$ & $\begin{array}{l}\text { Long-term weathering effects may diminish stability and strength. } \\
\text { - By-product may react with other materials. } \\
\text { - Potential use for pelletized by-product and gasifier slag. } \\
\text { - By-product use may reduce weight of final product. }\end{array}$ & $\begin{array}{l}\text { UCS and dimensional } \\
\text { stability } \\
\text { Bulk density }\end{array}$ \\
\hline \multicolumn{3}{|c|}{ Market Area: Pollution Control } \\
\hline $\begin{array}{l}\text { Acid } \\
\text { Neutralization }\end{array}$ & $\begin{array}{l}\text { AFBC, FSI, and other alkaline ashes may be used to neutralize } \\
\text { acidic waste water. } \\
\text { - By-product may contribute metals. } \\
\text { - Permitting may be difficult. } \\
\text { - Demand may be limited. }\end{array}$ & $\begin{array}{l}\text { Available lime index and } \\
\text { calcium carbonate } \\
\text { equivalent. } \\
\text { - Chemical and TCLP } \\
\text { analysis }\end{array}$ \\
\hline $\mathrm{SO}_{\mathrm{x}}$ Control & $\begin{array}{l}\text { By-product with high concentrations of unreacted sorbent may be } \\
\text { recycled. } \\
\text { - Abrasive by-products may induce wear. }\end{array}$ & - Available lime index \\
\hline \multirow[t]{2}{*}{ Liners } & - Poz-o-tech ${ }^{\mathrm{TM}}$ and similar processes have been widely used. & \\
\hline & $\begin{array}{l}\text { By-product may provide chemical attenuation. } \\
\text { - By-product may be incompatible with some waste types. } \\
\text { - Liners need to meet performance standards. } \\
\text { - Permitting may be difficult. }\end{array}$ & $\begin{array}{l}\text { - Cation exchange capacity } \\
\text { - Permeability, dimensional } \\
\text { stability, and UCS }\end{array}$ \\
\hline
\end{tabular}


example, is representative of a reuse opportunity which involves other industry sectors to produce an end product which must compete in open markets; it also serves to illustrate all of the elements of a successful reuse market development. However, strategies for developing, testing, and marketing reuse in the form of manufacturing applications are beyond the scope of this manual. The perspective of this report is that this form of reuse will augment, rather than replace, landfill disposal as the primary byproduct management strategy.

Masonry block manufacture has been proposed as a possible market for advanced coal technology by-products. Several studies conducted over a period of nearly 15 years have suggested that mixtures of AFBC byproduct and PFA can attain sufficient strength for use in structural applications $\mathrm{s}^{2,4}$. In combination these materials form a "cementless concrete" which owes its strength to ettringite mineralization rather than the calcium silicate and calcium aluminate minerals in ordinary Portland cement. These studies identified several technical barriers to successful commercialization of cementless concrete products, including unpredictable swelling during cure, slow development of maximum strength, and potential loss of strength following prolonged exposure to water.

Additional research conducted by Wormser Development Co., conducted under a Small Business Innovative Research (SBIR) grant from DOE, produced prototype masonry units with high strength and negligible swelling, avoiding the major obstacles to commercial development of cementless concrete structural units identified in earlier studies. A proprietary FBC ash hydrator is key to Wormser's process, since complete hydration of lime and gypsum in the raw ash is required to eliminate unpredictable swell during curing. Because FBC/PFA mixtures are fine grained and readily molded, the Wormser process has the potential to make structural blocks with more precise dimensions than traditional cement/aggregate blocks if swelling during cure can be avoided. The potential improvement in manufacturing precision introduces the possibility for tongue-andgroove designs and thinner joints between the blocks. These features would allow the blocks to be aligned easily and joined with flexible adhesives, rather than cement-based mortar. Substantial reductions in installation costs and improvements in structural strength could be realized if these features were successfully implemented.

Wormser Development Co. designed a testing program to address remaining technical, manufacturing, economic, and regulatory issues related to commercializing cementless concrete block manufacture. A four-year testing program was planned to provide all data required for product acceptance under industry standards and federal, state, and local building codes. Technical issues remaining to be addressed under this program included longterm stability in the presence of water and atmospheric carbon dioxide, and compatibility with other construction materials. More thorough documentation of the strength characteristics, fire-retardency, freeze-thaw durability, and other material properties was also planned. Some changes in the manufacturing process typically used for concrete blocks would also be required for production of cementless block; several manufacturers expressed an interest in working with Wormser Development Co. to refine process conditions. An initial economic analysis of cementless concrete block manufacture, based on pilot plant data, found a unit cost similar to standard concrete block and substantially lower installation costs, because of the self aligning features of the blocks. The high value of the cementless blocks was estimated to more than offset disposal costs, and could, under favorable circumstances, provide a source of revenue from the FBC by-products. 
There are no current plans to proceed with testing and commercial development of the cementless concrete blocks. The long lead time required for testing and certification of new products, and the lack of additional funding for the project caused the project to be abandoned. The information developed in this effort remains instructive for other groups seeking to commercialize processes involving reuse of advanced coal technology by-products, as it illustrates both technical and market barriers to product development.

\subsection{Citations}

1. Electric Power Research Institute. EPRI CS-2801. FGD By-Product Disposal Manual, Third Edition. Palo Alto, California, 1983.

2. Minnick, L.J., 1982, "Development of potential uses for the residues from fluidized-bed combustion processes; Final Report covering results of research program and recommended practices for potential users," NTIS DOE/EET/10415-T6.
3. Bland, A.E., 1987, "Utilization of fluidbed combustion ash in construction applications," Pittsburgh Coal Conference, Pittsburgh, PA.

4. Dearborn Environmental Consulting Group, 1988, "Utilization potential of CFBC residue in construction applications," prepared for CANMET Energy, Mines and Resources, Canada. DEGC File No. S10-608, Mississauga, Ontario, Canada.) 
This Page Intentionally Left Blank 


\section{Performance-Based Design Process}

The intent of this chapter is to help utility personnel and design professionals evaluate performance standards for a proposed disposal facility and to provide a general overview of the performance-based design process. As discussed in Chapter 4, most states regulate by-products from advanced coal technologies as industrial solid wastes.

Typically, these regulations are written to cover a broad range of industrial wastes. Therefore, most states include specific design features such as composite liners and cap systems with leachate collection. Fortunately, most state regulations also provide exemptions, waivers, or reduced-requirement landfill designs if the applicant can demonstrate that the proposed design will meet applicable performance standards without adverse environmental impact.

The objective of applying the performance-based design process to a proposed disposal facility is to quantify how the facility will affect groundwater quality or, in a broader sense, human health and the environment. To quantify the effects of the disposal facility, the following information is required:

- Estimated quality of leachate produced from the by-product material;

- Potential for leachate production and infiltration into the groundwater; and

- Anticipated fate and transport of chemicals of concern from the landfill to the point of compliance (typically defined as the boundary of the disposal facility).

The first information required for a performance-based design is whether the leachate concentrations of the chemicals of concern (COCs) exceed regulatory values. The COCs vary from state to state; however, an example of some typical maximum contaminant level (MCL) values are listed in Table 33. This table is reproduced from Subtitle D, Part 258, of the Resource Conservation and Recovery Act ${ }^{1}$ (RCRA). In general, Advanced Coal Technology (ACT) by-products do not contain measurable amounts of any organic species listed. Most states also reserve the right to add constituents to this list, depending on the type of material that will be placed in the disposal facility.

If it is determined that leachate from the by-product material does exceed the MCL for any COCs listed for the specific state, the demonstration will take on an added dimension. In some cases if the MCLs are exceeded by a large amount (typically a factor of 100), it may be determined that the advanced coal technology by-products exhibit RCRA Subtitle $C$ hazardous characteristics and are subject to stringent regulation. If the MCL for any COC is exceeded, even by a smaller amount, there will be a need to predict the fate and transport of the $\mathrm{COC}$ from the landfill to the point of compliance. The following performance-based design topics will be expanded upon in the following two sections:

- Performance-Based Design Demonstration (8.1)_Various methods used to determine how the facility will affect groundwater quality are discussed, including leachate studies, methods to determine leachate generation, and fate and transport of leachate constituents. 
Table 33

Chemicals of Concern Listed in RCRA Subtitle D, Part 258

\begin{tabular}{||l|c||}
\hline \multicolumn{1}{|c|}{ Chemical } & $\begin{array}{c}\text { Maximum Contaminant Level (MCL) } \\
(\mathrm{mg} / \mathbf{L})\end{array}$ \\
\hline Arsenic & 0.05 \\
\hline Barium & 1.0 \\
\hline Benzene & 0.005 \\
\hline Cadmium & 0.01 \\
\hline Carbon tetrachloride & 0.005 \\
\hline Chromium (hexavalent) & 0.05 \\
\hline 2,4-Dichlorophenoxy acetic acid & 0.1 \\
\hline 1,3-Dichlorobenzene & 0.075 \\
\hline 1,2-Dichloroethane & 0.005 \\
\hline 1,1-Dichloroethylene & 0.007 \\
\hline Endrin & 0.002 \\
\hline Fluoride & 4 \\
\hline Lindane & 0.004 \\
\hline Lead & 0.05 \\
\hline Mercury & 0.002 \\
\hline Methoxychlor & 0.1 \\
\hline Nitrate & 10 \\
\hline Selenium & 0.01 \\
\hline Silver & 0.05 \\
\hline Toxaphene & 0.005 \\
\hline 1,1,1-Trichloroethane & 0.2 \\
\hline Trichloroethylene & 0.005 \\
\hline 2,4,5-Trichlorophenoxy acetic acid & 0.01 \\
\hline Vinyl chloride & 0.002 \\
\hline
\end{tabular}

- Performance-Based Design Example (8.2)-A hypothetical example of a performance-based design demonstration is presented.

It should be noted that this chapter is not intended to address all scenarios that may be considered for a design demonstration. However, by providing an overview, the designer should be able to apply the same basic approach to perform a design demonstration.

\subsection{Performance-Based Design Demonstration}

A performance-based design allows a utility to demonstrate to the applicable 
regulatory agency that a proposed method of by-product disposal will not affect groundwater quality or other environmental resources, despite changes to the agency's specified design. Because this design standard is performance-based, there are an unlimited number of design alternatives and methods to demonstrate that the selected alternative meets the applicable state standards. The intent of this section is to provide a general overview of some of the more common methods used to quantify landfill performance. The four basic components of a performance-based design demonstration are shown in Figure 71. The first step (the determination of regulatory requirements) is discussed in Chapter 4. Steps 2 through 4 are discussed below. The discussion focuses on groundwater protection, since this is the primary concern of most landfill regulations.

\subsubsection{Determination of Leachate Quality (Step 2, Figure 71)}

Leachate is defined as any liquid that has passed through or emerged from solid waste and which contains soluble, suspended, or miscible materials removed from such wastes $^{2}$. Typically, if it can be shown or demonstrated that the chemical concentrations associated with leachate produced by the byproduct material are below all applicable MCLs, then the design performance demonstration can be considered complete.

For example, if a utility shows, through leaching tests and data from similar facilities, that the concentrations of all chemicals of concern in the leachate are less than all applicable MCLs, then, typically, the utility will not have to determine leachate quantity (Step 3-Figure 71) or predict the fate and transport of any COCs (Step 4-Figure 71). Unfortunately, obtaining representative values of leachate chemical concentrations for a proposed facility can be difficult due to the uncertainty of by-product composition, the lack of prior experience with advanced coal technology by-products, and changes in the leaching potential of the by-products over time (see Chapter 9).

The following sections will outline procedures for predicting leachate chemical concentrations from advanced coal by-products. In addition, factors that influence leachate quality will be presented along with typical values obtained from the field-scale test cells constructed as part of this project.

\section{Factors Affecting Leachate Quality}

In most operations, several factors affect the composition of the by-product material and subsequently affect leachate quality. The main factors that affect byproduct composition include:

- Coal composition;

- Sorbent loading; and

- Facility operating conditions.

The coal is the source of many potentially leachable COCs, primarily trace metals such as arsenic, cadmium, chromium, lead, and selenium. Major analytes associated with the coal, such as sulfate, chloride, and total dissolved solids (TDS), may also be regulated in some states. Coal composition varies significantly on a regional basis as well as between individual mines, and even between loads from a single mine. Some COCs may be associated with the coal matrix itself, while others are associated with clays, pyrites, and other mineral matter commonly found in coal. Changes in coal source or coal cleaning practices can change the abundance of COCs found in the combustion by-products and may change the leachable concentrations of these chemicals as well. 


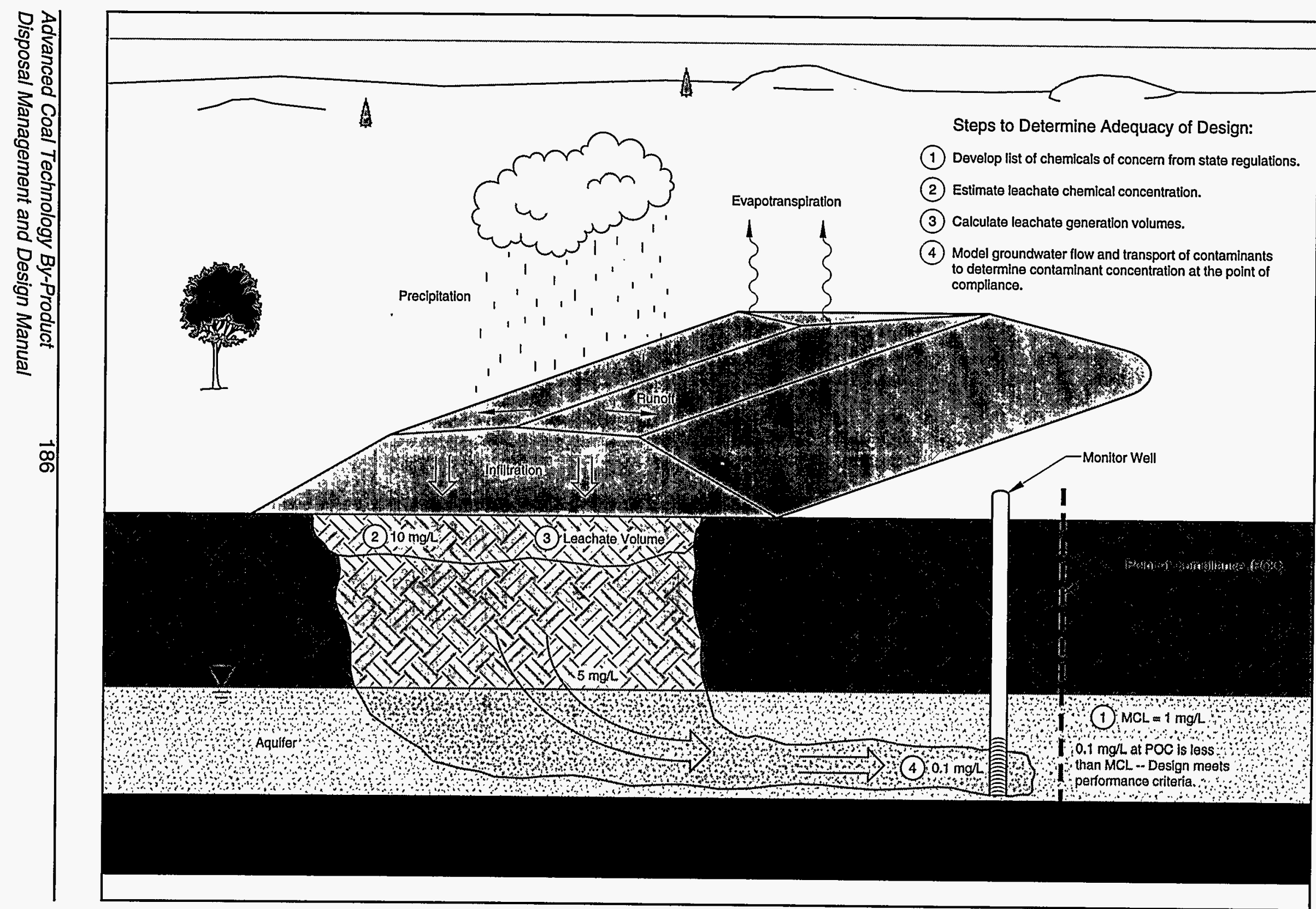

Figure 71. Methods Used in Demonstrating a Performance-Based Design 
The sorbent used for $\mathrm{SO}_{x}$ control is the second major component of the combustion byproducts, following the coal ash. The sorbent may also contribute to the concentrations of some chemicals of concern. More importantly, sodium- and calcium-based sorbents typically contribute considerable alkalinity to the combustion by-products. In extreme cases the alkalinity may be so high that the by-product fails the RCRA corrosivity criteria $(\mathrm{pH} \geq 12.5)$, leading to regulation under Subtitle $C$. In general, the high alkalinity of most advanced coal combustion by-products can affect the leachability of many COCs; some elements are more mobile at higher $\mathrm{pH}$ values, while others may be fixed in the solid phase. Changes in the sorbent loading rate may alter the leachate $\mathrm{pH}$, leading to changes in the leachable concentrations of COCs.

Facility operating conditions, including coal/sorbent ratios, combustion temperature, residence time in the combustion zone, and SO $x$ and particulate collection efficiencies, can affect the composition and leachability of the combustion by-products. The balance of coal and sorbent inputs controls the overall composition of the by-products, as discussed above. Combustion temperature and residence time influence the form of the by-product. Higher temperatures or longer residence times can promote formation of glassy or slag material from the coal ash and can also "hardburn," or render unreactive, some sorbent reaction products. The efficiency of particulate and $\mathrm{SO}_{x}$ removal systems affects the size distribution and chemical composition of the by-products, which may in turn affect their leachability.

\section{Leachate Quality Prediction}

This section presents a methodology for predicting leachate quality for combustion by-products from facilities that use advanced coal technologies. The three basic methods for predicting leachate quality are as follows:
- Use information from a similar, existing facility. Care should be taken to ensure that the coal source, boiler type, ash collection, and disposal operation are similar to those of the proposed facility.

- Perform laboratory leaching experiments that are conducted on simulated waste material or waste material from a similar facility as described above.

- Construct a field-scale test cell similar to the test cells described in Chapter 9 of this manual. Test cells need to be monitored for leachate production and leachate quality for a period of months to several years before the final results of the demonstration can be obtained.

As mentioned previously, the determination of leachate quality is the most critical factor in a performance-based design demonstration. If the generator can demonstrate that leachate chemical concentrations are below applicable MCLs, the alternatives for the disposal facility design are numerous.

Regulatory agencies may require a combination of these methods to demonstrate leachate quality before approval of a performance-based design. In addition, regulatory agencies are likely to require periodic demonstrations of leachate quality during the life of the landfill to verify the assumptions regarding leachate quality made during the design phase.

\section{Leachate Tests}

Two types of tests can be used to evaluate the leachability of advanced coal byproducts. Batch leaching processes are relatively quick, inexpensive, and simple tests which are highly reproducible in a single laboratory. Column leaching is more time- 
consuming and costly, but it can provide information on the leaching characteristics of a waste under various conditions designed to more closely represent actual landfill conditions than is possible with batch tests.

The Toxicity Characteristic Leaching Procedure (TCLP) is the batch test used for regulatory determination of the status of wastes under RCRA and many state programs. It uses parameters which are not necessarily specific for the particular type of by-product being evaluated, nor indicative of actual conditions of the disposal site. However, it is generally required by regulators and provides an initial indication of the leaching characteristics of the by-product.

A column study has the ability to simulate the saturated or unsaturated flow and vertical segregation of materials occurring in a landfill or landfill/liner system. It can also provide information on how leachate changes as it moves through a landfill or liner. One laboratory procedure for column leaching is American Society Testing and Materials (ASTM) D4874, "Standard Test Method for Leaching Solid Waste in a Column Apparatus." It provides a method for generating aqueous leachates from materials in a saturated upgradient flow. Many other column test configurations are possible.

There are a number of chemical and physical parameters which affect the leachability of solids when using batch leaching procedures. The chemical parameters are associated with the type of extracting solution used and include solution $\mathrm{pH}$ and the presence of complex-forming ions. Physical parameters also influence the leachability of solids. These variables include:

- Sample preparation (grinding);

- Solid-to-liquid ratio;
- Contact time between leaching phase and solids; and

- Method of agitation or mixing.

The $\mathrm{pH}$ of the extracting fluid is one of the most important factors which influences the solubility of many of the trace elements. The TCLP uses extraction fluids which are buffered with acetic acid to $\mathrm{pH} 2.88$ and 4.93. A screening test is used to determine which extraction fluid to use based on the acidity or alkalinity of the solids to be leached. Deionized water is used as the leaching fluid in the ASTM D4874 column leaching test. Deionized water at neutral $\mathrm{pH}$ may be a more appropriate leachant than dilute acid solutions in a solid waste landfill. Other leaching fluids may be selected to model specific landfill conditions.

Complexation or chelation of species present in the solids by ions contained in the extraction or leaching solution can also affect leaching behavior. The TCLP extraction fluid is formulated to represent municipal landfill leachate containing organic acids as complexing agents. These acids are not generally present in utility waste monofills. The deionized water used for some column leaching tests contains no complexing agents. This provides a more realistic leaching medium for typical coal combustion by-product landfills.

Physical parameters also determine the leachability of the solids. Grinding can increase the surface area of a given mass of material, increasing contact with the leaching fluid. Pelletized material, on the other hand, has much lower surface area than typical unprocessed combustion by-products. A uniform particle size is conducive to obtaining more reproducible samples and results. Solids for TCLP extraction must be reduced in size to pass a 9.5-mm (3/8-inch) sieve. Columns are usually packed with material to standard or field density without any particle size reduction. 
The liquid-to-solid ratio utilized in batch tests and the volume of leachate percolated through solids in a column can significantly influence the concentration of constituents in the liquid phase. High liquidto-solid ratios often will dilute out the concentrations of trace species. The liquid-tosolid ratio typically found in utility solid waste landfills is quite low, especially early in a landfill's lifespan. The TCLP uses a fairly high 20:1 ratio, while the leachate volume collected in a column study will depend on such factors as rainfall, permeability, climate, and site characteristics which are being modeled by the test.

Contact time is important in determining leachability. The contact time should be long enough to allow species to approach chemical equilibrium. Batch tests, such as the TCLP, are usually based on an 18hour extraction time. The contact time of the leachate in a column study should be long enough to approach actual disposal conditions, generally a period of several months. Compaction effort, column permeability and the hydraulic head are among the variables affecting residence time of leaching solution with the solids in column studies.

The agitation technique used in the batch tests should be chosen to maximize solid/liquid contact without causing particle or container abrasion. Agitation is needed to avoid concentration gradients in the leachate in contact with the solids. Adequate mixing is achieved in the TCLP by a circular rotation at $33 \mathrm{rpm}$. Column studies utilize percolation of the liquid to contact the solids rather than agitation.

In summary, the general advantages of batch leaching are simplicity, low cost, reproducibility, and a short testing period. The major disadvantage is that they do not model the dynamic flow regime found in actual disposal conditions. Column studies have an advantage over batch leaching in their ability to simulate the flow and vertical segregation of materials occurring in an actual landfill or disposal site. They can be operated successfully to provide reproducible data on leaching tendencies of solids and attenuation capacity of various soils or substrates. However, column studies have disadvantages including greater expense and length of the testing period.

\subsubsection{Determine Leachate Quantity (Step 3, Figure 71)}

The next step in the performance-based design process is to estimate or predict the quantity of leachate produced by the landfill during operation and after landfill closure. As mentioned earlier, this step may not be needed if the applicant can demonstrate to the regulators that any leachate produced by the byproduct stored in the landfill will not adversely affect the environment. The quantity of leachate which can be produced is directly related to precipitation. In some parts of the country the potential for leachate generation is minimal due to the relatively low amounts of precipitation. Generally, if a landfill is located in an area that receives less than 20 or 25 inches of annual average precipitation, then leachate production will be minimal from that site. This was demonstrated at the Colorado test cell (see Chapter 9). Over a three-year period, this site has yielded little or no leachate (average annual rainfall at this site is 11 inches).

\section{Landfill Water Balance}

Figure 72 shows a typical water balance for a landfill. Of the precipitation that falls on the site, a portion runs off, some is lost through evapotranspiration (loss of water through the uptake by vegetation and subsequent evaporation) and the remainder percolates through the fill. Water percolating through the fill will eventually leave as leachate unless it is chemically or physically trapped by the by-product material. The portion of precipitation which runs off or is evaporated may vary considerably from one 


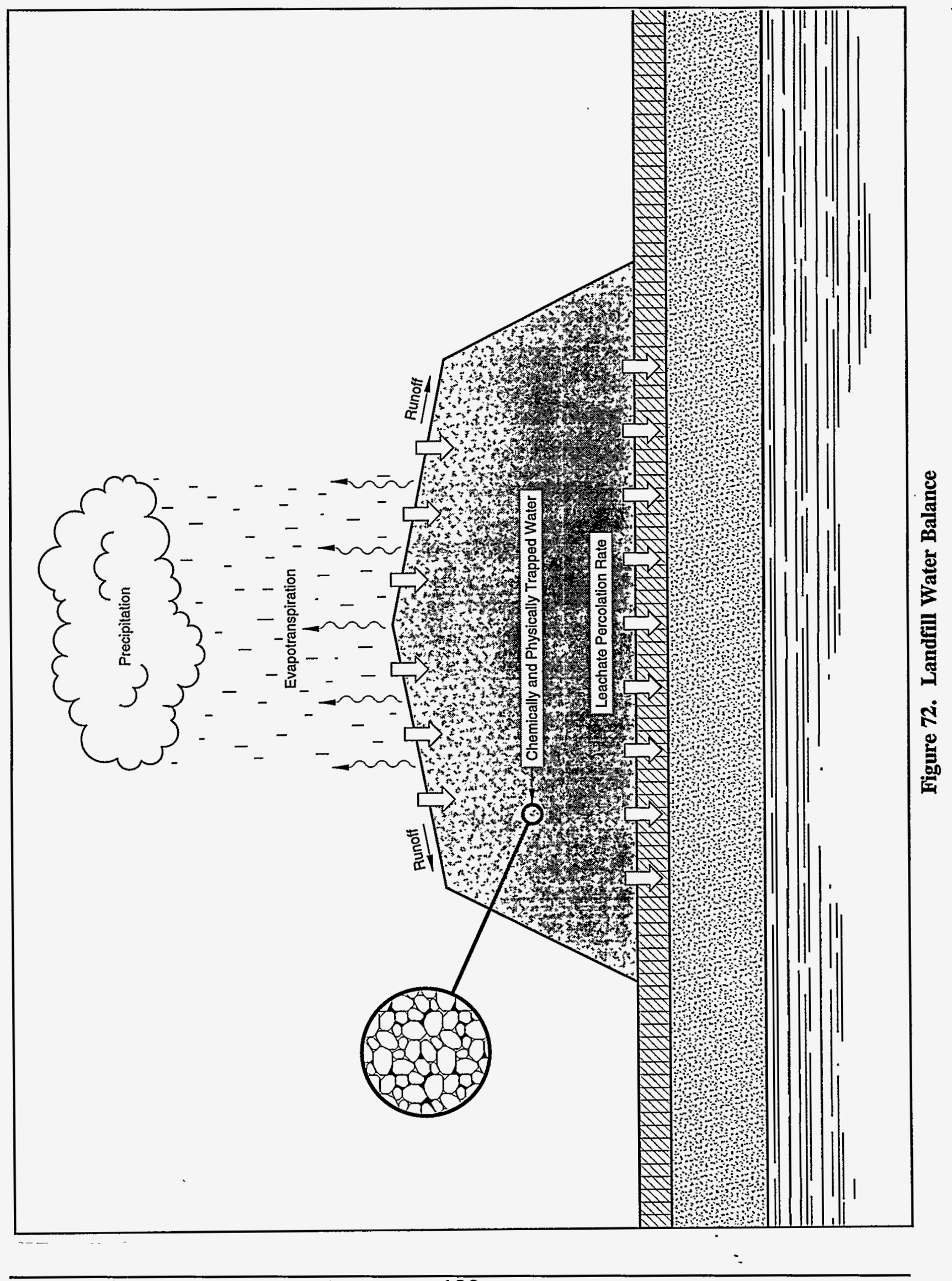


site to another, depending upon site-specific conditions. Important factors influencing water loss include surface slope, type of vegetative cover, permeability of the barrier layers and by-product material, climate variables (temperature, humidity, wind) and disposal site management procedures ${ }^{2}$.

The basic water balance equation for landfills is presented below ${ }^{3}$ :

$$
\begin{aligned}
& \text { Leachate Volume }=\mathrm{P}-\mathrm{ET}-\mathrm{R}-\mathrm{S} \\
& \mathrm{P}=\quad \text { Precipitation } \\
& \mathrm{ET}= \\
& \mathrm{R}=\quad \text { Evapotranspiration } \\
& \mathrm{S}=\quad \begin{array}{l}
\text { By-product moisture storage } \\
\text { volume }
\end{array}
\end{aligned}
$$

The ultimate amount of leachate depends on the amount of rain water that infiltrates the subsurface soils. As mentioned above, precipitation, evapotranspiration, surface runoff, and storage volume are all factors affecting the amount of leachate that will reach the ground below the by-product material. By properly planning the design and location of a landfill, one can greatly reduce the amount of leachate that reaches the groundwater below the facility. Precipitation is dependent solely upon the geographical location of the landfill, which may or may not be a reasonably changeable parameter. The other three parameters, however, can be manipulated in the design and operations of the landfill to minimize the amount of leachate. As mentioned earlier, evapotranspiration is a factor of evaporation from the cover soil surface and transpiration from the surface soil by plant life. Maintaining a healthy vegetative cover allows a large percentage of the rainfall to be taken up by plant roots and evaporated into the atmosphere, keeping it from ever entering the fill. Another design technique that will aid in minimizing infiltration is properly sloping the cover soil. By mildly sloping the surface layer, rainfall from heavier precipitation events will drain from the landfill surface before it infiltrates into the covering soil. The third parameter, moisture storage, can be manipulated by operation to minimize leachate production. Freshly placed FBC by-product ash traps large quantities of moisture in its pore space and in the formation of hydrous minerals. After a certain amount of time, which is dependent on the volume of available moisture and the volume of ash, the properties of the ash change and trap less moisture. Therefore, by manipulating the thickness of the lifts and the frequency of adding new lifts, the water that infiltrates into the ash can be kept from leaching into the groundwater by trapping it indefinitely in the fill material.

\section{Hydrologic Evaluation of Landfill Performance (HELP) Model}

The HELP program was developed by the U.S. Army Engineer Waterways Experiment Station, Vicksburg, Mississippi, for the U.S. Environmental Protection Agency (EPA), Hazardous Waste Engineering Research Laboratory, Cincinnati, Ohio, in response to needs identified by the EPA Office of Solid Waste, Washington, D.C. Several other leachate models exist; however, HELP is generally the standard for modeling landfill leachate production.

The HELP model is a quasi-twodimensional hydrologic model simulating daily water movement into, through, and out of landfill systems. It is capable of modeling the effects of covers, liners, and leachate collection systems as well as other natural and man-made soil conditions. As part of the solution, HELP calculates a hydrologic water budget for the system which includes estimates of surface runoff, evapotranspiration, lateral drainage to collection systems, percolation through liners, changes in soil moisture storage, and average depth of saturation in the surface liners.

The HELP model computes runoff by the Soil Conservation Service (SCS) runoff curve number method. Evaporation is evaluated by the modified Penman method. Flow through soil and any waste layers is 
assumed to be Darcian, and it does not account for potential flow through preferential flow pathways such as cracks or fractures ${ }^{4}$.

Input requirements for the HELP model include daily climatological data, soil characteristics, and design characteristics. Daily precipitation data may be user-specified, selected from a historical database that the model contains, or generated stochastically from default or user-specified mean monthly temperature and solar radiation data. Input values for the leaf area index and evaporative zone depth are also required. Among the soil properties that the model requires are the porosity, field capacity, wilting point, hydraulic conductivity, and initial moisture content. All of the parameters necessary for input are further defined in Table 34.

HELP generates a variety of useful output. The program is simple and quick to run. The model can be run several times, varying the design parameters to find the landfill and cap structure which best controls the leachate percolating into the groundwater.

\subsubsection{Fate and Transport of Leachate Constituents (Step 4, Figure 71)}

Leachate exiting the bottom of a landfill generally tends to travel via gravity into the subsurface soils and may ultimately reach groundwater. Some of the constituents which are transported in the leachate may become lodged in the subsurface soil and never reach the water table. The remaining constituents, diluted by the volume and flow of the groundwater, are transported in the groundwater. Again, some of these contaminants, dependent on the aquifer chemistry and soil type, may become lodged in the aquifer materials and be effectively removed from the groundwater. Those constituents that remain in the groundwater continue to be diluted and disposed of as they are transported farther away from the landfill. The point of compliance (POC) is a designated monitoring well, or series of monitoring wells, typically placed along the downgradient edge of the landfill facility's property boundary. The concentrations of the COCs are monitored for compliance with permit conditions at that point. Because of the natural filtering and dilution that occurs along the path of the leachate and groundwater, the concentration of constituents that reach the POC is typically much smaller than that immediately below the landfill.

\section{Multimedia Exposure Assessment Model (MULTIMED)}

MULTIMED is a multimedia exposure assessment model that can predict contaminant concentrations at groundwater receptors at the water table beneath a landfill or at various locations in an aquifer downgradient of a landfill $^{5}$. MULTIMED can implement the exact analytical solutions to unsaturated and saturated flow transport equations based on a relatively small number of parameters. The program is composed of a set of modules, some of which interact with each other, and some of which communicate only with the main controlling module. This feature allows one to choose and model only the particular contaminant migration pathways that are of concern to the user.

The output of MULTIMED lists the input parameters and the simulated "concentration after saturated zone model." This concentration is the amount of a constituent that the model predicts will be present at the point of compliance, based on the input parameters. If the input parameter for "initial concentration at landfill" is 1 , then the reciprocal of the predicted concentration at the point-of-compliance monitoring well is the dilution-attenuation factor (DAF). This is the factor by which the concentration is predicted to decrease between the bottom of the landfill and the point of compliance. For a given chemical in a given landfill, the DAF calculated by MULTIMED can be applied to any input concentration of interest to predict the point of compliance concentration. 
Table 34 HELP Parameters ${ }^{1}$

\begin{tabular}{|c|c|c|}
\hline $\begin{array}{l}\text { Variable } \\
\text { Name }\end{array}$ & Units & Description \\
\hline Leaf area index & - & $\begin{array}{l}\text { Dimensionless ratio of the leaf area of actively transpiring vegetation to the } \\
\text { nominal surface area of the land on which the vegetation is growing. The HELP } \\
\text { input program displays a table of typical values. }\end{array}$ \\
\hline $\begin{array}{l}\text { Evaporative zone } \\
\text { depth }\end{array}$ & inches & $\begin{array}{l}\text { Maximum depth from which water may be removed by evapotranspiration. The } \\
\text { HELP input program displays a table of typical values. }\end{array}$ \\
\hline Porosity & - & $\begin{array}{l}\text { Volume of void space between a soil's individual particles divided by the total } \\
\text { volume of the soil (including void space). The preferred source for this } \\
\text { parameter is field data; otherwise it can be obtained from a database or geology } \\
\text { field book keyed to soil or rock type. }\end{array}$ \\
\hline Field capacity & - & $\begin{array}{l}\text { Soil water content after a prolonged period of gravity drainage. The preferred } \\
\text { source for this parameter is field data; otherwise it can be obtained from a } \\
\text { database or geology field book keyed to soil or rock type. }\end{array}$ \\
\hline Wilting point & - & $\begin{array}{l}\text { Lowest soil water content that can be achieved by plant transpiration. The } \\
\text { preferred source for this parameter is field data; otherwise it can be obtained } \\
\text { from a database or geology field book keyed to soil or rock type. }\end{array}$ \\
\hline $\begin{array}{l}\text { Initial soil water } \\
\text { content }\end{array}$ & - & $\begin{array}{l}\text { Ratio of the volume of water in soil to the total volume occupied by the soil. } \\
\text { The preferred source for this parameter is field data; otherwise it can be obtained } \\
\text { from a database or geology field book keyed to soil or rock type. }\end{array}$ \\
\hline $\begin{array}{l}\text { Saturated } \\
\text { Hydraulic } \\
\text { Conductivity }\end{array}$ & $\mathrm{cm} / \mathrm{sec}$ & $\begin{array}{l}\text { Used in Darcy's law governing flow through porous media based on media } \\
\text { properties. The preferred source for this parameter is field data; otherwise it can } \\
\text { be obtained from the HELP manual based on known soil characteristics. }\end{array}$ \\
\hline Number of layers & - & $\begin{array}{l}\text { Number of layers of soil types through which HELP will model percolation. } \\
\text { This is a user-specified landfill design parameter. }\end{array}$ \\
\hline Layer type & - & $\begin{array}{l}\text { Type of soil layer which is defined for every layer that the user wishes to input. } \\
\text { The HELP input program displays a table of typical types with corresponding } \\
\text { explanations. }\end{array}$ \\
\hline Layer Thickness & inches & User-specified thickness of each layer. \\
\hline $\begin{array}{l}\text { SCS runoff curve } \\
\text { number }\end{array}$ & - & $\begin{array}{l}\text { Number relating runoff volume to soil types and vegetative cover. The HELP } \\
\text { manual includes a figure showing typical curves. }\end{array}$ \\
\hline Area of surface & $\begin{array}{l}\text { square } \\
\text { feet }\end{array}$ & User-specified area of the surface of the landfill. \\
\hline
\end{tabular}

${ }^{1}$ The Hydrologic Evaluation of Landfill Performance (HELP) Model, User's Guide for Version 3. Nadim M. Aziz, Paul R. Schroeder, and Cheryl M. Lloyd. April 15, 1993.

SCS $=$ Soil Conservation Service 
For the purpose of the example presented in Section 8.2, only the saturated zone module is used. The source plane for the saturated zone module is the vertical plane that intersects the downgradient edge of the facility perpendicular to the direction of groundwater flow. The module predicts the concentration of contaminants at the point of compliance, given hydrogeological parameters describing the aquifer the position of the well screen (in three-dimensional space), and the input contaminant concentrations. Table 35 lists all of the parameters used by this module and gives a brief explanation of each.

A program called PREMED is used to input data to MULTIMED. PREMED is a menu-driven stand-alone program that allows the user to easily build a MULTIMED input file. Once the input file is complete, the MULTIMED program can be executed.

\subsection{Design Example}

An example performance-based design will be developed in this section to further illustrate the methods used to make a design demonstration. In this example, a fictional midwestern utility is in the process of converting its plant to a fluidized bed combustion (FBC) process. As part of the system conversion, the utility is preparing a solid waste permit application to allow the disposal of FBC by-product material on a 200 -acre site near its facility. The proposed landfill will be an aerial or above-ground fill similar to the examples presented in Alternative 2, discussed in Section 7.1. In this case, state industrial solid waste regulations call for a complex composite liner and cover system unless the applicant can demonstrate that its specific design will provide adequate protection of the environment. The proposed design, as well as other characteristics of the site and the byproducts, and an explanation of the demonstration are presented in the following sections.

\subsubsection{Characteristics of the Example By-Product Landfill}

The hypothetical proposed site is located in the midwestern United States in an area that receives about 36 inches of rainfall per year. A plan view and section of the completed by-product landfill are shown in Figures 73 and 74. During the preliminary phase of this example project, the permit applicant concluded that the planned landfill would not require the standard cover and cap system (as specified in the regulations) to effectively protect surface and groundwater quality. This decision was based on several factors, including the results of a leachate testing program that showed that leachate from the proposed FBC by-product material would probably not exceed the specified MCLs listed in the state regulations. In addition, a continuous, 10-footthick layer of silty clay material with a low hydraulic conductivity separates the groundwater from the by-product material.

The landfill shape and cover design are detailed in Figure 74. As shown, the landfill will be approximately 60 feet high, and the final cover will include a barrier layer of 24 inches of low-permeability by-product material. This material will consist of a blend of FBC by-product and pulverized coal fly ash (PFA) that is hydrated and compacted in 6-inch-thick lifts. During the preliminary design phase of this example project, laboratory studies showed that this blended and compacted material could achieve a permeability of less than $2 \times 10^{-7}$ $\mathrm{cm} / \mathrm{sec}$. An additional 24 inches of soil that will support native vegetation (top soil) will overlay the barrier layer and will be seeded. In this case, groundwater is found approximately 20 feet below existing ground surface and flows to the east, with a gradient of $.006 \mathrm{ft} / \mathrm{ft}$. The facility will be operated so that only 10 acres are "open" or uncovered at any one time. The remaining areas will be either undisturbed land or completed cells where final cover or temporary cover has been placed. 


\section{Table 35 MULTIMED Parameters ${ }^{1}$}

\begin{tabular}{|c|c|c|}
\hline Variable Name & Units & Source/Comments \\
\hline \multicolumn{3}{|r|}{ General } \\
\hline - Run Option & - & Steady-state* \\
\hline - Active Models & - & Saturated Zone Parameters and Source Parameters** \\
\hline \multicolumn{3}{|r|}{ Aquifer Saturated Zone Parameters } \\
\hline \multicolumn{3}{|c|}{ - Depth and particle characteristics } \\
\hline -Aquifer porosity & $\begin{array}{l}\text { unitless; } \\
0.0-1.0\end{array}$ & $\begin{array}{l}\text { Volume of void space between a soil's individual particles divided by the } \\
\text { total volume of the soil (including void space). The preferred source for } \\
\text { this parameter is field data; otherwise it can be obtained from a database or } \\
\text { geology reference book keyed to soil or rock type. }\end{array}$ \\
\hline -Bulk density & $\mathrm{g} / \mathrm{cc}$ & $\begin{array}{l}\text { Oven-dried mass of a soil sample divided by its field volume. The preferred } \\
\text { source for this parameter is field data; otherwise it can be obtained from a } \\
\text { database or geologist's field book keyed to soil or rock type. }\end{array}$ \\
\hline -Aquifer thickness & $\mathrm{m}$ & User-specified landfill design parameter. \\
\hline \multicolumn{3}{|c|}{ - Hydraulic and Dispersion Related Parameters } \\
\hline $\begin{array}{l}\text {-Hydraulic } \\
\text { conductivity }\end{array}$ & $\mathrm{m} / \mathrm{yr}$ & $\begin{array}{l}\text { Rate at which water moves through soil. The preferred source for this } \\
\text { parameter is field data; otherwise it can be obtained from a database or } \\
\text { geology reference book keyed to soil or rock type. }\end{array}$ \\
\hline -Hydraulic gradient & $\mathrm{m} / \mathrm{m}$ & $\begin{array}{l}\text { Slope of the top surface of an aquifer. The preferred source for this } \\
\text { parameter is field data; otherwise it can be estimated from typical known } \\
\text { values from the region of interest. }\end{array}$ \\
\hline \multicolumn{3}{|c|}{ - Well Related Parameters } \\
\hline $\begin{array}{l}\text {-Receptor distance } \\
\text { from site }\end{array}$ & $\mathrm{m}$ & $\begin{array}{l}\text { Distance from the downgradient edge of the facility to the point of } \\
\text { compliance. User specified landfill design parameter. }\end{array}$ \\
\hline -Angle off center & degree & $\begin{array}{l}\text { Angle between the plume centerline, which is parallel to groundwater flow } \\
\text { direction, and a line drawn from the downgradient edge of the receptor well. } \\
\text { Most conservative approach is for the angle to be zero.*** }\end{array}$ \\
\hline $\begin{array}{l}\text {-Zone distance from } \\
\text { water table }\end{array}$ & $\mathrm{m}$ & $\begin{array}{l}\text { Distance measured vertically downward from the water table to the well } \\
\text { intake screen. Most conservative approach is for this parameter to be set to } \\
\text { zero.*** }\end{array}$ \\
\hline \multicolumn{3}{|c|}{ - Source Contaminant Data } \\
\hline -Infiltration rate & $\mathrm{m} / \mathrm{yr}$ & $\begin{array}{l}\text { Steady-state rate of leachate generation expected to escape from the bottom } \\
\text { of the landfill. The HELP output for leachate is the value for this } \\
\text { parameter. }\end{array}$ \\
\hline $\begin{array}{l}\text {-Area of waste } \\
\text { disposal unit }\end{array}$ & $\mathrm{m}^{2}$ & Area of the landfill. It should be a user-specified landfill design parameter. \\
\hline -Recharge rate & $\mathrm{m} / \mathrm{yr}$ & $\begin{array}{l}\text { Rate of infiltration into an aquifer downgradient of the landfill. The value } \\
\text { should be obtained from the first HELP output (see explanation of example). }\end{array}$ \\
\hline $\begin{array}{l}\text {-Initial concentration } \\
\text { at landfill }\end{array}$ & $\mathrm{mg} / \mathrm{l}$ & $\begin{array}{l}\text { Initial concentration of a chemical in the leachate to be modeled. } 1 \text { is used } \\
\text { so that the model output can be easily translated to all constituents.**** }\end{array}$ \\
\hline
\end{tabular}




\section{Table 35 (Continued)}

${ }^{1}$ The information in this table was mostly paraphrased from the U.S. EPA publication, User Manual Supplement: Using MULTIMED to Evaluate Subtitle D Landfill Designs, February 1993.

*

**

***

$* * * *$
Using the steady-state model simplifies the modeling greatly by reducing the number of parameters. Using steady-state is also the more conservative approach.

By excluding biodegradation from the simulation, the unsaturated zone can be omitted for the steady-state case. Modeling only the saturated flow is a simpler, more conservative approach to modeling the leachate transport.

Environmentally conservative estimates of the effectiveness of a landfill require the well to be located at the top of the aquifer along a line drawn parallel to the groundwater flow direction and perpendicular to the downgradient edge of the facility, intersecting that edge at its midpoint.

A single MULTIMED simulation can account for all constituents for which the source term and which decay at the same rate (steady-state source and zero attenuation in the example case) (0). In this case the expected input concentration of each MCL constituent is divided by the DAF from a single MULTIMED simulation to determine the constituent's expected concentration at the point of compliance. 


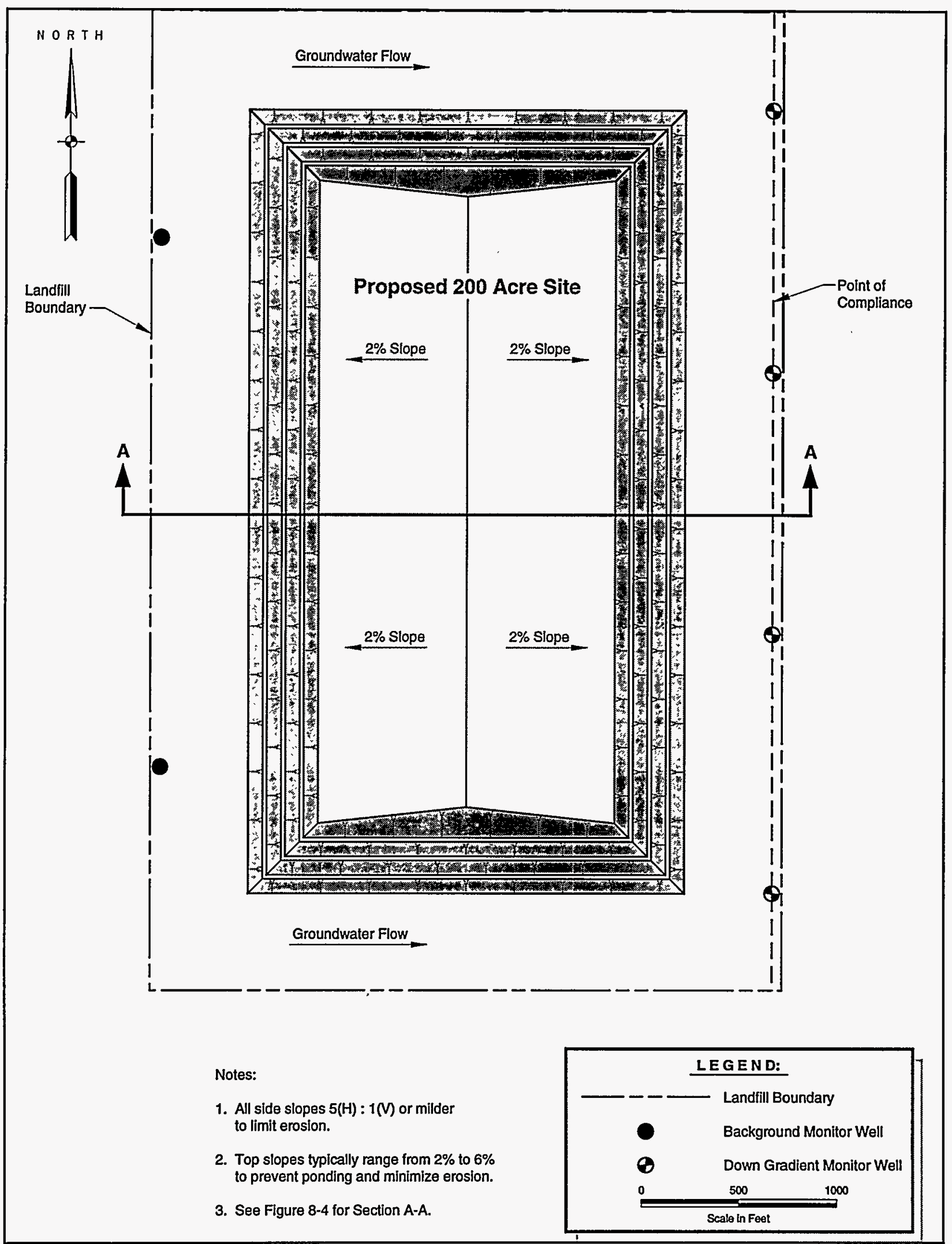

Figure 73. Plan View of Proposed Landfill 


\section{Performance-Based Design Process}

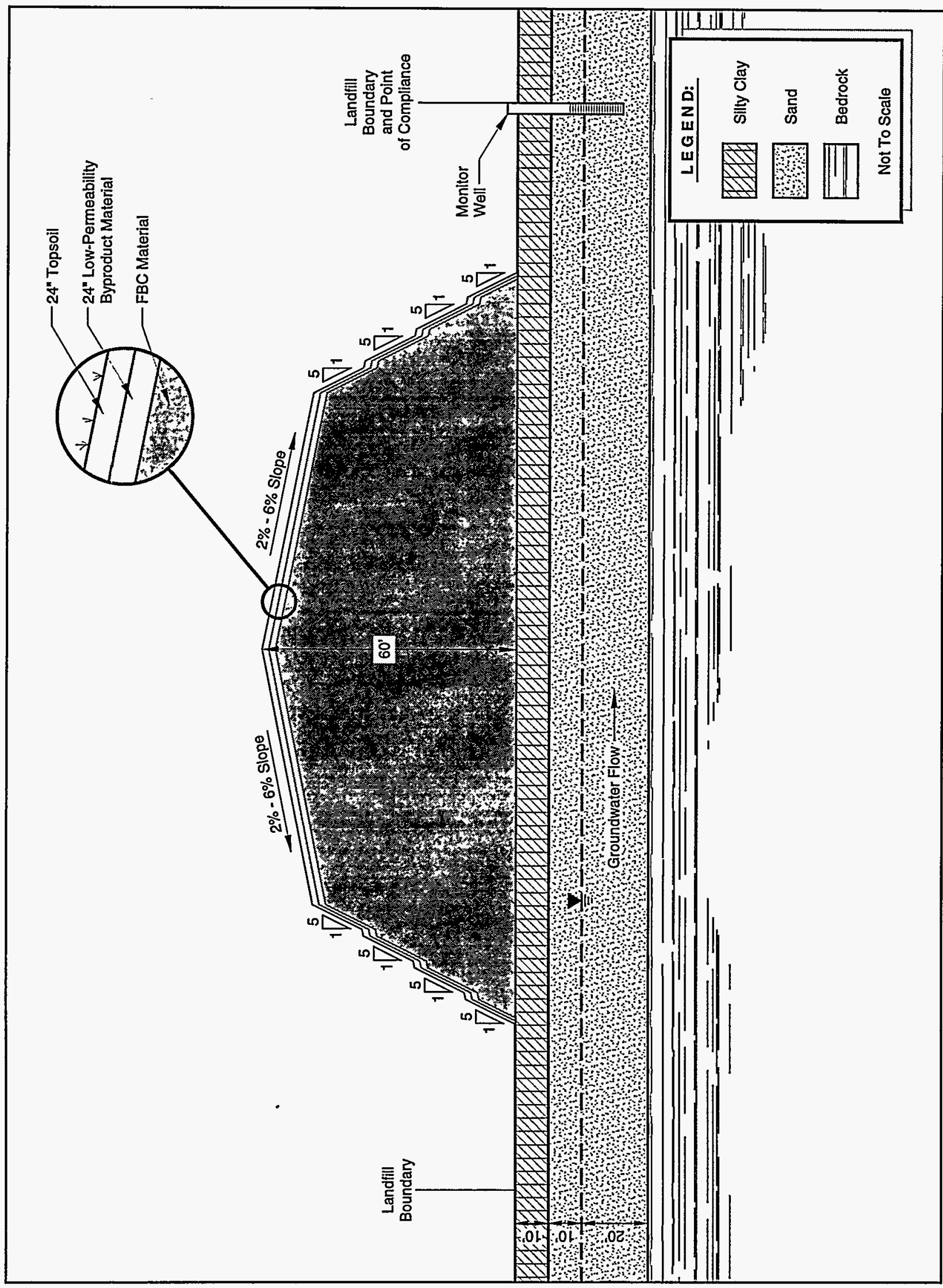




\subsubsection{Characteristics of the Proposed By-Product Material}

During the preliminary design phase, the applicant gathered leachate quality, permeability, and strength information from byproduct material from similar facilities and also by performing leachate studies on simulated by-product material. The results of these studies are presented in Table 36. The leachate characteristics presented in Table 36 are generally the maximum values that could potentially be generated from the proposed landfill, while strength and permeability values reflect average performance. These values were selected to provide for a conservative design. A more complete discussion of the physical and chemical properties of FBC by-product material can be found in other sections of this report. It should be noted that these values were selected for illustrative purposes only.

The operation of the model landfill is very straightforward and similar to that described in Section 6.3.5. The FBC byproduct arrives on site dry. The material is mixed in a screw conveyer where water is added to hydrate the FBC material. The FBC material is then placed in the landfill, and a minimal effort to compact the hydrated material is made. A 2-foot-thick barrier layer composed of FBC and PFA is then constructed over the hydrated FBC material. Greater care is taken to both hydrate and place this blended material. This material is placed to achieve an initial permeability of less than $2 \times 10^{-7}$ $\mathrm{cm} / \mathrm{sec}$.

\subsubsection{Regulatory Requirements}

In this example case, one of the first steps the permit applicant took was to determine the regulatory requirements applicable to their proposed landfill. The industrial solid waste regulations, in this case, were developed in a very broad manner that allowed each applicant to demonstrate the effectiveness of their proposed design. After several meetings with state regulators, it was determined that the
Table 36

Typical FBC By-Product Characteristics ${ }^{1}$

\begin{tabular}{||l|c||}
\hline \hline Chemical of Concern & Results (mg/L) \\
\hline Arsenic & 0.116 \\
\hline Barium & 0.077 \\
\hline Chromium & 0.041 \\
\hline Lead & 0.031 \\
\hline Selenium & 0.152 \\
\hline Calcium $^{3}$ & 1000 \\
\hline Chloride $^{3}$ & 2500 \\
\hline Sodium & ${ }^{3}$ \\
\hline Sulfate & 2500 \\
\hline $\begin{array}{l}\text { Strength (unconfined } \\
\text { compressive) }\end{array}$ & 3500 \\
\hline Hydraulic Conductivity & $1 \mathrm{X} \mathrm{10^{-4 }} \mathrm{cm} / \mathrm{sec}$ \\
\hline
\end{tabular}

${ }^{\mathrm{t}}$ Based on leachate samples from field tests.

${ }^{2}$ Other trace metals regulated under RCRA and most state codes include mercury and silver. These metals are typically present in negligible quantities in advanced coal technology by-products. Chemicals of concern and regulatory limits may vary from stateto-state.

${ }^{3}$ Although no MCLs have been established for major ions such as calcium, chloride, and sodium, these ions contribute to the overall total dissolved solids content of the leachate, which is regulated under the federal secondary drinking water standards.

permit applicant would demonstrate that their proposed design was adequate by showing that the concentrations of the COCs listed in Table 37 would not exceed the regulatory limits at the defined point of compliance in the uppermost aquifer during the life of the site and a 30-year post-closure period. The state regulators added four constituents to their standard list of COCs because of the properties of the FBC material. These four constituents were calcium, chloride, sodium, and sulfate. In addition, the regulators stated that there should not be a significant change in the concentration of these parameters when compared to their background concentrations $(230 \mathrm{mg} / \mathrm{L}$ each) that were determined in the groundwater characterization study. 


\section{Table 37 \\ Listed Chemicals of Concern}

\begin{tabular}{||l|c||}
\hline \multicolumn{1}{|c|}{ Chemical } & $\begin{array}{c}\text { Maximum Contaminant Level (MCL) } \\
(\mathbf{m g} / \mathbf{L})\end{array}$ \\
\hline Arsenic & 0.05 \\
\hline Barium & 1.0 \\
\hline Benzene & 0.005 \\
\hline Cadmium & 0.01 \\
\hline Calcium & NA \\
\hline Carbon tetrachloride & 0.005 \\
\hline Chloride & 250 \\
\hline Chromium (hexavalent) & 0.05 \\
\hline 2,4-Dichlorophenoxy acetic acid & 0.1 \\
\hline 1,3-Dichlorobenzene & 0.075 \\
\hline 1,2-Dichloroethane & 0.005 \\
\hline 1,1-Dichloroethylene & 0.007 \\
\hline Endrin & 0.002 \\
\hline Fluoride & 4 \\
\hline Lindane & 0.004 \\
\hline Lead & 0.05 \\
\hline Mercury & 0.002 \\
\hline Methoxychlor & 0.1 \\
\hline Nitrate & 10 \\
\hline Selenium & 0.01 \\
\hline Silver & 0.05 \\
\hline Sodium & NA \\
\hline Sulfate & 250 \\
\hline Toxaphene & 0.005 \\
\hline 1,1,1-Trichloroethane & 0.2 \\
\hline Trichloroethylene & 0.005 \\
\hline 2,4,5-Trichlorophenoxy acetic acid & 0.01 \\
\hline Vinyl chloride & 0.002 \\
\hline & \\
\hline & \\
\hline
\end{tabular}

NA - not available; no MCL established. . 


\subsubsection{Demonstration Example}

After the regulatory requirements were established, the permit applicant was ready to proceed with the demonstration. In summary, the goal was to show that the MCL concentrations of the listed COCs would not be exceeded at the point of compliance (downgradient monitor wells) due to the landfill operations. This requires that the following two situations be simulated:

1) Active portion of the landfill: The active portion of the landfill is defined as the area that is receiving FBC material and is not covered. For this facility, it is assumed that no more than 10 acres will be active at any time. Other landfill areas will either be closed or not used while this 10 -acre area is in operation.

2) After landfill closure: This situation involves modeling the landfill after it has been completely filled and final cover has been placed over the entire facility. Typically, state regulations require a facility to continue monitoring a closed facility for a period of 30 years after closure.

The computer programs HELP and MULTIMED were selected to demonstrate the effectiveness of the landfill design. This demonstration will consist of the following four-step process for both the active and closed landfill situations discussed above:

1) Calculate the normal groundwater recharge rate using HELP;

2) Calculate the leachate production or percolation from the landfill using HELP;

3) Calculate the DAF using MULTIMED; and
4) Calculate the predicted concentrations of $\mathrm{COC}$ at the point of compliance (downgradient monitor wells) using the DAF.

To perform this demonstration using these two computer models several assumptions are needed. As discussed previously, some of these assumptions are intrinsic to HELP and MULTIMED; however, some assumptions are also needed to describe the geologic setting, landfill operations, etc. It is usually advantageous to make conservative assumptions to compensate for the inadequacies of the computer programs. For example, in this case it is assumed that the unsaturated zone (i.e., silty clay and sand layers) does not exist. Therefore, one major attenuation mechanism of the COCs is not accounted for in the computer model. This greatly simplifies the analysis and also builds in an extra safety factor to the design. This demonstration process is further developed in the following sections.

\section{Active Landfill}

As mentioned earlier, for this facility only 10 acres will be active at any given time. Typically the open, active landfill will be the "worst case" situation as far as leachate production is concerned; however, by placing the FBC material in lifts (as described previously), the amount of leachate is greatly reduced because of the moisture-retaining properties of the material. Infiltration into the FBC material will be much greater during operations than after the final cover is constructed. But new material can retain most of that early infiltration if it is placed with a low initial moisture content. Therefore, by balancing the thickness of the lift and the frequency of adding new lifts with the amount of rainfall, one can almost eliminate leachate production prior to cell closure. Figure 75 depicts a typical section of the active landfill and further illustrates the demonstration procedure. A detailed description of the 


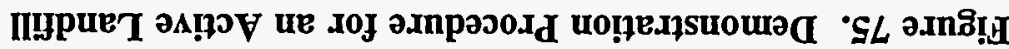

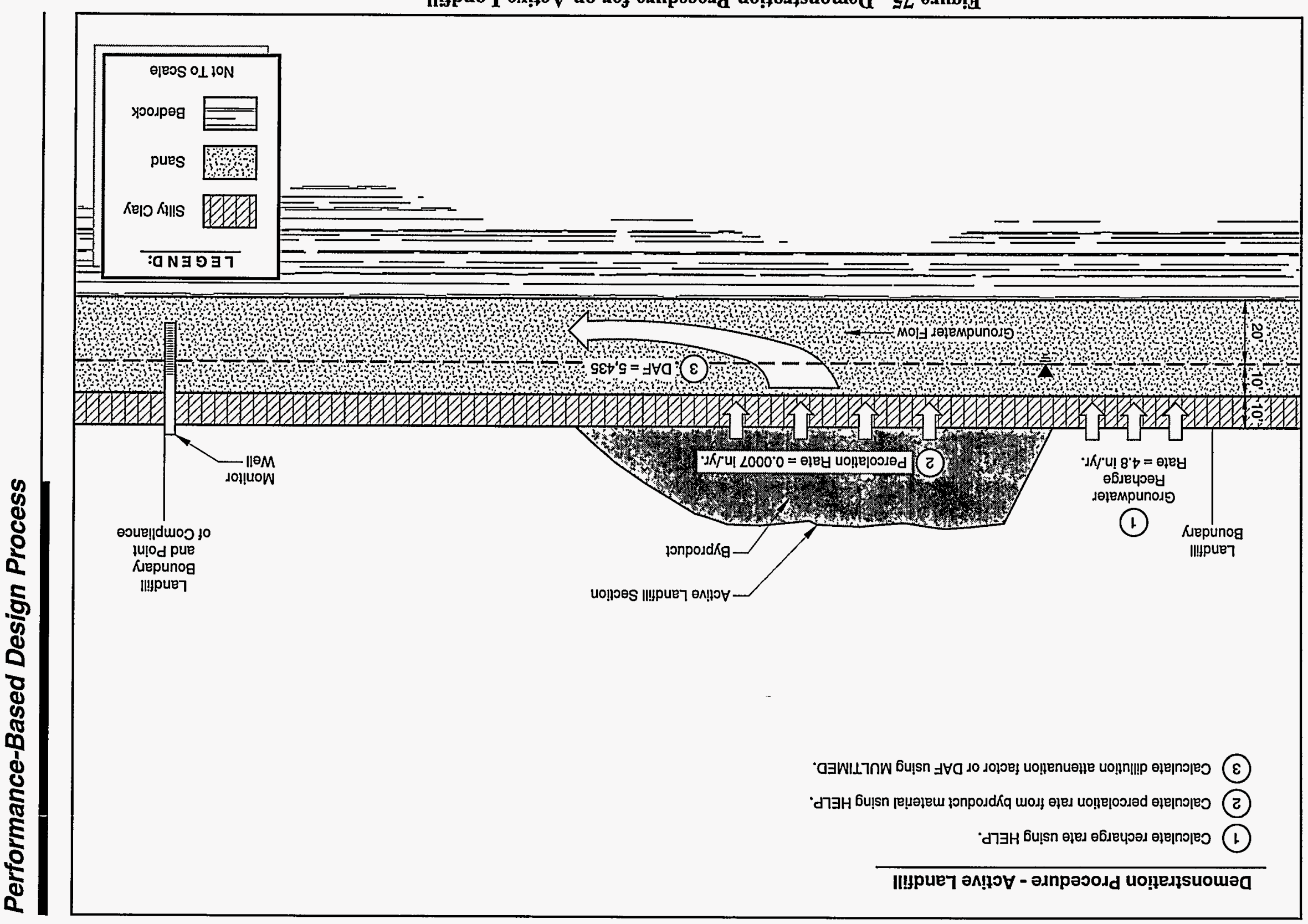


demonstration process for the active landfill is provided below.

Step One: Calculate Recharge-The first step is to calculate the normal recharge rate of the aquifer being considered from the land surrounding the landfill. This is necessary for later calculations involving MULTIMED. The HELP model provides an easy way to approximate the recharge rate. Table 38 explains the choice of parameters for this simulation run. The example HELP run output is in Appendix A. The resulting recharge to the aquifer from this simulation is taken from the average annual total percolation for a fiveyear simulation. The calculated value is 4.84 inches/year.

\section{Step Two: Calculate Percolation}

Rate-The next step is to estimate the amount of percolation from the active cell. As previously discussed, the active portion of the landfill will be approximately 10 acres and will be uncovered for a period of four years. For the purpose of this example, it is assumed that the fill material will be placed in 10- foot-thick lifts and that a complete new lift will be added each year. The landfill will be capped after placement of the fourth lift. Therefore, the maximum direct exposure to rainfall that each layer will receive will be one year. Table 39 lists and provides further explanation of parameter values chosen for this simulation run. The actual output is in Appendix B. The estimated average annual percolation rate was $7 \times 10^{-4}$ inches/year (as shown in Figure 75) from the by-product material to the underlying loamy sand soil. This number is low because of the FBC by-product's ability to trap water, as described previously. Since the amount of percolation is so small, only a 1-year simulation is necessary. Because a new layer is added each year, and it should display the same characteristics as the underlying layer, the leachate percolation rate should not exceed $7 \mathrm{x}$ $10^{-4}$ inches/year.
Step Three: Calculate

DAF-MULTIMED will be used to calculate the DAF for the active landfill. To complete the first MULTIMED run, the results from the first two HELP simulations will be used. The results from the simulation of leachate transport from open cell to the point of compliance are included in Appendix C. The parameters are explained in Table 40. The final line in the output (Appendix C) gives the "concentration after saturated zone model." For this example run, that number is $1.8 \times 10^{-4}$. Because the input parameter for "initial concentration at landfill" is 1 , this result indicated that for every parts per million of a constituent in the leachate, only $1.8 \times 10^{-4}$ part per million will be detected at the point of compliance for this particular scenario. Such a small change is unlikely to be distinguishable from background variability. The DAF is the reciprocal of the final concentration, or 5435. Since the conditions of this model run do not include any attenuation, the 5435-fold reduction in contaminate concentrations are purely a result of mixing and dilution with the surrounding groundwater.

\section{Closed Landfill}

The closed landfill scenario models the closed 200-acre landfill illustrated in Figure 76. A detailed description of the demonstration process for the closed landfill is provided below.

Step One: Calculate Recharge-The same run presented in the Active Landfill section can be used here.

\section{Step Two: Calculate Percolation} Rate-Another HELP simulation is necessary to estimate the quantity of leachate production from the entire landfill after closure. Table 41 lists and provides further explanation of parameter values chosen for this simulation run. The actual output is in Appendix D. The estimated average annual percolation rate after 20 years was 0.003 inches/year (as shown in Figure 76). The low-permeability cover layer 


\section{Table 38}

\section{Pre-Construction Groundwater Recharge Rate}

\begin{tabular}{|c|c|c|c|}
\hline $\begin{array}{l}\text { Variable } \\
\text { Name }\end{array}$ & Units & $\begin{array}{l}\text { Value } \\
\text { Used }\end{array}$ & Source \\
\hline Leaf area index & - & 2 & $\begin{array}{l}\text { Program provides table and explanation of each possible } \\
\text { value. Two was selected to represent a fair grass } \\
\text { condition. }\end{array}$ \\
\hline $\begin{array}{l}\text { Evaporative zone } \\
\text { depth }\end{array}$ & inches & 20 & $\begin{array}{l}\text { Program lists example depths and their relations, (i.e., } \\
20 \text { inches is for fair grass). }\end{array}$ \\
\hline Porosity & - & 0.3980 & \multirow{5}{*}{$\begin{array}{l}\text { Selected default values listed in model literature for a } \\
\text { silty clayey loam (classifies as SC using the unified soil } \\
\text { classification system) }\end{array}$} \\
\hline Field capacity & - & 0.2440 & \\
\hline Wilting point & - & 0.1360 & \\
\hline $\begin{array}{l}\text { Initial soil water } \\
\text { content }\end{array}$ & - & .2440 & \\
\hline $\begin{array}{l}\text { Saturated } \\
\text { hydraulic } \\
\text { conductivity }\end{array}$ & $\mathrm{cm} / \mathrm{sec}$ & $1.2 \mathrm{E}-4$ & \\
\hline $\begin{array}{l}\text { Number of } \\
\text { layers }\end{array}$ & - & 1 & Modeling the top layer of natural soil only. \\
\hline Layer type & $\therefore$ & $\begin{array}{l}\text { vertical } \\
\text { percolation } \\
\text { layer }\end{array}$ & $\begin{array}{l}\text { Selected this parameter to represent flow through silty } \\
\text { clay soil. }\end{array}$ \\
\hline $\begin{array}{l}\text { Thickness of } \\
\text { layer } 1\end{array}$ & inches & 120 & $\begin{array}{l}120 \text {-inches was selected as it represents the thickness of } \\
\text { this layer. }\end{array}$ \\
\hline $\begin{array}{l}\text { SCS runoff } \\
\text { curve number }\end{array}$ & - & 80 & Model default value. \\
\hline Area of surface & $\begin{array}{l}\text { square } \\
\text { feet }\end{array}$ & $13,068,000$ & $\begin{array}{l}300 \text { acres was chosen as an arbitrary large number for } \\
\text { this example. }\end{array}$ \\
\hline
\end{tabular}


Table 39

HELP for Modeling Open Landfill

\begin{tabular}{|c|c|c|c|}
\hline $\begin{array}{l}\text { Variable } \\
\text { Name }\end{array}$ & Units & $\begin{array}{l}\text { Value } \\
\text { Used }\end{array}$ & Source \\
\hline Leaf area index & - & 0 & $\begin{array}{l}\text { Ground will be bare and } 0 \text { corresponds to bare ground } \\
\text { on model generated list. }\end{array}$ \\
\hline $\begin{array}{l}\text { Evaporative } \\
\text { zone depth }\end{array}$ & inches & 18 & Estimate based on field studies of ash material. \\
\hline Porosity & - & 0.6020 & $\begin{array}{l}\text { Typical value derived from field studies of recently } \\
\text { deposited ash material. }\end{array}$ \\
\hline Field capacity & - & 0.4481 & $\begin{array}{l}\text { Typical value derived from field studies of recently } \\
\text { deposited ash material. }\end{array}$ \\
\hline Wilting point & - & 0.2459 & $\begin{array}{l}\text { Typical value derived from field studies of ash } \\
\text { material. }\end{array}$ \\
\hline $\begin{array}{l}\text { Initial soil water } \\
\text { content }\end{array}$ & - & 0.2460 & $\begin{array}{l}\text { Typical value derived from field studies of ash } \\
\text { material. }\end{array}$ \\
\hline $\begin{array}{l}\text { Saturated } \\
\text { hydraulic } \\
\text { conductivity }\end{array}$ & $\mathrm{cm} / \mathrm{sec}$ & $1 \times 10^{-4}$ & $\begin{array}{l}\text { Typical value derived from field studies of ash } \\
\text { material. }\end{array}$ \\
\hline $\begin{array}{l}\text { Number of } \\
\text { layers }\end{array}$ & - & 1 & Only modeling percolation through landfilled material. \\
\hline Layer type & - & $\begin{array}{c}\text { vertical } \\
\text { percolation } \\
\text { layer }\end{array}$ & $\begin{array}{l}\text { Most accurate description of layer type. See model- } \\
\text { provided list. }\end{array}$ \\
\hline $\begin{array}{l}\text { Thickness of } \\
\text { layer } 1\end{array}$ & inches & 120 & Modeling 10 feet of FBC by-product. \\
\hline $\begin{array}{l}\text { SCS runoff } \\
\text { curve number }\end{array}$ & - & 82 & Model default value. \\
\hline Area of surface & square feet & 435,600 & This is equal to 10 acres. \\
\hline
\end{tabular}


Table 40

MULTIMED for Open Cell

\begin{tabular}{|c|c|c|c|}
\hline Variable Name & Units & Value Used & Source/Comments \\
\hline \multicolumn{4}{|c|}{ General } \\
\hline - Run Option & - & $\begin{array}{l}\text { deterministic- } \\
\text { steady state }\end{array}$ & Steady-state* \\
\hline Active Models & - & $\begin{array}{c}\text { saturated zone } \\
\text { parameters and } \\
\text { source parameters }\end{array}$ & $\begin{array}{l}\text { Saturated Zone Parameters and Source } \\
\text { Parameters** }\end{array}$ \\
\hline \multicolumn{4}{|c|}{ Aquifer Saturated Zone Parameters } \\
\hline \multicolumn{4}{|l|}{ Depth and particle characteristics: } \\
\hline -Aquifer porosity & - & 0.437 & $\begin{array}{l}\text { Characteristics listed in model literature } \\
\text { for loamy sand. }\end{array}$ \\
\hline -Bulk density & $\mathrm{g} / \mathrm{cc}$ & 1.4 & Estimated value for loamy sand. \\
\hline -Aquifer thickness & $\mathrm{m}$ & 6.1 & See Figure 8-5. \\
\hline \multicolumn{4}{|c|}{ - Hydraulic and Dispersion Related Parameters } \\
\hline -Hydraulic conductivity & $\mathrm{m} / \mathrm{yr}$ & 536 & $\begin{array}{l}\text { Characteristics listed in model literature } \\
\text { for loamy sand }\left(1.7 \times 10^{-3} \mathrm{~cm} / \mathrm{sec}\right) \text {. }\end{array}$ \\
\hline -Hydraulic gradient & - & .000 & See Figure 8-5. \\
\hline \multicolumn{4}{|l|}{ Well Related Parameters } \\
\hline -Receptor distance from site & $\mathrm{m}$ & 121.9 & $\begin{array}{l}\text { Point of compliance at } 400 \text { feet } \\
\text { (see Figure 8-5). }\end{array}$ \\
\hline -Angle off center & degree & 0 & Most direct path to point of compliance. \\
\hline -Zone distance from water table & $\mathrm{m}$ & 0 & $\begin{array}{l}\text { Most direct route to screened area of } \\
\text { well. }\end{array}$ \\
\hline \multicolumn{4}{|l|}{ - Source Contaminant Data } \\
\hline -Infiltration rate & $\mathrm{m} / \mathrm{yr}$ & $2 \times 10^{-5}$ & $\begin{array}{l}\text { Percolation from landfill }\left(7 \times 10^{-4} \mathrm{in} / \mathrm{yr}\right. \\
\text { as determined from HELP). }\end{array}$ \\
\hline -Area of waste disposal unit & $\mathrm{m}^{2}$ & 40,468 & 10 acres. \\
\hline -Recharge rate & $\mathrm{m} / \mathrm{yr}$ & 0.122 & $\begin{array}{l}\text { Infiltration rate determined from using } \\
\text { HELP ( } 4.84 \mathrm{in} / \mathrm{yr}) \text {. }\end{array}$ \\
\hline -Initial concentration at landfill & $\mathrm{mg} / 1$ & 1 & $\begin{array}{l}1 \text { is used so that the model output can be } \\
\text { easily translated to all constituents. }\end{array}$ \\
\hline
\end{tabular}

* Using the steady-state model simplifies the modeling greatly by reducing the number of parameters. Steady-state conditions are also the more conservative approach.

** By excluding biodegradation from the simulation, the unsaturated zone can be omitted for the steadystate case. Removing the unsaturated zone is a simpler, more conservative approach to modeling the landfill leachate. 

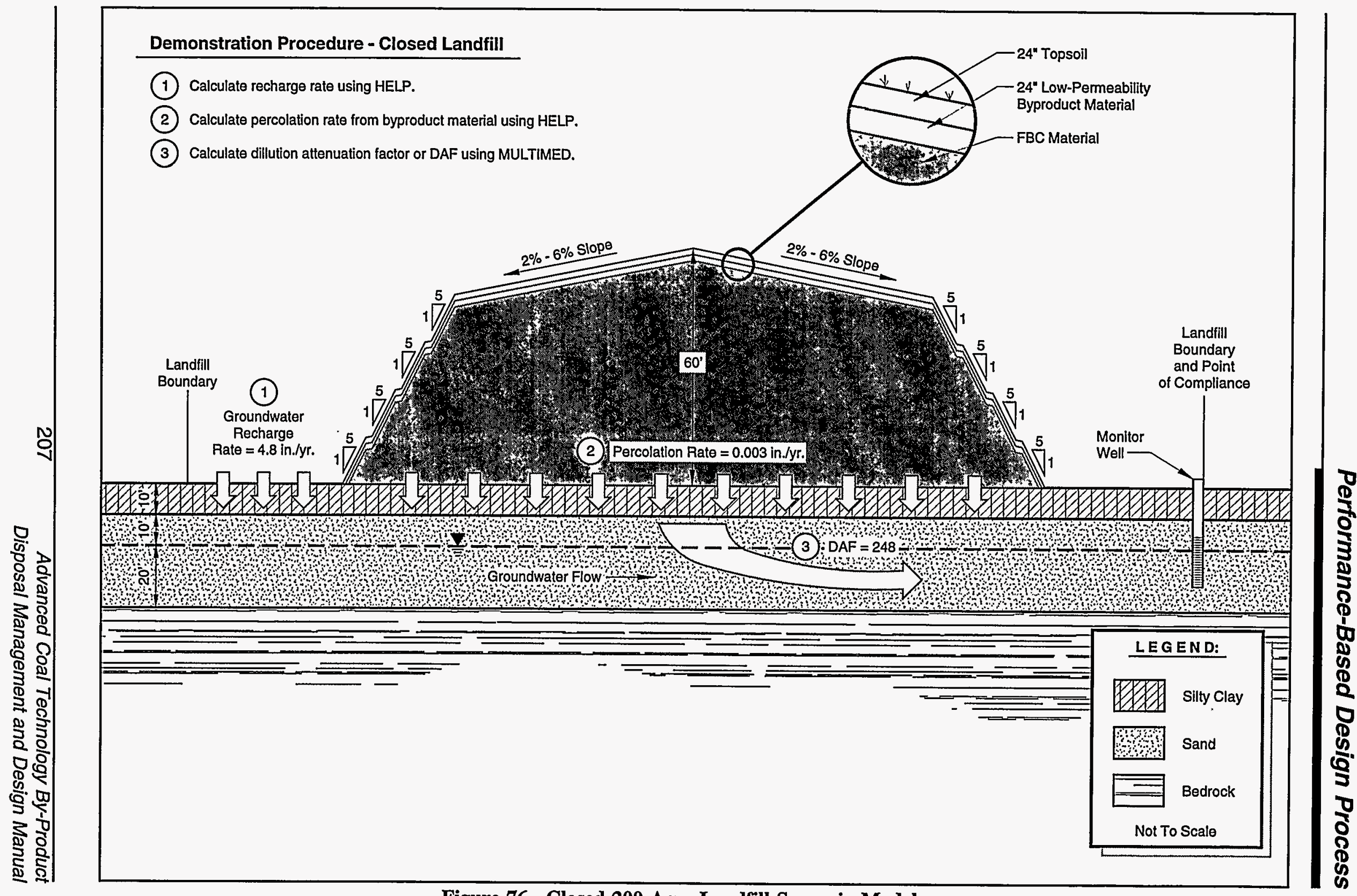

Figure 76. Closed 200-Acre Landfill Scenario Model 


\section{Table 41}

HELP for Modeling Closed Landfill Cell

\begin{tabular}{|c|c|c|c|}
\hline $\begin{array}{l}\text { Variable } \\
\text { Name }\end{array}$ & Units & $\begin{array}{l}\text { Value } \\
\text { Used }\end{array}$ & Source \\
\hline Number of Layers & - & 3 & $\begin{array}{l}\text { Simulating soil cover, Low-permeability by-product material, and } \\
\text { FBC by-product. }\end{array}$ \\
\hline Leaf area index & $\overline{-}$ & 2 & Two corresponds to fair grass in model explanation. \\
\hline Evaporative zone depth & inches & 20 & Typical value derived from field studies of ash material. \\
\hline Cover material: porosity & - & 0.3980 & $\begin{array}{l}\text { Selected default values listed in model literature for a silty clayey } \\
\text { loam (classifies as SC using the unfired soil classification system) }\end{array}$ \\
\hline Field capacity & - & 0.2440 & $\begin{array}{l}\text { Selected default values listed in model literature for a silty clayey } \\
\text { loam (classifies as SC using the unfired soil classification system) }\end{array}$ \\
\hline Wilting point & - & 0.1360 & $\begin{array}{l}\text { Selected default values listed in model literature for a silty clayey } \\
\text { loam (classifies as SC using the unfired soil classification system) }\end{array}$ \\
\hline Initial soil water content & - & 0.2440 & $\begin{array}{l}\text { Selected default values listed in model literature for a silty clayey } \\
\text { loam (classifies as SC using the unfired soil classification system) }\end{array}$ \\
\hline $\begin{array}{l}\text { Saturated hydraulic } \\
\text { conductivity }\end{array}$ & $\mathrm{cm} / \mathrm{sec}$ & $1.2 \mathrm{E}-4$ & $\begin{array}{l}\text { Selected default values listed in model literature for a silty clayey } \\
\text { loam (classifies as SC using the unfired soil classification system) }\end{array}$ \\
\hline Thickness of layer 1 & inches & 24.00 & Assuming 2 feet of cover material. \\
\hline $\begin{array}{l}\text { SCS runoff curve } \\
\text { number }\end{array}$ & -- & 80 & Model default value. \\
\hline $\begin{array}{l}\text { Low-permeability cover: } \\
\text { porosity }\end{array}$ & - & 0.4300 & Typical value derived from field studies of ash material. \\
\hline Field capacity & - & 0.3660 & Typical value derived from field studies of ash material. \\
\hline Wilting point & - & 0.2800 & Typical value derived from field studies of ash material. \\
\hline Initial soil water content & - & 0.2460 & Typical value derived from field studies of ash material. \\
\hline $\begin{array}{l}\text { Saturated hydraulic } \\
\text { conductivity }\end{array}$ & $\mathrm{cm} / \mathrm{sec}$ & $2 \mathrm{E}-7$ & Estimated value derived from laboratory tests of ash material. \\
\hline Thickness of layer 2 & inches & 24 & Two feet of low-permeability cover. \\
\hline $\begin{array}{l}\text { Landfill material: } \\
\text { porosity }\end{array}$ & - & 0.5876 & Typical value derived from field studies of ash material. \\
\hline Field capacity & - & 0.3566 & Typical value derived from field studies of ash material. \\
\hline Wilting point & - & 0.2459 & Typical value derived from field studies of ash material. \\
\hline Initial soil water content & - & 0.2460 & Typical value derived from field studies of ash material. \\
\hline $\begin{array}{l}\text { Saturated Hydraulic } \\
\text { Conductivity }\end{array}$ & $\mathrm{cm} / \mathrm{sec}$ & $1 \times 10^{-4}$ & Typical value derived from field studies of ash material. \\
\hline Thickness of layer 3 & inches & 480 & Typical landfill design height. \\
\hline Area of surface & $\begin{array}{c}\text { square } \\
\text { feet }\end{array}$ & $8,712,000$ & Equal to 200 acres. \\
\hline
\end{tabular}


and surface slope of the completed landfill prevent most rainfall from entering the landfill. However, the percolation rate is higher than the active cell percolation even though actual infiltration is lower. The FBC material's properties stabilize after absorbing several years of infiltration. Therefore, the infiltration into the landfill material is less likely to be trapped and will pass through as leachate.

Step Three: Calculate DAF-MULTIMED will be used to calculate the DAF for the closed landfill. The only parameters that change between the open cell run and this one are the "infiltration rate" and the "area of waste disposal unit," which are listed in Table 41. For the second simulation, the infiltration rate is taken from the closed landfill HELP results ( $0.003 \mathrm{in} / \mathrm{yr})$, and the landfill size is the full 200 acres. This MULTIMED run is shown in Appendix E. The resulting concentration at the point of compliance from this MULTIMED simulation for a closed cell is $4 \times 10^{-3}$. Therefore, for every part per million of a constituent in the leachate from a closed cell, approximately $4 \times 10^{-3}$ parts per million will be detected at the point of compliance for this particular scenario. The DAF is the reciprocal of the final concentration, or 248 .

\section{Conclusions}

Table 42 presents the constituent concentrations at the point of compliance on the basis of DAFs calculated in these two scenarios. Even though the approach to modeling the active and closed versions of the landfill was conservative, all the COCs were estimated to be under the regulatory limits. These scenarios illustrate that groundwater can be protected using simple engineering measures without the use of complex cap and liner systems specified in most state industrial solid waste regulations.

Table 42

Estimated Leachate Contribution to COC Concentrations at Point of Compliance $(\mathrm{mg} / \mathrm{L})$

\begin{tabular}{||l|c|c|c|c||}
\hline $\begin{array}{c}\text { Chemical of } \\
\text { Concern }\end{array}$ & $\begin{array}{c}\text { Regulatory } \\
\text { Limits }\end{array}$ & $\begin{array}{c}\text { Concentration in } \\
\text { Leachate }\end{array}$ & $\begin{array}{c}\text { Active Cell with } \\
\text { DAF = 5435 }\end{array}$ & $\begin{array}{c}\text { Closed Cell with } \\
\text { DAF = 248 }\end{array}$ \\
\hline Arsenic & 0.05 & 0.116 & $2.1 \mathrm{E}-5$ & $4.7 \mathrm{E}-4$ \\
\hline Barium & 1 & 0.077 & $1.4 \mathrm{E}-5$ & $3.1 \mathrm{E}-4$ \\
\hline Calcium & $250^{* *}$ & 1000 & 0.18 & 4 \\
\hline Chloride & $250^{*}$ & 2500 & 0.46 & 10 \\
\hline Chromium & 0.05 & 0.041 & $7.5 \mathrm{E}-6$ & $1.7 \mathrm{E}-4$ \\
\hline Lead & 0.05 & 0.031 & $5.7 \mathrm{E}-6$ & $1.3 \mathrm{E}-4$ \\
\hline Selenium & 0.01 & 0.152 & $2.8 \mathrm{E}-5$ & $6.1 \mathrm{E}-4$ \\
\hline Sodium & $250^{* *}$ & 2500 & 0.46 & 10 \\
\hline Sulfate & $250^{*}$ & 3500 & 0.64 & 14 \\
\hline
\end{tabular}

* Secondary MCLs listed in 40 CFR Part 143.

** Assuming background concentration of 230, total of leachate plus background should not exceed 250 . 
The models also illustrate that in many instances groundwater contamination by advanced coal technology by-products may consist primarily of common chemical compounds regulated under the total dissolved solids (TDS), chloride, or sulfate MCLs under federal secondary drinking water standards, rather than specific toxic metals such as arsenic, chromium, or cadmium. Furthermore, the models used above assume a constant source concentration over the entire 20-year period considered. In reality, the concentrations of many of the common salts which create the high TDS leachate decline rapidly in the first few years after landfill construction (see Chapter 9), reducing the longterm contaminant loading.

Finally, it should be mentioned that field tests suggest that low-permeability byproduct liners, such as the FBC/PFA cap described in this scenario, may not maintain a permeability as low as the $2 \times 10^{-7} \mathrm{~cm} / \mathrm{sec}$ value used in the model over their entire design lifetime. Increased liner/cap permeability will tend to increase infiltration and reduce the DAF. Field tests of FBC/PFA materials are continuing.

\subsection{Citations}

1. 56 Federal Register 50978 (October 9, 1991).

2. Electric Power Research Institute. EPRI CS-2801. FGD By-Product Disposal Manual, Third Edition. Palo Alto, California, 1983.

3. Bagchi, Amalendu. Design Construction, and Monitoring of Sanitary Landfill. John Wiley \& Sons, New York, 1990.

4. U.S. Environmental Protection Agency. The Hydrologic Evaluation of Landfill Performance (HELP) Model, Vol. II, Doc. for Version 1. EPA/530-SW-84 101. Cincinnati, Ohio, 1984.

5. U.S. Environmental Protection Agency. User Manual Supplement: Using MULTIMED to Evaluate Subtitle D Landfill Designs. Cincinnati, Ohio, 1993. 


\section{Results and Conclusions from Case Studies}

This chapter summarizes the results from the field testing program conducted from 1989 through 1994 at test sites located in Colorado, Ohio, and Illinois. Each site consisted of one or more landfill test cells constructed with dry lime-based $\mathrm{SO}_{2}$ control by-products. The sites were monitored to assess constructability, changes in by-product characteristics over time, and environmental performance. This chapter consists of a conceptual model of the behavior of the materials in the test cells in terms of cement formation, weathering, leaching, and migration of regulated constituents, and a compilation of summary data describing the performance of each of the test cases.

The conceptual model of landfill behavior developed in the first part of this chapter is limited to materials initially containing some mixture of coal ash, lime, and calcium sulfate/sulfite, since these are the basic components of the dry, lime-based $\mathrm{SO}_{2}$ control by-products included in the field study. Some discussion of the probable behavior of other types of advanced coal technology by-products, based on the initial characterization data from Chapter 3, is included at the end of this section. The data on transport and attenuation of dissolved constituents contained in the landfill leachate are likewise site-specific, and while they may represent general trends they should not be applied to other sites without further testing.

The second portion of this chapter discusses the field results from the six landfill test cells at the three test sites. The construction of these test cells generally followed the construction scenario detailed under Option 5 of Alternative 2 discussed in Chapter 7. The minimal design and engineering specifications of this option result in "worst case" results in these test cases; the amounts of water infiltrating the landfill test cells far exceeds what could be expected in a landfill constructed with a cap engineered to exclude water, and the leachate volumes affecting the groundwater are much greater than for landfills constructed with any sort of liner/leachate collection system. The changes in physical and chemical properties of the landfilled materials themselves are also much more rapid than would be expected for a landfill designed to exclude water. On the other hand, full-scale landfills will require continued monitoring for approximately ten times as long the test cells constructed for this project, given the standard thirty-year post-closure bonding period.

\subsection{Conceptual Model of Landfill Behavior}

After construction of a landfill with advanced coal technology by-products, natural forces will tend to gradually alter the initial state of the landfill. The weathering of the landfill materials represents a general trend toward chemical equilibrium with the surface environment. Dry, calcium-based $\mathrm{SO}_{2}$ control by-products have a high reactivity with water, and can undergo rapid initial reactions as a result of water added during construction activities. These reactions can lead to substantial changes in the physical properties of the landfill materials over a time period of months to years, especially if additional water is available. The physical changes can in turn affect the continued weathering of the landfill, including the quantity and quality of leachate produced from the landfill. Leachate percolating from the base of the landfill may migrate downgradient with the groundwater. 
As it migrates, leachate may undergo further reactions and dispersion. Transported leachate may eventually affect the concentrations of regulated species at point-of-compliance monitoring locations.

The conceptual model developed on the basis of field observations made under this project attempts to address all of the elements related to landfill performance, from landfill construction to permit compliance monitoring.

\subsubsection{Weathering and Changes in Mineral, Physical, and Chemical Properties}

Weathering of advanced coal technology by-product landfills is primarily caused by the actions of water infiltrating from the surface of the landfill. Surface erosion by wind or water is a secondary problem which is easily controlled through proper maintenance. In contrast to the cementitious reactions which occur after initial wetting and compaction of these materials, long-term exposure to water generally has a deleterious effect.

Water added during the landfill construction to aid placement and compaction initiates cementitious reactions, forming calcium hydroxide, gypsum, and ettringite. Over the course of the initial 30 to 90 days, these reactions increase the load-bearing strength of the materials and reduce permeability in comparison with the freshly placed materials. Long-term exposure to water reverses these trends and can gradually reduce the material to a loose, friable state. The rate and extent of the weathering depends on the initial composition of the by-products, how they are placed in the landfill, and the total amount of water which infiltrates the landfill. The process of cementation and weathering is shown schematically in Figure 77.

The initial composition of the byproducts will affect the extent of mineralization reactions which occur. In many cases the amount of water added during construction will not be enough to satisfy the long-term chemical water demand. In general, either the initial free lime content $\left[\mathrm{CaO}\right.$ plus $\left.\mathrm{Ca}(\mathrm{OH})_{2}\right]$ or the sulfate content of the ash will limit the total amount of water which can be incorporated into the solid in the long term, as shown in Table 43. Following initial construction, additional water infiltrating the landfill will first be partitioned into additional cement-forming minerals. Additional cement formation can produce further increases in load-bearing strength and decreases in permeability beyond the 30 to 90 day values, however, if the initial cementation has formed the compacted materials into a rigid structure, and if sufficient quantities of additional cements are created, fracturing and expansion may occur.

Fractures can reduce the load-bearing strength of the landfilled materials and may present structural problems depending on their location and the design slope and height of the landfill. Fractures also provide a channel for infiltration of additional water into an uncapped landfill. During a heavy rain, surface water can move rapidly along fractures and penetrate beyond the zone of evapotranspiration, increasing the fraction of incident rainwater that becomes leachate.

Standard tests for expansion such as American Society for Testing and Materials (ASTM) C-490 can provide an indication of the expansive potential of a given material. The test may require over a year to complete however, since expansion occurs after initial set of the materials and is slow. In addition, there are not enough data available to predict the correlation between expansion seen in the standard test and expansion in a landfill setting. The compressive forces exerted by overlying by-products and soils may tend to reduce the expansion ${ }^{1}$, but there is no standardized test or rule of thumb to quantify this effect.

If fracturing does not occur, continued growth of ettringite and other cementing minerals may continue to increase material 


\section{Micro View Macro View}

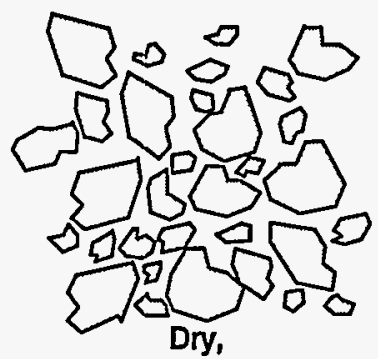

unconsolidated ash

\section{Key \\ Components}

Spent Sorbent Components:

- Anhydrite $\mathrm{CaSO}_{4}$

- Lime CaO

Coal Ash Components:

- Aluminosilicates
- Gypsum $\mathrm{CaSO}_{4} 2 \mathrm{H}_{2} \mathrm{O}$

- Portlandite $\mathrm{Ca}(\mathrm{OH})_{2}$

-Aluminosilicates

\section{Water addition}

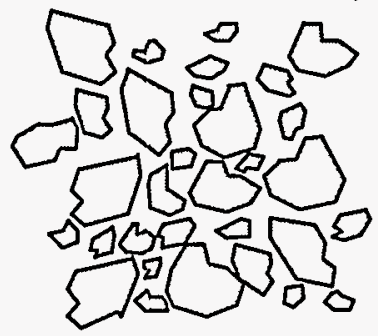

Anhydrite concentrations are dependent on the amount of sulfur in the coal.

Lime results from excess sorbent. Increased levels of sorbent-related materials "dilute" coal-ash materials like aluminosilicates.

Water is added to prevent dusting, improve ash handling, and aid compaction.

Cementing begins as gypsum forms.

Alkaline pore liquid forms.

\section{Wetted ash \\ Compaction, water and air exposure}

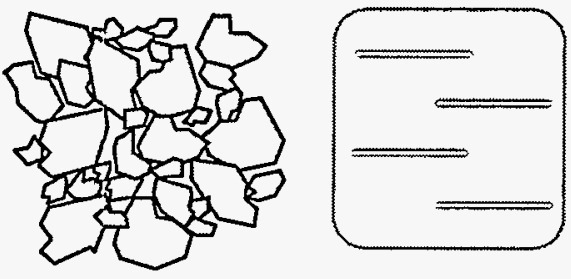

Consolidated fill
- Gypsum $\mathrm{CaSO}_{1} \cdot 2 \mathrm{H}_{2} \mathrm{O}$

- Portlandite $\mathrm{Ca}(\mathrm{OH})_{2}$

-Aluminum

- Calcite $\mathrm{CaCO}_{3}$

- Ettringite

$\mathrm{Ca}_{6} \mathrm{Al}_{2}\left(\mathrm{SO}_{4}\right)_{3}(\mathrm{OH})_{12} \cdot 26 \mathrm{H}_{2} \mathrm{O}$

- Calcium silicate hydrate

$(\mathrm{CaO})_{x} \mathrm{SiO}_{2} \cdot 11 \mathrm{H}_{2} \mathrm{O}$

Hydration reactions go to completion.

Cementing results from:

- Gypsum formation;

- Calcite formation; and

- Ettringite formation.

Strength increases.

Alkalinity is being consumed. Leachability reduces.

\section{Continued water exposure over time}
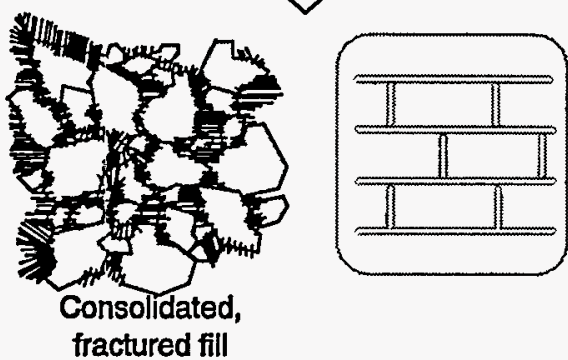

-Ettringite

-Thaumasite

$\mathrm{Ca}_{6} \mathrm{Si}_{2}\left(\mathrm{CO}_{2}\right)_{2}\left(\mathrm{SO}_{4}\right)_{2}\left(\mathrm{OH}_{12}\right.$

Increasing strength is potentially offset by swelling.

Decreasing permeability is offset by fracturing and secondary porosity.

Calcium and sulfate are consumed from gypsum, portlandite, and calcite to produce ettringite.

Thaumasite formation. Secondary gypsum formation in pores and fractures.

Figure 77. Conceptual Model for Hydration and Weathering of Calcium-Based Advanced Technology By-Products 


\section{Table 43}

\section{Theoretical Mineralization Potential and Chemical Water Demand of Advanced Coal Combustion By-Products}

\begin{tabular}{|c|c|c|c|c|c|c|}
\hline $\begin{array}{c}\text { Coal } \\
\text { Sulfur } \\
(\%)\end{array}$ & $\begin{array}{c}\mathrm{CaSO}_{4} \text { in } \\
\text { By-Product } \\
(\%)\end{array}$ & $\begin{array}{c}\text { Ca:S } \\
\text { Ratio } \\
\text { (molar) }\end{array}$ & $\begin{array}{c}\text { Available } \\
\text { Lime } \\
(\%)\end{array}$ & $\begin{array}{c}\text { Potential Ettringite } \\
\text { + Thaumasite } \\
(\%)\end{array}$ & $\begin{array}{l}\text { Chemical } \\
\text { Water } \\
\text { Demand } \\
(\%)\end{array}$ & $\begin{array}{c}\text { Limiting } \\
\text { Component }\end{array}$ \\
\hline \multirow{3}{*}{0.75} & 14.71 & 1.50 & 8.33 & 34.75 & 14.87 & $\mathrm{CaSO}_{4}$ \\
\hline & 16.15 & 2.00 & 11.40 & 37.92 & 16.46 & $\mathrm{CaSO}_{4}$ \\
\hline & 17.43 & 2.50 & 14.14 & 40.71 & 17.88 & $\mathrm{CaSO}_{4}$ \\
\hline \multirow{3}{*}{1.00} & 18.21 & 1.50 & 10.31 & 42.09 & 18.60 & $\mathrm{CaSO}_{4}$ \\
\hline & 19.72 & 2.00 & 13.93 & 45.32 & 20.32 & $\mathrm{CaSO}_{4}$ \\
\hline & 21.03 & 2.50 & 17.06 & 48.08 & 21.82 & $\mathrm{CaSO}_{4}$ \\
\hline \multirow{3}{*}{2.00} & 23.34 & 1.50 & 16.05 & 61.61 & 29.80 & $\mathrm{CaSO}_{4}$ \\
\hline & 29.51 & 2.00 & 20.84 & 64.01 & 31.32 & $\mathrm{CaSO}_{4}$ \\
\hline & 30.46 & 2.50 & 24.70 & 65.92 & 32.56 & $\mathrm{CaSO}_{4}$ \\
\hline \multirow{3}{*}{3.00} & 34.79 & 1.50 & 19.70 & 72.84 & 37.25 & $\mathrm{CaSO}_{4}$ \\
\hline & 35.37 & 2.00 & 24.97 & 74.15 & 38.18 & $\mathrm{CaSO}_{4}$ \\
\hline & 35.81 & 2.50 & 29.04 & 75.14 & 38.89 & $\mathrm{CaSO}_{4}$ \\
\hline \multirow{3}{*}{3.50} & 37.21 & 1.50 & 21.07 & 76.82 & 40.10 & $\mathrm{CaSO}_{4}$ \\
\hline & 37.49 & 2.00 & 26.47 & 77.65 & 40.71 & $\mathrm{Al}(\mathrm{OH})_{3}$ \\
\hline & 37.71 & 2.50 & 30.58 & 78.24 & 41.15 & $\mathrm{Al}(\mathrm{OH})_{3}$ \\
\hline
\end{tabular}

$\mathrm{CaSO}_{4}$ in by-product calculated based on $60 \%$ sulfur removal at $\mathrm{Ca}: \mathrm{S}=1.5$, and $10 \%$ ash in coal

$70 \%$ sulfur removal at $\mathrm{Ca}: \mathrm{S}=2.0,10 \%$ ash in coal

$80 \%$ sulfur removal at $\mathrm{Ca}: \mathrm{S}=2.5,10 \%$ ash in coal

Available lime calculated as $\mathrm{CaO}$ assuming $95 \%$ calcination.

Ettringite plus thaumasite formation was calculated assuming that ettringite is the only phase formed under conditions where $\mathrm{CaO}_{\mathrm{O}}$ or $\mathrm{CaSO}{ }_{4}$ is limiting.

Fly ash composition is assumed to be $45 \% \mathrm{SiO}_{2}$ and $25 \% \mathrm{Al}_{2} \mathrm{O}_{3}$; excess water is assumed.

Percentages expressed in terms of total sample weight after reaction.

Chemical water demand expressed as percent initial dry weight.

strengths. Well-cemented fragments of Limestone Injection Multistage Bruners (LIMB) material in one Ohio site test cell developed unconfined compressive strengths of up to $2000 \mathrm{psi}$, and the maximum average strength for unfractured portions of the test cells was over $1200 \mathrm{psi}$, reached approximately 10 months after construction. Correspondingly, the permeability of well cemented samples may be as low as $10^{-7} \mathrm{~cm} / \mathrm{sec}$. Mixtures of FBC by-products with pulverized coal fly ash such as those tested in the Illinois site Cells 2 and 3 can achieve even higher strengths and lower permeabilities, and generally exhibit lower expansion than the LIMB ash.

Despite the high strengths attained by some fragments, weathering reactions tend to degrade the physical properties of the byproducts. The total amount of water infiltrating the landfill will affect the rate of weathering reactions. Over time, as additional moisture moves through the landfill, zones of weakness tend to develop, producing a greater 
spread of values in unconfined compressive strength tests and increased permeabilities in core samples. Over time, fracturing and dissolution may make the physical properties of advanced coal by-products resemble those of soils, rather than cemented materials ${ }^{2}$. Two factors which are implicated in these continued changes in physical properties are 1) the development of large secondary pores, and 2) the growth of the mineral thaumasite.

Secondary pores develop as surface water with initially low dissolved solids concentrations moves through the landfill and leaches out soluble species. Rainwater is generally slightly acidic and ettringite is stable only at $\mathrm{pH}$ values greater than about 10 , so ettringite breaks down along fractures carrying percolating water, leaving a lining of gypsum. Residual portlandite is also subject to dissolution. As the number and size of secondary pores increases the permeability also increases. The growth of secondary pores is directly related to the volume of soluble material removed, and thus the amount of water which moves through the landfill.

The secondary pores not only provide additional channels for the rapid movement of water through the landfill, but may also significantly affect the composition of the leachate produced from the test cell. Since pores rapidly become lined with gypsum, the percolating water experiences an environment significantly different from the bulk composition of the landfill, which may consist primarily of ettringite, thaumasite, gypsum, and portlandite. Equilibrium chemistry suggests that the leachate from gypsum-lined pores will have a much lower $\mathrm{pH}$, lower total dissolved solids, and higher calcium concentration than samples from the bulk material, which are in contact with a non-equilibrium assemblage including portlandite, calcite, and ettringite. This assemblage tends to increase the $\mathrm{pH}$ and depress the calcium concentration of the solution. Low calcium concentrations can cause the concentrations of sulfate and other ions to increase dramatically since they are linked through the solubility properties of gypsum and other solid phases.

Continued weathering of lime-based advanced coal technology by-products can also result in thaumasite formation. The mineral thaumasite, which is structurally similar to ettringite, can form instead of ettringite when sufficient carbonate and silicate are present in solution. Thaumasite formation is associated with decreased strength and increased permeability of the landfill materials. The mechanisms for these effects of thaumasite formation are unclear, although the flat, matted habit of thaumasite may provide planes of cleavage whereas the ettringite needles provide an interlocked, three-dimensional network.

In the LIMB test cells where it was found, thaumasite formation was first noted approximately one year after construction. No significant amounts of thaumasite have been detected in any FBC test cells. The amount of soluble silicate glass present in FBC residues may be insufficient to form detectable amounts of thaumasite. The delay in thaumasite formation may be due to the cooler temperatures following the first winter of exposure and the availability of dissolved carbonate. Some authors suggest that thaumasite forms only at temperatures below $15^{\circ} \mathrm{C}^{3}$. The first detection of thaumasite in the Ohio test cells occurred following the first winter when the temperature was $15^{\circ} \mathrm{C}$ or less throughout the test cells.

The carbonate required for thaumasite formation may be derived from calcium carbonate present in the initial ash or from $\mathrm{CO}$ ${ }_{2}$ absorbed from the atmosphere. Only a small amount of carbonate is required to form thaumasite; the dissolution of approximately 2 weight percent calcite supplies enough carbonate to form 30 weight percent thaumasite, based on the nominal formula for pure endmember thaumasite. Semi-quantitative $x$-ray diffraction analyses suggest that a loss of calcite of this magnitude accompanied the formation of thaumasite in the LIMB test cells 
although this is near the limit of quantification for the method. Scanning electron microscope (SEM) micrographs of landfill cores also show dissolution pits on calcite grains, again indicating that calcite became undersaturated in the test cells and could have served as a source of carbonate for thaumasite formation.

Respiration in the root zone of vegetation established on the soil cover approximately one year after test cell construction may also have supplied some dissolved carbonate to the test cells. Although there is no clear correlation between thaumasite abundance and proximity to the soil cover, thaumasite is found largely along fracture surfaces which represent pathways for the movement of percolating water. This mode of occurrence suggests that an external source of carbonate may be important to thaumasite formation as well as the calcite contained in the ash.

In the long term, additional weathering of ettringite and thaumasite is likely. The details of the ettringite and thaumasite alteration are not well understood at present, but will be affected by both equilibrium and kinetic effects. Both of these minerals are stable only at alkaline pHs. The excess free lime which is present in most lime-based $\mathrm{SO}_{2}$ control by-products will buffer the $\mathrm{pH}$ of the bulk material at $\mathrm{pH} 12$ to 12.5 , but as calcium hydroxide is dissolved away, first near larger pores and fractures and then in the bulk material, ettringite and thaumasite will be subject to attack. By-products containing higher concentrations of calcium sulfate relative to lime, reflecting a higher $\mathrm{Ca}$ utilization value, may be totally depleted of free lime following ettringite and thaumasite formation. Without lime to buffer the $\mathrm{pH}$, these materials may be subject to more rapid weathering.

Rain water and soil pore waters carrying dissolved $\mathrm{CO}_{2}$ are slightly acidic and will gradually alter ettringite and thaumasite into a mixture of common soil minerals including gypsum, calcite, and aluminum and silicon oxides or hydroxides. Despite these equilibrium constraints, ettringite and thaumasite may persist as metastable phases for a considerable period of time because of kinetic barriers. Altered ettringite and thaumasite will not simply dissolve away, and the alteration products may retain the physical shape of the original crystals despite chemical and mineralogical changes. The long-term strength and stability of soils derived from an altered ettringite/thaumasite assemblage has not been determined, and the time scale required to complete these mineralogical changes is unknown.

More details of the weathering process and mineralogical transformations of the landfilled materials in specific field examples are provided in Section 9.2.

\subsubsection{Leachate Generation and Attenuation}

The lime-based advanced coal technology by-products examined in the field study initially were able to absorb large amounts of water without producing leachate. The combination of chemical reactions which bind water into the solids and the microporous structure of the bulk material allow large amounts of water to be held without drainage. In some samples the field capacity was near $100 \%$ on a dry weight basis. The high field capacity of these materials may allow all or most of the rainfall incident on the landfill during its uncovered construction phase to be stored without drainage. If run-on controls and an engineered cap system are included in the final design little or no leachate may be produced even in relatively wet environments.

In the field test cells constructed for this project, the cover soils were engineered to support a vegetative cover and minimize erosion, but not to exclude water. With this type of cap and with continued exposure to precipitation, in most disposal environments the field capacity of the materials is eventually reached and leachate drainage begins. The amount of leachate generated under these 
minimally engineered conditions depends on the amount of water percolating past the zone of evapotranspiration, generally the uppermost one to two feet of the cover soil. Under the site conditions in Illinois and Ohio this resulted in an average of approximately $20 \%$ of the incident rainfall percolating through the test cells and emerging from the base of the landfill as leachate.

The test cells constructed for this project represent a worst-case scenario in terms of leachate volume produced. As discussed in Chapter 8, leachate production can be reduced by increasing evapotranspiration, increasing surface runoff, providing lateral drainage, or by including a low permeability barrier layer in the cap design. Measures which increase evapotranspiration include better vegetation and slower percolation of water past the root zone. Runoff can be increased by increasing the surface slope of the completed landfill or by reducing the permeability of the surface layer. Lateral drainage is created when a permeable layer overlies a less permeable zone with adequate slope. Low permeability barriers can consist of compacted clay or clay amended native soil, or synthetic membrane liners.

Leachate production models such as the Hydrologic Evaluation of Landfill Performance (HELP) model $^{4}$ (refer to Chapter 8) are common tools used to guide regulatory requirements for landfill design and operation. Because of the unique properties of lime-based advanced coal combustion by-products, these models should be used with care. Default values derived from non-reactive soil materials or pulverized coal fly ash may not apply to advanced coal combustion by-products. More specialized leaching models, such as the FOWL ${ }^{\text {TM }^{5}}$ code developed by the Electric Power Research Institute (EPRI), may better represent the leaching of advanced coal byproducts. The reactive potential of the materials must also be accounted for in predicting the amount of free water which will be produced as leachate. Fractures and other discontinuities in the material properties of the landfill are also not accounted for in most models, and can contribute significantly to the overall bias of the results.

Leachate quality is related to the initial composition of the materials placed in the landfill, the extent of subsequent reactions in the landfill, and the amount of leachate that is produced. The initial composition of the landfill materials places certain limits on leachate composition. For example, materials with a very low concentration of a particular trace element generally will not produce leachate with high concentrations of that element unless it is strongly partitioned into the liquid phase. Likewise, materials which do not contain free lime or other alkalis will not have an elevated $\mathrm{pH}$.

Reactions that change the mineralogy of the landfilled materials can have a profound effect on their solubility and on leachate quality. In addition, trace species leachability can be changed by mineralogical reactions, as some species are strongly bound to newly formed solids. Research has shown that many trace metals (i.e., arsenic, boron, and selenium) can be removed from solution into ettringitestructure minerals under some circumstances ${ }^{6}$.

Leachate volume is inversely proportional to leachate concentrations for many common ions that are not controlled by solubility. If only a small amount of leachate is generated, it will contain relatively high concentrations of the most soluble species. After a large amount of leachate has been produced, the concentrations of many species are significantly reduced as the most soluble species are washed out ${ }^{7}$.

The transport and dispersion of landfill leachate in the vadose zone below the landfill and in the shallow groundwater downgradient of the source area can be modeled with a variety of codes of varying complexity. Water movement in the unsaturated and saturated zones can be evaluated using models such as 
HELP and MULTIMED ${ }^{8}$, which are discussed in Chapter 8 of this manual, or other independently developed models such as EPRI's FOWL ${ }^{5}$, MYGRT $^{9}$ or FASTCHEM ${ }^{10}$ models. Site-specific and by-product-specific data may be required for model input and, depending on the variability of the hydrogeological conditions at a particular site and the amount of data available, model predictions may be possible only within broad limits. Regulatory requirements should be checked before any site modeling is initiated.

Chemical reactions that immobilize some leachate components can take place in the soils or groundwater as the leachate encounters changing conditions of $\mathrm{pH}$, oxidation-reduction potential, temperature, and the presence of other chemical components in the soils or groundwater. In general, these reactions either retard the rate of transport of dissolved species relative to the rate of transport of the water itself through reversible reactions or reduce the dissolved concentrations of some species by means of irreversible reactions. Reversible reactions may include surface adsorption and/or cation exchange reactions that have a limited capacity to fix leachate components. Cationic species, and polyvalent metals in particular, are generally more highly retarded than anions or uncharged species since they are more strongly bound to cation exchange sites on clay minerals. Precipitation reactions are the most important irreversible reaction mechanism; precipitation can provide an essentially unlimited sink for certain species under stable subsurface conditions.

A number of models are available to predict transport on the basis of more or less sophisticated chemical codes. Most models do not treat geochemical reactions mechanistically (the EPRI FASTCHEM model is an exception), but use overall "retardation factors" to represent all processes of precipitation and adsorption. Accurate mechanistic modeling requires a considerable amount of site-specific data as input for both the chemistry and hydrogeology of the landfill area. Localized variations in aquifer properties such as discontinuous bedding, fractures or faults, and oxidation-reduction boundaries are common and complicate both physical and chemical modeling. Although models should not be relied upon for precise estimates of contaminant concentrations in groundwater or plume migration rates, they can be very useful for applications such as siting compliance monitoring locations and determining critical design sensitivities.

Anions, and particularly highly soluble species such as chloride, are useful as early indicators of leachate migration from landfills since they generally travel faster in groundwater than the trace metals which are the primary regulatory focus. Although compliance monitoring often does not require measurement of these species, early warning of any problems may reduce the need for corrective action, justifying the additional monitoring expenses.

The data on leachate generation and contaminant migration gathered during the field testing associated with this project are described in greater detail with specific examples from the field test cases in Sections 9.2 and 9.3.

\subsubsection{Behavior of Other Advanced Coal Technology By-Products}

The weathering of other types of advanced coal technology by-products can follow quite different pathways than those discussed for calcium-based $\mathrm{SO}_{\mathrm{x}}$ control systems. The different technologies can be grouped according to whether the coal ash fractions and the sulfur/sorbent fractions are managed separately or together and according to the sulfur removal technology employed. These two variables determine the range of chemical components present in the by-product stream and their mineral form. These initial conditions play a large role in determining type of reactions which will occur following 
disposal and the appropriate landfill design criteria. Table 44 summarizes the different weathering reactions and by-product management issues for a range of advanced coal technologies.

Ash from pressurized fluidized bed combustion (PFBC) is similar to the materials used in this field study; although the amount of free lime contained in PFBC ash is much lower than in atmospheric fluidized bed combustion (AFBC) ash, essentially the same suite of minerals is initially present, although if dolomite or dolomite limestone is used as the sorbent, magnesium oxide will be present in the ash $^{11,12}$. Similar reactions to form gypsum and ettringite are likely. The lower initial lime content will limit the amount of ettringite which can form and may lead to more rapid dissolution of these minerals since the $\mathrm{pH}$ is not as well buffered. In the short term, heat generation on wetting and expansion because of ettringite formation will probably not be important considerations with $\mathrm{PFBC}$ ash.

Sodium injection shares many characteristics with the LIMB process included in this field study; however, the landfill behavior of the two types of by-products is likely to be quite different. Sodium injection by-products do not contain any calcium in addition to that which is contained in the mineral fraction of the coal. In the case of coals producing class $\mathrm{F}$ fly ash, the amount of calcium may be too low to permit formation of significant amounts of ettringite or thaumasite as suggested by the low strengths reported for prepared samples of sodium injection byproducts ${ }^{13}$. The low liquid limit and the high solubility of sodium injection by-products suggest that severe stability problems may result from exposure to any significant amounts of water. Poor leachate quality, primarily from the dissolution of highly soluble sodium sulfates, is also a major concern with sodium injection by-products. Highly alkaline, sulfaterich leachates from sodium injection byproduct landfills may cause ettringite precipitation if they interact with calcium alumino-silicate minerals beneath the landfill.

By-products from advanced wet FGD and spray-drier technologies differ from the materials considered in the field study in that the mineral portions of the coal are typically managed separately from the flue-gas desulfurization by-products. Coal ash associated with these processes is typical of pulverized coal fly ash and has been discussed extensively in other publications ${ }^{14,15}$.

The by-products from advanced FGD systems differ from traditional FGD sludge primarily as a result of additives, typically organic acids, which are added to the system to improve $\mathrm{SO}_{2}$ removal efficiency and sludge handling characteristics. Although these additives do not generally affect the mineral composition of the FGD by-products, additives may affect the utilization potential and disposal characteristics of the materials. Some additives may result in by-product gypsum that does not meet established criteria for reuse in construction materials or agriculture although results from an internal proprietary study at Radian Corporation suggest that this is not a major concern ${ }^{16}$. Organic acids subject to biological decomposition will increase the chemical and biological oxygen demand of the waste and may result in anaerobic conditions. Under anaerobic conditions, sulfate or sulfite in the FGD sludge may be reduced to sulfide, potentially creating hydrogen sulfide gas.

The by-products of coal gasification generally include the mineral components of the feed coal and elemental sulfur recovered from the gasified fraction. The elemental sulfur is generally marketed for reuse rather than disposed of and represents no special handling problems. The coal ash fraction resulting from gasification is significantly different from the coal ash resulting from pulverized coal combustion. Gasification is carried out under reduced or only partially oxidized conditions; the minerals in the coal are not fully converted to the oxide form and 
Table 44

Management Issues for Various Advanced Coal Technologies

\begin{tabular}{|c|c|c|}
\hline Technology & Potential Reactions & Potential Management Issues \\
\hline AFBC & $\begin{array}{l}\text { Lime hydration } \\
\text { Anhydrite hydration } \\
\text { Ettringite formation }\end{array}$ & $\begin{array}{l}\text { Heat generation on initial hydration } \\
\text { Dusting during dry handling/transport } \\
\text { Premature set during wet transport } \\
\text { Swelling and dimensional instability possible } \\
\text { High leachate pH, possibly over } 12.5 \\
\text { Elevated TDS and trace metals in leachate }\end{array}$ \\
\hline LIMB & $\begin{array}{l}\text { Lime hydration } \\
\text { Anhydrite hydration } \\
\text { Ettringite and thaumasite for- } \\
\text { mation }\end{array}$ & $\begin{array}{l}\text { Heat generation on initial wetting } \\
\text { Premature set during transport } \\
\text { Swelling and dimensional instability likely } \\
\text { High leachate pH, possibly over } 12.5 \\
\text { Elevated TDS and trace metals in leachate }\end{array}$ \\
\hline PFBC & $\begin{array}{l}\text { Anhydrite hydration } \\
\text { Magnesium oxide hydration }\end{array}$ & Elevated TDS and trace metals in leachate \\
\hline Gasification & Largely inert glass & $\begin{array}{l}\text { Possible mobilization of PAHs and reduced car- } \\
\text { bon species } \\
\text { Trace metal mobilization in leachate } \\
\text { Leachate } \mathrm{pH} \text { may be alkaline or acidic }\end{array}$ \\
\hline $\begin{array}{l}\text { Advanced } \\
\text { Wet FGD }\end{array}$ & $\begin{array}{l}\text { Additives may chelate metals } \\
\text { Additives may create reduced } \\
\text { sulfur compounds }\end{array}$ & $\begin{array}{l}\mathrm{H}_{2} \mathrm{~S} \text { production } \\
\text { Organic acids may mobilize trace metals } \\
\text { Additives may make by-products less attractive } \\
\text { for utilization. } \\
\text { High chemical oxygen demand }\end{array}$ \\
\hline $\begin{array}{l}\text { Spray- } \\
\text { Dryers }\end{array}$ & $\begin{array}{l}\text { Possible ettringite/ } \\
\text { thaumasite formation }\end{array}$ & $\begin{array}{l}\text { Alkaline leachate } \\
\text { Elevated TDS and trace metals in leachate } \\
\text { Cementitious reactions similar to LIMB ash if } \\
\text { combined with class F fly ash }\end{array}$ \\
\hline $\begin{array}{l}\text { Sodium } \\
\text { Injection }\end{array}$ & High solubility sodium salts & $\begin{array}{l}\text { Rapid leaching and strength loss after initial set } \\
\text { High leachate pH; may be above } 12.5 \\
\text { Elevated TDS and trace metals in leachate }\end{array}$ \\
\hline
\end{tabular}

TDS $=$ Total Dissolved Solids

FGD = Flue Gas Desulfurization

PAH $=$ Polycyclic Aromatic Hydrocarbon 
some residual refractory hydrocarbons may remain in the ash fraction. Gasification ash is generally a glassy slag with much larger particle size and lower leachability than pulverized coal fly ash. Some gasification processes may also generate a separate fly ash stream. Process conditions and feed coals used in various gasification technologies vary considerably and can effect ash characteristics. Under some conditions acidic leachate can be generated as reduced sulfur species in the ash oxidize. Organic fractions associated with gasification ash are generally either highly condensed molecules or are bound to residual graphite and are generally not leachable in water ${ }^{17,18}$.

\subsection{Data from Landfill Test Cells}

This subchapter provides data summarizing the initial ash composition, landfill construction engineering, and environmental performance for each of the six landfill test cells constructed at three separate locations. Data for the single test cell at the Colorado site and the two test cells at the Ohio site cover a three-year monitoring period. (The monitoring programs in Colorado and Ohio are complete.) Additional samples, collected approximately five years after test cell construction, are currently in analysis. Because of permitting and construction delays, only two years of environmental data are available for the fluidized bed combustion (FBC) test cell at the Illinois site, and less than one year of data is available for the two FBC/fly ash mix test cells.

The complete sets of results for three years of testing at the Colorado and Ohio sites have been compiled in two site-specific reports. These reports and their appendices are intended to serve as the primary record of testing conducted under this project; electronic data files will also be made available to interested researchers. Readers desiring more complete results and discussion than are provided in this summary are referred to these two reports ${ }^{19,20}$. A complete site report also will be prepared for the Illinois test cells at the completion of all monitoring at that site.

\subsubsection{Colorado Site Results}

Results from engineering and physical properties tests of the FBC ash during construction operations and from subsequent environmental performance testing are presented below.

\section{Engineering Results}

The engineering properties of the FBC material in the landfill test cell are controlled by the initial by-product composition, the method of placement, and the climate of the test site.

By-Product Composition-The Nucla plant FBC residues are relatively low in lime and sulfate because they are the product of combustion of a low sulfur western coal. The FBC residues were collected during Nucla plant test runs firing a sub-bituminous coal with $0.7 \%$ sulfur, and using a low-magnesium limestone sorbent. The low overall lime and sulfate content of the residues limits the cementitious activity of this material.

Climate Factors-The test site climate is temperate and semi-arid, with an average annual rainfall of 11 inches. Landfill construction occurred in June 1989 during warm, dry weather.

Ash Moisture-Construction-The dry ash was conditioned with sufficient water to prevent dusting during transport. The moisture content of the ash trucked to the site varied from $1 \%$ to $40 \%$, with an average of approximately $35 \%$ (dry basis). The optimum moisture content for compaction was 37 percent. At the test site a bulldozer spread and compacted the ash across the cell in lifts 4"-6" thick to make a total thickness of approximately 8 feet. Evaporation during cell construction reduced the moisture content of the wastes to less than 20 percent. Compaction 
during construction resulted in a dry density of $52 \mathrm{lb} / \mathrm{ft}^{3}$, only $65 \%$ of the maximum dry density (Proctor density) of $78.6 \mathrm{lb} / \mathrm{ft}^{3}$ for the fly ash/bottom ash mix placed in the test cell.

Ash Moisture-Long-Term-The moisture content of the landfilled FBC residues has increased $3 \%$ to $4 \%$ per year as shown in the top left graph in Figure 78. The present moisture content is well below the field capacity of the materials, and no drainage of leachate has occurred. Analysis of laboratorygenerated leachates from soils underlying the test cell indicate that no leachate migration has occurred. If the current trend of increasing moisture continues, the moisture content would theoretically reach saturation, at approximately $52 \%$, and some leachate drainage may begin to occur. Long term predictions using the HELP model suggest that the current trend will not continue, and that no drainage will occur over the next 20 years. The results of the model simulation are shown in Table 45. The rainfall value used for the long term model run is based on data from Grand Junction Colorado, and is somewhat lower than the average measured rainfall at the test site.

\section{Table 45}

Colorado Site Hydrologic Budget Simulation Results for Long-Term (20-Year) Simulation, Average Values

\begin{tabular}{||l|c|r||}
\hline \multicolumn{1}{|c|}{ Parameter } & $\begin{array}{c}\text { Inches of } \\
\text { Water }\end{array}$ & Percent \\
\hline Precipitation & 7.94 & 100.00 \\
\hline Runoff & 0.00 & 0.00 \\
\hline Evapotranspiration & 7.634 & 96.12 \\
\hline Percolation & 0.00 & 0.00 \\
\hline $\begin{array}{l}\text { Change in Water } \\
\text { Storage }\end{array}$ & 0.308 & 3.88 \\
\hline
\end{tabular}

Ash Permeability-The permeation of water through the materials of the test cell is largely controlled by the presence of fractures. Permeability estimates from the literature for indurated FBC materials were two to three orders of magnitude lower than measured values. This is a result of the fractures and the variable nature of the landfilled material. The landfill permeability was measured both on core samples and by using an in situ permeameter, as shown in the upper right graph in Figure 78. Mean core permeabilities increased steadily over time, although individual measurements vary considerably. In situ permeability measurements, that are considered more reliable, remained relatively constant during the three years of field monitoring. In situ measurements vary less since a larger volume of material is tested, thus averaging out the variability introduced by small fractures. The predicted correlation between decreased permeability and pozzolanic activity appears to hold true at the microstructural scale based on SEM observations of the materials.

Load-Bearing Strength-The average compressive strength of the landfilled materials has not changed significantly over the course of the three years of monitoring. Initial strength development was greater in some portions of the landfill than in others. The variability in strength measurements increased during the monitoring period. The bottom graph in Figure 78 shows results of strength tests on core samples from the test cell. According to the results of microstructural analysis, strength development appears to correlate with ettringite growth in zones accessible to percolating water.

\section{Environmental Measurements and Long-Term Monitoring Data}

Environmental data collected at the test site included information on runoff volumes and runoff water quality, changes in ash mineralogy, and ash leachability. 

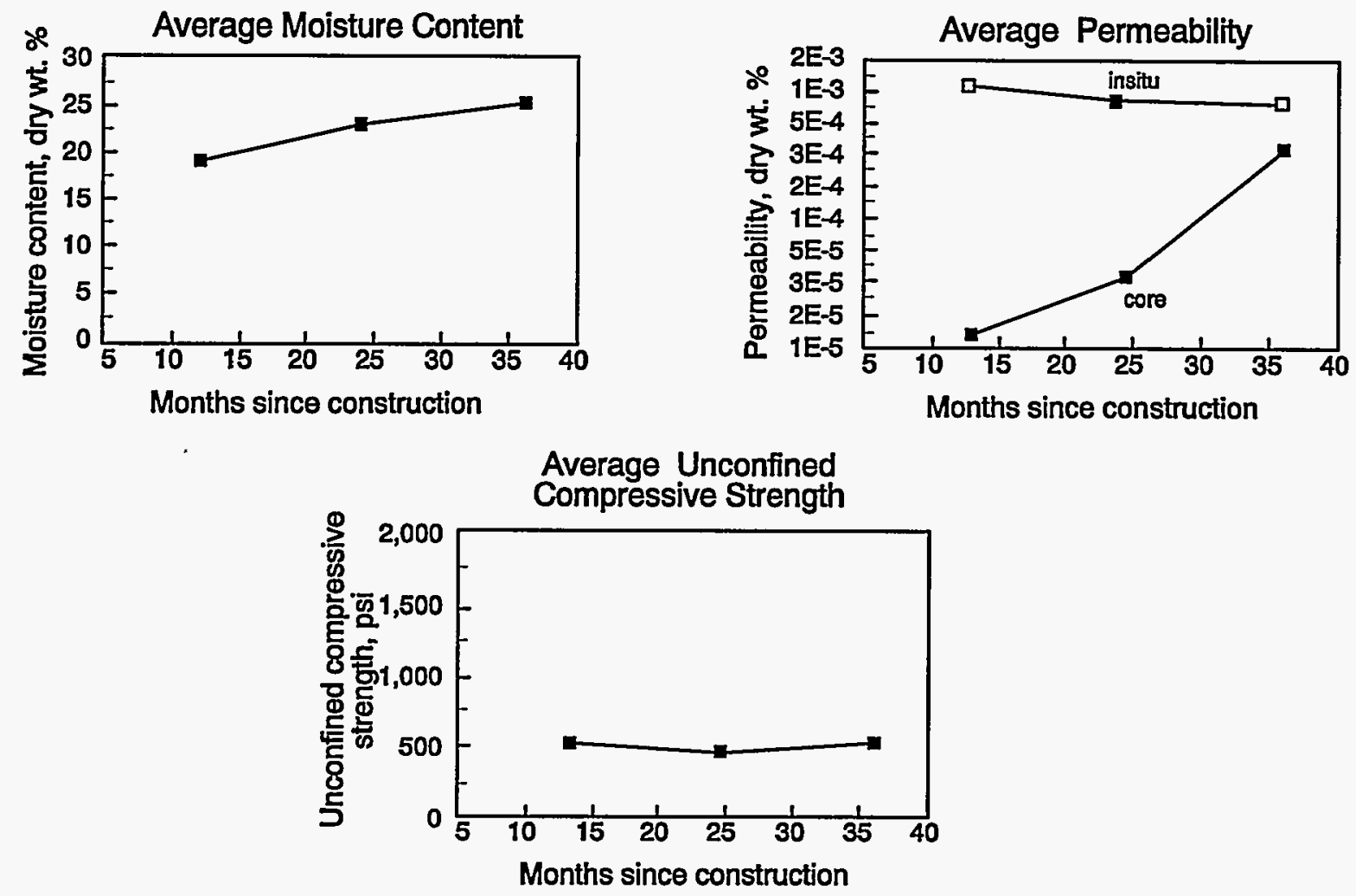

Figure 78. Average Physical Properties of Core Samples from the Colorado Test Cell

The moisture content of the ash increases over time despite the excess evaporation rate at the site. The permeability of core samples also increases during the monitoring period. The average compressive strength remains constant, although the variability of individual measurements increases.

Surface Runoff Volume-The only documented releases from the test cell at the Colorado site were small amounts of surface runoff. Runoff samples were collected twice during the first year after cell construction. After one year the landfill was capped with soil and the runoff collection system was removed. The total amount of runoff from the test cell was less than five gallons. The microporous nature of the FBC ash in the test cell appears to be able to absorb rainfall from light to moderate events without producing any runoff. The generally dry climate and the low slope of the landfill surface also reduce the runoff potential.

\section{Surface Runoff Quality-Both} samples of runoff were analyzed to determine the runoff water quality. The two samples were generally similar in composition. Calcium and sulfate were the primary dissolved species. Low concentrations of other common analytes, including chloride, fluoride, mag- 
nesium, and sodium, were also present. The $\mathrm{pH}$ was between 8 and 9 . These results suggest that runoff occurs primarily during heavy rainfall events and that the resulting runoff is a dilute calcium sulfate solution with low alkalinity and moderate $\mathrm{pH}$.

\section{Landfill Mineralogy-Significant} changes in mineral composition of the $\mathrm{FBC}$ ash occurred during the three years of monitoring. The changes in concentrations of selected reactive phases are shown in Figure 79. The concentration of the mineral anhydrite declines as it is converted to gypsum and ettringite in the presence of water, while calcite is initially formed via the carbonation of hydrated lime and later broken down and converted to other species. These compositional changes generally follow the conceptual model of FBC hydration presented earlier in this chapter. The amounts of mineral growth are consistent with the moderate cementation observed in the test cell.

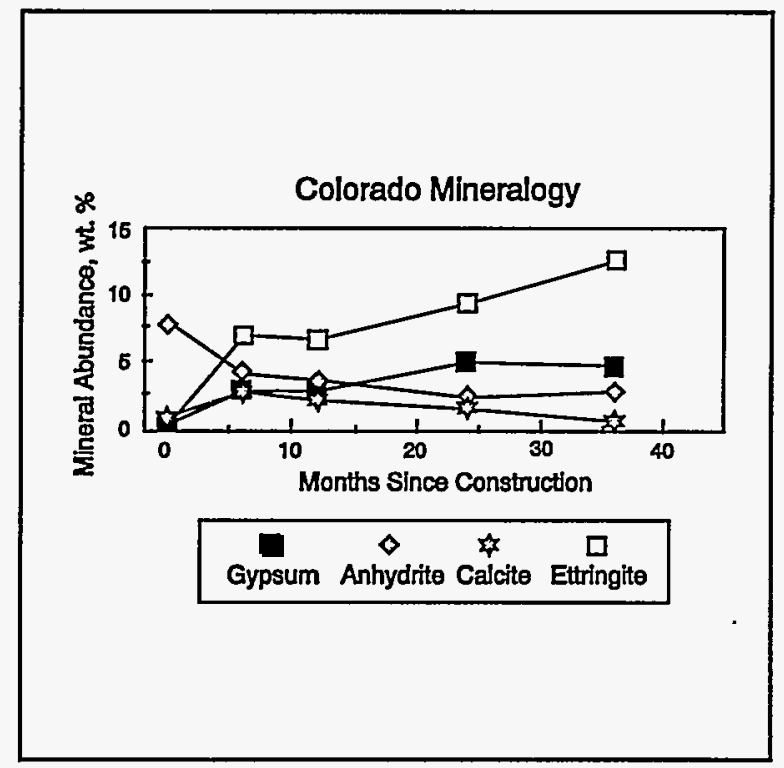

Figure 79. Mineralogy of Core Samples Collected from the Colorado Test Cell

Values shown represent averages for all samples collected during each time interval. Ettringite and gypsum progressively increase in abundance as the ash hydrates. Anhydrite and calcite are consumed.

\section{Leachability Test}

Results-Mineralogical changes in the FBC ash have contributed to changes in the leachable concentrations of major and trace analytes in the ash. Calcium and sulfate concentrations drop from approximately 1100 and $1300 \mathrm{mg} / \mathrm{L}$, respectively, in the initial ash leachate to 500 and $800 \mathrm{mg} / \mathrm{L}$ in the leachate from samples collected after three years exposure. The leachability of the trace element barium also drops sharply in between the initial ash and the weathered samples collected from the test cell, as shown in Figure 80. Molybdenum and zinc show a similar distribution. Other trace elements exhibit different patterns of mobilization or fixation. Lead, arsenic, chromium, and silver have similar leachability in both the initial ash and the weathered samples, while selenium and vanadium concentrations are higher in leachate from weathered samples than in leachate of the fresh ash. Even elements such as selenium and vanadium, which are mobilized relative to the initial ash, have soluble concentrations well below regulatory limits.

\subsubsection{Ohio Site Results}

Results from engineering and physical properties tests of the LIMB ash during construction operations and from environmental performance testing are presented below. Results from both test cells are presented together except in some instances where the data are very similar and only one set of results is shown for clarity. The North Cell, which was constructed first, contains LIMB ash wetted only to control dusting. The South Cell contains LIMB ash wetted to optimum moisture for compaction and placed with a target density of $95 \%$ of the maximum dry density.

\section{Engineering Results}

The engineering properties of the LIMB material in the landfill test cells are controlled by the initial by-product 
Arsenic

Dectection limit $=0.005 \mathrm{mg} / \mathrm{L}$

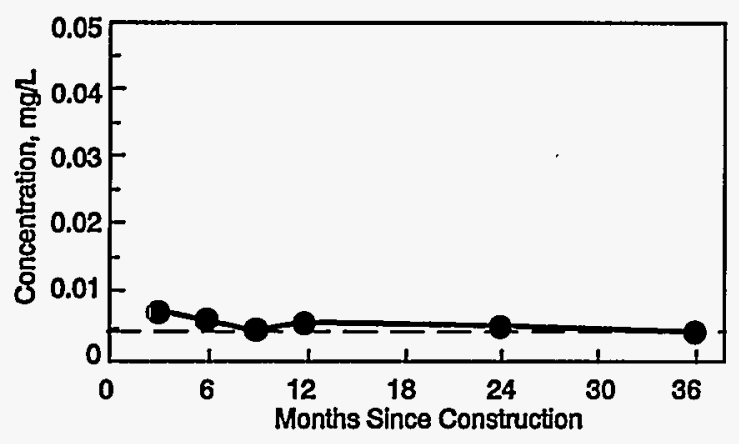

Chromium

Dectection limit $=0.01 \mathrm{mg} /$

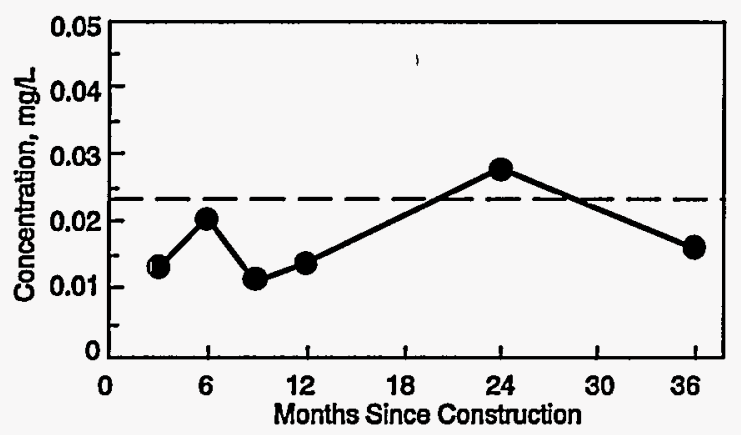

Selenium

Dectection limit $=0.005 \mathrm{mg} / \mathrm{L}$

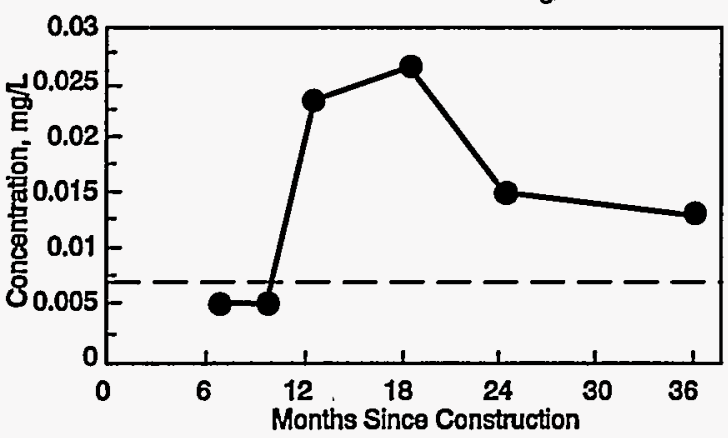

Barium

Dectection limit $=0.01 \mathrm{mg} / \mathrm{L}$.

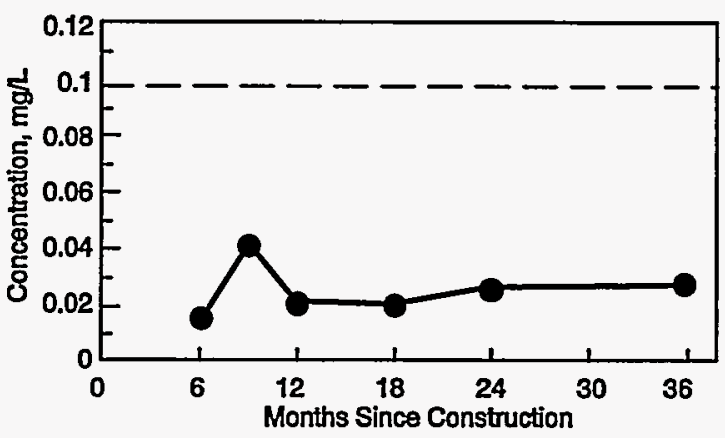

Lead

Dectection limit $=0.003 \mathrm{mg} / \mathrm{L}$

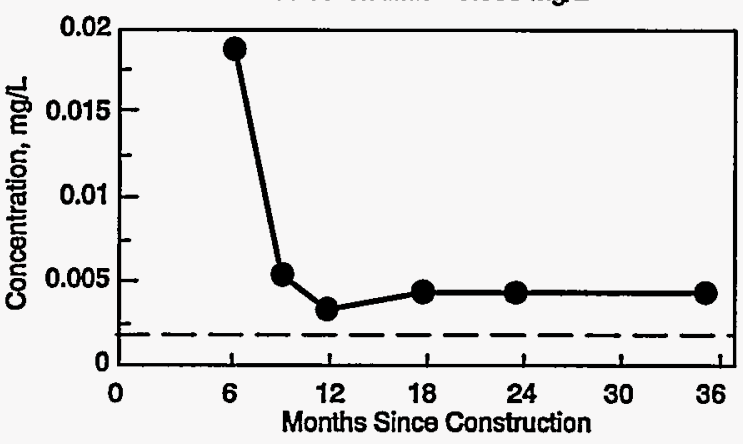

Silver

Dectection limit $=0.01 \mathrm{mg} / \mathrm{L}$

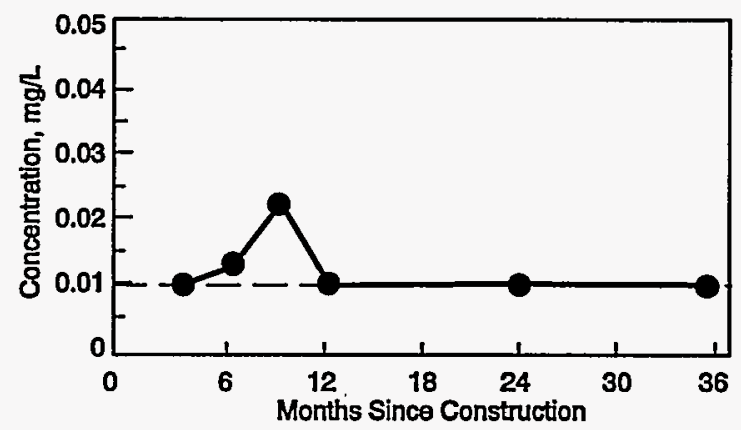

Figure 80. Concentration Trends for the RCRA Trace Metals in Deionized Water Leachates of Colorado Ash Cores

The leachable concentration of each element in the fresh ash is also shown for reference (dashed line). Core leachate data represents an average for all samples for each time interval. Values below the analytical detection limit were considered equal to the detection limit. Other trace metals follow similar distributions; molybdenum and zinc (not shown) behave in the same fashion as barium, while the vanadium distribution (not shown) is similar to selenium. 
composition, the method of placement, and the climate of the test site.

By-Product Composition-The LIMB ash contains approximately $30 \%$ free lime, $25 \%$ calcium sulfate (anhydrite), and coal fly ash material. The ash has a very small particle size and a high surface area, allowing rapid reaction of the material with water. As a result, the landfilled ash has undergone extensive reaction, forming large amounts of secondary minerals.

Climate Factors-The test site climate is moist and temperate. The average annual rainfall during monitoring was approximately 46 inches. The test cells were constructed in February and April, 1989 during cool, damp weather. Groundwater is present 10 to 15 feet beneath the base of the test cells and drains to a swampy area approximately 100 feet to the east.

Ash Moisture-Construction-The LIMB ash was moistened to approximately $25 \%$ in the North Cell to prevent dusting. The South Cell moisture was increased to optimize compaction. The South Cell moisture was adjusted to approximately $38 \%$ by spraying water onto the ash as it was spread in the cell. The ash was spread in six-inch-thick lifts and compacted with a D-5 Caterpillar tractor to a dry density of approximately $68 \mathrm{lb} / \mathrm{ft}^{3}$ in both the North Cell and the South Cell, based on dry density measurements of core samples collected after construction. This is close to the maximum dry density of 70 to $75 \mathrm{lb} / \mathrm{ft}^{3}$ measured on preconstruction samples. The expected difference in compacted dry density between the two test cells is not reflected in the field data.

\section{Ash Moisture-Long-}

Term-Moisture contents determined on core samples collected from the cells during the three-year monitoring period are shown in the upper left graph in Figure 81. These moisture values represent both free water and structurally bound water contained in hydrous minerals. The moisture contents of the initial cores from the South Cell ash were close to the as-built value at about $35 \%$, while North Cell initial cores increased from the as-built value of $25 \%$ to nearly $50 \%$ moisture. Formation of a hard crust on the surface of the South Cell may have prevented infiltration of rainwater initially. Cracking in the South Cell later increased rainwater infiltration (see strength and permeability discussion below) so that it gained moisture at a higher rate than the North Cell. After three years of exposure, the moisture contents of both test cells were between $90-95 \%$ on a dry weight basis.

Long-term modeling of the test cell water balance using the HELP model predicts that over a 20 -year period an average of $18 \%$ of the incident rainfall will exit the landfill as leachate. Approximately $79 \%$ of the rain will be lost to evapotranspiration, while $3 \%$ will contribute to increased ash moisture. After the ash is fully saturated to field capacity the average percolation will increase 21 percent. HELP model results are shown in Table 46.

Ash Permeability-Initial core permeabilities for the two test cells show a wide separation depending on the ash placement conditions, but these initial differences are evened out over time. Results of permeability tests for core samples are shown in the upper right graph in Figure 81. Initial North Cell cores have a permeability of approximately $3 \times 10^{-5} \mathrm{~cm} / \mathrm{sec}$. South Cell cores are much less permeable, averaging approximately $1 \times 10^{-7} \mathrm{~cm} / \mathrm{sec}$. Fracturing in the South Cell and additional cement formation in the North Cell acts to even out the initial differences during the monitoring period. After three years, the permeability of both test cells is close to $1 \times 10^{-4} \mathrm{~cm} / \mathrm{sec}$, well above the target values of $1 \times 10^{-6} \mathrm{~cm} / \mathrm{sec}$.

Permeability measurements show a high degree of variability in both test cells, reflecting the fracture-dominated environment. In situ permeabilities from both cells (not shown) average near $1 \times 10^{-4} \mathrm{~cm} / \mathrm{sec}$ over the entire 3 -year monitoring period. 


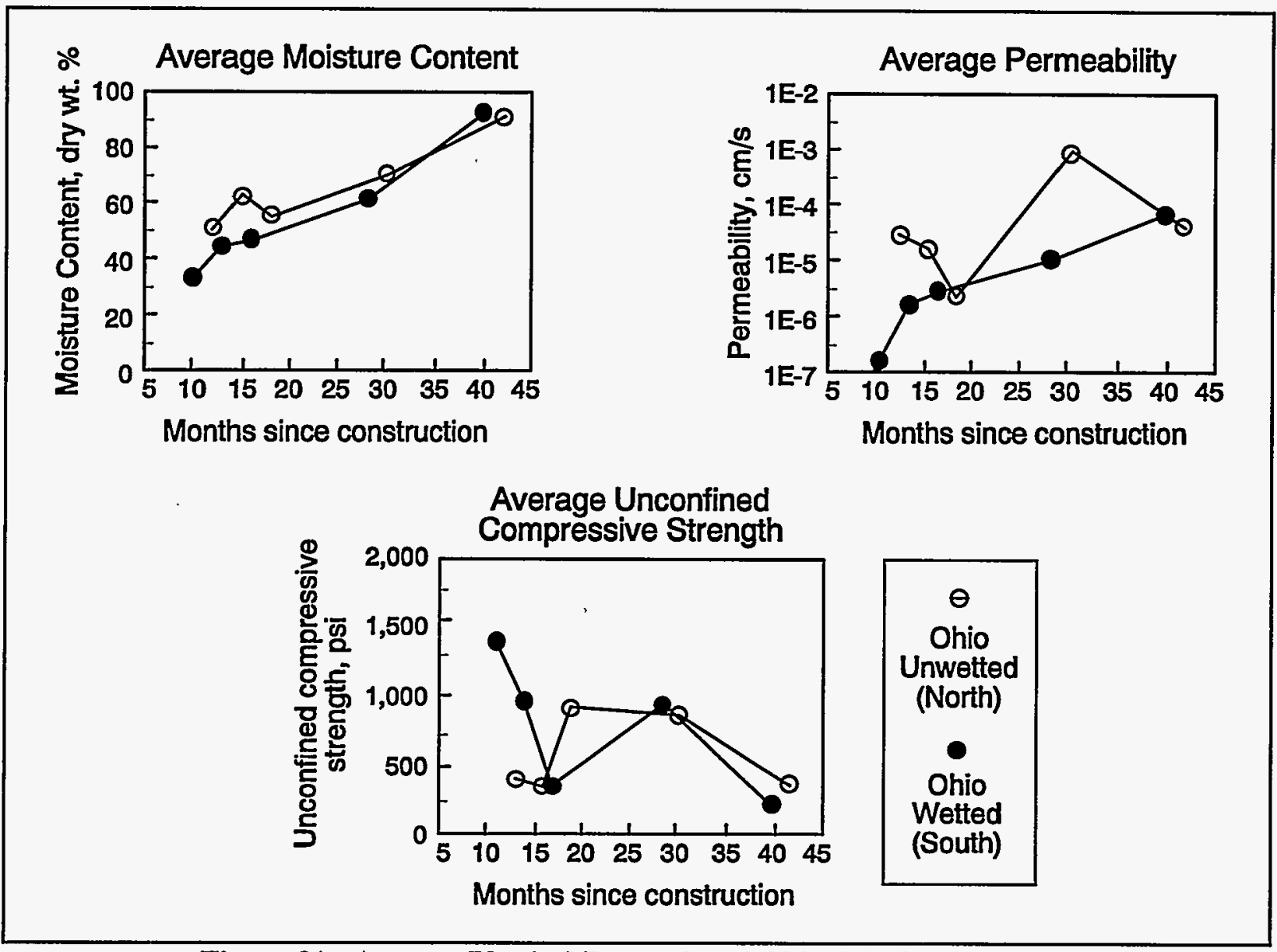

Figure 81. Average Physical Properties of Ohio Ash Core Samples

The moisture content of the ash approaches $100 \%$ on a dry weight basis as the ash hydrates and becomes fully saturated. The ash permeability initially decreases in the unwetted cell as early cementation reactions take place; in the wetted cell permeability increases continuously, accompanied by extensive fracturing. Strengths follow the opposite pattern. Strengths and permeabilities in both cells are virtually identical after three years.

\section{Table 46}

Ohio Site Hydrologic Budget Simulation Results for Long-Term (20-Year) Simulation, Average Values

\begin{tabular}{||l|r|r|}
\hline \multicolumn{1}{|c|}{ Parameter } & Inches of Water & Percent \\
\hline Precipitation & 34.37 & 100.00 \\
\hline Runoff & 0.00 & 0.00 \\
\hline Evapotranspiration & 27.08 & 78.80 \\
\hline Percolation & 6.21 & 18.09 \\
\hline Change in Water Storage & 1.068 & 3.11 \\
\hline
\end{tabular}


Load-Bearing Strength-The load bearing strength of both test cells is more than adequate for slope stability and equipment support. Strength declines over time and may not be sufficient for structural fill purposes in the long term. Results from unconfined compressive strength tests of core samples from the North and South Cells are shown in the bottom graph in Figure 81. Initial cementation in the South Cell produced average core strengths of nearly $1500 \mathrm{psi}$ after 10 months, while core strengths in the North Cell were less than 500 psi at this time. After three years, strengths were similar in the two cells and averaged between 200 and 300 psi.

Strength declined rapidly in the South Cell during the first six months as a result of extensive fracturing. In the North Cell fracturing was minimal, and strengths increased as additional cementation took place. Fracturing in the South Cell was intense and was accompanied by expansion, producing pressure ridges over six inches high. Figures 82 and 83 show views of the North Cell and the South Cell in May 1990.

Field Permeability Measurements-Field permeability measurements are shown in Figure 84. Field measurement averages out the effects of small fractures and eliminates sampling bias inherent in individual core measurements. The field measurements show little change over time, but indicate that the surface zones of the landfill are significantly more permeable than the deeper material, and that the base soils are less permeable than the ash. South Cell field permeabilities are generally slightly higher than in the North Cell, and the cover soil permeabilities are slightly higher than the ash in either test cell. This trend allows water to infiltrate the test cells easily and causes it to pond near the base of the cells.

\section{Environmental Measurements and Long-Term Monitoring Data}

Environmental data collected at the test site included information on runoff volumes and runoff water quality, changes in ash mineralogy, ash leachability, and groundwater and pore water chemistry.

Surface Runoff Volume-Surface runoff was monitored only during the first year of test cell operation, before the landfills were covered. Runoff volumes were small, reflecting the porous nature of the ash and the low surface slope of the cells. The total measured volume of runoff was approximately 240 gallons in the North Cell; some additional runoff is presumed to have occurred during several months when the measurement system was not operational. According to the test design, no flume was installed in the South Cell, and no runoff measurements were made in the South Cell.

\section{Surface Runoff Quality-Surface} runoff from the Ohio site test cells initially contained several hundred $\mathrm{mg} / \mathrm{L}$ of common ions, including calcium, potassium, and sulfate. Over the first year of exposure the total dissolved solids content of the surface runoff declined from approximately $1500 \mathrm{mg} / \mathrm{L}$ to a low of approximately $300 \mathrm{mg} / \mathrm{L}$. Small amounts of suspended solids, primarily calcium sulfate, were also generated.

Landfill Mineralogy—Ettringite and thaumasite formation dominate the mineralogical changes in the landfilled ash, shown in Figure 85. After three years the sum of ettringite plus thaumasite contents equals $60 \%$ to $80 \%$ of the total ash. Anhydrite disappears in the first year. The gypsum content remains relatively constant after initial hydration, although detailed core examination shows it is actively dissolved and reprecipitated within the landfills. Calcite initially increases slightly in abundance, especially in the wetted cell, then declines marginally after thaumasite formation begins. 


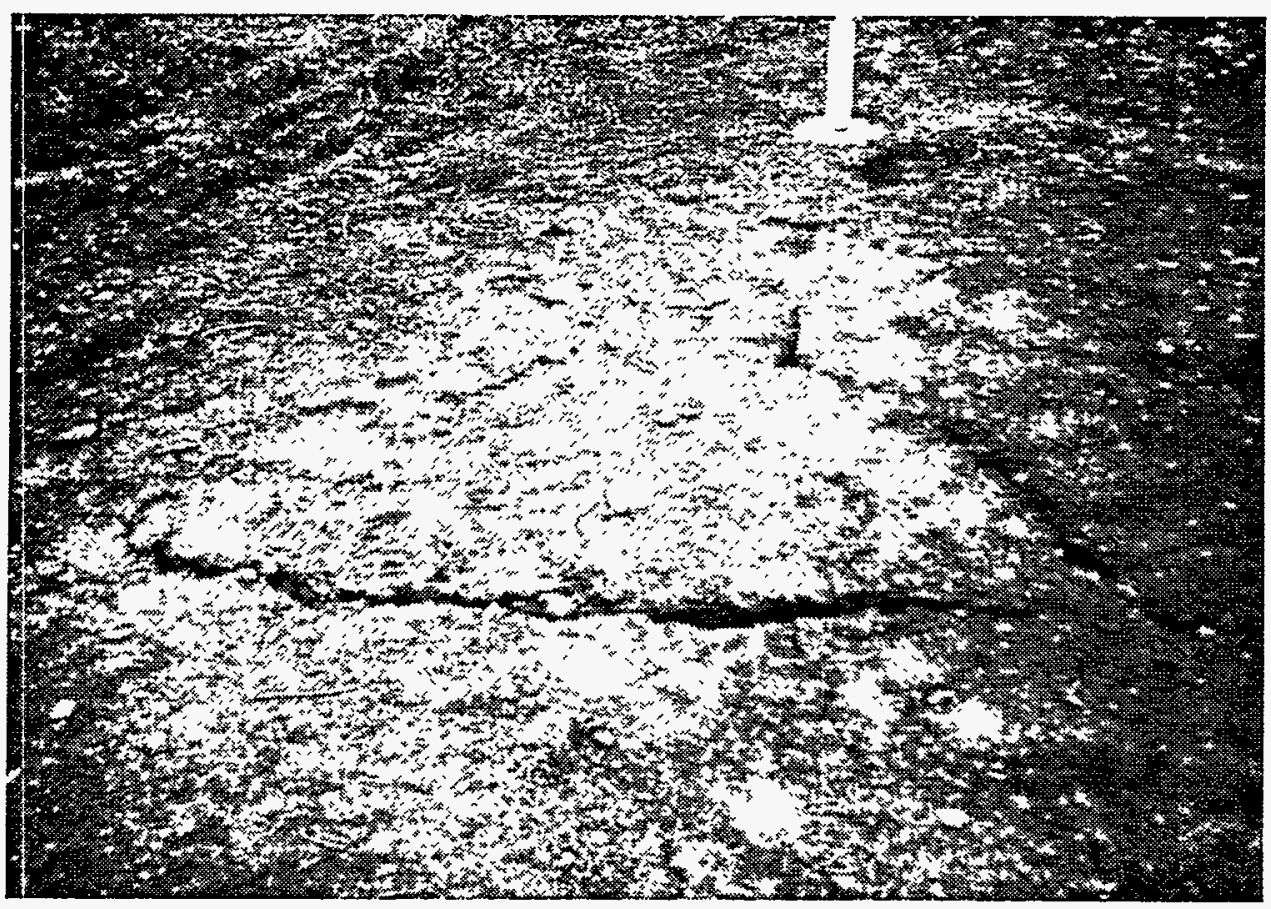

Figure 82. Fracturing in the North Cell

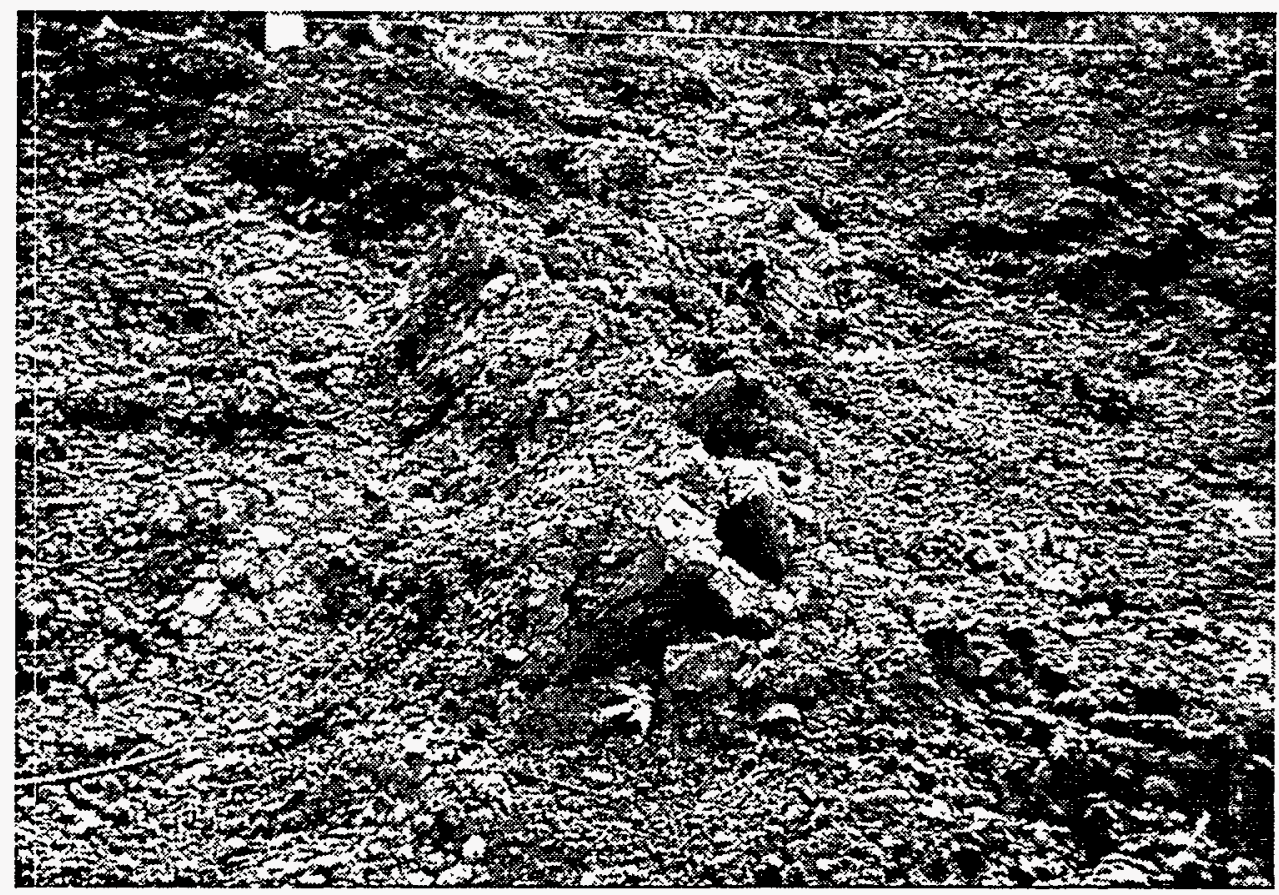

Figure 83. Fracturing in the South Cell 
Field Permeability vs. Depth

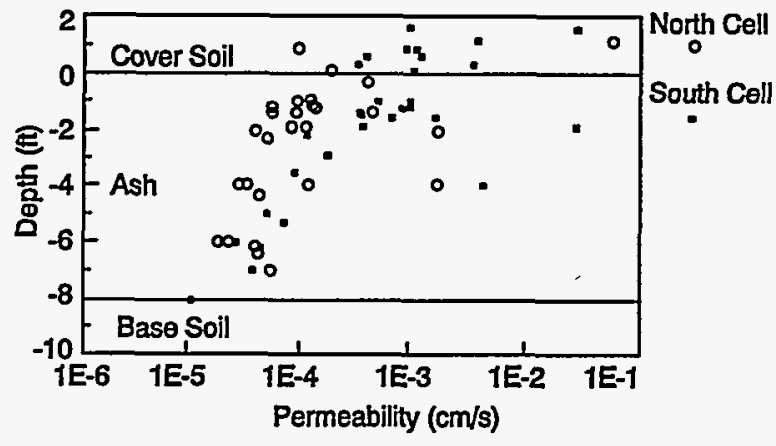

Figure 84. Field Permeameter Results from the Ohio Test Site

Field permeabilities vary significantly with depth in the test cells. Cover soils are more permeable than the ash, and ash permeability decreases with depth. The average South cell (wetted cell) permeability is slightly higher than the North (unvetted) cell permeability, consistent with the large surface fractures observed in the South cell. No consistent trend in permeability versus sample data was observed.
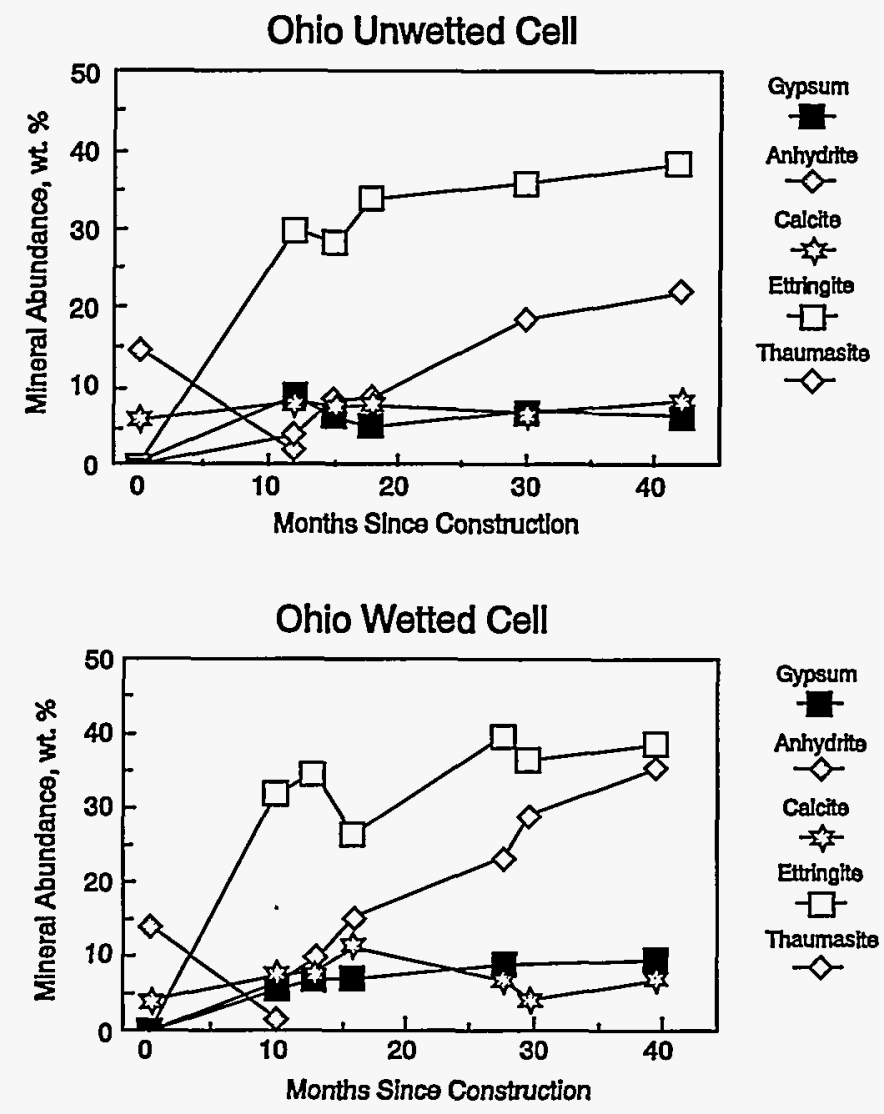

Figure 85. XRD Mineralogy of Ash Cores from the Ohio Test Cells

The materials are characterized by the extensive growth of ettringite and thaumasite in both test cells. Anhydrite converts completely to gypsum during the first year. Calcite abundance increases initially, then decreases slightly as thaumasite forms. 
Leachability Test Results-The leachability of major species in the weathered ash is significantly less than in the initial ash. Figure 86 shows the sharp decline in calcium, chloride, and sulfate concentrations in deionized water leachates of ash cores; potassium is liberated from the ash solids during weathering reactions, which increases its concentration from initial values. The $\mathrm{pH}$ of the weathered ash leachate is significantly lower than the $\mathrm{pH}$ of the fresh ash, declining from over 12 to approximately 10.5 as weathering reactions convert lime to ettringite and other minerals.

Weathering also redistributed soluble materials in the test cells. Initially, concentrations of soluble species were fairly consistent with depth in the test cell, as shown in the lefthand chart in Figure 87. After three years of exposure soluble species were depleted in the near surface zone and concentrated at the base of the test cell, as shown in the right-hand chart in Figure 87. These data also indicate that migration out of the base of the test cell was limited.

Trace elements in the weathered ash are generally less leachable than from the fresh LIMB material. Figure 88 shows the averaged concentrations of the RCRA regulated metals (excluding mercury, which was not determined) in both deionized water leachates and lysimeter samples collected periodically over the course of three years. Barium, boron, cadmium, chromium, selenium, silver, and zinc concentrations in deionized water leachates of weathered ash are consistently lower than in the initial ash leachate. Arsenic, lead, and molybdenum leachability in water is essentially unchanged by weathering. Strontium is the only trace element whose deionized water leachability increased during the study period.

Pore Water Quality-Pore water provides a better approximation of actual landfill leachate composition than deionized water leachates do. Trace elements may be either mobilized or fixed by weathering reactions in the ash, as shown in Figure 88. All regulated trace metal concentrations were below RCRA limits, although the average concentrations of arsenic, chromium, and selenium exceeded drinking water standards for some events. The trace element composition of pore water samples is more highly variable than the deionized water leachate samples from cores. Arsenic, chromium, lead, molybdenum, and selenium were mobilized in the weathered ash, and were sometimes more soluble than in the initial ash. However, high detection limits on some analyses for lead and selenium produce apparent spikes in concentration which may not reflect real changes in the solubility of these elements.

Groundwater Quality-Background groundwater quality at the LIMB test site varies with depth and laterally across the test site. The major ions in solution are the cations calcium, magnesium, and sodium, and the anions bicarbonate and sulfate. Changes in groundwater quality attributable to the test cell are restricted to an increased chloride concentration in one well downgradient from the initially wetted (South) cell and possible increases in concentrations of calcium and total dissolved solids in that same well, shown in Figure 89. No statistically significant downgradient increases in trace metal concentrations were found at the $95 \%$ confidence level, based on three different statistical treatments of the data.

The soils beneath the test cells appear to be effective in immobilizing or neutralizing most leachate constituents except for soluble anions such as chloride. The soils consist of silts and clays overlying weathered shales. The sorptive capacity of the soils, measured as the cation exchange capacity, is moderate to high, ranging from 6 to $25 \mathrm{meq} / 100 \mathrm{~g}$. The permeability of the soils is low, ranging from $9 \times 10^{-}$ ${ }^{6}$ to $1 \times 10^{-8} \mathrm{~cm} / \mathrm{sec}$, suggesting that groundwater movement is slow. Mix ratios calculated from leachate data suggest that substantial amounts of leachate have affected the shallow groundwater downgradient of the initially 


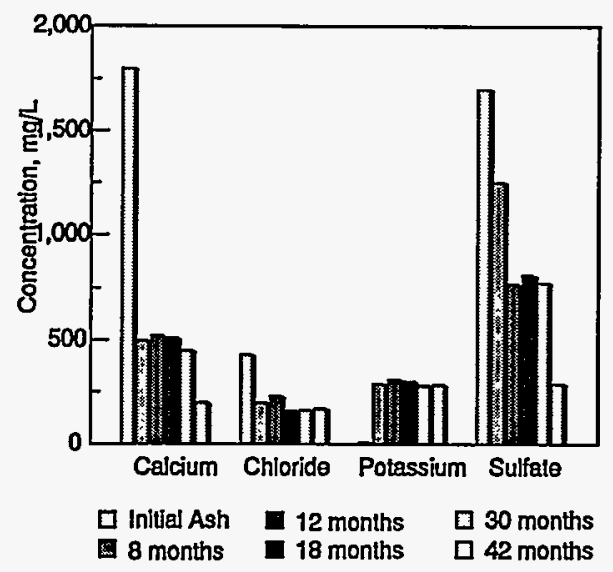

Figure 86. Average Concentrations of Selected Analytes in ASTM Deionized Water Leachates of the Initial Ash Composite and Core Samples from the Ohio North Cell

Leachable concentrations of calcium, chloride, and sulfate in cores are lower than in the fresh ash, reflecting mineralogical changes in the material. Potassium is freed by alkaline attack on fly ash glass, and collects in solution. South cell trends are similar.

N Cell Aug - Dec 1990

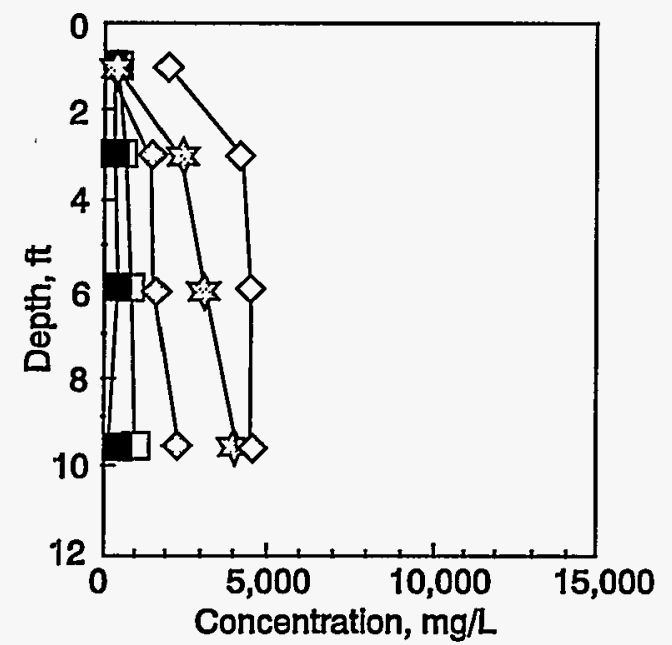

\section{N Cell Jan - Aug 1992}

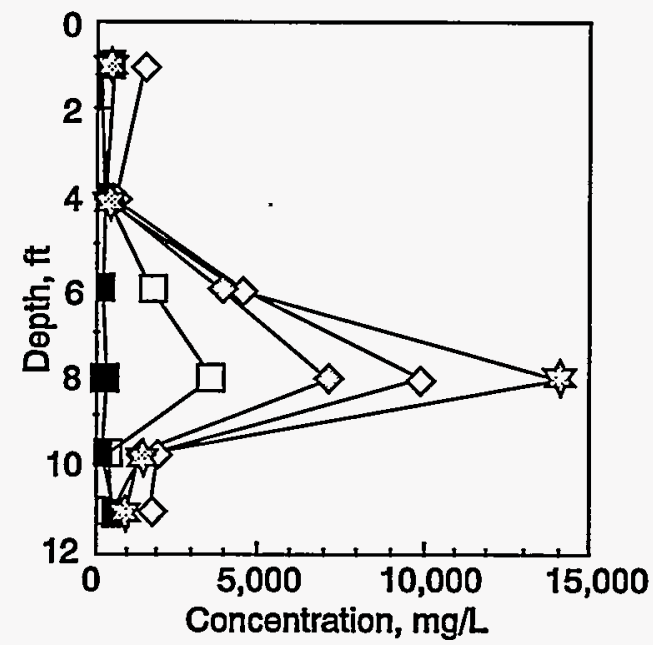

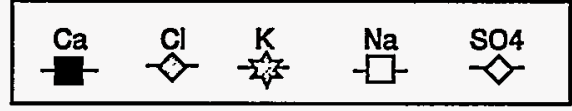

Figure 87. Chemistry of Pore Waters from the North Cell

Where more than one sample was available from a given depth for the time period shown the results were averaged, although in some cases the values shown represent a single analysis. The major soluble species were present in equal concentrations over the vertical profile of the test cell after the first year (left graph). Weathering resulted in movement of soluble species to the base of the test cell after three years (right graph). 


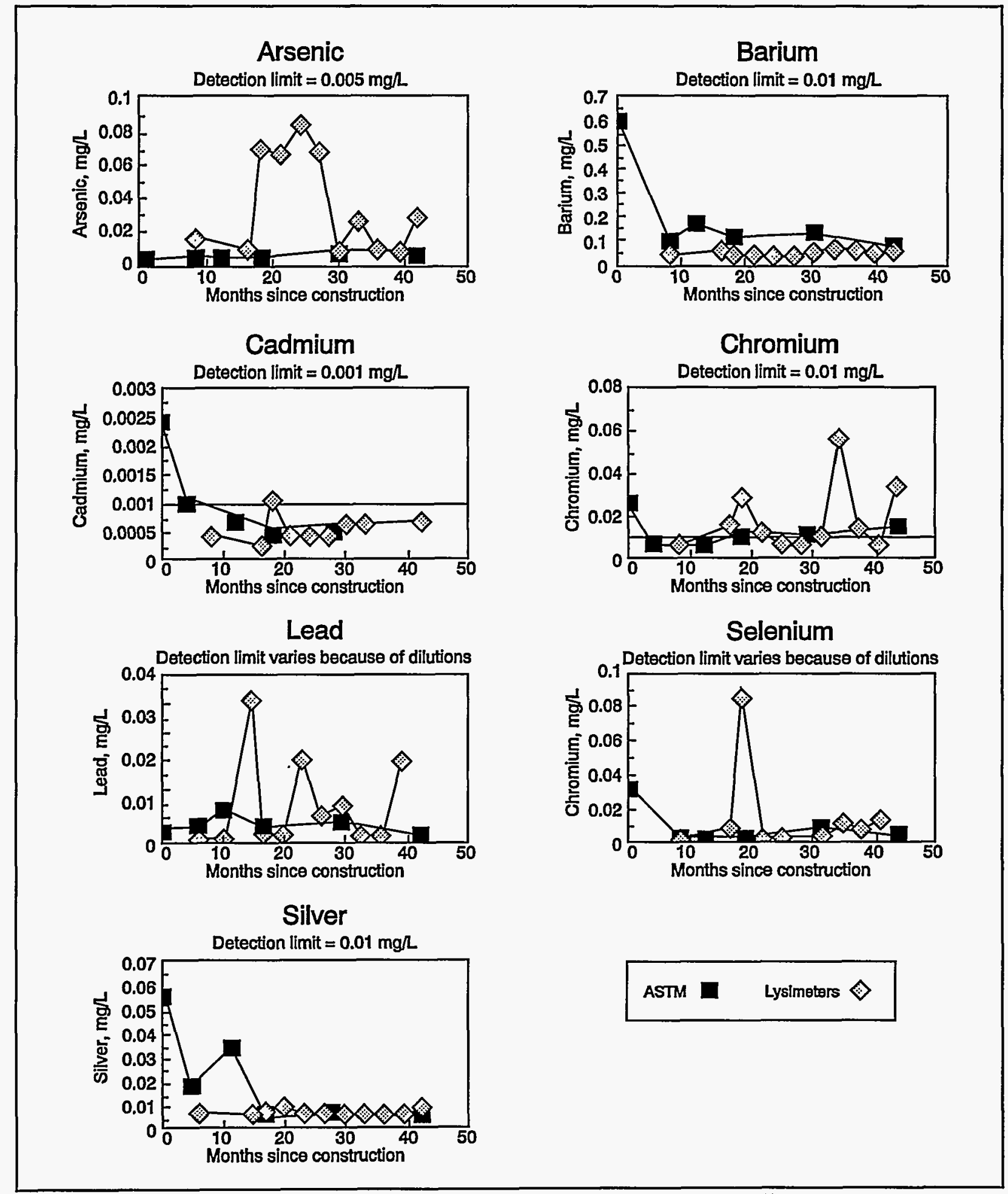

Figure 88. Average Trace Element Concentrations in North Cell Lysimeters and Deionized Water Leachates of Core Samples for Each Sampling Event

For purposes of calculation, all results less than the analytical detection limit were set equal to one half the detection limit. Other trace elements follow similar trends; for example, boron behaves like barium, and molybdenum like arsenic. 


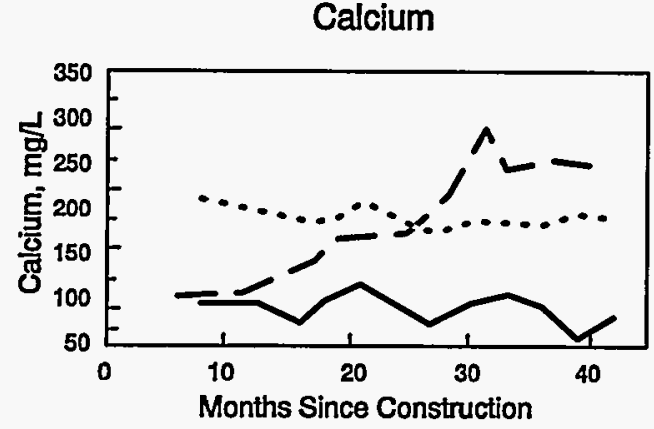

Sodium

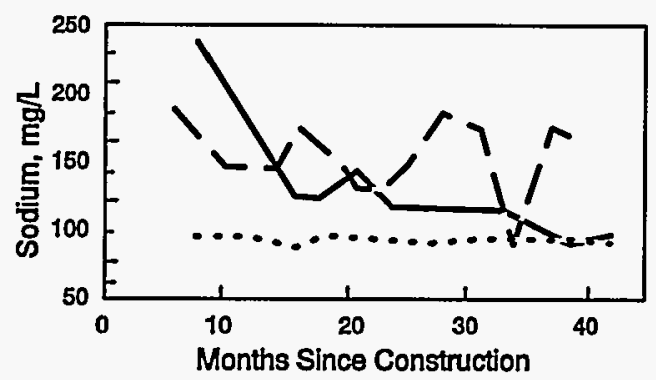

Chloride

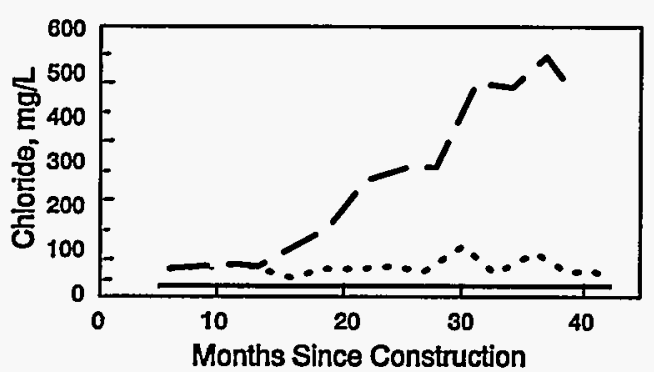

Alkalinity

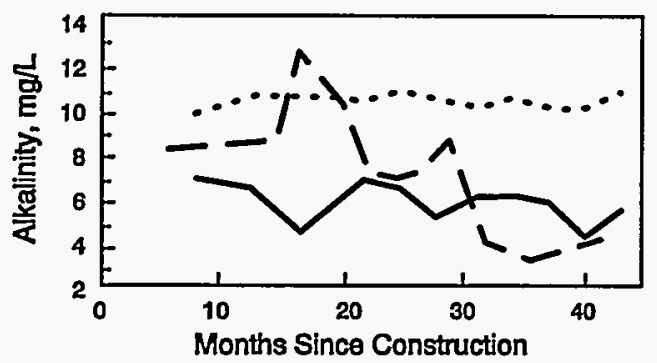

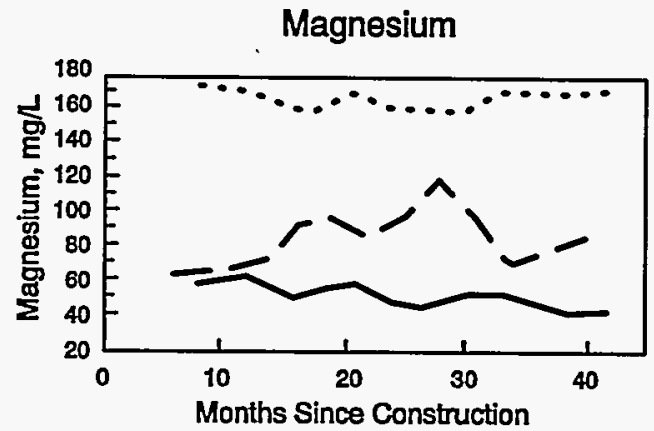

Total Dissolved Solids

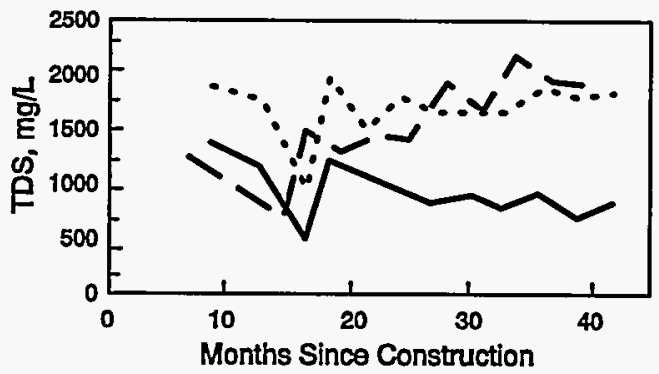

Sulfate

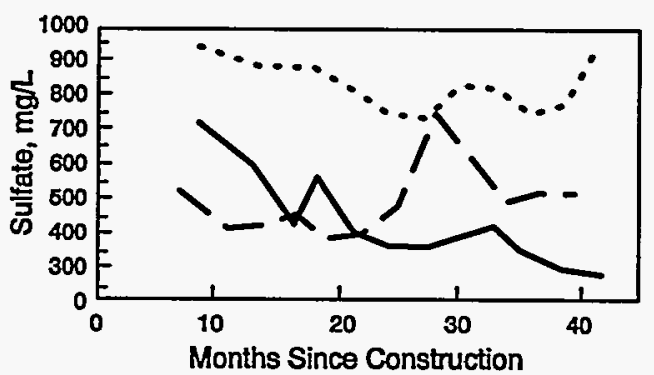

DG north

DG south

- -

Upgradient

Figure 89. Groundwater Quality at the Ohio Site

The seven species shown in the graphs were identified as having significant statistical differences in upgradient and downgradient concentrations. Only the increase in chloride concentration is clearly linked to leachate from the South cell. 
wetted cell, and may account for as much as $50 \%$ of the water sampled from that location. The water table elevation and groundwater flow direction varied over the course of the study in response to rainwater recharge of the shallow aquifer and seasonal effects. Changing groundwater flow and leachate composition prevented average mix ratios and relative retardation factors for other solutes from being calculated.

\subsubsection{Illinois Site Results}

Illinois Cell 1 was constructed from bubbling fluidized bed combustion (BFBC) ash wetted and compacted in place. Cells 2 and 3 were constructed approximately 2 years later from a mixture of $\mathrm{BFBC}$ ash and pulverized coal fly ash (PFA) in a 1:1 ratio. In Cell 2 this mixture, which was soil-like, was compacted in place at optimum moisture, while in Cell 3 the mixture was placed as a flowable mix. (Construction procedures for Cells 2 and 3, referred to as the South and North Cells respectively, are presented in Section 6.4.) Results from engineering and physical properties tests of the BFBC ash and BFBC/PFA mixes during construction operations and from subsequent environmental performance testing are presented below. Results from all three test cells are presented where available; in most instances only Cell 1 results are complete enough for presentation.

\section{Engineering Results}

The engineering properties of the $\mathrm{BFBC}$ and BFBC/fly ash materials in the landfill test cells are controlled by the initial by-product composition, the method of placement, and the climate of the test site.

By-Product Composition-The BFBC ash contains approximately $26 \%$ free lime, $48 \%$ calcium sulfate, and coal fly ash material. The free lime and sulfate content of this ash are at the high end of the expected range of compositions for BFBC ash. The ash has a rapid reaction with water, producing a high heat of hydration. The fly ash used in Cells 2 and 3 is a class $F$ ash from the combustion of Illinois \#5 coal.

Climate Factors-The test site climate is moist and temperate. The average annual rainfall during monitoring was 42.6 inches. Groundwater surfaces during some portions of the year in a wetland area and drainage ditch south and west from the downgradient end of the test cells. Test cell 1 was constructed over the fall and spring of 1990-1991 during cool, damp weather. Cells 2 and 3 were constructed during May, 1993.

Ash Moisture-Construction-To aid compaction, the $\mathrm{BFBC}$ ash was moistened to approximately $26.5 \%$ in Cell 1 by spraying water onto the ash as it was spread in the cell. The ash was spread in six-inch-thick lifts and compacted with a D-5 Caterpillar tractor to a target dry density of approximately $80 \mathrm{lb} / \mathrm{ft}^{3}$. Materials for Cell 2 were mixed in an auger mixer and blended with $30 \%$ water (total moisture content) to provide a free moisture content (as placed) ranging from $19 \%$ to $25 \%$, compared with the optimum moisture content of $19.7 \%$ determined in pre-construction tests and $22.6 \%$ determined by Proctor tests performed on as-placed material. The measured in-place dry density ranged between 90.2 and $104.2 \mathrm{lb} / \mathrm{ft}^{3}$, compared to a maximum dry density of $90.7 \mathrm{lb} / \mathrm{ft}^{3}$ measured on fieldmolded samples. Cell 2 core samples had a dry density between 83 and $93 \mathrm{lb} / \mathrm{ft}^{3}$ after oven drying at $100^{\circ} \mathrm{C}$. Cell 3 materials were mixed in the same fashion as Cell 2, but using $42 \%$ added water to allow the mixture to be placed as a grout. Dry densities of Cell 3 core samples ranged from 57 to $70.6 \mathrm{lb} / \mathrm{ft}^{3}$ after oven drying at $100^{\circ} \mathrm{C}$.

\section{Ash Moisture-Long-}

Term-Moisture contents determined on core samples collected from Cell 1 during initial two years of the monitoring period are shown in the upper left graph in Figure 90. These moisture values represent both free water and structurally bound water contained in hydrous 

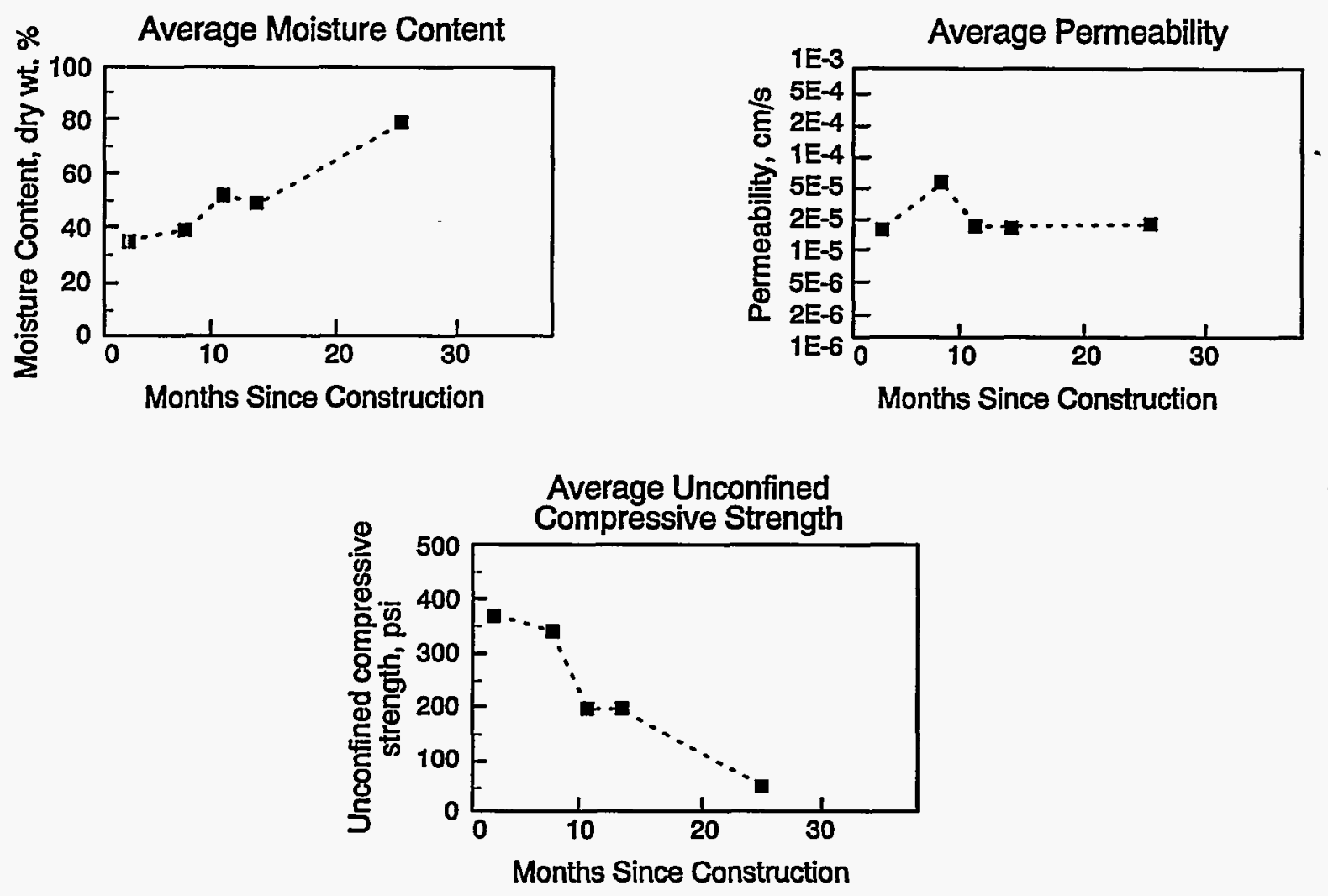

Figure 90. Average Physical Properties of Mlinois Cell 1 (FBC ash only) Core Samples

The moisture content increased rapidly as the ash hydrated and saturated. The permeability has not changed significantly, the initial permeability of this test cell is similar to the final values at the other sites after three years of weathering. The average strength of the ash has declined steadily from over 300 psi to less than 50 psi.

minerals. Moisture content monitoring for Cells 2 and 3 is still in preliminary stages and the results are not reported.

Long-term modeling of the test cell water balance using the HELP model is not completed for the Illinois site. Runoff volumes from Cell 1 have been negligible, as at the Ohio and Colorado sites, and infiltration rates comparable to those at the Ohio site are anticipated. Cell 2 runoff volumes are much larger, and infiltration is anticipated to be reduced correspondingly.
Ash Permeability-Initial laboratory permeability tests of the materials in the three test cells varied from $10^{-7} \mathrm{~cm} / \mathrm{sec}$ to $10^{-10}$ $\mathrm{cm} / \mathrm{sec}$ depending on the ash mixture and placement conditions. Measurements on core samples collected from the test cells show much higher permeabilities. Results of permeability tests for Cell 1 core samples are shown in the upper right graph in Figure 90. Cell 1 core permeabilities average approximately $2 \times 10^{-5} \mathrm{~cm} / \mathrm{sec}$, while initial cores from Cells 2 and 3 average $2.2 \times 10^{-7}$ and 8.2 $\times 10^{-3} \mathrm{~cm} / \mathrm{sec}$, respectively. 
Load-Bearing Strength-The loadbearing strengths of all three test cells are more than adequate for slope stability and equipment support, but tend to decrease over time and may not be sufficient for structural fill purposes in the long term. Results from unconfined compressive strength tests of core samples from Cell 1 are shown in the bottom graph in Figure 90. Initial cementation produced average core strengths of approximately 350 psi after 4 months. After 10 months, average strengths declined to approximately 200 psi. After two years, strengths averaged under 50 psi.

Results from strength tests of core samples from Cells 2 and 3 are available only for the first year of monitoring. Early strengths (4 months) average nearly $1900 \mathrm{psi}$ in Cell 2 and approximately 400 psi in Cell 3. These results compare with strengths obtained from field-molded laboratory-cured (for 4 months) specimens of the ash mixtures prepared at optimum moisture (soil-like mix) and as a slurry at $9 \%$ above optimum moisture (flowable mix). For the soil mix, a strength of approximately 1550 was obtained; for the flowable mix, a strength of approximately 1150 was obtained. The Cell 3 mix developed a compressive strength of less than 7 psi 30 minutes after placement (as measured by a pocket penetrometer), but would maintain a vertical cut without slump at that time. After 24 hours the Cell 3 mix had a compressive strength of between 20 to 35 psi.

No expansion has been noted at any of the Illinois test cells. Laboratory tests (ASTM C-490) for linear expansion on Cell 2 and 3 mixtures found less than $1 \%$ expansion under the test conditions.

Field Permeability Measurements-Field permeability measurements from Illinois Cell 1 are shown in Figure 91. The results indicate a moderate decrease in permeability over time and a general trend of decreasing permeability with depth within the test cell.

\section{Environmental Measurements and Long-Term Monitoring Data}

Environmental data collected at the test site included information on runoff volumes and quality, changes in ash mineralogy, ash leachability, and groundwater and pore water chemistry.

Surface Runoff Volume-Surface runoff was monitored only during the first year of test cell operation, before the landfills were covered. Runoff volumes in Cell 1 were small, reflecting the porous nature of the ash and the low surface slope of the cell. The Cell 2 runoff volume was much larger since the initial permeability of Cell 2 materials was lower. The total measured volume of runoff was approximately 700 gallons in Cell 1 and 1400 gallons in Cell 2. The flumes in both test cells were washed out during heavy rains shortly after construction. The volume of runoff lost during this incident is unknown. Runoff volumes were not measured in Cell 3.

Surface Runoff Quality-Surface runoff from Illinois Cell 1 was sampled during the first year of monitoring. Surface water samples were dilute calcium sulfate solutions with a $\mathrm{pH}$ between 7 and 9 . Other species including silicon, magnesium, sodium, chloride, strontium, and barium (in order of decreasing abundance) were detected in small amounts in most samples. Total dissolved solids were less than $1000 \mathrm{mg} / \mathrm{L}$, and total suspended solids were less than $30 \mathrm{mg} / \mathrm{L}$.

Landfill Mineralogy-Ettringite and gypsum formation dominate the mineralogical changes in the landfilled ash, shown in Figure 92. Anhydrite and lime are quickly hydrated to gypsum and portlandite. The abundance of gypsum and portlandite has gradually declined over time while other mineral abundances have remained constant, suggesting portlandite and gypsum dissolution. Ettringite formation is not as extensive as at the Ohio site, and no thaumasite formation was detected during the 


\section{In Situ Permeability vs. Time}

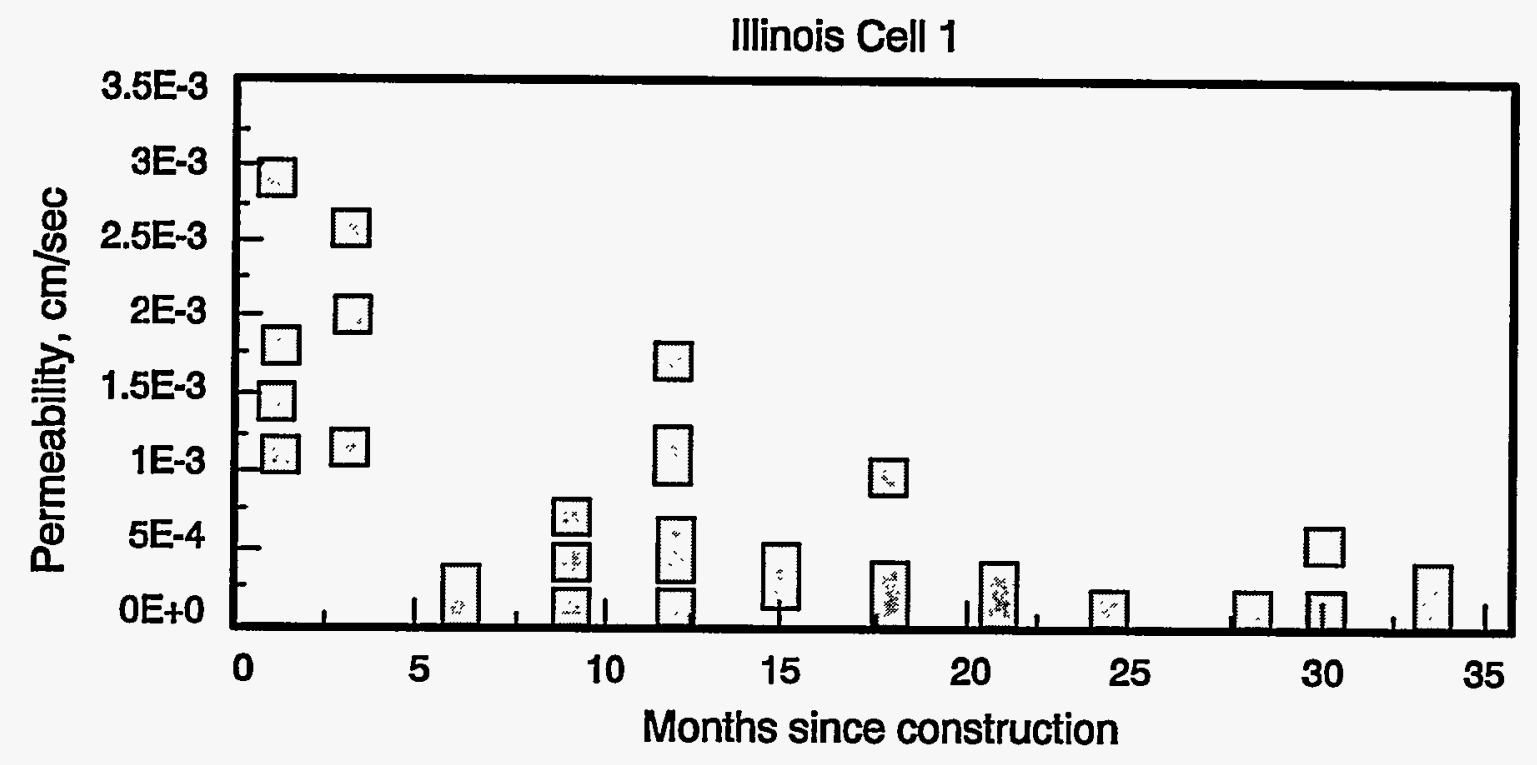

In Situ Permeability vs. Depth

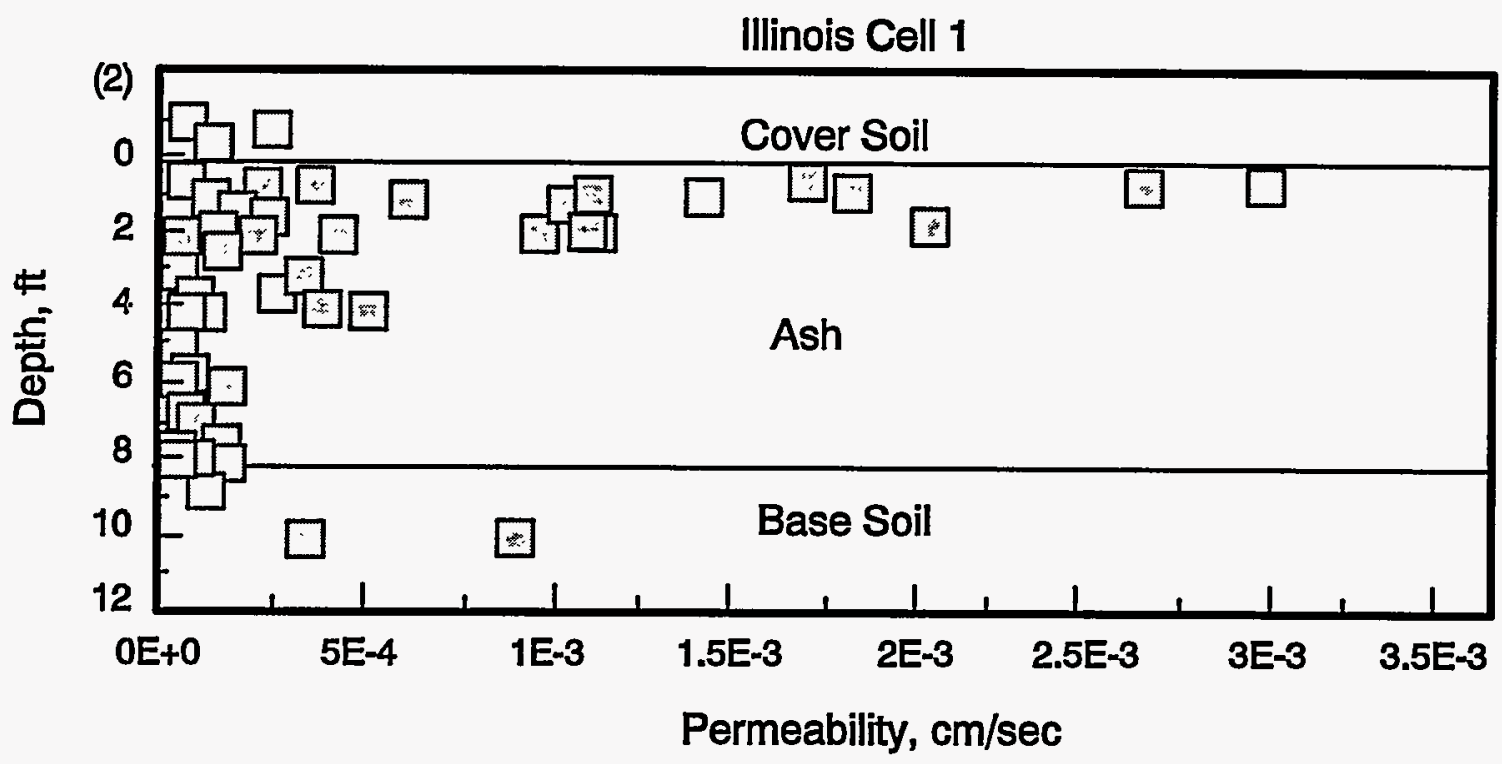

Figure 91. Field Permeability Measurements from Illinois Cell 1

The upper graph shows results plotted according to test date, showing a decrease in the average permeability over time. The lower graph displays results according to the depth of the tested interval, showing a decrease in average permeability with depth. note that the permeabilities are plotted on a linear scale. 


\section{Cell 1: FBC Only}

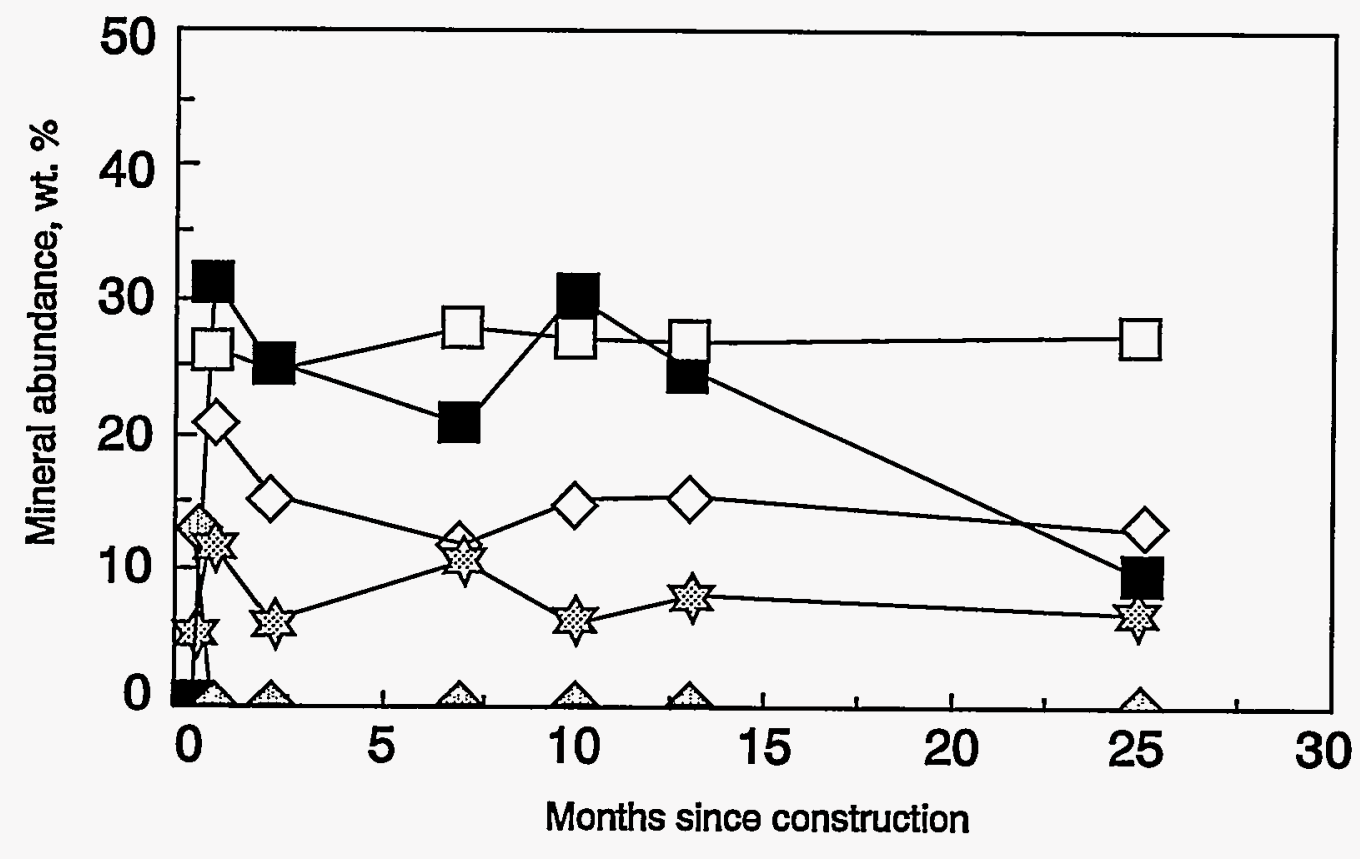

Gypsum

Anhydrite<smiles>CC1=CC=C1</smiles>
Calcite<smiles>[C+][CH2-]</smiles>

Ettringite $-\square-$ Portlandite

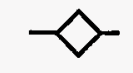

Figure 92. XRD Mineralogy of Illinois Cell 1 Ash Cores

The FBC ash undergoes rapid initial hydration as lime and anhydrite convert completely to portlandite and gypsum. Significant ettringite formation also occurs within the first moth or weathering. subsequent changes are largely restricted to the gradual loss of gypsum. No thaumasite formation has been detected in this material. 
first two years in Cell 1. Results for Cells 2 and 3 are not yet available.

Leachability Test Results-The leachability of calcium and sulfate in the weathered ash from Cell 1 is not significantly less than in the initial ash, in contrast to the Colorado and Ohio sites; the large amounts of unreacted portlandite which remain in the Illinois ash may be responsible. Figure 93 compares the average concentrations of calcium, chloride, potassium, sodium, sulfate, and silicon in deionized water leachates of ash cores and in lysimeter samples over the course of the monitoring period. Calcium and sulfate are the dominant ions in the deionized water leachates. Potassium and sodium are liberated from the ash solids during weathering reactions, and show a moderate increase from initial values in the deionized water leachates.

In the lysimeter samples calcium concentrations are much lower and sulfate much higher than in the deionized water leachates. Pore water concentrations of chloride, potassium, sodium, and silicon are also much higher than predicted by the deionized water leachates.

The $\mathrm{pH}$ of the deionized water leachates of the weathered ash are not significantly lower than the fresh ash, maintaining a $\mathrm{pH}$ of over 12. The $\mathrm{pH}$ is buffered at this value by portlandite which remains in the landfill. Pore water pHs vary from over 12.7 to near neutral.

Leachable trace element concentrations in the Illinois FBC ash are generally low. Figure 94 compares initial ash leachates to the averaged concentrations of the RCRA regulated metals (excluding mercury, which was not determined), plus molybdenum, in both deionized water leachates and lysimeter samples from Cell 1. Arsenic, cadmium, selenium, and silver are not detected in most of the samples from the weathered ash, although measurable amounts of cadmium and selenium were leached from the fresh ash. Barium is also less leachable in weathered samples than in the fresh material. Chromium, molybdenum, and lead concentrations in deionized water leachates of core samples are consistent with leachates of the fresh ash, but pore water concentrations of these species may be considerably higher. These elements are more leachable in some weathered samples than in the fresh ash, and may be preferentially mobilized under some circumstances. The average pore water concentrations of chromium and lead exceed federal primary drinking water standards during some intervals.

Pore Water Quality-Pore water provides a better approximation of actual landfill leachate composition than deionized water leachates do. Illinois site pore waters from Cell 1 are characterized by low calcium and chloride contents relative to the other sites. Soluble species are leached from the surface portions of the landfill within the first 2 years, while major ion concentrations in the leachate in the base of the cell increase, as in the Ohio test cells. Trace elements may be either mobilized or fixed by weathering reactions in the ash, as shown in Figure 9-18 and discussed above. All regulated trace metal concentrations were below RCRA limits, although the concentrations of lead and chromium exceed regulatory limits for drinking water in some samples.

Groundwater Quality-Background groundwater quality at the Illinois test site varies with depth; the shallowest wells have the highest total dissolved solids contents. The major ions in solution are the cations calcium, magnesium, and sodium, and the anions bicarbonate and sulfate. Changes in groundwater quality attributable to the test cells are restricted to increased molybdenum, potassium, sodium, and chloride concentrations in the shallowest well downgradient from Cell 1 , as shown in Figure 95. Changes in downgradient groundwater chemistry were not detected until two years after construction of Cell 1 . The lag time between cell placement and noticeable impacts on downgradient groundwater is 

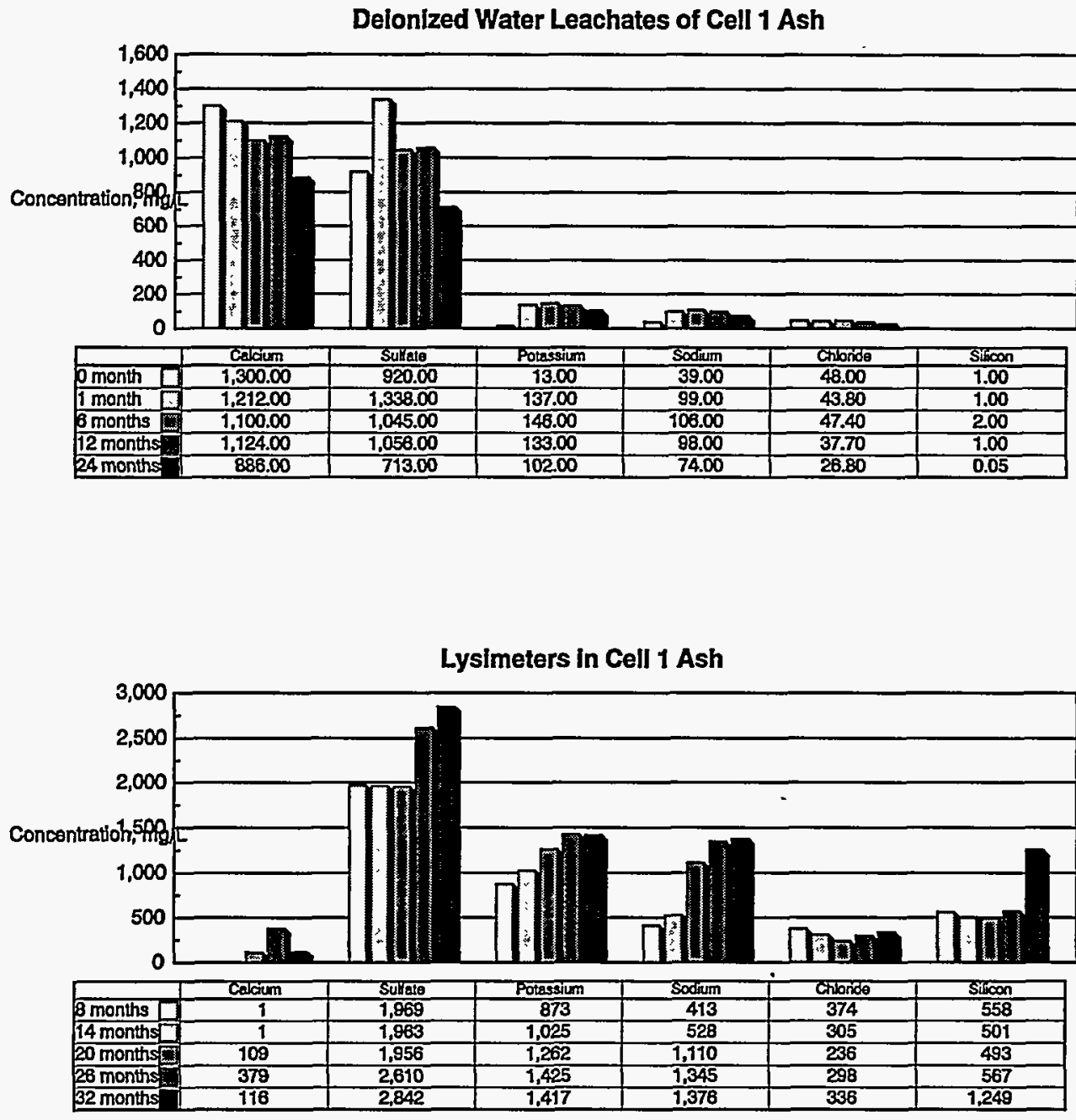

Comparison of the major element chemistry of average ASTM deionized water leachates of ash cores and average lysimeter samples collected in six month intervals (average of two sets of samples). Lysimeter data for sulfate and chloride at 14 months is derived by interpolation since no aliquots were collected for these analyses. ASTM and lysimeter concentrations of all analytes are significantly different.

Figure 93. Comparison of the Major Element Chemistry of Average ASTM Deionized Water Leachates of Ilinois Cell 1 Ash Core and Average Lysimeter Samples 


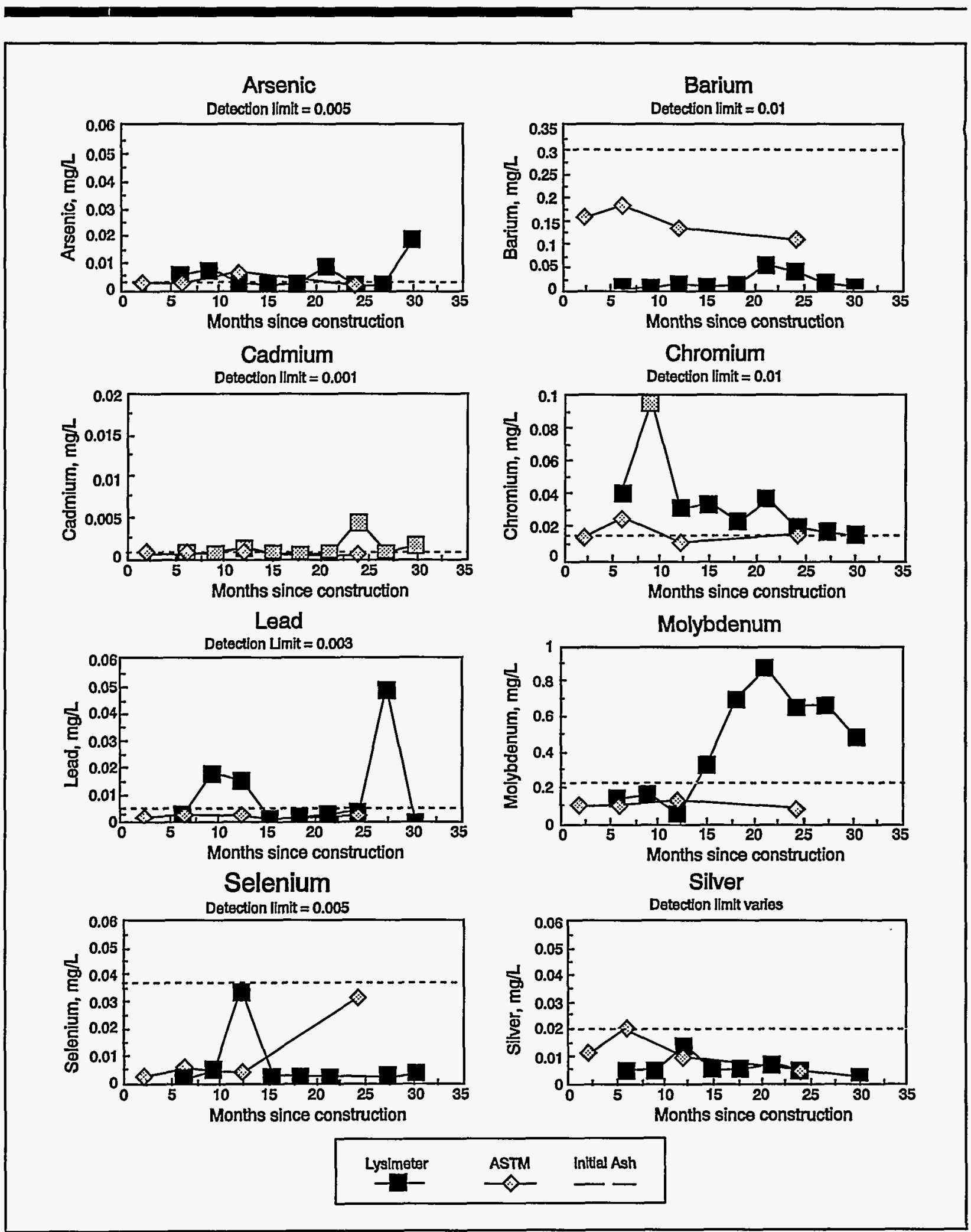

Figure 94. Average Trace Metal Concentrations in illinois Cell 1 Pore Waters and Deionized Water Leachates of Core Samples

Results below the detection limit were taken as one half the detection limit. Initial ash leachate concentrations are shown for comparison (dashed lines). 
Sodium

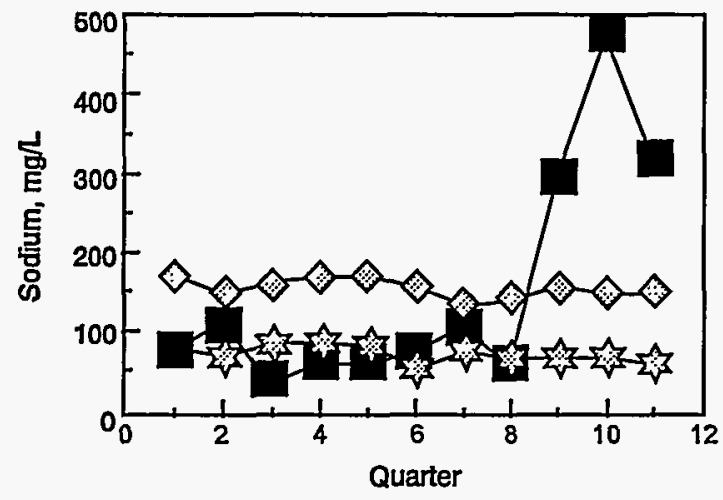

Molybdenum

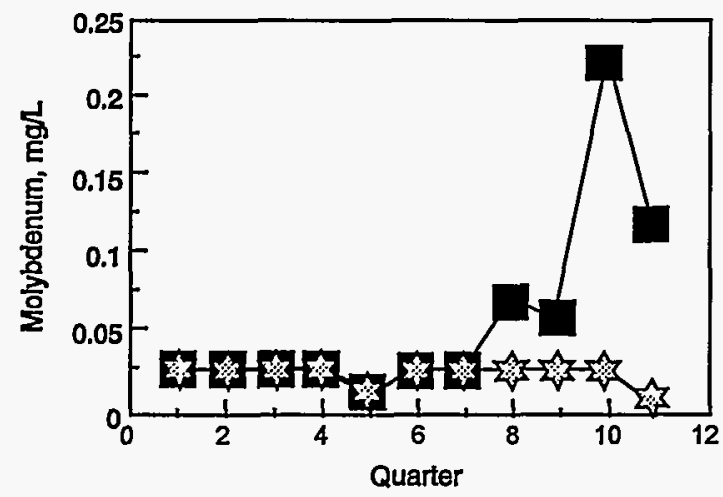

Potassium

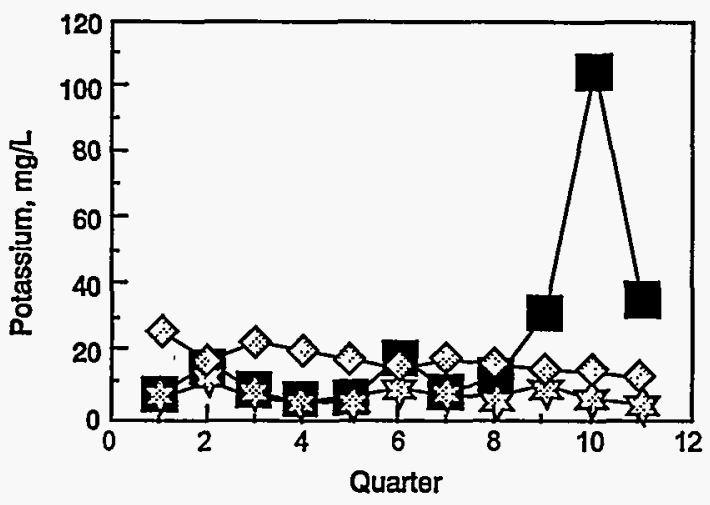

Chloride

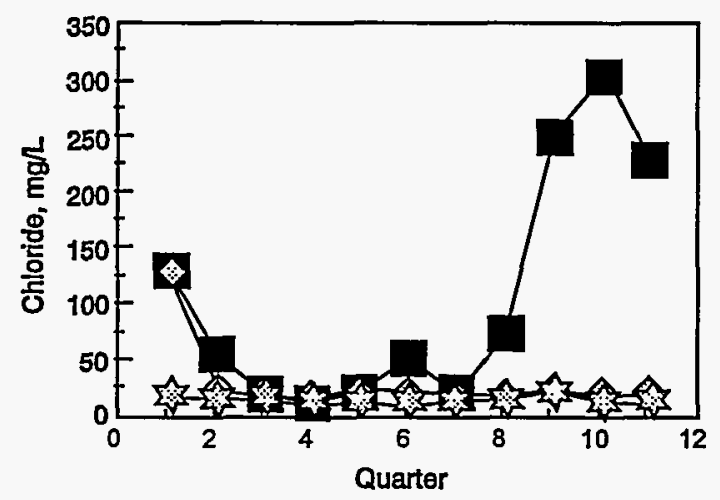

Downgrad.cell 1

Upgradient

Downgrad.cell 2, 3

$\diamond$

实

Figure 95. Concentration Trends of the Four Species in the Shallow Groundwater that are Affected by Leachate Migration from Illinois Cell 1

No other species exhibit a consistent increase in concentration over this period. Both anionic species, such as chloride, and cations, such as sodium and potassium, appear in the downgradient well at the same time. 
contributed to by three separate processes.

First, the test cell took nearly a year to reach saturation; second, the leachate had to percolate through the unsaturated sediments beneath the test cell; and third, the leachate was dispersed in the groundwater and transported to the well. The results from downgradient groundwater monitoring will be used to estimate site-specific and analyte-specific attenuation factors for use with predictive modeling efforts once three years of monitoring is completed at this site.

\subsection{Citations}

1. Hopkins T. and T. Beckhar, Kentucky Transportation Center, University of Kentucky. Unpublished report, presented September 1, 1993, University of Kentucky Center for Applied Energy Research, 1st Annual Conference on Ettringite.

2. Georgiou, D.N., R.K. Kissel, and G.G. Ross, 1990. "Geotechnical Characteristics and Landfilling of CFBC Residue." In: Proceedings of the 1989 International Conference on Fluidized Bed Combustion. American Society of Mechanical Engineers, New York, New York. pp. 849-856. 1991.

3. Kollman, H., G. Strubel, and F. Trost, 1977. "Reaction Mechanisms in the Formation of Expansion Nuclei in Lime-Gypsum Plasters." Zement-KalkGips, 30:24-228.

4. P.R. Schroeder, A.C. Gibson, and M.D. Smolen, The Hydrological Evaluation of Landfill Performance (HELP) Model, U.S. Environmental Protection Agency, Office of Solid Waste, Report No. EPA/DF-85/001b, 1985.

5. Electric Power Research Institute. EPRI EA-5742-CCM. "The Fossil Fuel Combustion Waste Leaching (FOWLTM) Code: Version 1 Users Manual." EPRI EA-5742-CCM.
6. P. Kumarthasan, G.J. McCarthy, D.J. Hassett et al., 1989. "Oxyanion Substituted Ettringites: Synthesis and Characterization and Their Potential Role in Immobilizing As, $\mathrm{B}, \mathrm{Cr}, \mathrm{Se}$, and V." In Proceedings of the 1989 Symposium on Fly Ash and Coal Conversion By-Products: Characterization, Utilization and Disposal; Materials Research Society Symposium Proceedings, Vol. 178.

7. Electric Power Research Institute. EPRI CS-5783. "Laboratory Characterization of Advanced $\mathrm{SO}_{2}$ Control By-Products: Furnace Sorbent Injection Wastes." May 1988.

8. Allison, T.L., 1993. "User Manual Supplement: Using MULTIMED to Evaluate Subtitle D Landfill Designs." USEPA, Office of Solid Waste.

9. Electric Power Research Institute. EPRI EN-6531. "MYGRTTM Version 2.0: An IBM Code for Simulating Migration of Organic and Inorganic Chemicals in Groundwater (Users Manual)." October, 1989.

10. Electric Power Research Institute. EPRI EA-5870. "FASTCHEM"M Package Volume 1: Overview and Application to a Chemical Transport Problem." 1989.

11. Dryden, R.T., 1993. "PCFB Environmental Performance and Efficiency, The Pyropower Perspective." In Bank, D.L. (ed) "Proc. Coal-Fired Power Systems 93-Advances in IGCC and PFBC Rev. Mtg.," Morgantown WV, 1 June 2830, 1993. DOE \#DI93000289. 
12. Dick, W.A., et al., 1993. "Plant

Growth and Soil Property Responses to Additions of Dry Flue Gas

Desulfurization By-Products." In Proc. $1993 \mathrm{SO}_{2}$ Control Symposium.

Boston, MA, August 24-27.

13. Electric Power Research Institute.

EPRI GS-6622. "Laboratory

Characterization of Advanced $\mathrm{SO}_{2}$ Control By-Products: Dry Sodium and Calcium In-Duct Injection Wastes." December, 1989.

14. Mattigod, S.V., et al., 1990. "Geochemical Factors Controlling the Mobilization of Inorganic Constituents from Fossil Fuel Combustion Residues: I. Review of the Major Elements." J. Environ. Qual. 19:188-201.

15. Warren, C.J., and M.J. Dudas, 1988. "Leaching Behavior of Selected Trace Elements in Chemically Weathered Alkaline Fly Ash." The Science of the Total Environment, 77 (1988) 299-246.

16. Huyck, K.A., G.S. Tatum, and D.P. DeKraker. "Management of Flue Gas Desulfurization (FGD) By-Products with System Additives," 1993. Unpublished report.

17. Gas Research Institute, 1988.

Characterization, Extraction, and Reuse of Coal Gasification Solid Wastes. Volume 1. Gas Research Institute Report: GRI 86/0203.

18. Electric Power Research Institute. EPRI GS-6439. Long-Term Leaching Tests with Coal Gasification Slag. 1988.
19. Weinberg, A., B.J. Coel, and R.D. Butler. "Advanced Coal Technology Waste Disposal: Colorado CFBC Site Assessment Report." Unpublished report prepared for USDOE, Morgantown Energy Technology Center.

20. Weinberg, A., R.H. Petrini, and R.D. Butler. "Advanced Coal Technology Waste Disposal: Ohio LIMB Site Assessment Report." Unpublished report prepared for USDOE, Morgantown Energy Technology Center. 
This Page Intentionally Left Blank 
APPENDIX A

HELP Model-Recharge Estimate 
THICKNESS

POROSITY

FIELD CAPACITY

WILTING POINT

INITIAL SOIL WATER CONTENT

SATURATED HYDRAULIC CONDUCTIVITY
IAYER 1

VERTICAL PERCOLATION I.AYER

$=120.00$ INCHES

$=0.3980 \mathrm{VOL} / \mathrm{VOL}$

$=0.2440 \mathrm{VOI} / \mathrm{VOI}$

$=0.1360 \mathrm{VOL} / \mathrm{VOL}$

$=0.2440 \mathrm{VOI} / \mathrm{VOI}$

$=0.000119999997 \mathrm{CM} / \mathrm{SEC}$

GENERAI STMUI.ATION DATA

SCS RUNOFF CURVE NUMBER

TOTAI AREA OF COVER

EVAPORATIVE ZONE DEPTH

UPPER IIMIT VEG. STORAGE

INITIAI VEG. STORAGE

INITIAL SNOW WATER CONTENT

INITIAI TOTAL WATER STORAGE IN

SOIL AND WASTE IAAYERS

$$
\begin{array}{ll}
= & 80.00 \\
= & 13068000 . \text { SQ FT } \\
= & 18.00 \text { INCHES } \\
= & 7.1640 \text { INCHES } \\
= & 4.3920 \text { INCHES } \\
= & 0.0000 \text { INCHES } \\
= & 29.2800 \text { INCHES }
\end{array}
$$

SOIL WATER CONTENT INITIAIIZED BY USER. 
CIIMATOLOGICAL DATA

- - - - - - - -

SYNTHETIC RAINFALL WITH SYNTHETIC DAILY TEMPERATURES AND SOLAR RADIATION FOR CHICAGO IIIINOIS

$\begin{array}{ll}\text { MAXIMUM LEAF AREA INDEX } & =0.00 \\ \text { START OF GROWING SEASON (JULIAN DATE) } & =128 \\ \text { END OF GROWING SEASON (JULIAN DATE) } & =282\end{array}$

NORMAL MEAN MONTHLY TEMPERATURES, DEGREES FAHRENHEIT

$\begin{array}{lccccc}\text { JAN/JUL } & \text { FEB/AUG } & \text { MAR/SEP } & \text { APR/OCT } & \text { MAY/NOV } & \text { JUN/DEC } \\ & & & -- & & \\ 21.40 & 26.00 & 36.00 & 48.80 & 59.10 & 68.60 \\ 73.00 & 71.90 & 64.70 & 53.50 & 39.80 & 27.70\end{array}$

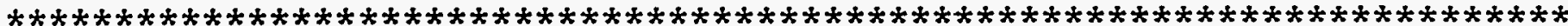
AVERAGE MONTHLY VALUES IN INCHES FOR YEARS

JAN/JUL FEB/AUG MAR/SEP APR/OCT MAY/NOV JUN/DEC

PRECIPITATION

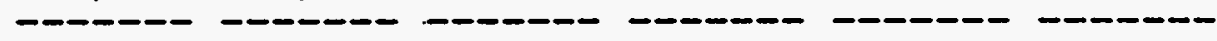

\begin{tabular}{|c|c|c|c|c|c|c|}
\hline \multirow{2}{*}{ TOTALS } & \multicolumn{5}{|c|}{-} & \multirow[b]{2}{*}{$\begin{array}{l}4.60 \\
2.04\end{array}$} \\
\hline & $\begin{array}{l}1.48 \\
4.87\end{array}$ & $\begin{array}{l}0.94 \\
4.08\end{array}$ & $\begin{array}{l}2.71 \\
3.42\end{array}$ & $\begin{array}{l}4.37 \\
2.66\end{array}$ & $\begin{array}{l}2.49 \\
2.38\end{array}$ & \\
\hline STD. DEVIATIONS & $\begin{array}{l}1.11 \\
4.14\end{array}$ & $\begin{array}{l}0.49 \\
1.48\end{array}$ & $\begin{array}{l}1.35 \\
1.49\end{array}$ & $\begin{array}{l}1.39 \\
1.29\end{array}$ & $\begin{array}{l}0.99 \\
0.25\end{array}$ & $\begin{array}{l}1.67 \\
0.65\end{array}$ \\
\hline \multicolumn{7}{|l|}{ RUNOFF } \\
\hline TOTALS & $\begin{array}{l}0.079 \\
0.584\end{array}$ & $\begin{array}{l}0.000 \\
0.173\end{array}$ & $\begin{array}{l}0.008 \\
0.009\end{array}$ & $\begin{array}{l}0.012 \\
0.031\end{array}$ & $\begin{array}{l}0.002 \\
0.001\end{array}$ & $\begin{array}{l}0.137 \\
0.005\end{array}$ \\
\hline STD. DEVIATIONS & $\begin{array}{l}0.177 \\
1.145\end{array}$ & $\begin{array}{l}0.000 \\
0.234\end{array}$ & $\begin{array}{l}0.011 \\
0.013\end{array}$ & $\begin{array}{l}0.016 \\
0.047\end{array}$ & $\begin{array}{l}0.005 \\
0.001\end{array}$ & $\begin{array}{l}0.170 \\
0.011\end{array}$ \\
\hline \multicolumn{7}{|l|}{ EVAPOTRANSPIRATION } \\
\hline TOTALS & $\begin{array}{l}0.693 \\
3.405\end{array}$ & $\begin{array}{l}1.247 \\
3.723\end{array}$ & $\begin{array}{l}2.398 \\
2.826\end{array}$ & $\begin{array}{l}3.625 \\
2.427\end{array}$ & $\begin{array}{l}3.180 \\
1.109\end{array}$ & $\begin{array}{l}4.116 \\
0.857\end{array}$ \\
\hline
\end{tabular}




\section{RECHARGE}

$\begin{array}{lllllll}\text { STD. DEVIATIONS } & 0.280 & 0.208 & 0.289 & 0.343 & 1.436 & 1.294 \\ & 2.567 & 0.950 & 1.292 & 0.820 & 0.398 & 0.326\end{array}$

PERCOLATION FROM IAAYER 1

$\begin{array}{llllllll}\text { TOTALS } & 0.4258 & 0.3891 & 0.4906 & 0.4963 & 0.4271 & 0.3357 \\ & 0.4102 & 0.4504 & 0.3682 & 0.3344 & 0.3141 & 0.3951 \\ \text { STD. DEVIATIONS } & 0.2746 & 0.2587 & 0.3296 & 0.3978 & 0.2755 & 0.1866 \\ & 0.2654 & 0.3566 & 0.2773 & 0.2328 & 0.1656 & 0.1861\end{array}$

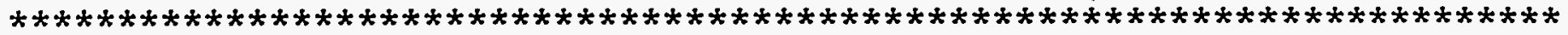

\begin{tabular}{|c|c|c|c|c|}
\hline AVERAGE ANNUAL TOTALS \& & (STD. & DEVIATIÓNS) FOR & YEARS & $\mathrm{JGH}$ \\
\hline & & (INCHES) & (CU.. FT. ) & PERCENT \\
\hline PRECIPITATION & & $(6.599)$ & 39234496 . & 100.00 \\
\hline RUNOFF & & $(1.228)$ & 1135027 . & 2.89 \\
\hline EVAPOTRANSPIRATION & & $(4.465)$ & 32241940 . & 82.18 \\
\hline PERCOIATION FROM IAYER & 1 & $4.8371(2.7763)$ & 5267646 . & 13.43 \\
\hline CHANGE IN WATER STORAGE & & $(1.259)$ & 589876 . & 1.50 \\
\hline
\end{tabular}

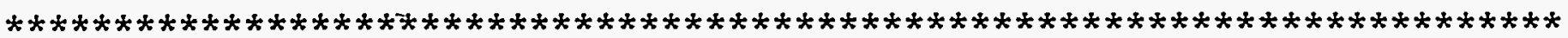

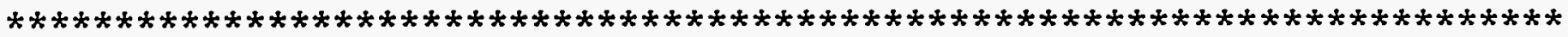

PEAK DAILY VALUES FOR YEARS 1 THROUGH 5

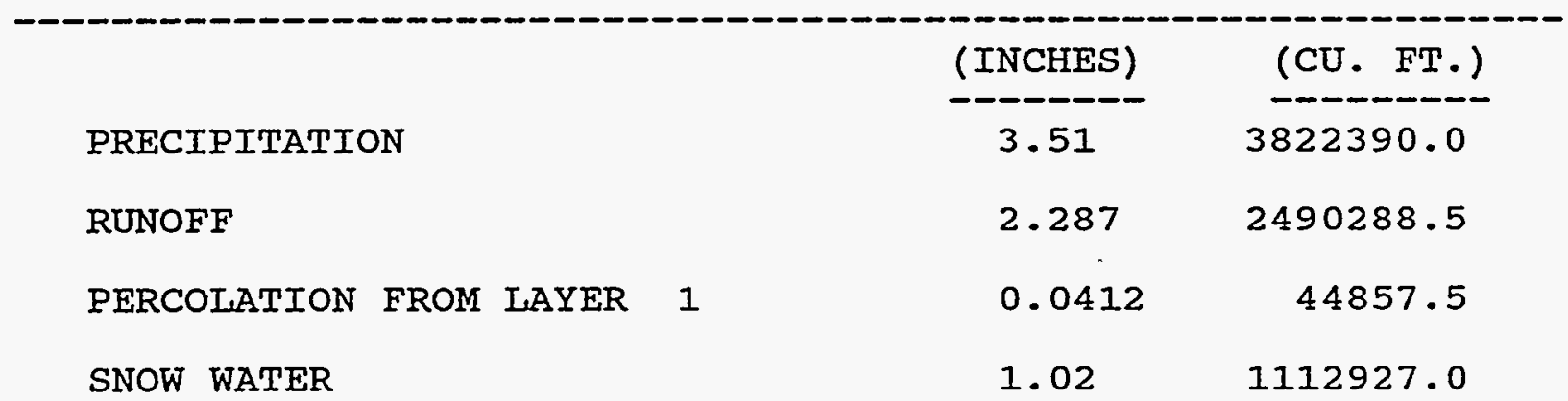



MAXIMUM VEG. SOIL WATER (VOL/VOI)
0.3640
MINIMUM VEG. SOII WATER (VOI/VOL)
0.1345

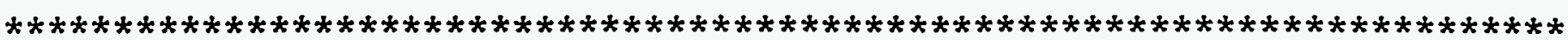

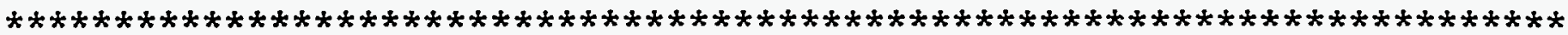

FINAL WATER STORAGE AT END OF YEAR 5

\section{LAYER}

1
(INCHES)

31.99
(VOI/VOI)

0.2666

SNOW WATER

0.00

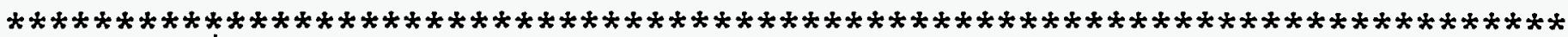

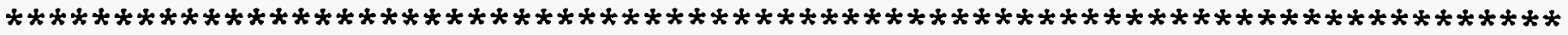




\section{APPENDIX B}

HELP Model-Open Landfill 
FIRST YEAR - OPEN CELL

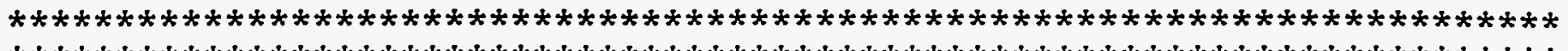

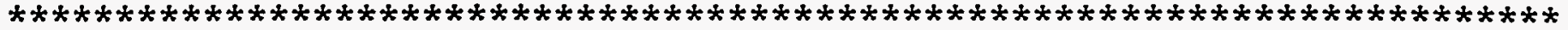

OPEN IANDFILL

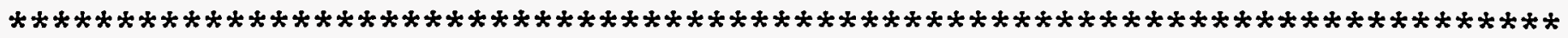

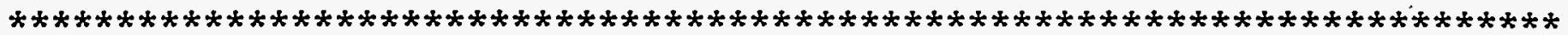

LAYER 1

VERTICAL PERCOLATION LAYER

THICKNESS

POROSITY

FIEID CAPACITY

WIITING POINT

INITIAL SOII WATER CONTENT

SATURATED HYDRAULIC CONDUCTIVITY
$=120.00$ INCHES

$=0.6020 \mathrm{VOL} / \mathrm{VOL}$

$=0.4481 \mathrm{VOL} / \mathrm{VOI}$

$=0.2459 \mathrm{VOL} / \mathrm{VOI}$

$=0.2460 \mathrm{VOL} / \mathrm{VOL}$

$=0.000099999997 \mathrm{CM} / \mathrm{SEC}$

GENERAI SIMULATION DATA

SCS RUNOFF CURVE NUMBER

TOTAL AREA OF COVER

EVAPORATIVE ZONE DEPTH POTENTIAL RUNOFF FRACTION

UPPER IIMIT VEG. STORAGE

INITIAL VEG. STORAGE

INITIAL SNOW WATER CONTENT

INITIAI TOTAL WATER STORAGE IN

SOIL AND WASTE LAYERS
$=82.00$

$=435600 . \mathrm{SQ} \mathrm{FT}$

$=18.00$ INCHES

$=1.000000$

$=\quad 10.8360$ INCHES

$=\quad 4.4280$ INCHES

$=0.0000$ INCHES

$=\quad 29.5200$ INCHES

SOIL WATER CONTENT INITIALIZED BY USER. 
CLIMATOLOGICAL DATA

SYNTHETIC RAINFALL WITH SYNTHETIC DAIIY TEMPERATURES AND SOIAR RADIATION FOR

MAXIMUM LEAF AREA INDEX

START OF GROWING SEASON (JULIAN DATE)

END OF GROWING SEASON (JUIIAN DATE)

$$
\begin{aligned}
& =0.00 \\
& =128 \\
& =282
\end{aligned}
$$

NORMAL MEAN MONTHLY TEMPERATURES, DEGREES FAHRENHEIT

\begin{tabular}{lccccc} 
JAN/JUL & FEB/AUG & MAR/SEP & APR/OCT & MAY/NOV & JUN/DEC \\
\hdashline & & - & & & \\
21.40 & 26.00 & 36.00 & 48.80 & 59.10 & 68.60 \\
73.00 & 71.90 & 64.70 & 53.50 & 39.80 & 27.70
\end{tabular}

\begin{tabular}{|c|c|c|c|}
\hline & (INCHES) & (CU. FT.) & PERCENT \\
\hline PRECIPITATION & 31.40 & 1139820 & 100.00 \\
\hline RUNOFF & 0.335 & 12177 . & 1.07 \\
\hline EVAPOTRANSPIRATION & 27.274 & 990062 . & 86.86 \\
\hline PERCOLATION FROM IAYYER 1 & 0.0007 & 26 . & 0.00 \\
\hline CHANGE IN WATER STORAGE & 3.789 & 137555 . & 12.07 \\
\hline SOIL WATER AT START OF YEAR & 29.52 & 1071576 . & \\
\hline SOIL WATER AT END OF YEAR & 33.31 & 1209131. & \\
\hline SNOW WATER AT START OF YEAR. & 0.00 & 0 . & \\
\hline SNOW WATER AT END OF YEAR & 0.00 & 0. & \\
\hline ANNUAL WATER BUDGET BALANCE & 0.00 & 0 . & 0.00 \\
\hline
\end{tabular}

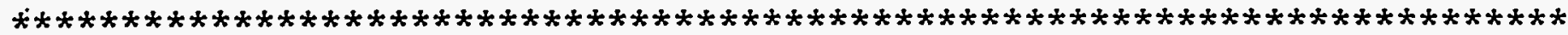
ANNUAI TOTAIS FOR YEAR 1 


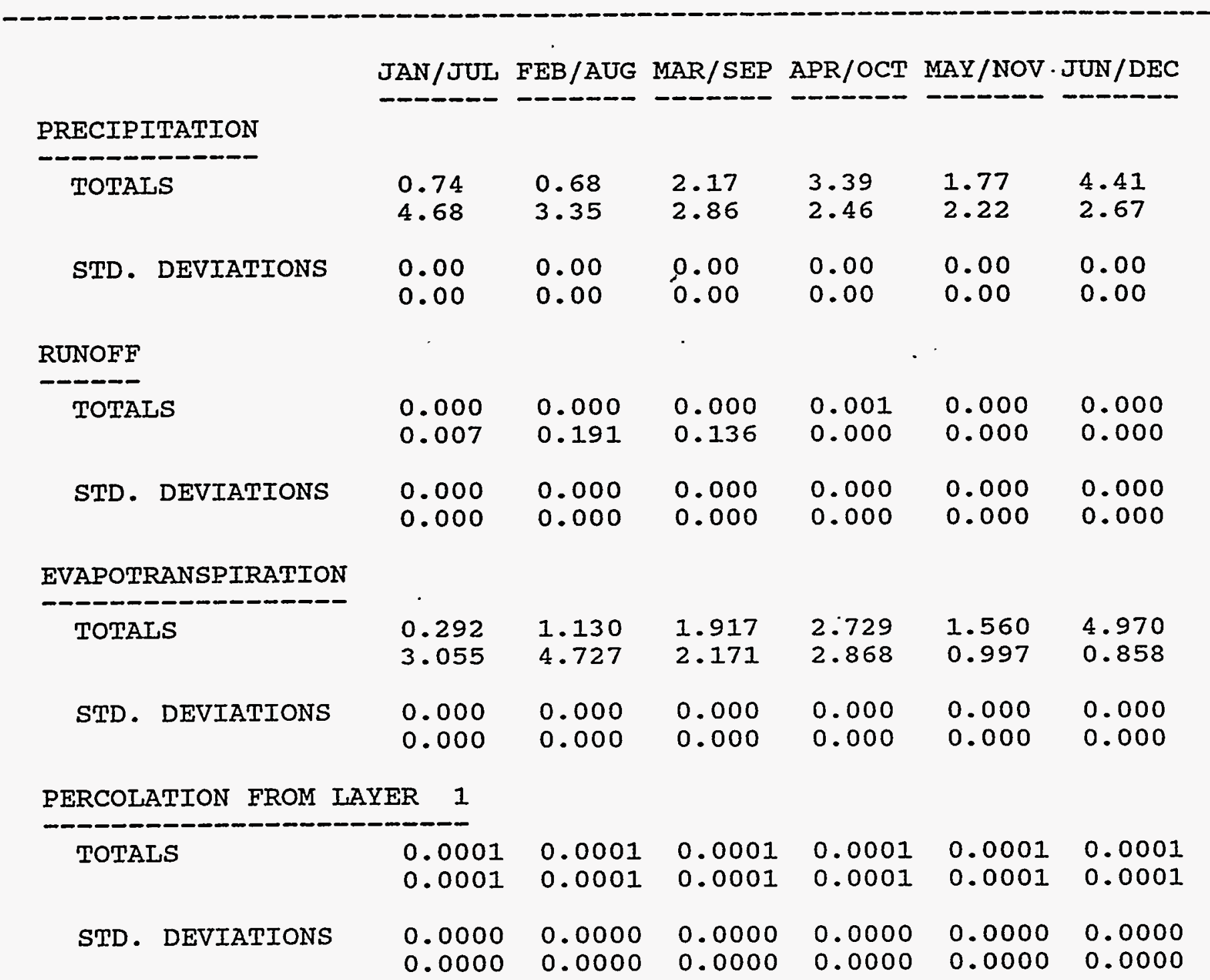

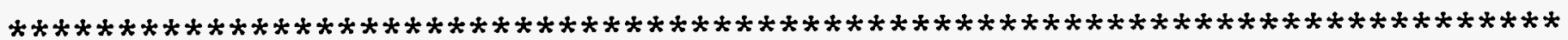




$\begin{array}{lcccc}\text { PRECIPITATION } & \text { (INCHES) } & \text { (CU. FT.) } & \text { PERCENT } \\ \text { RUNOFF } & 31.40 & (0.000) & 1139820 . & 100.00 \\ \text { EVAPOTRANSPIRATION } & 0.335 & (0.000) & 12177 . & 1.07 \\ \text { PERCOIATION FROM LAYER } & 1 & 0.0007(0.0000) & 990062 . & 86.86 \\ \text { CHANGE IN WATER STORAGE } & 3.789(0.000) & 137555 . & 12.07\end{array}$

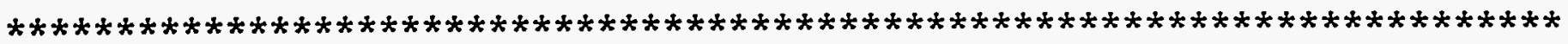

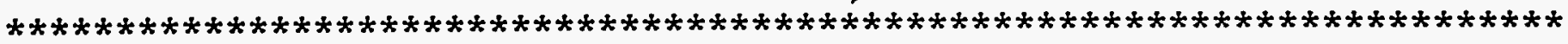
PEAK DAILY VALUES FOR YEARS 1 THROUGH. 1

$\begin{array}{lcc}\text { PRECIPITATION } & \text { (INCHES) } & \text { (CU. FT.) } \\ \text { RUNOFF } & 1.64 & 59532.0 \\ \text { PERCOLATION FROM I.AYER } 1 & 0.136 & 4945.0 \\ \text { SNOW WATER } & 0.0000 & 0.1 \\ \text { MAXIMUM VEG. SOIL WATER (VOL/VOL) } & 1.02 & 37097.6 \\ \text { MINIMUM VEG. SOIL WATER (VOL/VOL) } & 0.4470 & \\ \end{array}$

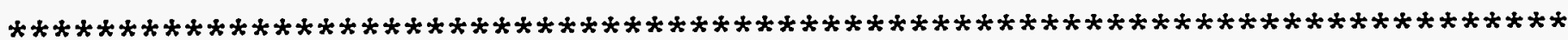

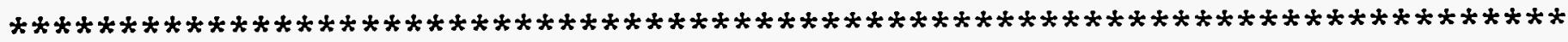
FINAI WATER STORAGE AT END OF YEAR 1

$\begin{array}{ccc}\text { LAYER } & \text { (INCHES) } & \text { (VOI/VOI) } \\ -1 & 33.31 & 0.2776\end{array}$


FIRST YEAR - OPEN CELL
SNOW WATER
0.00

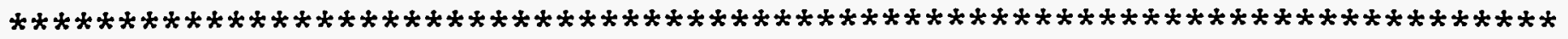

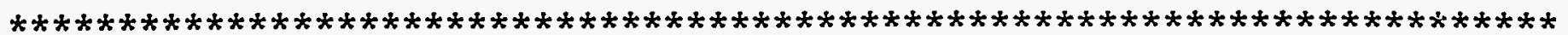




\section{APPENDIX C}

MULTIMED Model Results-Open Landfill 
U

乙

田

ర

4

$z$

O E-1

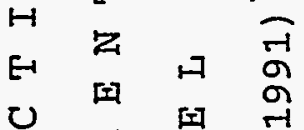

日 $\Sigma$ 四

$\begin{array}{llll}1 & \text { U } & 0 & \text { gु } \\ 0 & \text { os } & 5 & \text { b }\end{array}$

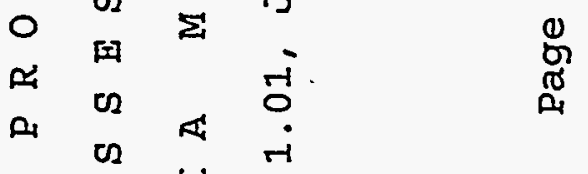

ᄀ A $H$ व

4 回 5 品

Z

다 on $E$

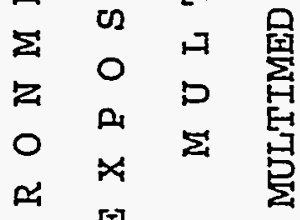

$H$ 回

$>$

z

田

نं

$\dot{p}$ 
1

Run options

... .........

SAMPLE

RUN

Chemical simulated is DEFAULT CHEMICAL

Option Chosen

Run was

Infiltration input by usex

Run was steady-state

Reject runs if $\mathrm{Y}$ coordinate outside plume

Reject runs if $Z$ coordinate outside plume

Gaugsian source used in saturated zone model
Saturated zone model

DETERMIN

1

CHEMICAL SPECIFIC VARTABLES

\begin{tabular}{|c|c|c|c|c|c|c|}
\hline \multirow{2}{*}{ VARIABLE NAME } & \multirow{2}{*}{ UNITS } & \multirow[t]{2}{*}{ DISTRIBUTION } & \multicolumn{2}{|c|}{ PARAMETERS } & \multicolumn{2}{|c|}{ LIMITS } \\
\hline & & & MEAN & STD DEV & MIN & $\operatorname{MAX}$ \\
\hline $\begin{array}{l}\text { Solid phase decay coefficient } \\
\text { Dissolved phase decay coefflctent } \\
\text { overall chemlcal decay coefflcient } \\
\text { Acid catalyzed hydrolysis rate } \\
\text { Neutral hydrolysig rate constant } \\
\text { Base catalyzed hydrolysis rate } \\
\text { Reference temperature }\end{array}$ & $\begin{array}{l}1 / y^{x} \\
1 / y^{x} \\
1 / y^{x} \\
1 / M-y x \\
1 / y x \\
1 / M-y x \\
C\end{array}$ & $\begin{array}{l}\text { DERIVED } \\
\text { DERIVED } \\
\text { DERIVED } \\
\text { CONSTANT } \\
\text { CONSTANT } \\
\text { CONSTANT } \\
\text { CONSTANT }\end{array}$ & $\begin{array}{l}-999 . \\
-999 . \\
-999 \\
0.000 \mathrm{E}+00 \\
0.000 \mathrm{E}+00 \\
0.000 \mathrm{E}+00 \\
25.0\end{array}$ & $\begin{array}{l}-999 . \\
-999 . \\
-999 . \\
-999 . \\
-999 . \\
-999 . \\
-999 .\end{array}$ & $\begin{array}{l}0.000 \mathrm{E}+00 \\
0.000 \mathrm{E}+00 \\
0.000 \mathrm{E}+00 \\
0.000 \mathrm{E}+00 \\
0.000 \mathrm{E}+00 \\
0.000 \mathrm{E}+00 \\
0.000 \mathrm{E}+00\end{array}$ & $\begin{array}{l}0.100 \mathrm{E}+11 \\
0.100 \mathrm{E}+11 \\
0.100 \mathrm{E}+11 \\
-999 . \\
-999 . \\
-999 . \\
100 .\end{array}$ \\
\hline
\end{tabular}

page 2 
FIRST YEAR - OPEN CELL

Normalized distribution coefficient Distribution coefficient

Biodegradation coefficient (sat. zone)

Air diffusion coefficient

Reference temperature for air diffusion

Molecular welght

Mole fraction of solute

Vapor pressure of solute

Henry's law constant

Overall 1st order decay sat. zone

Not currently used

1

Not currently used

$\begin{array}{cl}\mathrm{ml} / \mathrm{g} & \text { CONSTANT } \\ -- & \text { CONSTANT } \\ 1 / \mathrm{yr} & \text { CONSTANT } \\ \mathrm{cm} 2 / \mathrm{s} & \text { CONSTANT } \\ \mathrm{C} & \text { CONSTANT } \\ \mathrm{g} / \mathrm{M} & \text { CONSTANT } \\ -- & \text { CONSTANT } \\ \mathrm{mm} \mathrm{Hg} & \text { CONSTANT } \\ \mathrm{atm}-\mathrm{m}^{\wedge} 3 / \mathrm{M} & \text { CONSTANT } \\ 1 / \mathrm{yx} & \text { DERIVED } \\ & \text { CONSTANT } \\ & \text { CONSTANT }\end{array}$
$0.000 \mathrm{E}+00-999$.
$0.000 \mathrm{E}+00-999$.
$0.000 \mathrm{E}+00-999$.
$0.000 \mathrm{E}+00-999$.
$0.000 \mathrm{E}+00-999$.
$0.000 \mathrm{E}+00-999$.
$0.000 \mathrm{E}+00-999$.
$0.000 \mathrm{E}+00-999$.
$0.000 \mathrm{E}+00-999$.
$0.000 \mathrm{E}+00 \quad 0.000 \mathrm{E}+00$

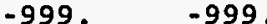
-999 .

SOURCE SPECIFIC VARIABLES

UNITS

DISTRIBUTION

PARAMETER

STD DEV

MIN

LIMITS

MEAN

MAX

Infiltration rate
Area of waste disposal unit
Duration of pulse
Spread of contaminant source
Recharge rate
Source decay constant
Initial concentration at landfill
Length scale of facility
Width scale of facility
Near field dilution

$\mathrm{m} / \mathrm{yr}$

CONSTANT

CONSTANT

0.200 E- $04-999$.

$0.100 \mathrm{E}-09 \quad 0.100 \mathrm{E}+11$

$\mathrm{m}^{\wedge}$

CONSTANT

$0.405 \mathrm{E}+05-999$.

$-999 . \quad-999$.

$\mathrm{m}$ DERIVED

$\mathrm{m} / \mathrm{yr} \quad$ CONSTANT

$1 / Y r$

$\mathrm{mg} / 1$

m

CONSTANT

-999 .

$0.122 \quad-999$.

$0.000 \mathrm{E}+00-999$.

CONSTANT

1.00

$-999$.

DERIVED $\quad-999.099$

DERIVED

1.00

$0.000 \mathrm{E}+00$

$0.100 \mathrm{E}-01-999$.

$0.100 \mathrm{E}-08$ - 999 .

$0.100 \mathrm{E}-08 \quad 0.100 \mathrm{E}+11$

$0.000 \mathrm{E}+00 \quad 0.100 \mathrm{E}+11$

$0.000 \mathrm{E}+00$ - 999 .

$0.000 \mathrm{E}+00-999$.

$\begin{array}{ll}0.100 \mathrm{E}-08 & 0.100 \mathrm{E}+11 \\ 0.100 \mathrm{E}-08 & 0.100 \mathrm{E}+11\end{array}$

Near field dilution

\section{AQUIFER SPECIFIC VARIABLES}


FIRST YEAR - OPEN CELL

\begin{tabular}{|c|c|c|c|c|c|c|}
\hline & & & MEAN & STD DEV & MIN & $\operatorname{MAX}$ \\
\hline $\begin{array}{l}\text { Particle diametex } \\
\text { Aquifer porosity } \\
\text { Bulk density } \\
\text { Aquifex thickness } \\
\text { Source thickness (mixing zone depth) } \\
\text { Conductivity (hydraulic) } \\
\text { Gradient (hydraulic) } \\
\text { Groundwater seepage velocity } \\
\text { Retardation coefficient } \\
\text { Longitudinal dispersivity } \\
\text { Transverse dispersivity } \\
\text { Vertical dispersivity } \\
\text { Temperature of aquifer } \\
\text { pH } \\
\text { Organic carbon content (fraction) } \\
\text { Well distance from site } \\
\text { Angle off center } \\
\text { Weli vertical distance }\end{array}$ & $\begin{array}{l}\mathrm{cm} \\
\mathrm{g} / \mathrm{cc} \\
\mathrm{m} \\
\mathrm{m} \\
\mathrm{m} / \mathrm{yr} \\
\mathrm{m} / \mathrm{yr} \\
\cdots \\
\mathrm{m} \\
\mathrm{m} \\
\mathrm{m} \\
\cdots \\
\mathrm{m} \\
\operatorname{degree} \\
\mathrm{m}\end{array}$ & $\begin{array}{l}\text { CONSTANT } \\
\text { CONSTANT } \\
\text { CONSTANT } \\
\text { CONSTANT } \\
\text { DERIVED } \\
\text { CONSTANT } \\
\text { CONSTANT } \\
\text { DERIVED } \\
\text { DERIVED } \\
\text { FUNCTION OF } \mathrm{x} \\
\text { FUNCTION OF } \mathrm{x} \\
\text { FUNCTION OF } \mathrm{x} \\
\text { CONSTANT } \\
\text { CONSTANT } \\
\text { CONSTANT } \\
\text { CONSTANT } \\
\text { CONSTANT } \\
\text { CONSTANT }\end{array}$ & $\begin{array}{l}0.100 \mathrm{E}-02 \\
0.437 \\
1.40 \\
6.10 \\
-999 . \\
536 . \\
0.600 \mathrm{E}-02 \\
33.5 \\
1.00 \\
-999 . \\
-999 . \\
-999 . \\
25.0 \\
6.20 \\
0.110 \\
122 . \\
0.000 \mathrm{E}+00 \\
0.000 \mathrm{E}+00\end{array}$ & $\begin{array}{l}-999 . \\
-999 . \\
-999 . \\
-999 . \\
-999 . \\
-999 . \\
-999 . \\
-999 . \\
-999 . \\
-999 . \\
-999 . \\
-999 . \\
-999 . \\
-999 . \\
-999 . \\
-999 . \\
-999 . \\
-999 .\end{array}$ & $\begin{array}{l}0.100 \mathrm{E}-08 \\
0.100 \mathrm{E}-08 \\
0.100 \mathrm{E}-01 \\
0.100 \mathrm{E}-08 \\
0.100 \mathrm{E}-08 \\
0.100 \mathrm{E}-06 \\
0.100 \mathrm{E}-07 \\
0.100 \mathrm{E}-09 \\
1.00 \\
-999 . \\
-999 . \\
-999 \\
0.000 \mathrm{E}+00 \\
0.300 \\
0.100 \mathrm{E}-05 \\
1.00 \\
0.000 \mathrm{E}+00 \\
0.000 \mathrm{E}+00\end{array}$ & $\begin{array}{l}100 . \\
0.990 \\
5.00 \\
0.100 \mathrm{E}+06 \\
0.100 \mathrm{E}+06 \\
0.100 \mathrm{E}+09 \\
-999 . \\
0.100 \mathrm{E}+09 \\
0.100 \mathrm{E}+09 \\
-999 . \\
-999 . \\
-999 . \\
100 . \\
14.0 \\
1.00 \\
-999 . \\
360 . \\
1.00\end{array}$ \\
\hline
\end{tabular}

CONCENTRATION AFTER SATURATED ZONE MODEL 0.1837E-03 


\section{APPENDIX D \\ HELP Model-Closed Landfill}




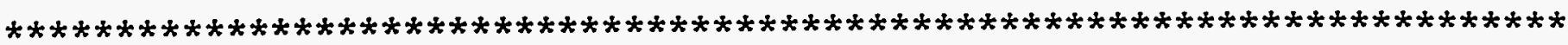

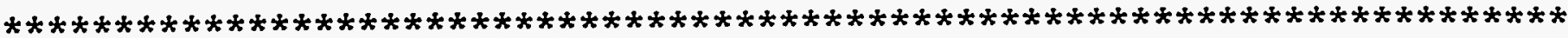

CLOSED IAANDFILL

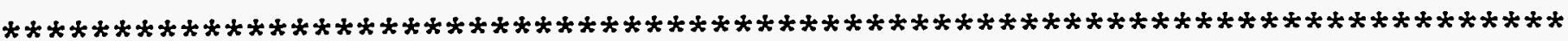

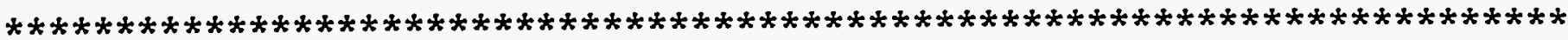

THICKNESS

POROSITY

FIELD CAPACITY

WIITING POINT

INITIAL SOIL WATER CONTENT

SATURATED HYDRAULIC CONDUCTIVITY
LAYER 1

VERTICAL PERCOIATION LAYER

$\begin{array}{ll}= & 24.00 \text { INCHES } \\ = & 0.3980 \text { VOL/VOI } \\ = & 0.2440 \text { VOL/VOI } \\ = & 0.1360 \mathrm{VOL} / \mathrm{VOI} \\ = & 0.2440 \mathrm{VOI} / \mathrm{VOI} \\ = & 0.000119999997 \mathrm{CM} / \mathrm{SEC}\end{array}$

\section{IAAYER 2}

VERTICAI PERCOLATION LAYER

\section{THICKNESS \\ POROSITY}

FIELD CAPACITY

WILTING POINT

INITIAL SOIL WATER CONTENT SATURATED HYDRAULIC

\section{VERTICAL PERCOLATIOI}

$=$

$=$

$=$

$=$

$=$

$=\quad 24.00$ INCHES

$=0.4300 \mathrm{VOL} / \mathrm{VOI}$

$=0.3660 \mathrm{VOL} / \mathrm{VOL}$

$=0.2800$ VOL/VOL

0.2460 VOL/VOL

$0.000000200000 \mathrm{CM} / \mathrm{SEC}$

LAYER 3

D-1 
THICKNESS

POROSITY

FIELD CAPACITY

WILTING POINT

INITIAI SOIL WATER CONTENT

SATURATED HYDRAULIC CONDUCTIVITY =

$\begin{array}{ll}\text { ION } & \text { LAYER } \\ = & 480.00 \mathrm{INCHES} \\ = & 0.5876 \mathrm{VOI} / \mathrm{VOI} \\ = & 0.3566 \mathrm{VOI} / \mathrm{VOI} \\ = & 0.2459 \mathrm{VOL} / \mathrm{VOL} \\ = & 0.2460 \mathrm{VOI} / \mathrm{VOI} \\ = & 0.000099999997 \mathrm{CM} / \mathrm{SEC}\end{array}$

GENERAL SIMULATION DATA

SCS RUNOFF CURVE NUMBER

TOTAI AREA OF COVER

EVAPORATIVE ZONE DEPTH

UPPER LIMIT VEG. STORAGE

INITIAI VEG. STORAGE

INITIAI SNOW WATER CONTENT

INITIAI TOTAL WATER STORAGE IN

SOIL AND WASTE LAYYERS

$$
\begin{array}{rr}
= & 80.00 \\
= & 8712000 . \text { SQ FT } \\
= & 20.00 \text { INCHES } \\
= & 7.9600 . \text { INCHES } \\
= & 4.8800 \text { INCHES } \\
= & 0.0000 \text { INCHES } \\
= & 129.8400 \text { INCHES }
\end{array}
$$

SOIL WATER CONTENT INITIALIZED BY USER.

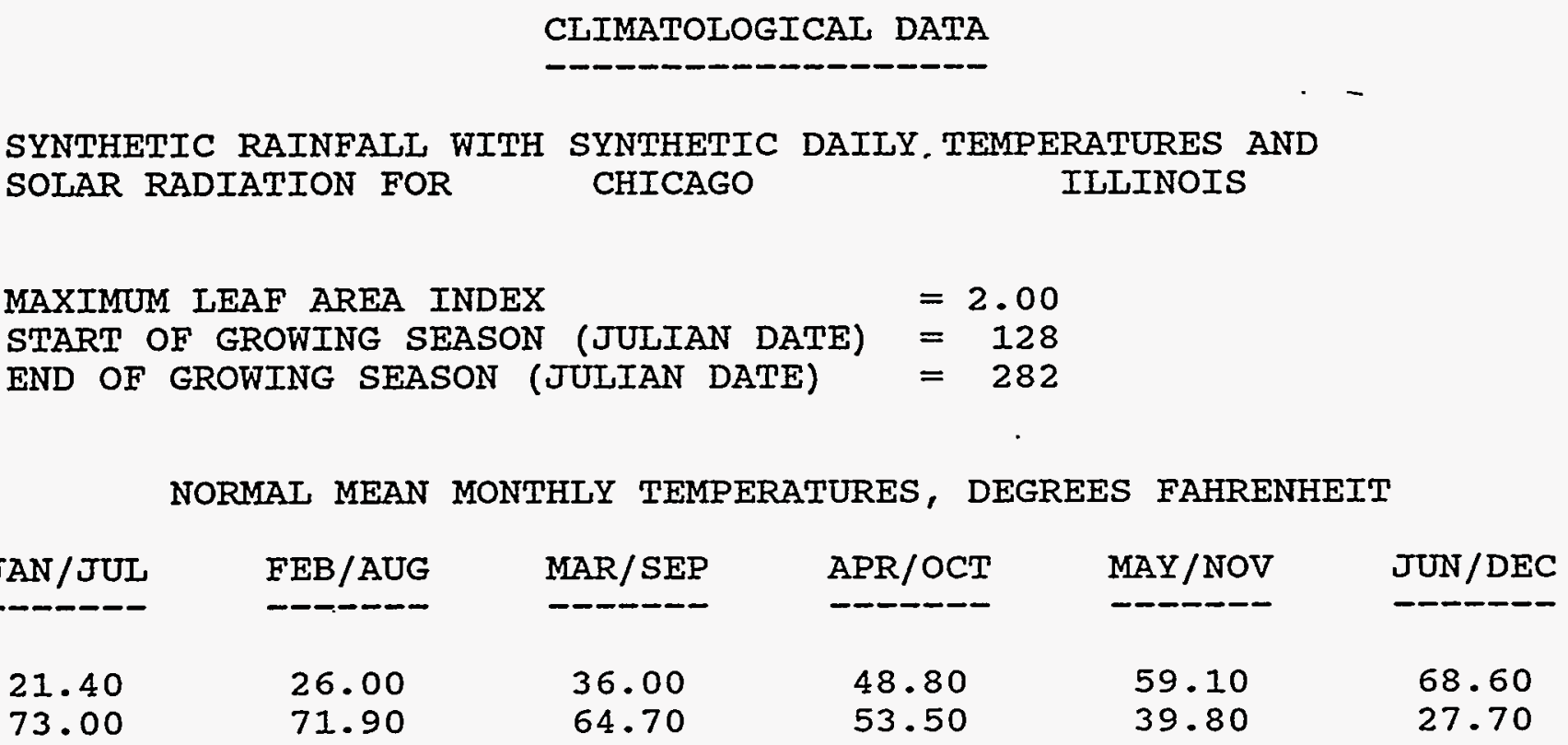


CLOSED LANDFIIL

ANNUAL TOTALS FOR YEAR 1

\begin{tabular}{|c|c|c|c|}
\hline & (INCHES) & (CU. FT.) & PERCENT \\
\hline PRECIPITATION & 31.40 & 22796404 & 100.00 \\
\hline RUNOFF & 0.125 & 90401. & 0.40 \\
\hline EVAPOTRANSPIRATION & 29.244 & 21231240 & 93.13 \\
\hline PERCOLATION FROM LAYER 3 & 0.0000 & 2 . & 0.00 \\
\hline CHANGE IN WATER STORAGE & 2.031 & 1474765 . & 6.47 \\
\hline SOIL WATER AT START OF YEAR & 129.84 & 94263840 & \\
\hline SOII WATER AT END OF YEAR & $13,1.87$ & 95738600 & \\
\hline SNOW WATER AT START OF YEAR & 0.00 & 0. & \\
\hline SNOW WATER AT END OF YEAR & 0.00 & 0. & \\
\hline ANNUAL WATER BUDGET BALANCE & 0.00 & -3 & 0.00 \\
\hline
\end{tabular}

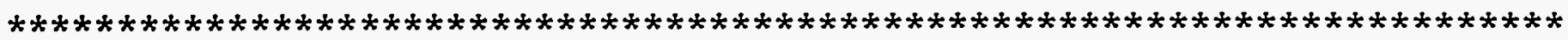
ANNUAL TOTALS FOR YEAR 2

$\begin{array}{lccc}\text { PRECIPITATION } & \text { (INCHES) } & \text { (CU. FT.) } & \text { PERCENT } \\ \text { RUNOFF } & -36.82 & 26731326 . & 100.00 \\ \text { EVAPOTRANSPIRATION } & 0.317 & 230428 . & 0.86 \\ \text { PERCOLATION FROM IAYER } 3 & 33.033 & 23982210 . & 89.72 \\ \text { CHANGE IN WATER STORAGE } & 0.0000 & 2.00 \\ \text { SOIL WATER AT START OF YEAR } & 131.87 & 95738600 . & 9.42 \\ \text { SOIL WATER AT END OF YEAR } & 135.34 & 98257280 . \\ \text { SNOW WATER AT START OF YEAR } & 0.00 & 0 .\end{array}$


SNOW WATER AT END OF YEAR

ANNUAL WATER BUDGET BALANCE
0.00

0.00
0 .

7 .

0.00

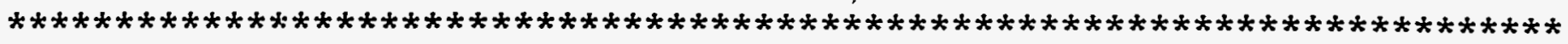

\begin{tabular}{|c|c|c|c|}
\hline ANNUAI TOTALS & FOR YEAR & 3 & \\
\hline & (INCHES) & (CU. FT.) & PERCENT \\
\hline PRECIPITATION & 45.82 & 33265318 & 100.00 \\
\hline RUNOFF & 4.653 & 3377918 & 10.15 \\
\hline EVAPOTRANSPIRATION & 38.772 & 28148494 & 84.62 \\
\hline PERCOLATION FROM ILAYER 3 & 0.0000 & 2 . & 0.00 \\
\hline CHANGE IN.WATER STORAGE & 2.395 & 1738925 . & 5.23 \\
\hline SOIL WATER AT START OF YEAR & 135.34 & 98257280 . & \\
\hline SOIL WATER AT END OF YEAR & 137.35 & 99712744 & \\
\hline SNOW WATER AT START OF YEAR & 0.00 & 0 & \\
\hline SNOW WATER AT END OF YEAR & 0.39 & 283458 . & \\
\hline ANNUAL WATER BUDGET BAIAANCE & 0.00 & -22 & 0.00 \\
\hline
\end{tabular}

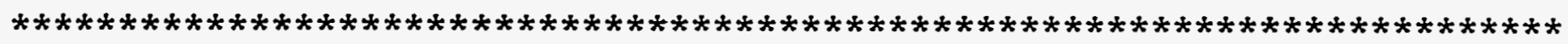

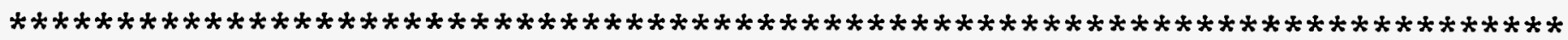
ANNUAL TOTALS FOR YEAR 4

$\begin{array}{lccc}\text { PRECIPITATION } & \text { (INCHES) } & \text { (CU. FT.) } & \text { PERCENT } \\ \text { RUNOFF } & 28.66 & 20807166 . & 100.00 \\ & 1.635 & 1187170 . & 5.71\end{array}$




$\begin{array}{lccr}\text { EVAPOTRANSPIRATION } & 25.251 & 18332412 . & 88.11 \\ \text { PERCOLATION FROM LAYER } 3 & 0.0000 & 3 . & 0.00 \\ \text { CHANGE IN WATER STORAGE } & 1.774 & 1287570 . & 6.19 \\ \text { SOII WATER AT START OF YEAR } & 137.35 & 99712744 . \\ \text { SOIL WATER AT END OF YEAR } & 138.77 & * * * * * * * * \\ \text { SNOW WATER AT START OF YEAR } & 0.39 & 283458 . \\ \text { SNOW WATER AT END OF YEAR } & 0.73 & 533518 . \\ \text { ANNUAL WATER BUDGET BALANCE } & 0.00 & 11 . & 0.00\end{array}$

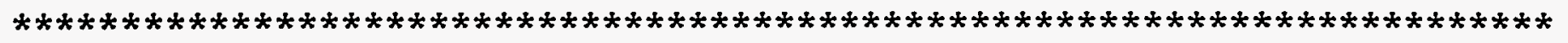

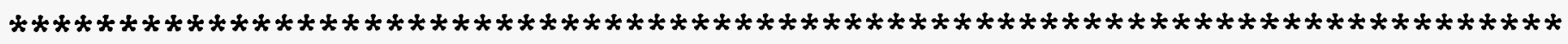
ANNUAL TOTALS FOR YEAR 5

$\begin{array}{lccc}\text { PRECIPITATION } & \text { (INCHES) } & \text { (CU. FT.) } & \text { PERCENT } \\ \text { RUNOFF } & 37.44 & 27181440 . & 100.00 \\ \text { EVAPOTRANSPIRATION } & 1.424 & 1033544 . & 3.80 \\ \text { PERCOIATION FROM IAYER 3 } & 34.098 & 24755262 . & 91.07 \\ \text { CHANGE IN WATER STORAGE } & 0.0000 & 5.00 \\ \text { SOII WATER AT START OF YEAR } & 138.77 & * * * * * * * * * & 5.12 \\ \text { SOIL WATER AT END OF YEAR } & 141.43 & * * * * * * * * \\ \text { SNOW WATER AT START OF YEAR } & 0.73 & 533518 . \\ \text { SNOW WATER AT END OF YEAR } & 0.00 & 0 . & 0.00 \\ \text { ANNUAL WATER BUDGET BALANCE } & 0.00 & 1392615 .\end{array}$


CLOSED LANDFILL

\begin{tabular}{|c|c|c|c|}
\hline ANNUAL TOTALS & FOR YEAR & 6 & \\
\hline & (INCHES) & (CU. FT.) & PERCENT \\
\hline PRECIPITATION & 36.51 & 26506258 & 100.00 \\
\hline RUNOFF & 0.915 & 664534 & 2.51 \\
\hline EVAPOTRANSPIRATION & 31.207 & 22656448 & 85.48 \\
\hline PERCOIATION FROM LAYER 3 & 0.0000 & 9. & 0.00 \\
\hline CHANGE IN WATER STORAGE & 4.387 & 3185271. & 12.02 \\
\hline SOIL WATER AT START OF YEAR & 141.43 & $* * * * * * * * *$ & \\
\hline SOII WATER AT END OF YEAR & 144.79 & $* * * * * * * * *$ & \\
\hline SNOW WATER AT START OF YEAR & 0.00 & 0 & \\
\hline SNOW WATER AT END OF YEAR & 1.02 & 742233 & \\
\hline ANNUAI WATER BUDGET BALANCE & 0.00 & -5 & 0.00 \\
\hline
\end{tabular}

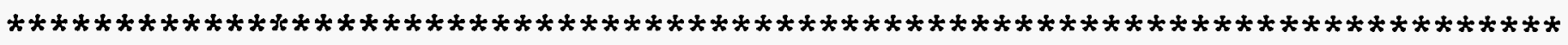

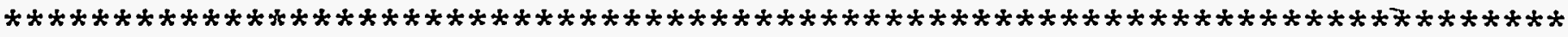
ANNUAL TOTALS FOR YEAR 7

$\begin{array}{lccc}\text { PRECIPITATION } & \text { (INCHES) } & \text { (CU. FT.) } & \text { PERCENT } \\ \text { RUNOFF } & 34.36 & 24945358 . & 100.00 \\ \text { EVAPOTRANSPIRATION } & 4.057 & 2945501 . & 11.81 \\ \text { PERCOLATION FROM LAYER } 3 & 26.991 & 19595754 . & 78.55 \\ \text { CHANGE IN WATER STORAGE } & 0.0000 & 15 . & 0.00 \\ \text { SOIL WATER AT START OF YEAR } & 144.79 & * * * * * * * * * & 9.64 \\ \text { SOIL WATER AT END OF YEAR } & 149.11 & * * * * * * * * *\end{array}$


SNOW WATER AT START OF YEAR

SNOW WATER AT END OF YEAR

ANNUAI WATER BUDGET BALANCE
1.02

0.02

0.00
742233

14643 .

-6 .

0.00

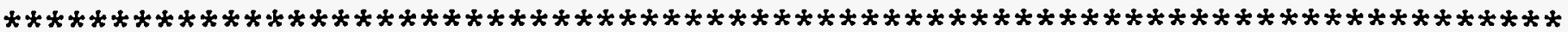

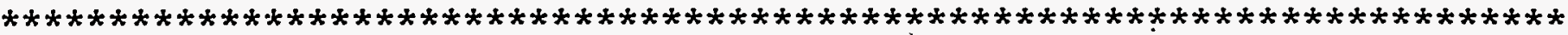
ANNUAL TOTALS FOR YEAR 8

$\begin{array}{lccc}\text { PRECIPITATION } & \text { (INCHES) } & \text { (CU. FT. } & \text { PERCENT } \\ \text { RUNOFF } & 36.43 & 26448180 . & 100.00 \\ \text { EVAPOTRANSPIRATION } & 3.798 & 2757248 . & 10.43 \\ \text { PERCOLATION FROM LAYER } 3 & 34.664 & 25166366 . & 95.15 \\ \text { CHANGE IN WATER STORAGE } & 0.0000 & 24.00 \\ \text { SOIL WATER AT START OF YEAR } & 149.11 & -1475472 . & -5.58 \\ \text { SOII WATER AT END OF YEAR } & 147.09 & * * * * * * * * * & 14643 . \\ \text { SNOW WATER AT START OF YEAR } & 0.02 & 0.0 & 0.00 \\ \text { SNOW WATER AT END OF YEAR } & 0.00 & 13 .\end{array}$

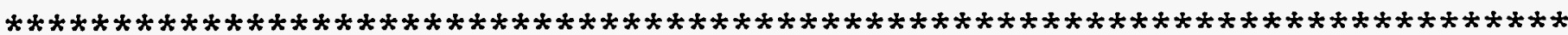

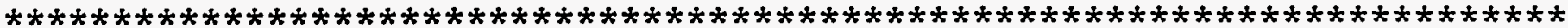
ANNUAL TOTALS FOR YEAR 9

\begin{tabular}{lccl} 
PRECIPITATION & (INCHES) & (CU. FT.) & PERCENT \\
\hdashline & 27.87 & 20233624. & 100.00
\end{tabular}




$\begin{array}{lrrr}\text { RUNOFF } & 0.088 & 63955 . & 0.32 \\ \text { EVAPOTRANSPIRATION } & 23.394 & 16984044 & 83.94 \\ \text { PERCOLATION FROM LAYER } 3 & 0.0000 & 35 . & 0.00 \\ \text { CHANGE IN WATER STORAGE } & 4.388 & 3185589 . & 15.74 \\ \text { SOIL WATER AT START OF YEAR } & 147.09 & * * * * * * * * * & \\ \text { SOIL WATER AT END OF YEAR } & 151.48 & * * * * * * * * * & . \\ \text { SNOW WATER AT START OF YEAR } & 0.00 & 0 . & 0.00 \\ \text { SNOW WATER AT END OF YEAR } & 0.00 & -1 . \\ \text { ANNUAI WATER BUDGET BAIANCE } & 0.00 & 1 * * * * * * * * * * * * * * * * * * * * * * * * * * * * * *\end{array}$

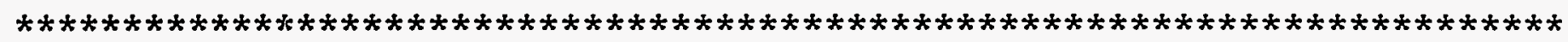
ANNUAL TOTALS FOR YEAR 10

$\begin{array}{lccc}\text { PRECIPITATION } & \text { (INCHES) } & \text { (CU. FT. } & \text { PERCENT } \\ \text { RUNOFF } & -19.57 & 2146782 . & 100.00 \\ \text { EVAPOTRANSPIRATION } & 0.123 & 89411 . & 0.42 \\ \text { PERCOIATION FROM LAYER } 3 & 25.390 & 18433088 . & 85.86 \\ \text { CHANGE IN WATER STORAGE } & 0.0001 & 54.00 \\ \text { SOIL WATER AT START OF YEAR } & 151.48 & * * * * * * * * & 13.72 \\ \text { SOIL WATER AT END OF YEAR } & 155.44 & * * * * * * * * & 0 . \\ \text { SNOW WATER AT START OF YEAR } & 0.00 & 0.057 & 0.00 \\ \text { SNOW WATER AT END OF YEAR } & 0.10 & -3.0\end{array}$




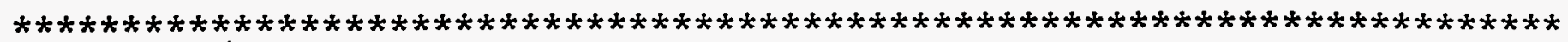
ANNUAL TOTALS FOR YEAR 11

$\begin{array}{lccc}\text { PRECIPITATION } & \text { (INCHES) } & \text { (CU. FT. } & \text { PERCENT } \\ \text { RUNOFF } & 32.17 & 23355424 & 100.00 \\ \text { EVAPOTRANSPIRATION } & 3.744 & 2718194.64 & 11.64 \\ \text { PERCOLATION FROM IAYER } 3 & 29.628 & 21510012 . & 92.10 \\ \text { CHANGE IN WATER STORAGE } & 0.0001 & 83.00 \\ \text { SOIL WATER AT START OF YEAR } & 155.44 & * * * * * * * * * & -3.74 \\ \text { SOIL WATER AT END OF YEAR } & 154.34 & * * * * * * * * & 73597 . \\ \text { SNOW WATER AT START OF YEAR } & 0.10 & 0.1 .202 & 0.00 \\ \text { SNOW WATER AT END OF YEAR } & 0.00 & 0.00 & 0 .\end{array}$

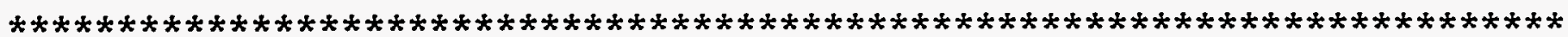

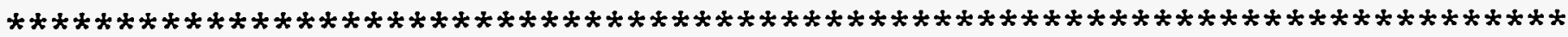
ANNUAL TOTALS FOR YEAR 12

$\begin{array}{lccc}\text { PRECIPITATION } & \text { (INCHES) } & \text { (CU. FT.) } & \text { PERCENT } \\ \text { RUNOFF } & -34.45 & 25010698 . & 100.00 \\ \text { EVAPOTRANSPIRATION } & 0.710 & 515323 . & 2.06 \\ \text { PERCOLATION FROM IAYER } 3 & 30.674 & 22269022 . & 89.04 \\ \text { CHANGE IN WATER STORAGE } & 0.0002 & 123.00 \\ \text { SOIL WATER AT START OF YEAR } & 154.34 & * * * * * * * * & 8.90\end{array}$


SOII WATER AT END OF YEAR

SNOW WATER AT START OF YEAR

SNOW WATER AT END OF YEAR

ANNUAL WATER BUDGET BALANCE
$157 \cdot 14$
0.00
$* * * * * * * * *$
-
0.26
0.00
0 .
189622 .
6.

0.00

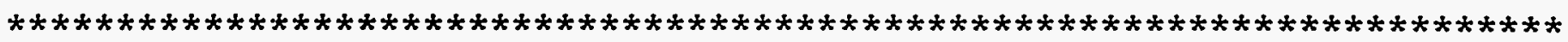

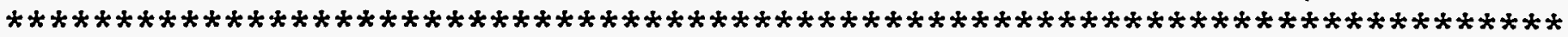
ANNUAI TOTALS FOR YEAR 13

\begin{tabular}{|c|c|c|c|}
\hline & (INCHES) & (CU. FT.) & PERCENT \\
\hline PRECIPITATION & $3 \dot{6} .72$ & 26658720 & 100.00 \\
\hline RUNOFF & 0.861 & 625254 & 2.35 \\
\hline EVAPOTRANSPIRATION & 31.873 & 23139440 & 86.80 \\
\hline PERCOLATION FROM IAYER 3 & 0.0002 & 179. & 0.00 \\
\hline CHANGE IN WATER STORAGE & 3.986 & 2893833 & 10.86 \\
\hline SOIL WATER AT START OF YEAR & 157.14 & $* * * * * * * * *$ & \\
\hline SOIL WATER AT END OF YEAR & 161.18 & $* * * * * * * * *$ & - \\
\hline SNOW WATER AT START OF YEAR & 0.26 & 189622 . & \\
\hline SNOW WATER AT END OF YEAR & 0.21 & 150321 & \\
\hline ANNUAL WATER BUDGET BALANCE & 0.00 & 14 . & 0.00 \\
\hline
\end{tabular}

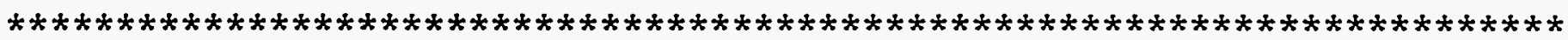

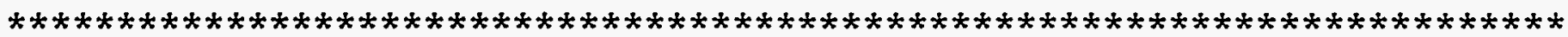
ANNUAL TOTALS FOR YEAR 14 


$\begin{array}{lcrr}\text { PRECIPITATION } & 38.56 & 27994556 . & 100.00 \\ \text { RUNOFF } & 2.982 & 2164665 . & 7.73 \\ \text { EVAPOTRANSPIRATION } & 35.267 & 25603732 . & 91.46 \\ \text { PERCOIATION FROM IAYER } 3 & 0.0004 & 273 . & 0.00 \\ \text { CHANGE IN WATER STORAGE } & 0.311 & 225885 . & 0.81 \\ \text { SOIL WATER AT START OF YEAR } & 161.18 & * * * * * * * * * & . \\ \text { SOIL WATER AT END OF YEAR } & 161.57 & * * * * * * * * * & \\ \cdot & & 150321 . & \\ \text { SNOW WATER AT START OF YEAR } & 0.21 & 96512 . \\ \text { SNOW WATER AT END OF YEAR } & 0.13 & -1 . & 0.00 \\ \text { ANNUAL WATER BUDGET BALANCE } & 0.00 & & \end{array}$

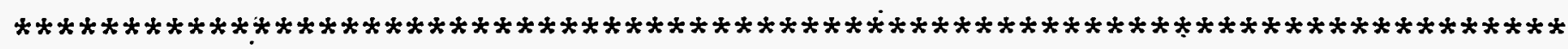

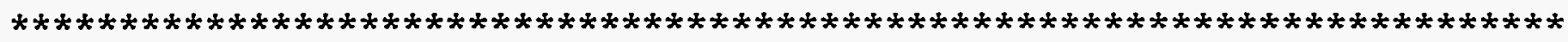
ANNUAL TOTALS FOR YEAR 15

$\begin{array}{lccc} & \text { (INCHES) } & \text { (CU. FT. } & \text { PERCENT } \\ \text { PRECIPITATION } & -35.97 & 26114218 . & 100.00 \\ \text { RUNOFF } & 1.968 & 1428661 . & 5.47 \\ \text { EVAPOTRANSPIRATION } & 30.444 & 22102098 . & 84.64 \\ \text { PERCOLATION FROM LAYER } 3 & 0.0005 & 397.00 \\ \text { CHANGE IN WATER STORAGE } & 3.558 & 2583061 . & 9.89 \\ \text { SOIL WATER AT START OF YEAR } & 161.57 & * * * * * * * * & 0.00 \\ \text { SOIL WATER AT END OF YEAR } & 165.26 & * * * * * * * * & 96512 . \\ \text { SNOW WATER AT START OF YEAR } & 0.13 & 0.00 \\ \text { SNOW WATER AT END OF YEAR } & 0.00 & 1 .\end{array}$


ANNUAL TOTALS FOR YEAR 16

$\begin{array}{lccc}\text { PRECIPITATION } & \text { (INCHES) } & \text { (CU. FT. } & \text { PERCENT } \\ \text { RUNOFF } & 33.08 & 24016078 . & 100.00 \\ \text { EVAPOTRANSPIRATION } & 3.982 & 2890825 . & 12.04 \\ \text { PERCOLATION FROM LAYER } 3 & 23.782 & 17265982 . & 71.89 \\ \text { CHANGE IN WATER STORAGE } & 0.0008 & 596.00 \\ \text { SOIL WATER AT START OF YEAR } & 165.26 & * * * * * * * * * & 16.07 \\ \text { SOIL WATER AT END OF YEAR } & 169.70 & * * * * * * * * * & 0 . \\ \text { SNOW WATER AT START OF YEAR } & 0.00 & 6.315 & 0.00 \\ \text { SNOW WATER AT END OF YEAR } & 0.87 & 0.00 & -14 .\end{array}$

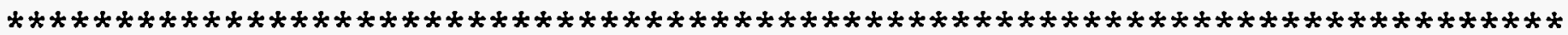

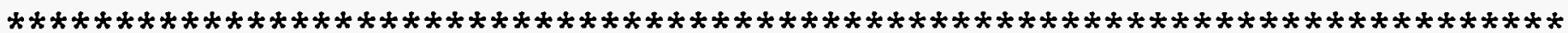
ANNUAL TOTALS FOR YEAR 17

$\begin{array}{lccc} & \text { (INCHES) } & \text { (CU. FT. } & \text { PERCENT } \\ \text { PRECIPITATION } & -16.01 & 18883262 . & 100.00 \\ \text { RUNOFF } & 26.01 & 9.01 \\ \text { EVAPOTRANSPIRATION } & 2.342 & 1700624 . & 99.66 \\ \text { PERCOLATION FROM IAAYER } 3 & 25.921 & 18818354 . & 0.00 \\ \text { CHANGE IN WATER STORAGE } & 0.0012 & 877 . & -8.67\end{array}$




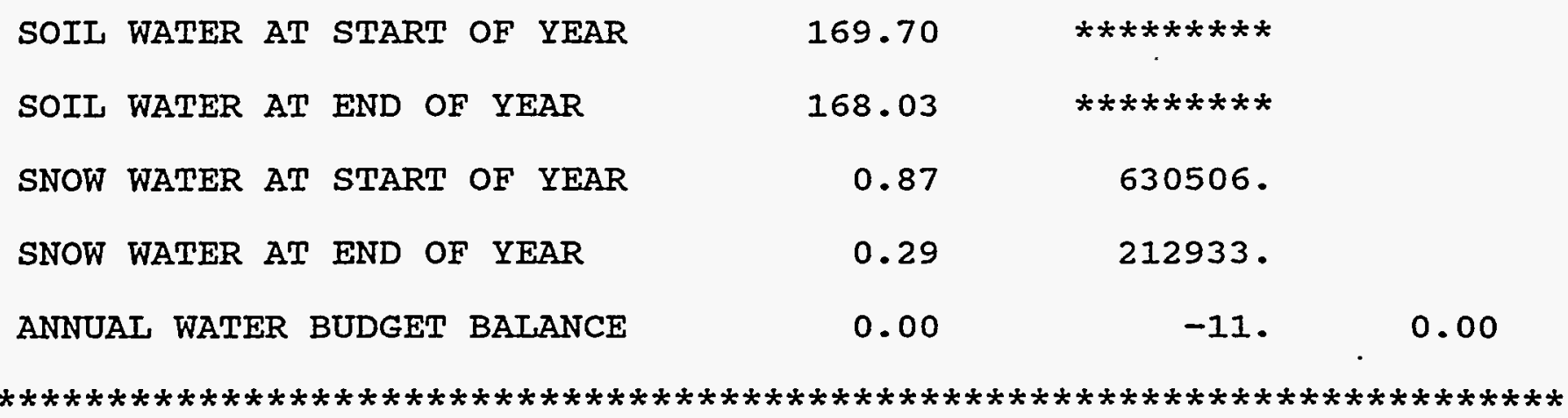

$* * * * * * * * * * * * * * * * * * * * * * * * * * * * * * * * * * * * * * * * * * * * * * * * * * * * * * * * * * * * * * * * * * * * * * *$ ANNUAL TOTALS FOR YEAR 18

\begin{tabular}{|c|c|c|c|}
\hline & (INCHES) & (CU. FT. ) & PERCENT \\
\hline PRECIPITATION & 33.92 & 24625926 & 100.00 \\
\hline RUNOFF & 0.426 & 309446 & 1.26 \\
\hline EVAPOTRANSPIRATION & 31.968 & 23208870 & 94.25 \\
\hline PERCOLATION FROM LAYER 3 & 0.0017 & 1199. & 0.00 \\
\hline CHANGE IN WATER STORAGE & 1.524 & 1106395 . & 4.49 \\
\hline SOII WATER AT START OF YEAR & 168.03 & $* * * * * * * * *$ & \\
\hline SOIL WATER AT END OF YEAR & 169.47 & $\star * * * * * * * *$ & \\
\hline SNOW WATER AT START OF YEAR & 0.29 & 212933 & \\
\hline SNOW WATER AT END OF YEAR & 0.38 & 273433 & \\
\hline ANNUAL WATER BUDGET BALANCE & 0.00 & 17. & 0.00 \\
\hline
\end{tabular}




\begin{tabular}{|c|c|c|c|}
\hline & (INCHES) & (CU. FT.) & PERCENT \\
\hline PRECIPITATION & 44.79 & 32517532 & $100: 00$ \\
\hline RUNOFF & 4.227 & 3068813 & 9.44 \\
\hline EVAPOTRANSPIRATION & 38.743 & 28127334 & 86.50 \\
\hline PERCOLATION FROM LAYER 3 & 0.0022 & 1618 . & 0.00 \\
\hline CHANGE IN WATER STORAGE & 1.818 & 1319782 & 4.06 \\
\hline SOIL WATER AT START OF YEAR & 169.47 & $* * * * * * * * *$ & \\
\hline SOIL WATER AT END OF YEAR & 171.59 & $* * * * * * * * *$ & \\
\hline SNOW WATER AT START OF YEAR & 0.38 & 273433 & \\
\hline SNOW WATER AT END OF YEAR & 0.07 & 52890 & \\
\hline ANNUAL WATER BUDGET BAIANCE & 0.00 & -15 & 0.00 \\
\hline
\end{tabular}

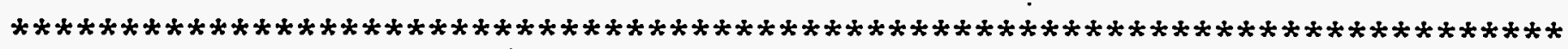
ANNUAL TOTALS FOR YEAR 20

\begin{tabular}{|c|c|c|c|}
\hline & (INCHES) & (CU. FT.) & PERCENT \\
\hline PRECIPITATION & 46.80 & 33976804 & 100.00 \\
\hline RUNOFF & 4.565 & 3314005 & 9.75 \\
\hline EVAPOTRANSPIRATION & 36.240 & 26310400 & 77.44 \\
\hline PERCOLATION FROM LAAYER 3 & 0.0030 & 2154 & 0.01 \\
\hline CHANGE IN WATER STORAGE & 5.992 & 4350246 & 12.80 \\
\hline SOIL WATER AT START OF YEAR & 171.59 & $\star * * * * * * * *$ & \\
\hline SOIL WATER AT END OF YEAR & 177.65 & $\star * * * * * * * *$ & \\
\hline SNOW WATER AT START OF YEAR & 0.07 & 52890 & \\
\hline SNOW WATER AT END OF YEAR & 0.00 & 0 & \\
\hline
\end{tabular}


ANNUAI WATER BUDGET BALANCE $0.00 \quad 1.00$

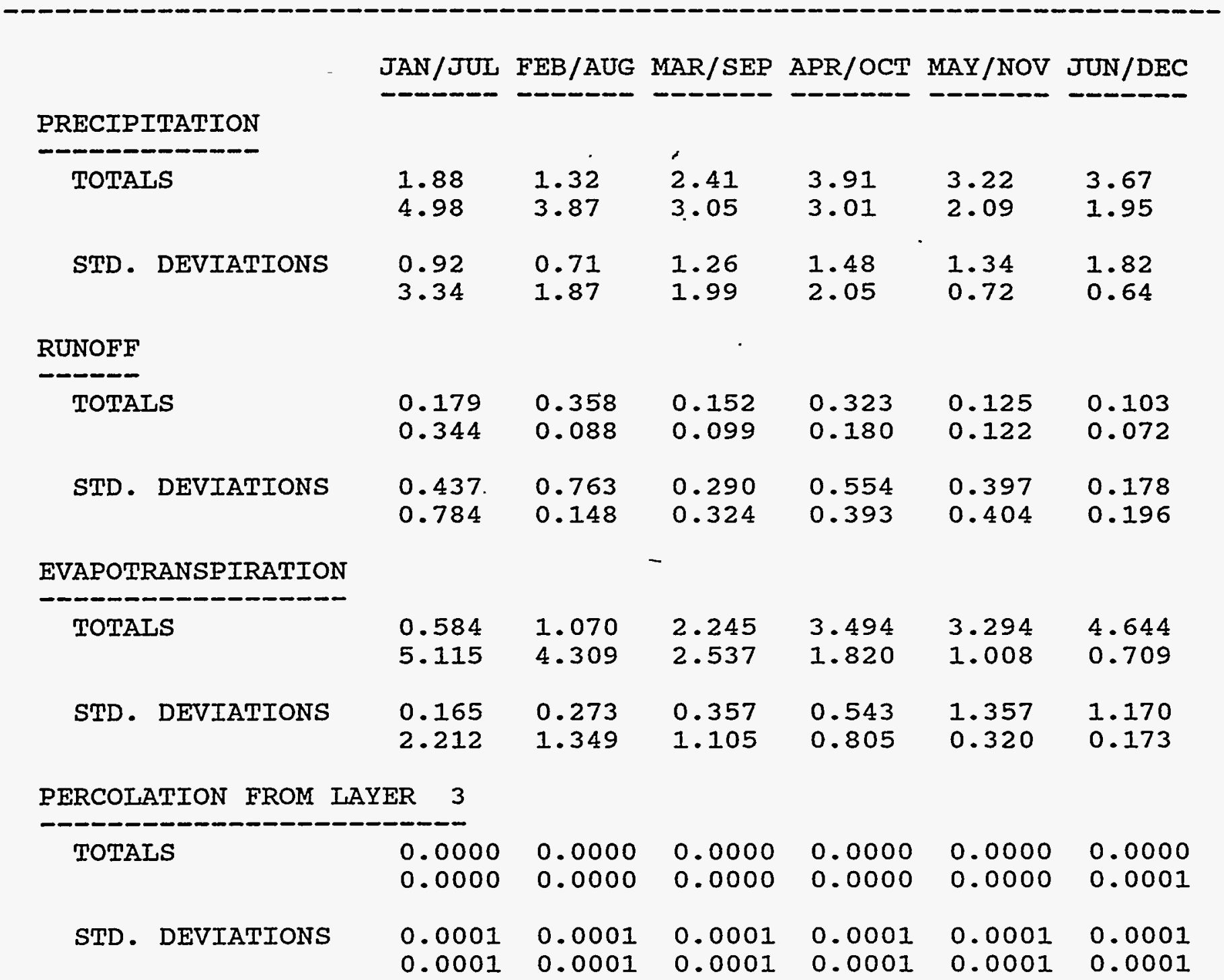




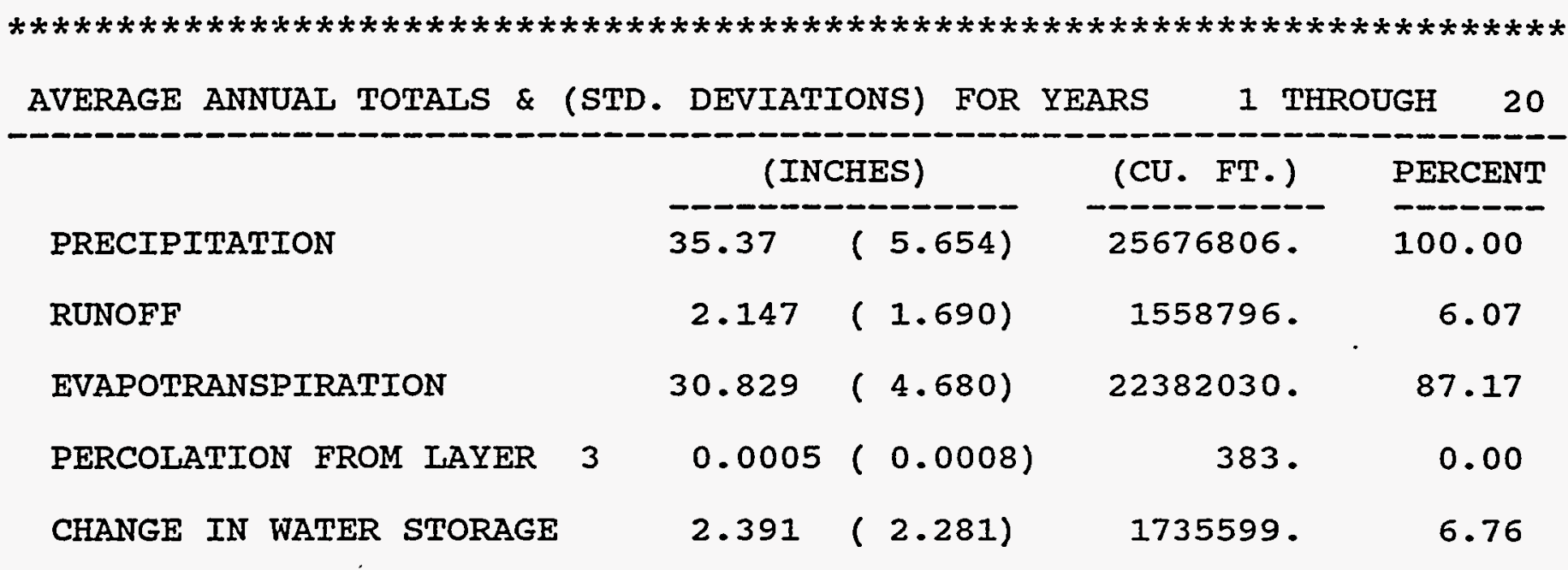

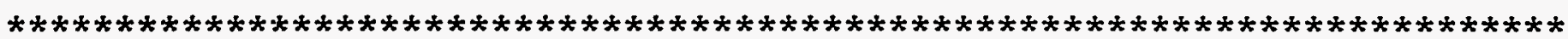

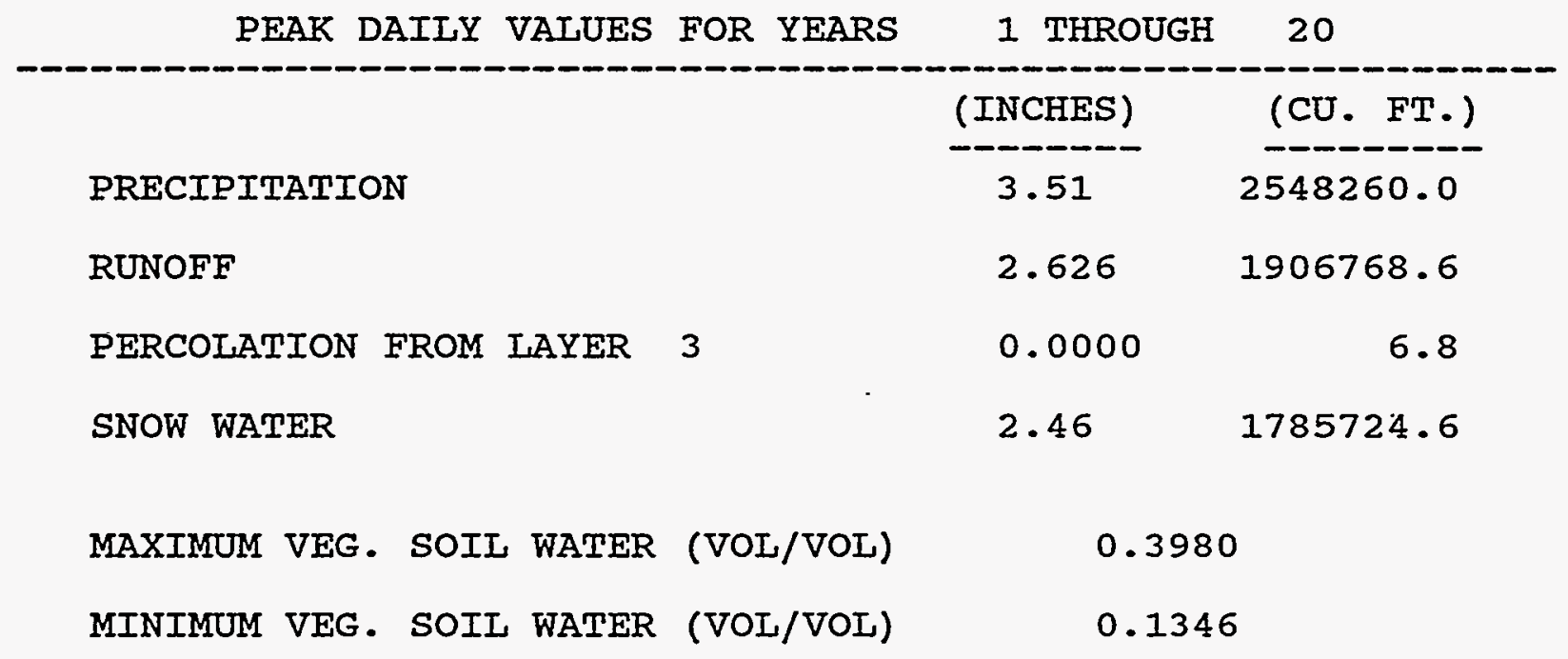

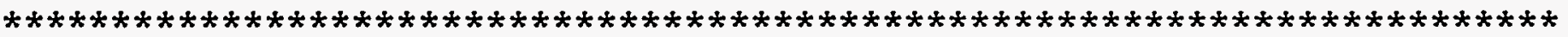




\section{CLOSED LANDFILI}

\begin{tabular}{ccc} 
LAYER & (INCHES) & (VOL/VOL) \\
\hdashline 1 & 9.51 & 0.3961 \\
2 & 10.32 & 0.4300 \\
3 & 157.83 & 0.3288 \\
& 0.00 &
\end{tabular}

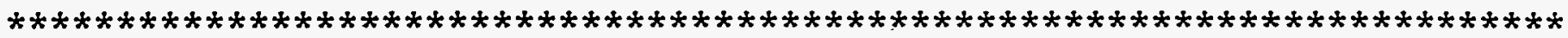

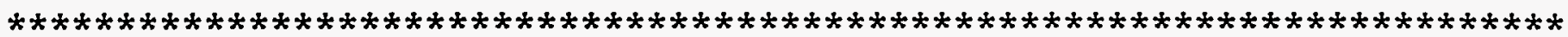

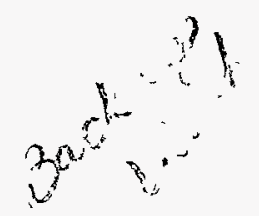




\section{APPENDIX E}

MULTIMED Model Results-Closed Landfill 
CLOSED LANDEILL

U. 5. ENVIRONMENTAL PROTECTION A GEN C Y EX POSURE A S S ES MENT

MULTIMEDIA MODEL

MULTIMED (Veraion 1.01, June 1991)

Page 1 
CLOSED LANDEILI

1

Run optiong

\section{SAMPLE}

RUN

Chemical simulated is DEFAULT CHEMICAL

\section{Option Chosen}

Run was

Infiltration input by user

Run was steady-state

Reject runs if $Y$ coordinate outside plume

Reject runs if $\mathrm{Z}$ coordinate outside plume

Gaussian source used in saturated zone model

Saturated zone model

CHEMICAL SRECIFIC VARIABLES

\begin{tabular}{|c|c|c|c|c|c|c|}
\hline \multirow[t]{2}{*}{ VARIABLE NAME } & \multirow[t]{2}{*}{ UNITS } & \multirow[t]{2}{*}{ DISTRIBUTION } & \multicolumn{2}{|c|}{ PARAMETERS } & \multicolumn{2}{|c|}{ LIMITS } \\
\hline & & & MEAN & STD DEV & MIN & MAX \\
\hline $\begin{array}{l}\text { Solid phase decay coefficient } \\
\text { Dissolved phase decay coefficlent } \\
\text { overall chemical decay coefficlent } \\
\text { Acid catalyzed hydrolysis rate } \\
\text { Neutral hydrolysig rate constant } \\
\text { Bage catalyzed hydrolysis rate } \\
\text { Reference temperature }\end{array}$ & $\begin{array}{l}1 / y r \\
1 / y x \\
1 / y r \\
1 / M-y r \\
1 / y r \\
I / M-y r \\
C\end{array}$ & $\begin{array}{l}\text { DERIVED } \\
\text { DERIVED } \\
\text { DERIVED } \\
\text { CONSTANT } \\
\text { CONSTANT } \\
\text { CONSTANT } \\
\text { CONSTANT }\end{array}$ & $\begin{array}{l}-999 . \\
-999 . \\
-999 . \\
0.000 \mathrm{E}+00 \\
0.000 \mathrm{E}+00 \\
0.000 \mathrm{E}+00 \\
25.0\end{array}$ & $\begin{array}{l}-999 . \\
-999 . \\
-999 . \\
-999 . \\
-999 . \\
-999 . \\
-999 .\end{array}$ & $\begin{array}{l}0.000 \mathrm{E}+00 \\
0.000 \mathrm{E}+00 \\
0.000 \mathrm{E}+00 \\
0.000 \mathrm{E}+00 \\
0.000 \mathrm{E}+00 \\
0.000 \mathrm{E}+00 \\
0.000 \mathrm{E}+00\end{array}$ & $\begin{array}{l}0.100 \mathrm{E}+11 \\
0.100 \mathrm{E}+11 \\
0.100 \mathrm{E}+11 \\
-999 \\
-999 \\
-999 \\
100\end{array}$ \\
\hline
\end{tabular}

Page 2 
CLOSED LANDFILL

Normalized distribution coefficient

Distribution coefficient

Biodegradation coefficlent (sat. zone)

Air diffusion coeffictent

Reference temperature for air diffusion

Molecular weight

Mole fraction of solute

vapor pressure of solute

Henry's law constant

Overall lat order decay sat. zone

Not currently used

Not currently used

$\mathrm{ml} / \mathrm{g}$
$1 / \mathrm{yr}$
$\mathrm{cm} 2 / \mathrm{s}$
$\mathrm{C}$
$\mathrm{g} / \mathrm{M}$
$\cdots$
$\mathrm{mm} \mathrm{Hg}$
atm- $\mathrm{m}^{\wedge} 3 / \mathrm{M}$
$1 / \mathrm{yr}$

CONSTANT
CONSTANT
CONSTANT
CONSTANT
CONSTANT
CONSTANT
CONSTANT
CONSTANT
CONSTANT
DERIVED
CONSTANT
CONSTANT
$0.000 E+00-999$.

$0.000 \mathrm{E}+00-999$.

$0.000 \mathrm{E}+00-999$.

$0.0005+00-999$

$0.0007+00-990$.

$0.000 B+00-999$.

$0.000 \mathrm{E}+00-999$.

$0.000 E+00-999$.

$0.000 \mathrm{E}+00-999$.

$0.000 \mathrm{E}+00-999$.

$0.000 \mathrm{E}+00 \quad 0.000 \mathrm{E}+00$

-999 . -999 .

-999 . -999.
$0.000 \mathrm{E}+00-999$.

$0.000 E+00 \quad 0.100 E+11$

$0.000 \mathrm{E}+00-999$.

$0.000 \mathrm{E}+00 \quad 10.0$

$0.000 \mathrm{E}+00100$.

$0.000 E+00-999$.

$0.100 \mathrm{E}-08 \quad 1.00$

$0.000 \mathrm{E}+00 \quad 100$.

$0.100 \mathrm{E}-09 \quad 1.00$

$0.000 E+00 \quad 1.00$

$0.000 \mathrm{E}+00 \quad 1.00$

$0.000 \mathrm{E}+00 \quad 1.00$

SOURCE SPECIFIC VARIABLES

VARIABLE NAME
Infiltration rate
Area of waste disposal unit
Duration of pulse
Spread of contaminant source
Recharge rate
Source decay constant
Initial concentration at landfill
Length scale of facility
Width scale of facility
Near field dilution

UNITS DISTRIBUTION

PARAMETERS STD DE

(1)

LIMITS MI $0.100 \mathrm{E}-09$

$\begin{array}{llll}\mathrm{m} / \mathrm{yr} & \text { CONSTANT } & 0.760 \mathrm{E}-04 & -999 . \\ \mathrm{m} 2 & \text { CONSTANT } & 0.809 \mathrm{E}+06 & -999 . \\ \mathrm{yr} & \text { CONSTANT } & -999 . & -999 . \\ \mathrm{m} & \text { DERIVED } & -999 . & -999 . \\ \mathrm{m} / \mathrm{yr} & \text { CONSTANT } & 0.122 & -999 . \\ 1 / \mathrm{y} r & \text { CONSTANT } & 0.000 \mathrm{E}+00 & -999 . \\ \mathrm{mg} / 1 & \text { CONSTANT } & 1.00 & -999 . \\ \mathrm{m} & \text { DERIVED } & -999 . & -999 . \\ \mathrm{m} & \text { DERIVED } & -999 . & -999 . \\ & \text { DERIVED } & 1.00 & 0.000 \mathrm{E}+00\end{array}$

.100E-09 0.100E+11

$0.100 \mathrm{E}-01$-999.

$0.100 \mathrm{E}-08$-999.

$0.100 \mathrm{E}-08 \quad 0.100 \mathrm{E}+11$

$0.000 \mathrm{E}+00 \quad-999$.

$0.000 \mathrm{E}+00 \quad-999$.

$\begin{array}{ll}0.000 \mathrm{E}+00 & -999 \\ 0.100 \mathrm{E}-08 & 0.100 \mathrm{E}+11\end{array}$

$0.100 \mathrm{E}-08 \quad 0.100 \mathrm{E}+11$

$0.000 \mathrm{E}+00 \quad 1.00$

AQUIFER SPECIEIC VARIABLES 
CLOSED LANDFILI

MEAN STD DEV MIN MAX

$\begin{array}{lll}\text { Particle diameter } & \mathrm{cm} & \text { CONSTANT } \\ \text { Aquifer porosity } & - & \text { CONSTANT } \\ \text { Bulk density } & \mathrm{g} / \mathrm{cc} & \text { CONSTANT } \\ \text { Aquifer thickness } & \mathrm{m} & \text { CONSTANT } \\ \text { Source thickness (mixing zone depth) } & \mathrm{m} & \text { DERIVED } \\ \text { Conductivity (hydraulic) } & \mathrm{m} / \mathrm{yr} & \text { CONSTANT } \\ \text { Gradient (hydraulic) } & & \text { CONSTANT } \\ \text { Groundwater seepage velocity } & \mathrm{m} / \mathrm{yr} & \text { DERIVED } \\ \text { Retardation coefficient } & -\cdots & \text { DERIVED } \\ \text { Longitudinal dispersivity } & \mathrm{m} & \text { FUNCTION OF X } \\ \text { Transverse dispersivity } & \mathrm{m} & \text { FUNCTION OF X } \\ \text { Vertical dispexsivity } & \mathrm{m} & \text { FUNCTION OF X } \\ \text { Temperature of aquifer } & \mathrm{C} & \text { CONSTANT } \\ \text { pH } & -\cdots & \text { CONSTANT } \\ \text { Organic carbon content: (fraction) } & & \text { CONSTANT } \\ \text { Well distance from gite } & \mathrm{m} & \text { CONSTANT } \\ \text { Angle off center } & \text { degree } & \text { CONSTANT } \\ \text { Weli vertical distance } & \mathrm{m} & \text { CONSTANT }\end{array}$

$0.100 \mathrm{E}-08 \quad 100$.

$0.100 \mathrm{E}-08 \quad 0.990$

$1.40-999$.

$0.100 \mathrm{E}-01 \quad 5.00$

$6.10 \quad-999$.

$0.100 \mathrm{E}+06$

$0.100 \mathrm{E}-08 \quad 0.100 \mathrm{E}+06$

536. $\quad-999 . \quad 0.100 \mathrm{E}-06 \quad 0.100 \mathrm{E}+09$

$0.600 \mathrm{E}-02-999$.

$0.100 \mathrm{E}-07 \quad-999$.

33.5

$0.100 \mathrm{E}-09 \quad 0.100 \mathrm{E}+09$

$1.00 \quad-999$.

1.00

$0.100 \mathrm{E}+09$

clent

$-999 . \quad-999$.

-999. -999.

$-999 . \quad-999$.

$-999 . \quad-999$.

$\begin{array}{ll}-999 . & -999 . \\ -999 . & -999 .\end{array}$

-999. $0.000 \mathrm{E}+00 \quad-999$.

$0.300 \quad 14.0$

$0.110 \quad-999$.

$122 . \quad-999$.

0.100E-05 1.00

$1.00-0.090$

$0.000+00-999$

$\begin{array}{llll}0.000 \mathrm{E}+00 & -999 . & 0.000 \mathrm{E}+00 & 360 . \\ 0.000 \mathrm{E}+00 & -999 . & 0.000 \mathrm{E}+00 & 1.00\end{array}$

CONCENTRATION AFTER SATURATED ZONE MODEL $0.4030 \mathrm{E}-02$ 